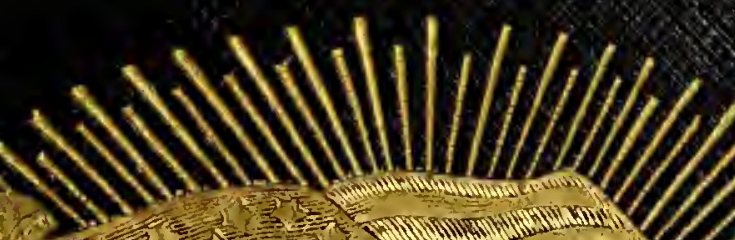

(3)

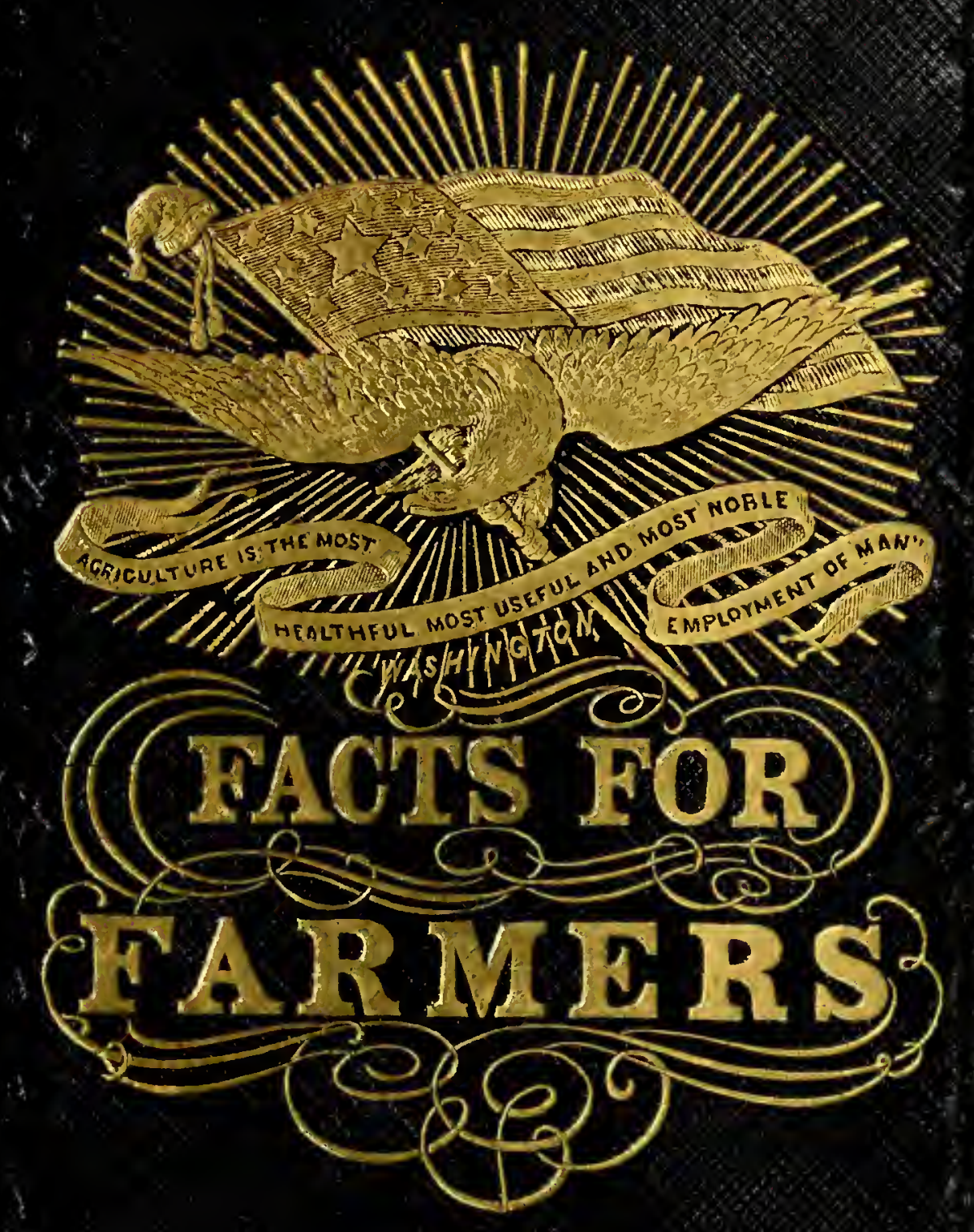


बद

T.

बतC

arce

ercer ach rere

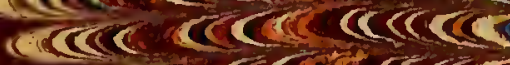

cmen actere corres

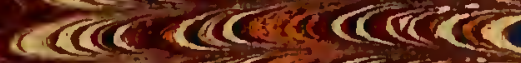

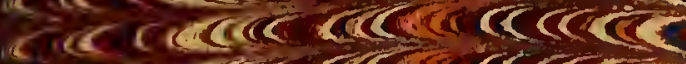

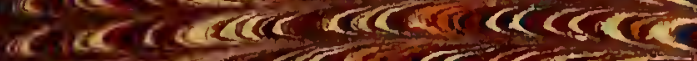

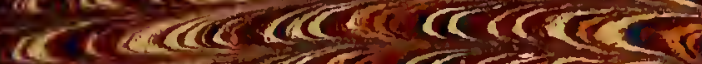

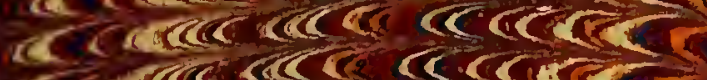

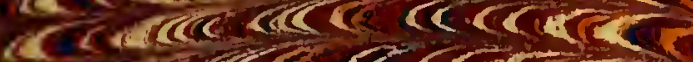

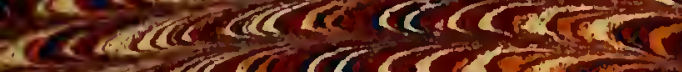

cenciker C C C L S

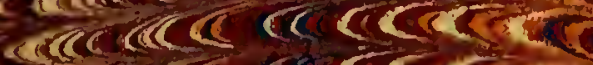

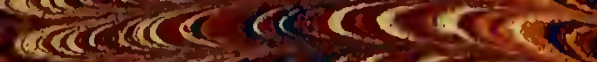

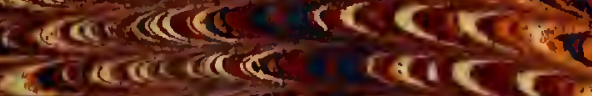

atecerers

Tinconice?

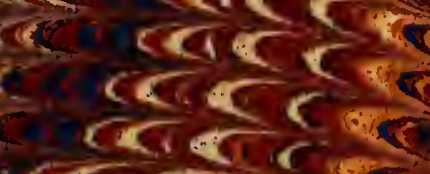

ask CR सE कर

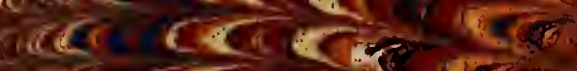

ace C.C. लि

ire ceras an

c Coserre

set?

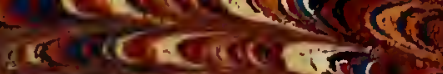

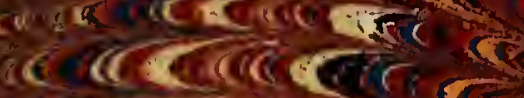

ic cocinas

de crosicts

$\operatorname{cocccos}$

Ge.coses

तC. बCब C

descess

(c) CCsare

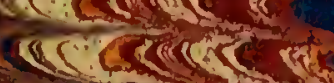

$-1<\cos 2 x$

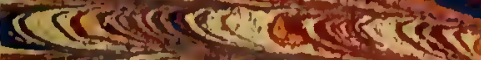

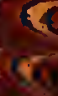

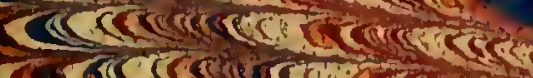

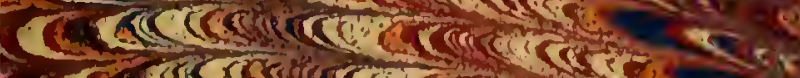

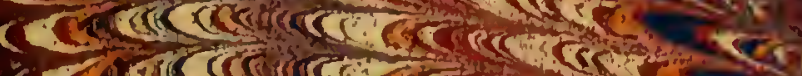

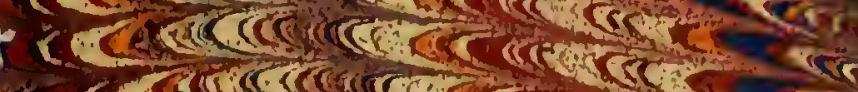

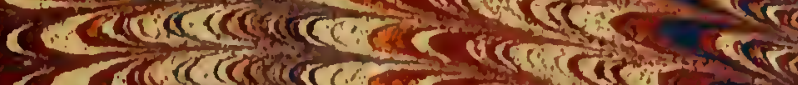

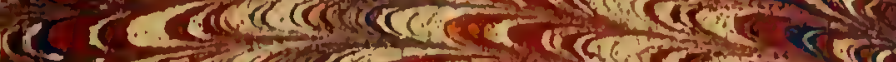

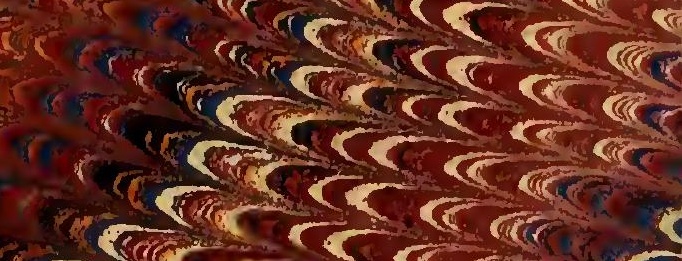

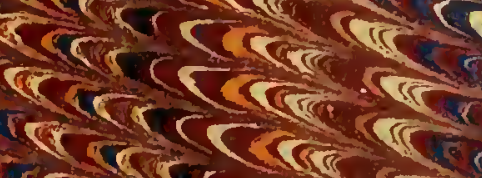
Cremcrem

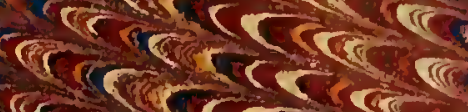

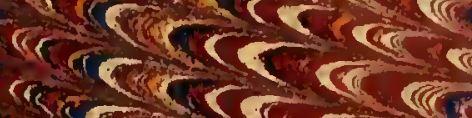

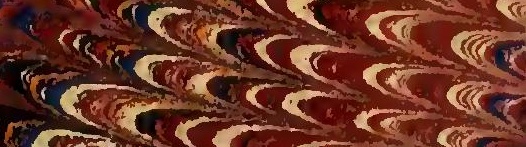

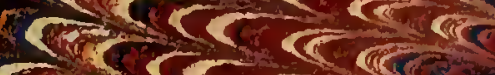
7 C $=15$ बर

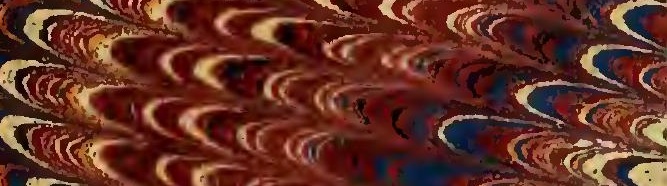

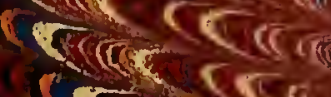

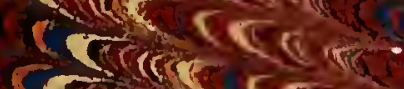

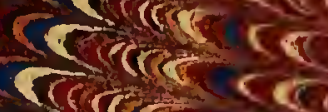
renter $\mathrm{Cl}$ re रre सबत्र $\cos$

$\frac{1}{2}$

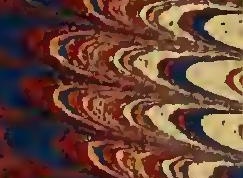

at re? CGTK crase सरातर बिरतेक एकितर बएक Cरते

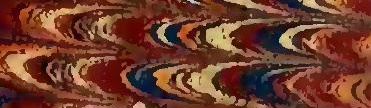
care cas Concerce croctcare resecror FreACCLC Correnteré

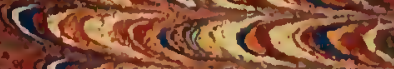
Sire Has

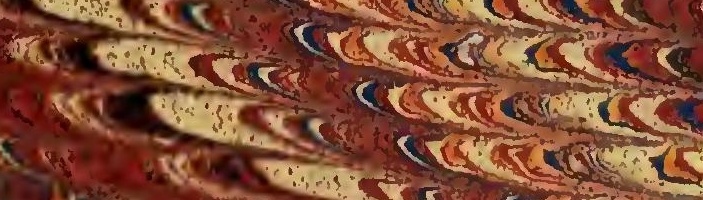
res? e 9 Ka

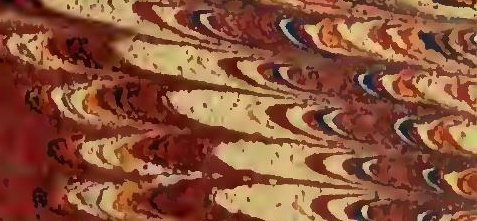


,

9 


$$
\text { C a a a i i }
$$








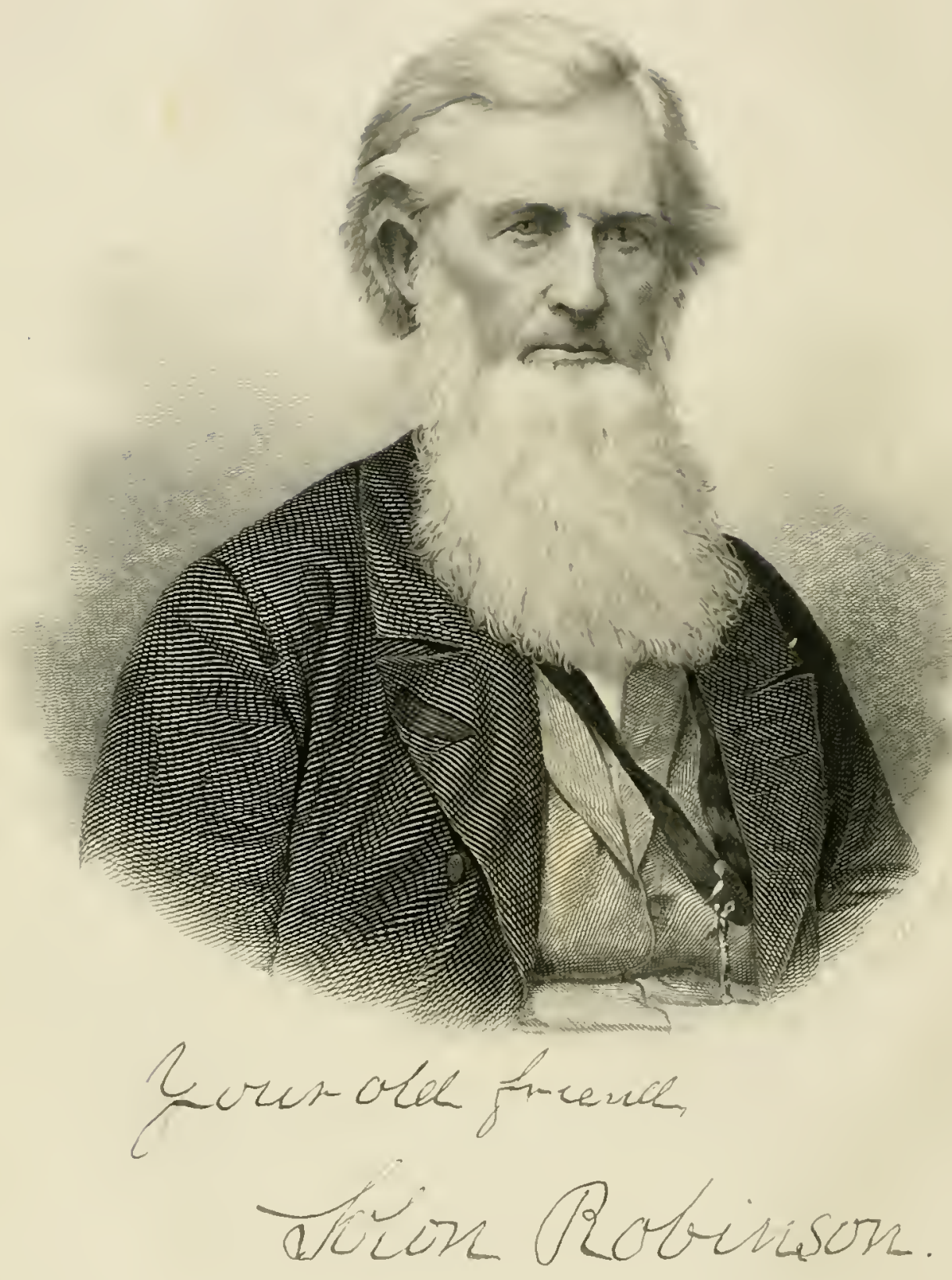






\title{
FACTS FOR FARMERS;
}

ALSO FOR

\section{THE FAMILY CIRCLE.}

A TARIETY OF RICH MLATERIALS FOR ALT LAND.OWNERS, ABOUT

DOMESTIC ANIIALS AND DOHESTIC ECONOMY; FARM BUILDINGS;

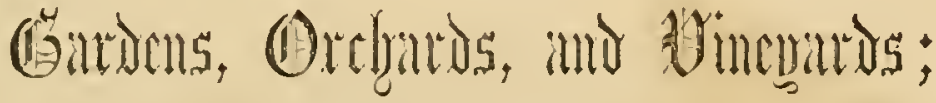
AND ALI.

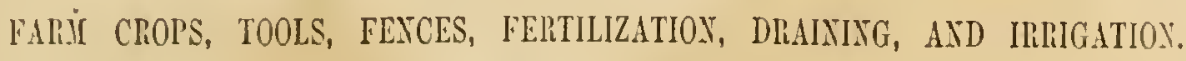
WITII AN APPENDIX ON THE

DISEASES AND CURES OF DOMESTIC ANIMALS.

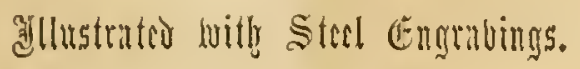

\author{
EDITED BT \\ SOLON ROBINSON,
}

AORICLLTCRAL EDITOR OP TTE NET TOLK "TIIEEXE," AND ATTHOR OR SETERAL POTCLAR WORKS.

\section{VOLUME I.}

NEW YORK:

$$
\text { A. T. T O I N S S N, }
$$

CLEVELAND, OMIO:

$$
\text { F. G. AND A. C. ROTVIE, }
$$
266 SUPERIOR STREET. 


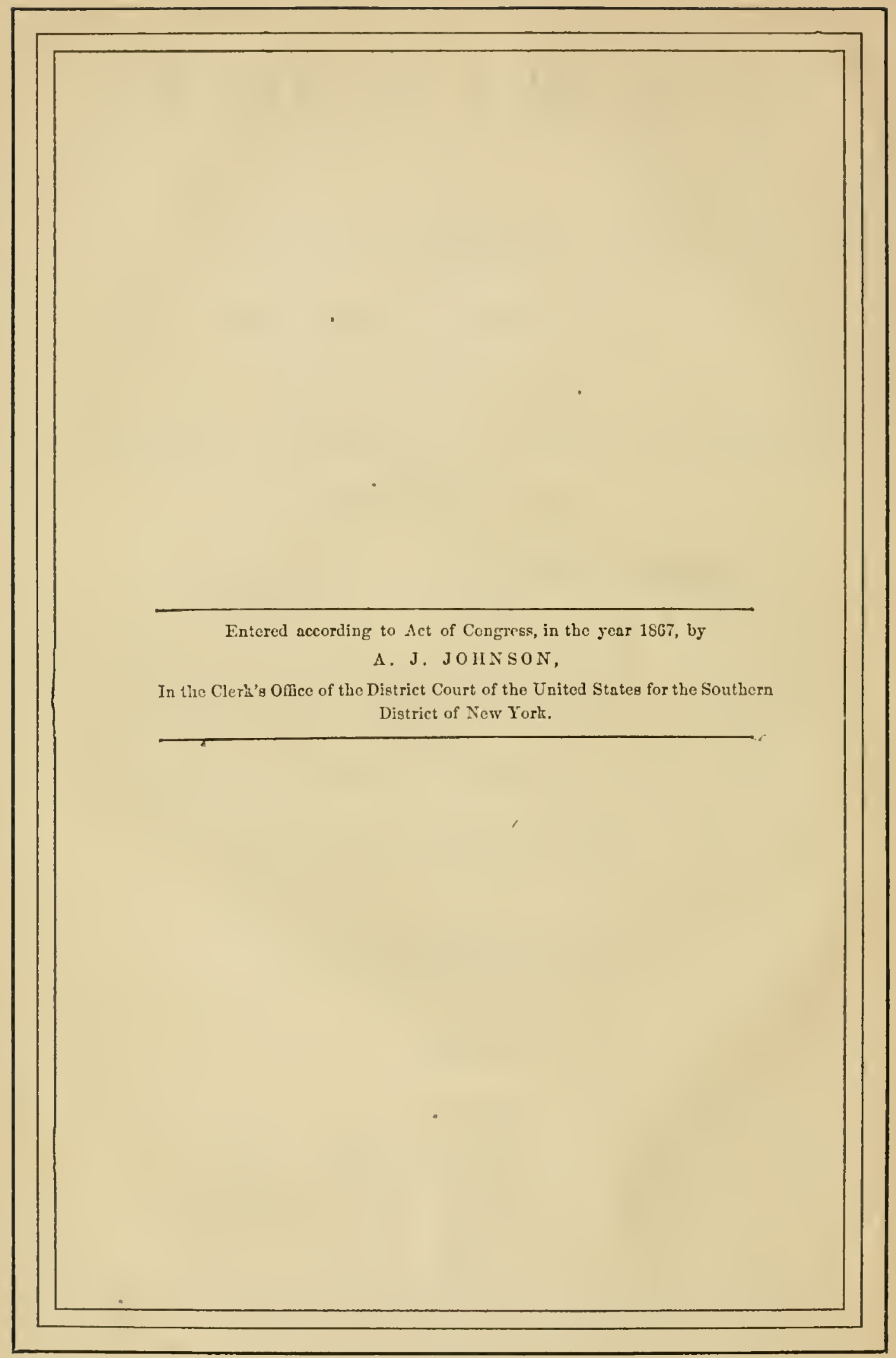




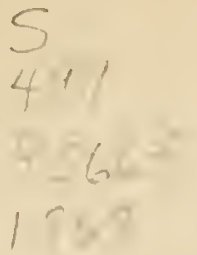

\section{PLATE I.}

( $($ II E F FONTISIECE.)

Turs is the genial face of a furmer, engaged in a work of love for his calling. It is placed here in opposition to the wishes of the anthor: He has been persuaded to allow his face to be seen by those who purchase this collection of things useful to a very numerous elass through the solicitation of the publisher, who knows that it will be a satisfaction to them to see how their old friend looks at the age of sixty. An old friend he will seem to those who read his earnest appeals for agricultural improvement twenty or thirty years ago. As a witer and lecturer upon agriculture, and extensive traveler to observe its condition in the United States, few men are better known than the original of this portrait. Therefore this likeness will be, the publisher believes, highly appreciated as well by those who look upon a familiar face as those who see it here for the first time.

'The author was born a farmer, and will probably end lis days where he now lives (a few miles ont of the busy hum of the eity), in the peaceful quict of his "home in the country," where this rolune of fuets for fumer's has been prepared as a last legacy of his good-will to the brotherhood.

Like other firmers' sons of New England, he learned to follow the plow there, though in early life he beeame a Western pioneer, and while a prairic furmer, became widely known as a writer adroeating agricultural improvement, and more widely, in 1841, as the originator of the National Agricultural Society, and earnest adrocate of State and County societies. His connection with the New York Tribume since 1850 will make this pieture interesting to all its readers. It is for these reasons that the publisher has incurred the expense of its production. 



\section{PREFACE.}

\section{THE AUTHOR TO IIS READERS.}

"Facts for Faruers?" "What facts?" "What new theories have we here in a ponderous volume? Is it filled with dry dissertations about what farmers should or should not do?" "What does this author know about farming?"

The author asks the reader of this book to judge for himself. He does not advance new theories. He only collects old ones. He has made a ponderous rolume, not of dry dissertations, but of short, crisp facts. The book is full of little things; glennings from many fields; from all reliable authority; from conversations of furmers; from talks at farmers' clubs; from books a little; from persoual experience much ; - from the memory of a long life devoted to the practice and study of agriculture, this volume is born. It is the fruit of years of labor in a great and good field. It certainly contains much that will be useful to all classes who till the earth, or live in farmers'. louses. It should be in every rural home, as a work of reference. It is arranged in the most conrenient form for this purpose. Each chapter comprises one general subject. Each section embraces a separate branch. Each numbered paragrapl is complete in itself, and conveys an item of information. Each subject is completely indexed. As a whole, though containing much, it is not an encylopedia of agriculture. It does not pretend to teach all that a farmer should know. That must be learned by reading, thinking, and acting. 
'l'hough not perfect, farmers will find this book a useful one. If not invaluable, I lope it is one that they ean not afford to do without. In its compilation, the anthor lias enjoyed many facilities and much experience; he las also labored under many difficulties, while daily engaged as an agrieultural editor of a great daily and weckly paper. Fou will find here stored up for future use many of the valuable little items that you have read approvingly from time to time but lave forgotten, useful to every man's family, and worthy of preserration. Usefulness instead of elegance has been aimed at. I have given more facts than theories. I have often given the opinions of several upon the same subject, and, as some of these vary, I leave the reader to adjust differences.

In trying to avoid diffuseness, I lave left much for inference, and purposely treated subjects in such a manner as to induce readers to make further research. A word of explanation. At the end of the volume you will find a list of individuals, nearly five hundred, some of whom are eminent authority in agricultural knowlecige. These individuals hate materially aided the author in producing a work which has been long needed by the American farmer, gardener, florist, fruit-grower, and housekeeper. From all these he has drawn matter, sometimes with, and sometimes without, credit to individuals, when facts have been eondensed from their articles. Conciseness has been a study; else, how could twelve hundred subjects be erowded into a thousand pages? Those whose articles I have used, must not complain that I have pruned too elosely, or failed to give credit in all cases where eredit is due. I freely acknowledge my obligations to all.

This book is one that may be opened at any page, profitably, to occupy five minutes' leisure. It is printed in such large, clear type that it can be easily read. The author and publisher hope that it will be. Then it is illustrated as no agricultural book published in America ever has been. Look at the many large, handsome, 
steel engravings! These alone are worth the cost of the whole rolume.

Farmers! you are earnestly invited to read, if nothing more, the titles and contents of chapters, and their subdivisions of sections. If you do that, and find nothing that promises instruction, lay the rolume aside. If so far it is promising, turn orer its pages, glancing at the black-letter titles of paragraphs. Of one thing be assured; lengthy as the volume appears, it is not made so by extreme -dilution; the list chapter is better than any that precedes it. Throughout, no subject is lengthily treated; no subject is treated that does not contain something useful to some one; something that you can not always remember, but which you should always have at hand, convenient for frequent consultation.

To those who know the name of the author-and the number is large-I hope this book will be a welcome bequest. I hope it will be the ineans through which that name may live in love and honor with your children and children's children around many an American hearthstone.

Of the author's portrait, a word. It is the publisher, and not the author, who inserts it. It represents him correctly, as he is at the agc of nearly sixty.

In conclusion, I earnestly liope these FAcrs will be an acceptable offering to a very large number of those whose prosperity I would promote, for I am one of the Brotienilood of American Parmens. To them it is commended, with the love and respect of their old friend,

SOLON ROBINSON. 



\section{0 N T E N T S.}

\section{CHAPTER I.}

DOMESTIC ANIMALS.

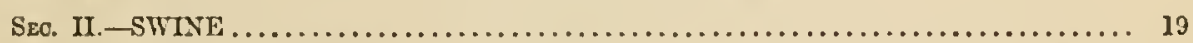

This section embraces facts about the best breeds, and best mode of feeding, gross and net weight, etc.

SEc. III.-COWS : What is a good cow, and how to choose one; food necessary; health; profit ; kind for butter-making ................................... 31

SEC. IV.-BEEVES : Record of the largest known, and their wcights.............. 51

SEc. V.-STATISTICS OF THE NEW YORK CATTLE MARKET, and Improvements in

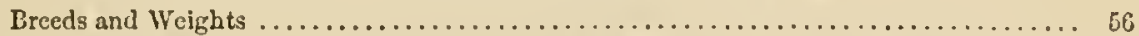

SEc. VI.-FEEDING CATTLE AND CARE OF FARM STOCK: Sclecting calres; shelter; training ; kindness ; value of kinds of feed ; use of salt ; watering ; diseases of cattle... 60

SEC. VII.-SHEEP HUSBANDRY : Brecds of sheep; care and management; weight of hay necessary ; mutton and its use; shearing and care of wool $\ldots \ldots \ldots \ldots \ldots \ldots \ldots . . . . . .61$

SEC. VIII.-HORSES AND MULES: Ilistory of the horse; rarictics; how to use; proper size; color; diseases; treatment of colts; how to shoe horses; lyreeding horses and

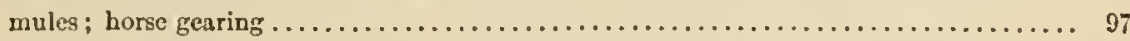

SEc. LX.-POULTRY : Full description of all kinds of poultry, and proper treatment ...... 123

\section{CHAPTER II.}

\section{G IS ALI ANIMALS AND INSEOTS.}

SEC. X.-BEES : Their history, use, and value, management, and reasons for keeping ...... 157

Skc. XI.-BIRDS : Reasons for preserving; their food; and laws for protecting ......... 176

SEc. XII.-ENTOMOLOGICAL: What are insects, and what kinds infest and injure various crops, and how to deteet friends from foes, and various rcmedies................. 203

Sec. XIII.-WILD AND TAME ANIMALS OF THE FARM : Dogs, cats, rats, mice, moles, rabbits, squirrcls, gophers, skunks, toads, goats, camels, and breeding fish for fanily use. 248

\section{CIIAPTER III.}

\section{T I E F A R M R Y.}

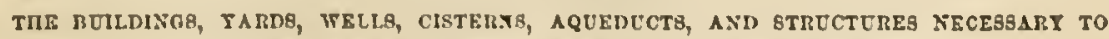
CARIYY ON TIIE BC'BINEBS OF THE FABS, BRIEFLY DESCRIBED.

SEo. XIV.-FARM-HOUSES: They slıould he convenlent, roomy, light, ventilated; their influcnce upon claracter; old-8tjle farm-house described..................... 275 
SEc. XV.-CELLARS, CHIIINEYS, AND ICE-IIOUSES : How to build them, and their proper size and use; how to store and keep ice........................ $\approx$.

SEc. IVI-THE B.RN AND ITS APPURTEX 1 NCES: Location, size, and use of barns; stables, how to build; stable yards and cheap sheds..................... 293

Sxc. TVII. - WATER FOR THE FARIERY : Cisterns, sizc, cost, aud how to build ; rgueducts and wells, how to construct; hydraulic rams.................... 308

SEC. IVIII.-STACKING ANI) STORIXG GIAIN; CORN CRIBS, PIGGERIES, AND PIG FEEDING; SMOKE-1IOCSE, AND CLIIFG 1BACON; FRUTT-1)RYING HOLSE. 318

SLC. IIX. - ECONOJICAL FARII BULLDIXGS: Balloon frames, concrete walls, and other cheap styles of building; how to make balloon frames, and their cost ........... 325

SEC. XX.-ROOFS AND ROOFIXG: Iaints and whitewash for farm buildings; nails; mortar ; farm gates; sawed shingles, their value, and how to preserve shingles........... 332

SEc. XXI.-LIGHTNING CONDUCTORS : Protection of farm buildings from fire; windmills

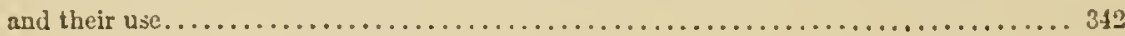

\section{CHAPTER IV.}

\section{DOMESTIC ECONOMT.}

SEc. XXI.-THE FOOD QUESTION : Quantity, quality, rariety, adaptation, adulteration, changes produced by cooking, water for cooking, aukl effect on health ............ 35l

SEc. XXIII -THE BREAD QUESTION : Farietics; quality; how to make breal and yeast,

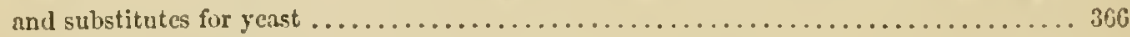

SEc. KXIV.-SUBSTITUTES FOR BREAD, in green corn, dried corn, pop-corn, hominy, and

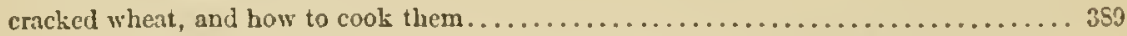

SEC. XXV.-EXCERPTA OF USEFUL KNOWLEDGE FOR HOUSEWIVES: Economy of lights; use of tca, coffee, and sugar ; preserving fruits, pork, hams, and beef ; remedies and disinfectants; beds and bedding and carpets, etc. . . . . . . . . . . . . . . 396

SEC. XXVI.DONESTIC WINES, CIDER, AND PRESERTES: Rules of wine-making from various fruits, and cider and vinegar making . . . . . . . . . . . . . . . . 419

SEc. IXIII.-HYGIENIC: Preparation of food for the sick; remedies for poisons, bites,

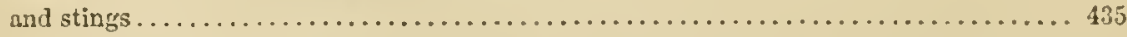

SEc. XIVII.-THE DAIRY : Butter and cheese making; how muclı milk for a pound of butter; Alderney butter; dairy room and utensils; working, salting, and packiug butter 411

\section{CHAPTER $V$.}

TIE GARDEN $\Lambda N D$ ITS FRTITS.

SEC. XSIX.PLEASURE AND PROFIT OF GARDENING : Origin and history of regetables ......................................... $46 \mathrm{I}$

Sec. XXX.-GARDFA CULTNARY TEGETABLES: Protection from insects; value of rarious things for food; chiccory culture; what should be grown in the garden; number of plants upon an acre..................................... 470

Szc. XXXI.-THE FLOWER GARDEN : Tarieties and cultiration of flowers ; suitable soil and preparation; lists of choice flowers; flowers grown as a crop.............. 500 
Sec. XXXII.-LAWSS: How to make and how to keep them; trees and plants suitablo for lawns; botanical names of trees; roses and their caltivation ................ 515

SE. XXXIII.-HOT-BEDS : Cold frames pant protectors; how to make and use hot-beds. 521

Se. XXXIV.-SUALL FRUITS OF TIIE GARDEN : Currants, varieties and cultivation; strawberries, variety and growth ; raspberries; blackberries ; quinecs............. 630

\title{
CIJAPTER VI.
}

\section{T II E O IE C II A I D.}

Sec. XXXY.-PROPAGATION, PLANTING, AND CULTTVATION OF TREES: Time to transplant ; preparation; protection; klucls for trees ..................... 555

Sec. XXXVI.-TIE: ART OF PRUNING, GRAFTING, AND BUDDING: How and when to prune; how and when to bud and graft; how to make wax............... 550

SEc. XXXVII-APPLE AND PEICII TRELS: Their gencral management; select list of apples, and descriptions; pench-trees, how to grow ; low to treat an old orchard ..... 559

Sec. XXXVIII.-CHERRIES : Best varieticon ; soll, situation, and cultivation; history, use,

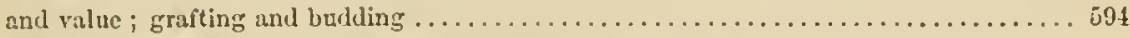

SEC. XXX1X.-PE.ARS : Soil, situation, cultiration, and varieties; select list of sorts; when

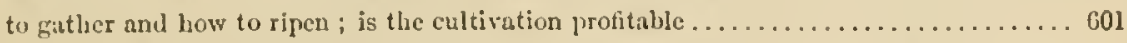

Sre. NL-PLUIS, NECTARINES, APliCOTS, MULBERRIES, AND OTHER FRUTT: Ilow to trausplint fruit ; cloice selection of plums ....................... 612

SEC, XII.MIISCELLANEOUS MATTEIS ABOUT FIRIT CULTULE: Cramberries as a crop; how to grow them; best varietics; cider-making ................... 621

\section{CIIAPTER VII.}

TII E VINEY A IR D.

Src. XLII.-HOW TO PLANT AND CELTIYATF VISES : What sorts to plant ; bistory of varictics; profits of culture ; grape-rgrowing in California ................. 630

Sec. XLIII.-CULTUR: OF GR.APES FOR WTSE: Rules for wine-making; wine from various kinds of grapes; rules of a lirencts wine-maker; rules of Amcrican wine-makers 657

\section{CIIAPTER TIII.}

\author{
C E I E A I, I $A$.
}

SE. XILIV.WWIEAT, RYF, OATS, BARLIY, MILLIY, BCCKWIIEAT: Prepamtion of soil and fertilization ; quantity of seed ; lurrvesting, stucking, and storing; thrashing and cleaningr; profits of whent culture; oata, low and when to sow; cultivation of barley;

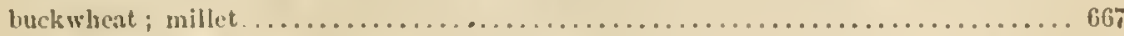

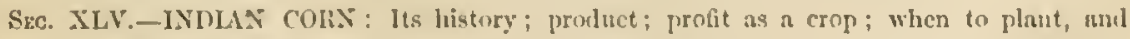
low to cultivate; great yield per acre, North nul sinth ; how to store corn, and how to mensure in lulk; seed cora, and varieties; broou corn.................... 709 


\title{
CIIAPTER IX.
}

TIE GRA S BES, TIIEII OULTIVATION AND USE.

SEc. ILVI,-MOWING AND PASTURE LANDS: Seeding land; varieties of grass; what is grass; what kinds are rocommended for cultivation; clover, its cultivation; harvest-

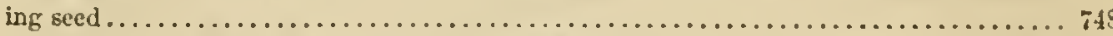

Sec. XLVII.-HAYIXG AND IIAYIG MACHINES : Iay caps; stacking; how much hay land should produce, and how much it is necessary to provide; how to measure hay in bulk.

\section{CHAPTER $\Gamma$.}

\author{
ROOT CROPSAND SUGAR CROPS.
}

SEc. XLTII.-POTATOES, TURNIPS, BEETS, CARROTS, PARSNEPS, ONIONS : How to plant and cultivate, and how much they should produce; history of the potato; character of rarieties; importance of the crop; what seed should be used, and how planted; substitutes for the potato; sweet potato culture; turnip culture; carrots as a crop, and sowing and cultivation; onions as a crop, how grown, and profits ............. 785

SEc. TLIX.-CHINESE SUGAR-CANE, AND SORGO-SUGAR MAKIKG : Preparntion and time of planting cano; soil and situation; harvesting; manufacturing, and yield and

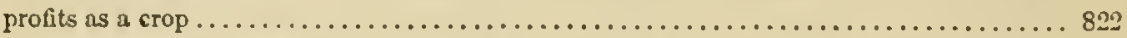

SEc. L.-MAPLE-SUGAR MLAKING : Tapping trees; spouts, buckets, and boilers ; process of manufacture ; cost, yield, and profit of maple-sugar

\section{CHAPTER XI.}

\section{FORESTS AND FENCES.}

SEc. II.-TRETS AND TREE PLANTING; WOOD OR COAL FOR FUEL: What trees to plant, and how and where; descriptive list of trees; value of various trees; how to make

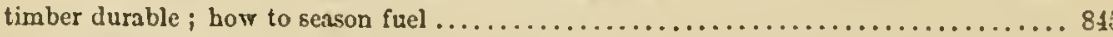

Szc. LII.-FENCES : Their cost; kinds most economical; laws regulating; how to make hedges, stone walls, wire fence, and farm gates; how to kyanize fence posts ; waste of land around fences ; portable fence, its uso..............................86

\section{CHAPTER XII.}

FERTILIZATION.

SEc. LIII.-TIE ART, USE, AND ECONONY OF MAKING, SATING, AND APPLTING MANURES AND FERTLLIZING FARM CROPS: Color, fineness, and moisture of manure affects its ralue; nitrates, muriates, sulphates, lime, plaster, and bones, how to apply ; guano, its history and use ; muck, its value; sea-weed and other matters ; value of salt; special manures for various crops; soiling to sare manure; manuring with clorer; water, its value as a fertilizer. 


\section{CIIAPTER XIII.}

IRRIGATION.-DIAINING.-PLOWING.-FARAING TOOLS.

SEc. LIV.--IRRIGATION AND TILE DRAINING : Talue of irrigation; its practice in Italy and other countrics; what lands are most bencfited; tile draining, its importance, cost, practice, and profit; how and what land should be drained; the mole-draining plow... 904

SEc. LV.-PLOWS AND PLOWING: History of cast-iron plows; subsoil plows, and their use and valne; steel plows and steam plows; other farming tools; labor saved by using

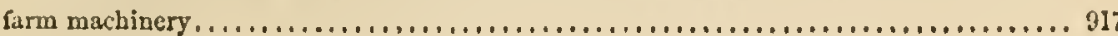

\section{CIIAPTER XIV.}

BOTTHERN STAPLE CROPB-COTTON, CANE, RICE, TOBACCO.

SEc. LVI.-HISTORY, GROWTH, AND MANUFACTURE OF COTTON: History of the cotton gin; upland cotton ; sea island cotton; how cotton is grown, picked, and prepared for market; profit of the culture; flax cotton ...................... 2. 28

SEC. LVII.-SUGAR-CANE CULTIVATION : Statistics of its culture in Lonisiana; yield of sugar per acre ; cost of making, and how it is made ........................... 943

Src. LVIII.-RICE: Its cultivation, production, and preparation for market; yield per acre ; value and profit; statistics of rice plantations; upland rice ................. 949

Sic. LIX.-TOBACCO : Its history, cultivation, production, and profits ; exports and consumption of tobacco ; effect of cultivation upon the soil ; its culture in New York and Connecticut; rulcs for cultivation, curing, and packing .................. 953

SEc. IX.-CULTIVATION OF HEMP, FLAX, AND OTLIER FIBROUS PLANTS : Hemp; soil and climate; how it is sown, harvested, and yicld fer acre ; cost and profit ; effect upon the soil ; flax cultivation; how to prepare the soil, sow the seed, and quantity per acre

\section{CHAPTER IV.}

\section{GLEANINGS OF TIIE FIELD.}

SEC. LTI.-IISCELLANEOUS ITEMS OF USEFUL FNOWLEDGE TO FARMERS: This last chapter embraces many things not classed under other titles, such as temperature for sceds to germinate and grow; nutriment in food substances; weights and measure of grain ; measuring land; proverbs and maxims for young and old farmers, farmers' wives and children; maxims of licalth; things to be thought about; how to dress skins, fix pumpe, mend pipes, and prognosticate the weather; farmers' clubs; farm laborcrs; farm acconnts; furm cconomy, and rwis .............................97-1010

\section{APPENDIX.}

DISEASES AND CURES OF DOMESTIC ANIMLALS....................... 1031 


\section{INDEX TO ILLUSTRATIONS.}

Plate I. - Likeness of the Autlior

Frontispifce

Pute II. Frontispiece of Chap. I., illustratrating the subject of Domestic Animals....... . lige I3

Plate III.-Froutispicee of See. III. This l'late is intended to answer the question, "What

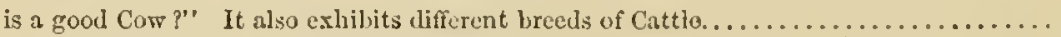

Pute IV.-Different Breeds of Cattle-Durham, Devon, IIereford, Ayrshire, Dutch, and Al-

derncy Bulls and Cows.

PuATE V.-The Milk MLirror, showing how to select a good Cow, and form of Tecth at dif-

ferent Ages.

PLATE VI.-Breeds of Sheep and Swine.

81 and 19

Plate VII.-Frontispiece of Sec. VIII.-Portraits of celebrated Horses, and Illustrations of

diffierent Breeds

Prates VIII. AND LX.-Illustrations of the Teeth of Horses at all Ages, shrwing how to

judge the Age from One to Eighteen Years ............................ I06

Plate X.-Fronttspice to Poultry, Sec. IX................................. I

Plate XI.-Turkeys, Dueks, Geese, Swans, and Pea Fowls ..................... 140

Puate XII.-The Bee-Keeper at his Work............................. 157

PLATE XIII.-The Farmery of Farmer Suug and Farmer Slack-Frontispiece of Chap. III.. 275

Plate XlV.-Frontispiece of the Garden and its Fruits, Chap. T................ 461

PLATE XV. Frontispiece to the Flower Garden, Sce. XXXI................... 500

Phate XVI.-Frontispicee to the Orehard, Clap. VI.-A Dessert fit for a Furmer-A Rural

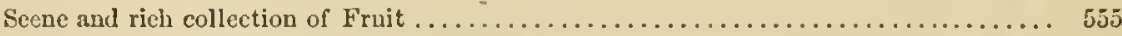

Plate XVII.-Frontispiece to Clap. VIII.-Cerealia, representing Insects injurious to Wheat ;

also Grapevine Pests.......................................

PLATE XVIII.-Frontispiece to See. XLT.-Illustrations of Insects which are injurious to

Farmers, and others whicl are beneficial............................. 703

Plate XIX. Frontispiece to Chap. IX.-Fhe Grasses.......................... 748

Puate XX.-Frontispiece to Chap. XIV.-The Cotton Plant and Cotton Field-Gathering

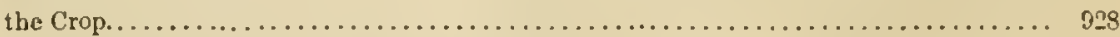

PLATE XXI.-Insects injurious to Cotton and Corn........................... 942

PLATE XXII.-Frontispiece of Sec. LIX.--Tobacco in all stages of Growth and Curing for

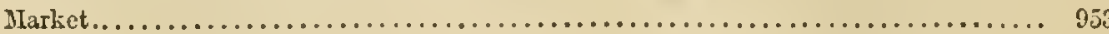




\section{PLATE II.}

(Page 13.)

Every American farmer will look upon this pieture with pride. It is a fitting illustration of a chapter upon Domestic Aximals. It contains representatives of a well-stocked farm, assembled in the farm-yard on the south side of one of the farmery buildings in one of the sumny days of spring, which are so well ealculated to make such a collection of well-fed animals feel, as these look, full of gliadness. There is no danger that such hogs as these will destroy young limbs and poultry. Here we see the sheep and lambs, goats and kids-goats that yield raluable fleces, which are described in this chapter-the work-horses and brood-mare and colt-the mules and their progenitor, who is in an attitude of war with a well-fed heifer that is absorbed in admiration of the peacocks on the roof of the poultry-house. How sullily the bull looks upon the whitefaced cow, which is deeply interested in contemplating the two hens that the cock has just ealled to enjoy a few grains of corn! By the earrest looking of one cow and two horses, we judge that they see their good friend and master approaching. Geese, ducks, turkeys, rabbits, and pigeons, and a boat on the water, enliven the scene, which, altogether, is one of tranquil beauty. It is a scene to contemplate and admire. It teaches a lesson. It will stimulate many a young man to a determination to become the owner of such a one, or something equally worthy of the artist who desires to represent American farm life. It will stimulate all, we hope, who look upon this pictorial index of this chapter to read it carefully. 


\section{FACTS FOR FARIIERS.}

CHAPTER I.

\section{DOMESTIC ANIMALS.}

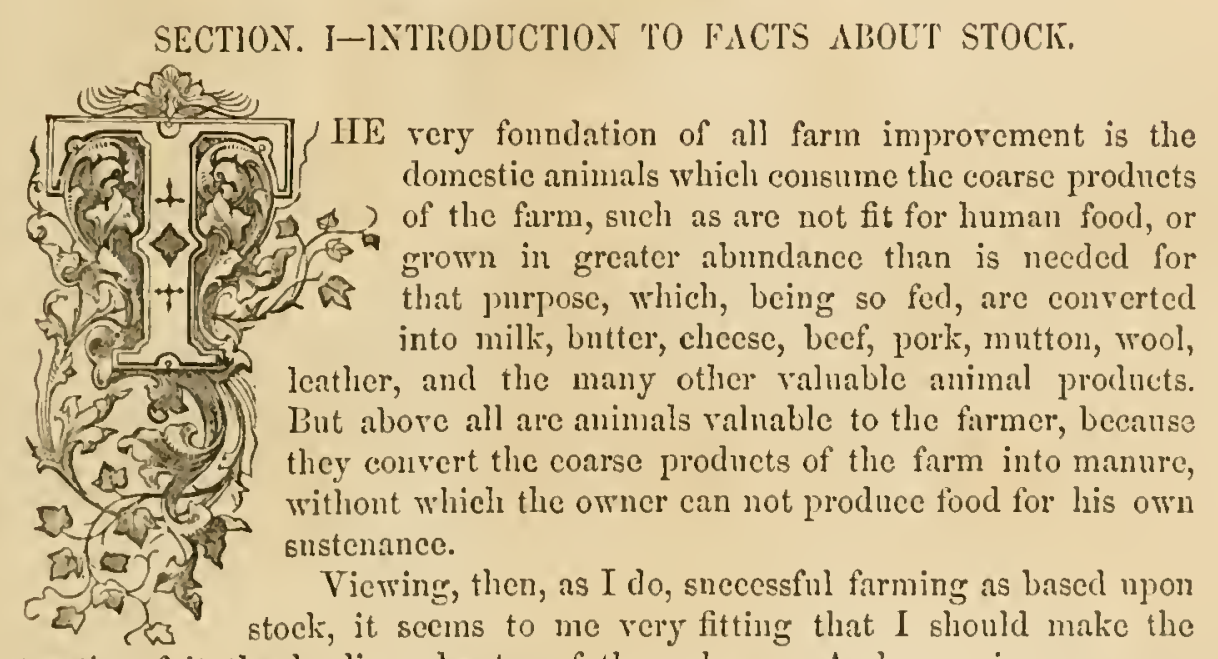
treatise of it the leading cliapter of the volume. And as swine are more unirersally kept by all classes of Americans, and the flesh more universally used every week in the year, it will be very proper to make this branch of farm-stock the leading subject.

I am not going to give learned dissertations upon stock-breeding, nor, in fact, long essays upon this or any other subject, bnt such little fugitive facts as come to hand, in short paragraphs, conscentirely numbered for reference, with black-letter titles to each subject, to attract attention, and so arranged that facts may be gatliceel at a glance, and valuable information obtained during leisure moments which might otherwise be lost.

Many of the statements given are not only for the purpose of giving interesting information-snch, for instance, as the weights of the largest animals erer slanglitered-lont as an incentive to others to try to produce the like. It is not to be expected that a man who nerer saw a bnllock of over $12 \mathrm{cwt}$ should attempt to make one of $36 \mathrm{cwt}$; nor will he be likely to make the attempt before he learns the important fict, that the particular breed which ho has kept all his life nerer attain that weight.

It is for the purpose of inciting improrement that I give some statisties 
of the New York livestock market, which I have been faniliar with for many years. Farmers should know that there is a certain market for all the meat-giving animals they can produce, and what they realize, as well as what rarieties sell best.

I have purposely adopted a desultory method, because I think it will be mole satisfactory to my readers, whom I do not expect to read the work in conseentive order, and because I find it more convenient to pick up the fugitire facts and jot them down in a sort of mosaie-work, something as nature does its autunn tints, which are now glowing before my window in the full effulgence of an October sun.

And here, too, as I look abroad upon my neighbors' fields, and at their eattle gnawing the short pasture, and running after every chance apple dropping from the trees, and then stretching up their necks, looking for more, and browsing off the lower limbs of the trees, I am forcibly reminded that this is not a profitable nethod of leeping furm-stock. Day by day the mileh eows fail to gire the supply that good pasture will always give in this good butter-making month of October; and day by day the fiesh of all tho animals is wasting, so that, by-and-by, when the eold and storms of Norember force their owner to bring them into winter quarters, they are not in such a condition that he may earry them eeonomically through. There is a great error in farming, that the seene before me foreibly reminds me of-it is the error of kecping any kind of farm-stock upon short pasture, and most particularly in autumn, so that they come to winter quarters falling off in flesh, rather than gaining, which is the condition that all animals should be in when brought from the pasture to the stable or feeding lot.

Some of the farmers of the Eastern States of the kind just allnded to, who keep their stoek upon the shortest possible pasture, and eonsequently generally have serubby animals, and always meet with great difficnlty in wintering those, wonld learn a useful lesson if they wonld risit the bluegrass pastures of Kentucky, and see in what luxnriant feed the slcek Durhams of that region are kept. They would there learn one of the secrets of ralue of that breed, and why they attain at three years old a size and weight of beef never equaled at six years old by the scrub breed common in Virginia and in the hilly regions of Ohio and Indiana, which are sometimes designated in the New York market as "pony eattle," or "old style," and areraging, when fat, about six hnndred pounds in the beef. A similar scrub breed is known in Kentueky as "mountain cattle," and the same style is very common in North Carolina, Georgia, and other Southern States, where I hare often seen full-grown stcers, and fat, killed for beef at four years old, that would not average four hundred pounds of beef. These eattle were treated, too, all their lives, just like too many of the same class in all the New England and Middle States-like those now before nne, eking out their existence upon the seanty herbage of autumn, in a closely-cropped summer pasture, and never fed with forage prepared for winter, until the owner is driven to it by an early winter stol'm. 
Such is not the right way to keep stock; but so long as men will keep it tlius, it is not of mueh adrantage to try to improve the breed.

There is a great want of information, not only upon the subject of improvements in the kinds of stock, but in the modes of keeping it. It is not my intention, in this chapter upon domestic animals, to attempt to gire all this information, but ouly a few brief hints, which may lead to reflection and improrement.

Above all things that will tend to improvement, are annual visits to great cattle-shows, where the rarieties in the breeds of cattle may be studied, and judged as to which would be the most profitable, or whether either would be more so than the old-style breed at home.

It would be of great importance, too, to all farmers to travel more. How strange it would secm, at first sight, to a Yankee far'mer, who had occupied a forty-acre farm all his life, to see a thousand logs, and half as many bullocks, all turned into a grand-prairic corn-field, of a size large enough to eorer his entire farm and that of twenty or thirty of his neighbors! His first exclamation would probably be, "Ol, what a waste!" IIis subsequent opinion would be about like this: "Well, after all, I begin to believe that is not so bad a way of harresting corn as I thought it was."

And this is not the only emrious thing that he might see in relation to fil'm-stock in trareling tluough the West. Ile would sec the same bad management as at home, about bringing the stock into winter quarters, for they are too often allowed to run in a corn-field, after the grain has all been harrested, living upon the dry stalks until after the first snows of winter. IIe might also see some rery amusing, as well as instructive things, in connection with eattle.

Shipping cattle on a Mrssissippi steamboat, as I onec mitnessed, afforded infinite amusement; and I am disposed to give a plotograph of it, before I take up the more practical details of firm-stock.

Eugagements for boats to stop and take cattle on board at various landiugs are frequently made before leaving port, and it often happeus that the boat reaches these points in the night; and then a scene oceurs which might employ a more graphic pen than mine to deseribe, or rhich would have been a fit subject for Iogarth to paint.

I will try to give my reader's some idea of such a seene, although one so common on the Mrississippi it rarely meets a passing notice; yet it is full of interest.

The steamer left St. Louis about sundown of a dark day, during the latter part of which tho rain canc down in torrents, corresponding to the size of the great river they were elestined to fill. Of course mud was a component part of all the littlo tributary streams; but it did not discolor the great river-that is always muldy.

At ten o'elock we saw a light on tho right bank, and rum in for it. Though the rain liad ceased, the night was dark-one which gave tho pilot but little chance to see any but the most prominent landmarlis. 
"Whose place is this?" sung out the captain, when he had approached as near the light as he thought safe-for in time of "a fresh," the master" of a boat always approaclies shore with great care.

"Why, dis is my massa's place; what boat dat? If you is de Henry Clay, den dis nigger mighty glad, 'cause, gorra, cap'en, hab been wateluing all dis two free nights for de old Clay."

"Ilave you got your cattle there?"

"All in de lot-gorra bress you, den you is de Henry Clay, sure-light here by de light."

"Is the water good in sliore?"

"Why, spee lim is good for the steamboat, but not rery good to dlink."

"How deep is it near the bank?"

"Oh, Lord, massa, dat mor'n dis nigger kuows for sartin, "cause him mighity deep."

"That will do. Forward there. Get your lines ready. Light them torches-let's see where we are. Call all hands; here is a hundred head of cattle to be got aboard."

In $a$ few minutes the lights flashed a bright glare orer the boat and shore, bringing to view a scene worth a long journey to beliold. The torches are composed of "light rood," which is the concentrated pitch of old pine trees, of the long-leat" rariety-the richest of all the finnily in turpentine. This wood is split in small pieces and put in an iron frame, with a staff not unlike the common hod used to carry mortar, so it caln be carried about or stuck in the ground, where by a little replenisling it will burn for hours, giving a light unequaled by any other portable contrirance I ever saw. In the present ease, it disclosed more mud than anything else. The whole bank was allurial clay loam. The face was steep, and sixty or eighty feet high. The boat, made fast to stakes driven into the soft earth, lay within twenty feet of the shore, between which and the guards was a gangway made of long planks lashed together, about six or eiglut feet wide, witlout side-railing, or anything to prevent springing down in the center. The cattle were in a yard on the top of the bank, where, around the watehfire, huddled about a dozen slecpy negroes, amongst which the anxious face of massa soon made its appearanee, having been awakened at lis liouse, two miles distant, by the tremendous noise which is made by one of these liver steamers, by the puffs of her high-pressure engine.

"Halloo, Captain Snith, is that you? I might liare known it, though, for no other fool would come here in the night for such a job as this. What are you going to do-hold on till morning?"

"Hold the _-!"

"Well, I might just as well as hold you. I do believe, if the Clay's engine should break going up stream, the boat would not stop-there is steam enough in the eaptain to keep ler going."

Evidently pleased with this compliment, he jumped ashore, with that most encouraging of all words, "Come, boys," and floundered up the muddy 
road, to greet his planter friend with one of those liearty shalies of the hand which alone is equal to a whole volume on the man's character.

"Well, captain, you see low it is. I am all realy" the cattle are here, wet, wild, and mudely, and the bank awful. I conldn't liclp it. It woule] l'ain, and the river is on the fall. I donbt whether your men can stund on the slippery bank. Ary boys will take down some of the gentle ones, hut Lord lielp you with two or three; we hat to bring them in with the dogs."

"So much the better, then, that the road is wet-they will slide the easier. Ropes and men will bring them down; don't you fret, colonel."

“Well, well, I'll leave it to you ; I'll risk the cattle, if you will your necks. Better wait for daylight, though-what say ?"

"Nerer! what should I do with that suplus steam you say I carry? Wrat -no; I intend to have them all aboard, and win half of them playing poliel with you before morning; and at daylight I an going to talke in Tom Kilgure's, at Tocky Landing. So bear a hand, boss. Stir up your ligrts, and rouse 'em ont, one at at time, and often."

In a few minutes there was a line of men and bullocks from the top of the bank to the boat. The first dozen or two came down very orderly to the end of the gangway, where, if they hesitated, a rope was thrown over so as to encircle them behind, and two or three stunt fillows at each end gave then material aicl abont coning on board. Fille orner said we shondel see fim directly, but not curing to participate in it personally, he took care to make himself one of the spectators, in a sate, contortable position on bourd the boat. Upward of half were brought down without griving us a taste of the pronised anusement, thongh the whole seene was exceedingly interusting.

At length they got lold of one of the animals, which the colonel sald was wildur than forty deer, and vicions as an old buck ju runing time: and then there was fun. Ife was a great, longr-legged, five-yentold steer, of the monse color, long taper-horned Spanish cattle, who had never before fult the reight: and strength of a man's hand upon his heretufore unrestrained will-wools liberty. Round and round the yaul le went, currying or dragging through the mud as many negroes, sailors, and firemen as conld find horn, ear, nuse, or tail to hold to. Finally they got a rope romd his horns and drew him nu to a stake at the edge of the bank, to wat till oflers were canght to lead down first, thinking that he would better follow than take the front rank. IIe did follow. When about a dozen or fifteen heal were on the way down, the will one wats east oft from his monrings and led up to the elge of the bank, when just at that monent the engineer hlorred ofl steam, at which the frightened animal leaped forwarl on to the slippery path, lost his foothold, and down he went against the next, and the next, and so on: like a row of bricks, one tumbled or slid against another. upsetting men aud least, till the whole came down like an avilanclse upon the end of the platform with sueh force that the strain upon the moning line of the low drew out the stalie, when the strong enrent almost instanty swmer her off shore so far, before the men conlel get hold of the line and make fist again, that the platform 
[Cirar. I.

dropped ofl into the water, and with it eight or ten men and stecrs, among which was the one that caused all the mischicf. I must say the fun was not so "great as the fright, for a minute, as it did not take much longer to finish off" the "reatest fuat of "sliding Jown hill" which I have witnessed since the haleinn days of hand-sleds and hoyhood upon the snow-elad, wintry hills of my native land. That all were got out safe was owing to the instant thought and action of the mate, who sprang ashore with a pole which he placed in the whecl, so as to prevent the cattle from floating down past the stcrn, where it would have been impossible for them to get up the soft, slinery bank. Is it was, some of them were in the water orer an hour; the catamomnt, as the colonel called him, being purposely left mntil the last, amt surerely flueatened with being towed to New Orleans. But when he was at length taken ont, there was not a more clocile anmal in the herd; he had been completely subdnel. The whole aftair, though fraught with danger at first, aflorded all hands a seene of most uproarions mirth. Even at the time when it looked as though half in score of men might be killed in the mland tumble, it was almost impossible to avoid laughing, the whole thing wats so extremely ludicrons.

()ne big negro fellow, finding limselt hard pressed by the bullock he was lcading and hilf a dozen more behind him, cither for sport or to sare his slius, jumper upon the animal's back and came down with a surge into the water; but he never let go thll he had him sale ashore again, where he unct some of the nost liearty, though rude congratulations of his companions, for his slillful feagt of horsemanslip on an ox.

Finally, in spite of mud and peril, the grand entertainment of shipping cattle on the Mississippi was conclueled, and the boat was of before daylight for the next landing, where the operation was to be repested. Owing to better gromd and a diflerent flan alopted, this was not quite so entertaining. The cattle were yarded in a loag, narrow pen, which came near the shore. A rope being passed orer the horms of the forward steer, with the other end through a snatch-llock on the boat, a dozen or fifteen men would lay hold of it, while two men by the tail to steer, and one on each side to kecp him on the gangway, wonld have the fellow out of the pen and sliding up the flankis before he knew what he was bellowing for.

is in all cases where science and skill direct human efforts, the labor was lessened and business expedited.

Ind so in all eases where science and skill are cxereised in regard to all kinds of domestic animals, success may be looked for.

Ancl now, after this little ineidental digression from the main intent of this chapter, in the exhibition of a life-like seene on the Mississippi, we will begin to arrange our facts in order and shape for useful reference, always aminge more at the practical than ornamental.

Is we shall alrange each sulject under its separate and proper head, we will begiu the chapter upon domestic animals with that kind in most universal use. 


\section{SECTION II.-STVINE.}

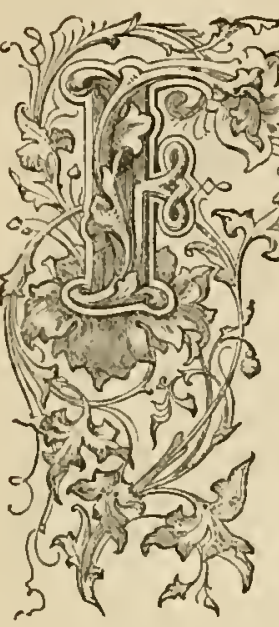

cediug Pigs and Fatting Pork.-Next to procuring

a good breed of swine-that is, a breed suitable

to the purposes for which it is required-the best way to feed the stock hogs, and the eheapest and best way to fatten them, is the inost important matter for a farmer to consider. No man can say, "Ny breed is the best of all," muless he specifies for what purpose it is best for. A good grazing brecd would be best for some situations; quite the contrary for some others. The Berkshire, Essex, and Suffolk liave each been denominated "the gentleman's pig," because well fitted for lieeping up in close pens, one or two to a fumily; while a much larger breed is required by the great conn-growers of the West. And this brings us to the next most important question.

3. Corn and Pork-How nach Porls whll a Bushel of Corn make?-This is one of the most important questions that can be asked by erery man who raises a bushel of corn or feeds one to a hog. Iet it is a question that not one in ten can answer. To see the ignorance of mankind upon subjects of most importance to them, makes us ready to exclaim, Does anybody know anything abont anything? In conversation with many farmers, we have not yet found a man who could say how much com it required to make a hundred pounds of poik, and consequently could not fix upon any relative price of one or the other, at which it would be profitable to feed corn to logs. In some experiments made by IIenry L. Ellsworth, at Lafayette, Ind., in warm weather, with tlnitty young porkers in a pen, fed with corn in the ear, if we remember aright, he gained $12 \mathrm{lbs}$. of pork per bushel of corn.

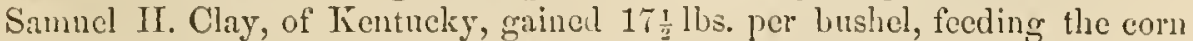
in the form of eooked meal. As a greneral thing, we should like to know if corn, fed as it usually is in the West, arerages six pounds of pork to the bushel of sliclled com.

We have received sereml answers to this question, but they only proximately settle the point. Leroy Buckingham, of Cadiz, Cattarangus Co., N. Y., says, a pigr that weighed 52lus. when commeneed with, fed on the Erare milk from one cow and soolbs. of raw corn-meal, weighed 364 lbs. (live ol' dead not stated) when killed at seren and a liall' months old. Ile thinks cach bushel of corn male about 20 lbs. of porli.

The two following letters we print entire, and commend them to the careful attention of all farmers, althongh they do not contain all that is necessary to be known upon the subject: 
"Glexis's l'sLL, X. Y., Oct. 23, 1858.

"Sir: Fon think it important that famer's shoukl linow how much pork a barrel of com will make. It is an important question, and I am sorry to sajo I think there are ten lawyers and mechanics to one firmer that can answer the gluestion correctly. I once made a rery accurate experiment in New York; the first day of september I weighed into the pen two horss, a year and a lialf old, and three pigs, six montls old. I measured old con accurately, and liad it ground. At night I wet with boiling water (to a comsistency that would run frecly) meal sufticient for the next day's feed. The loogs liad $n 0$ slops from the honse-nothing but the meal and water. I killed them the first of Decenber, dedueted fire cents per pound for what they weighed the first of September, and foumd, at six eents per pound for the pork, they had paiel ninety-eight eents per bushel for the corn, which would give about sixteen and one third pounds of pork to the bushe]. One real since I fatted fifreen old hogs and thirty-five pigs on India wheat and potatocs. I measured the feed aceurately, steamed the potatoes, and mixed the meal in while lot, twelve lours before feeling. At fire cents per pound for the pork, they paid forty-two cents per bushel for the India wheat, and fiftecn cents tor the potatoes. Of course the relative rnlue of the wheat and putatoes is guessed at in that cxperiment. I "worked" the loogs in the manure bnsiness, curting in muck, weeds, etc. I got 15 cords of manure although less pork-I suppose for the working the liogs. I would like much to know if any one (especially in the Western States) lias made the experiment of turning longs into the corn-field, with free aceess to water, and let them help themeelres.

"If any other class of business men knew as fer facts in regard to their business as fammers do, thoy would all fail erery year. NEw MAlish."

1. G. Perry, of Newark (State not named), weighed a thrifty pig, fre montlis old, 150 Ibs., and then fed it 56 lbs. corn-meal, mixed with hot water, thin enough to auswer for victuals and drink. This was eaten in six and at lalf days, and the gain was 18 lbs.

A correspondent writes from North Chathan, Columbia Co., N. Y. :

"The 24th of August I put "p a sow to fatten-a large proportion Suffolk -her wejeght, $235 \mathrm{lbs}$. Price on foot, 4 cents per pound. For food from August 24 th to October 4 th, gave lier $309 \mathrm{lbs}$. ryc bran. Rye bran is worth liere $\$ 112 \frac{1}{2}$ per 100 lbs. October 4 th her weight was 295 lbs., making 60 Ibs. increase from the bran. From Oetober 4th until Norember 1 th I fed her 10 bushels, by weight 560 lbs., of marketable coln. Filled her Nor. 17th. Her live weight, just before killing, was 413 lus. Increase from the 10 bushels corn (or $560 \mathrm{lbs}$.), being 118 Ibs. pork-it taking a traction more than $+\frac{1}{2}$ lbs. corr for 1 llb. pork-and is a fraction less than $12 \mathrm{lbs}$. pork from 1 bushel of corn, making the increase per day a little less than $2 \frac{3}{4}$ lbs. The present price of corn here is 70 cents per bushel, and the pork 7 cents per pound, being barely a paying business." 
J. J. Carter, of Hormille, Chester Co., Pa., says that B. P. Tirk kept a debt and credit account with his pig. He fed $+9 \frac{1}{10}$ bushels of corn, at 60 cents a bushel, and added the tirst cost of the pig, at two months old, 55 , making a total of $\$ 3 t 46$. At 17 months ald the animal weighed $649 \mathrm{lbs}$., and sold for $7 \frac{1}{2}$ cents a pound, making $\$ \pm \$ 67$, giving a profit of $\$ 1 \pm 21$. A little bran was fed, but that was redueed to the equiralent of com, anil comnted as abore. The breed of logss common in Chestel Comity is one of the best in the world. The hogs are of a white color, medium-sized, casily fatted to weigh 300 to 400 lbs. at 10 to 15 months old, and have small bones, finc-grained flesh, large hams, well marbled, and large leaves of kidney fat. It is a distinct American breed, and one of the best for farmers who desire to graze their logs in part, and then fatten them easily upon honse-slops, apples, potatocs, and coarse grain. Even for large farmers, and for making pork upon a large scale, there are not many, if any, breeds of swine in this country superior to that known as Westehester, or Chester County (Pa.) logs. And as I consider it an important fact that farmer's slonld know where to get a real good breed withont paying fancy prices, I am glad of the opportunity to make this breed better known.

D. C. Nye, of Lexington, Mass., in reply to an inquirer in the Genesee Furmer, writes that-

"The Chester Comty hogs are distinguished for theil early matnrity, great facility for fattening, and are very quiet and docile. They are well covered with bristles, and, unlike the Sullulks, can endure the heat and cold. The Chesters will probably make as mucl pork (and of a superior quality) on a given amount of food as any other breel-some of them, when well fed, having attained the weight of six or seren limelred pounds."

Another correspondent of the same paper says, in addition, that the thorongh-bred Cliester logs are always white, and that "they are peculiar in being fit for slaughtering at any time."

But to proced with the subject of feeding logs. The second letter is rery much to the point. It says:

"In answẹ to your question, "How much pork will a bushel of corm make?" I send you the result of two experiments, made some years ago, while ocenjying a fim in the northern part of Clester County, Pa.

" Ify first experiment was with five very ordinary pigs that I bonglit of a neirghbor; weiglied, October, 1S51, $249 \mathrm{lbs}$; fed on corn and cob meal, boiled into mush, of which they consmmed in 30 diys $2791 \mathrm{bs}$, and gained 57 los. live weight.

"In the next 32 days they consumed $375 \frac{1}{2}$ lbs., and gained $751 \mathrm{bs}$. live weight, making a gain of 157 lls. in 62 days, having consmmed $65 \pm \frac{1}{2}$ lbs. of eorn and cob meal, which is equal to about $9 ! \frac{1}{3}$ bushels pure meal; or one bushel pure meal cooked made 16.5 llus. live weight.

"My second experiment was witl a lot of fire very superior pirs. of the Chester breed; they weighed, Feh. 7,1553 , 695 lbs; eonsumed in 9 days 
25-1hs. corn and cob meal, sealided, and ganed islbs. In the next 8

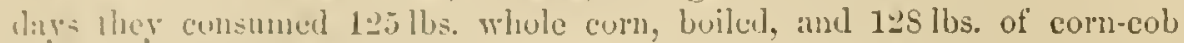
meal, scahlul, :ml grancel 5- 11 s.

"In lhe next 9 ilays they consumed 27s libs. corn-cub meal, sealded, and milned fulls., making a gain in 2T days of 205lbs. on a consmmption

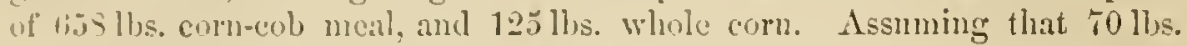
of the cub-meal contains 56 lbs., or one bushel pure meal, we lave $9 \frac{2}{5}$ bushels of pure meal and $2 \frac{2}{4}$ bushels whole corn, making a consmmption of $11 \frac{3}{4}$ busluels nearly, and a gain of $205 \mathrm{lbs}$. flesh; or $56 \mathrm{lbs}$. of pure meal, scalded, made 17.tt los. of live weiglat.

"The above surprising gran for food consmued was the result of very canctul feeding, clcan and wam bedeling, and a tight honse.

$$
\text { "Tirchard Thitcher, Darby, Pa." }
$$

Thomas IIoag, of Somhanock, $N$. I., has sent ns a detailed statement of the feeding of $1 \mathrm{cn}$ pigs, ont of a litter of twelve from a native-breed yearling sow, laken from her at seren weeks old, and ferl till slanghtered, at forty wecks old, with the following smbstances, with estimates of expense added:

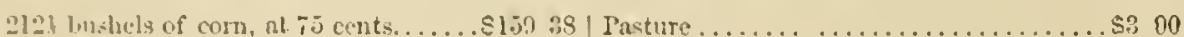
(ii) lintrels of oats, ist 45 cents........ 28 35 Wool used in boiling food............. 200

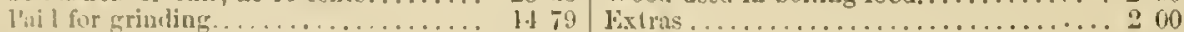
1:i hushels of smill potatoes, 12 cents. 103 Vialue of pigs at seren weeks old.......80 00 (i) linils wi pumplius, at $\$ 1 . \ldots \ldots \ldots \ldots .600$

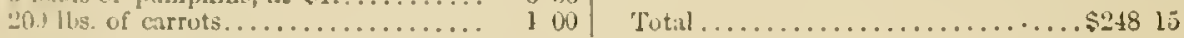

These logss weighed, dressed, 4,066 pounds, and sold,

(in 18.53), at I ansingburg, $\mathbb{X}$. Y., at $\$ 750$ per ewt............. 830495

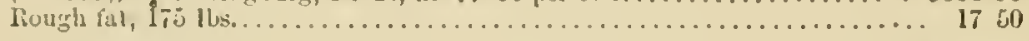

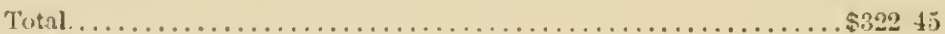

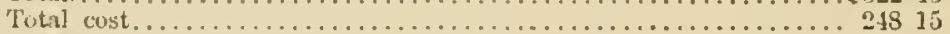

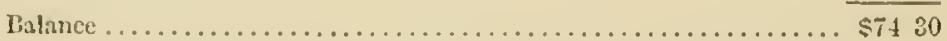

This is the amount of profit, or, rather, pary for labor, and the spare milk of tonr ordinary cows fel to them, and not estimated as above.

At six cents a pound the result would have been

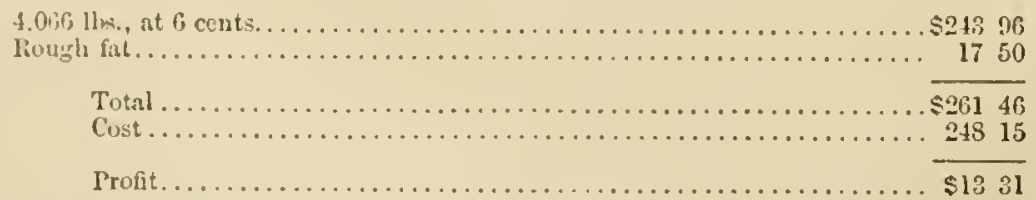

This certainly dloes not grire a rery fluttering picture of the probable profits of pork-making in this section of the comntry, where every lind of feed is salable at high prices.

Other letters were subsequently reeeived, from one of which we gather the following information: Wrm. Reniek, of Circleville, Ohio, a large farmer, and long engaged in the raising of cattle and hogs, writes more cxtensively than we ean find room for. Mr. Renick thinks that farmers are not ignorant of the fitct "how much pork will a bushel of eorn make," and says: 
"Probably nine tenths of onr best practical farmers conld, without hesita. tion, give you an approximate answer in general terms."

This is exactly what we supposed, and that they would give nothing but an approximate answer in general terns, hecanse there is a general lack of positive information upon this and many other important matters connected with the faming interest. Mr. Renick gives the gain upon five hogs fed by himself in the common rough method of the West-that is, turned into the corn-field, 200 head together. Three of these hogs weighed, at seren months old, 140 lbs. ench, and two older ones weighed $125 \mathrm{lbs}$. each. After feeding 120 days, the three weighed $286 \mathrm{lbs}$. net arerage, and the two $185 \mathrm{lbs}$.

"Now, say that hogs on an arerage will eat 20 bushels of corn per hundred head per day for the first 60 days, 16 bushels for the next 30 days, and 12 bushels per liundred head per day for the last 30 days, and we liare 21 bushels per liend for the whole time of 120 days (though this is under rather than over the mark), and we have a production in the case of the three hogs of $10 \frac{1}{3}$ lbs. of gross pork for a bushel of corn, and but a small fraction orei 5 lbs. per bushel for the two liogs."

Now, this is exactly in proof of what we originally stated. It is all guesswork. Mr. Renick funther says :

"The large feeders of hogs and eattle are oftentines greatly mistaken in their calcnlations in regard to the quantity of stock their corn will feed, sometimes langely overumninger, and again falling largely short of their. calculations."

This is not to be mondered at, when it is considered that no one pretends to lare any settled rule of action, but buys as many lean cattle or hors as he guesses he can fatten. Mr. Renick thinks the nost common answer to the question would be something like this:

"That hogs fed in the ordinary way will gain from one pound to one and a half pounds per day, and they will consume some twenty busheis nl more ol corn in thee and a half or four months; that it all depends mon the quality of the hogs, quality of the corn, weather, and other contingencies."

The gain raries from five to trelve pomuls gross per bushel. So lie sars: " Wre will compromise the matter by guessing that, all things fivorable, one bushel of corn, fed in the ordinary way, will make seren pounds gross weight." It is, after all, then, nothing but guessing. And we guess that feeding (onn, where it is worth a dollar a bushel, as it frequently is in and abont Nell Jork, won't pay while dressed hogs are sold from the hooks, as they generally are, at seven or cight cents a jound, and the arepage price of live lones is less than six cents a pound. With our arthmetic we cun not tignue mp any profit for a liamer liereabouts to keep a single logr more than lie wants io eat up the milk and house-slops, and a little waste grain; and pubbal,y that could be more profitably fed to ponltry.

The greatest alvantage from fuediug grain to make pols in all the New Engrand States must be lookel for more in the manure thon in the meat. Where manure must be purchised, it may be profitable to purchase com- 
meal to convert into mannre through the pignen manufactory. The next parteraple is to the point in this connection, ot feeding pigs to make mamure.

4. Working Pigs.- $W \mathrm{C}$ onee recommended famers to make their pigs working animals. To this a writer in an agrienltmal paper objected; ba(anse, its he illegres, the same amount of food consumed by an idle hog will make 12 pounds of pork as easily as it will make $S$ pounds if the animal is allowed to exereise his natural propensity to root. In this we entirely argec, and have often contended that when a log is shut up to futten, if he was confined in a Elip so uarrow that lie could not turn romd, having one side of lis narrow prison male su as to be noved out as lie increased in bulli, he would fitten faster than in any ofher position. Now, will the witer, who thinks that we differ from him in opinion, real orer angin the article thit lie eriticises, and see that it is the pirg-pen, and not the fatting-log pen, that we were talking abont. Onr fuets are not intended to be claboliterl into prool's and argunents for farmers, but rather as texts for thinking unen to think ores and reason upon with themselves and neighibors. Om opinion is, that all the swine family should be kept imprisoned, it not in close pens, certainly in strongry fenced lots; and $j$ all the Eastern States, where manure is so valualle, it is very doubtinl whether a farmer ean affurd to let any of the fumily ont of the pen-whieh, ns we before hinter, should be a great mamre manufactory-exeept, perhass, fur a short scason to eat clover, peis, or grlcan a stublile-ficle. It there is a greater neighborhood nuisance tham loess in the highway, we have yet to find it out; and as we would always liecp "Mls: Pig" in the pen, we recommented to malie linn work in the manufictory, finmishing a part of the materials to be worlied, and the firmer the remander. In his immerliate preparation for death we don't "are how idly le spents the last of his diys. As long as fiumer's will persist in making the thesh of swine their leading article of food, we shall contend that the flesh of an animal that has wolked his way up to a mature ane, and is then fattenel ready for slaughter, will make more healthy foot than the oily fatness of one always kept in a state of obesity and inlenes from his birth to death. It is this great plysiologrical faet that causes the llesh of the wild log to he sought after and eaten with gusto. We fully asgree with the rutholoxy of E. M. Brewster, a model famer of Griswoh, Comm., who says if he was to finten a half-dozen logs upon a flat rock, he wond be sure to have two rings in ach nose. The latitude that we desire our readers to grive to our suggestions is just this: to make a distinction between worling and fattening animals, and make the pig a useful one.

"Lecping piogs eighteen months to fitten them the last three is not a paying business. Feed a deeent pig well from weaning until eight mouths uli, aml you will get $250 \mathrm{lls}$, to $300 \mathrm{lbs}$ of pork, and you do not usually get 50 lbs. more for those ten months older. There can be no question but an animal can consume much more to prodnee in eigliten montlus about the same quantity of meat which is made by another in half that length of fecling. If the olject of raising a $\log$ is to makic pork, that end should be 
kept steadily in view-lis swineship slould see it, and cat for it." This is oul view exactly. Winter none but autumn pigs, keep them in pens, and always growing. "To keep a pig growing, one unust keep him enting, and eating about all the time. To do this, there is nothing like 'change ant variety' - now a little corn, then a little milk, a few boiled potatoes, a few raw apples-now a pudding, then a dish of greens-anything to keep them cating and stufing when awake, even if it does require a little extra attention."

5. Cooking Food for Swine-Cireumstances must gorern the feeder. If corn is morth but twenty-five eents per bushel, it is plain that it will not pay to expend much money either for eooking or erushing it; but where food is lighl, a small quantity saved pays for considerable labor, ete. It will hardy pay to expend dear labor upon cooking elieap roots to make low-prieed pork. It has been provel that erushed balley, soaked in cold water $t 6$ homs, gave more increase of weight to sheep than when not soaked; but crushed malt did not. The figmes are: Fumr sheep in 10 weeks ate 250 lbs. of ernshed barley not steeped, and 3,567 lbs. of mangel-wurzel, and inereasech in live weight 81 lbs.; while four sheep, with barley crushed and steeped, ate 280

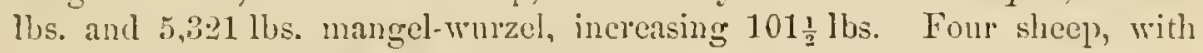
cruslied malt, not steeped, ate in 10 weeks $227 \frac{1}{2}$ lbs., and 3,755 lbs. mangel. wurzel, and increased Stlbs.; while four sheep, with malt crushed and steepel, ate $226 \frac{1}{2}$ lbs. malt and $4,45 \mathrm{~S}$ lbs. mangel-wuzel, and gained only 7811)s. In the abore experiment, the question is, Did the additional $20 \frac{1}{2}$ lbs. pay the extra trouble and extra feed of roots?

An experinent in Ireland, lately made, proves that hogs gained more upon raw thim cooked regetal)les. Eiglit liogs were selected and divided into two lots, as eveuly as could be, and put in to fatten, on the 27tls of November. Each lot was fect regularly three times a day, having each 12 lbs. of luan and barley meal, the only difterence being that one lot had steamed ruta bagas, and the othes julped or rasped ruta bagas. The experiment wals continned 39 days; the lot laving coolich food ate 468 lbs. bran, ete., and $10,920 \mathrm{lbs}$. ruta bagas, and inereased 103 Ibs.; while the lot havingr uncootied tiod ate $468 \mathrm{lbs}$. bran, ete., anch only $5,460 \mathrm{lbs}$. ruta bagas, and grained 110 lis.

Samuel II. Clay, of Bourbon, líy., las been experimenting in feeding several lots of hogs, changing them from l'atw to cooked, and from ground to ungromel food, with the following results: One bushel of dry eorn made $5 \mathrm{lbs} .10 \mathrm{oz}$ of live pork; one busleel of boiled corn made $11 \mathrm{lbs} .7 \mathrm{o} \%$ of pork; one lushel of gromnd corn, hoiled, made in one instance $16 \mathrm{lbs} .7 \mathrm{oz}$, in another nearly $15 \mathrm{lbs}$. of polk. 'lo get the ralue of corn, estimate the pork at $S$ cents a pound; we liave as the result of one bushel of dry corm, 45 cents' worth of pork; of one bushel of boilerl enrm, 115 eents' wortl of pork; and of one bushel of gromel corru, 136 cents' worth of pork.

6. Pig lecel-Boiled Weeds-A widow, who was short of feed for lier pig, said, in presence of lier little boys, that sle thought she would liave to sell 
it, for she had so little to feed it with. and conld not afford to buy feed. One of the little fellows promptly answered that he knew what would be gond to feed pigeg with, and of which they had plenty.

"What is it, my sou?"

"Grecus, mother-boiled greens. They are good for us, why not for pigs? And we can gatlice thenl, and pick up wood and boil them in the big liettle out doors, and it will be real fun."

So it was settled that jig should eat greens-all sorts of weels boiled; and eat them he did, and liked them, and fatted on them, with the small addition that conlel be made of bran and house-slops, mixing the slops and greens together.

This is a hint worth remembering and acting upon. The weeds were destroyed, the boys employed, the pig kept groming, and the boys had the satisfaction of feeling that they liad been usefully employed.

7. Hog Pasturs, It being generally understood that hogs live by "special providences" nntil it is time to fitt them, there is little attention paid to the most economical way of growing them 11p. Certain it is that a good, casy-liceping varicty will make commendable progress on grass.

It may be safe to calculate that a good-sized, thrifty pig will gain in six months, on grass, 100 lbs. or more. If an acre of grass would lieep three logs and add 100 lbs. to the weight of each, that would be $\$ 12$ for the acre ot pasture, reckoning the 300 lbs. gain at fonr cents a pound, live wejerlit. Instead of being foreed to bite twice at a short, dirty, dried, and battered spear of June garss by the roadsicle before gretting any oft, imagine a clean and comcly Suffolk in a fresh, green pasture of clorer, fom inches ligh, filling himselt with evident relish.

S. The Pig-Pen and its Value.-As a manure-maker, there is no animal equal to the log, provided lie is furnished with suitable facilities. The cating and slecping apartments of Mr. Pig should always be a good frame bnilding, witl a plank floor and shingle roof, and it will in many places be fond ceonomieal to gire him an iron eating trough. Iris lonse slonuld be cleaned ont every day, and washed as often as necessary to keep it clean. All the washings and elemings shonld go into an adjoining pen, which may as well be unde of fence rails, on account of cheapness and convenience of remoral, into which the tenants of the hog-honse must be invited by a little corn, scatterel in erery day, to induce them to mix up a compost of their own ofial with sods, mold, leares, reeds, and all sorts of trash. This pen should be equal to ten feet square for erery two logs, and so long as it is worked every day it will not much injure ly exposure to the weatler; bnt it should afterward be corered, and it should always hare stuft enongh put in it to keep the hogs from getting into a very muddy condition. If you have not mold enougl to entirely absorb the ammonia, you must use plaster or charcoal dust. It must be kept strect, or you will lose much of its value; and where manne is ralnalile. if you neglect to use your swine for the purpose of increasing it, you will lose about all the profit of maling your 
own pork. There is another way in which you can make the pig-pen valuable. If you have a spot of ground that you want to enrich and work deeply and thorouglily for fruit-trees or for garden vegetables, plant it with Terusalem artichokes, and then yard yom logrs upon it, taking care to grive them room enough, so as not to necessitate them to make a quagmire. Again, you may use these animals to aclvantage if you hare a pice of grass land infested with grubs. Fenee off a piece, and shut your swine in upn it for a few days withont feed, and if they leave a sod unturned or grub meaten it will be a wonder. It is the best preparation of such a spot for a hoed erop, or for sowing again in grass, that can be giren. There is no gront reason why the pig slould be always kept in idleness or mischief. Let him be trained to be useful in his life as well as at his death.

9. Ilay Seed for logs.-A correspondent of the Country Gentleman mites: In addition to the grain and meal griven to growing hogs in the sty, they should hare a daily allowance of green clorer, or in winter. when this is not available, a liberal allorance of hay-seed from the barn, mixed with their slop, which they will eat with aridity. He knows of no mode by which so great an amount of growth and weight can be induced, with equal cost of fuod, in the winter season, as ly this haying system.

10. Cinders for I'igs.-J. J. Mechi, of Tiptree Hall, England, says, in publishing his experience in fattening swine, that among other things, lie hits leamed the fact "that pigs are very fond of" coal-ashes or cinders, and that you can lardly fut pigs properly on boarded floors withont giving them a moderate supply daily, or occasionally." He says: "In the absence of coal-ashes, burned clay or brick-dust is a good substitute. If you do not supl]y ashes, they will srnaw or eat the brick walls of their sheds. I leare to science to explain the cause of this want. It is notorious that coaldealers, whose pigz have aceess to the coals, are generally successful pig feelers. Those who find that their pigs, when shut up, do not progress farorably, will do well to try this plan. A neighbor of mine found that a score of fat pigss consume quite a basket of bumed clay ashes daily. We know that there is an abundance of alkali in aslıes."

11. I'arched Corn and lloney for Ilogs. -1 correspondent of the IIighlanel Dimocret, published at Peekskill, N. I., furnishes that paper with the following communication:

A few jears ago I clanced in Albany to meet a famer who is noted fol raising unusually heary logs. The year hefore lie liad brought to marliet one that reighed over 700 llos, and sad that year that he shonld have one of 900 lbs., or near that mak. As there always seens to be a cause tor erery effet, I wis anxious to know the conrse lie pursned.

"TVell," said he, "you must first select the lighlıt lind of a eritter. Get the right breed, and then pick ont the good-natured ones from the lifter ; I ean't aflord to feed a eross critter; I sell them when they are pigs." "How can you julge?" said $\mathrm{C}$. "Well, if you watch them when they ane foeding, you will find that some pigrs are allers fighting about their vietuals, and 
Eone go in for eating. There is as much difference in pigs as there is in fultis."

"Well, when you have selected the right kind of a pig, what next is important ?"

:Well, then yon monst lave a nice place for the critters to live in, and feed them on the rierht kind of victuals."

"What kind of tood ?"

"Well, the best and cherpest kind of food I have found, when it comes time to junt on the fat, is parched corn. I generally manage to buy a barrel or two of Sonthern honey, if it is chenp, which I mix with the parched corn, for my fatting hogs."

12. Fecting stanting Cern to Hors-in the Field-or Gathered, Ground, and rooked-C'omparative Adrantages of these Methods.-The metlod often practiced ly large finmers of turning fattening hogs into the fields of standing corn, if properly conducted, has its advautages orer that of gathering the corn and feerling it dry to the hogs in the pen.

The carlier in the season the process of fattening swine is begnn the better, after the grain has reached a certain period of maturity, whether it be rye, oats, or corm, because all farm animals, and hogs in particular, will fatten much faster in warm than in cold weather. And the grain between the periods of its lunghy state and full maturity, or dather, before it lyecomes dry, is more easily digested, and assimilated, and converted into flesh and fint than when it has passed into its dry state. It is clear, then, that the snoner the hogs gre: turned into the ficld after the grains of com are fully formed, and while yet in the milk, the more speedily they will fatten; for if the weatler be dry, the corn hardens very rajidly.

A very interesting experiment in feeding logs is detailed by Mr. James Buckingham in the Prairie Fumer. On the 6th day of September (in ordinary seasons corn, at this date, is too far aclvanced to eommence fueding to the best adrantage), the hogs, $159 \mathrm{in}$ mumber, were weighed, and footed up in the aggregate $19,600 \mathrm{llos}$. A morable fence was used, confining the logrs to an area suflicient to afford feed for two or three days. The entire field, thus fed, contained 40 acres, with an estimated arerage of 40 bushels per acre. The consumption of this corn gave a gain of 10,740 lbs. The hogs, when turned into the com, cost three cents per pomd, equal to $\$ 5 s s$; worth, when fud, four cents per pound, or \$1,213 60 -riving a return fol' eacli acre of corn consumed of $\$ 156 \pm$. Adding to this $\$ 1$ per acre for the improvement of the land by feeding the corn on the field, making the actual gain per acre $\$ 166 t$, equal to $t 0$ cents per bushel, standing in the fiell. The whole cost of corn per acre, exclusire of interest on the land, is set down at $\$ 365$.

liy way of eomparing the arlvantages of ground and cooked food over that which was merely ground, and that which was unground, Mr. B. put "up three hogs into separate pens. To one he fed two and a half bushels of corn in the ear, duriug a period of nime days, feeding all he would eat; this 
gave a gatin of $19 \mathrm{lbs}$; another ate in the same time one and three quarter bushels of corn, ground, and gained also 19lbs.; and to the third he feel one bushel of corn, ground and boiled, which gave a gain of $22 \mathrm{lbs}$. By this it will be seen that one and three quarter bushels of corn, when gromel, will grive a gain of tlesh equal to two and a half bushels of muground corr, and that one bushel, when ground and cooicd, gave a gain greater than either.

The comparitive lesults of these thee methouls of feeding may thus be set down: one bushel of corn, ground and cooked, is equal to nearly three bushels when fed dry and unground; and one and timec quarter bushels when ground and meoolied is equal to tro and a lialf bushels when tied whole.

Or it may be stated thus: one bushel of dry corn in the car makes $S$ ! lbs. of pork, which at four cents per pound is equal to 33 cents per bushel for the conn; while one bushel of corn, ground and boiled, makes 22 lbs. of pork at four cents per pound, and is equal to SS cents per bushel for the corn. This result about sustains our calculations made upon the experiments ly Ml. Samuel II. Clay, of Tientucky, as appears in 5.

It is wortly of remark for those who wish to feed corn in the field, that had the logs been turned into the field when the com was in the milk, it would liave given a result more nearly like that of the hog fied upon gromul and cooked food.

The obstacles which seen to be in the way of adopting an improved method of fittening hogs result from the imperfect apparatns used for urejaring the food. Sending corn a long distance to mill to be ground, and then to cook the meal in an ordinary liettle, even if it holds a banel, will prove an expensive operation, as all have foumd who liare undertaken it. But to realize the full advantages of feeding prepared food, a complete rrinding and steaming apjuaratus must be erected on a large seale, with the view to perform the grinding, cooking, and feeding with the greatest ficeility and at the least possible cost. This may be done to adrantage by employing steam for grinding, using the same boiler to finmish stean for cooking the meal.

13. Origin of the Chester County logs.-It is stated that Captain James Jeficris, a sci-captain, somewhere about 1520 , ol a little later, in one of his royages from England, brought orer a pair of pigs of the Bedfordshire breed, which he sent to his farm on the Brandywine, whence the breed has been disseninated, and lost its origrinal name. Some of the characteristics of the Chester Connty log are, large size, remarkably symmetrical form, ensy keeping, compratively little oftil, great depth and length of eareass, and producing larere quantities of lard. Spring pigs are often put in market at nine or ten months old, and weighling at that age from 200 to $250 \mathrm{Jbs}$. This weight is of conrse produced hy good feeding and proper attention.

14. To prevent sows Killing their Pigs. $-\Lambda$ correspondent of the Maine Furmer speaks of severil cases of sow destroying their pigs-which, indeed, is not musul-and commends as an easy and sure prevention, "to gire 
the suw about lnalt a pint of good rum or gin, which soon produecs intoxication, and the drunken mother becomes entirely liarmless toward her young, and will $\mathrm{ercr}$ aceommodate ler position to the best advantage of the pigr-, retaining this disposition erer afterward." The editor contirms this statement from eases within his own knowledge.

15. Pig-Brecling. - Notwithstanding the fact that more people are interested in the lneeding of pigs than of any other class of domestic animals, the attention paid to improrement of the stoek is rery small. Ilow few fumers know that the sow slould always be larger thin the male, and that he should always be of the nost perfect form, of good color, and perfectly somd and healthy, because aluost invariably the pigs take the qualities of the sire instead of the mother; that is, his good or bad points will preponderate largely orer those of the sor. Farmers, please think of this fact, and protit by $\mathrm{jt}$.

16. Lange Hors, - Isaac Ilarison, of Burlington County, N. J., fatted, in 1S5S, 32 logs that averaged $569 \mathrm{lbs}$. each; and William Taylor, of Oecan Connty, fatted 30 that averaged 537 lbs. each. Thomas Hood, of Oecan County, fatted 11 that averaged 533 hos. each. So says C. IV. Hartshorn, of Burlington County, who sends us a list of weights, among which are rery few under $500 \mathrm{ll}$ s, ; the lightest that we notice weighs 125 lbs.

1\%. Gross aut lift Weight of Swins.-The rule of ascertaining the net reight of lat logss is to dednet one fiftl of the gross weight. It is an eas way to make the calculation, or reduetion of gross to net weight, by using the decimal S-10 as a multiplier, entting off one right-hand figure of the product, to slow the net sum. Thus: 10 logs weigh 2,729lbs.; multiply by. S, which will make net 2,183.2 lbs.

If you have the gross weight of a drove of hogs at home, which you may lave taken to market and sold at net weight, and wish to ascertain how the net and gross compare, take your sum of the net weight, say 2,183.2. Divile by $\mathrm{S}-10$, and you will find the quotient 2,729 .

This will be fonth a very couvenient and useful lule. Sometimes a person may be ofiered one smm as a gross price, and another as a net price of the same lot, and would like to know at once which offel is the best. This is quickly done. Yon have simply to apply the same rule of division by eight tenths to the priee, instead of reight. For instanee suppose the offer isas it sometimes is in New Tork- $\$ 5.5$ per ewt. gross, or $\$ 650$ net. Divide $\$ 525$ by $8-10$, the quotient will be $\$ 656.2$, showing that it will be six cents and two mills per crt. gross to the owner's advantage to sell at 8525 gross.

15. Salting Meal Warm,-C. Bovie, of Gullprairic, Michigan, asks : "Will pork cure, if preked before the animal heat is all out of it?" He then answers: "Last year I killed my hogs and packed them while warm. I lave some of the pork now, and I never ate any sweeter pork than this is. The most of farmers think pork salted, while warm, will not keep."

We have tried the experiment repeatedly of salting pork as soon as we conld ent it up after dressing, and certainly prefer it, as it will, when drysalted, eure much quicker. 


\section{PLA T E I I I.}

(Page 21.)

This plate is intended to answer the question: "What is a good cow ?" It slows a model cow, without regard to breed, as described in 75 , and a portrait of the "Oaks Cow," which was one of the most remarkable of the early age of stock improvement as a great butter producer. She gave 467 pounds from May 15 to Decomber 20, 1816. Another portrait gives the side view of what is taken as a model of a good dairy cow. The Dutch dairy cow is alsc considered a model, not only of that breed, but of a form that shows a good cow for milk. The Hereford cow and bull, and Devon cow and bull, also give good studies, and make up a picture no where else to be found in such compact form and such beauty of execu. tion. 
19. Species of Animals.-The Revue IIorticole, of Paris, gives a rery interesting acconnt of a discussion in the Academie upon the species of animals. The primitire source of animals is lost; the fossil bones of the lorse are identical with those of the present day. There is no account of anything new in animal life since the Mosaic account of creation.

20. Animal strncture.-"The bony frame-work of the animal owes its solidity to phospleate of lime, and this substanee must be furnished by the food. A perfect food must supply the animal with these three classes of bodies, and in proper proportions. That proportions are the proper ones we liave at present no means of knowing with acemracy. The ordinary hinds of food for cattle contain a large quantity of regetable fiber or woody matter, which is more or less indigestible, but which is indispensable to the welfure of herbaceous animals, as their digestive organs are adapted to a bulky and rough food. The addition of a small quantity of feed rich in oil and albuminous snbstances to the ordinary kinds of food, has been found highly advantageons in practice. Neither hay alone, nor coucentrated food alone, gires the best resmlt. A certain combination of the tro presents the most adrantages."

The above is the ricw of an eminent professor of agricultural chemistry (S. WV. Jolnsons), and it contains a great fact that should be adopted into the every-lay practice of every furmer, and not only for his stock, but his own houseliold. Every animal of a higher organization than a rorm needs a dirersity of food to make up a healtly animal strueture.

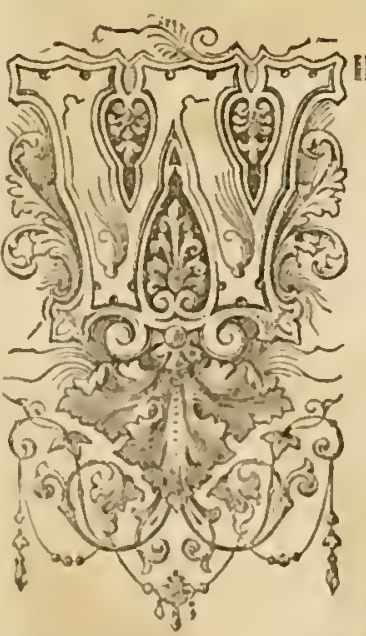

\section{SECTION III.-COTIS.}

HIT is a Good cow? - This is a question that many owners of cows can not answer, becamse there is no standard. Every one has his omn, and one person may recommend a cow on sale as positirely grood, that is not lialf as raluable as one that comes oulyup to the standard of another person's idea of goodmess. liesiles, one cow may be good for producing milk for sale by the quart; another good for making butter, where that alone is the object; a thirl nnc may be good fur a cheese dairy and rely poor for lutter; and a fourth not good for cither purpose. and shonld at once be tmmed ont for beef. Farmers do not experiment enough with their cows to aseertain these ficts. Te hare known ane cow discarded from a butter dairy because slie gare less milk than another, when one was to be sold, wighout auy other proof that the rejected one was not cyually 
good. For buttel-making, we think a eow which gives 14 quarts of milk a day, when fresh, and 14 lbs. of bniter a week, a good cow, and that that might le adopted into use as tho meaning of a good butter-dairy cow. A good many cows, it is true, gro above thit, but they should be ranked as extra goorl. A cow that gires 12 or 14 guarts of milk a day, and $10 \mathrm{lbs}$. of butter a weck, might be cilled a filir medium eow; and one that gives $S$ to 12 quarts a day aud 6 or 7 lbs. of buter a weck, should be called common, and all below that inferior, as in fact they are; and so is a cow that gives 15 or 16 quarts of milk a day that yiclds only a pound of butter, and there are many of this deseription. The lowest late we ever heard was 3 quarts of milk for $1 \mathrm{lb}$. of butter ; but that is very ruce, the arerage being orel 12 quarts.

It would be an excellent plan for some leading agricultural socicty to establish a standard for a good cow. We think a cow that comes up to the standard of that owned by Otis Hunt, of Eaton Village, N. I., will pass for a good one. Ile gives the following statement of the amount of butter made from her: "Amount made from April S to July S, 191 lbs.; amount made dming the month of June, $7+1 \mathrm{bs}$. ; amount made during the year, 516 lbs., besides furmishing all the milk and cream used in a family of four persons (and oceasional visitors) all the time."

The breed of this good cow is given as " native," and the quality of milk and butter excellent.

22. Garget in Cows.-A letter from Fort Independence, Castle Island, Boston Harbor, Mass., says:

"Within the last two years I have purehased at different times three cors, say about one erery six months. After they are on the island a few montlis they become ' gargety ;' therefore I should think the complaint is brought on from eating some reed peculiar to this island, which is limited in extent, say about thirty acres."

No, sil"; it is because they have not eaten some weed-a reed called polic or scoke, producing the "scoke-berrics" that robins and selool-children are both fond of gatlicring in the fall. This scolic is the natural eure for garget. It is said that the disease nerer affects cows that run in pastures where it grows. We lave known the dried roots sell for $\$ 2$ a lb. in Vermont to feed cows, and to make little plugs to insert in the teats to eure the garget. It is there known by the mame of garget root. (phytolaced decandra).

23. How to Increase the Value of a Cow,-Erery one who owns a cow ean see at a glanee that it would be profitable to increase the value of lier, but every one can not sec low to do it. We ean, and we think that we can make it equally palpable to onr readers. If a cow is kept for butter, it certainly would add to her value if the butter-making properties of her milk should be improred. In summer or winter this can be done, just as the yield of a cultirated crop can be improved by what is fed to each, and it is simply a question of, will it pay, in manming one or feeding the otluer. Indian corn will add to the quantity and quality of the butter to a rery sensible degree, 
and it is simply a question of easy solntion, by experiment, whetl.er it will idel to the profit of the butter-maker to buy corn at one or two cents a pound, and convert a portion of it into butter at 25 cents a pound, or whatever the market price of con and butter may be, and another portion of it into fat, and anotler portion of it into manure, for that is the natmal result of the chemical ehange produced in the laboratory of the cow's stomach. The same result will follow any other kind of feeding. Good pasture will produce an abundance of milk, often as much as the eow can earry; but does it follow that even then it will not be profitable to feed her with some more oleaginous food to increase the quantity of butter, just as it sometimes proves jrofitable to feed bees, to enable them to store.more honey ? It certainly cloes appear to us that the value of a cow feeding upon ordinary winter food may be almost dombled by making tlrat food suitable for the purpose of increasing the quantity of milk, if that is the object, or the quintity of butter, if that is the purpose for which the cow is kept. Farmers generally understand that they ean convert corn into beef, pork, and lard, amel some of them know exactly at what price per bushel it will pay to convert it into these substances; bnt does any one know at whęt rate it will pay to courert corno or any other grain into bntter, or any other kind of feed into any of the dairy products? Is the whole business a hap-hazard one? We fear so. Some persons linow that they can increase the salable value of butter by alding the coloring matter of earrots to it. Does any person know the ralue of a bushel of carrots fed to a cow to inerease her vilue as a butterproducing laboratory? Experimental proof upon this point would be far more worthy of agricultural prizes than it is to sce who ean show the largestsized roots; for by a few carefully-contlueted experiments we slould be able to inerease the value of a cow almost at pleasure.

24. Pasture- How many Cows to an Acre-In Cheshire, England, which is a great grazing county, the land that has been mudedrained and topdressed with ground bones, will carry one cow to each acre through the summer, but the land not thus treated will only cary one cow to two acres. The dressing of bones upon pasture land is 12 to $15 \mathrm{cwt}$ per acre once in seren years. But eren if not repeatel at that time, it still eontimues better than it was before the bones were applied.

Now, how many acres of pasture, on the arerage, does it require in this country to the cow? Would it not be econony to improve our pasture lauds up to the Clieshire standard?

25. Food Consumed by a Cow,-It is generally estimated that a cow needs eaclu day three per cent. of her weight in hay. That is, if she weighs $S$ ewt., which a firir-sizel cow will do, in working order, she will require $2+1 \mathrm{bs}$, or its equivalent, of hay. For five months' feeding - 150 days-yon will require 3,600 lbs. In the New England States the feeding period averiges nearer six than five months, and therefore two tuns of hay slionld be allowed for eacli cow.

26. Feed, Exercise, and Sirelter have a jowerful influence upon the liealth 
and comfort of all domestic animals, and upon none is it more marked than upon the most valuable of all, the cow. Every judicions farmer, who has an eye only to his jurse, will see that his cows are bountifully supplied with proper food to jroduce the largest flow of milk, and ricl in cream, and that Ihis meadows and pastures are free from noxions weeds, that will impart a disagrecable taste to the milk and butter. A mixture of timothy and white clover is the most desimble pastme for the dairy; and the best and sreetest butter is generally produced in May and Tune; for then kind Nature sends up a spoutuneous supply of rich, juicy food, and the air is cool and pure, and all things combine to render the dairyman's task casy and delightful. But when the sun las seorelied the regetation and impared its nutritive properties, and the temperature of the atmosplere is like an oven, then there is need of skill to counteract the opposing influences of nature; and the task, though difficult, can be accomplished, and a cool atmosphere created in the milli-loom, and proper food supjlied, as the reward of well-directed labor.

Every farmer should practice, at least on a small scale, growing extra feed for lis cows, when pasture fails. One of the easiest things grown for fall feed is cabbage. It gives an immense amount of food per acre.

27. Feeding Cows for Bntter-Making, $-A$ writer in the Farmer and $G(r)-$ dencr (Phila.) says: "The use of com and cob-meal in my practice has lubduced more fat than butter. The best feed I have tried is two bushels of ship-stuff to one bisliel of ground corm. In the nse of corn fodder, I liare found great adrantage in not only cutting, but steaming it. Many cows will not eat it withont its being steamed. Turnips are good enough, if the taste they impart to the butter is not objectionable. Pumplins add largely wo the quantity of milk, but the crean, in chuming, is always frothy, and requires a louger time to be converted into butter.

" My plan of feeding is as follows: I always let my cows go dry about the first of the new year, giving them, by this plan, a rest of some two months. During this period of rest I feed them on hay, corn-fodder, and straw. As soon as they begin to spring, I add four quarts of meal to each cow, which, after being mixed with the long straw and fodder, is steamed, and fed a little warm. Until the calres are separated from the cows, this anount of food is giren once a day, after which time I feed them three times a day."

2S. Health of Cows - A sickly cow not only yields a diminished profit, but she yiclds sickly milk, and sickly in a ligher degree than her flesh.

If a cow eats anything that has a strong or disagreeable odor, it appears in her milk.

If slie eats anything medicinal, it comes out in her milk.

If slie is fererish, her milk shows it.

If she has sores abont her, pus may be found in her milk.

If she is fed upon decayed or diseased food, her milk, since it is derired from her food, will be unhealthy. It is as impossible to make good milk from bad food, as to make a good building from rotten timber. 
If there is anything wrong about her, it will appear in the milk, as that is an effective source of casting it from her organism.

These facts should at all times be well impressed upon the minds of dairymen, but more especially in the cold season of the year. Closely confined in their narrow stalls through the long winter, where the air is not always fresh and pure, nor water and exercise always had when desired, nor their food always free from fonl medicinal weeds, as thistles, daisies, white top, etc., cows are very likely to vary from a perfectly healtily condition; spring cheese will be faulty enongl, do the best we can-that every dairyman knows. The liealth of the cows should not, at any rate, be allowed to become a cause of deterioration. Green food shonld now, if it has not been betore, alternated as often as possible with the dry; for this purpose, beets, carrots, turuips, potatoes, cabbages, parsneps, and apples are valuable.

Ventilation and watering should be promptly attended to, and salt and meal, made by pulerizing burned bones, should be kept where daily access can be had to them, if desired, nor shonld their strength and flesh be allowed to fuil for the want of a sufficiently nutritious diet. The best flavored butter and elieese ean not be made from cows that are bally fed, or ailing, or poor.

As bad health in parents transmits a tendency to disease in the offspring, it is important that erery kind of animal we desire to continue on our furms sliould be kept vigorous and healthy.

As an unliealthy animal can not consume food to as good adrantage as a well one, it is again economical to avoid disease.

29. The Amount of llay required for Cows-The Cost of Milk,-Otis Brigham, of Westborough, Mass., after seventy years' experience in farming, Eays, in the Nero England Furmer, that good cows will eat, on an average, $20 \mathrm{ll}$ s. of hay per day when giving milk, and $15 \mathrm{lbs}$. when dry-not by guess-work, but tested by actual weighing, for months at a time. Then it is easy to calculate the eost of milk. In the neighborhood of New Tork, the average value of hay is one cent a pound, and the quantity of nill not over six quarts. At three and a h:lf eents a quart, it will pay the lay bill, and one cent a day orer. If otler feed is given, the incrense of milk must yay for that. The manure will be worth at least the cost of attendance and milking. If the milk is worth more than three and a lalf cents, it gives a profit; and if less, a loss.

30. For licking Cows. - Take a short strap, and fasten the ends together. Next prepare a jin of some soft wool, about six or eight inclies long, one and a half inclies in diameter. Tithe the cow by the off fore-leg, and donble it at the knee-joint close; pass the strap or loop over the knee, pressing it back until you can insert the pin between that and the knee-joint, and she can not kick.

31. Jirections for Spaying Cows,-Dr. Dadd, reterinary surgeon, in the American Stock Journul, says that the milk of spayed cows gives more cream than ordinary milk, and that the butter made from it is nore delicious in taste. The milk is also invaluable for mursing infunts. Ile thinks there is 
no dantrer in performing the operation, if slillfully done, and the animal put muler the infuence of sulphuric ether.

I)r. Tigggs, a reterinary surgeon, does not approve of giving chloroform to cows. He says: "It is no ensy task to give ether or chloroform to animals generally, and it is usually quite as distressing to them as so slightly painful an operation as spaying. The operation of casting is a very awliward one, and needless, and interferes with the ease, if net the certainty, of the operation. The ovaries are attached near the back-bone; henee, when a cow stands mp, the panuch and intestines fall away from them, and leave clear working space; but when she is thrown mon her side, the case is rifferent, and when the cow is in good flesh, there is none too much space any way."

I)r. Rirges allows the cow to stand up, her heal tied short, and an assistant holds her by the nose with elasps; a rope is tied loosely abont her hind legs, to keep her from kicking; an assistant pushes ler up against a partition or wall, and another aids in the first part of the operation. Thus, the cow is not at all alarmed or uncomfortable.

The skin is folded so that the hair ean be shaved off where the ent is to be, and thus a straight line, three quarters of an inch wide and five inches long, is laid bare. The skin is then drawn up in a fold, at right angles, to this line and in the middle of it. The operator grasps this fold on one side of the shaved line, in lis left hand, and his assistant grasps it on the otlier side; then, with a single, well-directed stroke, with a shap knite, he serers the two thicknesses of hide exaet?y in the shared line, letting go at the same time; a straight, clean ent through the skin is seen, and the cow suffers almost no pain at al!-not so much as that produced by the blow from a whip. If the ent is made slowly, it is the most painful part of the operation. There is little feeling in the tissues forming the walls of the eavity of the abdomen, and when these are cut through, the hand may be casily introduced. The con winees a little when the edges of the shin are rubbed, but shows no signus of pain.

The removal of the ovaries appears very easy, but it is not. If the operator has a strong, sharp thumb-nail, he can work of eut them loose; but if not, or if the orary is strongly attached, the operator is obliged to do as the books say- "in short, pull them away"-and in this is the great danger to the cow; internal hemorrhage or inflammation is apt to cusue. Dr: Riggs aroids all this by the use of the "steel thumb-nail." This is simply a shan" knife, shaped like and bound upon the thumb-nail of the right hand. There is no danger of cutting in the wrong place. A elean ent does not produce bleeling, as was feared at first, and it greatly simplifies and shortens the operation. Dr. Riggs lias nerer operated upon a cow with this instrument when she struggled or attempted to get down, bnt onee, and then she was a little nervous, and came down upon her knecs, but soon got up agrain. Usually there is no silnggling throughout the operation.

32. Calomel for Cows. - A correspondent of the American Farmer mrites: "I wish you would say to your readers that ealomel, in onc-ounce doses, will 
cure a cow of almost any discase. At least, let me give my experience. I have two finc, valuable cows; they have lad, it seenus to me, some of the worst discases thit prevail-black-tongrue, nurrain, dry murrain, etc.-and when I saw they were dying, I mised one ounce of calomel in dry corn-meal, which they would lick up, and it has never fililed to cure."

33. Keep Cows Gentle.-If you milk out doors, with the cow loose, provide good stools for each milker. See that they are never used to pound the cow with; and never allow man or wonnan to kick or pound a cow in the stable or milking yard. If gentle means will not make a cow gentle, harsh means never will. It nily be necessary to reduce a cow to obedicnee by a little punishment-to teach her, as you would a hor'se or ox, that you are master; but to accomplish this, nerer use anything but a light lash or smart switch, and never use that in anger. An angry man is a fool, compared with a sensible cow.

3t. Ayrshipe Cowso-In Massachusetts, the improvement of dairy stock by the introduction of Ayrshire blood las become so apparent, that no argument could induee those acquanted with their value to return to the hazirds of native breeding. We conld point to farmers in Essex, Middlesex, and Worecster comnties, who, under the most purdent mangement, avail themselves of every opportunity to introluce Ayrshire blood into then herels, and our own olsservation teaches us that the importations of the Massachusetts Suciety for Promoting Agriculture, of Capt. Randall, of New Bedford, and others, have been vastly benefieial to om dairy stock. The bulls of this breed can be traced wherever they have been, by the rood stock they have left behind them. One of them was kept upon a scelnded farm in Esex Connty, and rendered it famons for its tine dairy cows. Another gare superior character to the herd of one of onr well-known farmers, and to all the dairies in his neighborhood. An imported Ayrshire cow, not far from us, lias prodnced, through a varicty of mixtures and pure brecding, a little herd of cows and heifers of the highest uniformity of cxecllence.

35. Poor Bufter Cows.-The Teterinarian gives a remedy for this difticulty with cows that ave well kept, and whose milk has becn previonsly rich in butter. It is to these that the remedy is principally directed. The remedy consists in giving the animal two onnees of the sulphuret of antinony, with three ounces of coriander seeds, powdered and well mixed. This is to be given as a soft bolus, and followerl lyy a dunght composed of half a pint of vinegar, a pint of water, and a handful of common salt, for three successire nornings, on an empty stomach.

This remedy, aceording to the author, rarely fails, and the milk produced some days after its exhibition is found to be richer in ereann. The first eluming yields a larger quantity of butter, but the second and third are still more satisfactory in their results.

A letter from a fammer states that he had fourtecn cows in full milk, from which the obtained very little butter, and that of a bad quality. Guided by the statements of M. Denenbourg, which had appeared in the Amuches Tet- 
crinaires, he laal separately tested the milk of his cows, and found that the bal quality of it was owing to one cow only, and that the milk of the others vickled good and abundant bntter. It was, therefore, elearly established that the loss he had so long sustuined was to be attributed to this cow only. IIe at once alministered the remedy recommended by M. Denenbourg, which effected a cure.

36. Winter Feed of 0range Connty Dairy Cows-Mr. C. Edward Brooks, one of the best dairymen in the comnty, elaims that rye makes more milk than corn or oats, or other neal. Brewers' grains were formerly bonght so as to cost 6 cents delivered at the farm, but now, at 12 cents, they are not so profitale as rye feed at 75 cents per bushel. Oats he estecms the poorest kind of grain for milk. He thinks that by currying a cow, and keeping her and her stable serupulonsly elean, she will give her full quantity of milk on laalf the feed required if she is negleeted. Ilis daily allowance to each cow is five poumds of meal, either corn, corn and oats, ol buckwheat or wheat bran, changing the kind frequently-for practice approves what theory teaches, that amimals thrive best on a frequent change of diet. The auimals are fed and milked at regular hours-generally at four o'clock in the atternoon and six in the moming; in winter, somewhat earlier in the afternoon and later in the morning. Care is taken to observe great pumctuality as to time of milling, for the animals gire much less tronble and thrire better. Mr. Brooks chaff's lis liay, steeps it in warm water to soften it, and sprinkles the meal over it, mixing it thoronghly. Thronghout the day as much long hay is fer as the cors will eat. The feed is mixed in a long box, shaped like an ordinary bath-tmb, which runs on small irou truck-wheels, one at either end, and two at the sides, half way between. This is a very conrenient method for carrying the whole mess along the passage between the stalls, and with a wooden scoop giving to each cow her share as her stall is passed. The water to steep the lany is heated in a caldron, in a small out-building, and condueted to the cow-stable throngh a small tin pipe.

Mr. Seeley C. Roe, near Cliester, a large dairyman and an intelligent farmer, thinks that half-elover hay, well made, and lialf grain, is better for nill production than twice as mnch timotly with grain. He does not cut and stecp his hay, lunt dampens it with cold water, and adds meal, as usual. Ile finds it an exeellent plan to feed buckwheat whole, and prepares it by boiling the grain with the hulls on, and when it has become thoronghly soaked, puts it into the feed-box at the rate of two quarts to each eow. He adds to this two quarts of diy meal, and the heat and stenm of the cooked buckwheat cooks the meal. Four quarts of this mixture are allowed to aach cow-two in the morniug and two at night-and the animals are lept on this feed until turned ont to grass.

Mr. Gregory has an eight-horse power engine for cufting hay, threshing, grinding, etc., and uses the waste steam for steaming lis liay. He has constructed a large chamber, eapable of holding one hundred bushels of eut lay, which, before being steamed, is dampened. The steam-pipe from 
the engine ompties into the elamber, and the lay is steamed for abont a quarter of an hour, and then fed to the stock mmixed with meal-that is, given in the form of a warm mash.

37. Sugar-Canc for Cows.--If the Chinese sugar-eane does not prove to be a profitable sngar-making plant, we think it will be a profitable one for forage. The IIomestead says that Deieon Elward Hayden, of East Hartford, Comn., has raised the Chinese sugar-cane for two years, and has used it for feeding mileh cows with great suecess. The first ycar the stalks were left in the field, scattered about, we believe, and oeeasionally in dry weather brought to the barn to the cows, which ate them up elean, stalks and all. This was merely a sort of aecidental experiment, as no especial value was set upon the eanes. The past year he raised more, shoeked in the field, and left it there. It enred well, and the eows ate it with great avidity, and Mr. Hayden esteems it as a great milk-prodneing diet.

38. Fecding Roots.-I have a word to say on winter feed for stock. It is more by way of query, and for feeders to think of, than by way of instruetion. My experience in feeding domestic animals is not suffieient to warrant me in giving instruetion. I lave served my time in too rough a sehool for that. I have fed a grood deal of hay, worth from $\$ 150$ to $\$ 5$ a tun; and cor'n from 10 to 25 ecuts a bushel, and other grain in proportion, and straw absolutely valueless. While living in such a district, I hare often been asked the question, Why I did not raise more roots tor my eattle? I answered: Simply because it would not pay. I licl buy a lot of ruta bagas one antumn, delivered at my house at six eents a bushel, and the nse of them tanght me that they were dear food. I would now, if living in snel a district, feed roots to stock just so far as I thought ueeessary to keep the animals in good liealth, and no more; not if I conld buy at the sane price, which was one fourth the price of sound eorn; and I question the economy of feeling any kind of roots at the same rate of ralne to any greater extent than is required for health. That roots, particularly white turnips, are too largely fed in cold weather to young eattle, I have no doubt. 'They are so full of water that too much of it is taken into the stomach with the fool. It roots, or any other watery food, are too largely ferl to milch cows before and after calving, you will be smre to have a mean ealf. It we will think, and take reason for a guide, as to what man requires for healthy fool, we slall not go fur wrong with domestic animals. Man likes roots oceasionally, and so lue does soup, or other sloply food; but what would he be rood for if ted week after week upon such watery stuff as turuip's, or such porridge as some people compel their eattle to eat? After all, this question of winter feeding is a question of valnes; and it is not alone the value, eounted by first cost, but the valne of results. Now, what is the use of giving my opinion that this or that kind of food is the best, or most cconomical, when I ean not say of a single thing, I know. I don't know, and don't know mylody who does. It is all guess-work, and at the present price of cattle-tood. it is expensive guessing. 
3!). Wintering Cows. The method of feeding cows in winter is not so important as it is to make the change from grass to luay and from hay to grass rithout producing any leteriontion in their condition. It is higlnly inportant, if your cows are riving milk upon autumn pastme, that you do not allow them to fall off in milk or flesh for want of a little extra feed. I have never found anything quite equal to com-meal for cow-feed, partienlarly when yon are making butter. It may not be necessary nor economical to feel cows meal in antmm, even if pasture does fail, if you hare green cornstalks, jumpkins, turnips, cabbage, etc., which must be consmmed, becanse not gool to keep through winter. But in spring, when cows are first turned to grass, they are very apt to fall away, and then it will be fonnd to be good economy to feed meal every night in the yard, and so it will before the cors nre turnel ont, if not in first-rate condition.

I see the caleulation of one witer that com-meal, thus fed, was worth $\$ 3$ a bushel, fed at the rate of one quart a day to a cow, for twenty or thirty days. He says :

"I have also found, by other experiments, that there is a great difierence in the manner of gretting aninals to grass. When turued ont carly, witly little or no other feed, they fall awar greatly; on the contrary, if fed all the good hay they will eat, night and moming, with a judicions feeding of meal of some kinrl (and I prefer mixed feed-that is, mixing the different srains together beture they are ground-to any one variety), they will soon begin to gain finely by snch a course, and eary theị extra weights through the season. In an experiment now being conducted, I have a cow that has, since the first of December last, been quietly laying on her two pounds per day (or nearly so), and her feed has been only moderate, as I am no adrocate for forcing. bnt simply good fair keeping and care; then, with good animals, we are sure of a fair l'emuneration for care and feeding.

"I rould that what I have already written conld leach the ere of every farmer in these United States, and that each one would set himself about making at least one experiment in the care of farm-stock."

40. Cous Baliy Wintered are Unprofitable.-A furmer ean not afford to winter any stock poorly, and least of all, milch cows, or those which are to produce calves in the spring. Look at the following statement, and see if the Thestern lieserve famers can afford thus to winter cows.

A letter from Warren, Trumbull Connty, Ohio, written in April, 1560, Eays: "The present times are the worst we have ever known in this comntry" Cows and cattle are dying by the hundred; six hundred head have died within the three adjoining connties this winter for want of food. The weather is still dry and cold."

This is only one, among many illustrations, of the folly and wrong committed by Western farmers in keeping more stock than can be housed and fed. This is the case all throngh the Western conntry. Travel over any portion of it, and yon will see seores of cattle shivering in the cold storms of winter, without shelter, and so poorly fed that if they live through the 
serere scason it is more by chance than for any care which they receive. On the prairies, cattle can be kept so easily in summer that erery one is tempted to orerstock himself to such a degree, while the grass is green, that a portion must die in winter. Now we would say to the farmers, yon can not afford this. Every one of these six lundred cattle which perished in Olno could have been sold at a low price by the owners, who were short of feed, to others who would have carried them through the winter. And low infinitely better this would have been than to allow snch an amount of stock to die of starvation!

It is not only in Trumbull County that cattle have perished in winter; the entire West has suffered equally in this respect with Ohio. On the Illinois prairies, where there is no limit to the amount of hay that might he cut, cattle have died in large nmmbers for the want of a quarter more liay than they had eaten dning the winter. And yet the famers of those districts persevere in their criminal folly, althongh the result of cach year's experience ought to be suflicicut to open their eyes to a proper realization of the trutli. No famer can afford to keep more cows or horned cattle than lie can proride lay for at the rate of two tuus per liead; he slonld never attempt to licep more cattle than lie can house wamly, mless he has hay to waste, and is willing to sacrifice at least one fourth of the stock.

It is one of the most painful sights to be met with in traveling through the Wrest, wlile jassing the little eabins of the new settlers, to see cows and ealres, oxen and young stock, all huddling together, withont any slielter from the cold rinter storm. Is it any wonder that one lualf of these fanished, neglected things should perish before spring? Farmers, you must lenn wisdom from the calamities of severe winters. Fieep fewer eattle, and licep them better, and you will make more money. Wre might give hundreds of extracts from country papers to convinee you that feed is searce every year, hut it would be superfluons. The richest com country of Indiana las suffered quite as muclı as its sister States during many hard winters; and this is because it is a rich com comtry, and rich in nothing else. Iarge farms ritlont grass; cattle withont food, dying by thousands ; farmers lnsing all their stock, "because it is a late spring," or, lather, hecause they undertook to winter an umeasmable mumber. Will the fumers of our country nerer take advantage of the experience of the past, and learn that they can unt aflord these wasteful and ruinous sacrifices?

41. To Chose a Good Milch Cow-Selcet from a good breed. We prefor the Devons-bright bay red. 'Jlhe Durlams are roan, red, white, and mixtmes of these colors. Ayrshire cows are generally red and white spotted. 1 loretorels, red or darker colored, with white fitees. Aldeneys, pale red and mixed with white. These are the principal colors of the sereral hrests, of which the Durhams are the largest and Xlelerneys the smallest. Different indiriduals will contend for cach breed being the best and only one that shonld be selected for their milking qualities. But animals of each breed, and of croses of them, often jure remirkable milkers, and so do some of the 
native stock of the comntry. Two fanilies of cows-one owned by Colonel Jaques, of Ten Hills Farm, near Charlestown, Mass, and one owned by Major Joln Jones, of Wheatland Farm, near Middletown, Del.-were called native breed, yct were the most remarkable butter-makers we havo ever seen. We have seen Col. Jaques produce good butter in throe minutes, by simply stirring the eream in a bowl. It we were about selecting a milch cow, we wonld endearor to get one ont of sueh a herd of good milkers; one with a soft, velrety-feeling skin, slim neck, fine legs, broad stern, with what is called a large escutcheon-that is, the hair of the stern pointing inward; a large udder, slim teats, and large reins, commonly called milk veins, on the belly. Above all tlings, select your cow of a gentle, pleasant countenance, because a first-rate milker may be so vicious as to be worthless. Do not look for Hesh, as the best corrs are seldom fat; their lip-bones are often very prominent, and they have the appearance of being low in flesh. $A$ beefy cow is seldom a good millier.

The next thing is, what is a good milker? That is, how mucl milk must she yichl per day? A cow that will arerage 5 quarts of milk a day through the year, making 1,825 quarts, is an extraordinary good cow. One that will yield 5 quarts a day for 10 months is a good cow, and one that will arerage 4 qualis during that time is more than an average quality. That wonld make 1,200 quarts a year, which, at three cents a quart, is $\$ 36$. We believe the Orange County milk dairies average about $\$ 10$ per cow, and the quality of the cows is considerably above the average of the country.

It is as important to keep a cow grood as it is to get her good. This ean nerer be done by a carcless, lazy milker. Always milk your cow quick and perfectly elean, and never try to commeract nature by taking away her calf. Let it suck, and don't be afraid "it will butt her to deatll." It will distend the udder, and make room for the secretion of milk. Be gentle with your cow, and you will have a gentle cow. Select well, feed well, house well, milk well, and your cow will yield well.

42. The Different Breeds of Cows,-TVe advise you to examine, in this connection, the different breeds of cows, so that the general appearanee, so far as ontline of form is concerned, may be very well understood. Good and full descriptions may be found in a standard work upon "Milch Cows and Dairy Farming," edited by Charles L. Flint, secretary of the Massachusetts State Board of Agriculture, and we give a few short extracts from that work, upon each breed, as follows:

43. Ayrshire Cows.Described. - "The Ayrshires are justly celebrated throughout Great Britain and this comtry for their excellent dairy qualities. Though the most reeent in their origin, they are pretty distinct from the other Scotch and English races. In color, the pure Ayrshires are generally red and white, spotted or mottled-not roan, like many of the short-horns, but often presenting a bright contrast of colors. They are sometimes, though rarely, nearly or quite all red, and sometimes black and white; but the favorite color is red and white brightly contrasted, and by some, straw- 
berry color is preforred. The head is small, fine, and clean; the face long, and narrow at the muzzle, with a sprightly, yet generally mild, expression; cye small, smart, and lively; the horns short, fine, and slightly twisted upward, set wide apart at the roots; the neck thiu; body enlarging from fore to lind quatters; the back straight and narrow, but broad across the loin; joints rather loose and open; ribs rather flat; hind quarters rather thin; bowo fine; tail long, fine, and bushy at the end; lair generally thin and soft; udder light color and capacious, extending well forward under the belly; teats of the cow of medium size, generally set regularly and wide apart; milk-veins prominent and well developed. The carcass of the purebred Ayrshire is light, particularly the fore quarters, which is considered by good judges as an index of great milking qualities; but the pelvis is eapacions and wide orer the lips.

"On the whole, the Ayrshire is good-looking, but wants some of the symmetry and aptitude to fatten which eharacterize the short-horn, which is supposed to hare contributed to build up this valuable breed on the basis of the original stock of the connty of Ayr."

41. Yield of Wilk of Ayrshire Cows. - " Yonatt estimates the daily yicld of an Ayrshire cow, for the first two or three months after calving, at fire gallons a day, on an arerage; for the next three months, at three gallons; and for the next four months, at one gallon and a half. This would be 850 gallons as the annual average of a cow; but, allowing for some unprodnctire corrs, he estimates the arerage of a dairy at 600 gallons per annum for each cow. Three gallons and a hali of the Ayrshire cow's milk will yield one and a half pounds of butter. Ile therefore reckons $257 \mathrm{lbs}$. of butter, or $51+$ lbs. of cheese, at the rate of $2+1 b s$. to 28 gallons of milk, as the yield of every cow, at a fir and perhaps rather low average, in an Ayrshiro dairy, during the year. Aiton sets the yicld much higher, saying that "thonsauds of the best Ayrshire dairy-cows, when in prime condition and well fel, produce 1,000 gallons of milk per anum; that in general three and three-quarters to four gallons of their milk will yicld a pound and a lialf of butter; and that $27 \frac{1}{3}$ gallons of their milk will make 21 lbs. of fullmilk cheese." Mr. Rankin puts it lower-at about 650 to 700 gallons to each cow; on his own farm of inferior soil, his dairy produced an average of 550 gallons only."

45. Vicld of Milli of Breds Compared.- "In a series of experinents on the Earl of Chesterficld's dairy farm, at Bradley IIall, interesting as giving positive data on which to form a judgment as to the yicld, it was found that, in the heiglut of the season, the IIolderness cows gave seren gallons and ono quart per diem; the long-horns and Alderneys, four gallons and threo quarts; the Derous, four gallons and oue quart; and that, when rade into butter, the above yuantities gave, respectircly, $38 \frac{1}{3}$ ounces, 25 ounces, and 25 ounces.

"The Ayrshire, a cow far smaller tham the IInllerness, at fire gallous of milk and 34 omees of bntter per day, grives a fair arerage as to yield of 
milk, and an enormons prodnetion of butter, giving within four and a half wunces as much from her fire gallons as the Holderuess from her seren galluns and one quart ; her rate being nealy seven ounees to the gallon, while that of the IIolderness is considerably under six ounces.

6. According to Mr. Irarley, the most npproved shape and marks of a good dairy cow are as follows: Head small, long, and narrow toward the muzzle; lon'ns small, clear, bent, and placed at considerable distance from cach other; eyes not large, but brisk and lively; neck slender and long, tapering toward the head, with a little loose skin below; shonlders and fore quarters light and thin; hind quarters large and broad; back straight, and joints slack and open; careass deep in the rib; tail small and long, renching to the heels; legs small and elıort, with firm joints; ndder square, but a little oblong, stretching forward, thin-skinned, and capreious, bnt not low lumg; teats or paps small, pointing ontward, and at a considerable distance from each other; milk-reins capacions and prominent; skin loose, thin, and soft, like a glore; laair short, eoft, and roolly; general figure, when in flesb, handsome and well proportioned."

46. The Ayrshires for the Dairy - Their Value Considered,-Upon this point $\mathbf{A}$ 1. Flint quotes and indorses the following opinion:

"For purely dairy purposes, the Ayrshire cow deserves the first place. In enusequence of her small, symmetrieal, and compact body, combined with \& well-formed chest and a capacious stomach, there is little waste, comparatively speaking, throngh the respiratory system; while, at the same time, t'iere is very complete assimilation of the tood, and thus she converts a large I mportion of her food into milli. So remarkable is this fact, that all dairy finoners who have any experience on the point, agree in stating that an -4 yrshire cow generally gives a larger return of mith for the food consumed than a con of any other breed. The alsolute quantity may not be so great, lut it is obtained at a less eost; and this is the point upon which the question of profit depends."

4i. The Jersey or Alderney Cow-There is a great diversity of opinion about the valne of this breed of cows. It is onr opinion that they are the most raluable of all, wliere only one or two are to be kept, and when butter is the main object. The milk of an Alderney cow is the richest of all for houselıold consmmption, and nuakes the most and best butter; and the cow is generally very docile, and in her native country is frequently kept upon very much such food as we keep a pig upon in this country. The greatest objection that we liare lieard mrged upon them is their small size and lack of beanty, as compared with the symmetrical forms of Durhams, Derons, A yrshires, and some of onr natires. It is objected, too, that butter and cheese made from Alderney eows' milk will not keep, because it is "too rich." If it is mixed with otler milk, it improves both, for then the butter and cheese are rich, and have no lack of kecping qualities.

45. Origin and Deseription of Jersey Cows. "The Jersey race is supposed to lave been derived originally from Normandy, in the northern part of 
France. The corss hare been long celebrated for the production of rery rieh milk and cream, but till within a quarter of a century they were comparatively coarse, ugly, and ill-slaped. Improvements have been very marked, but the form of the animal is still far from satisfying the eye. The head of the pure Jersey is fine and tapering, the clieck small, the throat clean, the muzzle fine and encireled with a light stripe, the nostril ligh and open; the horns smootl, crmmpled, not rery thick at the base, tapering, and tipped with black; ears small and thin, deep orange color inside; eyes full and placil; neck straight and fine; eliest broad and deep; barrel hooped, broad and deep, well ribbed up; back straight from the withers to the lip, and from the top of the hip to the setting on of the tail; tail fine, at riglit angles with the back, and hanging down to the hocks ; skin thin, light color, and mellow, eorered with fine, soft hair; fore legs short, straight, and fine below the linee; arm swelling and full above; hind quarters long and well filled; lind legs short and straight below the hocks, with bones rather fine, Equarely placed, and not too close together; hoofs small; udder full in size, in line with the belly, extending well up behind; teats of medimm size, squarely placed, and wide apart, and milk-veins rery prominent. The color is generally erean, dnu, or yellow, with more or less white, and the fine head and neck give the cows and heifers a fawn-like appearanee, and make them objects of attraction in the park; but the hind quarters are often too narrow to look well, particularly to those who judge animals from the amount of fat they carry."

49. Fattening Properties of a Jersey Cow.- "It is asserted by Colonel Le Contenr, of the island of Jersey, that, contrary to the general opinion here, the Jersey cow, when old and no longer wanted as a milker, will, when dry and fed, fintten rapidly, and prodnee a good quantity and excellent quality of butehers' meat. An old cow, he says, was put up to fitten in October; 1850 , weighing $1,125 \mathrm{lbs}$, and when killed, the 6th of January, 1S51, she weighed 1,330 lbs., haring gained $205 \mathrm{lbs}$. in 98 days, on $20 \mathrm{lbs}$. of hay, a little wheat-straw, and 30 lbs. of roots-eonsisting of carrots, Swedes, and mangel-wurzel-a day."

50. The Short-horn Durham Cow-There is no room for dispute abont the Durhams being good for beef. For butter or for general dairy purposes, I should not choose them. Mr. Flint says:

"In sections where the climate is moist and the food abundant and riel, some families of the slort-horns may be raluable for the dairy; but they are most frequently bred exclusively for beef in this comntry, and in sections where they liave attained the highest perfection of form and beanty, so little is thought of their milking qualities, that they are often not milked at all, the calf being allowed to run with the dam."

Crosses, lowever, of this breed upon other breeds have produced exeellent milkers. In Westchester Comity, N. Y., there is a raluable strain of dairy stock known as "Dutch and Durhan."

51. The Dutch Cow,-The old Ilolland stock shows a very symmet- 
rical, handsome form, but not quite as much so as the Durlum, which was made up, it is generally supposed, by a cross of the Dutch brecd upon the 'Teeswater stock. The Dutch cow is not as heary an animal as the improved Durhan, but she is more highly esteemed for dairy purposes.

52. The Hereford Cow.- "The Hereford eattle derive tlicir name from a county in the western part of England. Their general cluaracteristics are a white face, sometimes mottled; white throat, the white generally extending back on the neck, and sometimes, though rarely, still fartlice along on the back. The color of the rest of the body is red, generally dark, but sometimes liglit. Eighty years ago the best Irereford cattle were mottled or roan all over; and some of the best herds, down to a comparatively recent period, were either all mottled, or had the mottled or speckled face. The expression of the face is mild and lively; the forelicad open, broad, and large; the eyes bright and fiull of vivacity; the horns glossy, sleuder, and spreading; the head small, though larger and not quite so clean as that of the Derons; the lower jaw fine; neck long and slender; chest deep; breastbone large, prominent, and'very muscular; the sloulder-blade light; shoulder full and soft; brisket and loins large; hips well dereloped, and on a lerel with the chine; lind quarters long and well filled in; buttocks on a level with the back, neither filling off nor raised above the lind quarters; tail slender, well set on; hair fine and soft; body round and full; carcass deep and well forned, or eylindrical; bone small; thigh short and well made; legs short and straight, and slender below the knee; as handlers very exeellent, especially mellow to the tonch on the back, the shonlder, and along the sides, the skin being soft, flexible, of medimm thickness, rolling on the neck and the hips; laar bright; face almost bare, which is characteristic of purebred Herefords. They belong to the middle-horned division of the cattle of Great Britain, to which they are indigenous."

There are indiridual grood milkers among the Herefords, as there are among the Durhams, but like them, we must say they are better for beef than milk. We eertainly never slould select tlie IIereford breed for dairy purposes. The form of the cow, as represented among the specimens we have seen of the best lierds in this comntry, is that of a beef-producing animal, or a breed for good working oxen, for which it is noted.

53. The Devon Cow. "This beantiful race of cattle dates fartlier back than any well-established breed among us. It goes generally muder the simple name of Deron; but the eattle of the sonthern part of the connty, from which the race derives its name, differ somewhat from those of the northern, haring a larger and coarser fiane, and far less tendency to fatten, though their dairy qualities are superior.

"The North Devons are renirkable for hardihood, symmetry, and beanty, and are generally bred for work and for beef rather than for the dairy. The liead is fine and well set on; the lorns of medium length, generally eurved; color usually briglit blood-red, but sometimes inclining to yellow; skin thin and orange-yellow; lair of medium length, soft, and silky, making 
the animals remarkable fine handlers; muzzle of the nose white; eyes fill and unild; ears yellowish, or orange-color inside, of moderate size; neck rather long, with little dewlap; shoulders oblique; legs small and straiglit, and feet in proportion; eliest of good width; ribs round and expanded; loins of first-rate quality, long, wide, and fleshy; hips round, of medium width; rump level; tail full near the setting on, tapering to the tip; thighs of the bull and ox muscular and full, and high in the flank, thongh in the cow sometimes thought to be too light; the size medium, generally called small.

"As milkers, they do not excel, perhaps they may be said not to equal, the other breeds, and tliey liave a reputation of being decidedly below the arerage. In their native country the general average of a dairy is one pound of butter per day during the summer.

"They are bred for beef and for work, and not for the dairy, and their" yicld of milk is small, though of a rich quality.

"On the whole, whaterer" may be our julgment of this breed, the faults of the North Deron cow can hardly be orerlooked flom our present point of view. The rotundity of form and compactuess of frame, though they contribute to her remarkable beauty, constitute an objection to her as a dairy cow, since it is generally tlonght that the peculiarity of form which disposes an animal to take on fat is somewhat incompatible with good milking qualities, and hence Touatt says: "For the dairy, the North Devons must be acknowledged to be inferior to several other breeds. The milk is good, and yields more than the arerage proportion of cream and butter; but it is deficient in quantity.' He also maintains that the value of this breed for milk conld not be improved without probable or certain detriment to its grazing qualitics.

"But the fairest test of its fitness for the dairy is to be found in the estimation in which distinguished Deron breeders themselves have held it in this respect. A scale of points of excellence in this breed was established some time ago by tlie best judges in England; and it lias since been arlopted, with but slight changes, in this comtry. These judges, naturally puejudiced in favor of the breed, if prejudieed at all, made this seale to embrace one lundred points, no animal to be regarded as perfect unless it exeelled in all of them. Each part of the body was assigned its real value in the seale: a finlt]ess liead, for instance, was estimated at four; a deep, round eliest at fifteen, etc. If the animal was defective in any part, the number of points which represented the value of that part in the scale was to be deducted pro rata fiom the hundred, in determining its merits. But in this seale the cow is so lighlity estecmed for the dairy, that the udder, the size and sliape of which is of the utmost consequence in determining the eapaerty of the milch (c)w, is set down as worth only one point, while, in the same seale, the horus and ears are valued at two points each, and the color of the nose and the expression of the ere are valued at four points cach. Supposing, therefore, that cach of these points was valued at ono dollar, and a perfect North 
Deron cow was valued at one lundred dollars; then another cow of the sanc blood, and equal to the first in every respect, execpt in lier ndeler, whicl is such as to make it certain that slie can never be capable of giving milk enough to nomrish her calf', must be worth, according to the estiunation of the best Deron breeders, ninety-nine dollars! It is safe, therefore, to say that an animal whose ndder and lacteal glands are regarded, by those who best know her eapacities and her merits, as of only one quarter part as much consequence as the color of her nose, oi hiulf as much as the shape and size of liel horns, can not be recommeneled for the dairy. The improved North Devon cow may be classed, in this respect, with the IIereford, neither of which hare well-dereloped milk-ressels-a point of the utmost consequence to the practical dairyman."

5t. The Mik-Mliror.-This is a term giren in the Guenon method of selecting good cows, to the escutclieon formed by the cliange of direction in the hair on the lear part of the udder and parts adjacent. If this mirror is large, it is supposed to indieate a good milker. For the better understanding of it, we recommend a careful study of the "milk-mirror," and see how it is generally developed upon all real good milkers-that is, good for quantity rather than quality.

"Milk-milors vary in position, extent, and the figme they represent. They may be divided, according to their position, into mirror's or escutcheons, properly so called, or into lower and upper tufts, or escutcheons. The latter are rery small in comparison with the former, and are sitnated in close proximity to the vulva, as seen in different breeds of cows. They are very common on cows of bad milking races, but are rely rarely seen on the best milel cows. They consist of one or two ovals, or small bands of np-growing liair, and serre to indicate the continuance of the flow of milk. The period is short in proportion as the tufts are large. They unust not be confounded witl the escutclicon proper, which is often extended $u p$ to the rulva. They are separated from it by bands of hair, more or less large, as you will find from careful cxamination."

It requires some skill to determine the exact size of a milk-mirror, since it is not equally well defined in all cows, being at first sight apparently large in some, which, upon close examination, will show faults-that is, that the escutelieon of ont-growing hairs is broken by tufts of down-growing hairs. Mr. Flint says :

" We often find cows whose milk-mirror at first sight appen's rery large, but which are only medium milkers; and it will usually be fonnd that lateral indentations greatly diminish the surface of up-growing hair. Many errors are comnitted in estimating the value of sucls cows, from a want of attention to the real extent of the milk-mirror.

"All the interruptions in the surfuce of the mirror indicate a diminution of the quantity of milk, with the exception, however, of sinall oral or elliptical plates, which are found in the milror, on the back part of the udders of the best cows. 

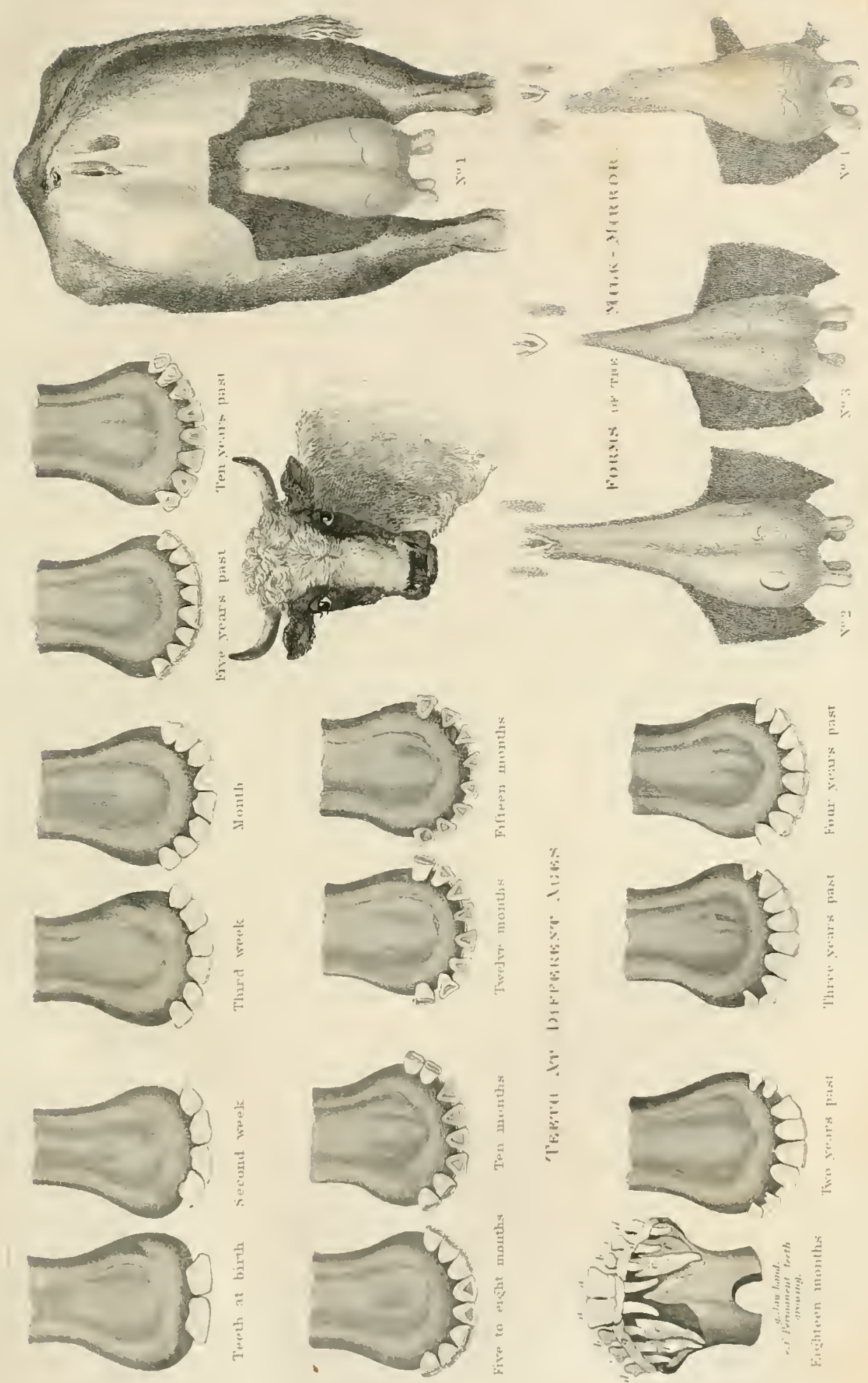



\section{PLATE V.}

(Page 48.)

I'nus is a rery instructire picture to erery young farmer, and there are a good many old ones who may make of it a raluable study. Many persons are not aware that the age of a suckling calf, weck by week, ean be told by examining the teeth. Look at these dirawing and sec how easy it is to learn the art-an art which crery farmer's boy should understand. So the age of a cow, as well as a horse, can be told from year to year, by looking at the teeth, more certainly than by the horns. For this purpose this plate possesses great value; but it has a greater one in the illustration of what is now well known as the "milk mirror", which is described at if 54 , and much more fully in Guénon's work, from which the theory is derived. In this plate the mirror is represented by coloring the pieture so as to show the field of upturned hair around the udder in its most fully developed form upon No. 1, and quite defective in No. $t$. By studying these, and comparing then with living cows, something of the theory may be learned. It is very fully illustrated in Flint's work upon milch cows and dairy furming. It is a subject worthy of the attention of all furmers. 

In a fat cow, with an inflated udder, the mirror would appear larger than it really is; while in a lean cow, with a loose and wrinkled udder, it appears smaller. Fat will cover faults; this is a fact to be kept in mind in sclecting a cow; because good fatting qualities are not the qualities which the purchaser is desirous of obtaining.

"These marks, though often seen on many good cows, should be considered as ecrtain only when the veins of the perinemm form, nuder the skin, a kind of net-work, which, without being rery apparent, may be felt by a pressure on them, when the milk-veins on the belly are well doreloped, though less knotted and less prominent than in cows of the first elass; in fine, when the udder is well dereloped, and presents veins which are suthiciently numerous, though not rery laige.

"There are cases where a knowledge and careful examination of the form and size of the mirror becomes of the greatest imporiance. It is well known that certain signs or marlis of great milkers are developed only as the capacities of the animal herself are fully and completely developed by age. The milk-reins, for instanec, are never so large and prominent in heifers and young cows as in old ones, and the same may be said of the udder, and the veins of the ndder and perinemu, all of which it is of great importance to observe in the selection of milch cows. Those signs, then, which in cows arrived at maturity are almost suflicient in themselves to warrant a conclusion as to their merits as milkers, are, to a great extent, wanting in younger animals, and altogether in calres, of which there is often dont whether the' slall be raised; and liere a knowledge of the form of the mirror is of immense advantage, since it gives, at the outset, and before any expense is incured, a somewhat reliable means of judging of the future milking capacities of the animal, or, if a male, of the probability of his transmitting milking qualities to his offspring."

55. What kind of Cows to Buy.-"In buying dairy stock, the furmer gencrally finds it for his interest to select young leifers. They grive the promise of longer nsefulness. But it is otten the case that older cows are elected, with the design of using them for the dairy for a linited period, and then fecling them for the butelier. In cither case, it is actrisable, as a rule, to choose animals in low or medium conclition. The farner can not ordinarily aflord to buy fat; it is more proper! lis business to make it and to have it to sell. Good and rell-marked cows, in poor condition, will rapjelly gain in all flesh products when removed to better pastures and lifgler licejing, amel they cost less in the original purchase."

56. Gencral Conchusions, - We lare now devoted all the space that we can afforit to the subject of cows. We have given them a largo share of our attention, because we consider them of more importance than any other single branch of our domestic animals. They not only furnish it great amount of food, in milk, eream, butter, checse, and meat, when done tiurnishing milk, but they are the foumation of prosperity in American fumbur. "A good cow may produce a bad calf," but it is only "m may-be-it loes not 
hold as a rule. It is therefore very important to select good cows, and lecp none but gool cows-certainly nerer breel from a poor one.

We slall now grive some important facts relative to other branehes of neat stuck. And first we refer the reader to the following facts conceruing bulls of rarious breeds.

57. The Ayrstire Bull.-In comparing this with those of other.breeds, it should be bome in mind that the Ayrshires are not bred for beef, in their own comntry, as much as they are fur dairy purposes. For working oxen, they are of tiair qualtty, but not the best. For feeding purposes, they should be crossed with Durhans.

"It is the opinion of good breeders, that a high-bred short-horn bull and a large-sized Ayrshire cow will prorluee a calf which will come to maturity eurlicr, and attain greater weight, and sell for more money, than a pure-breal Ayrshire. This eross, with feeding from the start, may be sold fat at two or three years old, the i!nprovement being especially eeen in the earlier matnlity and the size."

58. The Jersey Bull.-So far as beanty is concerned in the sexes, the males of the Jersey or Aklerney stock have the largest share. It is a somewhat curious plysioggical fact, that the Alderney cows in this country produce two or three times as many bulls as heifers, so that bulls can generally be purcliased at lower priees than cows.

"The bulls are usually very different in character and disposition from the eows, and are mneh inelined to become restive and eross at the age of three or four jears, mnless their treatment is uniformly gentle and firm. In all portraits of Jersey bulls, they are represented as handsomer animals than they are generally considered by American farmers.

59. Sloort-born or Durisam Bull,-This breed has been nore largely imported and bred from in the United States than any, in fact all, other:. It is the great beef-producing breed of the West, particularly in Ohio and Kentucky.

"The desirable characteristies of the short-horn bull may be summed up, according to the julgment of the best breeders, as follows: He should have a short lunt fine head, rery broad aeross the eyes, tapering to the nose, with a nostril full and prominent; the nose itself should be of a yich flesh-color; eyes bright and mild; ears somewhat large and thin; horns slightly enrved and rather flat, well set on a long, broad, museular neck; cliest wide, decp, and projecting; shoulders fine, oblique, well formed into the chine; fore legs sliort, with upper arm large and powerful; barrel round, deep, well ribbed home; hips wide and level; back straight from the withers to the setting on of the tail, but short from hip to chine; skin soft and relrety to the touch; moderately thick hair, plentiful, soft, and mossy."

This picture gires only a fair impression of the fine form of the best animals of this breed.

60. The Dutch Bull.-The form of Dutel and Durham bulls is not unlike. W. W. Chenery, of Watertown, Mass., whose name has sinee beeone famous 
as being identified witl the alarming cattle discase prevaling in Massaclnsetts in the snmmer of 1860 , is one of the largest importers of the valuable stock known as the Duteh breed.

61. The Ilereford Bull.-This always fairly represents this good breed of eattle. Good, at least, for beef, and excellent for working oxen. Their beef rates lighest of all in the London mallet, and the few grades which lave been bronght to New Iork have been highly esteemed. The objection to them is, that ther do not come so early to matmity, or, dather, to a salable condition, as the Durlams. The breeders of IIcrefords contend that the liceping that will starve Durhams will keep the Ilerefords in a thriving condition.

62. The Deron Bull.-In color and form a Deron bull is perfeet; always of a pure bay-red color, of medium size, and progenitor of the handsomest working oxen in America. The defieiency in size of the pure Derons, for working oxen, is made np lyy erossing njon larger animals. These grade oxen make as fine beef as any bronght to the New York market.

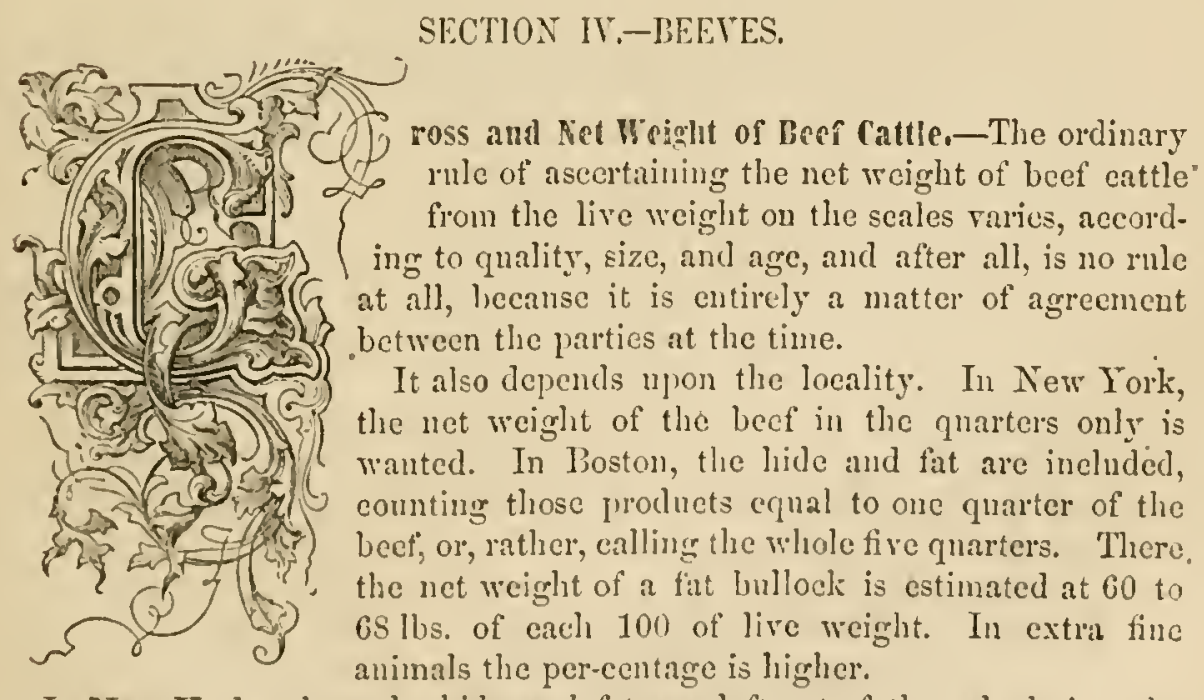

In New York, where the hide and fat are left ont of the calenlation, the bullocks are estimated at 55 to 60 lbs. net to each 100 lbs. gross; and it the animal is very fine, the estimate rums from 61 to $6+$ llbs. net to each 100 lbs. gross. Extraordinary animals sometimes dress 65 or 66 lbs., and even highlier, and ordinary and lean stock run from 5.5 down to 47 llss, though not often below 50 lbs, or one half the live weight at home. The eommon practice at the West is, to weigh fatted eatle some homs after feeding and a little exereise, and calculate the net weight at 55 lbs. jer 100 of the live weight. 
6t. The Largest Bullock-The Great Massacliuselts Steer.-Tho question of "what is the greatest weight of any bullock?" we definitely answer and place on record in the following notiecs. The heaviest alive and dead was sold by Joln Sanderson, of Jernardstown, Mass., in February, 1862, to Bryan Lawrenee, buteher, Centre Market, New Iork, by whom he was publicly exhibited, killed, aud weighed. Ifis live weight at home was 36 ewt. IIere, when very empty, 33 ewt. Ilis dead weight was, fore quarter's, 743 , $732-1,4 \% 5$ lbs. Hind quarters, 496, 502-995 lbs. Total, 2, 473 lbs., after slurinking a week. This is within 2 lbs. of 55 per cent. of lire weight. This stecr had been kept in a small yard and stable, cating meal and hay two years; was eiglut years old; a closs of Durham and natiro Vermont stock. Ile girted back of shoulders, $10 \mathrm{ft}$. $8 \mathrm{jn}$; forward of hips, $11 \mathrm{ft} .5 \mathrm{in.}$; light, $6 \mathrm{ft} .3 \mathrm{in}$; length from horns to tail, $9 \mathrm{ft}$. $\mathrm{S}$ in.; breadth across hips, $3 \mathrm{ft}$. $6 \mathrm{in}$. This is the largest bullock of which we hare any certain record. Tre also place upon record the weights of screral other remarkalle large bullocks. All stories of bullocks of $40 \mathrm{cwt}$. we disbelieve.

65. The Washington 0x.-The ox George Washington was 5 years, 9 months, and 14 days old when slaughtered, in the year $18 \pm 0$.

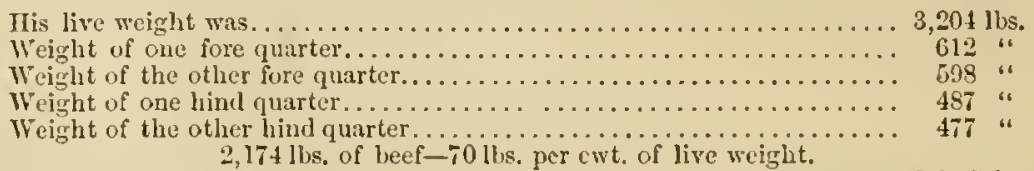

Measurement from button to root of tail ................. $9 \mathrm{ft} .7 \mathrm{in}$.

Girtl......................................... 4 " 4 "

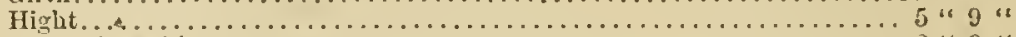

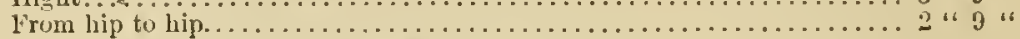

The ox Red Jacket, killed March 5, 1851,

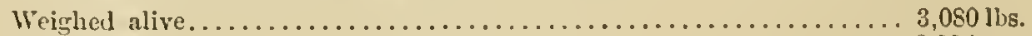

Weight of meat. ...................................

Loss, 3 I per cent.

The ox John Hancock, killed the same timc,

Weighed alive........................................

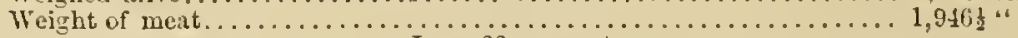

Loss, 33 per cent.

Robert L. Pell's two-year-old heifer, fatted at Pcllham Farm, 30 miles up the IIudson,

Weighed alive.

Loss, 81 per cent.

66. A Big ox in 0lden Time.-Te print, as we find it, the following extraet from "Thacher's Military Jommal of the Revolution," under" date of Jume 24, 1759:

"I have just liad the satisfaction, with a number of gentlemen, of viewing a remarkably large fut ox, which las been presented by some gentlemen in Connecticut to his Excelleney, Gen. Washington. He is $6 \mathrm{ft}$. $7 \mathrm{in}$. high, and weighs on the hoof 3,500 lbs., the largest animal I ever beheld."

67. The 0x Leopard.-An ox called "Lcopard," raised and fed by Dr. 
Win. Elmer, of Bridgton, N. J., was slaughtered, Feb. 21, 1S32, at the age of 6 years and $S$ montlis. His live weight was 3,360 lus. Size-length from nose to runp, $10 \mathrm{ft}$. 6 in.; from nose to end of tail, $15 \mathrm{ft}$; girth behind fore shoulders, $9 \mathrm{ft}$. Sin.; around the body, $10 \mathrm{ft}$. $9 \mathrm{in}$; amomd the brisket, $10 \mathrm{ft}$. $3 \mathrm{in.}$; length from shoulder to rump, $7 \mathrm{ft}$; along the back from horns, $9 \mathrm{ft}$; width across the hip, $2 \mathrm{ft} .10 \frac{1}{2} \mathrm{in}$; hight of fore shoulder, $5 \mathrm{ft}$. $6 \mathrm{in}$.; behind, $5 \mathrm{ft}$. $\mathrm{Sin}$; ciremuference of leg below the linee, 1 foot.

63. Two Big 0xen in Pennsylvania.-We have a letter from James Stewart, Pennsylvania, and another from Andrew M. Frantz, giving the weight of tro bullocks heavier than the Washington. One known as the "Lancaster" Comnty Ox," M[r. Stewart writes, "was owned and fed by Emamuel Landis, near this city; was a half-bred Durham, deep red, large fore quarters, long, fine horns, and was over seven year's old. Wh. F. Miller, of Lancaster, purchased him for $\$ \$ 00$, and slaughtered him on the $22 d$ of February, 1558. This ox reighed:

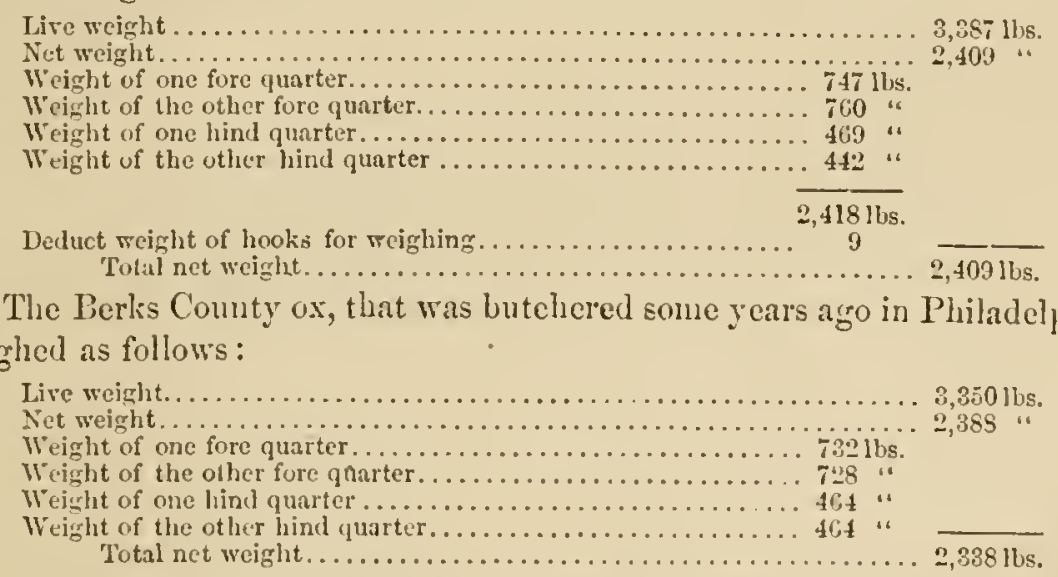

"There has long lieen a generous rivalyy between the farmers of Berks and Lancaster counties in regarl to which conkl grow the fattest and largest oxen. As it now stands, Lancaster is ahead, but we may look out for comething ere long greater still from Old Berkis, for the resources of that comity are astonishing, as even politicians can testify.

"There was another steer butchered in this city, in February, 1556, by David Killinger, owned and fed by Abran Landis, of Manhein townhip" that netted 2,10S llus., but that weight, and greater, has been frequently attained in this State, and even in this county. The first two (whose weights I have given) I will not say are the largest cattle ever slaughtered, even in Pennsylyania, but they are the largest that have ever enme muder my obscrration, and in regand to whose weight there was no dispute. I, howerer, entirely coneur with the writer in the Tribune, that there never was an ox fed to the weiglit of 4,000 lbs. gross. An animal that will weigh 613 lus. more than the one butchered in this city in February last, has certainly never been yet produced." 
Mr. Frantz says the Berks Connty ox was fed by a man named Soetz, anel was slinghtered, he thinks, in $18 \pm 6$. If so, his weight should havo been known lero and remembered, hut it was not by one of the butehers and other's that we thought likely to know, of the many of whom we songht information. We hare often heard of henvicr bullocks, but lack the proof, as in the case below. The above fignres are now matters of record, where they ean be referred to in future.

69. 'The Saratoga Big Bullock--Since writing the above, we see the following in the Country Gentleman of May 27, 1560:

"The Saratoga Conenty I'ress says that J. MI. Cole, of Saratoga Springs, slanglitered an ox, in 184i, whose live weight was 3,520 lbs.; dressed, 2,567 lls."

Let Mr. Cole grive us the ronchers. If he has made an ox of that weight, he has probably beaten the world, and should give the world the proof. It wants to know certainly the weight of the heaviest bullock.

70. Weights of the Crystal Palace Stow Cattle.-The following are the net weiglits of the nine liead of fat bullocks, exhibited as a slow at the Crystal Palace. Some of them were full-blood Kentucky and Olio Durliams, and other's, grades of that blood. They were bought by Jim Irving, of Washmgton Marlet, and fairly weighed as follows:

The best pair weighed-one, 2,1\%s lbs._and his quarter's, 604 and $612 \mathrm{lbs}$. for the fore quarters, and 480 and $48211 \mathrm{ss}$. for the hind quarters. The other weighed 2,066 lbs.-the fore quarters 570 and $5681 \mathrm{bs}$, and the hind ones 470 and 4 s's lbs.

Another pair weighed together $3,650 \mathrm{lbs}$. The old cow, which was excessirely fat, weighed $1,460 \mathrm{lbs}$, dressing, it is said, $78 \mathrm{lbs}$. per cwit. The best steer dressed $72 \frac{1}{2} \mathrm{lbs}$. per ewt. The other four head weighed 2,024, 2,00S, 1,930 , and $1,860 \mathrm{lbs}$.

Forty head of Illinois grade Durhams, five and six years old, sold in 1S58, in the $\mathrm{New}$ Tork market, areraged $22 \mathrm{cwt}$. each alive, and one hmolred liead areraged orer $20 \mathrm{cwt}$. ench.

71. The Ihaxtun Steer,-The Inaxtun steer was raised by E. IIaxtun, in Beckman Township, Dutehess Co., N. Y. IIe was out of a cow bought from a drove that came from near Cleveland, Ohio, which was probably three fourths Durham, and a full-bred short-horn bull, of Mrr. Sheaf's (Dutchess County) importation. The steer was called $\frac{1}{1} \frac{5}{5}$ ths Durham, part of the blood appearing to indicate a descent from the long-horn of the old lientucky importation. II is eolor was nearly all red, having some whitish roan spots, and he was, notwithstanding his great size and fatness, one of the liandsomest-formed fat lullocks we have ever scen, and as firm on his legs almost as he ever was, and was in appearance as fresh and healthy as ever, taking his rations regularly. Ifis feed was 14 quarts a day of menl, made of two parts Indian cern and nne part oats, and as mueh hay as he wonld eat. His feeding commenced in the fall, after he was four years old, and he was seven years old the spring before lie was killed. His weight at home, Dec. 1, 1859, was 
$3,472 \mathrm{lbs}$. He was probably weighed full at that time; but after a railroad passage of 75 miles, he was weighed here, Jan. 9, 1560, before he was filled up with food and water, and his fair, honest weight, as given by David Allerton, who weighed him, was 3,4521 bs. Three days afterward, weighed upon the same seales, by the same man, with scales earefully balaneed, he weighed 3,415 lbs. Afterward, upon two other seales, his weight was 3,419 . He was sold Jan. 10, 1860 , to $\mathrm{W} \mathrm{Wm}$. Lalor, of Centre Market, for $\$ 550$; and was slanghtered and dressed at Patterson's slaughter-liouse, Jan. 19, by the sane man who dressed the Washington, aud hung until Jan. 26, when the quarters were weiglied, under the careful supervision of Barney Bartram, Jolın IIaris, Joln M. Seanan, and James L. Stewart, and in the presence of a large company of lookers-on, many of whom were considerably interested, having invested largely in the way of bets upon the net weight.

The following was the result: fore quarters, 700 and 668 lbs. $-1,365$ lbs.; the lind quarters, 492 and 462 lbs. - 951 lbs.; total, 2,319 lbs. This was $2 \frac{2}{3}$ lbs. orel $67 \frac{3}{4}$ lbs. per ert. of the last live weight. The shrinkage was estimated at 50 llos.; but he was lung just the same leggth of time as the Washington, and, like him, has had his hide stufied and form preserved, being, up to that time, the largest bullock ever bronght to New York. The fatting of this steer has been one of the most perfectly suecesful experiments to produce a monstrous animal, so erenly formed and faultessly sliaped, that no one could say where he could be improved.

72. Other Large Emllocks.-A pair of oxen, ealled the "Cayuga Prize Oxen," was also sold in the New York market, the same week, for ş700, which was considered remarkable; their live weiglit, lowever, was 2,5651 bs. each ; they were six years old.

The Michigun Farmer of Jan. 20, 1860, says: "We lately gare an aeeount of several fat eattle which were killed in this eity on the week betore the New Year. The pair weighed 6,437 llos., or 3,215 libs. each. The net weight was estimated at 68 lbs, per ewt." Of some others the Furmer said: "The actual yield of the cattle killed by Wrilliam Smith, in this market, was 66 lbs. to the 100 lbs. of live weight, or 2,150 lbs. from 3,215 lbs. It will be seen by this, therefore, how those great oxen killed in the Detroit market approximated to what is considered the largest and fittest animal ever lilled in the United States."

We liave a letter before us from Isaae IIubbar, of Claremont, N. H., who is ninety years old, but not too old to read with interest the accounts of these fat bullocks. Ile says that, seeing an aecount of the II:xtun steer, which interested him very mueh, induced him to grive the history of a fat bulloek fed ly lim twenty odd years argo.

The ealf was dropped Jan. 4, 1832, and wis then estimated to weigh 100

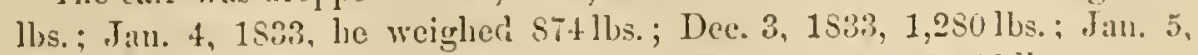
1535, 1,500 lbs.: Dec. $26,1835,2,350$ llis.; F(t). 15, 1537, 2,910 lbs.

In Oet., 1838, Mr. II. endel him, and he was conveyed to IIarford, Conn., and weighed $3,3 \% 0 \mathrm{lbs}$. This steer was bought by Paran Sterens, since of 
great hotel notoriety, and was extensively exhibited in this country as "the largest ox ever scen." Perlaps some persons in this State may remember the exlibition of this mamnoth ox.

In 1840, this great show animal was sent to England for exlibition there, and, it is aaid, attracted much attention. From there he was taken to France and Belgium, and exlibited as the great bullock of the world. He was brought back to England and slaughtered, but his weight at the time, either alive or dead, was not published, bnt it was less in this country tlinn that of eeveral whose weights we liave publishled. This is one of the great show bullocks which have been exhibited and advertised as weighing orer $\$, 000$ lbs., a weight that never las, so far as we have any satisfactory records, yet been attained; and although we believe that $4,000 \mathrm{lbs}$. is abore the limit that can be attained by one of the borine race, we would not discourage the efforts of those who hare made noble attempts to improre this class of livestock, both in form and quality, and who will not be content until the utmost possible limit of weight is accomplished.

The name of Mr. Hubbard's steer was "Olympus," in this country, but in Enrope he was exhibited under the name of "Brother Jonathan." He was of the "native stock," common in New Hampshire; his color a clapple-bay or red, a little changeable in the sun, with white spots on the face and legs.

It is not, however, generally profitable to feed snel great bullocks as we have noticed; but, to see what has been done, it will always be an interesting matter of referenee. So will be the matter we slanll gire in the next eection.

\section{SECTION V.-STATISTICS OF THE NEW YORK CATTLE MARKET.}

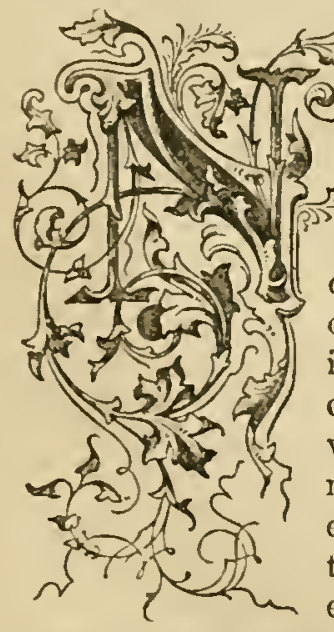

umbers of Butchers' Animals Annaally sold in rew

Tork, - Farmers are very justly accused of a neglect of statistical information in relation to the business upon whieh all their prosperity depends. In the very important matter of fumishing the cities with bullocks, the producers had no means of foming estimates of the needed supply, until we instituted reports of the eattle markets of all the principal eities, and particularly the city of New York, which is an enormous consumer of fresh becf. To this market we have deroted many years, attending almost every weekly market, and liave given the farmers statistical tables of immense ralue to them. We now embody some of this useful statistical information, where it can stand as a lable of permanent reference; and we earnestly commend it to all who are engaged in agrienltural pursuits. 


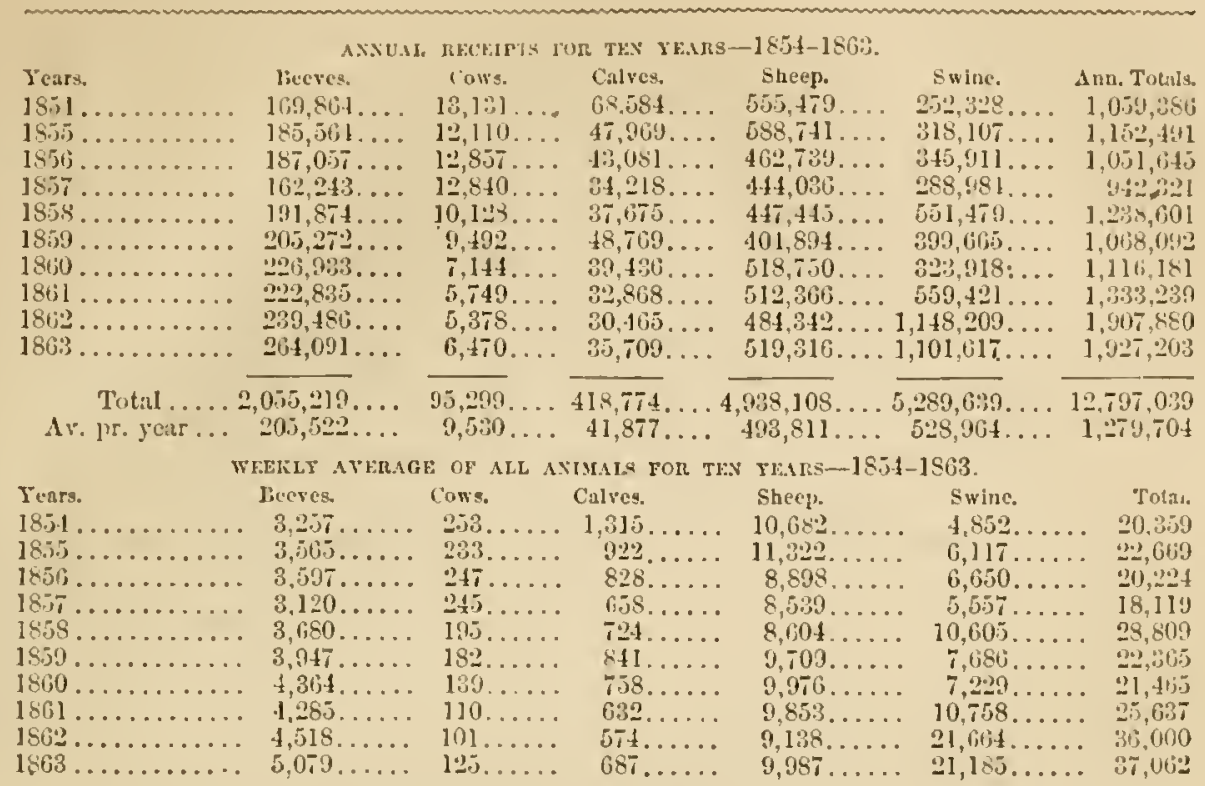

The increase of bullocks in this decade is 55 per ecnt. Cows have fallen of' more than lailf, and calves nearly the same. The supply of sheep remains nearly stationary, but swine have inereased enormously. The following is the estimated number of pounds of meat, derived from slaughtered animals in 1863, and the wholesale valuc. In the estimate, cows are added to the bullocks, because the most of them, eventnally, go to the butcher.

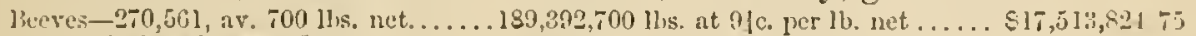

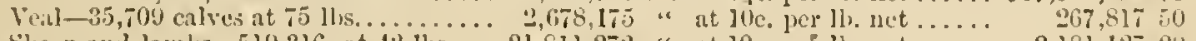

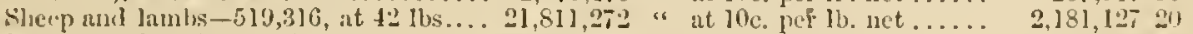

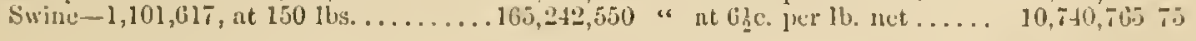

Total ............... 379,124,697 lus. .

$\$ 80,708,53520$

It is also rery important for farmers to know where the supply comes from. Of $2 \mathrm{i} 0,38+$ bullocks sold in 1863 , the six following States funished the respective numbers, viz.: Illinois, 115,692; New York, 2s,955; Ohio, 19,269; Inclinna, 14,232; Michigran, 9,01.t; Kentueky, 6.752. As the same proportion liolds good for all the cattle receivel in New lork, it will be secn that Illinois furnishes $50 \frac{1}{3}$ jer cent. True, a good many credited to that State come from lowa, Missomi, ancl other States.

The proportion of loggs from Illinois is probahly greater than upon beef eattle. The great bulk of pork from the logs slanghtered here is packed and sent to other places for eonsumption; large (plumtities of it to Europe. A small portion of the beef is packed and sent abroad. The great bulk of it, and all the veal and nearly all of the sheep, and a vast quantity besides that eomes in ready dressed from the comntry, goes to fumish firesh meat to the cities of $\mathrm{New}$ York and brooklyn, thee small citics in New Jersey, and sereral towns within fify miles, ships in port, and most of on smed ships

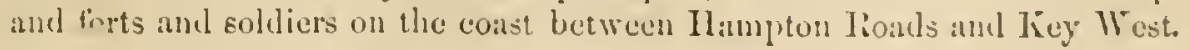


Estimated average price of beef cattle jer net pound cach year, $155+63$ : 1554,9 cents full; 1555,10 conts; $15.56,9 \frac{1}{3}$ cents nearly; $1557,10 \frac{1}{2}$ cents

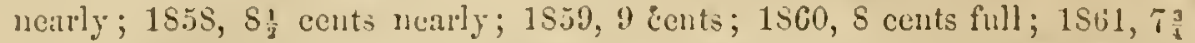

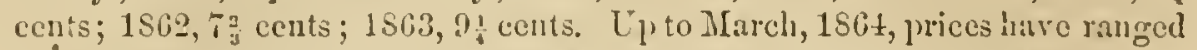
from 2 to 16 cents a pound net, which was higher than belore since $185 \%$.

During 1863 , the live-weight price of corn-fed logs ranged from to to cents per pound. In February, $156 t$, it reached $8 \frac{1}{3}$ and 9 cents per pound, which was the highest juice for W Western stock ever attained.

That all who read this page may see what an immense interest is inrolved in the live-stuck trade of the country with New Iork city, we add the following calentation of number of pounds of uncat and estimated ralue:

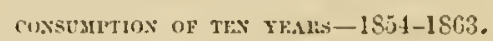

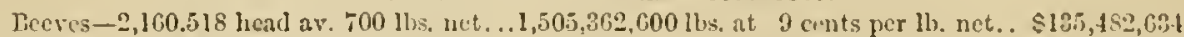

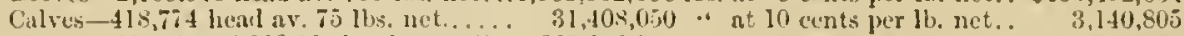

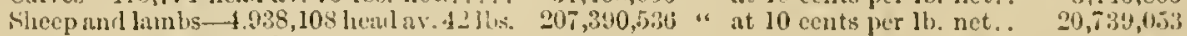

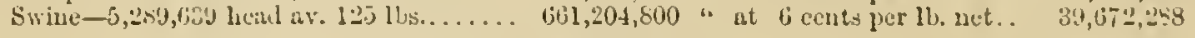

Total..................,

$\$ 199,0: 34,7 \times 0$

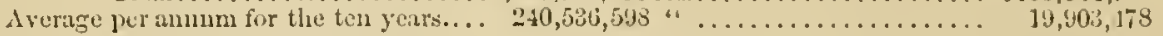

Faners, look at these figures. They teach you an important lesson; one weli worthy of being placed upon this permanent record, to remind you and your childyen of the grent inportance of the live-stock interest of the country. You see by the tables the rapplid increase of the trade, and the enormons smm that it amounts to in ten years. Lest you should be confused by the sum in numerical figures, let us repent it in worls. Tro billions four hundred and five millions three humbed and sixiy-fire thousand nine hurdred and cighty-six pounds of meat, amomting to one huncled and ninety-nine millions thirty-four thousand seren luundred and eighty dollars. This is the sum that New York"eity has dishursed to the farming interest for ten. Jear's' supply of meat, derived from the slanghter of twelre millions seren liumdred and ninety-seren thonsand and thirty-nine animals.

These statisties enable us to realize the rast resources of America. The country is now fecding a million of men in the army, figliting for freedom, full rations of meat, and sending nearly two millions a year of animals to the eity shambles of Now York, for which the city is sending back to the country twenty millions of chollars.

This is the greatest meat-cating eountry in the world; it produces all that it consumes and a great surplus to send abroad.

74. Calle Transportalion.-Nearly all the stock sold in the New York market is transported upon railway cars. We assume that the beeves for ten years' supply liave paid a tariff of $\$ 10$ a lead arerage to railroads, making the sum of $821,505,150$; calves at fifty conts a liead, $\$ 209,387$; shecp it screnty-five cents, $\$ 3,703,6 \$ 1$; hogs at $\$ 125$ each, $\$ 6,612,0+\$$. Total $\$ 32,030,296$, as the estimated amomnt paid for the transportation of animals butehered in New York for ten years.

Improvement is needed in transportation. Animals are forced to stand without food or water two or three days, or as long as their tired legs will 
sustain them, and when they fail, as sometines they do, the fainting creature - falls and is trampled to deatl.

We must have an improsement in cattic-ears. It certainly wonld not be diflicult to construct them so that cattle slould stand with licads to one side, where water could be criven them in a trougl by means of hose; and if this can not be done, it must be made a criminal offense to keep the aninals on a car more than 80 homrs withont water. In fact, it wonld be better for all parties if the number were limited that a cal should contain, and that in no case should the stock remain on the cars over 30 hours, withont being mnloaded, rested, fed, and watered. The present practice is a loss to owners and an injury to consumers, by making the beasts feverish and unhealthy, besides being an outrageous aet of crnelty to animals. The whole community is interested, and should cry out against the wicked practice, which is enongh to make humanity shudder.

75. Comparative Mreasurements of Catte.-Inquiries are often made in regard to the relative size of different breeds of cottle. It is not easy to rive a rery definite answer to questions of this lind ; but as several of the leading breeds of this comntry were derived from Lnghand, where they are bred in greater numbers than they are here, an idea of theil comparative size may be liad from certain measurements taken of prize animals at the English shows. We gire the following tables in reference to Short-horns, IIerefirds, and Derons, which took prizes at the slows of the Iioyal Agricultural Society, in $185 \mathrm{~S}$ and 1859 . The first was prepired for the Society by Mr. liobert Suitly.

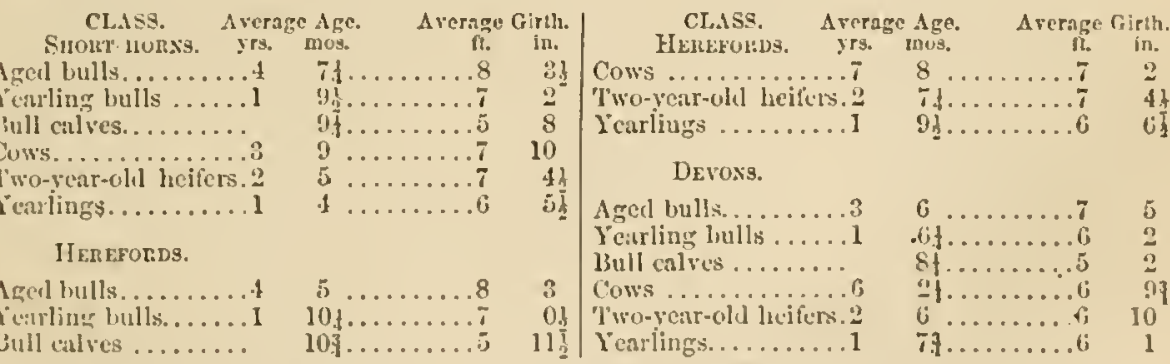

The next table was furnished by Mr. Thos. 1)uekham, the editor of the "Iferl-Book of IIereford Cattle." As fitr as it groes, it comprises mensurements of Short-lorms and IIerefords, which received mizes at the Warwiek show that year, the runk of the awards litving been according to the order observed in the table.

\begin{tabular}{|c|c|c|c|c|c|c|c|c|c|}
\hline CI.ASS. & \multirow{2}{*}{\multicolumn{2}{|c|}{$\begin{array}{c}\text { Avermge Age. } \\
\text { ys. mos. }\end{array}$}} & \multicolumn{2}{|c|}{ A veragu Girth. } & CIASS. & \multicolumn{2}{|c|}{ Average lige. } & \multicolumn{2}{|c|}{ Averagu Oirih. } \\
\hline SHoHt-HORNg. & & & $n$. & In. & IIE⿺𠃊tious & Ps. & mos. & s. & In. \\
\hline Aged bulls...... & $\ldots 4$ & 0. & .8 & 6 & Agerl liulis..... & $\ldots 2$ & 10. & & j \\
\hline " $\quad \ldots \ldots$ & $\ldots+1$ & 8. & & G & " $\quad \ldots \ldots$ & $\ldots 4$ & ti & $\ldots . s$ & i \\
\hline$"$ & $\ldots$ & 7. & & 71 & " $\quad \ldots$ & $\ldots$. & $10 \ldots$ & $\ldots .8$ & \\
\hline Fearling bulls... & $\ldots 1$ & 10. & .7 & 7 & learling bulls . & $\ldots 1$ & !. . & .7 & \\
\hline $\begin{array}{lll} & \ldots\end{array}$ & $\ldots 1$ & 8. & & 2 & ". & $\ldots 1$ & $11 \ldots$ & $\ldots i$ & \\
\hline " & $\ldots 1$ & 11. & $\ldots 7$ & 1 & 4 & $\ldots 1$ & $\because \ldots$ & $\ldots . .7$ & \\
\hline Bull calves.... & & $\because$. & $\ldots 5$ & $2 t$ & l'ull crlves ... & $\ldots$ & 11. & $\ldots l i$ & \\
\hline " $\quad \ldots$ & & 10. & . 6 & $\ln 1$ & แ $\quad \ldots$ & ( & 11. & $\ldots \ldots t i$ & 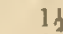 \\
\hline Cows........... & $\ldots 4$ & 8. & $\ldots .8$ & $0^{2}$ & Cows.... & $\ldots 3$ & $7 \ldots$ & $\ldots . .8$ & \\
\hline
\end{tabular}


76. The Improvement in Breels and Weights of Cattle.-What lias raised the average weight of beef cattle from 500 to SuOlbs., and some individuals up to $3,600 \mathrm{lhs}$. What has raised the crops of corn to double their former yield, and in several instances produced orer 190 bushels of corn to the acre -that was in Fentucky; but in the State of New. York whole fields lare averaged 100 bushels. In Connecticnt, $13+$ bushels of curs of corn have been produced upon half an acre, ut an expense for culture and havest of less than \$3. What has indueed men to root up old orchards of natural nouit, "five to the pint," and plant pippins, baldwins, greenings, russets, etc., some of which have been sold from $\$ 8$ to $\$ 20$ a barrel, and retailed at a gninea a dozen? What has induced ingenious men to derote the best energies of their minds to inventing plows, harors, drills, reapingr-machines, and every other implement of husbandry, while every class of domestic animals has also been improved-neat cattle probably the most of all?

The answer is, the publication of just snch facts as we are now giving, which tend to show what has been done by some men, and may be done by others. This encourages us to continue our labor.

\section{SECTION YI-FEEDING CATTLE AND CARE OF FARYI-STOCK.}

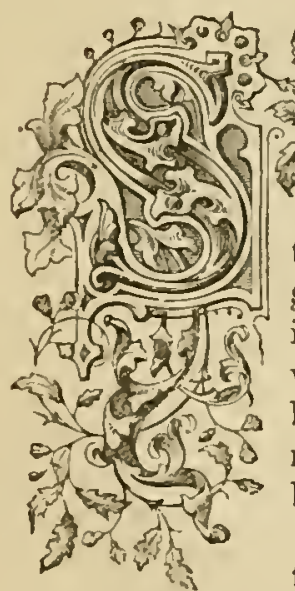

fy $\gamma$ electing falres for Rearing. - Use judgment in selecting such heifer calves as are to be reared. Select only those whose mothers are good milker's, and whose sires have come from good milling stock; at the same time, the calf itself should have those charneteristics that indicate an aptitude to develop good milking qualities, riz. : small, fine head, rather long in the muzzle; bright eres; thin, tapering neck; small, well-shaped legs; long body; large hind quarters, set wide behind; soft skin ; fine hair-the color of which is immaterial; and, alove all, the milk-mirror or udder-reins should be large and well developed.

The raising of bull calres for breeders had better be left to those who have time and means to derote their attention to it, who procure the bcst animals to begin with. It rould be no loss to the conntry, were the numerous specimens of scrub bulls, too often seen, condemned to perpetual exile.

Int there is no reason why a portion of the male ealves, at least, should not be reared as bullocks, either for the team or the butcher; and it is important that such as are reserved for this purpose shonld possess certain points indicative of future excellence, riz.: well-shaped head; small cars; slıort, thick neck; deep brisket; broad chest and shoulders; fine bone; long 
body, well rounded behind the shoulders; straight back; wide loins; full quarters; tail thin and tapering; skin soft, and not too thin.

It is too often the case that animals are selected for rearing from being of pretty color-that takes the fancy of some nember of the family-or the calf of some pet cow of the dairy-maid, without attention leing paid to its promise of excellenees. Not unfernently raluable calves are tattened for real, simply becanse their color is unpleasing to the eye.

This is about the most important branch of the stock-raiser's business. Too many persons pursue the careless mode of the person who wrote the following item:

"In the spring of $1555 \mathrm{my}$ two cows had bull calves, which I determined to raise for sale, and so gare them a good chance to grow, adding an extra in the shape of a liandtul of barley meal, with their feeds of milk. They grew finely, or rather Bobby did, for Billy, taking a sudden dislike to sour milk, had rather slim ratious for the last six weeks before weaning. I told him lie might starve if he liked, and took no special pains to humor his fancies. In September I land an ofier of 86 for Bobby, and coneluded to let him go, but the buyer was behind time about two wecks, and thought. the additional leeping worth nothing, so I did not tum him off. So, of course, Bobby was kept, and grew uj to propagate the race of Bob calres."

78. Calves-Give them Shelter.-It is almost impossible to winter calves withont shelter; if they survive the winter, they are mere skeletons, and have to be lifted up betore spring, and nerer make anything but poor, rawboned, unprofitable stock. Sheep are many times allowed to pick up what they ean get for half the winter; but the dead lambs, and probably dead slicep, that lie scattered orer the fields, tell the profit of such a course. When protected, all food not required to maintain the natmal waste of the system goes toward inereasing the growth of the animal. To obtain perfeet form, animals should be kept continnally growing until they arrive at matmity. They are often turned out in the spring so poor that it requires lalf the summer to make them as good as they were the fall before-il loss of three quarters of the year in the growth of the animal. A grazier lately said to us, in speaking of such a lot of eattle that he bought, "It took the whole summer to soak tlieir hides loose, so that they conld begin to grow. They seemed as hard and dry as a pair of old boots, and in some spots as destitute of hair."

79. Training steers-At the Mrane State Fair, a boy of fifteen years, from the town of Woodstock, had a pair of threeyearold steers, which obeyed him as an obedient boy will his parents. Iy a motion of his hand they would go forward, halt, and return, go to the right or left, kneel down, and perform other things, mueh to the surprise of some older farmers, who are in the habit of putting the brad through the hide. At a New York. State Fair there was a perfeet liarey of an ox-tamer, who practices loreaking sicers for farmers, and as he never treats them inlumanly, he soon has them under perfeet control, and as bidable as well-trained cliildren. 
So. Cnruly Animals. - As a general rule, our domestic animals are never mmly, exeept when taught to be so. For instance, some persons, in turuing stock from one field to another, only let down a tew of the top rails or bars, and foree the animals to jump orer. Too lazy to put up as well as to let down, they leave the gap lialf elosed, as a temptation to the stock to jump back again. A few practical lessons of this kind make stock muruly. Carelessness in regard to putting up fences when thrown domn, or in repairing weak spots, confirms the habit. A witer Eays his practice has almays been to teach his cows, calres, slieep, aud hogs to go through or muder, ratler than orer, the bars or fences, always leaving a rail or bar up at the top. Tauglit this way, they never think of jumping, and he las nerer been troubled with unruly animals, even when lis fences were low.

81. Kinduess to Brutes.- To man ean afford to be nnkind to his domestic animals, beeanse animals which are treated the most kindly are the most gentlc and obedicnt, and also thrive the best; lience, no one can ufforl to use them mkindly. By kindness, mingled with fimnes, the most ferocious animals are subdued, and it is vain to smpose that the same means wonld not be effectual in training domestic amimals. Surely, no one should degrade limselt by continuing a practice which is both unprotitable and inlumana practice that makes man the brute instead of the quadruped. There is no cconomy in half starving any stock through the winter, and cansing them to take all the storms withont auy shelter; but, on the contrary, it is a clear waste and loss to the owner.

82. Shalter for Cattle.-Next to the neecsity of an adequate supply of food for stock, comes the importance of shelter. It needs 110 argument to prove the truism that animals ean not live vithout food; and it is just as certain that our domestie stock, artificially susceptible to the storms and ebanges of our Northern climate, can not thrive withunt proper shelter. It secms now to be well settled, that a due degree of wamtl is equivalent, in a measure, 10 food; and we all hnow that an entire abundon to ease and comfort, while in a state of rest-a perfect fieedom from appreliension of any kind, which may arise from a lack of food, or from exposure, or any other eause-is necessary to the maximum of thrift or uscfulness.

On old, improred, rich lands, it wonld be policy in the famer to stable or yard lis cattle and horses during the whole year ; but I should prefer yarding in the summer senson, as more air and room for exereise would be allowed, both of which rould be condueive to the health of the animals.

One acre of land, in good condition, sown to corn, and cut and fed from the time it begins to tassel until it begins to glaze, will keep six lead of catlle during the time, and perhaps more-say tro months-while it would have taken six acres of pasture to keep them the same length of time.

On farms where the pastmre is generally the ronghest, poorest part of the furm, and that which conld not be applied as profitably to otber purposeson such lands the cattle must be allowed to get their own living in summer.

The above are excerpta from sereral cxcellent essays in the Genesce 
Furmer, and miglit have been much more extended, only that we have a great many other good things to glean from other sourees.

S3. Straw for Caltle-Mr. Johnson says, in a letter to the Genesee Famer: "Yon say that I put straw in my boxes for my cors. This is mot so. No man ever saw me feed straw to cattle, at least for the last twenty-five years. If they clioose, they can eat the straw spread out for litter, but I never compel them to eat straw. I know cattle can be fatted on grain and straw, but $I$ don't thiuk so profitably as part grain and part hay, or part oil-cake and part liay. Grass is tlic natural food of slieep and cattle; and hay made fiom girnss, if properly made, puts on fat, eren if very little else is fed. I am satisfied that either cows or fatting eattle do mucl better in yards, with ample slieds and plenty of straw for clean, dry beds. I can not feed any hind of stock profitably muless they liare such beds."

St. Wintering Catte.-There is yet a good deal of wisdom to be learned upon this sulject, eren by those whose tall is of bullocks, and particulanly in wintering calves. The one great error is in neglecting them in antunn, after the frost has destroyed the sweetness of the grass, and allowing them to commence getting poor before winter feeding is commenced. There is no error mole fatal to success than such neglect. It is often the foundation of discase that the animal nerer recovers fiom. There is no condition so good for an animal going into winter quarters as a thriving fatuess; and if that can be kept up till mid-winter, the danger of starvation upon rery light feed in the spring is greatly diminisled. It is one of the worst things in all farm economy to neglect feeding stock in the fall, becanse it is not yet time to begin to fodder. Jou lad better begin in July, if your pasture fails, so that your animals begin to lose flesl. All that is sared of fodder in the fall, "pon the plea that "cattle can shift a while longer," exactly rerifies the old saw about "saving at the spigot and wasting at the bung."

S5. Fecling Pumpkins -1 subscriber sends a long communication against fecling pumplins to cows. The writer's reasoning is not entirely sound, and does not agree with om own experience and observation. As a general rule, we are quite sure that pumplins increase rather than diminish the quantity of milk; and instead of making nent stock grow poor, we liare fattened large numbers of eattle on pumpkins alone. 'There is one suggestion in our correspondent's letter, howerer, which may be worthy of attention. IIe refer's to the fact that the seeds of pumpkins have a decided diuretic (unineproducing) eflect upon the luman organs, and that if they lave the sanie effect upon cows, the execssive flow of urine must necessarily reduce the flow of the milky fluid. II adrises that when pumplins are fed, the secls slould be taken out. The idea is jlansible, and woril being acted on.

86. Kecping Stock Warm, and Varicty of Food,-Man eraves a viniety of food ; that is, a raricty of substanees, either one of which would sustaiu lile: lut would not be satisfitetory. Nature demands the rariation, and the mixing together the several sulstanees. Why? Simply hecause no one will give all the elements that go to make mp the animal cconomy. One article 
furnishes pliospliate fur bones, which amother article is destitute of, yet it may contain matter that will clothe the bones with muscle. Food that contains neither fat nor suga will be foumd sufficient to keep up the animal heat. Food that contained all the elements of bone, muscle, fiber, fat, and heat-producing qualities, might be so eoneentrated as to be muliealthy.

$\Lambda$ man fed mon pemmican, would have a disposition to cat straw, husks, and twigs, or guaw the barli from trees, to gret something to distend the stomach and enable it to perform its funetions liealthily. Let this be thonght of in feeding domestic animals. It rill furnish an easy rule for your guidanee. Julge them by yourself, and act aecordingly; you will find it an easy and sure road to suceess. The do not for animals, quadruped or biped, recommend a variety of food at the same meal-only a ehange from time to time, so as to gire rariety, and consequently all the elements necessary to produce growtl.

- Never negleet to give your eattle water until you learn to do without it yourself, and never offer them drink where you would romit if compelled to slake your own thirst.

Nerer leave a horse, a cow, a shecp, ont in a cold winter storm, until you arrive at that condition of unfeclingness that you could endure it yourelf. When you think you could find comfortable shelter under a.common rail fenee, you may leave your cattle there. No domestic animal can ever reach the higliest state of perfection its nature is capable of mless always kept in a healthy, crrowing condition, in an equable climate, or in warn shelter it the inhabitant of a cold one.

Farmers do not pay suffieient attention to the warmth of their stock, but suffer them to roam about in the open air, exposed to the inelement weather. The amount of exercise is another most important point to attend to. The more an animal moves about, the quicker it will breathe, and the more starch, gum, sugar, fat, and other respiratory elements it must have in its fool; and if an additional quantity of these substances be not giren to smpply the increased demand, the fat and other parts of the body will be drawn upon, and the aninal will become thinner; also, as before observed, every motion of the body produees a corresponding destruetion of the muscles which produee that motion. It is therefore quite evichent that the more the animal moves abont, the more of the heat-produeing and flesh-forming jrinciple it must receire in its food. Ilence we sce the propricty of keeping our cattle in shects and yards, and not suffering those (particularly which we intend to fitten) to rove about, consuming more food, and wasting away more rapidly the various tissnes of the body already formed, and making it more expensive and difficult to futten them.

8. Fattening Cattle upon Ilay.-Speaking upon this subject, a committee of the Massachusetts Beard of Agrieulture, of which John Brooks and Paoli Lathrop are members, remark:

"Fattening cattle in winter upon hay alone is a resort of many farmers, and where hay is plenty and distant from market, the practice is not incon- 
sistent with ceonony. If well attended, good animals consuming four per ecut. of their live weight of grood hay daily, will gain daily two ponnds of flesh. Suppose the flesh grained to be worth 16 eents, it will be equal to $\$ s$ a ton for the lay. The better praetice, however, is to give only three per cent. of the live weight of the animal in hay daily, and an equivalent for the other one per cent. in Indian meal or loots. The gain wonld be greater for the same cost of food."

Another remark wortl quoting is the following:

"The best age for feeding cattle for beef is from four to eight years. Toung growing eattle may be fittened, but it will require more food in proportion, and longer time."

SS. How to leed Roots.-There seems to be much diversity of opinion as to the value of turnips, earrots, etc., for feeding. One man feeds lis liogs a great amount of them, but neglects to provide a bed secure from the intrusion of cold winds and snow, and then wonders they do not grow; or feets a cow four bushels per day, and wonders she does not fat. How could she? She is almost pliysicked to death, and her urinary organs are injured by over-exertion; and although she is thoroughly littered with straw, still her feet are in the water; and when she lies down, her side.is wet.

After many trials in a similar way, many liare cone to the conclusion that root feeding is an mprofitable bnsiness in our elimate. It hogs must sleep in snow-banks, give them corn by all means, and give them plenty of it. It" cattle can not be stabled, or kept so sheltered that they may be dry, then roots will not give one lialf the return they wonld under a judicions systen of management.

Ifter many trials of fattening sheep and homed cattle, and feeding store stock of all kinds with roots, I eame to the conclusion that they are all valuable when properly fed with hay and grain, but that their relatire ralue to grain is often overated in this country of cheap corn. Roots, unless cooked, are not economical food for swine.

The great error in relation to feeling roots is, that they are too much fied to the exclusion of grain. I farmer lias shoats to winter, or lorued cattle to fatten; he first feeds his turmips, cilrrots, beets, small potatoes; rext his corn or meal. This is wrong. 'The corn slionld be fed from the first. A dozen slioats of 100 lbs. each would profitably receive a bushel per day of roots, if cooked with com. A fiuttuning ox should have one binshel, or not over two, per dity, with six or eight quints of meal. Cows should have one halt bushol per day, whetler being milker or not. That amount will bring then ont, in the spring, fit and realy to do grood service at the pail, provided, of conrse, that they have hay and stalks in dne proportion. Calves and yearlings should always have one fourth bushel per day, with a very small allowance of graill.

The above is partly from the Stock. Foumal, and the following from the Torling Fermer; botls of which are good anthority.

Wo beg agrain to remind our leaders, particularly those who are engraged 
in dairy and stock farming, to appropriate a full amount of land to rootgrowing. Carrots, beets, turnips, larsucps, may all be raised with profit whererer stock is to be fed. For liorses, carrots are invaluable. For milch cows, they not only furnish a milk of superior flavor, butter of fine color and odor, but, when used as a portion of their food, they guarantee a healthful condition. The power of the peetic acid of the carrot to gelatinize all vegetable matter held in solution in the stomach, puts its contents in such a condition that the peristaltic motion of the intestines ean manage it. Flatulence is prevented, and thorough digestion secured. The dung of the horse fed partly on currots, nevel contains the undecomposed shell of the oat, nor large amomts of starch unappropriated; and it is for this reason that a bushel of oats and a bushel of carrots will do more for the horse than two bushels of oats; and not because the carrot contains as much fleshmaking matcrial as the out, but becanse it causes all the flesh-making material of the oat to be appropriated, instead of being roided with the excretia. For cows and oxen, other roots may occasionally be substituted with profit, as varicty to all animals is pleasing in their food; and no one root should be so contimuously used. Since the introduction of pulping machines, pulped roots mixed with ent hay, cut straw, and other chcap material, add much to the economy of the farm as well as to the health of the eattle.

s9. Feeding Linsecd and Cotton-sced 0il-Cake-Nerer having had persomal cxperience enough in feeding oil-cake, having always preferred colnmeal, to gire an opinion which we would ask others to rely upon, we select the following from a lecture by Prof. Vockeker, before the meeting of the council of the Royal Agricultural Society of England, in Junc, 1S60. It is worthy of attention from all cattle-fecders. He says :

"It is not my object, in giving a practical tum to the lecture to-day, to record any experiments of my own, or in any way to presume to teach the feeler of stock in what way he may best expend his money in the purchase of food, but I shall endeavor simply to give to the practical man some indications whereby I hope he will be enabled to form for himself a trustrorthy opinion respecting the relative value of difierent eakes, and likewise what is perhaps of more importance to him, to introdnce some remarks which will cnable him to distinguish a good from a bad cake; and in conclusion, shall allude briefly to the various substances with which oil-cakes are at the present time often largely adulterated.

90. Fat in Food.-"Let me first point out to you some peculiaritics in the composition of oil-cakes. A reference to thcir composition is necessary to the understanding the remarks which will follow. I would then obscrve, that what characterizes oil-cakes, distinguishing them from all other artieles of food pre-eminently, is the large amount of oil that is left in the cakes, obtained by cxpression of the oil-sceds. If you glance at the diagram (see table on page 71), you will find that they contain a considerable quantity of oil-from 6 to 12 per cent.; and in some instances, as in the decorticated cotton-cake, even 16 per cent. of oil. I may obserre at once that the value 
of oil-cake in a very great measure depends upon the amount of oil which is left in the cake. And I may further say, that the tendency of the manufacturer at the present day is to produce an inferior description of cake, inas much as improved machinery enables him to squeeze out more oil than formerly, and thus to render the refuse less fattening, less valuable to the feeder of stock. I am very much inclined to believe that the oil is by far the most valuable constituent of all oil-cakes. I am aware that it was the fashion, not many years ago, to measure the feeding properties and cven the fatteniug qualities of articles of food by the amount of nitrogrenous or fleshforming matters; but these views are not supported by any practical experiments, nor, indeed, by the every-day experience that we liave respecting not only human, but cattle food. We pay more for food rich in starch, mucilage, and matters eapablo of prodncing fat, than we pay for food which, like bean-meal, is extremely rich in nitrogenous matter, bnt which does not produce so much butchers' meat. It is a matter of much importance to the farmer to know how mneh he gets back for the money he expends in the purchase of food. I have no liesitation in saying that more money is made by the purchase of food rich in oil, starch, or sugar, than in the purchase of food which contains an excess of nitrogenous matters.

91. Flesh in Food.- "Still, we ought not to leave umoticed that the flesh-formfig matters are ver'y important indeed, and that oil-calies are peculiarly rich in them. In one sense they are perhaps most essential-perlaaps even more essentially necessary than the cther constituents of food which produce fat, or are employed in the animal economy to keep up the animal heat. They are more important in this sense; whereas the animal organization has the power to make fat from gum, sugar, mucilage, and even from young cellulose or young regetable fiber, it has not the power of making a particle of flesh. Unless, therefore, fool is given to animals which contains ready-made flesh, an animal can not grow, and the other constituents of food remain unavailable. It is in this sense that the nitrogenous matters of food are extremely valuable; but in a purely practical sense they are not so valmable as the oil, stareh, or sugar of fond, hecause by spending a ecrtain amount of money in food, we do not get so great a return in the shape of butchers' meat by purcliasing these flesl-forming matters as by purehasing feeding substances rich in oil or starch. Iowever, in speaking of the relative value of the various constituents, especially the oily and the flesh-forming constitnents, we are not to overlook that the quantity of nitrogenous matter which is not applied for the formation of flesh, passes throngh the animal, and is obtained again in the dung, with the exception of a small quantity that escapes by evaporation through the sliu or through the lungs. A certain quantity of nitrogenous fool evaporates through the skin, or with the perspiration; but by fir the largest proportion, according to some experiments, nineteen twentieths, of the flesh-forming or nitrogenons matters of food are found argain in the dung; acconding to others the amount is seven eighths. But, speaking in round numbers, I think we are not fur wrong in saying that 
we may fairly cxpect three fourths of the nitrogenized matters of oil-cake back again in the manure; and perhaps we are safe, likewise, in asserting that fully one half of the money value of rape and the best cotton eakes is obtained back again in the manure. So we must not put down these constituents, which are called nitrogenous, as uscless, because they alone do not produec much butehers' meat; nor must we estimate the value of oil-cake entirely by the increase in the live weight of eattle fed upon the eake, but also, and ehiefly, I believe, by the increased value of the manure which is produeed through the instrumentality of oil-cake.

32. Bone in Fool._- "I will now direet attention to the inorganie matters or asl of oil-eakes. These inorganic matters may be called bone material; for the ash of oil-calies is particularly rich in phosphates of line, or the material of which the greater part of the bone is composed. Now, the large proportion of oil ; next, the large proportion of flesh-forming matters; and third, a considerable proportion of bone material are characteristies that confer a particular value upon oil-cake, either directly as food, or indirectly as nseful material for increasing the ralue of farm-yard manure. For let me observe, that oily matters and substances that make butchers' meat are the most valuable constituents in all fecding materials, and therefore also in an oil-cake. On the other lrand, the flesh-forming constituents and the boneforming materials - in other words, the nitrogen and the phosplates of the cake-are the two most raluable fertilizing constituents. We hare thus in oil-eakes, in a concentrated state, materials that produce butelers' meat, and, at the same time, yield the most valuable fertilizing constituents. 'There is no other deseription of food which unites these useful properties.

93. Linseed-Cake.-" Ton are all aware we distinguish chiefly the following liuds of linseed-cake: English cake, American eake, and foreign cakes. Among foreign eakes there are rarious descriptions. There is the Baltic, the Marseilles, the Naples eake, and various others. We have here an exeellent specimen of good English eake. The English eake is made now of two qualities, thick and thin cake; the latter is made in imitation of the American barrel cake; of which specimens are before you. Iou observe how closely the thin English cake resembles the Ameriean barrel enke. The latter has gained much faror, and tlerefore the manufacturers in England lave found it to their advantage to imitate the form in which it is sold. In the first place, notice tluat the American cake occasionally is as bad as English and foreign cakes. It is not erery description of American cake which is good, but generally speaking, as it comes into the market, especially the barrel eake, it is of a very superior character. But the question whether it is generally superior to the English eake or not, is one which is not very readily decided; yon may get English cake quite as good, if not better, than the American eake.

"Some rears ago it was the fashion to buy the English cake in preference to any otlier, but it is now the fashion to buy the American barrel cake. I can only account for this by the fact that the English cake, being produced 
in good quality, was rapidly consumed; the American cake was usually sent in a very damaged condition to this country, coming as it did in bags; oul sharp Anerican friends rery soon found that they must send their eake liere in a good condition. They dried it previously to sending it orer, and imported it in barrels, and this improved condition of the Ameriean cake greatly increased its reputation, which lias been kept up; so that at the jres ent time in most markets, American cale, especially tlie barrel cake, fetelies a higher price than the English. But a reference to the diagram will show you that there is no essential difference between good English calic and good American; indeed, if anytling, the adrantage is in faror of the specimens of English cake. The difference is extremely small. There is the same quantity of oil in both cases. The proportion of flesh-forming matters is rather larger in the English than in the American. There is the same amount of ash in both. The proportion of sand liardly amounts to one per cent. in the English cake, and in the American it is only a lalf per cent. These differences are extremely small and mimportant, so that you may get, and often do get, as good English cake as American. And occasionally, also, you get bad American cakes; but on the whole, the exporters of Anerican cake are very jealons as to the kind of article they send to this country, especially if they go to the expense of packing it in barrels.

14. Cotton-Cake.-" We distinguish now prineipally two kinds of this cake -the one made of the whole seed, and the other of the shelled seed. The difference in the two qualities of eake will at once become intelligible by: an examination of the seeds, or the raw materials from which the calies are made. The decorticated or shelled cake is made of the kemel of the cotton seed; the whole cake, in which we recognize an abmelance of the husk, is made of the entire seed; and inasmuch as the cotton seed contains fill half its weight, and some descriptions contain as much as 60 per cent. of the hard husk, we must not expect that the cake made of the whole seed should be so valuable as the decorticated cake. There are several specimens of cottoncalie on the table. There is rery little ralue in the lusk itself; the difference in the two kinds of cotton-cake, then, arises from the different mode in which they are made. The one, the decorticated ealie, is malle from the kernel; the other kind is male from the wlole seed. The difference in the composition of the two kinds of cake is very great. The decorticated cotton-calie contains 16 per cent. of oil (more than any other leseription of cake), while the whole-seed eake contains only 6 per cent. The proportion of albuminous or flesl-forming matters in the decorticated eake amounts to 41 per cent.; in the whole-seed cake it is only 23 per cent, or just onc lialf. So with respect to the other constituents, the proportion of wondy fiber is rery mucl larger in the whole-seed cake than in the other. The lusk in the wholeseed cake for a long time was a great impediment to the general nse to which cotton-cake is now applied in this comtry. I remember when the first eargocs of colton-cake came into England, before the decorticated cotton-cake was known; trials rere made of it, which provel quito unsuc- 
cessul. People did not like it at all, and I believe the cotton-cake wonld never have been extensively used if it had not been for the invention of a very useful machine, patented in America, by means of which the hard husks ean be remored from the kernel. The nse of this inachine gives us a superior oil and a superior cake. The cotton-seed oil made from the keruel alone is a very useful article, and so is the cake, whercas the oil expressed from the whole seed is dark-brown in color, and can not be used except for the commonest purposes for which oil is employed. The difference in the value of the two descriptions of cake is so great, that I almost think two tuns of the oil-cake, male of the whole seed, do not go further than one tun of the best decorticated cotton-seed eake. Moreorer, there is a eertain danger in using the whole-seed cake. Sereral cases of so-called poisoning liave been brought under my notice within the last year or two. Animals that have fieely partaken of the whole-seed cake have died suddenly, and people have imagined that there was something injurious in the husk; but examination has shown that the effect produced is very much like that which is occasionally produced in the case of boys who die from inflammation of the bowels in conntries where cherries are rery abundant. Being rery greedy, and eating the cherries with the stones, they get a stoppage of the bowels, and so die from inflammation. There is nothing poisonous in the husk of the cotton-seed, and when given judicionsly, no injury will result; but if animals are supplied witl an unlinited quantity of dry food with the whole seed, there is indeed a danger. The hard lusk is indigestible, and may roll together in such large masses that inflammation of the bowels will ensue. There is no such danger, however, in the use of decorticated cottoneake. The deeorticated cake occurs of varions degrees of quality. And allow me to observe, with respeet to all kinds of cake, that not only the eomposition, but, even in a higher degree, the condition of the cake, determines in a great measure its value. I lave here a specimen which you would hardly recognize as of the same description as anotler specimen also on the table, of a very beantiful character; it is the same kind of cake, only it is in a bad condition. I say, then, the condition of a calie determines everything.

95. Condition of cake._- "Sonne time ago I was very much gratified in finding what great eare Mr. Stratton, of Broad Hinton, a celebrated shorthorn brecder, takes in sclecting the very best of American burel cake for his stock. We often forget that animals hare appetites as we have, and that they like food in a good condition better than food in a bad one. The composition of two samples of the same food may not vary much, yet the practical effect produced by them may vary exceedingly. There is nothing remarkable in this, for we know that if we get good, wholesome bread, which is one or two days old, we do well upon it; but if it remains in a damp cellar and gets moldy, stale, and moist, it loses its fine flaror, and in this condition may do us harn. So it is with stale, moldy calies. Animals never do well on very old cakes. In examining, therefore, the different 
calies, we ought to examine particularly their condition. I allude especially to the exanination of cotton-eake, becanse every person has the means of exanining its condition with very little trouble. It is not so casy to exannine the condition of linseed; it presupposes an extensire acquaintance with various descriptions of linseed-cake. You must have seen a great many samples of cako before you can give a trustworthy opinion. Not so with decorticated cotton-cake. In this the color affords an excellent criterion as to its freslness. The freshest cotton-cake is as yellow as mustard. I loold a piece of cake in my liand, the exterior of which is brown; but if I cut away a portion, you will observe that the interior is bright yellow-very different from the part that has been exposed to the air. This was an excellent eake when we first got it for feeding purposes, and we are feeding it extensirely on our farm at Cirencester. When we first liad it, it was of a bright yellow color; but you observe low it has since changed. From this we may lean a very useful lesson, that we may take the color as a guide to the condition and age of the cakes. If we are presented with a cake which is as browu as the specimen before me, and if you find on cutting it that the brown color has penetrated deep into the interior, we may at onee conclude that it is a stale old cake. The deeper it has penetrated, the older the cake, and the more it las suffered by bad keeping. If it is kept in a damp place, its color and condition are rapidly deteriorated.

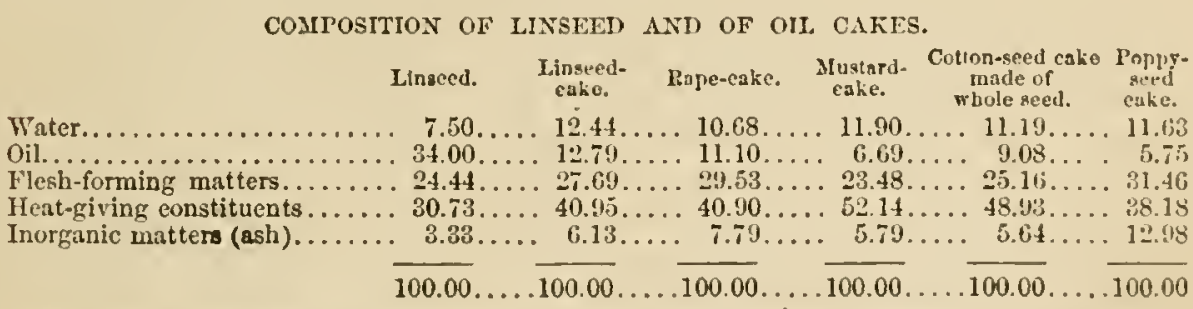

96. Salt for Stock,-A great deal lias been written "ypon the use of salt for animals, and much reasoning employed to prove various positious; but very few accurate experiments have been made. Loose and general observations have been the basis for most of the opinions formed. $A$ certain quantity of salt is unquestionably useful; an excess is as certainly lurtiul. The proper amount is what we want to have determined. All ordinary food of auimals contaius more or less salt-as, for example, a tum of barley or oats straw, and of some kinds of hay, contains six pounds of salt; a tum of carrots contains four pounds. We cam not, therefore, speak of animals eating no salt - they all partake of it, but we wish to know the right quintity.

The Genesce Farmer, from which wo have frequently extracted useful facts, and to which we are indebted for the next half dozen, says of Ealt fol cattle feeding for the shambles:

"We have lıad our cloubts wlyether it was good economy" to allow animals feeding for the butcher the free use of salt. Salt is donbtless conducive to liealth, faroring the formation of bile, and aiding in carrying effete matter 
from the system; but there is no reason to suppose that it favors the acenmulation of fat. Liebig, indeed, asserts that 'the absence of common sult is farorable to the formation of fat', and that the 'fattening of an animal is rendered impossible, when we add to its food an exeess of salt, although short of the quantity required to produce a plirgative effect.' liccently, lowerer, in allusion to experiments male since the publication of the work in which the above sentences occur, Liebig says: 'Salt docs not act as a producer of flesh; but it nentralizes the injurious actions of the conditions which must be united in the umnatural state of mimals fed or fattened in order to produce flesh; and the advantayes attending its use can liardly be estimated too highly.'

"Poussinganlt is also in faror of salt. Two lots of steers were fed thirtecn months, one with and one without salt. The arerage weight per head of the salted lot, at the commencement of the experiment, was $995 \mathrm{lbs}$; at the end of thirteen months, 2,090 lbs. Increase, 1,135 lbs. They consumed per. hend $15,972 \mathrm{lbs}$. of hay. One tun of hay, therefore, produced $143 \mathrm{lbs}$. of increase of amimal.

"The second lot, which received no salt, averaged at the commeneement of the experiment $\$ 96 \mathrm{lbs}$; at the end of thirteen months, $1, \$ 90 \mathrm{lbs}$. Increase, $994 \mathrm{lbs}$. They consumed per head 1t,553 lbs. of hay, or one tum of hay produced 137 lbs. of increase of animal.

"The stecrs receiving salt produced six pounds more increase for ench tum of hay consumed than those which were not allowed salt. This nay be considered oulyoa slight advantage, and in France did not pay tlie cost of the salt; in this comntry, howerer, where silt is mucli cheaper, its nse will doubtless be profitable. Bonssinganlt remarks: 'The salt excreises no considerable influence on the growth, yet it appears to exert a benefieial eflect on the appearance and condition of the animal.' Up to the first fourteen dass no pereeptible difference was observed between the two lots; but in the course of the month following, the difference was visible, even to the unplracticed cyc."

With such good authority, it is presumed feeders will continue the nse of salt; lnt let us give them this one word of caution-do not gire it in excess. If you can not get rock-salt, or if that is too expensive, mix fine salt with soft clay, and diy that in large calies, and lay them under corer for the cattle to lick.

97. Rock-Salt. We reiterate that rock-salt is not only the most cconomical, but the most conrenient for the farmer to salt his cattle, since it ean be placed where they can lick it at their leisure, and there it will remain, smmuner and winter; the rains have very little effect npon it while in a lnmp, as it comes from the quarry, it being really what its name indicates, a picee of rock. When broken fine it dissolves easily, but not before.

A farmer who has the least idea of cconony should learn how much he can sare in a year, or a lifetime, by the simple operation of substituting rocksalt in place of that in ordinary use for farm-stock. A lump of rock-salt 
may le placed in any ont-door situation, whele cattle ean go and lick it whenerer their appetite inclines them to do so, and it will not waste by exposure to dew or rain, leeause it is not hygrometric, as is the manufactured salt in common use. Another thing in its faror is this-your stock, with salt always before them, will nerel eat too much. Neither will they eat it too fast, as they almost always do when salted with fine ealt; nor waste it by scattering it in the dirt, or leaving it to dissolve and sink into the earth. Another difficulty is obviated by the rse of rock-salt coustantly within reach of stock, and that is, the hooking and punching of the weaker animals by the strong ones, in fighting their way to the once-a-week, or periaps oncea-montl, salting-place.

Rock-salt is a mineral as mnch as marble, and almost as solid and hard, and is quarried out of mines, like coal or other mineral substanees. The most extensire salt mines are at Cracow, in Poland, where there are regular cartways, streets, and villages of miners' huts, where men, women, and children, and donestic animals live deep down in the earth. Our principal supply of rock-salt comes from Cheshire, England, where there are extensire mines. In its mineral state, the salt is of a slightly reddish color, and dingy white, and some of it needs to be melted and pmrified for culinary purposes. The purest portion may be reduced at once to powder by brealing and grinding, and is then quite white. The salt lnown here as Liverpool salt is refined rock-salt from the Cheshire mines.

A lump of rock-salt as big as a man's head may be fixed by pins upon a rock or block, where the water will not stand around it, and it will remain until all licked away by the cattle's tongues. In ease of stock in stables, a lump may loe placed in each manges:

95. Iones for Animals. - A good deal has been lately said about feeding animals with bone-neal. We give several opinions upon the subject:

E. C. Wright, of Gallatin County, Ill., states, on the authority of the Rer. Joln Crawford, of Crawford, in that comty, that the bones of swine dying with what is called log cholera, decay as rapilly as the flesli, and that portions of the skin ontlast the bones. IIe wants scientific men to give attention to this strange consumption of the solids, aud thinks that it may be the means of suggesting a remedy for the disease so fatal and so pecuniarily distressing to a vast number of farmers in the West. Now, as we know that feeding bone-neal to animals and phospluate of lime to plants that need it, has prored beneficial, is it impossible or improbable that fecding it to swino suffering from a disease that produces the eflect described, may not be the means of enring or preventing the discase?

Dr. Watchlury says: "There aro some new theories in relation to feeding phosphates to animals. It is possible that this may lave some eflect. There is an idea prevailing that feeding material that makes bones will increaso their size. It is a subject well worthy of more attention."

Prof. Mapes states that, when a calt is deficient in bone, that is, too reak to stand, feeding bone-meal to the cow that sucliles tho calf will furnish it 
with the necessary material. This fact is well known to many farmers, and that cows eat old bones with great avidity. We also know that physicians are using a solution of phospluate of lime in their practice, and there is no doubt it may be administered to domestic animals with equally good effect; and whether, in the case named, it worlied a cure or not, it is well worth trying. Many things much more sinple liave produced wonderful results.

99. Water for Stock.-See that your stock have an abundance of clear, good water in hot weather. If it is pumped from wells, it sliould always be standing in boxes or troughs, so that stock can have access to it. Select, for hot days, fields witlı plenty of shade trees in them, to protect stock from the burning snn. Pastures should always contain shade trees, and they should be planted, if not there.

Mr. Strawn, the great Illinois farmer, has successfully tried this method of keeping water on a stock furm:

Dig a basin five or ten rods square, and ten feet deep, upon a lighl knoll; feed corn in the basin to your logs and eattle, until it is well puddled by the tramping of their feet, which will make it almost water-tight. Mr. Strawn says the rains of a single winter sufticed to accommodate several hundred head of stoek, and that it had been dry but once in twelre years.

For watering at the barn, in all situations where digging wells is cxpensive, cisterns should be provided, if running water from some brook or Epring can not be brought in pipes, or sent up by a water-ram.

100. Chafing Food for Stock.-There is no disputing the fact that cluaffing food, particularly all coarse forage, will pay well, where it is as dear as it is in the ricinity of New Tork. At the State Fair Farmers' Club, at Elmira, October, 1860, the following opinions were given upon the subject:

A. B. Dickenson said: "On good hay you can fat cattle, but you can not upon corn-stalks, but they are better than poor has. I can not make an acre of corm-stalls as good as an acre of grass. If you want to raise a big crop of corn, put on barn-yard manure year after ycar on grass, and afterward plow it in and make it mellow and rich, sixteen inches deep, and then corn will nerer exlanst the soil. Corn-stalks must always be chaffed to obtain their full value."

Col. Butterfield, of Utica, said: "Up to two or three sears ago, I thought but little of corn-fodder. I then ent the top stalks; now I cut up by the ground, and my cattle do first-rate on corn-stalks till March. To get the greatest benefit from corn-stalks, they must be chaffed and steamed."

Hon. T. C. Peters, of Darien, N. Y., said : "I grow corn for fodder as well as grain, and eut up from the gronnd, and chaff the stalks for feeding. There is no other feed for mileh cows in winter equally valuable if it is rell cured and then chaffed ; and if steaned, it is still better."

Mr. Lyman Barnard, of Stenben County, said: "I cnt up my corn from the ground, and eut the stalks up fine in a stalk-cutter, and mix with cut straw, and I find my cattle and liorses do as well, or better, than upon good timothy hay." 
Mr. Plumb, of Onondaga County, said: "Wre don't raise any crop as valuable as corn, and we do raise good wheat. I foddered 150 sleep and 12 cows till March upon ten acres of corn-stalks, allowing the stock to rum at a straw-stack besides. I raise the large eight-rowed yellow corn with a small oob, and like it better than Dutton corn. It yields better than auy white corn."

It is the opinion of some really scientific men we have conversed with upon the subject, that in all places where hay usually sells as high as $\$ 20$ a tun, and power is not unusually expensive, that it would pay, not only to chaff all hay, stalks, straw, ctc., but actually to grind these substances iuto meal-not very fine, to bo sure, but so that none of the partieles would he more than an eighth of an inch in length. We saw, a few years ago, the model of a newly-invented mill that was most admirably well calculated for doing such work as reducing hay and straw to moal. It was the invention of Mr. Blanchard, of Boston.

Flint, in his "Dairy Farning," in speaking of feeding milch eoms, says : "One of the best eourses is, to feed in the morning, either at the time of milking-which I prefer-or immeliatcly after, with cnt feed, consisting of hay, oats, millet, or corn-stalks, mixed with shorts, and Indian, linseed, or cotton-seed meal, thoroughly moistened with water. If in winter, lot or warm water is far better than cold. If given at milking-time, the cows will generally give down the milk more readily. The stalls and mangers ouglit always to be woll cleaned ont first."

101. Nutritive Value of Varions Kinds of Fodder.-The following tables will be useful, as showing the relative value of various substances:

\begin{tabular}{|c|c|c|}
\hline & & - Per.centage of Nitrogen,- \\
\hline 1. Meadow hay. & $\begin{array}{l}\text { Net. equivalent. } \\
\ldots .100 \ldots . .\end{array}$ & $\begin{array}{l}\text { Jiried. } \\
1.34 \ldots \ldots \ldots \\
\text { Undried. }\end{array}$ \\
\hline 2. lied clover hay & $\ldots 75 \ldots$ & 1.70 \\
\hline . Rye-straw .... & 479 & 0.30 \\
\hline 4. Oat-straw & 383. & 0.36 . \\
\hline Wheat-straw & $42 \%$. & $0.36 \ldots$ \\
\hline . Barley-straw. & 460 & $0.30 \ldots$ \\
\hline Pea-straw ... & $\ldots .6+\ldots$ & $1.40 \bar{c} \ldots$ \\
\hline
\end{tabular}

The following is the composition of these several substanees, in which their relative value will more distinctly appear :

\begin{tabular}{|c|c|c|c|c|c|}
\hline Water. & Woods nber. & $\begin{array}{l}\text { Stareh, Oum, } \\
\text { Sugar, }\end{array}$ & $\begin{array}{l}\text { Gluten, Al- } \\
\text { bumen, ete. }\end{array}$ & Fatty matter. & Saline matter. \\
\hline 14 & ...... $30 \ldots$ & & & .. 2 to 5 . & .. 5 to 10 \\
\hline 12 to 15 & ...... 25 & .. 40 & 9.3 & 3 to 5. & - 9 \\
\hline 12 to 15 & . 45 & 38 & 1.3 & - & 4 \\
\hline 12 & ......45 & $35 \ldots$ & 1.3 & 0.8 . & ... \\
\hline 12 to 15 & .50 & 30 & 1.3 & 2 to 3 . & 5 \\
\hline 12 to 15 & 50 & 20 & 1.3 & $=$ & 5 \\
\hline 10 to 15 & . . 25 & 45 & 12.3 & 1.5 & $\ldots 4$ to 6 \\
\hline
\end{tabular}

-From these tables it will be secn that, taking good English or meadow hay as the standard of comparison, and calling that one, 4.79 times the weight of ryc-straw, or 3.93 times the weiglt of oat-straw, contains the samo amount of mutritive matter; that is, it would take 4.79 times as much ryestraw to produec the same result as good meadow hay. 
NLThILIVE LQUivalexts. (Practical and Tueormical.)

\begin{tabular}{|c|c|c|c|c|c|c|c|c|c|c|c|c|c|}
\hline \multirow[b]{3}{*}{ ARTICLES OF FOON, } & \multicolumn{6}{|c|}{ THEORETJCAL VALEES. } & \multirow{2}{*}{\multicolumn{7}{|c|}{ 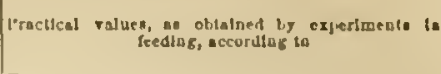 }} \\
\hline & \multicolumn{4}{|c|}{ Bulangealt. } & \multicolumn{2}{|c|}{ Fлкв:ме. } & & & & & & & \\
\hline & $\begin{array}{l}8 \\
\vdots \\
z\end{array}$ & 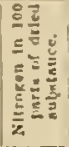 & 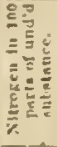 & 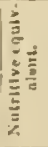 & 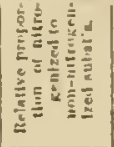 & 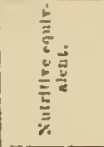 & 薝 & $\dot{\bar{\Sigma}}$ & 悹 & $\stackrel{\Delta}{\underline{\Delta}}$ & $\stackrel{\vec{\Delta}}{\underline{\Delta}}$ & 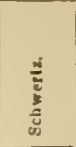 & 总 \\
\hline Jinglish hay... & 11.0 & 1.84 & 1.1 .0 & $l(k)$ & - & 100 & 100 & no & 100 & 104) & 100 & ino & 100 \\
\hline & & 1.060 & 1.35 & 83 & & & & 00 & - & 00 & & 101 & \\
\hline & 10. & 1.70 & 1.51 & 75 & 1 to 6.09 & 73.9 & $10_{0}$ & 90 & $=$ & wo & & 100 & - \\
\hline green) & $i t$. & - & .64 & 811 & - & & 430 & - & $=$ & 4.50 & & - & \\
\hline livi & 1s. & .80 & .21 & 479 & 1 to 24.40 & 3? 7.12 & 200 & 300 & 150 & 666 & a & - & 267 \\
\hline & 21. & .36 & .30 & $8 \$ 3$ & it to 12.00 & $4155-12$ & 200 & 200 & 150 & 19) & 200 & 400 & 20 \\
\hline & 30. & 2.91 &.$\$ 5$ & 195 & - & - & - & - & - & - & - & - & - \\
\hline & 91.0 & $1 . \$ 3$ & .17 & 6.6 & - & - & $\overline{0}$ & 300 & - & 800 & 9.00 & 201 & \\
\hline a bect......... & 5,6 & $\overline{1.43}$ & $\overline{18}$ & $\overline{669}$ & 1 to 7.26 & 321 & 806 & 400 & 250 & $\$ 60$ & 250 & 833 & 3661 \\
\hline & & 2. & .80 & $3=2$ & 1 to $\overline{7} . \$$ & 542.1 & $\overline{360}$ & $\overline{250}$ & & $\overline{300}$ & $\overline{850}$ & $\overline{271}$ & $\overline{810}$ \\
\hline & $\pi$ & 1.50 & .86 & 319 & I to 9.110 & $33+5-12$ & 210 & 200 & 15) & 290 & 200 & 200 & 200 \\
\hline lotat & 76. & 1.19 & .80 & $3 \backsim 3$ & - & - & 400 & - & & & - & - & - \\
\hline lBeans... & 7. & 5.50 & 5.21 & 23 & 1 to 2.9 & $8+5-12$ & 80 & 54 & 50 & 73 & 40 & - & 80 \\
\hline l'ens .... & 8.6 & 4.20 & 3.84 & $2 \pi$ & 1 to 2.14 & सt & 81 & is & 45 & c6 & 40 & Boune!n- & 80 \\
\hline & 15.0 & $2.0 \%$ & 1.64 & 50 & 1 to $6.5 \%$ & - & - & 52 & - & - & - & 69 & - \\
\hline & & & 2.1 & 55 & 1 to 6.05 & $935-12$ & - & 64 & - & - & - & - & - \\
\hline $13: a$ & 13 & 2. & $1 . \%$ & 65 & 1 to 4.25 & - & 3.3 & 61 & 53 & $\pi 6$ & $5 \cdot 1$ & - & 8.5 \\
\hline & 12.4 & 2.22 & 1.92 & 60 & 1 to 4.118 & os 11.12 & $34 ?$ & 71 & - & SG & 60 & - & $3 \pi i$ \\
\hline & 11.5 & 2.27 & 2.00 & 53 & i to 4.42 & & 23 & 5.5 & 51 & 71 & 60 & - & $33 i$ \\
\hline & & 2.83 & 2.09 & 5.5 & 1 to 2.42 & $385-6$ & 2: & 53 & 40 & 64 & 4) & - & $811^{\circ}$ \\
\hline O:1.eake (linseed)..... & 13.4 & $6 .(n)$ & 5.20 & 22 & & & 42 & 108 & - & - & - & - & 43 \\
\hline
\end{tabular}

Oats in the bundle, well ent up, straw and all, make excellent, cheap feed for horses other stock; in many cases it is meh better than threshing them. For heary teams lard at work, a little sound corm-meal mixed wet with them, makes, a feed that can not well be beaten. It is a highly economical and satisfactory ray of feeding, both to man and beast, where oats. sell at a low price by the bushel.

102. A Treatise on Feeding, $-A$ valuable treatise on feeding, which unight be studied with profit by all farmers, has been made by Mr. Ilorsefall, an English farmer, and published in the journal of the Royal Agricultural Society, which may be found complete as an appendix to Flint's "Dairy Farming."

103. Soiling Cattle.-Soiling is a term applied to the practice of confining animals to the stable, and growing a green crop, such as sowed corn, sorgo, wheat, rye, or oats, elover, ete., which is cnt up as needed, and earried to the animals, instead of allowing them to hare the range of the pastures. Mr. Plilo Gregory, of Chester, Orange Co., N. I., sowed a patch of half an acre, with eorn for fodder, making the rows thirty inches apart. With the product he kept twenty-five cous for six weeks without other food.

The most extensive and successful system of soiling is pursued by IIon. Josial Quincy, Ji:, of Boston, who has published a small volume giving details of his practice. One of the great advantages of soiling is the saring of manure, the quantity being largely increased orer that made by an equal number of cattle at pasture, or fed in the ordinary way. Te recommend any one disposed to attempt the soiling system to read MIr. Quincy's book.

10. Diseases of Cattle.-We shall not attempt to give a treatise upon the 
diceases of eattle and the remedies; for this, we must refer the reader to Dr. Dadd, veterinary surgeon, Loston, and his valuable writings, as well as several other good publications, not forgetting the Stock Joumal, New York. We will give, however, the following sensible remarks upon one of the most common diseases, or symptoms of disease, from Thos. E. IIatcll, líeene, N.H.

105. The Horn Mil.-Mr. Hateh says: "Morn Ail,' or 'Hollow Horn?' is an absurd misnoner for an imaginary disease in many cases, and for a symptom of fever in others. Many a farmer las reluctantly 'cut off one inch," or more, from the tail of a beantiful animal, when it was turned out to pasture, under the erroneous impression that it wonld do better, 'for the hail lung in curls,' although the animal was in perfect health and good condition, and needed mo remedy of any kind. In fever, the degree of arterial excitement is estimated in part by the heat at the base of the horn, which is very thin, and covers the most vascular bone in the animal, thereby displaying symptoms of great value to those capable of appreciating them.

"But even in ferer thele can never be the slightest occasion for 'cutting oft one inch of the tail,' nor for pouring boiling water upon the horns of a suffering aninal until he 'dodges.' A cathartic of epsom or glauber salts, sulphur or linseed-oil, combined with ginger, red pepper, or any stimulant aromatic, will do all the good, and much more, than the slight bleeding from the ent can do, and not leave the animal to thump its sides the remainder of its lifo with a nutilated stump, a living monument that all the darkness of the dark ages lias not yet passed away.

"The hope that I may be the means, in a single case, of preserving intact one of the beanties of the borine race, to the unfortunate animal suffering tion 'Trom Ail' or 'Tail Sickness,' is the only apology that I can offer for this communieation. I wonld as soon knock off the horr, or slit the ears of a firvorite anjmal, as to 'ent off one ineh of the tail,' and slould lave as good physiological reasons for so doing. 'The disfigmement in eitler case would be about equal, but the inconvenience which the animal would suffur from the loss of the long, silky brish so kindly furnished by nature, especially in 'fly time,' would be immeasurably greater."

The Ohio fiercuma, an onnee to a lose, given in whisky a few times to a cow with this disease, is recommended as a valuable cure. In our opinion, good feed and warm stables as a preventive are worth more than all the enres.

106. Cure of scours in Cattle.-An English furmer recommends the use of acoun-meal as a sure cure of diarhea in horned eattle, sheep, and lambs, and young stock generally. He says:

"I sent the dried acoms to the mill to be ground into flour, and when I fund symptoms of scour or cliarrhea in my cattle, I ordered two handfuls to be mixed in a bran mash, and given warm immediately, and to continue it nnce a day, until the diseaso disappeared. This proved a never-failing cure-insomich that I never lat any tromble from the disense afterwarl; and my neighbors, seeing this, Jad reconrse to me for a little of my acorn 
flour, when the discase appeared in their eattle, which, of course, I was glad to give them, the result being the same as in $11 y$ own case."

107. To Cure Lice on Caltle.-Some farmers liave great faith in the efficacy of onions for ridding cows or oxen of lice. Mir. Roe, of Orange County, N. I., claims to have fond them an infallible remedy in lis practice. They also give a tone to the stomach, and are especially valuable in hot weather, when working cattle will lie in the shade at noon-time, and refuse to eat. Mr. Roe uses the "scullions," or sunall, unsalable onions, and those which becone soft or spronted toward spring. IIe gives a feed of lialf a peck once a day, at noon, and says that two feeds are suthicient to extiryate any number of vermin.

A correspondent recommends the following remedy for lice or ticks: "One tablespoonful of sulplunr to one pint of salt, mix thoroughly together, and feed to cattle or sheep once a week, in quantitics, as we usually feed cattle, for two months in succession, and there will be no tieks or lice on them."

10s. Cattle Poisoned vith Brine.-Many famers liave learned to their sorrow that old brine, placed within the reacle of loggs, cattle, and perhaps other farm-stock, will canse death; and as there are others who may not hare learned this fact, we now place it on record for their bencfit. We will also give the results of certain inrestigations made at the Veterinary School, at Ayort, France, by M. Reynal, which throw additional light upon the sulject. It is ascertained that the poisonous properties of brine are not immeriately acquired; but it assumes this condition only after it has becn in contact for sereral months with the meat, when, if mixed with the food of stock, even in small quantities, it will produce death; but when hogs and other stock can get to it, unmixed with food, its effects are still more speedily fatal. The poison acts as a local initant, excitiug violent intestiual congestion and inflammation. It likewise increases the secretion of the skin and kidneys, and exerts a direct effect upon the nervons system, giving rise to trembling, loss of sensation, convulsions, etc.

The salt of the worst brine may be sared in a pure state by boiling the brine and carefully skimming off all the scum. The remainder may then be used as brine, or reduced to salt by still more boiling.

109. Cattle Poisoned by Wild Cherry Leaves.-It is not an unusual thing for cattle to be poisoned with the leares of the common wild elieriy-tree, which are almost sure death if eaten in a wilted state, unless a remedy is immediately administered. The most convenicnt, ready remedy which a farmer can use is logg's lard and molasses, mixed in about equal quantitics, by melting the lard and warming the molasses. It should be given in doses of a pint or a quart, by means of a black bottle, pouring it well down the animal's throat.

110. 0verstocking the Farm.-This is about the worst practice in farming, as regards stock, either in summer or winter. It is not only unprofitable to keep useless animals, such as horses or oxen, but if you arc orerstocked, the whole unust deteriorate. There is nothing about a farm that has a more 
distressed appearanee than half-starved animals, and there is nothing about farming that is more unprofitable. Even the manure accunnlated from such stock is far less valnable than that saved from well-fed animals.

The most important thing in farm-stock is a good team, and that should be the first consideration. IIave a tenm or teams suftieient to do all your work, except some particular things, such as threshing, and for such extra work liave a standing arrangement, if possible, with a neighbor to exchange tean work. You ean not afford to keep any extra team. You may be orerstoeked in any other kind of animals with less damage than working ones, but you ean in no way aftord to do without enongh of them, and the better they are, the better it will be for your. Farm-stock must be adapted to cireumstances to be profitable. When milk sells at two cents a quart, at or near the firm, mileh cows are profitable stoek, becanse if one average five quarts a day, her milk will bring $\$ 3650$ a year, and some of the mileh dairy cows near New York clonble that. The average we have heard estimated at $\$ 45$ for all the eows kept on a firm. We have lnown the profit of grazing a herd of fatting bullocks through the season often to range from $\$ 38$ to $\$ 40$ a head, but we eould not recommend erery one to go into the business, becanse it requires skill in buying, keeping, and selling that all do not and are not likely to possess. In all enses furm-stoek should be adapted to ciremustanees, and there is eertainly a want of judgment in this respect that is amaing. Men in Mississippi have tried to raise fine-wool sheep suited to Vermont, and men in Vermont have tried to use mules for farmwork, instead of their own liardy breed of horses, becanse they had read that they were mucl the most economical for furm-work in all the Sonthern States. The pastures of New England are noted for their sweet grass and excellent red cattle; and the blue-grass fields and fat Durhams of Kentucky are equally noted, and all should know that it would not serve either section to advantage to exchange breeds of cattle. The adaptability of stoek to the farm is a subject that we do not wish to dietate upon, but we ask reasonable men to take counsel with reason, and apply that in all cases to their own circumstanees.

111. Imported rs, Native Stock.-Robert Purris, of Byberry, Penn., has a farm in a high state of cultivation, one of the best in Pennsylvania, and consequently, in our opinion, his ideas are entitled to a share of our respect. IIe says :

"For many yenrs I have male it my business, as it has been my pleasure, to do what I eonld to promote the improvements of firm-stoek. My chicf attention has been given to cows, hogs, and fowls, though I have not been unnindful to other varieties. Of cows, I have rased the Durham, Ayrshire, and the Deronshire; of logs, the lierkshire and the Suffolk; and of fiswls, a great variety. I have confinel my attention chiefly to those of foreign growth or origin. That I have sueceeded as well as others, may bo inferred from the fact that at the varions shows I have taken a fair share of the preniums. Nerertheless, my sucess, though eneouraging, has not been 
altogether satisfactory; that is, it lias not proved to me that any of these foreign breeds, whether of cows, hous, ol fowls, are the best that we cinn lave in this comtry, ol are just the thing we want. On the contrary, it lias demonstrated to me quite the opposite, viz. : That before we can attin the desired success in this field of experiment, we must give more attention than we are now giving to animals which are the growoth of our oron soil. Not that I would mudervalue the advantages of importing the hest varieties of foreign breeds, for too mueh praise can not be rendered those public-spirited men who spend their money liberally in bringing to our shores the best Ejecimens they cau obtain of European animals; lut, at the same time, too little credit may be giren to others who are doing what they can to improve our natire breeds.

"I don't know how it may be with others, but according to my experience and observation, there is an unvarying tendeney in all imported stock to deterioration. Whether it is owing to the climate, or soil, or what, I don't pretend to eay; but this tendeney to degenerate in all foreign animals, whatever pains may hare been taken with them, has been, according to my knowledge, withont an exeeption. Now, assuming this to be true, which, understand me, I do not aver, the question arises: Would it not be better for us, in trying to improve our stock, to make our selections for the purpose withont regard to the animal's origin? In mileh cows, for instance, onght we not to choose the finest-looking animal and best milker we can find, whether native, imported, or mixed? and ought we not to see that the offspring are the product of a sire chosen on the same principle? Is it not likely, and does not experienee, so far as it has been made, show that the tendeney of tilis solt of breeding is to a continual improrement in the stock? I would ask the same questions in regard to hogs, fowls, horses, sheep, and all other kinds of animals. In other words, ought we not to make more aecount of our native breeds, and seek, by judieions erossing and care in other respeets, to attain the end which we hare not yet reached in the matter of stock-raising ?"

Do farmers generally sufficiently appreciate the reason why imported or higll-bred cattle look so much better than the natives? Is it not because one class is high-fed as well as high-bred, and treated with the greatest possible care, while many of the poor natives are treated with the greatest possible neglect-exposed to storms, snmmer and winter, and kept upon short pasture while it is possible for the animals to get a living; and then gludgingly fed coarse lerbage to carry them alive through the winter. With such treatment, the poor natires liave no fair chance to compete with the pampered stock lately imported; yet, with equally good treatment and constant care in breeding, we believe as good cattle nay be raised up out of some of the natives as can be found among those imported and maintained at such great extra expense. At least, we believe that if as much care had been bestowed on our native stock as has been on the imported breeds for the last thirty years, the natives would now be nearly equal to the imported. 



\section{PLATE VI.}

(Page 81.)

Tne subject of fecding swine is treated of in Section II., but to enable readers to understand the style of the different breeds, fed to a condition for show, are have preferred to direct his attention to this picture rather than to a written description. Upon the left hand he will see representatives of the Berkshire, black and white. In the center are the beautiful white, thin-haired Suffolk, and on the right the black, thin-haired Essex, a favorite breed in England, lately introdueed into this country. Indeed, all three of these named are favorite English breeds. On the right, in the rear, an American breed, the Chester County, is represented. All that is known of the history of this breed is briefly told in \&f 13 . This pieture of four families of swine is equal to any other ever printed. It is worthy of careful attention.

Above the swine, as they always should be, in the estimation of farmers, are the shecp, showing good representatives of the three great families of long wool, fine wool, and medium. On the right, the long-wool variety, under the name of Cotswold, are well represented. In the eenter, the pair of merinos stand as fair types of the fine wool, and are handsome portraits of the large-sized sheep of this variety. The noble South Downs on the left show what this breed looks like. Their black faces and legs and round, full bodies are characteristics of the family. Altogether, these four families of swine and threc of sheep make a picture that is not to be passed lightly over. 
Why should we inport hogs? All the improved English breeds are made up. And why we can not just as well make a breed here that shall suit our circumstanees, and need no acclimating, we can not imagine. The fecundity of pigs gires the breeder a greater facility in improving his logs than he possesses with any other large clomestic animal. Let him lave an object in view and steadily pursue it for a few years, and suceess and great profit are certain.

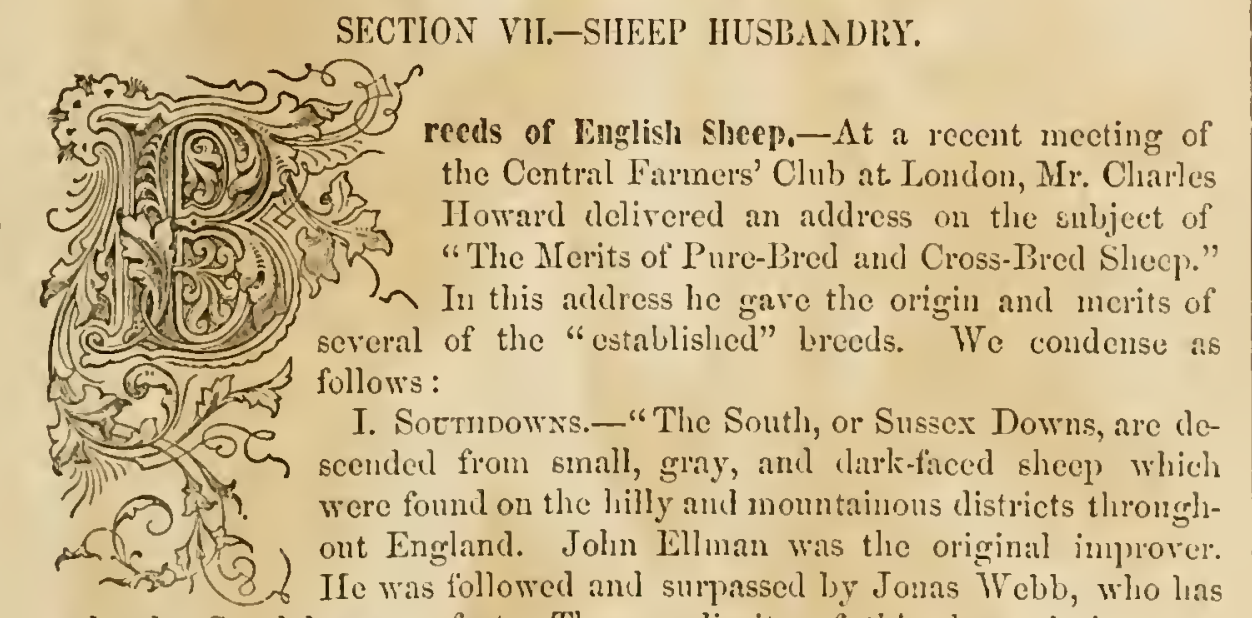
male the Sonthdown perfect. The peculiarity of this slieep is its supe. rior quality of mutton and wool. Arerage weight, from thirtecu to fiftecn months, is $126 \mathrm{lbs}$; weight of fleece, 6 lbs. The ewes are cerpital hreeders, and gencrally produce one third twins. They are best adapted to clevated situations and bare pasturage. Among the nobility and fancy firmers they are regarded as the élite of sheep.

II. IT aminime Dowss.- "This valuable slicep has been established from rarious crosses, commencing with the century. They present als great ? uniformity in wool, color, and general appearanee as their smaller but hand somer eousins, the Sonthlowns. They have risen into faror rapidly. 'They are very hardy, and of good constitutions, and good wool-bearers, the arerage flecee being 6 to 7 lbs., of early maturity, and have plenty of lean as well as fat ment, and will graze to almost any weighlt you may choose to make them. The ewes are good brecters and sucklers.

III. Luaterstens. - "These origrinated with lakewell. To this breel all other long-wooled sheep are indebted for their improved slape and greater disposition to fatten. Their chief characteristics are, great aptiturle to falten with a comparatively small consumption of food, and early maturitr: thece, 7 lbs.; careass, at fourteren or fifteen months, $140 \mathrm{lbs}$. They are not very good breclers, and it is a rave thing to have more lambs than ewes.

IV. 'Tu: Corswot.d.- "This is one of the oldest of the established bu'cels. 
They were originally lieary, coarse animals, with a thick, heary fleece, well adapted to the loleak, minclosed Cotswold hills. They are now very hardy, and will succeed well in almost any sitnation, and produce a great amonut of wool and mutton at an early age. They sometimes reaclı S6 lbs. to the quarter. The average weight of an ordinary flock when fit for the buteher, at fonrteen or fifteen months old, is about $180 \mathrm{lbs}$, and the weiglit of wool of the whole flock ronld be abont $i \frac{1}{3}$ lbs. eacl. Many of these sheep are now being exported to Australia to produce mutton for the miners.

$V$. Lixcolisuriss.- " $\Lambda$ s the western part of Great Britain is fimous for its Cotswolds, so is the northeastern esteemed for the heary-rooled and litrge-framed Lincolns, to which distriet tliey especially belong, and where for many years they held their own. They, like the Cotswolds, have been improved by an admixture of Leiester blood. The present improved Lincoln sheep partakes largely of the peculiarities of the Cotswold and Leicester, having the expansive frame and nobility of appearance of the one, with the cuality of flesh, compactness of form, beanty of countenance, and propensity to futten of the other; but they far exeeed either in weight of flecee. Three-year olds sometimes weigh $96 \frac{1}{2}$ lbs. to the quarter, and yearlings 71 lbs. The weight of wool of an entire flock, under fair arerage management, is about $S \frac{1}{2}$ lbs. eaeh; weight of careass at twenty-eiglit months, $160 \mathrm{lbs}$. The Lineolu breeder's consider the mutton excellent, having less fat and a greater proportion of fine-grained, lean flesh than the Leicesters. The ewes are good breeders, but, like the Cotswolds and Leicesters, they are not good sucklers.

VI. Snropsinnes. "These are crosses. Their merit consists in their superiority orer any other breed in their own eountry. They possess liardiness of constitution, excellent quality of mutton, and are prolific breeders; but they are not equal to other breeds.

VII. Oxfordsure Dowss.-"This breed of sheep was produced twenty. seren years ago by crossing the IIampslire, and in some instances Sonthdown ewes, with Cotswold rams, and then putting the erosses together. They drop their lambs in February, and at thirteen or fourteen months old they are ready for market, weigling, on an arerage, $140 \mathrm{lbs}$. each, with a flecee varying from 7 to 10 lbs. The ewes are good mothers, and produce a great proportion of twins."

We might add liere, as these last two breeds are erosses, that Mr. Howard stated, at the conclusion of his experience and address, "that from a judicious pairing of eross-bred animals, it is practicable to establish a new breed altogether," and for eome locations better fitted than most of the existing breeds.

113. Protuction of Eexes among Sheep.-The Journal d'Agriculture Pratique has a paper giving a variety of fucts on this subject-from which the deduction is made, that the sex depends on the greater or less vigor of the individuals coupled. This has long been known and acted upon. It is further stated, as slown by careful observation and experiment, that more males are boru among the first and last birtlis in a flock reared by a single 
ram, than among the lambs born in the intervening period, when the male is weakened by excessire exertion; and that the ewes which produce males are on an average lighter than those which produee females, and lose more weight than the latter duriug the unrsing period. Thus vigor in the male tends to prodnce males, but more from the weaker than the stronger ewes; aud the opposite fuet in regard to females tends to keep up the equilibrium, and scenre the perfection and preserration of the species, by confining the reproduction of either sex to the most perfect type of each respectively.

114. First Imporiation of Merinos.-The first importation of Spanish sleeps into the United States took place in 1501 . Four were shipped by Mrr. Delessert, a banker of Paris, three of which perished on the passage. In 1802 a lasge importation was made by Col. Humplreys; and in 1909, '10, and '11, the IIon. Wm. Jarvis, the American consul at Lisbon, sent home large and valuable flocks to his farm in Weatlersfield, Vt.

115. General Care and Management of Sheep.-There are not many men in this country more capable of giving information upon this subject than T. S. Gold, of Cornwall, Connecticut. In the series of Yale College lectures, in the winter of 1859, ' $60,15 \%$. Gold gave a lecture upou sheep husbandry, in whicl, he made the following points, rortly of note by all sleep farmers:

"Thrift.-It should always be the object of the flock-master to keep his slicep in a thriving condition. The quality of the wool, as well as its quantity, and the general productiveness of the flock, demand this system.

"Shelter is the first necessity" in providing for wintering sheep sucecssfully. The Sonthdowns will bear exposure better than any othel class of sheep. The open fleece of the long-wooled parts on the back when wet, and admits the water, which completely drenches the auimal, so that his abundant flecce is no longer a protection from cold.

"Economy in feeling demands slielter for all sliecp, as not only less food is required, but also it is better preserved from waste. Water-soaked lay, or thut which is in any way soiled, is always rejected. The improvement in the quality of the manure forms another argument in faror of shelter. That this is not ouly healthful but grateful to the sheep at all seasons of the year, we see in the fact that even in summer they will seck their winter sheds at the approach of a storm it they are within their reach.

"Ventilution is of paramount importance as connected with slielter"; and to insure this, slieds open to the south are to be preferred. A stable with an oper window will answer for a small number, but the crowding of a linge flock in such a place affects the organs of respiration, and may result in serions disease, and should never be tolerated.

"The best form of rack lias posts three fect ligh in the cormers, a bottom of boards, the sides and ends of two hoards each, and the lower one the widest, with narrow perpendicular strips nailed on to keep the stronger sheep from crowding the weaker. The spaces are larger in their perpendicular than their horizontal onening. The size of these, as well as the width of the rack, must be in proportiun to the size of the slicep. Not more 
than one hnndred of the fine-wooled sheep shonld be confined in the same rard, while the long-wooled will not thrive with more than twenty-five. A hospitul, sung and comfontable, should receive any sheep that may be reak from age or disease, mutil, by eareful feeding and nursing, they can be returned to the flock.

"It is the worst possible practice to allow the sheep to fall away in flesh, as the grass fails in autmm. The increasing wool conceals the shrinking carcass, mueh to the disappointment of the careless flock-masters. Better confine them in the yad than allow them to ramble abont in search of somo field of winter grain, which furnishes a little green food, but too light to bo of any real ralue.

"Tinter folder shonld embinee, in addition to the dry food, a die proportion of that which is green and sneculent. Fiue early-cut clover hay, well cured-that from old meadors, consisting of a rariety of grassesforms the best dry folder. Economy demands that the quality should be good, else much waste enswes; yet the sheep is very fond of rariety, and almost all of the so-called reeds become a choice morsel. The botanist knows full well that a sheep-range will be most barren of the objects of his seareh. The immortal Limnans tested the plants most indigenous to Sweden by offering them, fresl gathered, to the rarious domesticated animals. Horses ate 262 species, and refuser 212; cattle ate 276 species, and refused 218 ; mlite sheep took readily 3S5, and refused only 141 species. For fattening, add to the hay, roots, grain, or linseed, or cotton-seed meal. The English system of winter feediug on tmmips in the field is here prevented by ex.cessive cold. Use them in the yards in moderate weather. Sudden ehanges from green to dry food, and the reverse, should be aroided. Regularity in the hours of feeding is very important.

"The amount of fodder varies with the kind of sheep, though it is not directly proportioned to the lire weight. Ten small, fine wooled sheep will eat as mucli as a cow, the larger ones requiring more. Two to two and a lialf, or eren three and one third per cent. of the live weight in liay ralue is estimated by different authors as daily required.

"No other animals except calves shonld lie in the yards with sheep. The losses from the horns of steers and the heels of colts more than balance any supposed gain. As the breathing of the sheep on the liay does not of itself render it distasteful to cattle, it may be gathered from the racks and fed in nnother inclosure.

"It is estinated that 300 lbs. of good hay will winter a small sheep, while larger ones may take three times the amount.

"Water is absolntely necessary to the thrift of the sheep in the winter. It is best bronght into the yards, as the steep banks of streams prove dangerous to the slieep.

"Salt may be provided in wintel by a moderate salting of the haytwo to four quarts a tmu; but exeessire salting must be aroided, for with it neither sheep nor cattle will thrive. 
"As the lambing season approaches, snug quarters must be provided for" the breeding ewes, where they can be clean, warm, and dry."

116. Grain for Shecp.-Major $W_{111}$. Lee, one of the most snceessful woolgrowers of western Pennsylvania, manages lis slieep as follows, according to the Ohic Furmer: "They are not contined to slieds; they are only provide. with a dry place for slielter and rest. Atter they r'se of their own accord, in the morning, he feeds again, two thirds corn, and one third barley or oats. Af: terwards he feeds hay, and also at three o'clock again, so that the shecp have finished eating before nightfall. IIe considers that corn will make more wool than oats, and general opinion favors out-door fecding. Shecp housed will not eat as much, nor will they slicar as much wool."

Another slieep-farmer says: "I am willing to mako affidavit that with me, in many years' experience carefully tested, shecp of the same kind, weiching from 110 to $130 \mathrm{lbs}$, will put on more fit and gain a great deal more weight on 1 or $1 \frac{1}{4}$ lbs. of grain or oil-cake per day, in three or fom months, with only straw for folder, than those weighing 80 to $90 \mathrm{lbs}$.; and I value a sheep weighing 125 to 130 lbs. as worth lialf a ecnt more per pound of live weight, for me to feed fist than one weighing 90 or 100 lbs. Now, no man will suppose that the straw will put on any lat, or make sheep gain in weight. If you teed sheep straw only, they would lose weight, and that greatly; but with a pound of meal or grain daily, they will gain daily. I can prove all I hare said by neighbors who have been teeding for a few years past, and whon will now only buy the largest slieep of their elass, or the largest cattle of their agre."

117. Weight of Hay for Sheep.-The question, How much hay do sheep or cattle require per day ? is thus answered by Alexander Speck von Steruberg, of Lutzchena, Saxony, to the IIon. Joseph A. Wright, American minister at Berlin. ILe says: "One thirtieth part of the weight of the live animal, in good hay, is considered neessary per day for its sustenance. According to the quality of the fodder, and its abundance or scarcity, this may be incereased to one twenticth part; but less than one thinticth part onght not to be giren. Taking good meadow hay as the fodder standare, a ram should receire about $3 \frac{1}{4}$ lbs. per day, a ewe ahout $2 \frac{3}{4}$ lbs., yearliurs, etc., in that proportion-taking the averare of a fult-rrown ram at $110 \mathrm{ll}$ s., of a ewe at 72 lbs., the weight of each varying, accordiug to age, size, and condition, between 105 and $125 \mathrm{lbs}$. as rerards the full-sized rams, and from 70 to $55 \mathrm{ll}$ s. as regilleds the full-erown ewes. The weight of a wether varies between S0 lbs. in lean condition, and 110 to 115 lbs., if strong and fit for tle buteher. One pound of gond mendow hay is considered equivalent to $11_{3}^{2}$ lhs. of oat, pea, wheat, or birley straw, 4 lbs. of turnips, or $216 \mathrm{~s}$ of grains in the wet state, as delivered from the brewery in winter. When the time for stabling for winter arrires, the sleep-master las lis supplies of straw, hay, and tumips allotted to him on the hasis of the abovo calculation, and lie is bomd to make them serve ont the proper time, under-feeding being as much guarded against as orer-feeding and waste." 
Another writer says: "The usual rate of the consmption of food is at the rate of $3 \frac{1}{2}$ lis. of liay daily for every 100 lbs. of live weight. If we tako the arerage of flocks, the live weight of 100 common sheep would be about 7,500 lbs., or from that "p to 8,000 lbs. It is rure that a whole flock of finc-rooled sheep, will average more than rolbs. for each head, though it may be that this weight is exceded in some instances. At the rate mentioned, a flock of 100 sheep should use up or eonsume 280 lbs. of hay per day, or a total of 25 tuns in the winter season that lasted 150 days. This wonld alse equal 50tlbs. to ench single sheep; or it may be stated as a general rule, that a full-grown Merino shecp, averaging in live weight from 75 to 100 lbs., will consume during the winter season a quarter of a tun of hay, or its equivalent, if comfortably kept. If grain forms a part of the ration, of conrse some of the hay may be sared; but if the animal is to be kept growing wool, it will need its full ratio of hay, and a little grnin, too."

11S. Changing Pasture.-Some slicep-farmers are very particular about ehanging pastures. This is riglit, if the inclosures are small. If there is a wide range, it is of no particular advantage to confine sheep to one portion of it, and then shift them to another.

119. Feediug Shep) vs, Beeres.-Mechi, who is a highly cnlightened and practical English agrieulturist, says he is convineed that beef must sell at 20 per cent. higher than mutton to make them pay alike. He also remarks, that he agrees with a friend of his, who says, that he who keeps many butlocks will never need to make a will.

Our observation in relation to the comparative profits in this country coincides with MIr. Mechi.

Thos. Bell, of Mommonth County, N. J., makes the following statement in regard to the profits of feeding sheep:

"I usually liecp about 100 sheep, and renew my flock erery ycar. My ueighlors and myself agree with a drorer to talse certain mumbers, and he goes up the Delaware into the State of New Tork, where he obtains a large strain of eommon sheep. I buy the hest ones in the flock, paying the highest market price, which this year was $\$ 350$ a head, while my neighbors prefer to take the lower-prieed sheep, graduating down to $\$ 250$ or $\$ 2 \quad 25$ a head. I get my new Hock in aljont the 1st of October, and inmediately put the ewes to fill-blood Sonthdown lucks, so as to hare the lambs dropped early in April. I have good antumn pasture, so as to keep the flock in good condition to go into winter quarters, where I keep them in yards with open sheds, fifty sheep in a pen, with feeding-raeks, and freedom to lay under cover or ont in the open weatler. Their own instinet governs them abont sceking shelter when it storus. I feed the flock once a day upon liay, and once a day upon whole stalks of Indian corn ent from the ground as Eoon as it is hard cnough to ripen in the shock, when the shocks are well cured, and afterward the corn is lunsked and stalks stored for winter. The sheep trim them of leares, and the dry stalks make good bedding for them. I wateh my eres and take them ont of the flock as the time approaches to drop their lambs, and put 
then in other yards, where they are fed on grain and good hay, and I scl. dom lose a lamb. I graze my tlock upon less than eighteen ateres of good pasture, which has been made to produce sweet grass by the application of green sand marl, by which I have renovated a worn-out farm. By the end of July I have my lambs, which are large and fat, and well marked with the Sonthdown characteristics, all off to the butcher-this year at $\$ t 75$ encli, selling the whole lot to one man. I could linve sold them in small lots so as to average $\$ 5$ a head. The ewes, after the lambs are taken off, become fat upon grass alone, so as to bring the best market price of that class of sheep in September. I have just sold all off, and find that the 100 hend which I purchased at $\$ 350$ one year ago, have yielded me in wool, lambs, and old sheep $\$ 750$ a head orer the cost of the stock. Last year I realized $\$ 7$ a head profit, or rather, I got that for keeping 100 liead of sheep one year, and I think that sum may be safely calculated upon every year. And besides this profit, I find my sheep are enriching my land and are more adran tageous in every way than any other kind of stock. Every farmer kecping sheep shonld have a lot of movable fence, and inclose small plots-say half an acre at a time- of the poorest parts of the furm, such as gravelly knolls, upon which to yard the flock nights. The only drawback to keeping sheep upon hundreds of farms near New York is the worthless eur dogs. In New Jersey we have a good law which gives out of the general tax $\$ 5$ a head for all sheep killed by dogs. That insures every common sheep, but does not warrant une in keeping full-blood Southdown or other valuable breeds. The State of New York needs a stringent law agninst dogs to protect the interest of furmers who keep shecp, particularly in the counties near the eity."

The above statement of $\mathrm{Mr}$. Bell is a very encouraging one, and wonld doubtless encourage many of the farmers convenient to the eity market to adopt the same course if the State Legislature wonld protect them against dogrs. The question resolves itself into this simple form: Is it of moro germeral advantage to the State to grow wool and mutton than it is to grow doys - dogs, too, of the most worthless sorts? It is ono of tho rarest things in the work that a shepherd dog or a good honso watch-(log ever kills sheep. It is only the meanest, prowling, thieving, worthless curs, of no raluo to their owners, that destroy sheep. Let us have a law to amilikate then, and then every man ean keep sheep with the same results as MIr. Bell.

Mr. Carpenter, of Elmira, said: "A neighlbor of mine makes just about the stme avernge upon his flock of grade Southdowns. Ho shears six pounds of wool per head, and he sells his lambs at st."

Samuel Thorue, of Dutehess County, N. Y., pursues tho samo course, with the same results, as Mr. Bell.

Mr. Wade, of Cauntal West, says: "That he prefers the long-Wool sorts, because they are more hardy. The mutton sells readily, and the wool, though not worth so much a pound as the fine-wool sorts, weiglis so much more that the ralue of the fleece is equal. We don't grow much corn, but we feed a grent many roots, and feed well. It is foolish to try to 
kecp any animal upon low diet. We feed anything that sheep eat best, and I fatten principally upon tumips and lay, with a little meal. The lung-wool sheep are better adapted to Canalin than the fine-wool. We shear eight pronts of clean wool per liead. The Cotswold variety are preferred; they has"u stronger constitutions than the Leicester sheep."

Gen. Ilamon, of Monne Connty, says: "I commeneed with fune-wool shecp, forty jears ago. I then tried Lcicestershire, and then came back to Mrerino. I liave less than 200 acres, and grow 30 or 40 aeres of wheat crery year; the land infuroves by slicep. My arerage weight of flece is five poumels. I keep, 330 hend, and get orer $\$ 700$ a yen for wool and increase. I stable 50 sheep in a room 14 by 10 fect, without ehange in the winter. I wash my slicep clean and let them rnu six or cight days, and then slica. I clon't breed fiom gummy sheep. I feed in board-racks, with straight sticks, so the sheep can put in their heads. There are abont 25 acres of reclaimed land ou ny fim that will licep slieep alive, but won't fut them. My farm is limestonc, and I prefer fine-wool shecp to any other for profit; and I eonsider slreep twice as profitable as cattle upon any grain farm. I nerer breed from ewes less than three years old. I don't like the eross of Iceicester bucks upon fine ewes. I have sold of wool and slieep orer $\$ 900$ a year."

Lewis F. Allen, of Black Rock, says: "I liare kept slieep twenty-fire years upou a elay loum, natural to street grasses, limestone formation, on the Ningara liver. There is no general rule as to the profit of leeping slieep. All depends npou eireumstances. In Canada I liare secn tho best long-wool slicep I crer saw, but these slieep are too fat for eating. You miglit as well dine off a eake of tallow as such incat. Such slieep may be profitable in Canada. With me those sheep require good shelter. They are not kept waru by their long fleeces. My sheep slienred five to eight jounds of wool. I don't approre of feeding many roots exeept to breeding cwes. They are likely to seomr slieep; at least they do mine.

"On some soils it may be best to flow in clorer; on other soils it is not. As to mutton sheep, I have fed Southdowns, and the cheapest way thant I can make mutton is upon grass, and wethers of $150 \mathrm{lbs}$. bring fire cents a pound gross at Buffilo. I would keep untton sheep if I had a gond furm on a railioal. I can always sell my lambs at \$2. MIy Southdown fleces bring s1 50 arerage. Southdown unton is the best we hare, and the sheep always sell well for mutton. The fine-wool sheep mutton is apt to taste of the greasy wool. The Merino slicep are a liardy race of sliecp, but they are not a good breed to feed for mutton."

Mr. Bowen, of Orleans County, says: "I liave bred both coarse and fine sheep. I liave raised coarse-wooled sheep that weighed $150 \mathrm{lbs}$. ench at one year old. I find the conrse-wool breed the most profitable. My slueep average six pounds of wool, that sells at 31 cents a lb. My sheep are a cross of Cotswold, and are elose-mooled and hardy. I live on a grarelly loam, wheat soil, and I think it desirable to increase the stock of slieep in 
this Statc. A field of clover fed off by sheep will yield more whent than if not fed of:".

Mr. Petribone, of Vemont, says: "If a man keeps but few slieep he should keep a mutton breed. If he keeps a large flock, or say 200 or 200 , he should keep fine-wool sorts. The tronble in sheep-loreching is in letting them run down in Oetober. I winter 300 head, and 100 ewes will grie 100 lambs. I use 400 acres, but many of them are on the momtain, and ralued at only ş an acre. I do not let all my ewes breed. I keep ny sheep in very close winter quarters on hay. I feed breeling ewes one peck of corn a day to 100 head. In eleven years I have not had a lamb die, and ewes are kept withont grain, but always with water and salt ly them. There is a material difference in the ralue of the fleece, according to the way sheep are kept. I prefer always to have my sheep fat. In Jamury I select my ewes, and nevel sell the choice oncs. I have a ewe that has proclueed cighteen lambs and shears four pounds of good wool. I do not select the most grumy slieep for my use; they are muel more tender than those less gummy. Still, yon must have greasy wool if you have fine wool. I feed grenerally twice a day-sometimes only once. The sales of my rool last year produced orer $\$ 2$ a head for my flock, and the arerage for fifteen years has becu four and three quarter pounds, such as sold this year at 50 eents a pound. My land is limestone clay loam. I have picked out and solel twenty wether lambs to a neighbor who sheared eiglit pounds a head, and solel two sheep for mutton at $\$ 350$ a head. A flock of 300 head of sheep ought to average five pounds of clean wool. I select in the fall eight or teu wethers, and feed them with meal throngh the winter, and grive them good grazing in summer, and kill throngh the summer, and the tallow arerages 10 or 12 lbs. and the meat 10 or 15 lbs. per quarter. The pelts sell at 75 cents. A three-year old wether, pure MIerino breed, often weighs 55 lbs. I liave sheared 14 lbs. of wool per head from bucks, which sold for 50 cents a lb., and 8 lbs. of wool from ewes."

A. B. Dickinson says: "I have sheared 11,000 sheep in a year, and know something of them. The man who raises sheep for mutton had better raise the largest kind, for they prodnce the most money, though they may not make the hest kind of mutton. For wool, I would keep none but the fine-wooled varicly of sheep, but I would not keep the gummy sort, because the clean wool will always prodnce the most money. In washing sheep, I am sure that the wool can al ways be mate cleaner when the sheep are washed in at rat than in a stream. If 20 sleep will weigh $20 \mathrm{cwt}$, they will eat just abont as mucli as two bullocks of that weight-that is, if they are inature sheep. Young sheep eat more, according to live weight, than old ones."

Mr. Jolnston bouglit thirty Leieesters one fall, put them in his yards, fed then ench twelve ounces of oil-meal with wheat straw, and no huy, all winter. In spring he slieared from them five pounds of wool each, pastured them all summer, kept them orer until the following February, and sold 
them for nine dollars and teenty ants each. 'They cost him two dollars. Slieep fed witl oil-cake meal or granin eat but little salt, make richer manure, more wool, and more careass. Ile grives usually one pomd of oil-meal when feeding with straw, and lialf a jound with hay. If there should be any signs of foot-rot in the flock, lie pares the hoof, and rubs into the sores a sa've of blue vitriol and lark. In very hot weather lie mises tar with the salve, to make it alherc. Sheep are never let out of the yards in winter, but to the yad they have free access at all times from the low, open sheds, and every part of the sheds ancl yard are deeply bedded with elean straw. The shepherd, instead of wading through a slough worse than that describel by Bunyan, walks on a soft bed of straw, so clean at any time as not to soil the white fleece of the cleanest Leicester.

Wm. H. Lald, of Ohio, bays: "My practice is to turn the lambs in with their mothere, after they lave been separated some twelve lours, and as soon as they nurse, separate them again; then, after twenty-four lours, allow them to nurse once more. Since I lave adopted this plan, I liave never liad a ewe's udder injured. Lambs should have a very little salt frequently, when first weaned, as the herbage lacks the large proportion of salt which the mother's milk contains. But great care slsould be used not to gire then much aalt at onec, or it will set them to purging; and if a lamb commences to purge soon after being taken from the mother, it seldom, if ever, recovers from it.

"Lambs that come early are invariably the largest, strongest, and most healthy; consequently they are the best breeders. The ewe that has her lamb carly has sufficient time to get in good order before winter, and after the lamb is weaned, she is not subject to weakness and disease, as those of late weaning, and is consequently a better breeder the next season. Poor, late feeble lambs and ewes shonld nerer be permitted to breed, for if such are, it invariably follows that the flock will degenerate. Generating or breeding eres sliould be carefully selected. Ewes sometimes continue strong and productive until trrelve or fifteen years of age; this depends on their general health and constitution."

120. Age of Sheep for Mutton.-A late English writer says: "A sheep, to be in ligh order for the palate of the epicme, should not be lilled earlier. than five years old, at which age the mutton will be rich and sncculent, of a dark color, and full of the rieliest gravy - whereas, if only two years old, it is flabby, pale, and flarorless."

121. Grub in Sheep.-Take one quart of whisky and two ounces of yellow snuff, mix, and warm to blood-heat. Let one man hold the sheep, and another take a small syringe, and discharge abont a teaspoonful of the mixture into each nostril. It is said to be a certain cure.

122. Gross and Net Weight of Sheep.-The usual estimate of gross and net weight of sheep is, that the dresserl carcass will weigh one half as much as the gross weight, and therefore, when the sheep are sold at, say fire cents a pound alive, the price is equivalent to ten cents a pound for the meat, sinking 
the pelt and all the offal, so that the butelier, if he conld sell the carcass at cost, would still have the pelt, rough fat, head, etc., tor a profit. IIence it will be seen how it is that mutton in the carcass is often quoted in market reports at less than it appears by livestock reports to have actually cost.

123. Westeri Irutton.-It is one of the incomprehensible things in Western agriculture that so listle attention is paid to the bnsiness of fattening sheep. Witl a rast conntry, as well adapted to making mutton as pork, and in many respects even better, it is one of the rarest things to see a furm devoted to the raising of sheep for their meat alone, while it is equally rare to find a farmer who does not raise hogs and fitten them for their port.

We are aware that the West is fill of sheep, and that the business is not considered very profitable. There are some gool flocks-in fact, some large flock-masters, whose principal business is to raise sheep-but it is for their flece alone. Very fer farmers, East or Test, have erer made a business of making mntton. The sheep are almost entirely bred for wool, not for meat. And besides this, more than one laalf of all the sheep in the United States are not bred distinetly for meat or wool, but simply because tley are sheep, and will answer in some sort for hoth purposes; but their flecee is often of a coarse, unprofitable kind, and their bodies lean and light. Sucl sheep are naturally slow to aequire fat, when fed for that purpose, just as their fleceo is naturally of light weight or coarse fiber. Snch sheep are not profitable, althougl so common all over the country.

Of all varieties of domestic animals, the flesh of sheep is least used, except in cities, in proportion to the quantity that is, or rather might be, protitably consumed. We estecm mutton almost the very best kind of meat provided for a civilized people. That its produetion would be found anong the most profitable we have no doubt, provided a good breed of sleep were selected, especially for their meat-producing qualities. For this purpose we estecm the Sointhdown variety the very best. Wi have known flocks of fat sheep of this sort sold here for $\$ 25$ per liead. Certainly this is a paying price. We lave several times reported sales of slieep in New York, of the long-wooled kind, at $\$ 12$ to $\$ 20$ per head, which was equal to 12 to 16 cents a pound for the meat. Is this a profitable price for the farmer, particularly tho famer of the West, the greatest comntry in the world for the production of pork ?

All the long-wooled rarieties of sheep, known as Bakewell, Leicester, Cotswold, Niew Oxforlshire, ete., are fittproducing animals; that is, they are as uaturally inclined to aequire fat as other animals are to produce only lean meat. In England, suclumuton is much estecmed. In this country the lean kinds are preferred. In Ohin and nther Western States there is a grade of sheep called common, that are as well fitted for the purposes of the Western fumer as any lie conlu obtain in this country (except the Soutldorns) to breed for mutton, if carcful selections were inale, and some care exercised in breeding and feeling. It is true they are a mougrel breed, nade up of crosses of all the varietics ever imported, but they are strong 
and laardy and longrelerencl, which are valuable qualities for the drover. Their bodies, when well fatten, at two or three years old, will weigh from fifty to sixty-fire pounds, and the meat is just fat enough to suit the American taste. The hearier careasses of the long-wooled variety are gencrally too fat, thongh we think the taste for fint mutton is an acquired one, like that for fat pork.

But, fat or lean, mutton will always find ready sale in this city at remunerating prices. Wrestern firmers should turn their attention more earnestly to the subject of raising sheep, not for wool, but meat for the supply of all the Eastern cities. We profess to be tolerably well acquainted with the great prairies of the West, and fully believe that there is no branch of agriculture eo certain to prodnce sure and profitable returns as that of raising sheep of the kind we have indicated. We know of no other pursuit that the new settlers in hiansas could adopt at all to compare with this. Such a town, for instance, as Lawrence, might own a hundred thousand slieep, all of which slionld be kept ont on the broad prairies in summer, nuder the eare of shepherds and their dogs, to gruard them night and day from their greatest enemy, the prairie wolf. In winter they conld be provided for on a hundred falms, uncler cheap shelter, with earth walls and grass roofs. 'They winter' well upon well-cured wild hay, without grain, except for those in hospital, if fed occasionally upon any kind of roots, such as ean be grown in great abundance in that soil. In the fall or later part of summer, select the best animals for market, and start them eastward across Iowa and Illinois, feeding them on cheap grain when the grass fails on the great prairie pasture.

The raising of cattle must be the business of liansas settlers, and we believe the best of all will be mutton sheep. The new settlers, too, must for a time make meat their prineipal diet-in fact, it is the national diet of that region, just as regetables are in China. We do not know of a greater act of folly, or a greater humbug, than inducing people to go to liansas to practice the peculiar, not to say stupid, doctrine of vegetarianism.

What the people of the West want-what all who grow meat and all who consmme it want-is to have the great sea of prairie grass converted into meat-cheap meat. This should be the leading object of all emigrants to the West. The business of grain-growing naturally belongs to a pastoral people, upon old farms, rather than to new settlers. It is a subject to be thought of both by enigrants and old settlers, which is the most profitable, stock or grain, and if stock, which particular lind.

124. Sheep in Texas,-There is, or has been, a sort of mania abont sheep in Texas. The start made a few years agro by G. W. Kendall, and his suceess, after going through all the phases of ill luck, losses, and discourarements, which persereranec overcame, has indueed mauy others to establish great sheep-farms in that State. Majol Wm. Leland, one of the proprictors of the Metropolitan Hotel in this city, is one of the number who has followed the lead of Mr. Kendall, with every prospect of suecess. There is, besides the fine wool-flocks established in Texas, a constant and large importation 
of the coarse-rrool sheep of Mexico. It is estimated that a fourth of a million of Mexiean sheep have crossed the line into Texas since the first of 1859 , and the number is constantly inereasing. These Hexican sheep are crossed with Northern stock, and make a valuable progeny, both for wool and mutton. We shall expect before many years more to see Texas mutton sheep in the New York market more freqnently than we now see Texas beef-eattle, and that they will be muel better liked, both by butehers and inutton-eaters, than the bullocks are.

A Massachusetts correspondent wants to know more than we do about sheep-farming in Texas. We commend him to Wm. Wilkinson, Comal Ranehe, near New Braunfels, Texas.

We don't know "what part of the State is most snitable for sheep husbandry," but we do know that part of it is, as above indieated, for there George W. Kendall and others liave sueceeded.

"What breeds of sheep are to be chosen?" We ean answer: All breeds that have sueceeded in the Northern States have sueceded in Texas.

"What are the pecuniary advantages?" This question we can answer by stating that the first cost of land for a location is very small compared with the eost in Massachusetts, while there is a boundless range of open country upon which great flocks ean be grazed, in charge of the elhepherd and his $\log$; and as for winter feeding, that is not worth mentioning, and the rudest shelters-nere earth walls-io break the foree of the wind, will anstrer at first in place of eostly barns. Subsistence, too, for hirelings, is also quite incxpensire, and, talien altogether, 'Texas certainly appears to hare many advantages for sheep husbandry.

There are, to be sure, some drawbacks. It is a long way from the great center of commerce to which wool must be transported, and so far as we can see, it is so far away from mutton-eating communities, that the meat is nearly ralueless. We rery well remember, howerer, when the same thing was true of Ohio, where thousands of sheep lave been slaughtered for the pelts and fat, and the meat fed to the pigs. Now, slicep are worth in Ohio within a dollar what they are in New lork. Time ma work a similar change for Texas, and then it will riral all other States as a sheep-producer, for that is a business that can and will be eonducted withont sluve latuor.

125. Producing Twins. - A large sheep-breeder has declared "that sheep highly fed with meal or other good provender, abont the time the buck is with them in the fall, will almost invariably have two lambs apieee, and that these may nearly all bo raised by proper attention to the mothers. The trieat mistake in regard to sheep is in not keeping them well enongh. If you wish them to be prolific or profitable, give them plenty of the best hay through the winter, and meal daily, and for shelter a warm barn-cellar, wherein is an open tank of pure water. No kind of grain need be ground for feeding slieep-the hardest is thoronghly masticated and digested by them. The importanee of good feeding is minuestionalule."

It is by no means an mheard-of thing for all the cwes of a flock to arerage 
twins. An average of 130 per cent. to 150 per cent. is quite usual, and witl some breeds a much greater increase is the general rule. The sheep oflers her ownel more sonees of profit than any otlier animal. First, lier natmal increase; second, her wool; third, her flesh; and this is the most important of all tine considerations connected with sheep husbandry, becanse a greatly increased consumption of the flesh of sleep will greatly promote liealth.

Sheep "come in play" wonderfully in well-managed furms, especially such as are pushed to their utmost eapacity, as a means of inereasing fertility in rarions ways, feeding off green erops, such as clover or rye, previons to plowing them under, securing thus the advantage of passing the erop through the animal system without moving it from the field, seattering the manure very crenly prerions to plowing, and giving what remains of the green crop when plowed in the advantage of undergoing its decomposition in contact with animal excrements. The sheep possesses other and greater achantages over other kinds of stoek, which recommend it for general culture. Among these is its great fecundity.

126. Numbering Sheep.-W. D. Dickinson, of Tictor, Ontario Co., N. Y., gives, in the Stock Journal, the following plan of numbering sheep:

"About twelve years since I commenced numbering, elassifying, and registering my flock, which has been of great advantage to me, enabling me to select at all times for sale (which I invariably do myself) such as are of the least value, whether with regard to age, weight of flecee, quality of wool, or ralue as breeders.

"My method of numbering is by notehes in the car", as follows: $\Lambda$ notch in the fore part of the left ear stands for 1 , one in the back part of the samo for 3. With these I number up to 10 ; thus, two notches in the fore part, 2 ; two in the back part, 6 ; two in cach, $s$, ete. $\Lambda$ notch in the fore part of the light ear stands for 10 , one in the back part of the same, 30 . With these I number to 100. This is as far as I have necasion to go in any flock, as I seldom have orer 300, and consequently nerer hare as many as 100 lambs of each sex in one year. This might be carried much farther by cutting off the end of the left ear for 100, and of the right for 200; a notel mirglit then be made in the end of the left ear for 400 , and in the end of the right for 800 .

"The age of my slieep is known by the holcs through the cars. A hole through the left ear stands for 1 -that is, the year 1841 , '51, or ' 61 , showing the year in which the sheep was born; one in the right ear for 3 , so that a slicep born in the year ' 56 would have two holes through the right ear; if in '57, two holes through the right and one throngl the left; for ' 55 would requive two throngh each, instead of which I simply make a notch in the end of the left ear; and for' ' 59 , one in the end of the right. The years ' 40 , ' 50 , ' 60 , ete., the ears are left without any holes-thus commencing anew erery ten years, by which time those of that age are usually gone. I number my lanbs as they are äropped, comnencing each year with No. 1, both buck and ewe lambs. 
" $\mathrm{My}$ book is kept in the following manner :

\begin{tabular}{|c|c|c|c|c|c|c|c|c|c|c|}
\hline $\begin{array}{l}\text { No or } \\
\text { liwes. }\end{array}$ & $\begin{array}{l}\text { year } \\
\text { born. }\end{array}$ & Class. & $\begin{array}{c}\text { Live } \\
\text { weiglic }\end{array}$ & $\begin{array}{l}\text { Weight of } \\
\text { Fleece. }\end{array}$ & Buck used. & $\begin{array}{l}\text { Yeaned. } \\
\text { April. }\end{array}$ & $\begin{array}{l}\text { Sheared. } \\
\text { June. }\end{array}$ & $\begin{array}{l}\text { I'uck } \\
\text { Lambs. }\end{array}$ & $\begin{array}{l}\text { Evivo } \\
\text { Lamis. }\end{array}$ & I'emarks. \\
\hline $\begin{array}{r}7 \\
15 \\
3\end{array}$ & $\begin{array}{l}51 \\
51 \\
54\end{array}$ & $\begin{array}{l}3 \\
1 \\
2\end{array}$ & $\begin{array}{l}81 \\
93 \\
83\end{array}$ & $\begin{array}{l}6-1 \\
4-1 \\
4\end{array}$ & $\begin{array}{l}34-53 \\
39-53 \\
51-53\end{array}$ & $\begin{array}{l}12 \\
13 \\
13\end{array}$ & $\begin{array}{l}11 \\
26 \\
21\end{array}$ & $\begin{array}{l}1 \\
2\end{array}$ & 1 & \\
\hline
\end{tabular}

"In the first colmmn is the number of the ewe; in the second, the year in which she was born; in the third, the class denoting the quality of the wool, which is regratated by the number of curves to the inch; the first containing 24 and upward ; the sccond, 22 to 24 ; the third, 20 to 22 ; the fonrth, 15 to 20. The founth colnmn gires the weight of the sheep when sheared; the fifth, the weight of flece ; the sixth, the number of bnck used and the year in which he was born; the serenth, the montl and day the lamb was dropped; the eighth, the time when the erre ras sheared; the ninth and tenth, the number of the buck and ewe lambs. My flock now numbers 267, principally breeding ewes and yearlings. $M y$ average weight of flecees, when well washed, is usnally about $4 \frac{1}{2} \mathrm{lbs}$, the quality of wool equal to medium Saxon, numbering from 20 to 25 cnrves to the ineh, areanging abont 24 ."

Another plan is giren as follows, for mumbering sheep, which, though not quite as permanent as the method detailed above, may be preferred by some jersons on the score of humanity.

"We were handed a sheet of paper mpon which was noted the weight of flece of each slicep in the flock; opposite was set the number of the sheep, a corresponding number liaving been branded upon the animal itself at the time of taking its last clip, by applying a mixtme of lamplack and tal with cast-iron figures. This course had beẹn pursued for some years, and its results were apparent in a wool crop brought up from an arerage of four pounds to orer five, and a corresponding increase in the size and quality of shecp. The practice had been to slangliter and otherwise dispose of all animals ranking lowest in weight of flecee and to improve upon the quality of the remainder by judicions crossing."

127. Shearing Sheep.-An old sheep-slicarer, who can clip a sheep handsomely in three minutes, or shear and tie up the tlece in four minntes, who lias often clipped 100 sheep a day, wants us to give our readers the benefit of his plan of doing it. First, have two pairs of good sliears; one pair to trim witl, and the other to do the principal work, and never use dull shears. $\Lambda$ good oil-stone is the best sharpener. What is termed a down-set shear, with blades fire inches long, he considers best. In using then, never draw the slears backward while making the elip, hut rather push forwall aud lieep the shears lerel and close, and nerer clip trice in one spot, as that cuts the wool.

'To hold the sheep, have a hench as high as the lower part of the kneecap; or if the sheep is large, it may be lower. Lay the elieep back to you, with head to your right inand. Int your right knee gently on the sheep's neek, with its right fore leg in the hend of yours as you kneel, having the blieep close to the elge of the bench, with its back braced against your left 
leg. Rest your left arm on the sheep's left flank, while you lold its right hind leg in that hand, stretehed out to the elge of the beuch, and holding to it if you wish, if the sheep is disposed to struggle.

Commence shearing at the opening on the left side of the breast, and trim off all the wool on the belly and inside of the lind legs, and remore it to one side till the flecee is oft, when the trimmings of clean rrool are to bo wrapped in it.

To shear the body, place your left leg on the bench astride of the sheep, taking the jaws in your left hand, and clipping the foretop and right side of the neck, and down on the left breast. Then you change position, stepping back a little and raising the sheep on its hips, by catching liold of the left hind leg with your right liand withont laying down the shears. Pull the sheep close to the edge of the bench and place your right leg between its hind legs, with its neck and shonlders on your left knee, as it rests on the bench. Fow elip over the point of the shoulder, and then straighten the neck with your left hand, without stopling the shears, and finish off the brisket and the neck, and then elip on down the side, and over the lijp and back, letting the sheep down gradually, so as always to liare the slin you are clipping free of wrinkles. Now take your left knee off the neck, and hold it with your left hand while you remore your right leg and place the left one in its plaee, so that you can bring the right knee upon the bench, liceping the shears going all the time with the right hand. Then lift the head with the lett liard, and clip that side over the point of the shoulder, and, raising the sheep gently, bring its liead between your legs, while you finish elipping. Tale care that the sheep does not struggle, and when done, lift it clear of the flece, so as not to tear it. Fold the fleee with all the loose wool that is elean inside and roll it very suug, with the cut end of the wool out, and tie with cotton twine, so as to look neat and bear liandling without getting loose and ragged.

Following the abore directions, you will need to stop but twice for a moment to turn the sheep, so that the shears are almost incessantly clipping from the tine you begin till you hare finislied.

125. Tagring.-One of the cares of sheep most important for their health and comfort is tagging, and this is most often neglected. Probably the only attention ever given to this matter is at shearing-time, and we have seen, even then, sheep sent off ont of the shearer's hands with the tag-locks untonched. If there is anything in farming more slorenly than this, we dou't linow what it is.

129. To Cleanse Fine Wool,-There are a few old-fashioned houses from which the spinning-whecl is not yet entirely abandoned. The inmates of such do not always know how to cleause the mum ont of Merino wool before sending it to the carding-machine. Let them be sure to remember this direction, by which we have cleamed many a hundred-weight, some of which was almost as blacli as my hat, with dirt and gum, characteristic of all finewool shecp. 



\section{P'L A TE VII.}

(Fige $9 \vec{i}$ )

Is this plate we present to the reader such a collection of excellent portraits of the most celebrated horses in America as ean nowhere clse be proeured. The four upper figures will be at onee recognized as correct likenesses of aumals that have won a name that makes them famous in equine history. That of the Justin Morgan horse will be found in this chapter. He is the progenitor of a fimily that has won the hearts of the people. Flying Childers stands as the representative of the race-course. Patehen and Flora Temple are the most noted of the great family of American fast trotters. The Arabian here represented is a portrait of one of the noted horses presented to Hon. William H. Seward, and by him to the New York State Agricultural Society, and this pieture gives one a good iclea of the spirited appearance of that breed. The Cleveland Bay is the representative of a elass of noble earriage horses which has given character to maxy of the same elass in this country, particularly in Central New York.

The Norman horse, as we see him here, gives a good idea of the appearance of the heary diligenee and common work-horses of France, having a thick neck, short, strong legs, and round, compact body, capable of sustaining great burdens, and pulling immense loads at a slow gait, as compared with some of our American fast horses. This breed was made quite notorious in this comtry by the importation of the late Edward Harris, of New Jersey, about twenty Jears ago." The portrait of the Canadian horse is a fine representative of his class, which was formed by a mixture of the Norman horses of the early French settlers of Canada with some smaller breed, which, by negleet and exposure, and carelessness of improvement in breeding: has produecd a race of small, hardy horses, known as Canadian, which are sometimes, though erroneously, called ponies. A careful study of these portraits will be useful to all farmers, as well as many other persons. 
For 100 lbs. of wool, take four gallons of urine and eight gallons of rainwater; mix and heat a little above blood-heat, until the scum rises, which skim off. Keep it at the sime lieat in a kettle on coals or a little fire out of doors. Put in what wool the kettle will conveniently hold, and let it remain about five minutes; take it ont on a board that will drain the liquid back into the kettle, or else put it in a basket over a $t u b$, so as not waste the liquid, for it will be equally good for the last bateh as the first. When it is drained, put the basket under a stream of water running on it if comvenient, or in a rumning stream if you can, or else with plenty of clear water in a large tub; it will wash rery easily, and le as "while as wool."

Don't forget to sprinkle the dirty liquid "yon the poorest spot in the garden, for it is a powerful manure.

The same kind of liquid is the best thing known to take the dirt and grease out of any kind of foul woolen clothes or yan.

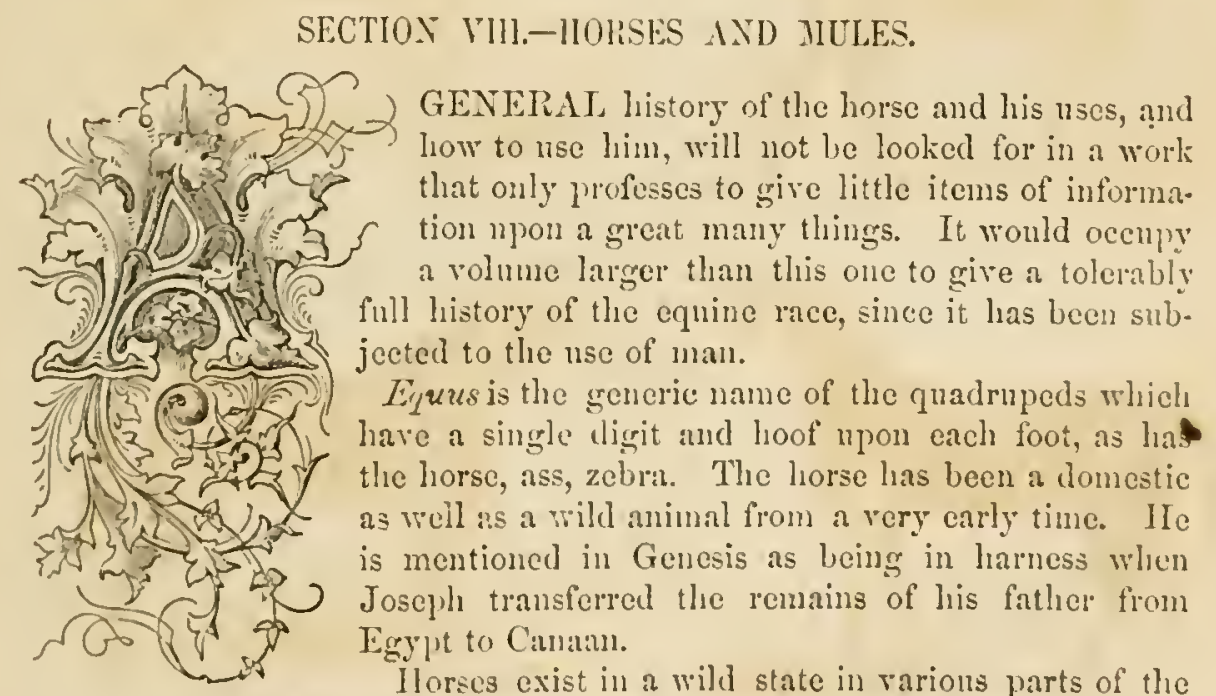
globe. They were once quite numerous in the territory embraced in some of our most western States. Domestication works material change, the most marked of which is an increase in the size of the trunk. Then follows an increased size of all parts, and a loss of the fleetness natmral to the horse in lis will state.

The Arabian lorse, thougl domesticated by a semi-savage race, still retains some of his wild charateristics, one of which is flectness and long endurance. The Arab tratition in regard to the horse is, "that ho was created out of the wind, as Adam was ont of the earth." Hence, "flect as the wind," is often applied to the loorse. The tradition is, that the male of the horse was created first, as the more noble of the two, and that tho liorse 
was created before man, and after he was created lie was toll to choose the most beautiful of all anmals, and he chose the horse; upon which God said to Alam: "You lave chosen that which is a glory to you, and will be to rour children." The Alabs protess to know the pure Arabian horse, the descendant of Zad-el-liuket, which Solomon presented to their tribe, by the finmess of his lips and eartilage of the lower part of the nose; by the dilata-. tion of his nostrils; by the leanness of the flesh about the reins of his head; by the elemance of the neck and shoulders; by the softness of his hair, mane, and shin; by the fullness of his breast; by the large size of his joints; and by the dryness of his extremities; and also by his moral indications, for a noule liorse has no malice in him. Ile lores his master, and frequently will suffer no other to monnt him. IJe refrains from doing what nature prompts as necesery while his master is on his back. IIe will not eat food left by another horse. He lores to s]lash limpid water whenever lie meets it. II is instinct, smell, sight, learing, intelligence, and address are all used for his master; and he will fight for lim. Hence the Arab's love of his horse. It will be well for us all to remember some of the traditions of the Arab, for they describe raluable points in a lorse.

130. Thorough-Bred.-This tem does not appear to hare any rery definite meaning in this comtry. It is generally supposed to trace back to something in the way of pure blood, of a better stock than the common one of the country; but what that stock is, perlups not one in ten who own: horses can tell. A writer in the (English) Farmer's Magazine says:

"The term, thorongli-bred is an expression not clearly defined as recrards any of our domestic animals, but it wonll be very desirable to have some rnle established. It may be accepted as a principle that brecding from animals endowed with certain properties and perfections throngl sereral gen- crations, constitutes the claim to distinction; but there is no adopted rule to determine hou many generations are suficient to establish the iitle."

Yet, according to our understanding of the term, a "thorough-bred" horse must trace back, free from contamination of baser blood, to the pure Arabian stock. The original of that stock in England, so far as pedigrees are attempted to be traced, was the "Darley Alabian," brouglit from "Araby the blest" by a Mr. Darler. That horse was the sire of Flying Childers, and grandsire of Eelipse, one of the most renarkable horses ever on the English race-course. He was not what would be considered a liandsome horse, by a brecler of Morgan stock, but his fleetness and endnrance were beyond com. petition, and liss stock have followed in his footsteps. He died at the age of twenty-fire years, after having begotten a greater number of prize-win ning colts than any other horse that erer lired.

If a horse can trace back to old Eclipse, or any of his famous colts, there is no mistake about his being "thorongh-bred." So he would be if he traces back to the "Godolphin Arabian," a Barb that was introduced into England at a later period than the Darley Arabian.

There slould be some definite rule established among lorse-breeders and 
our several State agricultural socicties as to how far back and to what stock the pedigree of a horse should go to make him eligible to a prize as a "thorough-lired."

131. English Hunters, -This is a term given to a breed of English horses Which are ligh up in thoronglh-bred blood, with a strain of other blood possessing great powers of endurance. The liead of a lunter of perfect form is suall; his neck thin, particularly below; a firm and arehed crest; jaws wide, and rery light on the bit.

132. An Einglish Coach-Horse.-The type of this rariety is the "Clevoland Bay," some of which lave been imported into this country, and lave left their mark upon the finest eoach-horses we have in the United States-such as are to be found more abundantly in Central New Iork, than in any other locality.

133. Wnglish Roalsters,-The term more eommon for this class in England is "Ilackney"-a term seldom leard in this country, and if leard, would be more likely to be mulerstood as meaning a "hack-lorse." The nearest type of a hackney that we have, as a distinct breed, is the Morgan horse.

Fouatt says: "A lackney is a hunter in miniature. Ilis light sloould rarely exceed fifteen lands and an inch. IIe will be sufficiently strong and more pleasint for greneral work below that standard. He should be of a more compact form than the hunter, of more bulk according to his hirglit. It is of essential consequence that the bones bencath the knee should be deep and flat, and the tendon not tied in. The pastern slonld be short, and less oblique or slanting than that of the hunter or race-horse. The foot slould be of a size corresponding with the bulk of the animal-neither toe lollow nor too flat, and open at the heels. The forelegs slould be perfectly straight ; for a horse with his knces lent will, from a slight cause, and especially if overweighted, come down. The back should be straisht and short, yet sufticiently long to leave comfortable room for the saddle between the shoulders and the luck without pressing upon either. Some persons prefiel a hollow-backed horse. It is generally an easy one to go. It will canter well with a lady, but it will not carry a heary weight, or stand mueh hard work. The road-horse should be high in the foreheal, romel in the barrel, and decp in the chest."

134. 'The English Iray-Horse-There is a variety of horses known as the dray-horse, or more generally in this conntry as the English cart-horse; a rery heary, strong, slow-gaited horse, origrimated by a eross of the Flanders or Norman loree with the Suftolk Punch, a sorrel horse of fifteen or sixteen liands high, with low, rounded shonldess; thick on the top; low back: deep, round eliest; longr back; highl eroup; large, stroug duarters; full flunks; round legs, and short pasterns. This is a good description of a strong work-liorse. We liave something like it, tlough rather increased in size, in the Pemsylvania wagon-horse.

135. Morgan Ilorses,-The most distinet strain of American horses-in fact, the only one which assumes the eharacter of a race-is that now widely 
known as the Morgan. 'The origin of this race is giren in the following extracts from letters written by a son and a relative of the original owner of the old Morgan horse:

The following is an extract from a letter of Justin Morgan, originally furnished for the Cultizator (rol. ix, p. 99), dated Stockbridge, Tt., March 1, 1st2. After stating that his fither owned the liobe from which the race of Morgan horses spurung, he says:

"I will now relate the facts relative to said Morgan horse as I recollect them. My father, Justin Molgan, brought said liorse, or ratler said colt, into Randolpl, V't., in the summer or autmmn of 1795. Said colt was only: two years old when my filther brought him to Randolph, and lad never been handled in any way, not even to be lerl by a halter. My father went to Springficld, Mass, the place of his nativity, and the place from which he renoved to Randolph, in the spring or summer of 1795 , after money that was dne to him at that place, as lue said; and instead of getting money, as he expected, he got two colts-one, a three-ycar-old gelding colt, which he led : the other, a two-yenr-old stallion colt, which followed all the way from Springfield to Randolph; liaring been, as my fatler said, always liept with and much attached to the colt he led. Said two-year-old colt was the same that has siuce been known al! over New England by the name of the Morgan horse. My father broke said colt limself, and, as I lave before remarked, owned and kept him to the time of his decense, which took place in March, 1795, and said horse was firo rears old the spring my father died; and, as befure stated, "soon after my father's decease, lıe passed fron my father's estate into the possession of Wm. Iice, of Woodstock, Tt. I can not state positively that my father purchased said colt in Springficld, Mass., but I am very confident that he purchased him in that town or in the immediate vicinity, on Connecticut River."

We next offer an extract from a letter of Joln Morgan (see Cultivator, rol. ix., p. 110), in which it will be seen that the material points set fortl ly Justin MLorgan are confirmed, and some further light given in regard to the blood of the first Morgan liorsc. Jolnn Morgan resides at Lima, New lork, and is, we believe, a relative of Justin Morgan, Sr., and was a near ncighbor of the latter previons to his removal from Springfield to Vermont. In referenee to the colt above described by Justin Morgan (2d), John Morman says: "ITe was sired by a horse owned by Sealy Norton, of Enst IIartford, Conn., called the 'True Briton, or Beautiful Bay.' Ile was liept at Springficld one season by the said Justin M[organ [Sr.], and two years after, I kept him two seasons. This horse was said to have been raised by General Delancy, commander of the refugee troops on Long Island, and rode by him in the Rerolution. It was said that one Smith stole the horse from the General at King's Brilge, while the General was in the tavern; ran him across the bridge and took him to the Ameriean arny, near White Plains, and sold him to Joseph Ward, of Hartford, Conu., for $\$ 300$. It. was also said at that time that lie was sired by the imported horse ealled "Traveler," 
said to liave been kept in New Jersey. Ward was a merehant, and kept the liorse three or four years for a saddle and carriage horse, anl then trided him off to Norton, and Norton kept lim for mares wlile lie livel. The description of the Morgan breed griven by Mr. G. Barnard (Cultivator, vol. ix., l'.33), answers well to the stock of 'True Briton.' I hare always understood that Morgan kept the colt for a stallion at Randolpli, and was very celcbrated for lis stock."

The above statements of Justin and John Morgan comprise, as we belicre, the true history, so far as it is known, of the origin of the far-famed Mcurenu horses. From the position of the Messr's. Morgan, they liare hal the liest possible facilitics for obtaining correct information on this subject, and we are not aware of anything which should hinder their statement from receiving full credence.

"Of the old Morgan's progeny, three became famons as stallions, riz., the Slierman Morgan, the Woodbuly or Burbank, and the Chelsea. Of these the Sherman Morgan was greatly the most distinguislied. I have ascertained to a certainty that he died in the wintel of 1835. Black Inaw was sired by him."

136. Black-Ilawk Morgans,-Fifteen years ago, S. WT. Jewett, of Vermont, wrote of these as follows:

"I believe the MLorgan blood to be the best that was ever infused into the 'Northern liorec.' They are well known, and are esteemed for activity, hardiness, gentleness, and docility throughout the New England Sitates; well adapted for all work; goos in erery spot, except for racers on the turf. They are lively and spririted, lofty and elegant in their action, carrying thenselves gracefully in the lianess. They have size in proportion to hiesht: bone clean ; sinewylegs; compactness; slort, strong backs; powerful lungs; strength and endurance. $\Lambda$ mixture of the Aforgan blood, though sumall, may be easily known from any other stock in the country. There is a remarkable similarity prevailing in all of this race. They are known hy their slort, lean licads, widle across the face at the eyes; eyes lively and prominent; open and wide in the under jaws, large windpipe, deel brisket, heary and round in the body, broad in the back, short limbs in proportion to size, broad quarters; a lirely, quick action; indomitable spirit; move true and easy in a good round trot; fast on the walk. Color: dark bay, clicstnut, brown or black, with dark flowing wary mane and tail ; hearl up, and move withont a whip) ; about fifteen hands high ; action powertul and spiritcel.

"They are highly celebrated for general usetuluess, make the best of roalsters, and live to a great age. In fact, they are the perfect 'I ankec lianess liorse.'

"The Morerans are very like the noble Arab, with similar eyes, uprigrlt ears, high withers, powerful quarters, hocks well placel under their weight, vigorous arms and flat legs, short from the knee to the pastern, clnse joinferl, possessing immense power for their size, witl great fire and cuurage. lint a few of the MLorgans, however, evince extraordinary speed. 
"It is said that the best stock of horses in the New England States are found mmong the progeny and descendants of the Sherman Morgan, which was ownel by Mr. Bellows, of Termont.

"The figure given on another page is a portrait of Black IIawk, 'a colt of the Slierman Morgan, which was got by the old Justin Murgan horse. The dam of Black Ilawk was a three-quartel-llooded English mare, raised in the jrovinee of $\mathrm{New}$ Brunswick. She conld trot a mile in less than thee minutes, and wejghed 1,025 lbs., and was in every respeet a most perfect animal.'

" liack Hawk was bred by Mr. Matthews, of Durham, N. II. IIe is a jet-black color; weighs, in good flesh, 1,040 lbs.; his hight is tifteen hands and one inch. A line drawn from the hiperen with the ham, just below the setting on of the tail, is fou inehes longer than the back, or the distance from the hip to the withers. A line dropped perpendicular from the neck, parallel with the fore leg, is nineteen inches forward of the junction of the withers. The distance between the hip and the ribs is only one and a lialf inches. ITe has a broad and rigorous arn, fat and clean leg, large museles, short from the knee to the pastern, large windpipe and nostril, well open when under inotion. He is one of the best proportioned and most elegant moving horses that can be produced. He is perfectly sound, a close-jointed, clean-limbed animal, and carries a beatiful waving head, mane, and tail. II is legrs are flat and hard, clean from long hairs on the fetlock; his eyes stand out prominent; his disposition kind and playful. He keeps fat with very little feed of oats and bran, three quarts of each daily, and five or six pounds of timothy each day.

"No fault can be found with the horse, muless it be in his size; howerer, his stock are sufficiently large for roadsters and for general usefulness in this State."

137. The Faults of the Morgan Horse.-Of the Mlorgan lorses as they were at the time Mr. Jewett wrote, particnlarly the Black Hawk strain of the blood, we liave no fanlt to find-we rather indorse his statement. But fiftecu years have wrought a change. As a general thing, Morgan horses hare been bred too mneh in-and-in, and withont regard to size. They are no longer "lofty" in proportion to the weight, bnt, on the contrary, are "squatty" and to the eye of a good judge of horses, far less attractive than they were formerly. What is needed, is an infusion of blood of a taller race - such as gave character to the Black Hawks. Wherever they have been crossed with Messenger stock, Cleveland Bay, or other's of similar form, the improvement lias been marked, and some of the very finest roadsters and curriage-horses hare resulted. The Morgans, erossed upou other good breeds, do not improre those as much as it improves theirs. It is still a favorite breed of horses in New England, but not as much so as it was some years ago. The uniform color of the family lias been a great recommendation, and there has been also a greater degree of general beanty in the Morgan family of horses than in any other ever extensively bred in this country. 
We shall now give a few useful items for owners of horses of wlatever breed, mongrel or thorongh-bred.

13s. Iriving-The Start.-The first mile is the most important of the joun!ney. More horses are injured in the start than in the balance of the whole day. You shonld earefnlly avoid rapid driving immediately after a horse has been full fed. Many old trarelers feed orer-night all the grain they intend the horse to eat in the twenty four hours. Others feed at night and at noon, and then give time after the horse has eaten his mess before starting, or else drive very slowly for an hour, making up time as night approaches. In all cases when a horse has been fed and watered an honr or two before starting upon a journey or drive of sereral miles, it is proper to drive slowly for the first mile or two; but when the feeding and watering have been more recent, the propriety of going along at a jog or easy pace is still more urgent. Colic, founder, broken wind, have all of then resulted from too rapid driving when a horse was full. A friend of ours, a plyysician, who had occasion sometimes to violate this dictate of good management in lis liaste to reach some case of great urgency, onee informel us that when he drove at a rapid rate immediately after feeding, his horse would scour almost invariably, and scem to suffer considerably.

Fven in snch cases where a horse must be driven upon a full stomach, it is better to divide the distance into equal parts-say ten miles, which you intend to drive in an hour, and give forty minutes to the first half, and do the other five in twenty minutes. In that case be eareful, when you stop. not to leare the horse to cool suddenly. If the weather is hot, and you have driven hard, don't mind trying to get your horse in a cool shade. The sum won't lunrt liim.

There is another great error in driving which has often been suggested to us. It is that of constantly urging a horse to exert limselt beyond what is natural to him. For instance, if a horse is urged to perform in two hours a clistance that he wonkl, at his natmral pace, recunire three hours to do, it will injure him more than four hours' driving at his regular pace; and if this urging is continued all day, he will break down, just as a man would, it' urged to double his speed in walling.

139. Size of Roalsters, $-A$ road horse shonld be abont fifteen hands high (a hand being four inclies), measured from the top of the shoulder or withers to the ground, when the horse stands naturally; his weight should be about $1,000 \mathrm{lbs}$; for such weight in an animal fifteen hands high, in moderate flesh, indicates compactness and power somewhere. Experience has jroved that horses of this size carry their weight better on long journers, injure their feet less on the parements and hard roals, and are apt to be more leet than those of a larger class; for while greater length and hight will give an increased stride, either ruming or trotting, the jower to gather rapidly, and especially for long distances, requires much greater muscular exertion in large than in small horses, from the greater weight to be propelled. Onr fastest trotters hare generally been from this class. 
110. Walking liorses, -The best gait a holse ever had fol every-day use is a rood walk. It is a gait that not one in ten possesses. Colts are not trained to walk in all the Eastern Stities. Fonng America wants more speed. Fentucky lias more good walking horscs than any other State, for there horseback traveling has long been in fashion for men and women orer a country where mudly roals, at some seasons, rendered any other gait impossible, and fo lorses have been bred for the suddle and trained to a walking gait. This is also the case in all the TVestern States, and perliajs might have been so in New England, when onr grandmotlıers rocke to meeting on a pillion behind our grand fatlicrs. Int one-horse wagons have put horseback riding ont of faslion, and now a good walking horse is more rare than one that can trot a mile in 2.40 .

At the Springfield (Mass.) horse show of 1560 , the writer was one of a committee to award prizes to the two best walking horses. Out of serenteen entered, the committe found but one which was considered a first-rate walker. This was a Morrill nure, which walked five miles an hour with ease. Two others were fair walkers, and the others knew no gait that could be called walking. At the New Fork State Fair the same state of ficts was agrain developed. A letter from Wiseonsin says: "I think holses trained to walk fist would be a greater benefit to farmers in general than fast trotters, as almost all of his work has to be done with a walk. I onee knew a man in Massachusetts who, before the railroads were built, kept from two to four teams at work on the road, ancl never allowed them to trot at all, and male the distance in quickel time than his neighbors, who made their horses trot at every convertient place. ITe said that when' a lorse commenced to walli. after a trot, he walked much slower than his common gait if kept on a walk, and thereby lost more than he gained." Will farmers think of this, and pay more attention to walking horses?

141. Instruments of Torture Ised by Horsemell.-The following sensible lemarks are from the Irish Farmer's Gazette. They are quite applicable here:

"The good old English roadster's style of walk, trot, or cantel" is too steary for your fast young man; he thinks it far beneath him to speak a kindly worl to his lorse, or to control him by an easy signal; and howerer quiet the lorse may be, he is rarely seen on his back withont at least four muneeessary instruments of torture-namely, two spurs with sharp rowels, one whip, and a serere eurb bridle. Why should it be tlie nuirersal custom in this comtry for men armed with these cruel instrmments of torture to ride quiet, docile horses, and often punish them for a fanciful fanlt which they themselves bring abont by their own want of experience and knowledge of the hor'se's nature?

"If a man has not the ability to handle a horse lightly, and at the same time keep his balance in the saddle, lue las no business to ride one of ralue and high comage. It wonld be better for the liorse and safer for the man to keep his teet on terra firma.

"The more a horse's mouth is used to a severe bit, the less he will care 
for it, as he will soon learn to neutralize its effects by pulling and liecping the reins in a state of tension, and thereby prevent the rider from checking or wrigrling the bit-to punish him. 'The dead, steady pull is fur less painful to hin than the jaw-brealing the rider would be able to intlict upon lim if allowed to keep lis reins slack and ready for a jerk.

"One of the many canses which makes pulling lorses is the mustendy sent of their riders. Many men can not vide a light-mouthed horse, but they can sit a puller with ease, becanse the firm hold this horse allows them to liave on the reins is the main thing upon which they depend to keep their halanee.

"I have seen the most inveterate pullers in some people's hands ridden in bits invented by their owners, regrula jaw-breaking or cloking power, and still pulling so had as to tear the skin of their roder's hands. And I have no hesitation in saying-luaving frequently proved my assertions by practice-that if one of these tear-away pullers elanged lands, and his new owner wonld bridle lim with an easy snafle, and let him stand in the stal,le -to feel the difference-an hour betore he was mounted ho would forget his oll liabit."

142. Saddle-llorses.-One of the meanest things erel tanght a saddleholse is to carort and enre, and go dancing and praneing about as though trying to keep within a circle just large enough to hold his four feet elosely d'awn together. If you are selecting a saddle-liorse, see that lic does not stand square mpon his forward feet. They should reach well formard, and then there will be such an easy spring that you may lide at a smat trot witlout fecling as though you are struck with a sledge at erery step, as you may upon some lorses wlose hoofs are square under the legs, and appear to liave alont the same degree of spring that you would have upon woolen pins stepping along, and brought down at every step like a parier's rammes. Nerer sclect a rery round-backed horse for the saddle. It does not hold its place, well upon such a back. $\Lambda$ good saddle-liorse must possess good sense as well as a good gait and grentleness.

1.3. Colon Indicative of fentleness.-It is asserted that the reason why eirens manngers seleet parti-colored lorses is not their funcy color, but because it indicates gentlencss and tractability, and that the animals will fubmit to training better than horses of nue color. A little thought ancl ubeervation upon this subject will enable any famer to settle the question lu his own mind. Perhnjs there is nore than appears at first riew in the common expression, "a fiery hlack horse." Is it not because black indieates a fiery temper? Independent of color, we would look in the counteuance of a liorse to see whether le would bear training. In some animals there is a general appearance of an nuly disposition. $A$ face broad and full between the eyes indicates good scnse, which is one of the most important things in a lorse.

1.t. [uorse stables slonld he light, roomy, and well ventilated. Nerer put a lorse in a cellar. Build your stables lighl : that is, lighl hetreen floors. Most stables are built low "hecuse they are wames." But such 
people forget that warmth is obtained at a sacritice of pure air and the health of lic animal. Shut a man up in a tight, small box; the air may be warm, but it will soon lay him out dead and cold if he continmes to breathe it. If stables are tight, they should liare ligh ceilings; if they are not tight, but open to admit cold currents of air from all directions, they are equally faulty.

Slatted floors are getting into roguc. My omm stable is built witl a tight floor nine feet long and four and a half feet wide for each stall, with a pitch of two inches. At the end of the plank there is a slatted portion, four feet wide, two inches lower than the plank. Through these slats all the urine runs into the manure pile in the cellar, and so leaves the beds of the liorses dry.

145. Saul for IIorses' Beds.-MA. Small, of Dundalk, Scotland, a reterinay surgeon of considerable experienee, states that sand is not only an excellent substitute for straw for liorses' beds, but superior to straw, as the sand does not heat, and sares the hoofs of the horses. Ile states that sand is exclusirely used for horses' beds in his repository.

146. To Remove ilorses from a Building ou Fire.-The great diflienlty of getting horses from a stable, where surrounding buildings are in a state of conflagration, is well known. Wilkes' Spirit of the Times says, a gentlemau whose lorses lıad been in great peril from sueh a cause, lıaving in rain tried to save them, hit upon the experiment of having them hanessed, when, to lis astonishment, they were led from the stable without difficulty. Throwing a blanket orer a lrorse's head will often answer, also, and may be easily tried before harnessing.

147. Proportion of Ilorses to Men,-The following curious account is given in Appleton's Encyclopedia, of the number of horses in the various parts of the world: "The general estimate has been eight to teu horses in Europe for every hundred inlabitants. Denmark las 45 horses to erery lundred iuhabitants, which is more than any other European country. Great Britain and Ireland liave 2,500,000 horses; France, 3,000,000; Austrian Empire, cxelusive of Italy, 2,500,000; Pussia, 3,500,000. The United States liave 5,000,000, which is more than auy European country. The horses of the whole rorld are estimated at $57,420,000 . "$

145. What Constitutes Legal Unsoundness in Ilorses. $-A$ Thee-sprung horse ean hardly be said to be unsomd. If may be a very fast horse, aud can cudne with ease the labor of any common, ordinary horse, although there is an alteration of structure which unfits him for the race-course. This wonld not be likely to produce disease or lameness; he would be more likely to grow better than worse, if used for common purposes. But if so bad as to produec stumbling and falling, he would be unsound, and a warranty should be taken against such deficts.

Capped Ilocks can not be considered unsomndness, if produced by an nucren stable floor or by kicking; but if produced by a sprain, and a permanent thickening and enlargement of the membranes, there would be unsonndness. A special warranty should be required in such cases. 

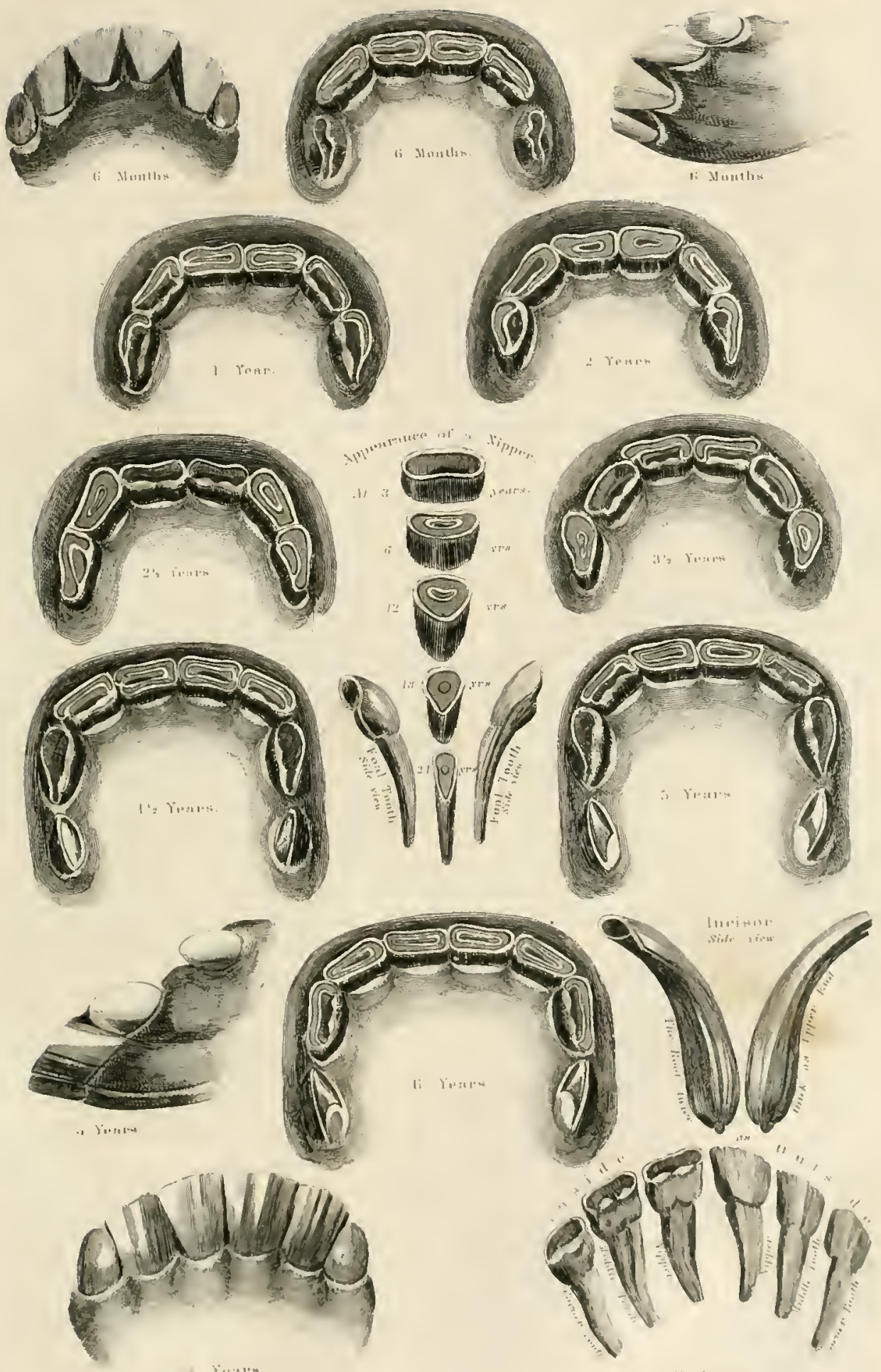

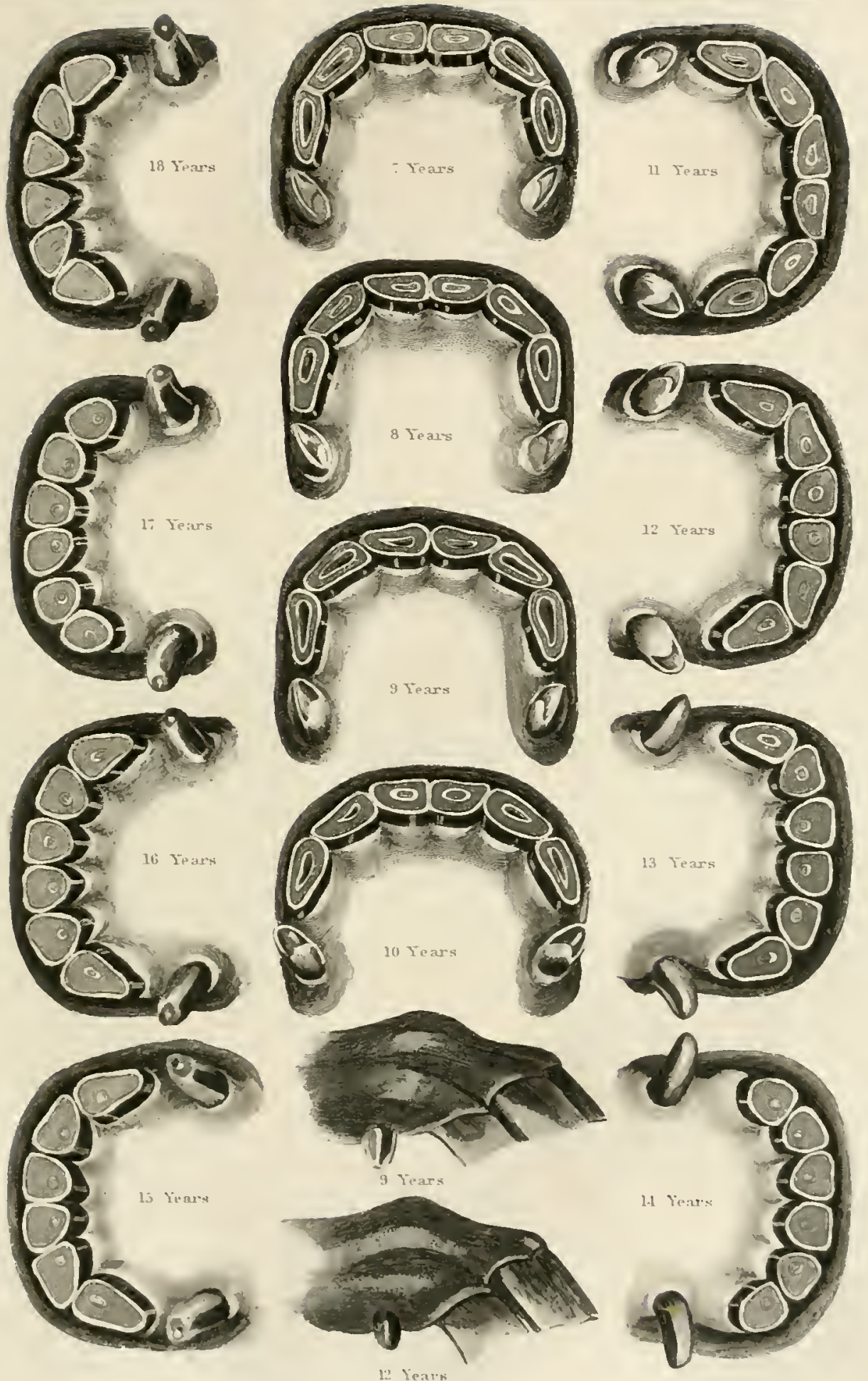


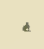




\section{PLATES VIII., IX.}

(Pages 106, 107.)

Triese plates need no description; they require study. As they contain all that could be said to fully understand the subject illustrated, we have written nothing about the art of "telling the age of horses by examining their teeth." Whoever studies these plates will learn that art. Observe the steady change, year by year, as it is mapped out before you. Open the mouth of your horse, and compare its appearance with the illustration of the year corresponding to his known age, and so on of all others. Thus you will learn the art and the value of these engraved representations. 

Contraction of the IIoof is a considerable deviation from the natural form of the foot, but does not necessarily constitute msoundness. It requires, lowerer, a most careful examination by the purehaser to aseertain that fluere is no fever or ossification of the eartilage; that the frog is not diseased; that the minal is not tender-footed or lame. Unless some of these symptoms ane indicated, he must not be pronounced unsound. A special warranty should be required where the feet are contracted.

Coms manifestly constitute unsomndness. Althongl few men lay much stress on this malady, still much inconvenience, and many times serions difticulties, must be cneountered by them, as they are seldom thoroughly cured. Many horses are almost constantly lame witl eoms, throngli a serofnlous habit of the system. A warranty against snch animals wonld be safe.

Trembling Inees.-This can not be considered mnsomnduess, yet it is a juecursory symptom of knee-spmung. Trembling of the knees, after a smart exercise, indicates weakness, and should be regarted as objectionable.

A Cough constitntes musomdness, lowerer slighlit or of short standing. If a louse is noticed to cough before the purcliase, or immediately afterward, lie is discased; but if warranted sound, and the cough is not discovcred till one or two days afterwarl, lie is not returnable; for a few honrs are suflicient to contract a congl, by taking eold while standing in a damp, musty stable, or by eating clifferent feed, musty lay, ete.

Roaring, Wheczing, or Whistling is unsonnduess, being the result of alter. ation of strneture or disease in the air-passagres. Although there liave been decisions to the contrary, courts and jurors are often at a loss for the want of intelligent witnesses; and it a veterinary surgeon is ealled to the stanl, not laving seen the animal, he is liable to be mistaken from misrepresentation. Hroken IFind is still more decidedly msonndness.

Crib Jiting. - A differenee of opinion exists as to this being msoundness, and conrts lave giren opposite decisions in respect to it. There are cribbers that ean searecly be said to be msonnd, as they are not pereptibly injured, and it does not interfere witl their condition or enduranee. Otlues inlaale and swallow a great amount of wind ; they bloat and are subject to colic, which interferes with their health and strength: this would constitute nusounduess. A warranty slonld alwas be talien agninst injury trom eribbing ; then if he breaks his teetl or injures himself, recompense may be hat.

Curb constitutes nusoundness as long as it lasts, and perhaps while the swelling remains, althongh no inflammation exists : for a lorse that lias once thrown out a eurb, is liable to do so again on the slightest exertion. I lonse, however, slonll not he returned if lie spring a curb five minutes aftel jurchase, for it is done in a moment, and dnes not indicate any previuns misommdness.

1.19. Soiling Ilorses, - We enmmend the following statement of .J. C. Mrlams, of Seymour, N. Y., to the attention of all owners of small farms, like the little one where we practice the same comrse:

"I lave in elose proximity" to my lam a pateh of gromud, $7 \frac{1}{2}$ rods by 16 
(thre quarters of an acre), seeled to elorer, firom which I kept one span of looses in thring eondition from the first day of Jume last to the last day of Angrust, besiles cutting 900 lbs, of good hay, which I put into the barm, and hillvested of the second mowing seed suflicient to stock an acre or two of mround. This may, and undonbtedly will, seem to many like a hig barm well stretehed. In faet, I should donbt the reality of such a story myselt, had not my eyes seen and my hands felt the truth of such a statement. Wy the time I lad mowed two thirds of this little patel, the remaindel was fit to be made into hay, which I accordingly did uy after the most approved fishion. Aud that part mowed first was suffieicntly large to mow again. I ferl them three times a day all they conld eat. They smelt not, touched not, tasted not one particle of grain during the three months; used them more or less erery day, and at the end there was a perceptible gain in flesh. Never, sinee I could say my team, have I summered a team so eleaply. The grreatest cost is entting and putting it before the horses. I offered them water, - but they did not drink to exeecd a pailtinl a week.

"I am of the opinion that if they had been tmrned loose mpon this picee of ground, ten days would have been sufticient time to eat u] and tramp] into the earth everything green upon it. As fire acres of grood pasture is little enough to summer a span of horses when allowed to run, there is almost an incalculable saring in soiling them."

150. Breeding for Longevity - We have had a few instanees of horses living to the age of thirty years, but they are so rare, that such an old horse is looked upon as a curiosity. Lewis B. Brown, of Westehester County, N. I., lias a team of four, the aggregate age of which is 105 years, the oldest being orel 30 years, and all in such rigor of constitution that but few teams can hold their own with this upon the road. The exhibition of this old team at the Springfield show, in 1860 , attraeted unirersal attention. This shows that such old hores are rare, and it proves that old horses are not worthless. It also induees the question, whether we can not breed with a special reference to longevity. If selections were made upon both sides, of stock which had ancestors noted for longerity, and this course continued through sereral generations, with mares and stallions which have arrived at mature age, still retaining a rigol like that exhibited in Mr. Brown's team, who can say that we shonld not obtain a breed noted for longevity, and that horses forty or fifty yen's old would then be no rarity? This is a subject worth thinking about.

151. Treatment of Colts.-Then first foaled, if parturition is at maturity, the colt should liave eight front teeth, four in each jaw; but it sometimes liaplens that these are not all cut through, and the gums are inflaned and so tender that the colt ean not suck well. This slould always be looked to, and the gums ent with a sharp knife, and, if need be, the colt fed until it can suck ficely.

Colts as well as calres are sometimes affecterl by lice; these may be got rid of in various ways. Take white-oak bark, boil it in water, making a strong 
decoction; wash the animals on the back and on the sides. In trenty-four hours the lice will be completely tamed. 'Timner's oil is also first-rate. So is suuft or a decoction of tobacco; and we have hear' ut Peruvian guano being used and answering the same purpose as snuff.

152. Remedies for some of the most Common Diseases of Ilorses.-There are a great many little simple complaints that van be curcd withont sending for a veterinary surgeon. We can afford room for only a few, becanse every ferson desiring information upon the diseases and cures of domestic animals, will find it in the Appendix.

153. To Cure Scratclies.-When the horse eomes in at night, lis legs should be washed elean and rubbed as dry as may be; then apply good vinegar, rubbing it well to the skin. Two applications a day are suflicient. I have always found it a sure preventive and a certain cure. If the legs have beeome cracked and sore, apply the vinegar freely and add a piece of copperas the size of a common hickory nut to a quart of rinegar.

Another exeellent remedy, which we have usel a great inany times, is beef' brine. If the dirt is earefully washed off with warm soap-suds, and then the legs well bathed with the brine, it will require but two or three applications to enre a rery bad case of seratches.

The Jaine Farmer gives another remedy. It says: "Take fresh slaked lime, and dust the affected parts well with it twice a day. It will not cause the horse any uneasiness, and will be sure to effeet a cure in a few days.

154. For Ileaves in Ilorses. -Take smart-weed, steep it in boiling water till the strength is all ont; give one quart every day for eight or ten days. Or mix it with bran or shorts. Give him green or ent-np feed, wet up with water, - during the operation, and it will cure.

155. Chafing Vuder the Collar. $-A$ gentleman who has tried the plan suecessfully for five years, commmicates the annesed method of preventing horses trom chafing moder the collar. IJe says he gets a piece of leather, and has what he terms a false collar male, which is simply cutting the leather in suclu a sliape as to lie singly between the shonlders of the horse and the collar. This fends off all the friction, as the collar slips and mores on the leather, and not on the shonlders of the horse. Chafing is eaused by friction, hence, you see, the thing is entirely feasible. Some persons put pads or sheep-skins under the collar; these, they say, to as mueh hurt as gooul, for they augment the heat. A single piece of leather, like that composing the outside of a collar, without any lining or stuffing, is better than anything else.

156. Yor Fistula.-Salt, one tallespoonful; soft soap, one tablespoonful ; whisky, one tallesponful; turpentine, one tahlespoontul. Mix in a tin cup; place on the lorse's nose a twiteh, to prevent his moring; lave your mixture placed on a little fire, and as soon as it boils up, pour immediately upon the diseased part ; repeat the operation every ten or twelve days, till ap1, hied three or four times, if necessany. It will not take off the hair or leare any scar. 
This is not more effectnal than the following much simpler remedy, which we hare proved for both fistula and poll-evil. Take a lump of potasls or saleratus, as big as you ean crowd into the pipe of the fistula, and it eanses it to discharge more freely for a day or tro, and then it leegins to heal. In one case of poll-evil, a large mare would not allow any one to tonch her head to apply the remedy, or in fict to be bridled. For tlis case we took about two ounces of saleratus and tied it in a eloth, in the form of a pad, inside the strap of a halter, where it crossed the top of the hearl, and by dint of persererance sncceeled at lengtl in getting it on and firmly secured, when we lid her go and live or die, as slie liked-we would do no more for her. $\Lambda$ shower fell soon after, and the next time we saw our patient she was partially healed: the canstie had taken the hair off, and it liad also affected the discase. $A$ fortuight later we caught her, and found slie did not object to being handled. The disease was enred, and the mare was worth a lindreel dollars. When turned out, she could not lave been sold for a liundred cents, and the cure had not cost five eents.

Here is another remedy which may be tried, if it is preferred to the other. The following is sent us as a raluable preseription for several of the ills that horse-flesh is heir to, such as fistula, poll-evil, ling-bone, big head, etc.: $12 \mathrm{oz}$. of alcohol, $1 \mathrm{oz}$. of spirits of turpentine, $1 \mathrm{oz}$. of corrosive sublimate, $1 \mathrm{oz}$. of eamphor gum, $1 \mathrm{oz}$. of oil of spike, $1 \mathrm{oz}$. of eastile soap, $1 \mathrm{oz}$. of aquafortis-mixed and dissolved, and applied with a swab for a day or two, and then intermixed, and apply again. Take care only to tonch the part atfected; and, to prevent injury to the hair or hoof adjacent, rub it well witl grease.

157. White Lead, its Talue on Sores, - Thite lead in oil, as an exterual applieation or zemedy, has no equal. In abrasions, or galls from the saldie or collar, or from any other eause, it will speedily aid the part in healing. Applied to the leg of a horse-the onter coating of hair and skin of which was torn off-with a painter's brush, cansed it to heal and leare no scal. It is good for scratches and all sores upon lorses or other animais, and cqually good for men. It forms an air-tight coating, and soothes pain. Every fillmer should keep a pot and brush ready for use, and he sliould not fail to apply it to all abraded spots on tools, as well as stoek. White lead is the carbonate of the metal, and, when pure, is very white. That having a grayish tint is impure, being generally adulterated. For use as a paint, a lead color is produced by adding limpblack, and a drab or stone color, by adding burnt nimber.

15S. Liniment for Streeney in Horses.-One oz. of oil of spike, 1 oz. of oit of amber, $1 \mathrm{oz}$. of Venice turpentine, and a small quantity of rock-oil.

159. Blind staggers.-This disease is more common in the Southem than it is in the Northern States. The Cotton Planter newspaper grives the following remedy: "Take 1 gal. of gleen hickory wood ashes, 1 half pint of epirits of turpentine, $1 \mathrm{oz}$. of gum camplior, and a sufficiency of lye to make a thin mush. Fill a horn with this mush, while boiling lot, and with a thin 
eloth stretehed over the end of the horn, apply it four times npon or over the regrion of the brain, each time filling the Horn with the boiling mush, which will blister the slin. In comnection with this, it is necessary to burn rags wet with spirits of turpentine under the horse's nose until you produce a fiee discharge. Yon silonld also bleed freely from the neek, and give one pint of linseed-oil as a purge.

160. How to Inetect Imperfect Vision or Blinoness in Horses,-Ton may have good gromeds for suspicion of imperfect vision when the horse moves his cars in a constant and rapid motion, directing them in quick smecession to every quarter from whence the least sound proceeds. Also if his action is lofty and faltering, and he lifts $u p$ his feet and replaces them on the ground as if stepping over some obstacle, when lhere is actually nothing to impede his fiee progression, notwithstanding these symptoms would be suflicicit to create suspicion, there are other canses by which similar symptoms would appear in horses. If a horse with perfect eyes were led from a lark stable into the sunshine, the sudden contration of the pupil of his eye would render it impussible, for a few moments, for him to see but rery indistinctly; hence symptoms of uncertainty in his morements, until the pupil becones stealy after the sudden contraction. The diating and contracting of the pupil fumish means of ascertaining whether blindness exists in one cye or hoth, as this pupil varies in size according to the degree of light which is bronght to bear upon it. In a dark stable the pupil is expanded, so that a greater portion of light fills upon the cornea; but if the horse is led to the door of the stable, the pupil will contract so as to exclude more light than could be endured, and if suddenly cxposed to the sun, the aperture will be all but elosed; therefore carefully notice the eyes, whether they contract or expand equally by the increase and decrease of the light. If the horse should be eximined in the open air, notice whether both pupils are of exactly the eame size. After this, curefully place the hand, so as not to alum the horse, orer each eyc, to shade off the light, and hold it there for a shor: time, noticing the extent to which the pupil dilates; then pass the hant orel the other eye, and ascertain whether is also dilates to the same extent, and if still it be uncertain, place both lands in the positions of slates orer both the eyes of the horse, and you will at once pereeive whether they are perfect, and it not, which of the two is imperfect.

Nothing tends more to injure the eyes of a horse tha:i dark or badly rentilated stables. Attention to the lighting, draining, and ventilation of horse stables is an imperative duty. There are thonsinds of stables in which the foor is the only aperture for the ingress or egress of pure air, and even this is in most instances elosed, both when the horse is at rest, or at work or exereise; thus he has. while in the stable, to constantly breathe ritinted air.

161. Remedy for Galls ou Ilorses. - İse whisky, saturated with almm, to wash the parts lialle to chafe, which tenls to havlen the skin and prevents its rubbing off. For galls alrealy formed, the tollowing receipt for a salve is good ; so it is for lıuman flesh-sores. 
"Take of honcy, twelve ounces; yellow beeswax, foul ounces; conupound galbanum plaster, six ounces; sweet oil, half a pint. Put the honey into a jar by the fire, then melt the other ingredients and mix then together; spread rery thin on linen, and apply twice every day."

162. Horse-Shocing - It is monderful how little the mass of smiths who sloe horses lnow of the anatomy of a hor'se's foot; of its delicate organization, and suseeptibility to injury by improper paring of the loof, formation of the shoes, and attachment of the same! IIorses are peenliarly sensitive to lameness, and it is obvious that great care in the particulars mentioned shonld he observed, in order that a firm, positive, and comfortable tread should be given the feet, so as to make then cajable of exerting the wonderful degree of muscular strength of which they are possessed without injury to the exquisitely constructed parts which are brought into play. In one of the numbers of the Dublin Agricultural Revicw we find a long artiele, written by William Miles, extracted from the Jomnal of the Royal Agricultural Society of London. We heartily commend this able produetion to the perusal of those of our readers interested in this important sulject. It commences as follows :

"It I were asked to account for my horses' legs and feet being in better order than those of my neighbors, I shonld attribute it to the four following circumstances: First, that they are all shod with few nails, so placed in the sloe as to permit the foot to expand every time they more; seeondly, that they all live in boxes instend of stalls, and ean move whenever they please; thirdly, that they hare two lour's' daily walking exereise when they are not at work; and fourthly, that I have not a head-stall or rack-chain in my stable. These four circumstances comprehend the whole mystery of keeping lourses' legs fine, and their feet in sound working condition up to a good old ange.

"All that is really required is, to take'one anatomieal and one physiological fact on trust, and believe that the lorse's hoof is lined by a very sensitive nembrane which must on no account ever be rounded, and that the hoof itself is elastic, and expands when the weight of the horse is thrown on the foot, and eontracts when it is taken off again; all the rest is purely mechanical, and merely calls for the exereise of a little thought and paticnce to mderstand the principle and apply it.

"The result of the numberless experiments I have male at various times on all sorts of horses doing every lind of work is, that there is but one principle to be observed in horse-shoeing which will adnit of no variation or compromise: the shoe must fit the foot, whatever the shape of the foot may hapjen to be, and it must be nailed to the loof in such a manner as will permit the foot to expand to the weight of the horse; this latter condition will be best eomplied with by placing three nails in the onter limb of the shoe, and two in the inner limb between the toe and the commencenent of the inner quarter; a larger number than five mails can never be required in any shoe of any size, or under any cireumstances, excepting for the sole purpose of counteracting defective and clumsy fitting. 
"No horse shonld have more than one foot bared at a time; howerer strong his feet nuy happen to be, he is sure to stand quieter on a shod foot than he can on a bare one, and it will ynevent his breaking the crust. A lorse with weak flat feet is in positive misery when foreed to sustain his whole weight on a bare foot, while the opposite foot is held up.

"A strong fout with an arched sole, when the roals are in good order, will reculure to have the toe shortened, the quarters and heels lowered, and the sole pared, until it will yicld in some slight degree to very hard pressure from the thumb; but on no account shonld it erer be pared thin enough io yield to moderate pressure; the angles formed by the crust and the bars at the heels must be eleared out, and all the dead hor'n lemoved therefrom, and the bars should be lowered nearly to a level with the sole.

"A wcak flat foot, on the contrary, will bear no sloortening of the toe, and very little paring or lowering anywhere; the heels of such feet are sure to be too low alrealy, and the sole too thin; in fact, the less that is done to them the better beyond clearing out the dead loom from the angles at the lieels, and making the crust bear evenly on the shoe; lunt the hollow between the bars and the frog, or the frog itself, must never be tonehed by a knite in any font, whether it be a weak one or a strong one; and as these latter directions difler materially from the usual practice of smiths, I may, perhaps, be cxpected to state iny reasons for wishing to cnforce them in opposition to what they no donbt consiler a time-honored custom; I mean the inveterate lnabit they all liave of trimming the fiog, and opening out the heels at erery shocing; lut I think I shall be able to show that 'it is a custom more honored in the breach than in the observance.'

"The slioe should be neither too light nor too narrow in the wob; light shoes are ajt to bend before they are half worn ont, and narow-weblent shoes cxpose the sole and frog to innecessary injury from stomes in the road. Every fore-shoe should be more or less seated on the foot-surtice, to prevent it pressing on and bruising the sole; but a perfeetly flat surfice should be preserved aromed the edge of the foot-surfine of the shne, from heel to heel, for the crust to rest upon. The amonnt of senting to be employed must ho determined by the description of foot to be shod; for instance, a broal fiust. with a fiat sole and weak horn, will require a wide web, considerably seated, to jrevent it conning in contact with the sole and brusing it; lut a narmw foot, with an arched sole and strong lorn, will require less widh of web and less suating, otherwise the dirt and srit of the roml wonlel become inpacted beween the shoe and the sole, and eanse as much pressure and injury as the ilon would have done."

Many men who own and nse horses secm to be indifierent as to the manner in whicls they are shod, so much so that they take them to nur one who can drive a nail, leare ererything to him, and take it for gramterl that it the horse has got forir gonel stout shees on his feet that will stay on as loner as they last, it is all right. This is a great mistakic, and will often leanl to the liscomfort and nltimate ruin of the lorse. 
No horse that is badly sliod can travel easily, safely, or well; and many who use horses that cut their legs or trip, suppose that the fanlt is in the horse, while in fict no one is in fault but the shoer. There are hardly two horses that require precisely the Eame shaped shoe, or that it be put on in precisely the sanne way; hence to shoe every liorse so as not to pinch, and consequently injure the feet, and at the same time so that he can perform lis work easily and well, requires considerable experience and more thatu common skill and intelligence on the part of liorse-shocrs.

One of the oljects in applying the shoe is to preserve the natural concarity of the sole of the foot. A horse in his natural state, and, indeed, $u_{p}$ ) to the preriol of his first introdnetion within the precinets of the "smithy," las generally a concave sole; and wiscly is it so ordained. Were it otherwise, the animal wonkt be unable to secure foothold; as it is, the inferior edge of the hoof-that is, the gromed surface-projecting beyond the sole, may he compared to the point of a cat's claw or the nails of a man ; they crrarp, as it were, bodies with which they come in contact, and thus secure a point of rsistance which aids in advaneing limb or body orer a smooth surface. Now, in order to preserre the natural mechanical functions of the horn and sole, the grround surtace of the shoe must correspond to the ground surfice of the font; that is to say, the ground surface of the shoe must be bereled cup fashion; its onter edge being prominent, takes the place of the hoof; its inuer surface being coneave, corresponds to the natural concavity of the foot. It is a custom anong some blacksmiths to rererse the abore procedure, and place the concrse surface next the foot, and often the ground surfice applents to be more convex than concare. An iron shoe tacked on to a horse's foot is one of the muaroidable evils of clomestication, yet, when properly applied, is not so grent an evil as some persons might suppose.

R. Jemungs, veterinary smrgeon, Pliladelphia, gives his viers as follows npon this subject:

163. Contraction of the Feet of Ilorses-The Cause and Remedy.-"The tendency of a horse's feet, in a healthy condition, is to expand whenerer the weight of the body is thrown mpon them. Being a very complieated piece of mechunism, they are rery casily disarrangred, and, once ont of order, are clifiente of repair; hence the necessity of preserving them in a sound condition.

"Contraction is causcd, 1st, by cutting away the bars of the feet, which are the main stays for the support of the quarters; $2 d$, by (opening the hecls, as the smith calls it) cutting away a portion of the frog, in consequence of which the moisture of the frog becomes absorbed, losing its clasticity and destroying its funetion, thus exposing the feet to injury by concusion; $: \ddot{d}$, by standing upon plank floors ; 4 th, by improper shocing.

"An orchinary observer will, "pon an examination of the common shoe, notiec that it inclines from withont inward at the heels, thus forming a concavity for the fect to rest in; the eonsequence is a lateral resistance to the expansion of the hoofs when the weight of the animal is thrown upon them 
The eficets of this resistance are to foree the licels together, creating pressure upon the sensitive parts within the horny case; estallishing terer, by which the moisture of the linofs is rapidly absorbed, rendering the hoots luard, lrittle, and liable to erack, and frequently eansing corms, navicular joint lameness, bony deposits to be thrown ont from the lateral wings or proceses of the cotfin bones, rendering the animal jermanently lame or unsonnd. 'These are but few ot the bad cffects arising fiom contraction-enourgh, however, to serve our purpose at present.

: Iiemedy.-Preserve a level bearing by making the sloes perfectly flat on the quarters, so as not to interfere with the expansion of the feet. Shoull contraction already. cxist to considerable extent, bevel the sloes slightly ontwarl at the heels, in order to facilitate expansion. Care shonld be used not to bevel too much, or bulging of the lower part of the looofs at the quarters will be the result. The shoes should in all cases be formed, and not twisted, ats is sonetimes done to save trouble by the bungling smith. Proper applications, to soften the horny parts and promote elasticity, slould also be nsed. Snch preparations are put up in the form of hoof ointments."

104. Hules.-Few of the fumers of this country are aware what a debt of Eratimule they owe George Washington for the introduction of mules into grcucrial use for film purposes.

Previous to 1753 there were but very few, and those of snch an inferior order as to prejulice furmers agrainst them as unfit to eompete with horses in work upon the road or farms. Consequently there were no good jaclis, and no disposition to juerease the stoek; bnt $W$ ashington became convineed that the introduction of mules generally among Southern planters would prove to them a great blessine, as they are less liable to disease, and longer lived, and work mpon shorter feed, and are much less liable to be injured by careless servants than horses.

As soon as it becanc known abroad that the illnstrious Washington desirel to stock his Mount Vernon estate witl mules, the King of Spain sent him a jack and two jennies from the roval stables, and Lafayette sent another jack and jennies from the island of Mitita.

The first was of a gray color, sixtecu hands high, heavily made, and of a slumgish wature. He was maned the Royal Gift. The other was called the Kinight of Malta; lic was abont as high, but lighter male, black color, and lithe and fiery, even to ferocity.

The two diflerent sets of ammals gare him the most farorable opportnnity of making improvements by crnss-breeding, the result of which was a favor. ite jack which he called Compound, because he partook of the best points in beth of the oricrinal jacks. The General bred his blooded mares to thatec jacks, even takjug those from his funily enaclo for tlat purpose, and puoduced suclu superb mules that the country was all agon to breed some of the same sort, and they sonn hecane quite common. This was the origin of improved mules in the United States; though over serenty yems sinec, thero

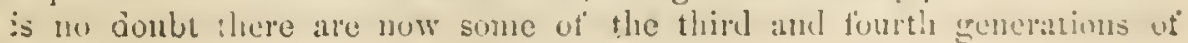


Finglit of Mralta and lioyal Gift to be found in Virginia, and the great benefits arisinge from their introduction to the country are to be seen upon almost every cultivated acre in the Sonthern States. Notwithstanding the enormous inerease of latre years, arising from a systematic conse of breeding in the Northern States for the Sonthern makket, mules were never more valuable than at present, or more ready of sale at high prices.

165. Longevity of Mules. - Te have mumerous reports of mules attaining the are of forty, fifty, or sixty years, and Col. Midaleton, of Sontl Carolina, stated some years agro that lie lad one at work on his plantation eighty yeats old; and we have seen an account of a mule in Ireland certified to have been at rork since 1707, making him orer 150 years old. This is, of eomrse, a rery uneommon age, but we are satisfied that, with proper usage, mules would commouly attain to albout forty years, being serviceable to the last, and this should be connted as one of their elements of value.

166. The Largest Mille in the World.-It the following statement is correctly given, it tells of the largest inule, probably, ever produced. Tre found it in the Commercial, of Cincinnati, in 1S60. It silys :

"The largest mulc erer produced in the world is now in this city. It is a mare mule, nineten and a half hands high, and weighs cighteen hundred and thirty-two pounds. This extraordinary animal is the property of Charles Frost, of Wayne County, Ind., recently purchased near Lexington, liy."

167. Mulues, Lorses, 0xch.-TVe read in almost erery agricultural paper, we hear in most igrjenltural addresses, and we often hear in conversation, that one or tho other of these animals is the oue, and the only one, that firmer's should use, yet we hare nerer seen a furmer who conld say, "I know." One who has always done his furml-work with oxen is sure that they are the best in all respects; while fifty miles away he wonld seareh a lundered finms to find as many yoke of oxen, and where he did find them he would probably be told they were only fit for drudgery-that horses only are suitable for fann-work, and their owners are ready with loads of reasons to substantiate their theory. But take another day's journey, and the theory is upset with mules-mules here, there, everywhere; nothing but mules, and nothing fit for a farm but mules, becanse they are so strong and hardy they nerei tire, and live upon almost nothing for their daily rations, and are the very personification of life everlasting.

Now, while the advocates of each class of animals disagree so widely, how are the seekers after trutl to satisfy themselves? Do they look to us for an opinion? We can give it; liere it is. All are best, and upon a large farm all wonld be found ceonomical to keep for different classes of work; and it is our opinion that no man who farms a lundred acres can afforl to do withont oxen, mules, and at least one horse. If his oxen are well trained, they will travel as fast before the plow and wagon as mules; but the lafter are so mueh more enduring in hot weather, at all sorts of hard work, that their ecrices are then particularly raluable. They are better, too, to go off upon the road, or to carry nroduee to market, because they may be, though nat. 
urally about as slow as oxen, trained to trarel lomeward withont a load at a romit trot. For working singly in the cultivation of crops, mules are far superior to horses, and of course can do a great deal of work that conld not be done by oxen. We lave seen mules that were fair substitutes for saldlehorses, haring one grood quality, that of sure-footedness. There is one o!)jection to mules on a tarm where the stock is generally pastured: there is nothing short of a Mississippi fenee that will hold them-that is, twelve rails ligen, and stake-and-ridered; and we have heard planters declare that they lud often known the brutes to elimb orer such a tence as that. In adrising a Northern furmer to keep mules, we therefore adrise him to make lis carculation to kecp them in a stable all the time they are ont of harness.

16s. Breeding of liorses and Mules.-There are ecrtain nuiversal laws of breeding which ean not be ignorel, except at the saerifice of all snceess. In Kentucky and lennessec, a very large strain of mules have been obtained by nsing jacks of immense size. We recollect secing one at R. Cockrill's, near Nashrille, orer eighteen hands ligh. We have seen several mules of that lighth, and nmmerous ones of sixteen and seventeen lands high. It is still a question whether such large mules are as ceonomical as the smaller sizes, which cost less at first and cost less for sustenance; and some persons contend that at ordinary labor the small mule will do as much and last longel:

In lurecling either linrses or mules, a writer upon the subject says: "If we would have sound stock, we must have constitutional soundness in both elam and sire. There are hundreds, ay, thousands, who will seour the comtry and compare the merits of a dozen horses-mill grive time and money to secme the services of a grood stallion-and all with the expectation of procuring a fine colt from a miserahle, puny, ill-shaped, broken-wiuled, spavined old mare. Ilow often do we hear it said, "Olı, sle will do to raise a colt from ; or-after hard service and eruel nsage lave left a mere wreck of what, away back in the farmer's memory, was onee a beast of power, activity, exeellent temper, and noble bearing-' we must now turn the old mare out to breed from.' The start is wong, the foundation is defective- - hat wonder slould the structure tumble to the earth?

"In the mare we need size and symmetry; if there be blond, all the be:ter-it will tell. Withont the first two, however-even though all the bhod that has flowed throngh thorough-lueds. firom the days of Godolphin to the present, were in her veins-she is utterly unfit for a breeder. Many animals possess some farorable peculiarity which owners wish to transmit, and though there may be a struetural defieiency in some other part. the mare is brought to the breeding padueck in the hope that the desiralide fuatures will be prominent in the colt, eren if it be at the expense of other points of strength and action. The breeder liere eommits an error. It would be better to let the mare gro, for in the very large majority of eases the deficieneies will be transmitted while the exeellenees will not.

"In choosing it mare for breeding purposes, slıe simuld be so formed in 
france as to be capable of earrying and well nourishiug her offspring ; that is, she should be what is called " poony." There is a formation of the hips which is particularly meft fur breeding purposes, and yet which is some. times carefuly selceted, because it is cousidered elegant; this is the level Im! straight hip, in which the tail is set on very high, and the end of the hannch bone is ncarly on a level with the projection of the hip bone. Nearly the npposite form is the more desirable, where, on examining the pelvis, it will be seen that the lanneh bone forns a considerable angle with the sacrum, aml that there is, as a consequence, plenty of room, not only for earrying the foul, but for allowing it to pass into the world. Both of these puints are important, the former evidently so, and the latter no less so on eonsideration; because, if the foal is iujured in the birth, either of necessity or from innorance, it will often fail to recorel its powers and will remain permanently injured. The pelvis, then, should be wide and deep-that is to say, larre and loomy, and there should also be a little more than the arerage length from lipp to the shoulder, so as to grive plenty of bed for the foal, as well as a good deptlı of back ribs, which are necessary to give the strengtl to support this increased length. Berond this roomy frame, necessary as the ege-sluell of the foal, the mare only requires such a shape and make as is well allapted for the purpose she is intended for-that is to say, for prorlucing colts of the style and form she is intended to produce. We will add, that she must have four good legs under her, and those legs stauding on a foundation of good, well-shaped, large feet, open heeled, and by no means tlat-soled.'

"' In health,' sars the sance writer, 'the brood mare should be as near perfection as the artifieial state of the animal will allow; at all events, it is the most important point of all, and in every case the mare should be very carefuly examined with a view to discover what deviations from a natural state lave been entailed upen her by her own labors, and what she has inherited firom her ancestors. All recidental defects, snch as broken knecs, dislocated lips, etc., may be passed orer; the latter, however, only when the stock firm which the mare is descended are famons for standing their work without this frailty of sinew and liganent. Spavins, ring-bones, large splente, side-bones, and, in fact, all bony enlargements, are constitutional defects, and will be almost sure to be perpetnated, more or less, aecording to the degree in which they exist in the particulal case."

"Having sail thus much upon the requisites on tle side of the dam, let us see what slonid be songht for in a sire. It is maintained by all writers upon this subject, that blood slionld be possessed by a stallion in an eminent legree; that the essential on the part of the sire is the greatest amount of pure blood compatible with size, weight, and power according to the pur. poses for which we intend to breed. Our best veterinarians argne that the degree of strength in the bone, sinew, and frame of a blooded horse is, in proportion to extent, rastly superior to that contained by his coarser and more mammoth brother, the English eart-horse. The differenee in the form 
and texture of the musenlar system, and in the lesser tendency to form flabby, useless flesh, is also in finvor of blood. In actition to all this, the general constitution of the animal is ealeulated to fumish him with greater vitality, recuperative energy, and plysical power-in proportion to size and reight-and, as a consequence, quicker movement, greatel connge, and better power's of endurance.

"IIerbert, in lis 'Ilints to IIorse-Keepers,' gives his riews upon this branch of our subject so coucisely and clearly, that we cun not refinin from quoting a paragraph, as follows: "To breed from a sunall lorse with the hope of getting a large colt; from a long-backed, legery horse, with the hope of getting a short, compact, powertul one; from a broken-winded, or blind, or Hat-footed, or sparined, or ring-boned, or navienlar-joint discused lorse, with the hope of getting a sound one; from a ricious horse, a eorrardly horsewhat is teehnically called a dunghill-with the hope of getting a lind-temperel and brave one; all or any of these would be the hight of folly. The blood sire (and the blood should always be on the sire's sicle) sloould be, fur the farmer-breeler's purposes, of medium hight, say $15 \frac{1}{2}$ Inands high, shortbacked, well ribbed up, short in the saldle-plaee, long below. IIe should have high withers, broad loins, broad ehest, a straight rump, the converse of what is often seen in trotters, and known ths the goose-rump; a liigh and muscular, but not beefy crest; a lean, bony, well-set-on head; a clear. bright, smallisl, well-placed eye; broad nostrils and small car's. Iis fure legr slonld be as long and as museular as possible abore the knee, and his linel legs above the hock; and as lean, short, and bony as possil) le below those joints. The bones ean not by any means be too that, too elear of excreseences, or too larye. The sinews shonld be elear, straightit, firm, and hard to the touch. From such a horse, where the breeder cam find one, and firom a well-chosen mare (slie may be a little larger, nore bony, more roomy, and ju every way coatser than the horse, to the advantage of the stock), sound, liealthy, and well-limbed, he may be certain, aecidents and contingences set aside, of raising an animal that will be ereditable to him as a scicntitie stockbreeler, and protitable to hiu in a pecuniary sense."

With these general remarks npon what we require in brecling, we think we may elose the section upon lorses. We hope what we have given in relution to breeding horses will be earetuily studied and breeds compareal, and that what we lave said will be just suffieient to awaken an interest that will tend to the improvement of this most fathful heast in the serviee of man. If we lave not got the right breel, let us inquire where is the deficieney, nurl anend it. $\Delta$ bove all, let us think whit purpose we are breeding for. and not attempt to get an animal suitalile for a lady's saldle from an Linglisl earthorse or the Noiman diligence.

169. Horse-ficaring,-If a New Mexican, or even a full-blood Nortl Carolina monntaineer, slıould appear in the city of New Fork with his loorse harnessed, as we liwe have often seen, it would attract much attention, as the wholo gearing might not have a particlo of leather or iron in its compo- 
sition, the eollar being nuade of braided corn-shucks, the liames of natural crooked sticks, the traces of raw hide, fistened to the hames by a hole and is Inot, aud to the whittletree ly a loop around the end. Rule as this gearing is, it answers at good purpose, and does not gall or swent the lorse like the great English cullars, or like those known in our boylood as the "old Untel collar," which was so much like the breeching of the same harness that it wis rather dithenlt to tell which belonged forward and which behind.

The old Euglish collar, specimens of which may be scen oceasionally in this country, wats a most cumbersome piece of horse-gearingr which a sensible man will not be likely to copy. It is made like our Aneriean collars, only very mnch heavier, and has attached to its upper end as an ornament two pieces of stiff' sole leather as big as the skirts of a saldle, with a great deal of ornumental stitching aromnd its edge. Some of these collars weigh 12 to 15 Ihs., and the luames are furnished with two brass liorus that stick up several inches abore the flap.

The Scotcls collars are also made with a great superfluity of leatler; and are very heary, though differing in form from the Englisl collars.

The weight of a Scotcl plow lianess is giren in Stepliens' book of "The Faru" at 35 liss. We have often seen a lorse equally well harnessed to a plow in this country when the whole gearing would not weigh half' as much, nor cost half as much, as an English collar. These Engrlish collars are often ormanented with red worsted fringe and tassels, and give a six-lorse team, wearing bells, a very formidable appenrance.

We recomment as au improrement upon our own light, easy, and, we think, liandsome collars-liandsome, because fitting for their purpose-that they should be made open at the bottom. Te drove one pair of horses from Chicaro to New Orleans, and from New Orleans to New York, making many detours, and in all driving some five thousand miles in one jonrney, with a pair of collars open at the bottom; and although out in all sorts of weatlier, never had a sore shonlder or eren chafed oft the hair. Neither did we use breeching in all that journey, yet we traveled orer some rery rough and monntainons roads. We are satisfied that a lorse will hold back a light carriage witl a grood strong padded girt as well as with breeching. Our plan of a harness is cxictly the contrast of an English one. Theirs is, to use up all the leather and labor possible, and ours to use just as little as possible. We do not believe in blinders, check-reins, breeching, nor heary collare. The harness shomld be made as light as it ean be and be strong. Strength is an important particular. For a furm-wagon or plow haruess we recommend short leather tugs and chains as preferable to long tugs or long chains.

170. Working Three Ilorses Abreast.-In the north part of this country it is not very common to see three horses worked abreast. It is quite common in Lonisiana, particularly in working. horses to carts. It is mueh practiced in England, and perhaps wonld be more so here if farmers had proper gearing. We have seen it jracticed sometimes by litching the midale lorse to the center of the swing-bar. This gives no chance of equalizing the dratt 
between the three horses. The English have what are called compensating bars between the swing-bar (which we call the louble-tree), and the flurec single-trees, so that each horse may be scen to pull equal to the others.

These bars should be made of iron, one and a lalt inches wide and three eighths of an inch thick. Two of the bars are each 27 inclies long, and these are attached, as the single-tree usually is, to the ends of the swing-bar, by a fulerum just one third of the length from the outer end. Then a ecuter bar, 20 inches long, is attached by working joints to the ends of these outside hars, and the single-tree of the center horse is attaclied to the center of this bar, and the single-trees of the ontside hores are attached to the encls of the other bars. This equalizes the strain upon all the horses, for it is impossible for one to start alical withont imparting motion backward to both of the other horses.

The irons of a single or donble-tree slonld always be made so as to clasp the wood, which should never have a hole bored throngh it to pull by.

171. Dimensians of lonble and Single-Trees.-Perhaps every farmer knows low to gear a horse, and what are the proper dimensions of a set of double or single-trees. But there are many persons who take to firming in afterlife, and others who may liare occasion to make this part of a set of horsegearing, and these will be glad to have the following directions to refer to.

The bar of a double-trec should be three fect nine inclies long and three and a lialf inclies wide at the eenter, and one and a quarter inches thick, and it shonld be made of the strongest kind of rood that can be procured, and straiglit grained and free from knots. The best wood we have for this purpose is second growth white ash, such as all of our best hoc and shorel liandles alc made of in the United States.

A single-tree shomld be three feet three inelies long, two and a lialf inches wide, and one aud a quarter inclies thick. The irons of double and singletrees may be all made of the same form and strength; that is, a piece of the rery best fiat bar iron, onc and three quarter inclies wide and one fourth of in inch thick, is bent so as to clasp around the back part, and the ends come about two thinds of the width towarl the frout edge, with half-inch holes through the end and through the wool. In this hole a picec of halfinch iron is to be inserted by tapering the ends so that they will go through the hole from each way and clinch fast on the flat iron. leaving the bend formarl so as to form in loop in which to put the hook of the single-trec, or the chain, or a loose ring, as may be required. These irons can not come off, eren if they shoull get loose, and the wood is not likely to hreak, because there is no strain upon it. The strain is all upon the irons, and when the loop wears ont, snew one is easily inserted in its place. The center irons of the double or single-trees are put on after the same fischion, the loop of the round inon being lack, instead of forward, and both the flat and ronnd irons for the centel may he a little stronger than the ends.

This plan is far better than making the irous to drive on like a ring, fastening then by a few stub-nails driven in the end of the single-tree. Aeci- 
dents often occur from the irons of single-trees, put on like rings, getting loose and working off. Such things seem always to liappen at the most nnpropitions times. We knew one num well, who lost his life in consequence of just such an aecident. He was crossing one of the Western prairies upon a cold, stormy night, when the accident oecured, by which he was unable to proeed, and, as was supposed, while getting his horses loose, that he migrht ride to the nearest house, some miles distant, he became so chilled as to be unable to mount on lorseback, and before morning his horses left him alone to perish-all in consequence of having bad gearing.

WTe have ourselves had some very unpleasant experience in our prairie traveling, arising from broken swing-trees, and therefore warn yon to make them very strong-no matter abont the looks. Utility is everything.

I'lowing with four horses, though not much practiced in this country, is sometimes necessary, and, for want of practice, bnt few know how to attach four horses to a plow so as to work in the easiest manner.

The common way is to hitel the double-tree of the leading pair to a look in the center of the double-tree of the rear pair. This gives a dead pull to the leaders without affecting the other pair. To obviate this, and give a compensating balance to both pair, the following plan has been adopted: Attached to the hook of the plow-beam is an iron prlley, about six inches dianeter. The chain from the first set of double-trees, instead of being hooked to the plow-beam, is rove through this pulley, and the end carried forward and hooked to the forward double-trees. The working of this is, that neither pair can give a dead pull independent of the other pair. If you toueh up the hind pair so that they start suddenly forward, the pull does not gire the plow a jerk, becanse the chain yields, around the pulley and soon draws back upon the leaders, giving them a hint to press forward, and thus keep the strain eren. To prevent either pair from drawing too much of the chain throngh the pulley, you can insert an open riug into a link at a suitable distance on eitler side.

There is no other plan that we have erer seen in operation, so simple as this is, to give a perfect equilibrium and balanee the forces of each pair of lorses. In fact, the whole fonr, by the aid of the swing-trees and pulley, are all kejet in equilibrium.

It will be well for the hind pair of horses to weal a common wagon necl: yoke, and pass the chain that extends to the double-trees of the forward horses throngh the ring, or if that is too high, through a loop attached to the ring. The ehain is sometimes supported by a strap siringing between the rear horses, each end attached to a back band on to the hames. 



\section{PLATE $\mathbf{X}$.}

(Page 123.)

Ters picture speaks for itself, and does credit to the artist. It is one that will interest more persons than any other. The descriptions of these fowls will be found in Section IX., If 180, 181, 182, together with several other kinds. Those here illustrated comprise most of the bestimproved varieties, and quite as many as any farmer will care to possess. By comparing the descriptions with the pictures, it will enable any one to make a suitable selection. The description of poultry fails to give satisfaction without pictorial aid. It is here complete. Te may well feel proud of this picture. 


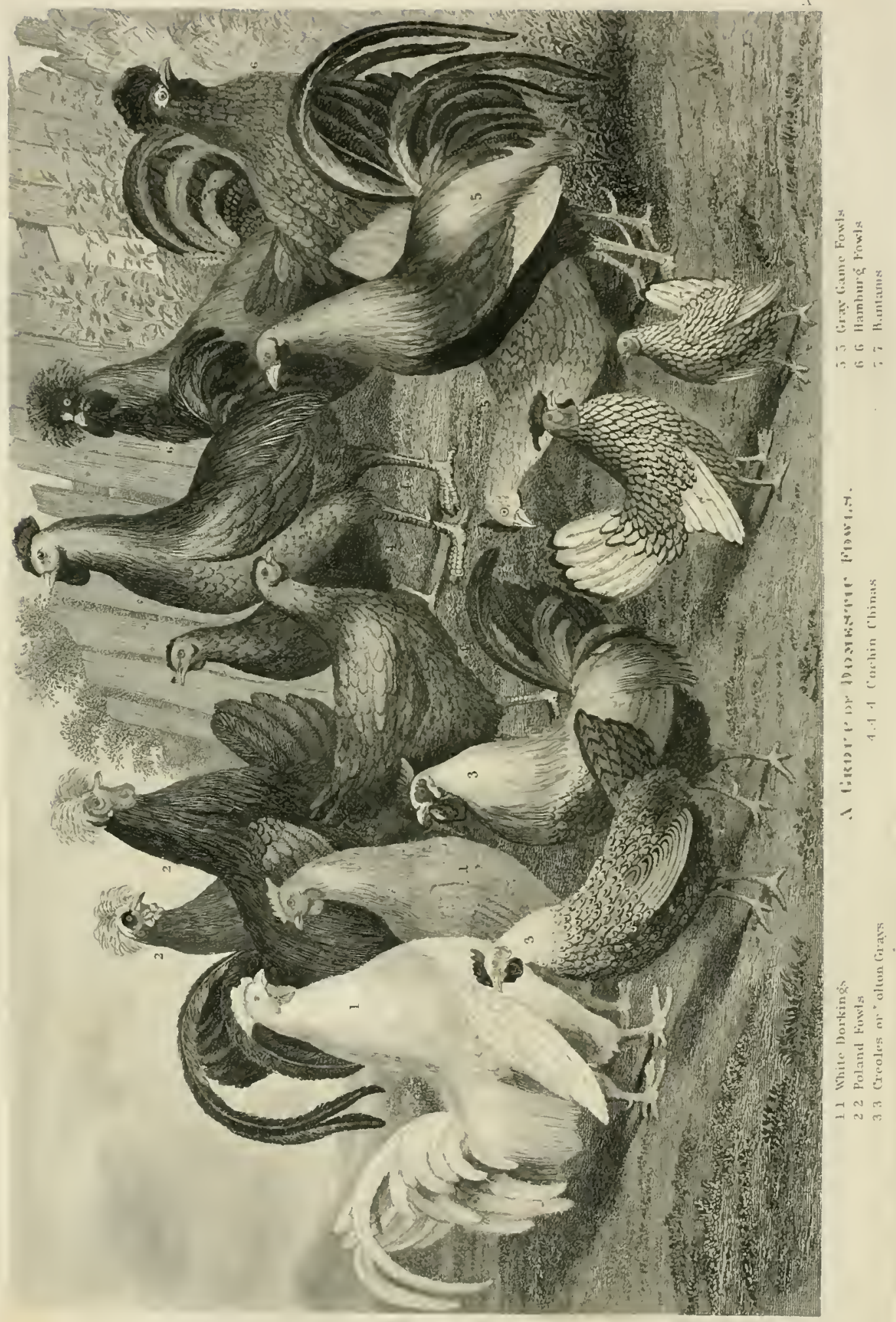




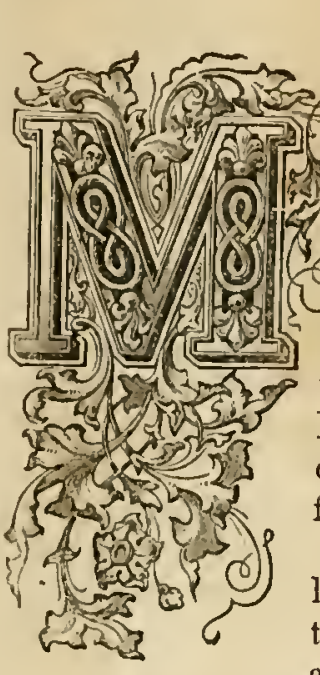

\section{SECTION IX.-P'OULTIIY.}

Fim for Poultry Kerpers.-Those who expect to be successful in raising or managing ponltry; ul lope to make it a paying part of farm business, shonld observe a few sinule rules which will save them from much disappointment and trouble.

1. It is not advisable to keep large numbers of hens together, or go into the ponltry lusiness on a large seale. It is found impracticable and unprofitable; besides, they can not be kept in so healthy a condition as where but few are together.

2. It is impossible to kecp hens to advantage without liaving a properly arranged lonse for their accommodation. This is as necessary as that a farmer should have a stable for his cattle or a dwelling for his family.

3. In connection with the honse, a poultry-yard shonld be provided, which should coutain a grass-plot, gravel, some quantities of slackel lime, and dry ashes.

4. The inside of the ponltry-honse should be whitewashed twice a year, or oftener, which will serve to kecp it free from vermin, and the hens will be kept in better condition.

5. Pure water, in sufficient quantities, must be provided sereral times a day, in wister and in smmer.

6. Feed should be given at regnlar periods. To fatten fowls, they must not be allowerl to run at large.

These rules are snbject to variation under ecrtain circumstanees. A new settler in the woods would not consider them applicable. It wontd be more profitalle to !et his peultry run at large. So it is npon all fillms at some seasons, but there aro but few farmer's who wonld not sometimes find it profitable to slut up all his poultry, the gallinacens portion of it particnlarly. For this purpose a poultry-yard will be fomd always a great convenience, if not a great profit. In should he so constructed that its first cost will not be money unprofitably sperit. Many persons have fouml it profitable to have a tolerably large incesosme for ponltry, and plant that with plum-trees. It is asserted that eureulio inseces never disturh phums mpon such trees. It is our opinion that it wouk? be found rery profitable to have a purtable poultry house and yard, which exuld be conveniently mored from place to place, kepping it upon ne spot one year, and upon snother the next. By this means some ball brier-patches wonld be subdued, and some poor spois cheaply enriched.

If poultry are liept in a yarl, the gronond gloula be niten dus up. If the yarl is large enongh, it may be plowed. lit is a good way to tave a large 
[ChAP. I.

yard in two parts, and plow and sow grain in one, and when it gets large enongh for the hens to eat, turn them in and plow and sow the other.

IIens that run at large are often very troublesome, sometimes doingr "more misehief than their neclis arc worth." 'The following derice is for such mischicrous pests.

173. Sluoeing Hens. - We observe a reent notice, in some paper, of the practice of making woolen slocs (or rather boots), to prevent liens from seratehing. A flock of fifty fowls, like our own, would lequire considerable labor in the manufacture of a luudred woolen boots, which mierht be worn through in a short time and necd renewing. It is much better, we think, to procure a breed that will not scratch. There is another point of importance-that is, to kecp the aumals well fed during the scason when scratching is most feared."

One man says: "I keep from thirty to fifty of the white Slanglac-a rery quiet, well-belaved, and profitable fowl-and adopt the most economical mode, namely, regular fecding with grain; and althongh there is no barrier between their ordinary range and the kitehen garden, they do not scrateh yearly enough to do twenty-fire cents' danage."

17. Number of liens to Keep, and Time to Sell.-A correspondent of the Illinois I'rairie Farmer says: "TVe liave kept as many as 150 forls, and fed them thïe pecks of shelled corn daily. But our experienec has been, that we conld get more than half as many eggs from twenty-fire fowls as we conld from one lundred. TTe have carricd chicks the size of quails to market and found them leady sale at trenty-fire cents each. Tre might liare kept them four months longer, and found them dull sale at a dime apiece."

175. Feediug Heus Meat.-Te have been adrised to feed plenty of meat to. our hens, it we wanted them to lay steadily. Now there is a time to feed meat and a time not to feed it. When the temperature is low and the ground is frozen, feed meat, but when the weather is warm, or cren moderate, if the chickens can scratel the ground and find rorms and insects, ther need no meat. The insects and worms furnish meat suffieicnt, and too much in many cascs, eansing them to lay egres withont any shell. They should then have plenty of lime or old mortar, grarel, etc.

Young chickens generally do best in coops, raised some inches from the ground, until they are six or eight weeks old; if they droop after this, the next hour of wam sumshine will bring them mp again. $A$ correspondent says, the last time he tried to raise them on the ground, lic lost 59 out of 60 . Ite has often raised 60 or 70 at a time since withont losing onc, simply by cooping them away from the ground until six wecks old.

A writer in the English Agricultural Gazette recommends that a piece of iron be kept constantly in the watel to which fowls liave access. Iron rust, lie sars, is an excellent tonic. A roll of brimstone is also recommended to be liept in the water.

176. How to Keep Ilens Shut mo-It is one of the most important matters 
about poultry liceping, particularly to small farmers and rillagers, to know low to keep licus in continement. It is very convenient for many persons who conld not allow them to run at large to annoy themselies and uciglyhors, to lieep enongh to supply the fanily with fresh egrgs, and penhaps a few chickens.

As continement is an umatural condition for fowls, it is often an 111 licalthy condition. The question is, can they be liept shut up in close quarters and licep healthy? If large numbers are together, they are very apt to get a discase which malies them lose their feathers. Sometimes they pull them off of one another. Great attention shonld be pail to cleanliness, where fowls are shut 12 . Lime for the liens to eat-lime seattered nver the floor-line nsed as whitewash, should nerer be neglected. The following rules are very good:

1st. Do not lecp more than ten liens confined in one small yard. They will he more profitable than fifty. If you wish to leep a large uumber, lave serernl places for them.

2d. Do not confine them in a damp or sliaded jlace, but in a dry onc, where they can have both shale and sunshinc. The latter is very inportant.

8d. As they can not remove from the filth that acenmulates, it slioull be remored from them. There is no permanent success in keeping fowls in confnement without the ntmost neatness. Their droppings should be laily removed from the roosting-place, and the yard should be well littered with fircili straw, tan, or othel unaterial, as often as is uecessary.

4th. The hen is omnirorons-that is, she eats almost everything; insects, flesh, grain, and fruit are taken with avidity. All attempts, therefore, to confine hens to a siugle article of diet will fail. Gire them a good sul!)? of grain and butchers' scraps, boiled potatoes, somr milk, and the ruftse of the kitchen, and during the summer months an occasional taste of fruit, and, in addition, earg-shells and oyster-shells crushed; or, if you can not get these, pound up the bones that always collect about yads. It is wonderful with what avidity fowls, especially when confined, will eat broken bones.

5th. J'lenty of clean water is always uecessury. Stagnant or filthy water will not do. It alone is sufficient to canse discase. Rimming water is bust, but clean, fiesh water will answer.

6th. Excreise is quite an important part of the plan. Tum them ont an hom lofore sunset to pick up insects, sravel, and other substances, and it will guicken their circulation and ald much to their prowers of resisting disease. We have hearl a poultry liceper say, who followed these rules, that with him the balance-slsect gave a larere purfit.

Although the abore remarks are applicalle principally to resichents of

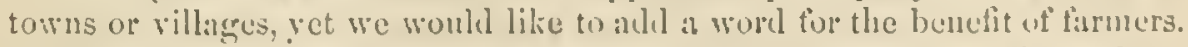
IJ fuw of them keep joulty at a protie! Inlect, as gencrally liept about the farm, with free range of the hurn, gran, and of end portions of the house, they are of 110 profit, and rery often are an almost intolerable misince.

17. The rood of powis.-This is a rery important qucstion. A grent 
many expedients liave been resorted to in order to clieapen the food of fowls. Chandlers' greares are largely used by parties in the vicinity of New lork to futten poultry for market. These are good for an oceasional feeding, lint for exclusire food we have our doubts, and think others will, after reading the following extract:

17. Are Fowls Wholesome which are led on Putrid Meat?-Such is the question considered by Dr. Dnchesne in the January number of the Annales d'Hygiène P'ublique.

It is well known that man can not indulge in putrid meat with impunity, and numerous cases are on record where isecidents liare occurred from this kind of food. Little is known, howerer, of the eftects produced by the flesh of animals otherwise in good health, but nourished witl flesh in a state of putrefaction. Certain animals can undonbtedly be nourished on such putrid matters; but it is important, in a hygienic point of view, to detemine the modifications which the exclusive use of putrid viands may produce in the quality and the preservability of fowls destined for the market.

On the oecasion of a complaint against a farmer in the neighborhood of Paris, Dr. Duchesne visited his establishment on a marm day in July, and toward the afternoon. The food of the poultry he found to consist of flesh in a state of putrid decomposition, which harl been obtained from the slangliter-lionses of Paris. The fat is first remored by cooking, and bran is added; and this mixture is giren moming and erening to the fowls, who figlt for it with avidity. $\Lambda$ very fetid odor came from the harrels in which the food was contained, from the ressels where it was supplied to the fowls, and also from the ground round about them. The fowls, lowerer, appeared to be in perfect health. Dr. Duchesne supplied himself with thee eggs laid that day, and also with a fowl and duck of a year old, which were killed before him. In three hours' time the poultry gave ont a very strong odor, and the intestines were so offensive that they had to be removed to a distance. Decomposition rapidly set in. The fowl, at the end of twenty hours after being cooked, had an mpleasant, strong taste, and the dnck, at the end of twenty-four lours, was in such a state that it conld not be eaten. Next day, when the flesli was cold, and the smell abated, portions of the duck were partaken of by the servants. The eggs, too, were found, if liept a reasonable time, to become very umpalatalyle. In fine, it was slown that though fowls nourished in this way were apparently healthy, and could be eaten at a pincl withont great inconvenience, yet that it was most probable that the continued use of suels articles of dict would be attended witl danger: The Council of Health at once interdieted the sale of fowls fed in this objectionable manner.

Dr. Duchesne continned his inquiries at the great knackery of Aubervilliers, where pigs and fowls are fed in great numbers on flesl, raw and cooked, and where similar animals are reared on a mixed food, consisting of flesh and grain. The results of lis observations are embodied in the following conclusions: 
1. Fowls and pigs may be fed on sound flesh, raw and cooked; ou flesh, raw and cooked, of animals affected with contagious discascs, as glanders, malignant pustule, hydropliobia, etc.; and cren on flesh, raw or cooked, in a very advanced state of putrefaction, withont any alteration in their health.

2. Chickens are reared with dificnlty if their food be restrieted to tlesh, raw or cooked, even when sound; and a larger number of them perish than when ferl on ordinary kinds of food.

3. The eggs of fowls thus nomished are as palatable as the egres of fowls nourished in the common way. The sliell, however, is thinner and unore easily broken.

4. The flesly of forls and pigs nomished on flesh raw or cooked, is softer, more diflienlt to preserve, and the fat is yellow and more diffuent.

5. The doctor has still doulyts as to the absolute wholesomeness of fowls and pigs fed on animals dying of glanders, ete., and recommends that the use of the flesh of such animals should be prohibited for the rearing of fowls and pigs.

6. The nse of flesh in a state of putrefaction, for similar purposes, should be absolutely prolibited as unwholesome.

7. Fowls slionld not be fed too long ol too abundantly on worms, enterpillars, beetles, ete., as such food communicates a strong taste to the flesh.

S. The continued use of flesh, otherwise healthy, and cither raw or coolied, ultimately injures the growth of the fowls and the quality of theid flesls.

9. The luest method of rearing undoubtedly is, to give flesh but once a dar, and to finisls with a meal of grain.

10. For matret use, the use of thesh should be stopled, and the fowls restricted tor some time to the use of a regretable diet.

179. thoice of a coch. - In brecling, the choice of a coek is a rery important matter. The following are some of the "points" insisted upon by poultry fancicrs :

It is accounted that he has erery requisite quality, when he is of crond sizc, carrics his hend high, has a ruick and animated look, a strong, shrill vice, the lifl thick and sliort, the comb a fine red, and in a manner varnished; a membrancons wattle of a linge size, and colored the eame as the comb, the breast broal, the wings strong, the thighs rery musenlar, the lears thick, the elaws with nails rather hent, and with a rery keen point; when he is fiee in lis motions, crows often, and seratelies the eanth with vicror and is constantly in scarch of wolms-not so much fol himself as his mateswhen he is sprited, ardent, and clever in earessing them, quick in detending them, attentive in soliciting then to eat, in lieeping them togetler in the dily, and assembling them at night.

There are some coeks, which, by being too high mettlel, are suappish and quinedsone. The way to quict the turbulent ones is pline : their toot munt be put through a leather, in a round shape; they lecene as quiet as men who are fietered at their hands, fect, and neck.

150. The Varieties of fonmon lowls, $-\lambda$ s to the variety to be chosen, that 
must be left to the funcy of those who are to raise the forls. In a farmer's family, this will generally be the female portion of it, and the gudewife or ehildren who take the fowls under their cliarge, should be consulted. It least the different rarieties shonld be male known to them, by plateing in their liands some grood treatise upon poultry. Several rolumes lave been published, with portraits and full descriptions, and how to conduct the business of poultry raising on a large or small seale. 15 c can not gire this information in full; we will only name the several sorts which are to be found among ponltry fanciers in this comntry, with short deseriptions, and lefer readers, for comparison of size and form, to the beatiful engraved illustrations of varieties, found in standard English works on Domestic Ponlty.

151. The Shanghae and China Brect. - I few years ago a good many people in this conntry, aflieted with the " hen ferer," went into cestasies orer the Shanghae, or China, breed of fowls, some of which are cnomously large. Cocks are spoken of as being twenty-eight inches high. The wiugs are sliort, and placed high upon the body. The tail is short, with a thick elump of feathers orer the root of the tail feathers. The coeks liare large combs and wattles; the hens are seldom large. The legs are feathered. The egrgs are not lare in proportion over the size of ergrgs of our old-style fowls; the color is nanken, and the ends rather blunt.

Those who breed Shanghae forls eonsider the flesh rery gond, and the full-grown bodies of cocks weigh cight or ten pounds, and pullets six or ciglit pounds. There are varieties of colors among the Shanghacs-some being pure white; others, a reddish brown, etc.

The rariety known as Cochin-China fowls differ very much in quality, habits, and general appearnee from the Slanghaes, to which they are closely related. Their egros are nearly the same shape, size, and color. The main difierence is in the somewhat deeper and fuller breast, and being gruerally smooth-legged. They also have the same hollow, harsh roice, when crowing, in their peculiar sonorons tone, long drawn out, and rery mulike the slurill ringing elarion of onr old-style barn-loor enck.

The Malay, or Chittagong, is another name of one of the rarictics of the China breed of fowls, which are supposel to be larger than the Cochins; the size, by weight, aceorded to some of them seems enomous.

We believe the rariety ealled Malay fow 15 are considered identical mith the variety ealled Chittagong. The full-grown Malay eock is said to weigh 12 lbs., and the hens $S$ to 10 lbs. They are of all shides of color, and havo small, thick combs and small wattles, and no top-knot; the legs not feathered. Their egres are larger than those of the other large varietics. The crow of the Malay eock is lond and liarsh, but terminates abruptly.

1S2. Ornamental Varieties of Fows. As the China breel, which we have deseribed, can not be said to be ornamental around a gented fil'm-honse or rumal residence, we will name some which are so, and at the same time are, at least some of them, rery raluable for all domestie purposes. The greneral appearance of the various sorts may be judged from realing the shout rotes 
which we append. 'The most omamental thing abont a yard full of fowls is to have them all of one varicty ; for instance, Duminiques, all looking so much alike that individuals wonld be hardy distinguishable.

The Jecasent-Mulay is the mame griven to a varicty of imported fowls. which are estecmed by some as quite desirable, particularly as ornamental stock. They are ealled good layers, good sitters, and good mothers. The cocks have black tails, and black on the neck and wings. Full-sized erous weigh two ounces each. The newly hatehed chichis are yellow, with a black mark down the back. Some of the liens are described as of a phensant culor, with long velvety black necks.

Guelderland fouls is the mame of another variety ; they are jet black in the plumage, witlont combs, and small wattles ; bodies slont and plump; legrs longr and teathered; eggs large, white, oval-shaped, and rich. 'The hens are not esteemed good layers nor sitters. This variety comes trom the north of Holland.

The Dorkings. - This, in onr opinion, is one of, if not the, best rarieties we have in this conntry for the erery-day purposes of farmers. It is the sust mostly used for caponizing in England. There are white, gray, and blown Dorlings. The legs are white or flesli-colored, smooth, and terminate in fiee toes. They feed well, to a good size, and the flesh is considered panticmarly delicate. The cock's comb is large and creet, and leep serrated, tree from top-knot; wattles, large. 'They are noted for hardiness; are prolific, and chickens easily raised. 'The egress arc large, pure white, very romb, and nearly explal in size at the ends. The clicks are hrownish vollow, with a broad stripe down the midlle of the back, and a narrower one on each side; feet and legs yellow.

liler Spanish is the name of a rariety of rery ornamental as well as nseful fowls. The plumage í glossy black; the combs of hoth cucks and hens large and red; and their general appenrmee spirited aml liandsmme. They lave a singrular mak, which distingruishes the raricty-it is a white mark on each clicel, not of feathers, but a fleshy substance, which in the cocks is very conspicuous. The liens are great layers, hut not inclined to sit. The ergess are larere and white, and so is their slin and flesh, which is tender and juicy. The chicks are black, with a white sjot on the lmeast, and are long in getting featlered ; so none but early spring chickens should be aftumpterl, and these must be obtained ly setting liens of another variety npon the Spanish exrgs.

Gume Fouls.-There are reveral distinctly marked solts of seme forslsblack, white, sray, and brown, all having the same reneral cliaracteristice,

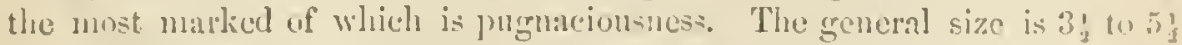
lls. The egrs are smallel than the egress of the mut common fowls, 1 miformly slatperl, and enok rich and delicate. In form the game fowl is tha handsomest of the rave. Tho heat is thin amel lougr eyes lange aml finl ; leak stont and crovked ; long neck; body compact, slort, and romed in tho breast; thighs thick, stont, landsome, taper-shaped; legrs long and thick 
and enlored like the heak; feet thin, broad, strong, with very long clatws. The cock walks with a proul, defiant courage, and appears always ready tor" a fight. It is a groul raliety to breed from for domestic pmposes, if care is talien not to allow cocks of any other sort mpon the premises, and nut to allow eockis ever to be pitterl aginimst each other.

The Mexicuns appean to have a variety of game fowls quite distinet from the English rarieties. It was first introdneed into the United States in $15+1$, hy Genelul Traddy Thompson, of Sontl Carolina. The cocks and hens line but few marks to distinguish one from the other. The original stoct are plieasant-colorecl, and in some of those bred in Sonth Carolina, black tail feathers, and a tendency to gray or light yellow plumage. This variety are great fighters; they lave strong, muscular frames, and are quick and firm in action. The eocks hitre large lustrons eyes and strong bills and upright combs. The hens are good layers and sitters, and grood nurses. This is the brecl of game-enclis patronized by General Santa Ama, who was the greatest eoek-tighter in Mexico.

The Java foul is a very large variety, of black color, said to be found, thongh probably not pure, on Long Island, and around Pliladelphia. They are sometimes called Saddle-backs, on aceount of being so broad aeross the rum]?.

The Jersey Blue is the name of a variety quite common in New Jersey, the excellenec of which is so great, that anything particularly grood is figmrutively spoken of as "one of the old b] ne hen's chickens." The color is light blue, sometimes appuoxeling a dun; legs generally dark, and sometimes lightly feathered. Cocks weigh 7 to 9 lbs.; and hens, 6 to 51 lhs.

The Polund fouls take their name, not from Poland, but from a resemblance to the tuft of white feathers worn by Polish soldiers. They are glossy black, exeept the top-knot, which resembles a full, white rose. Like the Black Spanish, the Polauds are great layers and bad sitters. The skin and flesh are white, and good for the table. The cocks weigh 4 to $4 \frac{1}{4}$ lbs, and hens, 3 to $3 \frac{1}{2}$ lbs. Their form is plimp, and legs not very long, being wellproportioned and handsome-shaped, and they are particularly ornamental to a comtry seat. The egres are of good size, and white, but though abundant, are not as rich as some others.

Awother variety of the so-called Poland fowls are white, with black toplinots; and another sort are gold-spangled. These are exeedingly ornamental; the erest being largre; golden, and bromn; legs, light blue, and toes partially webbed.

The Silver Polands are spangled with silver instead of gold, and the luons are the most ornamental. Even the chicks of this rariety are pretty.

The Poland varety of forls axe only fit for neat places, where they eau run upon grassy yajeds of lawns. In dirty pens the crest becoures loaded with dirt, and blinds the poor birds. Where they ean rnn at large around the house, even if the hens were not, as they are, such good layers, they might well be liept for omament alone. 
The spangled Ilambury fonols are another ornamental variety, with topknots and beantiful plumage, both grold and silrer spangled. The weight of male birds is abont $4 \frac{1}{2}$ or 5 llus., and the hens, 3 or $3 \frac{1}{2}$ lbs. The cock stands twenty inches high, and hen eighteen inches.

The Bolton Gray is anotler omanental variety, and also a very useful one, the hens being excellent layers. They ane sail to have come from Ifolland to Bolton, Engrand. 'The color is remarkable; the gromul work pure white, delicately penciled with black orer the body. The neck is white, aml heads sumounted with large, red, serrated combs. The weight of cocks may lee $t$ to $4 \frac{1}{2}$ lbs., and hens, 3 to $3 \frac{1}{3}$ lbs. They belong to the suall-sized varieties, but are the most perfect patterns of neatuess and syminetrical beanty of the domestie fowl family. The cliclis are white, except a dark streak on the head and hack of the neck, which secms curious, as, when grown, the neeks are white and bodies marked with black. The chicks are rather liard to raisc. The eggrs are small, tapering at one cul, and pure white.

The Silly fuwls are also classed among the omamental, and comprise sereral rarietics, originating in India. Some have white plumage, with lark skin and bones. The combs of some are liack, with black plumage and black bones; and the feathers are so mlike feather's, the heus get the nane of silky. They are not considered a valuable bird.

The Frizzled forels is another varietr, but not one that we can reconmend any one to cultivate. This sort may be known by the deseription griven to us when we first saw any of the kind in our boyliood, and asked the renson of their siugular appearance, and were told that the ehickens got turned in the shell in an eartliquake, which upset things grenclilly and turned the ehickens' fathers wrong end foremost. That is the appearance of the pure brecl. Every feather looks as though it had been emled and turned rrong end forenost with a pair of such curlingrotongs as the grirls used to frizzle their hair with in olden fine. 'To our mind, the Frizzles are ugly beasts, not worth raising on acenut of any good qualities, and only to be indulged in by those who ean aftord to lieep euriositics.

Ihe Curloo foul is a variety foumd in some Enerlish form-yarls, and perhaps in this country. It las a barred plumaere, somewhat resembling the breast of a cuckoo. The greneral color is a slate blue, tinged with white: the comb is small; the iris of the eyes, bright ormuge; feet and legs, light tlesh color; so that it will be seen that the hreed is rather an omanental one. The lirds grow to a large size; the egres ance very white, sunooth, and nhout two ounces weight.

The lilue Dun fouls originated in Dorsetshire. England, and arratier an nruamental variety, under size, slemler male, with high, deeply sermitcul, single combs. Sometimes the lilue Dum cock is gold or scarlet spangled, ant very pretty. The hens are good liners, and make good pets. The cocks are rather gamy. 'The hens are good mothers, and the chicks are real little curiosities. This variety is esteened tor the table. 
The Letrye-Crested foul is another old Tinglish ornamental variety, the crest being larger than the Polands, and the fowls of varions colors, some of them rery brilliant white-more dazzling than the white Guinen fowl, which gives them and the lonestead where they are kept a very lively appearance. When lressed for maket, their appearance is very clean and attractire. Their gencral good rualities make them fuvorites upon many a farm in England.

The Bentams are also rated anong the ornamental fowls. Some of them are really so. The Sebrights liave beautiful phumage of a delicate speckled dark and golden color. There are also black, white, and nankeen colored bantams. Their model is perfect and plunage beautiful, and of only about a pound arerage weight for the hens, and one and a quarter to one and a half pounds for cocks. They are great pets with many persons in England, and are licld at fimbulous prices. The bantams are good layers, aur grood sitters, and good mothers. Some of the coeks are very gamy. We decidedly approre of keeping bantams as ornaments of the farm-yard. And we recommend that the tenther-legged rariety be aroiled, as they are not so neat in muddy wentlier in their appearance as the naked-legged sort. The color is a mere matter of taste.

The Dominique foul is not only an ornamental variety, but a rery good one for erery-day purposes on the farm. The true color is a peculiar arrangement of white and blue, that gives a sort of grecnish tint to the plumage. The combs are donble; the wattles small; the legs white or yellow. The Dominiques are hardy; above medium size ; rery domestic ; and the hens are good layers, and most execllent sitters and mother's the egges good size and quality, and the birds excellent for the table.

There are many other sorts of ornamental forls not entirely worthy of recommendation for domestication in this country-among which is the Bankiva cock, from the East Indies, of the bantam order, but twice as large as the common bantams.

The Forked-Tuil cock is another India variety, something like the Bankira cock. This is a wild sort in Jara.

Sonerat's wild cock is also an Indian variety, which has been attenptcl to be domesticated on account of its beautiful plumage, which is a deep gray, tinged with lighter gray on the edges, with deep green tails; beak, legse, and fect yellow.

183. Chicken Coops, - Anybody knows how to make a chicken coop." No lie don't. Not one farmer in ten can make a decent chicken coop. Consequently, old barrels and boxes are substituted. They may be "good enongh;" they are not ornamental, and for ornamental poultry yon should hare ornamental coops. To make a convenient, light coop, take half or three-eighthinch boards, six inches wide, and nail them upon posts exactly like siding on a loonse, if that is the way your house and farm buildings are sided, so as to have a uniformity. If buildings are boarded up and down with battens, make coops in the same way. Board three sides close, and the other side fix 
with slats two inches wide and two inches apart, with extra slats that can be slored in between, leeing lield in place by a bar in flont at top, and one at bottom. One of the other slats should also be made morable, so it can be raised to allow the lien to gro in and out. If the coop is double, which we prefer, make a movale slat for each room. The dimersions of a lonble coop may be two fect long, one and a lualf licet wide, one and a half feet ligh on the hack, and two fect in front, with a close partition in the midalle. Make the roof of fre pieces of boards-one at each end and one in the middle, nailed fast, and two olhers hinged and luttoned down on the others, so as to make openings about six inches wide into the coops. One room is for the nest and one for the lrood. If two liens are rery docile, they may occupy one coop. Ontside of the front slats nail a little trougl, one foot long, to serve both rooms for water, which will be comeatalsle outside and in. These are the dimensions of a coop of the smallest size, which will be so light that a child can move it from place to place. It should have a foos: and if rats are tromblesome, it can be set "p from the ground, particular?y at night. The dimensions in length may be increased as much as desired. Set it face to the sun, and in case of stomn, or in coll nirhts, close all the slats, leaving open a hole in each end, high up, about two inches square or romul, for rentilation. If you wish to raise your chickens without a mother, line one room of the coop with old earpet, and put a boand, eovered with woolly sheep-shin, about six or eight inches square, in one corner, just high enomph for the chicks to creep under, and look well to them for a few days, and they will do hetter than with a bad mother. As they grow large enongh fu ga ont of cloors, let them in a small yarel, in front of the coop, to serateh aml hask in the sun. The best fence for such a yand is wore-wire, one and a half or two fect high. With nice, warm, dry coops, early chickens car be raiserl almost as sure as late ones, and where gruwn for sale, will gुenerally sell for as much when half grown as late ones will full grown.

Stores in Chiclien-IIouses. - It has heen fomd profitable, in raising camly chickens, to use artificial wamth. A small, wallu room, wamed in coll wenther by in store, so as to keep the temperature at about 55 elerrecs. will allow you to set your licus in Jammary or Furmary, and gest ehickens which will scil, when the size of quails (say in cents a jair), for as much as old fowls. These warm-lonse ehickens must not he allowed to rum ont in the collt or wet grass, but will be benefited by allowing them to rum ont in the sun. If we male a husiness of raising ponltry for market, we would set hens in a storeroom all winter. A tun of coal, costing say six dollars. would warm a ronm all winter, large enongh to rase two or three humber chickicns, which wonll sell in the eity marlicts, certanly at twenty"-fire ("ents apicee, when the size of quails.

1St. Set llems barly. - It is a great nlject to set luens as carly as possible

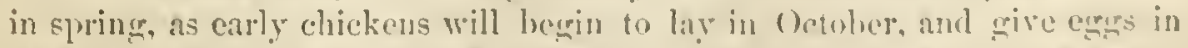
November and December. Le careful to rive your early sitcers a wam, dry nest. After the hen has leen sitting ten days, examine the egers to soe 
if all are srood, and throw ont the bad ones. To tell which are good, hold an eggr up to a hole or (reviee of a dark room, and look at it, and if all below the vacum in the butt is dark-colored opaqne, it is in a far way to hatel. If it is light-colored and yellowish, so that the sunlight ean be seen throngh it, yon may throw it ont at once; and if all are so, yon can dismiss the old hen with your thimks for lier good intentions.

"Double eggis" rarely hateh, and when they do, are just as likely to prodnce two distinct chickens as a Sianese one.

Nests shonld be made shallow. If boxes are used, not orer five inches deep.

1S5. Periods of Incubation.- $A$ common fow lien sits 20 days; a Guinea fowl lien, $25 \frac{1}{2}$ days; a dnek, 26 days; a turkey hen, 27 days; a goose, 29 days; a musk duck, 32 or 33 days; a pea-hen, 27 to 29 rlays.

To hateh healthy chicks in these periods, the birds must have good warm nests in a sheltered situation. Chiekens hare been hatehed in nincteen days, and the period has been prolonged to twenty-seren days.

\section{S6. Weights of Various Brceds of Fowls and other Poultry:}

\begin{tabular}{|c|c|c|c|c|c|}
\hline & Los. $\mathrm{C}$ & Oz. & & & \\
\hline Dlack Polish cock, three years old ...... & 5 & 8 & Musk drake (molting) . . . . . . . . & 9 & 12 \\
\hline "hun, $\quad$ " $"$ " $\ldots \ldots$ & 3 & 4 & White China gander, six years old & 12 & 13 \\
\hline$\ldots \ldots \ldots \ldots \ldots$ & 2 & 6 & 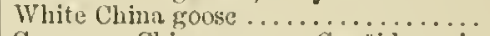 & 11 & 13 \\
\hline Golden l'olish cock ................ & 5 & 0 & Common China goose, Cynüides, six & & \\
\hline " hen $\ldots . . . \ldots \ldots \ldots \ldots \ldots \ldots$ & & & years old $\ldots \ldots \ldots \ldots \ldots \ldots \ldots \ldots$ & 10 & 10 \\
\hline nother lien.... & 8 & 10 & Cochin-China coek, aboit sixteen nonths & & \\
\hline Dlelen Polish pnl & 3 & 8 & vlei, molting...$\ldots \ldots \ldots \ldots \ldots$ & G & \\
\hline 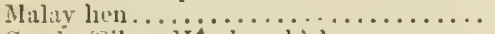 & 3 & 12 & Coclin-China hen, " $"$ ". & 4 & 6 \\
\hline Creule (Silver llfmburgli) lien ........ & 3 & 1 & Malay cock, about sisteen montlis old & 6) & 14 \\
\hline Black Nunclescript hen .............. & 4 & 10 & " lien. " " " " & 4 & \\
\hline lube-crestexl lolish hen ............. & 3 & 9 & Iherannt-MIalay cock . ....... & 5 & \\
\hline$\ldots \ldots \ldots \ldots \ldots$ & 3 & 4 & " " hen, molting. & 3 & \\
\hline Game-cock & 4 & 10 & ont five months & 4 & \\
\hline & 3 & 0 & Golden lambnrgh cockerel, just arrived & & \\
\hline Toung 1 & 3 & 6 & from a long jonmey, about five & & \\
\hline$\ldots \ldots \ldots \ldots \ldots \ldots$ & 3 & 0 & montlis old $\ldots \ldots \ldots \ldots \ldots \ldots$ & 3 & \\
\hline Large Dun Hy-buid lacn. . . . . . . . . . . . & 3 & 8 & "prillet, " " " & 2 & \\
\hline cocks, two years old, & & & Cochin-China eoc & 4 & \\
\hline & 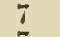 & 0 & Another, & 4 & \\
\hline " cockerel, fiv & 7 & 0 & Silver Hamburgh cockerel, after travel- & & \\
\hline$" h^{\prime} n \ldots \ldots \ldots \ldots \ldots \ldots \ldots$ & 5 & 1 & - ing, about fire months old.... & 3 & \\
\hline " pullet, seventeen months old..... & 5 & 3 & " pnllet, " " " " & & \\
\hline$\ldots \ldots \ldots$ & 5 & 8 & \$t & 2 & \\
\hline Speciled Surrey hen, two years old.... . & 5 & 12 & Anclalnsian cockerel, four months old . & 3 & \\
\hline Spanish $b$ & 5 & 0 & " pullet, " " " ". & 2 & Cis \\
\hline Two Dorking cocks, each....... & 7 & 0 & Black Spanish cockerel & 2 & 11 \\
\hline$"$ hens $\ldots \ldots \ldots \ldots \ldots$ & 6 & 8 & "pillet, " " " " & 2 & \\
\hline & 6 & & Silver Polish cockerel, four months and & & \\
\hline $\begin{array}{l}\text { Cock turkej, two years aul a half old. } \\
\text { len }\end{array}$ & 17 & 12 & & 2 & \\
\hline 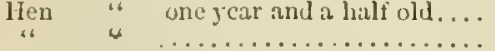 & 10 & 0 & Golden Polaud jnllet, about five months & & \\
\hline Turkcy cock, si & 16 & 0 & White-crested Golden l'oland pullet, " & $\tilde{2}$ & \\
\hline & & & & & \\
\hline
\end{tabular}

15. Capous and Foulardes,-These are terms applied to emasculated cocks and pullets. Every person who makes a business of ponltry raising to supply arcity market, should learn the art of making capons and ponlardes, because they will always sell for nearly twiee as much as other fowls. 
The instruments nsed to perform the operation are few and simple, and incxpensive, and the art easily learned.

A eet of first-elass eaponizing instruments is included in the following list: a scalpel, $62 \frac{1}{2}$ eents ; silver retractor, $\$ 150$; spring forceps, $\$ 7 \frac{1}{2}$ cents; spoon, with hook, 75 cents; double silvel canula, $\$ 175$; total, $\$ 50$.

A much chenper set of instruments would answer all practical purposes.

The proper age for caponizing chickens is trom one to three montls. The cock is eontined npon a table by weights upon the wings and legs, with the righth side up; the feathers are then plueked off a spot on the righth side near the hip joint, abont an inch aeross, where the ineision is to be made, ly. which the parts are exposed that are to be remored. The operation takes but a few minutes for a skillful operator.

1SS. Pea-Fowls. - Of all the ormamental ponltry erer kept on a place, the pea-fowls talie the lead, and well they might, for they are the most useless, and a very expensive luxury. They will not bear confuement; will not even loost in a lonse, but oecupy the tops of the highest buildings al tall trees. And for mischicf, from which they can not be restrained, they excel all the featlered tribe. They are euming beyond belief. They will watch opportmnities to visit the grarlen and steal fint, and be ont betore they are smipected. Driving them out with all possible marks of ill-treatment las no effect upon them, as it does upon other poultry. The pea-fowls will bear a repetition ol abuse every day, and every day return to their thieving. So no one who has a garden and lawn in one inclosure should attempt to keep pea-fowl; nor where there is any chance for them to get into mischiet.

$A$ manlenless mansion may, and should lrave mumbers of pea-fowls. A single pair makes but little show, while a flack makes a most dazaling, splendid apjearance. Pealuens are two or three years in coming to maturity. They then lay four to seren eggs, which require twonty-seren to twenty-nine days' ineubation. Peahens always steal their nests, and their egros must nerel be tonehed, if you wish the len to incubate them. They may be taken and incubated under a common fowl, ol, better, minler a turley, and then the pealien may find another sly place and lay again. The peacock has tho reputation of heing a bad father, and killing his own progeng. Therefore the lien hides trom lim as well as from men.

15!. Turkeys,-Fvery fanmer can and shonlil keep turkeys, and as there are several varicties, he shonld get the best and lieep no other.

Turkeys are less mischicrons than most other pultry, and in sone cases they are of great assistance to the farmer in destroying insects. The tobalecer planters kecp turkeys purposely to assist them in ridding the plants of the destructive worms.

The turkey is a much more recent introdnetion to the poultryareyl than the other varicties. It is said that the black sort was earried from ifs na.

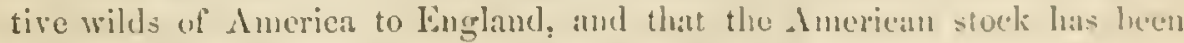
all drawn from the wools, sud that the dillerent sorts have conte from : Sonthern and Northern race. We think, Hough, that it has come from 
mixing the black will variety with a white or party-colored one inported from the other sicle of the Atlintic. We prefer the pure black breed, tor it gives us the largest and landiest birds, and we think, also, the handsomest. 'The pure whice tndkey, it is true, is quite ormanental, but it is not as liarly a sort as the lilack. Is for yellow or party-colored turkeys, we would not have them on a place a moment longer than necessary to fatten, kill, and eat them.

The will hen turkey is wild in the extreme, while the tame one is so domestic that you mily rob her secret nest erery day of the new-laid egor, yet she will return again and ingin mutil she has fuished her season, and then commence her jeriod of incubation mon the entyty nest. Now, if you have a nest prepared under cover, with the egers in it, you may bring home the lien and put her sently upon lier egers, and slie will manifest great satisfaction, and after carefully examining and placing them all right, will sit upon then as thongh the nest was all her own. Thirteen eggs are enough for an ordinary-sized turkey, and if she has a good nest she will cover that mumber, so as 10 grive all a fair chance to hateh. It is not necessary to tmrn the exress, as sone persons do-the hen attends to that $\rightarrow$ nor look at them mntil about the time the four weeks are up, when it will be well to remore the ehicks as they erme ont, or else take ont all the shells and rotten egers, if there are any, to rrive the chicks room, for they generally are better oft in a good nest. thon out of it. Shut the hen in a coop, where the ehicks can bask in the sun, and not get in the wet grass. Yon need not feed much the first day; ; few breal crumbs will auswer. Then give all they will eat of hard-boilexl egg, chopped tine; chopped meat, fat and lean; enrds, boiled rice or hominy, with cress, lettuee, and green onions. Don't stufi them with peppercolns. The idea that that is necessary is all stuft: Tiver, boiled and elopped up, is rood fool; so is barley meal and snet. Melt the suet and pour over the nueal and mix, and then crmmb up when cold. Many green things may be cliopped up and mised with mill and water and meal. Don't try to cut up feed very tine. The young turkeys, yon will find, ean swallow big lnmps. After ten days yon may let the hen run, if the weather is fine. In bad weather they are apt to take cold, and cramp, and dic. Care and high fucdingr are all that are needed to raise turkeys.

We knew a woman in Inuisiana who raised fifteen hundred ont of sixteen limelred Iatched. She had an old negro woman and a boy to attend to the wants of the turkeys, and in wet, chilly weather the roming hroods were all gatlerel into a log-cabin, warued ly a generons wood fire.

We have also before us another example of successtul turkey raising by a woman, that is worthy of attention by some other farmers' wires, who may go and do likewise. Iydia Eldrirlge, of Andover, Mass., writes her experience in raising turkeys, under date of Dec. 25, 1555:

"Last spring my husband purehased a farm in this town, and I obtained one turkey, and she lairl $2 \pm \mathrm{eggs}$, liatehed them all ont at one litter, and I raised them all. Festerday we dressed the last of them. The mited weight 
of the whole, when dressed, was $212 \frac{1}{3}$ llbs.; 195 lbs. were sold for a shilling a pound, New England eurrency, mounting in the aggregate to sise. The whole number at that price rould hare anounted to $\$ 35.51$. Now I think that is doing quite well, and if anybody among your anmy of jeaders can do better than that, I think they deserve a premimm; but until that is done, I thiuk I can claim the palm."

And, in our opinion, slie is fairly entitled to it. We hope, howerer, that some other woman will try to win it from her by far competition in this appropriate ficld of woman's labor.

And liere is another of the same sort, which should tend to encourage other women to attempt the same plan to make a little "pin [feather] money." It is to encourage others that we collect and publish these fincts.

"J. E. Alton, of Quinsigamond, Mass., writes ns that MIrs. MI. Bennett, of Aubmm, Mass., lad a three-fourtlis wild turkey, of very large size, which laid'11 egress, all of which she hateherl and raised. At six months olil the united weiglit of the eleren was 220 lbs. Some of the male birds weirged 34 lbs., and the lightest hens 17 lbs. One male sold for sit, and the whole for $55.5 . "$

These, howerer, are funcy prices; but at the steady market prices of dressed tmlieys, which will arerage 10 cents a pound wholesale, in New York, and considerably more for choice birds, the raising and fatting of tarkeys is a protitable lranch of farming.

It is true that young turkeys, from the time they are old enough to turn ont to range for themselves, aje rubacions eaters, and wonld destroy some crops, and so would swine, if permitted to run at lasge. The farmer finds it profitable to lieep a let for swine, and so would he to derote a whole field to turkers; and if he will do that, where they ean forage for themselres, they will need very little attention, and will not be likely" to get into much misclice. If rightly managed, a flnek of turkeys will do more good than harm on a farm, for they are great destroyers of insects. It will be found protitable to plant ealubages, turnips, bagas, peas, nats, wheat, and clover pmrposely for the turkeys to feel upon. This can be manared on a small seale to advantage lyy using a movable fence. We lave no doubt about the fact that a turkey fam would be as protitable as a sheep farm, or a mill farm, $0{ }^{\circ}$ a heef or pork-making furm. In all new seetions of eomntry, where mast is abundant, tmolieys will fatten upon it cutively ; and in all sections where fiek feeding is practicel, there is no better stock to run in a corn-field tham turkeys. Eyen where corn is worth a dlollar a bushel, it has been funnd profitable to feed it to turkeys to tatten them for market. One considerable irem in the acenmut in all the ohl states would be the ralue of the mamme inale fiom such feeding.

Tlie most important fuet in tulliey laising is not to nverstock yourself, for then your flock of turkeys will become pests to yourzeli and neighlyors-a set of maranding, piratical tlieres. 
A witer in the Gemmantown Telegrople furnishes that joumal with the following statement :

"Mnch has been published of late in our agrienltural journals respecting the alimentary properties of charcoal. It lias been repeatedly asserted that clomestic fowls may be fattened on it without any other fool, and that, too, ju al shorter time than on the most nutritive gran. I made an experiment, and must say that the result surprised me, as I had atways been rather skeptical. Four turkeys were confined in a pen, and fed on uneal, boiled potatoes, and oats. Fonr others of the same breed were at the same time eonfined in another pen and fed with the same articles, but with one pint of fiuely purrerized chareoal mixed daily with their meal and potatnes. They also had a plentiful supply of broken chareoal in their pen. The eight were killed on the same day, and there was a difierence of one and a half pounds each in faror of the fowls that had been supplied with charcoal, they being much the fattest, and their meat greatly superior in point of tenclerness and flaror."

T. H. Arery, of Wampsrille, Madison Comnty, N. I., is entitled to the first prize of hour for improrement in the breed of turkeys. From a eross of the American wild turkey, made fourteen years ago upon the best domesticated birds of pure black color that conld be obtained, and by careful attention to breeding since that time, he has suceeded in prodneing a male bird of superlative beanty, of glossy black plumage, which, at two and a half years old, weighed 34 lbs. alive; and a femate bird, two years rid, weighing $20 \frac{1}{2}$ lls. alive; and a female bird, one year old, dressed realy for the spit, $15 \frac{1}{4} \mathrm{lbs}$. weight; and ats the stock has been contimnonsly improving both in size, beanty of form, and plmmage for years, it is impossible to detemine any limit. Ife has lately precured a pair of pure rild hirds trom Canada for the purpose of infusing a new strain of wild blood into his stock whenever he sees a chance to improve. The ordinary weight of male turkeys, two years old, as they are prepared for the market, will not exeecd 15 lbs., and a female of 8 lbs. is acconnted a rery good one.

Just after the election of Mr. Buclianan, a cock turkey from Mrr. Arery's farm, that weighed 35 lbs., was bought at $\$ 1$ a ponnd, and sent to the President to serve as one of the members of his (kitehen) cabinet; and another of still larger size was presented to President Lincoln.

Turkeys grow big in Illinois, according to a correspondent who writes from Stebbinsville, who says that 25 to $361 \mathrm{bs}$. is not an nucommon weight for a wild turkey, and one old gobbler that lie shot weighed $41 \mathrm{lbs}$., and spreal a tail over mine feet around the circle. He thinks some of the brag " improvers of the breed" had better send for some of the Illinois wild stock for a eross mpon the biggest in all Yankeedom.

B. F. Langworthy, of Alfied Center, objects to our directions to scald tmlkeys. He says:

"Scalded turkeys and chickens sell about two cents a pound less in Boston than those picked dry-do not look as well, and certainly will not keep 
as long, nor please the customer as much; while the adrance priee will amply pay for the difference of time in dressing."

On the contrary, in New York, dry-picked poultry does not sell as well as that which is scalued.

190. The Gunea-Fowl-A union of two breeds of forls is seen in some measme united in the Guinea-fowl. It appears to hare some of the characteristics of the turkey and the pheasant. Its hend is bare like the turkey: its body and plumage, and general form and appearance, somerhat like the plieasant. 'The plumage of the most common sort in this comntry is of a bluish ground, delieately spotted with white. The wing feathers are nearly white. There are also fowls of this family entirely white. The greatest objection to the Guinen-foml is the almost continmal noise they make, which to some is intolerable. It is abont as musical as the sharp squeak of a crindstone or old cart. The noise is, however, tolerated for their grood quhlities, which are not a few. Their noise tends to keep of harks and other pests of the ponltry-yard. They are very ornamental, and grive a place a lively, pleasant appearance. Their flesh is pretty grood for the table; they are good layers, and their eggs are large, and rieh, and good for cookery, but not so grood as common liens' egros for the table.

The young chieks are liardy, and rery pretty. There is no prettier sight in connection with ponlty than a fine Gninea-hen with her brood. The hen sits a month, and nine eggs are enongh for her to corer. 'The eggs may be hatehed under a common hen, but a good sitter must be selected, becanse the time is longel than lier own. Mard-boiled eggs chopped fine, breal crumbs, clioplyed meat or suet, are good food for young chicks. Some persons procme maggots on purpose to feed chicks. Any kind of small worms are deroured greedily by the young Guineas, which are real cormorants. They will eat a dozen times a-dar, and a full supply of food is one of the great seerets of success in raising these as well as turkeys.

There is no domestic hen that gives such a bountiful supply of egas all the year round as a Guinea-hen; consequently they are not groul sitters, and other hens liare to be used when it is lesired to inerease the siock rapidly.

191. Ducks, - Wherever suitable conreniences exist for keeping ducks, they are not only ormamental to the furm. but profitable. Some of the rarieties are particularly ormanental-the little Wood duck the most so of all. The Pintail duck is a rery neat-looking bird. The Aylesbury sort are pure white. The plumage of the dralies of some of the wild sorts which latro been domesticated, is rery beantiful. A few ormumental dneks might lee kept upon almost every" fam, and fumislued with artificial water. We would never raise but a single brool or two a year, except we hat natural water. A drake and pair of ducks, with their progeny, would cost but little, and the amount of grood they" would lo is incalculable. Tlue are great destroyers of slugs, snails, worns, and all lanve; and it you should see an old duck pitch into a nest of young unice, you would learn what grood she can do in that way of ridling tle tarm of pests. 
Ducks' egges are not esteemed for the table, but are in cookery. The birds when well fatted are alwrys salable, or good for lome consumption, and pay as well for the corn they eat as anything in the poultry-yard.

In selecting a varicty of ducks, the purposes for which they are to be bred must be considered. If for ormanent, select the prettiest. If for scavengors, we wonld use the common grray duck and drake with green head.

The best white dnck is the Aylesbury. It lias yellow legs and feet and flesh-colored bill. White ducks should never be kept except where water and grass are both abundaut. In thie water or on a lawn they are pretty. In a mudly yard they are not so.

There is a great variety of eolors, but we recommend you to confine yours to a single color, whether white, black, gray, blne, or slate. The feathers of dncks are as grood as geese fenther's, and some lousewires pluck them in the saine way.

The duek sits thirty days; and the hen should be confined an erual length of time, whore the ducklets can go out, and into natural or artificial water. You can not feed them too much, and they are no way dainty. When large enongh, give them a wide range, bringing them loome at night. The best food for grown ducks is Indian corn, and the best ducks for the talle are domesticated wild ones, fatted on com, or wild ones that have had a full range in corn-fields. Beech-mast also makes the flesh of wild ducks cxcellent.

192. Gease-As gecse are generally kept by farmer's, they are neithel' profitable nor ornamental, but, on the contrary, an nnmitigated nuisance, befouling grass and water, door-yards and roadsides, and always poking their heads through holes into misehicf.

Geese nerer should be kept upon or about any farm, except in a lot appropriated to their particular nse. A man who would turn out a floek of geese mpon the public highway to pirate their living, we would not trust about our hen-roost of a dark night.

If geese are liept on a large seale, where water is good, and pastured like any other stock, and finally fatted for market, upon the same principle that pigs are fed and fatted, we will insure the largest profit from the geese, - particularly if the best breeds are selected.

The Chinese or IIong-Fong geese and the Bremen geese are mueh larger varieties than the bred common in this country. The Bremen geese have pure white plumage, with cloan ycllow legs and bills. They attain to great weight and age-twenty or thirty years, and as many pounds. The flesh of a young, fat Bremen goose is esteemed above all the domesticatel tribe, and the feathers are salable at the rery highest rates.

This breed is rery prolific, laying twelve or fifteen eggs a year, and the geese are good sitters and nurses. They are somewhat inclined to eommence laying too early in the season. To prerent this, shut the whole flock in a dark room, abont the twentieth of Febrwary, and feed and water once a day, and allow them an hour out once a week to wash and have a run. 'In a few 
VI

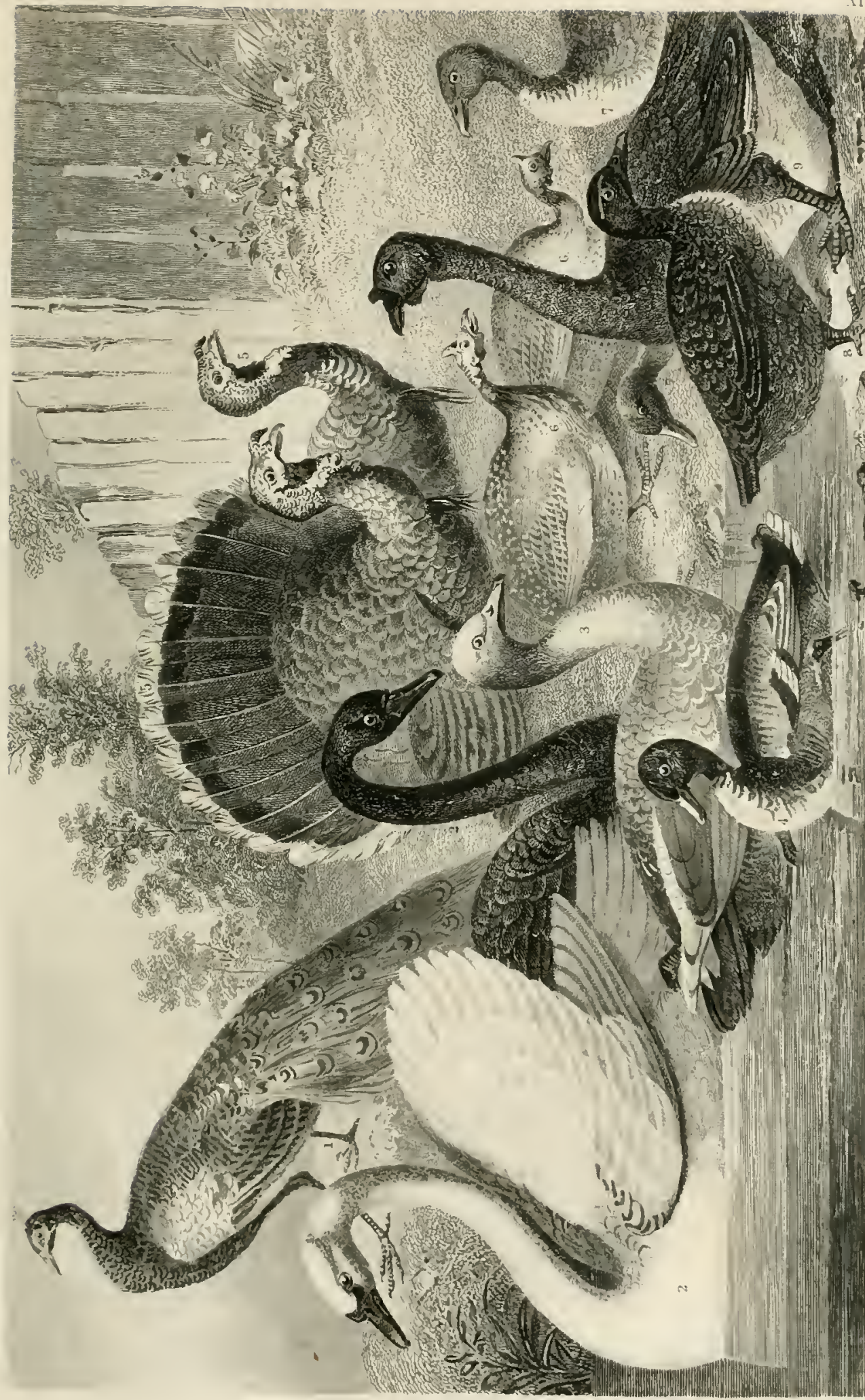





\section{PLATE XI.}

(Page 140.)

Here is another picture, more beantiful, if possible, than No. $\mathrm{X}$. It comprises some of the most ormamental, and some of the most substantially useful birds that help to adorn our landscape. Мany who read this book will have no opportunity to see the graceful swans that adorn the ponds in Central Park, New York. Let them study these life-pictures. The peacock is more common, yet many will get their first idea of its appearance from this picture. The Hong-Kong goose is also rare, and so are some of the ducks, and in many places the Guinea fowls are unknown. The turkey is common, still his likeness adds to the beanty of this scene. 


\section{.}


days after they are let ont of jail, the geese will malie nests and begin their work.

The eggs shonld be remored carefully every day, and deposited in entton in a dry, temperate room. Then when all yonr flock are ready to sit, which they will be abont the same day, hare capacions nests filled with elafiud straw, in which place twelve eggs for ench goose. Where a good many geese are liept, it will pay to have an attendant, who sliould be careful to allow only one sitter to leave the nest at one time. When one comes oft, slut the doors of the ofliel boxes till she returns. This will prevent confusion of getting on the wrong nests. By attention, nearly all the groslings of a large flock may be brought out in one day.

Goslings should be left in the nest twenty-four lionrs after they liatch, particularly if the weather is rongly; and as they are tender animals, they slionld be carefully nursed for a month, allowing them a small pool of water to bathe in, and plenty of green grass. The whole anser family belong to the graziers. It is not necessary to feed goslings on much grain.

The white China goose is as pure white as the Bremen, and should not be mistaken for that-the Bremen is preferable.

The Brent and Sandwich Island goose are both very small varicties, well suited to situations on the salt water.

The Berwick goose is said to be a great weed-eater.

The Camadian or wild goose variety are quite ornamental mpon a wellwatered location. This breed are greater worn and insect eaters than any other variety of the anser family. The hens do not lay until two years old in their domesticated state.

193. Swans.-This rariety of ornamental birds has been but little enltirated in this country. The greatest eollection is at the New Iork Central Park. This bird, of all others, puts the finishing stroke to the landscaje inclosing a still lake or pond.

There are white and black swans; both are magnificent, but the white ones are the most showy on the water, where they float by the hour as still as the water beneath them. Although domestic and tame, swans are apt in ro astray - to precent which the last joint of one wing is skillfully dissecte l. 'They are weed-feeders, but in places where they are generally kept they require feeding. Their feed is most abmulant in fonl, shallow water, and they are often seen abroat at night in pursuit of food. Besides regretables, they ("at minute insects foumd in the water, and probably fish-s])awn.

The hen birds are rery curious about their nests, and will select them, if possible, in some low binslyy islet or headland, and moler favorable circm. stances will hatel eiglit or niue young cyguek--the name which young swans are known ly. The male birds allow no intruders about the nests or young. I man would find a terrible antagonist it attacked ly a swan while swimming.

The cygnets, when fat, are esteened a great delicacy mpon the tahle. stuffed with the lean part of a round of heef, sensoned merely with carenue pepper and salt, and servel with rich gravy and currant jelly. 
194. The l'leasures of Poultry liaising,-Besides the profit of a well-eonducted poultry business, there is an actmal pleasure attending it orer that of keeping any other kind of domestic animals. Although the aim appears always to be profit, we think it those who ean keep poultry would look at it in another point of view, they would be better satisfied if it did not always pay. One adrocates having a lawn and a flower garden attached to his louse, saying that it will grive new life and beauty to all arome, and excrt a beantiful and enmobling inthence upon every member of the household, and even visitor's and passers-by will eateh from it a sweet syirit of lore and good-will; but the question with the calculating and caretul farmer is, Trill it pay? So with every improvement upon his house and around lis furm; if he does not see a prospeet ahead of a return in hard money for his ontlay of time and his work, the close-ealculating man sets it down as being a thing that wou't pay, and consequently abandons it entirely.

It is just so in regard to poultry. Nothing is kept for ornament; yet we have already shown that several rarieties are not only ornamental, but profitable. But setting all other considerations aside, we would keep poultry just for the pleasure attending the sight of the birds, particularly the dear little chicks. Quoting from a sensible writer upon this subject, we adopt his wolds :

"One of my neighbors says it will pay to keep just as many hens as will get their living around the barn through the winter; but he thinks it will not pay to keep them if they liave to be fed. I will own that I have a few motions in common with all poultry fanciers; I look somewhat to the profit, but make it a point of secondary importance. Farmers, in general, who keep hens, are more troubled with them than with any other one thing upon their furns, considering the amount of work which they do. They are always seratching in the garden, digging up corn, or committing other depredations which lieep the farmer and his girls rumning to keep them ont of mischief."

Of course they are, because they must serateh for a living. If you don't want hens in misehief, feed them; and at times when it is really necessary, slut them in a poultry-yard and feed them, and adopt this simple rule for feeding fowls, known to most housewives in the country who have charge of the poultry, but it may be useful to amateurs, and as it is very short, we print it. Here it is: Don't feed too mneh. That is all; though we may add that food should nerer be given to fowls unless they are liungry enouglı to "run erazy" after it; and just as soon as they stop running crazy, you stop throwing feed, and never-no, never-leave feed lying by your forls "for them to eat at leisure." This same rule does pretty well for all other" domestic animals-children included.

If you don't feed your hens, and let them run in the garden, and they scratch, don't swear. It is natural for them to serateh, and although they do mischief, they also do good. Then, don't set the dog upon them; it only makes matters worse. There is a enre for your trouble: build a yard in which to shut the hens when they are tronblesome in the garden, and train 
them so that they will follow you like a dog, and then just at night take them ont on a walk and see what an inmense number of lurtful insects they will destroy. Your hens are the most profitable stock you have if you treat them rightly. Don't swear at them; keep your temper and buill a poultry-yard, but don't keep it always closed. It is better for you, and the hens too, to let them lun at large at all times when they are not liable to do mischief.

We know of nothing around a country residence which gives the whole snch a lelightful and pleasant aspect as all kinds of ponltry. How Downing loved them when he wrote: "With proper convenienees for managing them, they are among the most agrecable, profitable, and useful objects in country life. To children especially, fowls are objects of exceeding interest, and form an almost necessary part of the means of dereloping the moral and industrial cnergies of a conntry honschold." Oh, who wonld be without them? What conntry resident wonlel neglect to have a noble collection of hens, dneks, and turkeys-with right modes to keep and manage them-to give a lively aspect to the secnery of lis lome, and impart beanty to the whole place? The merry eackle of the "old yellow hen" in the beantiful spring-time; the lore and kind protection manifested for her brood of young, and then to see them huddle together under her wing! The shrill sound of the cock as he proclaims the dawn of morning! Oh, who would not keep poultry, even if it didn't pay? We would not keep

Shanghacs.-These Chinese monstrosities, on the contrary, we recommend every one to get rid of as coon as possible. They have lad their day, and in spite of theit crowing, Barnnm's showing, and their owners' blowing, they are about blown ont. It begins to be fonnd out that 10 lbs. of meat can be produced upon two pairs of legs just as clieaply, and of much better quality, than upon one pair. No Shanghae, Cochin-China, Chittagong, or any other imported breed of fowls has erer been, or will ever be, more esteemed on all aceomint than the old $y^{*}$ ellow-legred Dominique, a domestic, handsome, and good-sized forrl.

A particular friend, candid and intelligent, said to us lately: "I liare tried almost all varieties of lacns, and liave settled upon the Black Spanish, or erosses of them upon the old stock, such as I can pick np in market at fifty cents a pail. I lave also tried the experiment of keeping hens in tha city and the cost of eggs. I keep them in a house at the back of the rard, letting then ont for exercise just betore roosting time, feeding them nn seraps from the kitchen, potatoes, meat, cte, and corn, and find my ergos cost just three cents a dozen on an average throngh the year."

Another one, alluding to the fact of feeling poultry mon dead horses at a wreat poultry establishment near P'aris, said : "The less liens I keep, I think the better fur me. I lave fed dear horses and all sorts of fool, but I can't make it profitable to myself, or neighliors either." Of course not. The last words tell the reason; lic lets them rm at large, half fed.

195. Ilen-Roosts and l'oultry Vermin.-The poles or ladders should be 
such that they can be whitewashed thoroughly erery June, and the whole hen-house should undergo the same operation. Poultry that are lonsy shonld have wood-ashes to wallow in, and a few liandfuls of flour of sulphur stirred in among them makes them much more eflicient. Good ashes will effect a curc, howerer. The fowls should have also dry earth or a dusty loal, for it will be found that they will usually alternate from one to the oiher. The best means for supplying line to hens is to crack np fresh oyster-shells with a hammer or a sleclge. Nests never should be made ol allower in the room where fowls roost. Kicep it clean of all trash, straw, ol nest-boxes. IIare them in anoflier apartment.

A poultry raiser asks ns to tell him how to gret rid of the great nnieance of lice mpon poultry. IIe says he feeds well, and gires the hens the range of a grass lot, and has nsed turpentine sprinkled in the nests, and applied blue vitriol mixed with grease to their bodies, and anointed them with lamp oil, and yet they are infested. The breed is that called Plack Spanish, but that, we think, las nothing to do with the diflieulty, which is so great that he is ready, if there is no remely, to sacrifice his liens and buy lis eggs and clickens. In a case like this, we should cudcavor to purify the roost of everything that could give shelter to an insect, and perlatps abanclon the old roost altogether, and take eare that the hens had a wallowjng-box, well supplied with dry wood-ashes, renewed by a little addition erery day or two, and feed sulphur occasionally in the food, and have a constant supply of lime for the hens, and kecp them firt; and if all these would not preserve them free of liee, we would abandon the business.

We have received sereral letters upon the important subject noticed under this head, giving "infallible" remedies to rid poultry of lice. The following looks as if it might be a "dead shot:"

"I have had the care of a poultry-yard for a number of years. Duriug that time a continual war of extermination was waged, and many expedients were resorted to, but nerer did anything, in a single instanee, prove a safeguard until tobaceo was tried. This weed, in my case, has nerer failed in auswering all practical purposes; and this fact goes far to show that it was intended to act ont higher and nobler ones than are commonly assigned to it. The fine-eut is the best kind, and in nsing it spread it thickly orer the surfiace of the nests, seatter it upon the floor, and suspend large leares about the different parts of the lousc. This, nsed in connection with your directions, will put the encmy to flight, and with it will disappear all the annoyances "our subseriber complains of."

Another letter says: "Sprinkle Scotch snuff plentifully on the fowls, so it will reach the slin, and I'll warmant that the vernin will be nore searee than eren money in these 'tight times.' As you say, 'the roost must be kept clean ;' also lime must be sprinkled on it to destroy the effect of the ammonia arising from their manure."

Another says: "All the remedies named are not equal to onions, chopped fine and mised with their food erery day for a week. This will exterminato 
them cntirely from the hens; and if the roosts and pen be washed with onion water, they will trouble your hens no inore."

Another writer says, hens that roost upon sassafras poles are nerer troubled with lice.

Now all these facts are worth linowing, as the vermin some years are mucommonly mumerous, and will eat more poultry than the people will, unless we can head then off with some of the remedies named.

196. Water your Door-Yard Fowis. - lill a bottle with watel and place it botton up tluough a hole in a boad, so that its nose shall be inserted into a sancer, or any shallow, open ressel. Is the fowls exhanst the water from the shallow vessel, the bottle will pay out new supplies.

197. Molle of Lilling Fowls, $-\Lambda$ firorite mode of killing fowls witl some persons is sticking an awl in the neck. They say that the blood adds tu the grood looks and value of all sorts of poultry.

198. Corn-Fed ceese-Valne of Corm-The following detail of an experiment in feeding con'n to geese, by linfus Brown, of Chelsen, Orange County, $V t$., is well worthy the attention of all firmers, and goes to prove that corn may be as profitably fed to poultry as pigrs. Mr. Brown writes:

"In answer to your question, "Does anybody know anything abont anything?' I answer, Ies. I kllow how much ten quarts of corn is worth. On the 2.2d of November I shut up a flock of goslings, which, alinwing the usual slurinkage for dressing, would not lave dressed orer six pounds per head, and wonld have heen called scalawags, and sold accordingly at six to seven cents per pound. Taking the maximum (seven cents), they would lare brought 42 cents each, dressed, at the time mentioned. They were put in a wam, well-littered stable, allowing three to four square feet of ron for cacl, and kept constantly furnisher with corn in the keruel and plenty of water ; this constituted their entire feed. They were thus lept till 1)ec. 9; they hal then consumed 10 quarts each; when, after allowing them one day of fasting. they were dressed aceording to the custom practiced from horhoul, and which I respectfully recommend to others, viz. : attel life laal hecone extinet they were carefully scalded by immersing heal first in boiling water, and allowed to reminin about one minute, and then taken ont lead first and allowed to drain, and then eorered in a thick woolen blanket and allowed to remain abont fire minutes; then carefully picked clean; then the intestines were drawn, their legs tien together and laid mon their balclss on boards in a conl place, with their necks turned muler amel latil celose together to keep the wings elose to their sides. They wore then considered choice, and solu readily to the dealer at $10 \frac{1}{2}$ eents jur lb.. and averared

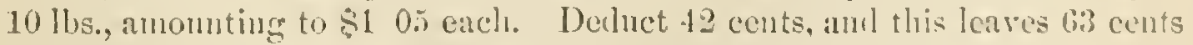
for the 10 quarts of corm, the market-price of which, at the time of feediug, was 75 cents a hushel.

199. I'rices of Poultry.-At the time of the great "poultry sliow" at Barnum's Museum, in 15.57, there was an atiction sale, and the following prices were realized, and although fancy birds brunght fincy juices npon the more 
common solt there was a dead loss upon the cost in England of about an arerage of 7 per cent. The following are decidedly among the funcies :

1 pail of white swans, $\$ 100 ; 1$ white female swan, $\$ 50 ; 1$ black female stran, $\$ 60 ; 1$ pail of black swans, $\$ 99 ; 1$ pair of Japanese peacocks, $\$ 100$; 1 pair of Barnacle greese, $\$ 10 ; 3$ hoop-bill dncks, $\$ 75 ; 1$ pair of golden pheasants, $\$ 18 ; 4$ pail of Engrisl pheasants, at $\$ 10$, $\$ 11$, and $\$ 15$ per pair ; : male golden pheasants, at $\$ 5, \$ 550$, and $\$ 1250$ cacli; 3 male silver pheasants, at $\$ 10, \$ 1050$, and $\$ 16$ cieh; 1 pair of Call ducks, $\$ 15 ; 1$ sheldrake duek, $\$ 10 ; 3$ spoon-bill ducks, $\$ 15 ; 1$ pair of piu-tail ducks, $\$ 19$; 1 pair of widgeon dueks, $\$ 12 ; 1$ pair of widgeon ducks, $\$ 7 ; 3$ widgeon ducks, $\$ 9$.

But the climax of fancy prices was reached in the sale of one pail of Mandarin ducks for $\$ 150$. This was a beantiful pair of rery rare bircls, and we hope will remain rare-that is, that no more will ever be imported at that priee. It was said that they cost 75 guineas in England. Mr. Barnum offered ş3 alranee upon the purehaser's bargain. They are about the size of our common rood duck, and of just about equal beauty. It is certainly somewhat extraordiuary that, with money "tight" with most people, any one can find loose eliange enongh to buy ducks at $\$ 150$ a pair.

The sales of Shanghaes, and birds in that line, went off at what the owner called "sickly prices:" The following indicate the prevailing rates:

1 pair of gray Dorkings, $\$ 10 ; 3$ gray Dorkings, $\$ 15$; 6 Sebright bantams, in two lots, $\$ 5$ each; 2 Sebright bantams, hens, $\$ 2$ each; 3 Golden bantams, $\$ 167$ eaeh; 3 English bantams, \$1 25 each ; 3 Enghish bantams, \$2 37 each; 4 Bramahpootras, 1 coek and 3 hens, $\$ 2$ 50 each; 1 Poland hen, $\$ 125 ; 1$ Bolton Gray hen, \$1 25; 1 pair of Golden IIamburghs, \$2 25; 1 pair of black Spanish fowls, $\$ 10 ; 1$ pair of black Spanish fowls, $\$ 550 ; 2$ black Shanghae hens, \$ิ3.

Turkeys. - 1 pair of beantiful white turkeys, $\$ 5$.

Geese. - 2 pair of barnacle geese, $\$ 12$ and $\$ 11 ; 2$ pair of Egyptian geese, $\$ 10$ and $\$ 16$.

200. Consumption of Poultry in New York-To give some idea of the quantity of poultry consumed in New York, we give the following extracts from an artiele published about Christmas, 1857 :

"On Dec. 23d the American Express Company had three car-loads to deliver from their dépôt in Duane Street, and about 11 tuns reeeired from Albany by the steaner: On Dee. 24th their reecipts are stated in ronnd number's at 40 tuns, making about 80 tuns reeeived in two days by only one transportation line.

"This Company's freiglit was nearly all from this State and Vermont, with a little from western Pennsylvania, and a very small portion from Olijo. A large quantity also cane from the rirel counties by steamers and barges on the IIndson, as the mildness of the winter lias enabled them to lieep rumning. Western New Tork also ent in great quantities by the Erie Railroad, while every New Jersey railroad and numerous wagons brought 
vast quantities from that State, and some from Pennsylvania. A great deal also came from Long Island, and considerable from Comnecticut.

"The Messrs. Beatty, who make a business of feeding joulty", had on sale at once by a commission-Jouse, two dings before Christmas, four tuns, all prepared upon their own premises, and some of the turkeys were as haudsome birds as we ever 8 a w, and sold for $\$ 3$ and $\$ 3,50$ each."

Mr. White, of Chautauqua County, another great poultry feeder and packer, lad as mueh more. It is really a blessing, both to producer and consumer, to have such men as those engaged in the business. The fumer jarticularly reaps a decided advantage, because such skillful poulterers ean and clo give them more for their birds than they wonld get if killed by themselves and scut to market in the rough condition that much of the poultry comes into this market. For instance, we noticed, while one commission-house was selling well-prepared geese at 13 cents, a lot of geese, side by side of these, were offered and refinsed at $6 \frac{1}{2}$ cents, the fuult being that they were not well fatted, and were picked dry and roughly packed.

Another lot of well-fatted ponltry, well packel, and received in good condition from Vermont, the owner was fully convineed would have netted him from one to two cents a jound more if he had followed the direetions griven in No. 201, for killing and preparing poultry for market.

Tielative to the eflect of the weather upon the business of fatting poultry and some other ficts, we are indebted to the Messrs. Beatty fur the followirrer. They say :

"Owing to the lateness of the season, furkeys did not grow sufficiently to fat well for the eary market. It is unprofitable to feed these birds to futten them until they get their growth; and in such wam weather as we have had this season they do not fatten well, being inelined to wander. To fitt turkeys well and cheaply we must have cold reather. It is owing to this, and having to feed a longer time, that we liave not been as suecessful as last year; and it was so warm when our Cluristmas lot was dressed, eonsisting of four tuns, that with all our appliances it required not only experienced skill, but great care to preserve the whole in grood orier till realy for shipment. The fumlt with that lot [allurling to one then unpacking] is, that the birds were packed before all the animal heat was out of them. This must be carefully gruarelel against in such weather as we have had this season.

"It has been very difienlt for furmers to raise turkeys the past summer on account of cold and wet, so that the stock in the country is probably not more than halt as large as it was last year, and that is the only reason that the price, notwithstanding the money pressure, has kept "p so well. We lave fed this year 1,000 turkeys in one lot together, having liad in all 1,300, and between 200 and 300 geese, with other joultry in proportion. We use, and recommend to others, to feed good, somnl Indian corm, and with it a liberal supply of charcoal, which we consider indispensahle. It promotes health and improres the quality of the flesh."

Will all poultry-raisers renember this important finet, which alone is 
worth more to them than all we shall ever receire for preparing this volnme of valuable information?

201. Preparing Poultry for Market.-Te hare repeatedly published directions for preparing poultry for market, and we can not make a moro valuable finish to this section upon poultry than by griving in brief such directions as all must rigilly follow, who send such farm produce to the great mirket of New Tork. The professional poultry feeders and packers need no instructions, but many fimmers do. Many of them liave already saved a liandsome per-centage on the value of their poultry by giving it a proper preparation, and other's may.

As a prelininary dule, and malie it unalterable, nerer kill a bird unless it is fat. Never cut off the head of a turkey or goose, but liang them by the lieels where they can not bruise themselres in the death-struggle, and stick them with a small knife and bleed them to death. Duckis and common fowls, if deeapitated, should be held or tied and hmug np to bleed to death. Nerer kill Jour birls until quite fit; you will lose in priec, in reputation, and in weigrlit. Nerer strungle them, so as to leave tlie blood in. The best plan is to tie all linds of birds to a line drawn from post to post or tree to tree, and stick them just in the formard end of the neek, either with a broadbladed awl or a penknife. It is undoubtedly the best mode of killing. If the head is cut off, the skin recedes, and the neck-bone looks repulsive. 'To obtain the best prices, the birds must look good as well as be good.

There is an cxecption, however, to the abore recommendation about sticking, for somo tlealer's puefer the birds with heads on, and some do not. In some towns it is always customary to ent off all the heads. When this is to be done, draw the skin back from the head as fir as possible, so that when you cut off the head, which shonld be done close to it, there will be some loose skin to draw orer the end of the neck-bone, where it should be tied close. Te doubt whether it is not worth while to pay freight mpon heads. It is wortli while to pay freight on the intestines, because the meat ean not be kept sweet long after they are drawn and the air admitted inside of the body. Therefore, never draw a bird.

It is a practice of some of the best poultrymen, while the birds are blectjug, to hold them firmly by one hand, and pluck the feathers with the other, is they come out easily while the fowls are warm. This treatment is only for turkeys and common fowls. They are then ready for scalding. Talie hold of the legs, and plunge the body in quick succession, two or tluree times, in boiling water. This sluonli be done in a wam room, and the birds lumg upon a line to pick clem, taking care not to tear the skin. Gecse and dueks are plunged two or three times in hoiling water, drawing them out by the head, and then wrapped in a roolen blanket to stean ten minutes. Tike them on your lap to pirck. Do not scald the legs, nor licat the boulies of birds against the sides of the liettle. Iftel the birds are neatly piclied, they are put through the plumping process. This gires them a finish, and increases their value in maktet. 
The rnle for "plumping" is to dip the birds abont two sceonds into water" nearly or quite boiling hot, and then at ouce into eold water about the same length of time. Some think the hot plunge sufficient without the cald. The neatest poultry-dressers nse both the lot and cold plunge. The ponltiy should be entirely cold, but not frozen before being packed. It poultry reaches market sound, withont freezing, it will sell all the better.

After plumping, hang or lay the birds where they will dry, and then remove them to the conling-100m, laying the bodies nicely arranged mpon clean bonds in a cold room till pertectly cool, but not finzen, and then jack in hoxes, with clcan rye straw, about 800 or 400 lbs. in a box, filled full; mark the contents on a paper inside, and on the lid ontside, and direct it to your commission-merehant plainly, and send it by expless, and one invoice by mail, and place anotler in one of the boxes, if there is more than me, and mark on that, invoice, and then it will be opened first, and the nnerehant knows whenee it comes, and what the consignment consists of. It is also a good plan to mark the contents of each box autsicle, thus: In box

Wo.1-12 turkeys, 144 lus. ; 20 geese, 160 lbs.; 50 s muing clickens, 125 los. To. 2-100 fowls, $3001 \mathrm{ls}$; ; 24 ducks, $96 \mathrm{lbs}$.

This lot will pack in two square dry-goods boxes. If elean liand-threshed rye straw ean not be had, wheat or oat straw will answer, if clean and free from dust. Place a layer of straw at the bottom of the box, then alternate layers of poultry and straw-tiking care to stow snugly, backs upwarl, filling racancies with straw, and filling the package so that the cover will dhaw down sungly upon the contents. Conmon dry-groods boxes, hokling not over 300 lbs., are the best packages.

Nerer kill your birds on a damp day, nor pack them, if you ean aroil it, execpt in a clear, cold, dry atmosphere; and try to avoid niglitwork, when yon are tired and your help slecpy, and all of you carelcss.

No matter how light your boxes are, they must look clem, or your poultry will not sell at first prices. In packing, press the wings close, and press the bira down liard on the breast, the legrs extending back, and fill each course full, and then lay on straw and another course of birds. Nail tigldi, but don't let a nail project inwarl to tear the birds.

Give your name and residence in full on the bill in the hox and on the invoice by mail. Don't think because you know in wlat State you live, that everybody else will know it if you mane the town.

Nerer pack in barrels if you can gret good dry-groods boxes, as the rolling of barrels injures the ponltry, where it is likely to he much liandled, mulese rery elosely packed. Pesiles, it does not pack to as good aclvantage to tle shape of the lirds as it does in boxes. Suall lots may be packed in "sloce or hat boxes," lunt they must be carefully honperl, and so slould he all boxes. Don't usc a rough, liack hoard for a cover; you lial hetter spend an lum to plane it. Don't aeknowlodere, by senuling unplaner linards, that rout don't own a plane. It is barl conomy to use heary packarges, or have any waste room, becanse freight is charged by the pound, and for long distances 
the express cliarges inay amount to four or five cents a pound, and all the weinht of the box counts equally with the contents.

It is a practice with some-and a very foolish practice it is-to stuff fowls just before they are killed, thinking to sell corn at the price of meat. Better give no food for twenty-four hours previous to killing. Food in the crop is liable to sour, ankl always injures the sale, for it looks to purchasers as thongh there was a lesign to eheat.

You may pick turkeys and fowls dry if you will not tear the skin, and then scald them atterward by dipping them suddenly in and ont of boiling water. Geese and ditclis must always be scalded. Do not scald the legs too much, whether you piek first or afterward. Be careful of that. Fon must pick them clean, and the after-scalding makes them look plump and good. Well-packed boxes of well-prepared lirds will keep sweet a long time in cool weatler, and may be transported by express from Ohio for three cents a pound; from Chicago and most of Illinois for five cents; from Iowa for six or six and a lalf cents, and arriving in good order, will lye sold at good prices, and your money remitted to you, less 10 per cent. Now, following these directions, and getting these prices, if it is better for you Ohio, Indiana, Illinois, Iowa, Wisconsin, and Michigan farmers to send your poultry Eastward fol sale, yon know how to do it; and if it opens to you a new and improved malliet, it will be worth more to you than the whole cost of this rolume upon erery box of poultry sold. In fact, these directions, giren in part heretofore to the jublic, have been the means of saring great sums of money to the poultry producers.

After boxes are packed, if there is any chance of not getting them immediately into market, or if a change in prices makes it desirable to hold back, it will be a grood plan to place them where the contents will freeze solid; then they will stand a long spell of warm weather, such as makes badlypacked poultry slimy. If you conld be sure of cold weather, so that the birds wonld remain frozen, rery little straw wonld be requisite in packing; but as a general thing, a liberal allowance of straw will more than pay its cost of trunsportation in keeping the linds in good order.

When packages are frozen before slipment, it will be well to adrise consignees of the fitet, as we liave known a thaw to come on gradually, until rery wann, and have then seen packages opened in perfect order that were frozen up two or three months before. In fact, we knew one such that got mislaid and corered with empty boxes in a cellar, that kept sweet till it was accillentally discoverecl in May.

Water for sculling any lind of ponltry slionld be as near to the boiling point as possible, without actually boiling; the bird being held by the legs, should be immersed and lifted np and down in the water three times; the motion lielps the liot water to penetrate the plumage and take proper effect upon the skin. Continue to hold the bird by the legs with one hand while plucking the feathers with the other without a moment's delay after taking it ont; if skillfully handled in this way, the feathers and pin-feathers may ali 
be remored without breaking the skin. A torn or bruken skin greatly injures the appenrunee, and the price will be low in proportion.

Do not send the birds with tail and wing feathers in, unless it may lue oceasionally in a very handsome turlicy.

Geese always sell best the week before Christmas, and they shonld always be stall-fed. Christmas priees are usually for well-fed gecse, such as will warrant their inereased production, since it is contended by persons wluse opinion is entitled to great respect, that with proper care and skill, upon i farm well fitted for the business, a tun of gecse can be male at the same cost as a tun of beef, leaving the feathers as an excess of protit.

Now let all who read, remember that eommon-sense attention to these rulcs, in regard to preparing poultry, will often insure 25 per ecnt. ligher prices than poultry of the same value originally will bring, if slovenly dressed and packed, and carelessly directed and stupidly forwarled, as often lappens. To bring the highest market-prices, poultry must be good and well liandled.

202. Preparing Game for Harket.-Wild tukeys, will ducks, and the smaller birds should be packed in the natural state. In cold weatler they may be packed sungly, backs up, with or without clean straw, taling care to keep the plumagre as smooth as possible. If the weather becomes wan during the transit, straw between the layers acts beneficially as an absurbent of moisture. Birds should never be drawn, and if mutilated ly gun-shot, the market ralue will be much redneed.

Woodcock, quails, and other small birds are in eool weather sometimes each wrapped in paper, and packed in lry sawdust. In hot weather they may be packed without the paper in coarse sawdinst and jec. They seldom arrive in good order if more than twenty-four hours on the way in liot weather.

In renison it is best to send only the hind part of the careass, incluling, say, two or three ribs with the saildle. The skin should be stripped frum the fore part and carefully wapped about the saddle, thus liceping it clean and in good orier.

By the "gane laws" of the State of New Tork, the lilling of any will deer, partridge, quail, wnolcoek, ol sujpe during the montls of Feluming, Mareh, April, May, June, and July is prolibited under penalty of s.2 for each offense.

Common earriers no their agents may, in the discharge of their legitimate business, transport decr or gane during the inlibited period withont vinlation of the law; and commission merehants and dealers are protected it they ean slow, to the satisfinetion of the court, that the game in question eame from any other State, or forcign comntry or that it was not liblled dnring the inlibited period.

The taking of speckled or brook trout is prohibited between the lithlu day of Septembel and the 15 th day of Felumary, muler the sume penalties and provisions as in the ease of game; but the Cayugra, Seneea, Cruoked, and Otsego lalies are excepted fiom this prohibition. 
203. liggs-How to l'roduce them in Winter.-Pork seraps ol greares, fed in molerate quantity, are found to hare a marvelous effect in the produetion of wintel eugrs. Give liens also sand, and gravel, and lime, and see that they have water. Egresliells slıould nerer be fel whole, lut they may be inaslied np fine and nixixed with feed to good adrantage. Some liens :lle much more productire of eggs than others. Eighty liens, belouging to Capt. Tlons. A. Norton, of Iarmonth, Mass., have laid during one year 6.37 clozen egrs. At the arelage price of egrse, that would be about $\$ 125$ for each lien.

20t. Ilow to letecl the Sex in Domestic Fowls' Ergs, _ I person who lias paid attention to the subject declares that he ean tell the sex of egres in the tollowing manner. Ile says:

"I begrun examining egrgs, classing them according to the difference I found in the formation of each, marling each class, and putting them under liens as soon as opportunity offered; when, in less than twelve months, I was fully convinced that I larl discorered either a methou or the method of furetelling the sex in the egg, which was proved by ocular demonstration in the chickens prodneed.

" At the large end of the egrg there is a cirenlar space or eavity containing air, which country folls call the 'crown' of the egre; its proper name I know not. When you examine the exg, hold it, the large end uppermost, before a canclle or gaslight, and in looking through it you will observe a dark circular nark, something similar to the moon when partially eclipsed. This dark circular mark is the space filled with ail or 'the erown' of the ergo, and when in the center it inclicates that the egg will produce a male.

" My methorl of examining the egro is as follows: I malie nse of the thumb and forefinger of my left hand as tro points, placing the small end of the egro on my thumb, my forefinger covering the large end of it, and as near the center of the end as posible. I then place the ecgo in this position stearlily lefore a candle and gently turn it around; if the crom be in the center it will be scarecly visible, the forefinger nearly covering it. On the contrary, if the erown be on the side you will only see it on one side of the erger as you tum it around." There is a little contrivance, ealled the ooniscope, to detect bad egrss. The egrs is placei in a lole of a box, and the light reflects on a mirror inside and tells uneringly the true condition of the egg. A little practice enables any one to discorer whether eggs are fresh or not.

205. Vitality of Egrs Affeted by Transportation.-It has been stated upou good authority that railroad transportation iujures the ritality of eggs. That pack them as you will, if they are carried any considerable distance, say 100 iniles, the continued slaking will shake the life ont of them. Traveling on the Harlem Road one day, re met an acquaintance earefully caryoing a emall basket in his hands. We remarked that he handled his basket as carefully as though he was carrying eggrs. "Ind so I am," he replied; "I am taking them about a hundred miles to a friend, and will insure every one to 
hatch ont a chicken, so fir as transportation may affect them. But I learned this by experience. I had a lot sent up the road only twenty-fire miles, in the ordinary way, and did not get one chicken to fifty engs, while out of another lot, carried in my hands in this way, not one missed." Tre said : " $\Lambda$ s a general rule, it may be set down for fict, that egres that hare beed iransported by railroad will never bring forth chickens." This is important information, and should be well remembered. So, too, let it be remembered that egros intended for inenbation can not be too carefully handled in tuking them from the nests and kecping them about the house till the hem is realy to take them in eharge.

206. Seling Eiggs by Weight.-W We have frequently recommended that egress should always be sold by weight, instead of by count. We recommended it becanse we thought it more fair both for prodncer and consumer ; but really, with the present system of trade, we do not see much to encourage the change, and nothing to cneourage the production of eggs of a large size while small ones sell at the same price as the largest, pel dozen or hundred, and consumers are guilty of the great folly of making no distinction. Dothey erer think of the diflerence in weight? Do they know how many eggs there should be to the pronnd? The largest-sized eggs of the common barn-door fow l weigh three onnees each, but the arerage is about ten to the pound. We inquired once of a retail groceryman, "IIave yon any fresh eggs?" "Ies; there is a lot of tine ones, just in, all of this State, in roorl order." "At what price?" "Twelve cents a dozen." "May I pick them ont at that?" "Oh, yes, certainly ; they are all alike, good." Of this we hat no doubt as to the good; but that they were otherwise alike, we intended to prove that he was mistaken. So we picked ont a dozen and lail them in the seales, with a $1 \frac{1}{2}$ lb. weight opposite, thinking they were just the size that takes eight to the pound, for that is just what grood, fair-sized hen's-egers always will arerage. 'These were a little heavier, and we alded two more, and bulaneed two pounds-seren ergss to the pouncl. 'Then we picked ont of the same cask thirteen more, and these weighed just one pomel, not quite 100 per cent. difference whether you buy large or small ears. Now, if farmers and tools meet, is it right that the one should take alvantare of the other in this way? or is it right that one man should keep a lruod of small hens, the keeping of which costs less than half that of lanereres, and get the same price tine the eggs? If honesty is the best policy in all of our dealings, then it is the best policy to sell eggrs ly the ponml, and nut hy the dozen.

207. To Preserve Eggs.-We can not vonch for the following. It it is as stated, it is much more simple and conrenient than packing in line, salt, ete. "Trovide a small cupboard, safe, or tier of shelres; bore these shelres frul of loles one and a quarter incles in diancter, and plaxe the egres in them, point downwarl. 'They will keep somul fur sereral months. Other modes, such as packing in salt, etc., tepent for their suceess simply on placing the points lown; the shelres aro more convenient and acessilile."

20S. Lggs Consumed in Eugland.-In the statistics of Britisl commerce, 
the home production is put lown at 75,000 tums anmally, whieh aro valued nt $\$ 15,004,000$. 'The importution of egres for eight years, ending with $18 \pm$;, ranged from $96,000,000$ in 1540 , to $77,500,000$ in $15 \pm 7$, and the importations of the succeding years are given in the following table:

\begin{tabular}{|c|c|c|}
\hline $\begin{array}{l}1818 . \\
184 ! \\
1850 \\
184\end{array}$ & 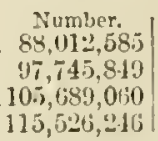 & 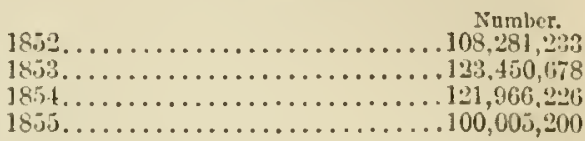 \\
\hline
\end{tabular}

The first six montlus of $1556,65,062,600$. This was nearly $14,000,000$ in exeess of the number received in the first six montlis of 1555 , but not so large as in 1S5t. The imports of eggs in $155 \pm$ were, from

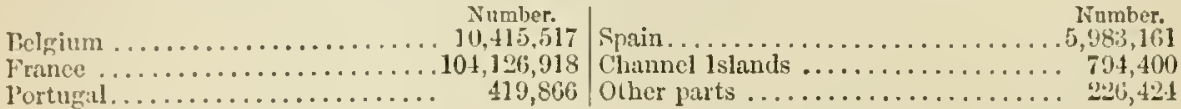

${ }^{\top} p$ to the Stll of August, 1S5t, eggs were entered ly number, but sinee that they have been entered by cubie feet, internal measurement. In order to reduce the whole to a uniform standard, 200 eggs are estimated to be packed in one cubic foot. The duty eharged is Sd. per eubie foot of eggs from foreign conntries, and half that duty from British possessions. In the metropolis the egg trade is a very important branch of commerce, giving employment to sixty egg mercliants and salesmen on a large seale, exclusive of the nmmber of shopkeepers who sell eggs. These salesmen distribute the boxes of eggs orer the rarious consuming localitios in light earts.

The prineipal importation is from France and Belgium. Quantities of Portugnese eggr are oecasionally imported into England by the Peninsular Mrail steaners. The egos of the Spanish fowls being rery large, are much esteemed, and ralued at $1 d$. to $1 \frac{1}{2} d$. cach. Spain imports a certain quantity from the French province of Oran, in Algeria. The eggs of the Bedouin fowls are sold in the European marliets at 5i. to $6 \mathrm{~d}$. the dozen.

The supplies of eggs sent fiom Ireland to Liverpool, and thence into the manufacturing districts, are enomous, frequently execeling $1,000,000$ a day. They are packed with straw in erates, boxes, or hampers. The erates contain frum 6,000 to $5,000 \mathrm{cgrss}$, the boxes abont 2,500. Sometimes large boxes eontain 13,000 or more egres.

In 1852, 9,260 tuns of lrish eggs were imported into Lirerpool, and it is estimated that that is not more than one fiftl of the product of that island.

209. liggs iil France.-M. Legrand, a liveneh statistical writer, estimated the consumption of eggs in 1535 in Paris at 135 per head of all the inhab. itants, and in the provinces at double that ratio. "The consumption of ergs for the whole kinglom," he obserres, "is estimated at 7,231,160,000 ; add to this number those exported and those neecsary for reproduction, and it will result that $7,380,925,000$ were laid in France during the year 1535."

Since tlat time the production lias largely inereased. M. Armand IIns. son, in his interesting book on the "Consommation" of Paris, just pul. 
lisherl, retmons the number of eggs consmmed in the Freuch metropolis at $175,000,000$, or 175 to each head of the population, worth about $\$ 135$. The value of the eggrs consumed in Paris one year wonld be also abont $\$ 300,000$; Jut probably thee quarters of a million sterling wonld be at nearer estimate of the poultry and ergos consmned annually in P'aris.

The consumption and prices nay be judgul of trom the following figures:

Number. Av.proper 1,000. $1847 \ldots \ldots 120,940,724 \ldots \ldots 57$ francs.

$1818 \ldots \ldots \ldots . \ldots 6,747,222 \ldots \ldots 48$ r. 40 centimes.

$1819 \ldots \ldots \ldots 113,587,732 \ldots \ldots 46 \mathrm{f}, 70$ centiues.

$1850 \ldots \ldots \ldots 1: 4,597,150 \ldots \ldots 43 \mathrm{f} .93$ centimes.

A number of Galignani's Messenger says that, in 1515, the number of egrs exported from France was $1,700,000$; in 1816 it rose to $5,000,000$. Six rear's later, in 1522 , the number was $55,000,000$; and $99,500,000$ in 1521. In 1830 the number declined to $55,000,000$; then gradually inereased until 1S15, when it was $\$ 5,200,000$, for which an export duty of 114,000 fraucs was paid. Nearly all these egogs go to Eughant. The yearly consumption of eggs in Paris is estimated at $165,000,000$, and the total consumption of all France at $9,000,000,000$; so that, reckoning eggs at a sou, this singlo article represents $465,000,000$ francs.

210. The Egg Trade in this Country.-Steamboats and railways liare done much to inerease and inprove the trade in poultry and corgs, in butter and milk, as well as in careass meat and fish of all kinds, for the supply of lange cities and dense populations in Europe and America, situate far from the clice seats of production or fishing. The poultry dealers of New Tork made their appenrance on the shores of the great American lakes within a few days after the regular trains were in motion on the Erie Railroal. Poultry and egges were swept aw:ly ly them at an alvanee of 25 to 30 pere cent. on their ordinary ralne, and a decided stimulus lias been given to the production of poultry and erge.

The Pritish American provinces are now supplying the Uuited States towns with eggs, which are imported duty fiee under the Reciprucity" Treaty. 1,260 dozen ergs from Nora Scotia were entered rery recently at the Custom-liouse, Boston, in one day. In the season of $185 \%$, atont $S, 0$ ro barrels of uggs, containing $S t$ dozen per barrel, were shipped from the port of Montreal to the United States, and sold at about lice. the dozen.

One merelnant in Manion Comnty, Olnio, has shipped in one season 12t,950 dozen of eggs, in 1, 755 barrels, costing, at 7 cents a dozen, s\$, it6 50.

211. Packing Eggs for Market.-There is jubably in no one article of the sane relative valne so much depreciation and loss from injudicions manarement and unskillful packing as in eggs. This is best illustrated in tho Westem trade, especially during the wam season, when the reverelye price of Westem eggs rules, say, three to five eents per dozen hulow those from this State; but at the same time we liave some Western marks that bring nearly or quite as much as the lest State, slowing conclusively that it is cutirely practicable to forward them in prime ordur from the fim West. If the fol- 
lowing directions are intelligently carried out, there will be very little doubt of snccess.

The sure (especially in the summer season) that your egrgs are not only somul, but recently laid. Eogs may be "endled" or examined by the "oöniscope," and repacked at the West; lut if they are stale, though stil] apparently somel, they will be sure to jeach this market in bad order, or will so rapidly change, on being opened, that dealers will be sure to lose money on thein. The motion of the ears orer such long distances so muddles all errse, not entirely fresli, that they appear cluudy and stale, and will soon spoil, it indeed they are not already musalable.

T'se rery strong, stifl barrels, put a little soft straw or lay evenly orel the bottom with a stifi paper on the top of the straw, then oats or ent straw, say, two to three inches, then a layer of egrgs, lail snugly together upon the sides, evenly imbedded in the oats, with the ends towarl but about one inch from the stares. Cover the layer with oats and shake down grently but thoroughly, leaving, say, one inch of oats upon the layer of eggs; thus continue Eliaking down thoronglily with each layer until the barel is fill. Place about thee inches of oats orer the last layer, then a stiff paper and a little soft hay or straw next the head, filling so high that the liead must be presacel to its place by a lever or other mechanical power, that the contents may be held so firmly that they can never shift or loosen in the barrels. In the winter, to guard against firost, use more packing, leaving the egros farthel from the siles of the barrels. Use clean, bright oats; they are salable at all seasons, though of late merchants seem to prefer ent straw. Mark plainly the number of dozen and the quantity of oats in cach barel. Be very particular to have the count right. 1 good reputation for aceuracy is rery villualle.

One person says: "I use a board some six or eight inclies square, with a loop 010 staple in the center for pressiug each layer of aats firmly down. There will be something gained by lifting and dropping the barrel square on the end, but not by shaking, as it disturbs the layers. When it gets too lieary to lift, use a board three fourths as large as the hend, and get on it, increasing your weight with a spring, and on the lead driving it in. The secret lies all in packing the oats. Oats are better worth sending to market than hay, and jinst as sufe. J hare sent ten barrels at a time without losing a singrle egre. You must pack tight. Remember that." 


\section{CHAPTER II.}

\section{SMALL ANIMALS AND INSECTS.}

\section{SECTION X.-BEES, AND THE PROFITABLE PRODUCTION OF IONEY.}

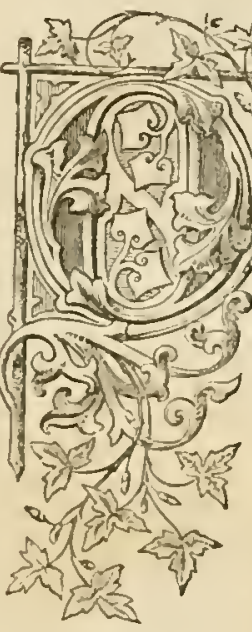

SOS UR opening clapter was deroted to a general surrey of farm-stock. 'This will be deroted to obseryations upon bees, birds, bncs, insects, and worms: dogs, cats, rablits, rats, mice, moles; cumcls as hensts of burden; gonts of Cashmere, their valne as firmstock; fish-breeding, for domcstic use or market; animals yielding fur, and alpaeas, and other small stock of the farm.

In the leading article of this eliapter we shall notice what may rery apropropriately be ranled as profitable stock upon a farm, for the product of the hire often affords a considcrable income, and it is nearly all clear profit. Birds, although they do not produce a direct incone, are among the greatest helps to that end, for they are great destroyers of those pests, the bugs, insects, and worms, which we shall also introdnce into this chapter. Dogs, as an adjunct of the farm, and when only liept in very limited numbers, alle not, perhaps, muprofitalhle stock; but as they at present exist, they are pests of the very worst kinds. Cats are a necessity, for without them we shonld be over-run with rats and nice, and so we give each a small space in this chapter. Rabhits, ton, though small, must have an place; and canels, though large cnough to fill a chapter, like the rabbit, must be contented with a paragraph. And the Caslmere goat, the only one of any value to farmers, is as yet so little diffusen anong them, that we can only aflord space to gire it a passing notice; and the alpaca, an equally important domestic animal, we mnst treat in the same short-liand way.

Fish-breeding is of rast importance to every finmer who has the faccility for making a fish-pond, and therefore we have added it to this sceond chapter of animals, domestic or wild, upon the firm. And funally, we ald fur animals, merely to call the attention of those who own suitable locations, to the fact that it is possible that such animals may be bred fur their skins, to say nothing of the value of their flesh.

So much by way of introduction. Now let us take up our suljects, item by item, each under its appropriate hend.

212. Bees.-Uistory of their Introduction.-It is not quite certain whether the honey-bee is indigenons to America or not. Onr opinion is that it is, 
[Cnap. II.

becanse several rarieties now exist upon the continent, and certainly those in Central Anerica apjear to be natives, so fir as it is possible to trace their history. It is possible that the carly immigrants, not finding bees in the districts first occupied by them, either in New England or Virginia, diel import them, though this supposition appears doubtful when wo considen the lengtlo of voyages in that age of ocean navigation. And it is still further against the theory of importation, to know that as early as 1645 -forty years only after Captain Joln Smith's adrent-George Pelton, of Virginia, was in possession of a grood stock of loney-bees; and they rere noticed by Bererly as a common thing among the Virginia planters previous to 1720 .

In 1755 , beeswax was an article of export from Sarannal, Georgia. It is impossible to state the quantity, because it is combined with myrtle-berry wax, and both are set down at 969 lbs. Five years later the quantity of both is given at 3,910 lbs., and in 1770 at $4,05 \mathrm{~s}$ lbs.

In 1767 , the export tables show 35 barrels of beeswas, sent from the port of Philadelphia; and only four years later the quantity is given as $29,261 \mathrm{lb}$.

The listory of Cuba credits Florida with bees imported from there in 1 t 64.

The alore facts prove that if there were no honey-bees in this part of the ccntinent when onr forefathers came to it, their importations were rery suecesstul, and the original stock was widely disseminated, and multiplied with great rapidity, for the census of 1850 gives the annul product of loney and wrx at $14,553,790$ lbs; and that at a time when the bee-moth epidemic had greatly lessened the stock in the country, and consequently the production was not as great as it had bcen.

It is a fact, too, that the immigrants of the Northwestern Territory found wild bees scattered all through the forests of what is now Olio, Indiana, and Illinois.

As an offset to this, it is a fact that the first American settlers of California found no honey-bees in that State, notwithstanding the fact of its early oecrpancy by the Spanish; and the first bees erer scen in that State have been carried there from Ner Fork, by sca, since 1550, and already the stock of bees has multiplied to an extent which would populate the State to as great or greater extent than the Atlantic States have been with both wild and domestic stocks, in a far less time than has clapsed since the landing at Jamestown or Plymontl. rock, of those who may liave introduced the bee from Europe.

Bec-culture in California has aheady assmmed such an importance that associations of apiarists lave been formed there, and the exhibition of bees is quite a feature at the State fair. Becs have become so numerous in the neighborhood of Saeramento, that tliey liave been cliarged with extensive depredations upon the vincyards, by sucking the sweets out of the ripe grapes. Mrr. Inarbison, a large bee-kecper, who went from Pennsylvania with a large shipment of them, two or three years ago, liowerer, denies the charge of bees injuring the fruit, and asserts that he has prored by actual experiment tliat they will only attack the grapes after the skin lias burst by the pressure of the interior growth. Still, there are many persons who are 
deeply interested in grape-growing in that State, who think this business and bee-keeping never can flourish together. It is a matter that will probably be investigated, sinee it involves two so great interests, particularly in California, where both branches flomish in so remarkable a degree of healthiness. Certainly, in no part of the United States has bee-keeping given such a promise of suecess.

Bees, although they appear to thrive best, or at least with but little eare, in warm latitudes, are not confined to those recrions. An article now betore us gives an aeeount of the successful introduction of bees into Aroostook County, Mane, where the thermometer sometimes fieezes, and alterwarl the discovery of a wild swarm in a hollow tree, which was remored to a hive and wintered in a dark, dry cellat, where they consumed very little loney. 'This is a very good way to winter bees in all cold regrions; for one of the greatest difficulties attending bee-culture in the most northern localities where they are found, is winter killing, not by freezing up in the live, though that sometimes oceurs, but by the bees being aroused from their tolpid state by a few sunny days, till they come ont of the live and are overcome by cold before they can letum again, and thus perish. We lave sometimes lost great quantities in this way, no further north than lat. $11^{\circ}$.

Notwitlistanding bees appear to possess a considerable degree of reason, and the power of ratiocination (a power that many men do not possess), they are, like inen and women, very apt to be canght by outside appearances, and venture forth from their wam homes upon sunny wings, to meet the clitling blast of the ontside rould, and perish.

Certainly, many acts of the loney-bee seem to be resnlts of a reasoning faculty ; or is it that undefined something that mankind call instinct? It is indeed wonderful that so tiny an insect should possess a faculy scarcely possessed ly man, of construeting its domicile, or rather store-lonse, so as not to waste an iota of material or space; for that is a fact, in relation to the honey-lsee's comb. And all their interior honsehold arrangenents, the order of their work, family rovernment, and perfect order and harmony, are Encle as should make mankind blush at their own inetheiency. Many of them slonld blush to think such an insect is so mueh more industrions and fingal than themselves, and so much more careful to lay uj winter stores.

One of the marks of reason, judgment, or instinet in the bee is manifistel in their never leaving the live, although ready to swarm, in a stormy dity, nor when a storm or very ligh wind is approaching, which would be liliely" to blow away ono portion of the swam from the other.

When the swarm does come forth it seems to be all by a given signal, and the movement is sudden aud simmltanens, gnided by the call of their quecu. If by any accident or mistalie the queen rets sepanated, or tirils to cluster with the swam, it is ille to try to hive them. They will not take a new abode without a queen. Is it reason that teaches them that they must retum to the old hive, where they can mako a new queen out of the goums larve in the cells of the old brooul-cumb? 
213. Bee-llives. - The best hive is one with movable smpports for each sliect of comb. Althongh hives of this kind may have been patented, the patent is not good for anylling, nor should it bar any one from the use of such a hire, becanse the invention is not new. Beran, an English writer upon bees, described such at hive many years ago, as in use by hin, and recommended it to others. More than twenty years ago, I deseribed a hive fol movable frames to sustain the separate slieets of comb, in the Albany Cultivutor, and althongh the plan might lave been patentable, it was dis. tinctly stated that it was not, nor would be patented, and any one who liked it was recommended to use $i$. The form of the hive there recomuended was to liang the frames by look-and-eye hinges to the back of the hive, so that all would swing like the leaves of a book standing on its end. The front, or cover to the edge of the leaves, being opened, by turning it around to the left hand, leaf after leaf conld be swung aronnd to the right, and a sheet of comb eut ont of any one, or the firme conld be lifted of its hinges and taken away, and a new one put in its place. We thought the plan a more convenient one than lifting the frames out at the top of the hive.

There is an objection to all movable frame hires, that they furnish harboring-places for moths. They also, on the other liand, afford facilities for searching after them, and remoring any infested comb.

Bees are like any other wild insect or animal that has been domesticated. Py good treatment they can be made very domestic, so that their keeper ean liandle them about as easily as any other pets.

The next best form of hire is a square box, made of planed boarls oneaud-a-hai or full onc-and-a-quarter inch stuff, well seasoned, and tongued, ard groored, and firmly nailed together, so as to be water-tight, and nearly ail-tight, and well painted. A box fifteen inches deep, and twelve inclies across each way, contains 2,160 cubic inches-ten in excess of a bushel. This is a good sizo and form for a hive. It will add much to the convenience of the live to insert a pane of glass in the side opposite to the openings where the bees enter, which shonld be six three-eighth-inch holes, an inch abore the bottom. The glass shonld lare a tight-fitting slinter; and ihe bottom should be serewed on, or hinged and fastened with a look so that it conld be opened. If it is screwed on, make an opening two inches across in the center of the bottom board, with a close-fitting shntter that you can take out occasionally to allow the bees to sweep out their loom. Open this only in the morning, and elose it before nigrtit. There will then be no critrance for the moth execpt throngh the bee holes, and these the sentinels will guard. Bore four inch holes in the top, and fit corks in them. Have a cap fitted on top to cover four boxes, five or six inches square, made with one glass side. When the lower part is filled, which you can tell by observation at the glass in the back, or by reighing, then open the top lioles, and put on the boxes, open side down, and shut the eap over them, and the bees will soon find that they hare extra store-room, and go to work and fill it with new comb, and fresh honey, free of bec-bread or brood-comb. As soon 
as a box is full, take it off, and put an empty one in its place. A stock of fify swarns in the spriug will produce two thousand pounds of surplus honey, and increase to a hundred swams in the autumu. Counting all labol bestowed in the care of a stock of bees, and all expense of lives, ete., and the cost of honey is estimated at only three to six cents a pound; rarying witl locations, and farorable or mafarable seasons. Put if it always eusts ten cents a pound, the bee-keeper would find sale for it at a profit.

214. Straw lives.-There are a few bee-keepers who still adhere to tho opinion that straw hires are the best that can be used. We can not think so. Their greatest adrantage is, that they maintain a more cren temperature than board hires, and are inexpensive. They can be manufactured hy the winter fireside, and packed away for future use in a small space, one within another. When wanted for use, a couple of eross-sticks must be put in to support the comb, as the hire is in the shape of an inverted bowl, and not as good to support comb as a straight-sided box. It is a grood plam, lowerer, to use the supports in all hives. They slould be so armangel that they can be easily taken ont, as it wonld greatly facilitate the removal of comb. If stiaw hives are used, they should be made to loold a hushel, of clean rye stram, tied very tightly together, so as to make the walls full an inch and a half thick, and smooth outside and in. Nerer use them after they get old, and never place them where they will get wet. If kept diy, the bees winter in straw hives better than boud ones.

It lias been recommended to make cases for board hires, to set orer them in winter as protection from the changes in the weatler. If this is lone, the cases shouid be taken ofi as soon as possible in the spring to prevent moths making harbors in them.

215. Patent Mives, - TVe hare nerer seen a patent for a hee-hire, nol "bec palace," that we would gire a dime for. They are no better than any liandy" man with tools can make himself. As to "bec-palaces," where bees are ti live in eommnnity, the thing is preposterous. It is fonnded upon rrongs principles.

Bec-louses, where collections of swarms in separate hires are to he kept, we have tried as well as the community srestem, and repudiate both.

Jovable comb-]ives may be made without buying a jatent, by making a chest of the eapacity to hold a bushel, besides the firmes, or say 15 inclies square inside, and make 10 frames of strips of boards an inch and a half wide, nailed together flatwise at the ends so as to form sashes that will set in the box and just fill it. L'oro boles for the entrance of the bees, througly the sides of the box and frames. The lid of the chest shuts tight, and mar be locked. When you want to draw a frame, insert a common wood-serew ol two to pull it out by. Fon can tell as soon as you lift it alittie, whether it is full or not, and if not, tity another.

We have tried screral patent hives, and if choosing between any one of them and a "bee gum," wonld take the latter for all practical purposes: not that we wonld recommend farmers always to use lollow logn, though 
[CпLP. II.

we certainly lave seen some most suecessful bee-keeving where the swams were liept only in that rough way.

216. Where to Hecp Hives-The location and mode of support are important matters in placing bee-lives. And here again, the most "rough and ready" way lias always appeared to be the best. We have frequently seen the hives standing about here and there, without any regard to order; some directly on the ground, and some on a flat stome or board; notwitlstandiug such apparent disregarl to all eare, the bees were doing better thin others where erery attention was paid to them. We do not adrocate quite so much negligence, but we do beliere the best situation for hives is in an open field, set a rod or trro apart, or, rather, suspended to stakes. An orcliard, where the trees are somewhat senttering, and the grass short, or hept short by mowing or pasturaga of some greese, turlieys, or sheep, is a good jlace for bee-lives, one under eacl tree. $\Lambda$ live may be fastened to a tree or post by two hooks and staples, eare being taken to fix it so it will be firm, and not liable to be shaken by wind. It may also be fixed upon two stakes set in the ground just wide enough apart for the hive to slip in between them and rest upon a block nailed upon each side of the live, motelied on the lower edge so as to clasp the top of the stake to prevent slipping sidewise. Hives placed about in the open ground slonld have a board laid orer the top, wide enongh to gire some shade to the hive. Lay this boarcl on four pebbles, or four nails driven in to keep it half an inch or an incli from the top. This shade-board may be held in its place by a serew or nail, or a stone. The live need not be placed more than six inches from the ground. A little strip', an inch wide, slould be uailed on level with the cntrance holes, for the bees to alight upon.

If lives are placed under a shady tree, they will need no other protection. It placed close together, a rongh slied may be built over a row of hives, so placed that it will shade then from nine till four o'elock in the day. A hire sloull be painted white, beeause that color does not absorb the rays of heat as much as a dark color. Sometimes a hive becomes heated so as to soften the cement, and let the comb fall to the bottom.

217. Swarming.-The location of bee-lives should be convenient to low bushes, such as lilaes, altheas, or small peach or plum trees, for them to light upon when swarming. We have lieard of elnstering bees upon a large wonlen stocking, stretehed orer the end of a pole, and held up in the midst of the swarm as they collected after leaving the live. When all have been gathered in the eluster, it is gently laid upon the table and the pole with. drawn, and a hive set over the bees. After they go np into the live, the stocking is taken away.

Swarming is just as natural for bees as ealving for cows. It inereases the stock. The process ean not be interfered with advantageously, either to retard or inerease the operation.

The owner of bees should make them as well aequainted with his person as lis horse or $\log$ is, and then lie can liandle them as easily. 
It is true there are some persons with whom the bees never will become friendly, or allow of any familiarity. Such persons shonld never try to handle bees. Others (the writer is one) can handle thein with impunity. I have often had them light upon my filee, and head, and hands, and remain as long as they liked, and then go away agrain.

When a swarm comes ont, go immediately right into the midst of it, and donot be alarmed if it should cluster upon your liat. Such things have been, and no harm come of it. You must show no excitement ; be moderate ancl calm in your movements, as if surronnded by a flock of wild birds which you were atraid of searing away. An excitable man will be rery apt to alarm the bees, and an angry one will be sure to make them angry and drive him from the ficld.

It sometimes happens tliat bees leare the hive pre-determined to fly awny. In suel cases it is difficult to stop them. If it is a dusty time, and they are gathering for flight so low that you can throw landful after liandful of dust among them, you may sueceed in eonfusing them until they will alieglit. Swarns have been stopped on the wing by firing a musket directly forwarel of them, so that both noise and smoke would confuse them. It is idle to fire after them, and shot sent into the swarm may kill the queen: when the bees must be returned to the hive, or put into one witl a pieee of brood-comb.

Some people make a great noise, beating drums, tin kettles, barrels, or blowing loms, when a swarm comes ont. The philnsophy of this is, that the noise may drown the roice of the queen, and thus confuse the bees, when they may alight; but, as a general thing, noise will liave no more effect toward stoppiug runaway bees than runaway lorses.

The rery best thing that we can recommend to a new beekeeper is: Be gentle, and keep yourself on familiar terms with your bees. Make them familiar with your presenee and personal appearanee, and always go among them, as near as possible, in the same garb; and never in a filthy garb, right from the manure-yard, perhaps ; and never in your shirt-sleeves, reeking with perspiration. There is nothing more oflensive to bees; for they are as neat as they are industrions, and never sweat anything out of their little bodies but clean white wax, of which they build their cells.

Thoroughly domesticated bees seldom offer to fly awa when they swarm, if yon lave conreniences for them to eluster; and sich bees are urays easily handled, so that they can be hivel without difliculty, even ly the gutervife or elildren, if the gurleman is awe'.

If you are afraid of stings, put on glores and tie your slectes down : tuck your pants in your boot-tops; jut on a broad-brimmel hat, with a piece of mosquito-netting over it, tucked in close around your neck, and thus proteeted, the most timid may go among his own, or strange bees, which always are the most dangerous.

It you happen to go near bees, and one enmes at you, do not fight, diun, nor screan. Walk away gently, and aim to get belind a busli, tree, fence, or building. 
Place your hive in the place where it is to stand, as soon as possible after the swarm is in ; beeanse the workers commence comb-bnilding immediately, and moving disturbs them, and if only a day or two at work, moving may break down the comb.

218. What a Swarm Consists of.- $\mathbb{A}$ swarm of bees in working order eonsists of one queen, two or three hundred clrones, and from ten to fifty thousand workers. The queen would more properly be called a mother, as she is so, in fact, of all the colony. The drones are the males; they never work nor fight-they are stingless. The workers are imperfectly developed fenales. According to T. B. Miner, anthor of a bee manual, the swarn in the spring consists. of the queen and about two or three thousand workers, and these increase as soon as food can be prorided in spring, enough to make a new swalm, which goes off, led by the old queen, while a new one is provided for the old eolony, which also goes off sometimes, with another swasm; and occasionally a third one is sent off, and finally, the swarm remaining consists of about 20,000 bees, and all but two or three thousand die off before spring; the life of a bee being calculated at only about nine months.

A queen-bee is so distinguished from other bees by her shape, size, and color, that when you have once learned low, you ean always distinguislı lier. So you can by the noise she makes. A queen is larger than a worker, but not as large around as a drone, though longer; and the rings of her abdomen are less fully developed, and consequently not so plainly distinguishable. In short, a queen is more wasp-like in her form than a drone; and is of a darker color, particularly upon the back part of the abdomen; while on its under side it is of a yellowisl hue. The wings of the queen, in proportion to her body, as compared to either of the others, are wider, stonter, and shorter. She is seldom on the wing; only at swarming time, and when she colnabits with the males. It is supposed that she is always impregnated during her flight, and that impregnation in the fall, before the drones are destroyed, serres for the eggs she will lay in the spring. Those who have made observations upon them, declare that a queen-bee is capable of laying hundreds, perhaps thousands, of eggs a day.

Drones are idle fellows; their only service being attendance upon the queen. Their life is a vely short one; generally from April to August; say four months. None are allowed to live over winter. Yon must not mistake the slaughter of the drones for war with other bees, which sometimes occurs.

The workers are always busy whenever it is possible for them to earry on their labors. They often begin the very hour they enter a new hive to build comb, and the second day the honey and pollen gatherers begin to bring in their stores. To work to adrantage they must have a good house. Sometimes when a swarm goes into a hollow tree, the labor is immense, to clear out and fit the room for use. So it is when put into a mean, dirty hive. It requires a great deal of labor sometimes for the bees to stop up the cracks of an old live with bee-glue-a substanee gathered in the forest, and not 
made by the bees. It is harder and stifier when dry than wax, and entirely uulike it.

219. Weight of a Swarm.-It is estimated that a full swarm of bees shonld weigh 11 to 12 lbs. Hence all excess ovel that is loney and eoml, so that the quantity can be ascertained by weighing the hive, if the weight of that is known, as it always should be, and marked upon it when new.

Hires slould always be construeted with some conveniences for weighing, such as a staple in the top, if that is a fixed one, or one in eacli side, and then have a movable bail to hook in, to attach to the hook of the. weigling balance.

220. Bee-Pasture and Ber-Feesling,-It lias been a question for a long time, whether a conntry could be overstocked with bees so that their pasturage would be short. In a conversation with $\mathbf{M} \mathrm{r}$. Quiuby, one of the greatest apiarists in the country, we learued his opinion was that it was next fo impossible to overstock any section with bees. We find from the "Tee Jomrnal," published in Germany, that the same opinion prevails there. MI". Dzierzon, president of a courention of apiarists at M[unicl, says :

"I lave numerous accounts of apiaries, in close ploximity, of from 200 to 300 hives each. Ehrenfels had 1,000 in three separate establislements, but so close that he conld visit all in half an hour's ride. In Russia and IIungary, apiaries numbering from 2,000 to 5,000 are not unfequent; and we know that as many as 4,000 colnuies are often congregated together on the heathe of Germany. Hence I think that we need not fear that any district of this country, so distinguished for abundant natural regretation and diversified culture, will very speedily become orerstocked, particularly after the importance of laving stocks populous early in the spring comes to be understood aud appreciated. Mrr. Iraden, one of the oldest contributors to the 'Bee Journal,' says that a district of comntry ean not be orerstorked with bees, and that howerel numerous the colonies, all can procure suflicient sustenance, if the surronnding country contain loney-yielding plauts in the usual derree; where utter barrenness prevails, the case is different, of conre, as well as rare.

"Aceorling to statistical tables, there are 600,000 enlonies in the provinee of Lunenbure, or $1+1$ to the square mile. The number of square miles in this country stocked even to this extent are, I suspect, "few and lar betreen.'

"A German writer alleges that the liees of Iunenburg pay all their taxes. and leare a surplus besides. The importance at taclied to bee-culture acconuts in part for the fact, that the people of this distriet (so barren that it has been salled the 'Arabia of Germany') are alnost without an exception in cary cirenustances.

"In the province of Attica, Greece, containing 45 square miles, 20,000 colonies are kept, or one colony to each inhabitant, prounciug annually 30 11.s. of loney and two of wax each. East Friesland (IIollanel), containing 1,200 square miles, has an average of 2,000 colonies to the squaro mite. In 
[CRAP. II

$155 \%$, the yield of honey and wax, in the Empire of Austria, was estimated to be worth over seren millions of dollars! !"

Could not still more fitvorable results be obtained in this country, under a lational system of mamagement availing itself of the aid of science, art, and kill ? The islind of Corsica produees about 800 lbs. of honey to the squite unile, per aunum.

There is no probability that any seetion of this eountry will reach such a state of productireness in this generation. Tet we hope all who read these extracts will think what an immense loss is sustained annually by our negleet to employ luaresters to gatlier the great erop of sweets that might be Eaved if our bee population were large enough to gather it all.

Upon the sulject of bee-pastnrage, and those plants from which bees draw their stores of honey, we find some useful hints in Harbison's work on Bees and Bee-keeping. Ile says:

". The best kinds of early pasturage are the alders, hazel, and willows, some of which yield honey and others pollen; most species of flowers yield botl. My observations lead me to believe that the male flower yields pollen, and the female honey; I have frequently seen bees gathering both honey and pollen from the same kind of flowers at the same time. It can be tested by examining both the loney-sack and the baskets on the thigh. These trees are the first to afford the bees provision in the spring; where these abound, the bes adranee earlier than elsewhere. The soft maple (acer rubrum) ichls a considerable quantity of honey very early, if the weather is fine; the colden or yellow willow also yiclds supplies quite early ; peach, cherry, and pear trees put fortl early; gooseberries, currants, strawberries, ete., all afford rich supplies. To close this list of early flowers, the dandelion and apple come forth in rich profusion, all of which are of the utmost importance tol the prosperity of the bees during the season. If this early pasturage fails, or if the weather should be so unfarorable as to prevent the bees from gathering a supply of provisions, they will fail to rear a sufficient quantity of brood to swarm early or to harvest the elover honey to advantage.

"It is but seldom, if ever, that a sufficient quantity of honey is gathered from these early flowers to canse the bees to store it in surplus boxes, yet enough is frequently obtained to fill up a large portion of the combs from which the honey lias been consnmed during the winter, and serves to supply their immediate wants until elover blooms.

"The next pastmrage eomes from turnips, cabbage, and the hard maple (acer saccharinum), which yield a considerable quantity of honey, but later than the soft maple. Turuips produce a very copions supply of both honey and pollen, and if left standing in the ground over winter, they bloom just at a time to fill the interval between the fruit-tree flowers and the elover. This is also the ease with the cabbage family, all of which yield large quantities of loney. A field of either tumips or eabbage at this early season is of greater ralue to the bees than the same quantity of either clover or buekwheat. 
"I would here impress upon the minds of all bee-keepers the importance of cultivating a field in turnips ench year. In the fall gather in all the larege, fine ones, either for marketing or for feeding sleep and cattle during the winter, for which they are very valualsle, and will well repay the expense of rasing them; enongl small ones will be left standing in the ground orer winter to make a rich field of pasturage for the bees in the spring, learing the ground in fine condition for a crop of buckwheat, or to sow down in wheat in autumm, or to again put down in tumips.

"The various kinds of blackberies, and the wild or bird cherry (cerusus serotina), yield honey, and serve to supply to some extent the interval above referred to. We have also a speeies of liale, or wild turuip, which if somen very early in the spring will commence to bloom toward the latter part of May, and is rery raluable.

"Raspberries of all kinds yield an immense amount of loney, and cnn. tiune blooming, giving a succession of fresh flowers, for about three weeks. But few if any flowers produce snch quantities of honey as the rasplyery, in proportion to the number of flowers.

"Catnip, mother-wort, hoarhound, honey-suekles, and various other kinds of flowers, put forth about the same time; each would be of great ralue, it in sufficient quantities.

"Then come other carly summer flowers. At the heal of this list pre-eminently stands white clover (trifolizm repens), which is found along the roalsides, in meadows, grain-fields, gardens, pasture-fields, in fact, it may be seen everythere. The seels, which are very abundant and very small, are driven in every direction by the winds; this has been orerlooked by previons writers. The lieads, which contain the seed, are quite small and rery light : the stalks stand erect until winter sets in and the ground is frozen, by which time the slalk of it las become brittle, and every wind breaks ofl and rolls along the ground a portion of these little seed-pods, until they meet snume obstruction; lere they will germinate. 'Thus they are seattered in every direction. I have frequently seen them driven furiously on the erust ot it slablow snow, through which the hends would project. The value of this clorer is entirely underrated as a pasture for cattle or ljorses, as well as bees; it is always selected by stock in preference to the red clover. The lroney gathered from it is of the highest excellenee, both in beanty and flaror ; and I believe in good seasons, all the bees, in any neighborhood where it abounds, could not gather the fourth part, so great is the quantity produced.

"The tulip-tree (liviodendron), or poplar, as it is called by some, by otlers white wood, is a great producer of lioney. Nothing of the tree kind that I have ever seen exceeds it; the flower's expand in succession, are of a lwelllike shape, montl upward. In dry, warm weather I have seen a teasponnlul of pure loney or saceliarine matter in a single eup or tlower. Bees worti upon it with the same vigor they manifest when enrying honey from somo other hive, or when it is tell to them.

"The yellow and black locust trees yield large quantities of honey. 
"The linden, or bass-wood (tilir Americana), produces loney to a large anount. All of these varieties of trees should be extensively cultivated, hoth is shade and ornanental trees, as well as for their timber and the vast quantities of loney they yield. Sumach also produees honey bountifully; the ditticulty, however, is, that there are but tew places where these are foum in sufficient quantities to be of importance. I trust they will be extensively cultivated.

"The common black mustard is one of the most raluable plants to cultirate as a pasture for bees; it is casily raised, by simply sowing it on ground when well plowed and pulrerized by harowing smooth, and then brushing it in with a light brush or very light liarrow. It should be sown early in the springer, on good ground.

"Ihose interested in bee-kecping should give the enltivation of mustard some attention. Is a bee-pastme it has few superiors, yielding both pollen and loney in great abundane ; it begins to open its flowers when quite young and continues as the bush expands, until it becomes rery large; each kay brings fortl new blossoms. A field of mustard in full bloom is a most magnificent sight; it is like a vast pile of golden flowers; the plants are completely enveloped with flowers, from the ground up as high as a man's hear. There is no other plaut that I ever noticed that prodnces so many flowers to any given quantity of ground, nor yiclds so much honey.

"In almost any of the Atlantic States it serves to fill the interval that oceurs letween the closing of the white clorer and the opening of the buekwheat flowers, a period of about four weeks, which is the very best part of the year for gathering lioney, as the weather is generally warm and calm; lience the propriety of raising this crop to employ the bees profitably.

"The honey produced from it resembles that yiclded from the linden, both in color and taste.

"Mignonette, a modest, mupresuming little flower, found in all wellassorted collections, is one of the greatest value as a bee-pasture, if grown in sufficient quantities to be an object. It is low growing and spreading in its labits, similar to white clorer, and yields both honey and pollen; it will bloom continnally, from the middle of June until killed by frosts in the fill. It is easily rased in large quantities if the ground is clear of reed seed, plowed, and well pulverized by harowing before sowing. Sow thinly and brush it in with a light brush; all that is required after this is to pull out any large-growing weeds that may chance to make their appearance before the mignonette spreads over the gronnd; where it takes possession of the ground, it needs no further care. $\Lambda$ bed of these flowers will perfume the air for quite a distance around, so rich is it. Bees will work on it from daylight until dark; two or three may be seen at once on a single head or flower.

"The cephalanthus Canarlensis, or butter-bush, which grows in swamps, and low, wet, marshy grounds in almost every part of the United States, preserving the same appearance wherever found, produces liouey of the lighest excellence. The honey gathered from this shrub is of a very light 
straw color, of a thiek, heary body, and rery excellent flaror. Bees thrive and store honey very rapidly when they have aceess to larere quantitios of these flowers. The time of bloming varies with different localities, but it generally begins to put forth flowers about the first of July; and continues for three or four weeks.

"In all places where buckwheat is raised, it becomes an important accession to bee-pasturage. A field of buckwheat yields an incredible cunantity of lloney, which perfiumes the air for a considerable distance around. When the weather is farorable, the bees store honey from it very rapidly, faster at times than they can build combs to receive it. I have seen them fill picees of old combs laid close to the entrance of the live, with honey, and have known colonies to fill four boxes of honey, or about 50 lbs., during the continuance of buckwheat. This is by no means an uncommon occurence, and goes to show that this honcy harvest is one of great importance to the beekecper. Buckwheat may be sown about a montlu earlier than usual, to furnish pasturage to come in about the close of elover, to great advantage."

In relation to artificial feeding there are many opinions. There is probably no better food for bees than brown sugar, moistened with honey, such as can be bought at a low price by the barrel or gallon in any town. Adel just enough lioney to the sugar to make it into a dongh by kneading. Pnt this feed in a slallow tray, with a few straws on top, and let the bees take their own way and time with it. It is well to give a little salt to bees, if they can not get it conveniently. The best way is to place a lump of rocksalt near the lives, and there let it remain year after year.

1 practical bee-keeper says: "If the season has been unplopitions, the hives should be carefully looked after. If any contain less than 20 lus. of honey, the swarm will need to be fed eitler with honey alone or mixed with sugar diluted to the consistence of horer, poured on to pieces of empty comb, and placed in the live in such a manner that bees from other hives will not find it. Perhaps the best method is to introduce the feed into the boxes direetly orer the bees; but should it be a common box live, it may be placed on the top of the live, where there is a communication through the top, and placing a cap over the whole; and then gently rapping on the top of the hive, the bees will press up throngh and find the feel. The feeding shonlel be done during wam wenther."

221. New Food for Bees.-The fact las been discorered in Finee, that bees will feed upon the oil-erke (soaked in water) that is made in the manuficture of oil from the Sesamum. Orientale, known here as the bene plant, so that they can be mucls easier rintered; and it is said the increase of stoclis is wonderful in comparison with those not thus fed.

The Flore res Serves, from which we horrow this, assures us that the results liave been astonishing, not only in a large increase of honcy-comb, but in cnabling tlie bees to multiply beyond all helief; nearly ten times the quantity being bred in consequence of the facility aflorded of obtaining abundint and, as it wonld seen, excellent nomrishment from this mexpected scurce. 
The experiment conld be tried in this country by apiarians planting the bene seed, and brnising and soaking the seed of the crop, and feeding it to the swarus after the natural food fails.

One of the greatest troubles in bee-keeping appears to be the want of suitahle food early in the spring to enable the swarm to prepare for anew colony that may go out early enough in the season to lay up, not only their. own stores for winter, but a surplus for theil owner. Many sralms that lave an abundance of honey for their own use and to spare in the spring, are inactive tol weeks, after the spring has become wan enongly for them to work, beenuse they hare nothing to work upon. The first business is not to ratler honey, but pollen, to malie bread for the young bees. So, although the weather is warm enongh, and the bees lirely enough, mutil the buds affiorl pollen, they have nothing to wolk upon to enable them to be in season with the new brood, to produce carly swarms. This is a serious drawback in late seasons, and in situations where pollen-prodncing plants are not plenty.

MIr. E. T. Sturterant, of Clereland, Ohio, claims that he has discovered a remedy for this diffieulty, and that he can bring forward his bees some two montlis carlier, and get good swarms the first of May. His plan is to feed lis hees witl unbolted rye-meal, strewn upon boasds convenient to the live, the bees pitching into it at once and working diligently, and in such an earnest way as fairly to scramble over one another. It is a lint worthy the attention of all bee-kecpers.

$\Lambda$ few years ago, a bee-kecper in Wurtemberg discovered that bees extracted food from carrots which had been rasperl and cooked for stock, and thereupon he boiled. some to a jelly and placed it near the lives, at a time when the fields afforded no food, and he found that they worked upon it as though the saccharum it contained was particularly angeeable.

We suggest an experiment with carrots cooked in this way, by bee-keepers in this country. We would also try parsneps; and, where they are grown abundantly, sweet potatoes. And since we know that bees are so fond of sweet apples in summer, why not keep them to feed swams when needing artifieial feeling in winter. It may add as mucls to the liealth of bees to feed green food, as it does to health of other farm-stock. Let the experiment be tried.

222. Ventilation of llives. $-A$ great deal has been said about the necessity, on account of rentilation, of making lives open at the bottom. In reply to this, let men think that bees in a wild state prosper well in the hollow of a tree where there is but one small loole for entrance of the bees or ventilation, and that open-end lires, standing on a bencl, are often cemented fast to it, and sometimes holes left, for ventilation, are sealed up as closely as tloough air was poison to the inmates of the live.

If you wish to rentilate, bore a two-inch liole into the upper part of the large box, and cover it on the inside of the box and on the outside of the case witls wire ganze, fine enough to keep ont ants and other insects, for a venti- 
lator. Bore inch lıoles throngh into both of the upper boxes, and corer in the same way.

Mr. Quinby says that he regards proper ventilation as very important, and yet proper ventilation is very imperfeetly understood. IIe also sars: "Any way to get lid of the moisture." The presumption is, that he would not freeze the bees at the outset as one of the ways, for that would surely prevent moisture; and if the madus operandi of some who give directions low to rentilate slould be put in practice in rery cold situations, the bees are just as surely frozen.

Moisture acemmulating on the inside walls of the live lias cansed the destruction of more strong colonics of bees than any one other casualty, except the fatal way of some bee-keepers to gret rid of the moisture by opening wide the apertures in the top and also in the bottom of the hire, and thus cansing a enrrent of external air to pass up through the interior-precisely the method to cool a live in lot weather-and also thus rendering the bees more esposed and liable to be frozen than they would be situated on the exterior of the hive. P'oper ventilation is simply to gire free rent for the air at the top of the hive, and not admitting any or lut rery little air through the botton. Under all cirenmstanees it is requisite to regulate the openings in the bottom with those in the top, which amounts to about the same thing withont the drawbacks of inverting the live.

There is a new form of bec-lives, used by J. L. Scribner, of Montpelier, Vt., a suecessful producer of honcy, so mneh so that he carries off all prizes at the comnty firir.

This live, being male of straw, serves almirably for rentilation. It is made of a frame of square sticks, say one inch diameter, and in capacity $12 \mathrm{by}$ 13 inches, and 13 inclues in hight, with a flat board roof projecting tro inclies each way. The frame is mailed together; the lower girts are placer $\frac{1}{4}$ inch above the bottom of the posts. The frame is eorered with straw serred together, just as it is in straw hives, witl a loop at the bottom, made of strips of boards one inch thick and two inches wide nailed together. In this loop a noteh $2 \frac{1}{2}$ inches long, $\frac{1}{3}$ inch deep, is cut for the bees. Plane all the wood, and use none but clem rye straw. On the roof, orer snitalble holos, the boxes for storing loney are placed. It is thus deseribed by Mr. Seribuer:

"The adrantages of this hive over all others that I have used are rery material in my riew. It is generally conceded that straw hives are the best to winter bees in; not altogether because they are so much warmer, but because they will 'keep ding, and the frost does not acenmulate as in hoard lives. Every experiencel apiariun knows that in wooden lives there is a contimual dampness, arising in part from the breath ame efturia of the becs. Not so in striw lives. Straw being of a dry and alsorbing nature, the moistmre is taken up. Now, I have learned that straw lives are as much better in summer as in winter, especially in the season of breeling, when we are sulject to frequent and sudden elianges of the weather, such is damp, chilly uights and hot days. The temperature of a straw hive is more eren: 
it loes not lieat excessively in liot weather nor cool suddenly, as do board hives. The natural wamth of the bees is relained, which is particnlarly conducive to their health and prosperity. Hence there should be no unneccsarmy rentilation by leaving an 'open space, as has been recommended by sume, 'all nromed the bottom of the live.' Especially in damp, chilly' weather, hees will breed faster and gather more honey in straw hives than in board hives, according to my experience. One reason for their gathering more lioney, probably, is becunse the young brond comes to matmity faster, consequently there are more 'laborers in the tield' in the carly loney season. This hive combines all the real adrantages of erery patent hive that has come to my knowledge, while it obviates all the objections and retains all the good qualities of 'the old-fashioned straw lives.'

"The less a firmer bothers himself with patent hires and bec-palaces, and the less he tries to counteract nature, the better he will be off. I am heartily sick of "patent bec-hives,' and it is time to abandon them."

223. Taking lloney, and llow to lieep the Bees from Stinging - When bees are alamed for the safety of their stores, they immediately rush to the cells and fill their sacks with loney, apparently to provide against any contingeney that might arise. When in this condition, they are perfectly harmless, never roluntecr an attack; conserimently, to tame bees, or render them docile and easily driven or handled, simply take advantage of this peculiar instinet. To contine them closely to their hive, rap repeatedly on its sides for a few minutes; this alarms them, and they will gorge themselres with honey, when they can be handled and controlled at pleasurc. But we have adopted the following plan, which we find best adapted to our use, and recommend it to others, with the assurance that it will gire satisfiction: Take clean cotton or linen rags, such as are used in the manufacture of paper; make a nice roll of these, about an inch in diameter, and from six to twelve inches long; wap this pretty tight, either with narow strojs or sireds torn from cloth, or, what is more conrenient, use wrapping yarn of some lind; prepare a number of such rolls, and kecp on hand in some box, or any dry place, near the apiary, together with some matehes. When you wish to open a hire or perform any operation, set fire to one end of a roll of angs; it unakes quite a smoke, withont any blaze. Upon opening the live, blow the smoke vigorously among the bees for a minnte or two, which terrifies them, withont doing any permanent injury; they immediately rush to the eells and fill their sacks witl. loney, when you can proced to lift ont one comb after another, and perform any opelation with perfect impnnity, withont any fear of being stung, mnless by those from other hives near at hand. Shonld there be sume, howerer, that would slow signs of battle, blow a little more smoke npon them, and repeat it from time to tine mutil the close of the operation. Toward the close of the honey season, when they are rich and increased in stores, they anc harder to control than at any other season of the year; when this occurs, put a small portion of tobacco or a few grains of sniphur in your roll of lags; this renders the smoke nore pungent, and will easily subdne the 
bees. Dried puff-ball makes a smoke that subdues bees without injury to them.

224. Bee Moths, and llow to Protect Bees from Them,-Xumerous patents liave been taken out to sell bee-kecpers, to keep the moths out of the lives. All of these contrivances fail in their object, or else have objeetions to them which have prevented their general introduction. One now before ns consists of a set of swinging dloors, just such as we have often seen at cat-lioles, hung at the top so as to fall into place as soon as pussy gets through. For the bees, a small tin, about the size of a dime, is hung in the entrance hole, which the bee can push open, but the moth can not-that is, so says the patentee.

Where open-end hives stand npon a bench, we have seen moths prevented from injuring the swam by raising the hive, during the inoth senson, about half an inch from the bench. The theory of this plan is, that the moth inserts her egrgs between the bottom of the hive and bench, where they hatel, and the bees can not get at the worms; but it it is raised up, there is no op* portunity for the moth to deposit her eges where they will be safe.

A elseap, good motl-trap is made in the following manner: Talie a piece of thin pine board, or a shingle, a few inclies square, and with yom pocketknife cut three-eornered grooves on one side, and lay it, groored side clown, on the bench under the hive. The moths will find a seeure place from the bees, and deposit their eggs, whieh you will find, or the worms, and destroy, by looking at your traps erery few days.

Mr. Quinby recommends the following mixture as a moth-trap: Sugar or molasses and a little vinegal and watcr, making the "contrast" agrecablethe sweet and the sour. Put this in shallow dishes, saneers, or tin baking dishes, and set them among the bees at erening. Next morning, moths of all kinds will be found in the liquid, and may then be strained out and destroyed, and the mixture used the following evening.

225. Introduction of Bees into California.-The honey-bee is not a native of California. The eredit of introducing them is dne to a man by the nanc of Shelton, who, after doing much for the interest of agricultulal improvenents in that State, lost his life, while still a very young man, by the explosion of a steanboat boiler on the Sacramento Rirer. He imported, in Marels, 1553, the first bees into California. Ile left New Jork with twelve stands, or hives, and arrived witli bnt one; from this one about one hundred and fifty swarns were credited in 1858 , and, of conrse, have largely multiplied since that time. There have also been very large exportations made by steaner from New York. The Messis. Harbison, of Pennsylrania, liare been rely successtul in shipping and selling swarns, and hare also established an extensive apiary at Sacramento. The common price of some of the first stocks scut to or produced in California lias been fifty to one humdred dollars a hive. The II ubisons male their first shipment, we believe, in 1S55-9.

It lias been thought singular that our people found no bees in California, when they were so abundant in Mexico and Central imerica. Sinee the introduction of bees from New lork, a Caliturnia paper states that sereral 
attempts to jmport bees from Mexico have failed. Captain Macondray had one or more Mexican swarms, but they soon dwindled away. In 1859, Mrs. Sutter, danghter-in-law to General Suter, lial forty-four lives packed on the: backs of Indians to Acapuleo, and brought on the steamer to San Francisco; two or three weeks after their arrival, there remained but two hives containing bees; they were taken to San José, bnt in al short time they also died.

It also says, and so does every one we have conversed with on the subject, that California is admirably adapted to the honey-bee, as the experience of five years fully demonstrates. In San José Valley, Sacramento Valley, Slasta; Bidwell's, Stockton, Columbia, and Napa they multiply rapidly and store ahmondee of loney. The willow affords the first material for pollen. The bees commence gathering it ly the 1st of Jamury; about the 15 th of January it is in bloom, and aflords considerable honey, though slightly bitter. The bees gather pollen and loney from the willow till Mareh. The wild mustard aftords an inexhaustible supply of loney from the 1 st of $A$ pril to the midlle of June. Later in the season, honey js obtained firom buckwhent and honey-dew.

Honey made from mustard blossom, from which most of the lioney is gathered in San José Valley, is excellent, and has sold in San Franciseo at from $\$ 125$ to $\$ 150$ per pound. New swarms issue as early as the 15 th of A pril, and the swaming season continues to the 16 th of June.

226. Stingless Bees.-There is a good deal said of late about groing to Brazil after "stingless bees." What is the ntility? We have a better sort here, and their stings are in no manner oljectionable. In fact, they are advantageons to the apiarian. They guard the store from thieves of all sorts, and they are much better honey-makers than the Sonth American variety, which las no sting, all of which are of a mneh smaller size than our common loney-bee, and some of them make honey that is somr, and others give it a bitter flaror. This may be owing to the flowers it is extracted from, as we liave known bees here to make uneatable lioney.

Welts, in lis explorations of Honduras, gives the names of fourteen varieties of honey-bees. Honey is very abmdant and low yriced. He was cliarged hut ten eents a quart for it. Ile says: "The bees are diminutive, and mostly stingless. Swarms of them may be seen every day, when traveling in the open country, hovering around some decayed tree, and but little trouble is necessary to bear the whole establishment to the nearest hacienda. One of the proprietors said he had sold enough, since owning the estate, to buy all the drilling, mantos, and artieles of that deseription, required at the hacienda."

The most curious thing about most of these bees is that they do not store honey like our bees, in combs of hexagronal cells, but in little saes, two inclies long, arranged in rows along the sides of the hive. The cells for the young are placed in the center.

227. Italian Bees.-During the year 1560, a good deal has been said abont the adrantage to be derived from the introduetion of Italian bees into the 
United States, and importations lave been made for that purpose. The plan is to breed queens, which, after being impregnated, are introduced into common hires, after removing the old queen.

$\Lambda$ writer in the Country Gentleman newspaper gives the following as the history of the introduetion of Italium bees into this comntry. Ile says:

"Mr. P.J. Mahan, of Philadelphia, is mentioned 'as being the first to land this new raricty on our shores.' As a matter of history, I would state that this is not so. For several years past the attempt has been made yearly by Mr. Richard Colvin, of Baltimore, Samuel Wagoner, of York, Pa., and Rev. L. L. Langstroth. These attempts rere unsuceessful, owing to bad packing and mismanagement in transportation, until the autmm of 185 , when Mr. Colvin received some Italian stocks, and hoped to have crueens from them for sale the past season, but these stoeks, mfortunately, dicl not survive the winter. Next in order of date is Mr. Malnan's importation from Germany, which was suceesstul on accont of his personal supervision. Shortly after Mr. Malan's importation, Mr. S. B. Parsons, of Flushing, Long Island, snceeded in getting a few swarms alive from Italy. From them he has sueceeded, aided by several skillful apiarians, in raising a la'ge mumber of queens, which have been sent to nearly every State in the Union, including California, mnder the supervision of Mr. Bigelow, a successful apiarian.

"The last suceessful importation was by Messrs. Colvin and Wagoner. All the above named are exerting themselves to multiply their stocks of Italian bees, and they will donbtless lave a demand for all the queens and stocks they ean supply next season, as the interest in this new bee is deservedly increasing. The question will naturally arise, Of whom shall I purcliase? Are these importations equally reliable, and if so, lave all taken the same pains and been equally successful ju keeping the breed pure? I would here remark that some situations are more farorable for maintaining purity than others. The Italian bees now in this country are from three diflerent sources, and erery one should decide for himself to which stock he should give the preference, and if the most reliable man and the most acliable bee can be found working together.

"Two of the importations are from Germany, and one from Italy. Of the importation from Italy there can be no reason to question its purity. The two importations from Germany are from different breeders. One of the importations from Germany I lare the fullest confidence in from personal inspection; and if the other be equally good, we are in at fir position to latve the country well supplied with pure stack in a few yenrs, provided sufficient interest is taken to maintain purity."

22S. Reasons for Kecping Bees.-In this section we liave only amed to Eay just enough to encouragre every reader to keep bees, who has anything like fir facilities for them to obtain a supply of honey from gardens and ficlds. which they will do if within a mile, and some bee-keepers say it within wo miles. Lut it is not profitable to allow hees to gro eo far, when the bec-lieeper las land mon which he can grow hee-food just as well as he can grow food 
for any other fam-stock. The filet that bees olstain a great deal of food from finit-trees should encourage fiumers to cultivate both together. Anl if he plants along the roulside long rows of willows, maples, lindens, poplars, he will not only have the advantage of then for shade and omanent, but his bees, if lie has them-and if not, let lim be encegragred to gret themwill find a great field up in the brancles, that they can use as pasture.

The strongest reason that can be given for keeping bees is this simple fact: They afford more clear profit than any other stock ever kept on the farm, and, renerally speaking, the nore labor is bestowed upon them in providing good hives and pasture, the better they pay.

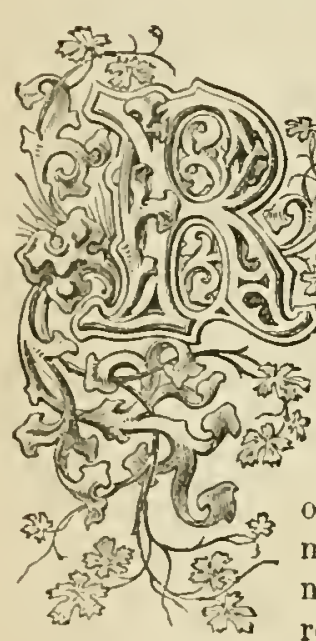

\section{SECTION XI-BIILS.}

cason and Religion in Preserving Birds.-Te don't linow how much we have written, said, and sung to induce farmers not to destroy the lirds, nor allow them to be destroyed, because we. look npon them as part and pareel of the farm-stock, and of more importance to the farmer than some animals he keeps, at much more expense than his stock of birds. We say his stock, because we consider the birds on the trees just as much the property of lim who owns the trees as the trees themselves; and he who would steal one would steal the other. A man who would come upon my farm and shoot my birds, without my permission, is not one of the noblest works of God. No man who takes reason for a guide, who orns a fam in any of the old States, can consent to have lis birds destroyed. He certainly will not destroy them himself, after he has taken time to think npon the subject. It is our object to indnce him to think, and the best place to do so is to go out anong them in a bright spring morning, and hear their music.

Go out among the trees in the orchard or through the grove, or look into the liedge-rows or peep under the old bridge down the lane, or go to the barn; go anywhere, everywhere, where you will, and at this season-that is, lovely Mry season-you will find the birds-bnsy, merry, singing birds; liard at work they are, too, building their houses-cradles, lather-and all the time leeping up a concert of sweet music. Various too are their tastes in selecting their sites for their nesting-places, some hiding away from man, some eoming up to his very door, or, like the martin and swallow, under his roof and protection. Robin-red-breast almost invariably comes into the orchard, sometimes on the trees, sometiules on the fence, sometimes, where kindly treated, under the shed by the barn or house. 
The woodpecker-the same one that was tapping "the hollow becch-tree" -makes holes in the old apple-trees, into which for years afterward the pretty blnebird creeps and rears its annual brood.

The blackbird, the most numerons of the fanily of small birds, mostly nests in the swamp; exept one variety, imitating the crow, that goes into the highest trees, such as the spruce, with a dark, thick top, where boys nor small shot can not come.

In the meadow we find the sly nest of the quail and lark and several small birds; and in the thickest bushes, the home of the brown thrush. IIe is a natural musician, a sweet bird full of glee and cheerfulness; but the merriest and most amusing of the whole family is the noisy little bobolink.

We look upon birds as among the essentials of a landscape, and wonld as soon think of elopping down the orchard, shooting the turkeys, and wringing the necks off of the barn-yarl fowis, or making mutton of the shecp or giving the lambs to the dogs, as to think of destroying the birls or hriving them from the premises.

"Going a gumning," with the murlerous intent to kill snch birds, ouglit to consign a man to the infuny that we are apt to attach to a savige or a brute who wantonly kills the finest of God's creation.

Without birds, a country is desolate; with then, it is always eheerful. Their songs would enliven the heart of a stone, or make a miser for the moment forget his money.

The association of children with birds, when tanght to love them and not destroy their nests, has as direct and certain a tendency to improve their watures as the chureh or family fireside. Teach a child that birls are among the good gifts of God to man, and it is hardly possible that the child will grow up to manhoor without being possessed of some of the attributes of the sweet songsters of the grove.

And yet there are parents who allow their children to waige incessant war upon the birds, nerer thinking of the injury they are doing their young minds, or how many destructive enenies they are entailing upon the crops in the shape of countless eaterpillars, grmbs, and worms.

We do not know of a ligher Christian duty for a minister to engage in than an effort to preserve the birds in his parish.

We would impress upon the mind of every child that the command, "thou shalt not kill," meant these dear little birds as well as things of a highther degree. Thon shalt not wantonly kill a single thing of all creation that is not necessary for man's sustenance, or that is not cletrimental to his interest.

Children should be taught not only to love the music of birds, but to look upon them as molels of beanty and affection to their mates and to their young. Instead of driving them away from the louse. encomiage them to come and pereh npon the window-sill and build their nests under the eares.

Do not tell us they destroy the smanl frmit. Plant enongh for lirish and men. It they do eat firut, they also eat worms, and you can well atlord to give them at few cherrics and currants for what they have done for you. 
Around the city there is a diffenty in preserving the birds, lecause all the groves are infested with an abominable nuisance in the shape of big boys and prowling loafer"s "ont for a day's slooting."

'They ought to lie ont for' al day's shooting, and that should be at their own ille carcasses, with tine salt and jepper-eorus, and every owner of land shouhl be allowed by law thus to salt and pepper any of these idle ragabonds who come npon his grounds withont leave to doom the birds to destruction.

Farmers! let your motto be-and impress it upon all your family-Never kill a bird !

In the early settlement of this comtry, there was such an abundance of birds that the people who were striving to raise grain enongh for the supjort of their fumilies, looked upon them as their enemies, beenuse they were naturally disposed to eome in for a slare of the crop, and some of them, such as the erow and the large blackbirl, sometimes depredated mon the seed, by which the crop was effectually cut off.

So a war of extemination was declared withont discrimination against all birels, and it was carried to such a bitter end that the clildren of the first Eettlers grew up with a fixed opinion that they were doing a Christian duty whenever an opportunity offered, in destroying birds and bircls' nests, and they entailed the same disposition upon their elifdren and their ehildren's elildren; and so the poor birds have been almost exterminated from the face of the carth with scareely a thought why or wherefore, exeept that they were birds, and birds must be destroyed-" father says so." Upon that ipse dixit some of the best friende of the farmer, instead of his worst cnemies, hare been almost annililated, while others have come to regard him as a being to be so aroided that they make their abodes in deep forests, and hide their nests and young from man as carefully as man wonld hide his young from a tiges.

Experience teacheth wisdom; and after two hnndred sears of teaching, the American farmer is just beginning to learn that birds are his best friends. IIe shot them mpon his plum and elierry trees beeause they took a share of the froit, and then eame the insects that the birds used to prey upon, and the days of plum-growing were over. So of many other inseets, real pests of the farmer, everywlere multiplying as the birds deerease.

Not one of the species mpon which man has made such uncensing war, but lias its use. Fren the owl, althongh it will eat chickens, is a great mousedestroyer; and the hated hawk is sometimes shot with a snake in its bill. Crows should be treated with as much eare about a firm as domestic fowls. Do they pull up your spronting eorn seed? Feed them and they will not. Sow corn broadeast through the field and they will not touch that which yon liare planted. Birds of all descriptions should be taught that man is a friend and not an enemy, and they will return the friendship.

Some lover of birls-and he who is not such is "fit for treasons, stratagems, and spoils" - may demur to om assertion, that they are less influenced by gratitude than their four-footed fellows. If our assertion is incorrect, we 
shall be happy to be set right, but we believe that facts are against the lirds; yet if this be so, the eirennstanee is not to their discredit. They are the humorists, the musicians, the conrersationists of the animal world; so fully occupied in talking, singiug, joking, eating, and rearing their families, that they lave little time to devote to those immense beings, pantalooned or looped, whom they undonbtedly regard from their airy lights with a sort of contenupt, as they bchotd then slowly plodding along, confined to the dull earth and unable to take a flight even equal to that of one of their newlyfledged offspring; and if they condescend to pick up a few crumbs seattered by some gentle land, they feel as little of the emotion of gratitude to their bencfuctor, as the squirel to the chestunt-tree which rains upon him his winter's supply. A certain degree of brain development is necessary for the existence of this cmotion, and birds, in this respect, are inferior to inost of the quadrupeds with which we are fimiliar.

Birds do not seem to be as susceptible as quadrupeds to kind treatment, and those species which have been domestieated appear to have lost whatever "smintness" they may origrinally have possessed. The whole tribe of domestic fowls-cocks, hens, ducks, geese, guinea-fowls, turkeys, pea-fowlsare unmitigatedly stupicl-acute in nothing but picking up corn and devastating gardens.

The crow is one of the birds that unthinking men destroy, because they pull up a little corn in the spring. Will you think what else he does?

IIe consumes in the year rast quantities of grubs, worms, and noxions vernin; he is a valuable seavenger, and elears the land of offensire masses of deceased animal substanees; lie hunts the grain fields, and pulls ont and devours the underground caterpillars, whenever he pereeives the signs of their operations, as erinced by the wilted stalks; he lestroys mice, young rats, lizards, and small suakes; lastly, he is a volunteer sentinel about the farm, and drives the hawk from its inclosure, thus preventing greater mischief than that of which he himself is gruilty. It is chicfly during secd-time and harvest that the deprerlations of the crow are committed; during the remainder of the year we witness only his services, which are so appreciated by those who have written of lirds, that I can not name an ornithologist who does not pleact in lis behalf:

Frighten the crows, but do not lill them, execpt one to use to keep his fellow oft your coln. Pick oft part of his feather's and scatter them on some spot in the ficld easily seen, and near by lay the carcuss of the dead crow and you will see his late companion sailing over the fietl and looking down "1]on what has been done, but very careful not to light where he too might fill a victim. If you can not kill a crow, you may make a very good sluw of a deal one with a black hen. . Crows are too valuable as relunin-alestro:ers on a furm to be wantonly destroyed becanse they jull up a little corn.

$\Lambda$ writer at Eaton, N. Y.. sends us the following item in titwor of the pursecuted crow, which makes linu out not quite so black as he looks-that is, when seen by the oyes of some of his enemies. Ife sirys: 
"For the interest of the farming portion of this comutry, I communicate the fullowing: Mr. Mlphil Brown, an enterprising farmer of this town, intomed me that, having acted this year upon the somewhat late suggestion of yours, of sowing corn brondeast orer the plinted ground, he experienced a new result. Upon four acres, where heretofore lis crop had been greatly injured by the derastations of the "white grub" and "gray com-worm," lie sowed broulcast, after planting, a lialf bushel of corn. This, of course, attracted the crows, which, coming to the ground in the cooler part of the afternoon and morning, found the worms on their usual visit to the surface, and, preferring the latter to tho corn, devoured them instead. The result is, that out of the whole field he las not lost to exceed fire hills."

230. The laeverse of the Crow Question.-Having given our opinion in favor of the crow, in the preceding paragraph, we feel that it is dne to a fair investicration of the question not to malie it an arbitrary opinion, and rest there, lut to give the opinions of others also. It is facts, not theorics, that we wish to give farmers.

One who signs himself a "Farmer's Boy," writes from Ridgefield, Conn., about erows, as follows:

"Having lately read your article mpon the subject of crows and others of the featliered tribe, I can not hold still my justy old steel any longer. I anree with you very well until you advocate the protection of crows; there I think you miss your man. There is but one thing you name that is in their faror-the digging of grubs. They are the enemies of all our small birds, which you adroeate preserving. They commence with the eggs, and continue their depredations until the young are nearly grown. They are nerer found destroying insects of any kind that could not be of more use than the crow, and eren the grub can be made a source of income to the farmer. An intelligent farmer told me, some years ago, he made 1,000 pounds of pork by letting his hogs feed on them in his meadows, which damaged his grass but little the first year, and thought it better the second by having the surface stirred. Tou speak of their derouring carrion. Now, in my opinion, no farmer that is a good ceonomist will allow any dead animal to lie and rot in the sun to make food for the erows. I consider the carcass of a horse, a cow, or an ox worth from three to fire dollars to any farmer. If so, it is quite too dear food for erows. Some say crows catch grasshoppers and crickets. 1 prefer a nice brood of turkeys, that will not look bad on the table when they have performed their work on the farm.

"Yon see I am a friend to almost everything but a crow. If there is anything made in rain, it is the crow. They destroy our little warblers; they catch our chickens, ducks, turkeys, and goslings; they dig our potatoes, pull onr corn and beans, from the time they appear above ground until they grow out of their way. Then, as soon as the grain is formed on the ear; they commenee their work again. Now, if such a pest as this is to be protected, it must be by some one who has a licart softer than I have; a creature that but one thing can be said in its furor, and the rest must go against it. I 
have not the least donbt but our town was taxed $\$ 500$ last year to feed clows."

Upon this we simply remark: If "Farmer's Boy" has a breed of crows abont lim that really eatch turkeys, goslings, ete., and dicr potatoes, lie is iveleome to be their enemy. Our crows are of another solt. Lnt is oul "boy" sure that he "can tell a hawk from a herushaw?" Beeause the raven, though one of the corvus family, is not a crow, as we understand the word; and it is just possible that the bird that eatelies turkeys and other bircls is a raven.

We lave another opinion, coming from a citizen of Montgomery County, Penn. He says:

"Leaving your crows under your protection, to enjoy their excellent repntations, we desire to say a word on the eharacter of ours. That we liave real, veritable elows that eatch young chickens, is a 'fixed fact,' well estahlished. The present senson, notwithistanding our eare, we lost by them, I suppose, from ten to fifteen, and avoided the loss of others only by the use of gumpowler. Omr experience on this subject, I may add, is that of many other's. This thing, then, om" "loreed' of crows do, and also carry ofl' spoiled eggs that may be thrown away, birds' eggs, ete. In referenee to rlueks and goslings, I am mable to speak, but have no reason to believe that they are distastefin, or that they do not eatch then.

"They lore, it appears, a variety. I near and reliable neighbor informs me that quite reecntly he saw one of our tribe in hot pursuit of a rabbit, which, atter sundry dodgings, secreted itself under the fence. So you see New Iork crows differ lrom ours, and, I ineline to think, from most other erows."

Tere is another opinion. This eomes from Theron Walcs, Windhan, Portage Comnty, Ohio. Ile says, in relation to our remarks npon the statement of "Fiuner's Boy :"

"I conclude you received it as doubtful. I can add testimony in part to the same effect. I liave seen the erow alight into the nest of lic robin and carry away the young birds to feed their own young. They are passionately fond of the egrgs of other birds, and I lave canght them in trajs with exgershells. Hunters of the wild turliey can testify to the latred between the crow and the gobblers. From the requent presenee of the crow orer the grobbling turkey, it appears they wateh for their nests. At least erery cry of the erow is answered defiantly by the turkey, and thus I have often heen led to approach the turkey and shoot him. While we were living upon the Berkshire IIils, in Massachusetts, it was not unfrequent that our neighluors' and our own young lambs latr their ejes picked ont by the early returnin! crows in the spring. Tint I lo not say these things for the salio of engraging in an exterminating war upon then. Al] things were ereated for sone wise purpose. Every crenture las in mature its encmy and destroyer, and every attempt on the part of man to grive preponderance to one part of lle wilel ereation orer another, will fuil. Civilization will of necessity drive alway" 
tlie bearer, otter, deer, and a host of forest birds, and their places will be rapidly suphlied by the wren, the rohir, the blnebird, the honey-bee, ete.

"The raven is more carnirorons than the crow. I once saw one alight into a kingbird's nest and carry away the young, in spite of the eries and eflorts of the old ones."

The crowning cliarge against the erows comes from Frecport, Me., in a letter written by E. I'ratt, Ju, who says:

"Now what 'your erow's' are, or what they eat, or how they get their liring, I know not; but the crows in Maine both dig and eat potatoes, incredulous as jt may appear.

"In some seasons I have known many acres, planted on light soils, in exposed sitnations, devastated by these miscreants, and that in my own neighliborhood.

"Their manner is, when the plant first breaks ground, to dig and pull it up with the tubers attached, though it appears by the partially eaten ones left here and there on the field, that they do not eat them with much avidity.

"I know that popular writers think the erow a great blessing to farmers, but I am jet to be convineed of this, and can only wish that those who think their company so desirable should hare the beuefit of my share."

There is but little doubt in our mind that most of these bad birds nere rarens, and not erows, particularly as Mr. Wales acknowledges the presence of the raven, and says that he is a carnirorons bird.

Now, having said our say, and allowed others to say theirs, about crows, we will drop down to wrens, by way of contrast.

231. Wrens,- We raked one morning-one of those May morningswhen ou domicile was a city one, with delightful sounds coning in at the window. They were the notes of sweet singing birds. What lorely music! It was the first of the season that had come to our cars, and it struck a chord that called to mind scenes of youth, long, long ago. We liastened to the window and looked ont. "Ha! ha! my old friends," we cried, "and so you liave come back again." It was the wrens, the same ones undonbtedly that we built a nesting-place for last year. There was one pair then, now two pair-the progeny, we suppose, of those that sung for us last year. "And so," we said, "you lare hoth come for a nesting-place, hare you? Well, there is the old onc-bnt you must have another. An increasing family needs more room. Tou shall liave it." Notwithstanding the morning was a rainy one, we fenred on pets might feel neglected, and so down we went to provide for their necessities. How amply were we repaid the little labol:! for all the time we were engaged, they were hopping about the peach limbs, picking off the insects, and singing all the while most merrily. Who would not cultivate such society as this? Who would not like to have their trees protected from insects that destroy foliage and fruit? Erery one, surely. Then protect the wrens. Build nesting-places for them, and they will come erery spring and send their sweet notes into your open window, some pleas- 
ant May morning, to waken you to see the beanty of sunrise, or lull you into dreams of the old farm-lionse, orchards, and singing birds.

A paper from Prof. Nash says he has domestieated the eommon wren in this city, by building them a suitable howse, very much to the amusenent and pleasure of the family. One pair hatehed and reared ten young ones in one season, and they acted as perteet seavengers of bugs and worms in the neighborhood. M[r. Nash says two hundred wren-honses were built last yual about Union Square, which were not only occupied by wrens, but sereral other kinds of birds, and these served to keep the park and neighborhood almost free of insects.

A writer in Hovey's Magazine recommended the use of wens to drive other birds away from the cheriy-trees. He says:

"I have seen the experiment of plaeing a wen-box on a eherry-tree, tried in several instances with apparent suecess. The best thing for this purpose is an olive jar. A hole should previonsly be drilled into the side of the jar. which shonld be fixed upon the tree, by thrusting the stmmp of an amputated branch, the more upright the better, into the mouth of the inveried far, of just suftieient size to admit a wren, but too small to allow a hueliril to enter ; since, if it were otherwise, the latter would be sure to get possession of it. The wren being a very jealous and pugmacions bird, is diligent in drising all birts from the tree in which his nest is built, and does not hesitate to attack birds as large as the robin. It is donbtful, howerer, whether the wren would perserere in his attacks, when the robins had become very mumerous, hut the expedient might he used with some ad rantage in all eases."

232. Protecting Trees from Birds.-Sone persons advise throwing a net over the trees, during the few days while the fruit is becoming mature. 'This may be done in some cases, if there are but few trees to be protected, and the owmer can aftord to undertake a job that must be both troublesone and expensive. Such an expedient would be hardly advisable exeept in cxtraordinary eases. Some fix a little windmill in the tree; but as the wheel is constantly turning, the birds soon beenme acenstomed to it, and cease to regard it with suspicion. If anything of this limel is to he nsed, it slionld be kept motionless, until the birds fly into the tree, and then put sudelenly into action by some person who is watehing it. Something like a watelumans rattle elerated on a pole, and fastened firmly to cach of the trees, with a cord to be pulled when the machine is to be set in motion, might answer a suod jurpose. A boy might be hired in this case to wateh the trees, and to jull upon the cords as the birds arrived. Cherries require so short a tinte to ripen, that no tree would neel to be watehed more than one weck.

$\Lambda$ birds always grive the greatest oflense, by their alepredations upun tiruit, to those who own but few trees, om armument is, that the best protection is to plant trees cnomght to serve you and the birds too, with all that all of you can eat. Yon would then not only have the satisfaction of laving what cherries you wanted, but the pleasure of seeing the birds. Fron experience every senson, we are satisfied that the robins sare us more eherries lhan 
they eat. Ont trees were infested with the same lind of yellowish bugs that ate the roses, and are commonly called rose-bugs. We have seen half a dozen of them eating upon a single cherry, attacking them before they were rifer, and before the birds clid. When at length the robins came in goodly mumbers, the bugs decreased, and if the robins ate eherres, they also ate lougs, and we believe more than they did cherries. At any rate we laad more cherries than the birls and all the fanily contd dispose of, and some for our frienls. So we diel not begrudge the dear little birds their share.

As there are some who en not aftord to share their cherries with the birls, and others who are unwilling, we give a way of keeping them off; which we find in the Gurdener's Chronicle, London.

"The following is a plan I once saw sneeced very well for some time, but the birls at last got familia. with it ; still I think it might answer for two months or so. An old gardener being greatly troubled with birch, applied to his master for nets to corer his fruit with; but no, they would be too expensive. Ile therefore got a liawk stuffed in what he ealled a horering position, put it on the end of a long wire, attached the wire to the top of a tree, and thus had the hawk snspended in the air as if it liad been alive. He laal, howerer, another hawk wlich really was alire put into a cage, and had the cage put into the same tree where the dead hawk was. The gentleman in the eage was by no means mute, and I may add that I scarcely erer afterward saw birds in that garlen, except perhaps a few sparrows."

Another plan that lias sweceeled very well at times is to suspend sinall looking-glasses, or bits of a broken mirror, to the limbs of the tree. Where the sm shines, and the wind blows a little, this device answers a good purpose. It is of no nse at other times, exeept that having previonsly frightened the birds, and prevented them from getting a liaunt in the tree, they will not be so likely to come when the mimor is still.

233. The Food of Birds. $-\Lambda$ few facts to show what the food of birds really is, will do something, we hope, to dispel the prejudice which has made man their bitter eneiny.

Wilson, the great ornithologist, computes that a red-ringed blackbird destroys, on an average, 50 grubs a day through the smmmer. Many other birls are equally useful to the farmer. No goll would buy the services performed by the birds. One often may be seen following the plowman hour after hour.

Then look at the eternal labor of the birds in fall, winter, and spring, pieking up the seeds of weeds, and upon these they lire until grain ripens, before it is possible for them to harm the farmer.

We therefore urge farmers to spare the birds. They pag more rent than tlie worth of all they eat. Robins hare been thoroughly proved to be insecteaters, and great destroyers of noxious pests to the farmers, by a committec of the Massachusetts IIorticultural Society.

This Society has done a deed wortlyy of eommendation by all the lovers of birds. A resolution was moved to get the Socicty to ask the Legislature to 
lepeal the law for protection of robins, npon the gromel that these birds were noxious to the farmer ; it being contendect that their food being reeretable, they were great destroyers of valuable fruits. Upon this, Prof. . Tenks (Prot. of 'Zoology) suggested that the Soeicty should first learn the habits of the rolin, and a committee, consisting of Plof. Jenks, C. M. IIorey, and E. S. Rand, Jr., were appointed, and have reported the following fizets: "I'tan Adopted for the Investigation.-1. To obtain birds at daybreak, midday, and sunset. 2. To obtain birds from both the village and the country. 3. To preserve in alcolol the contents of each gizzarl.

liesults in P'rocuring Specimens. - Beginning with the first week in Mareh, 1858, speeimens lave been examined at least weekly, and most of the time daily, to December, and duriug the winter months, at least semi-monthly to the date of the report, in the spring.

Results of Inrestigation.-1. Early in Mareh, numbers of this bird made their appearance in this vicinity (Boston); but, until the second week in April, unly the male birds.

2. The gizzards of those killed in the molning were, as a rule, either entirely empty, or but partially distended with food, well maecrated; while those killed in the latter part of the day were as miformly filled with food freshly taken.

3. From the almost daily examination of their gizzards from the early part of March to the first of May, not a particle of vegetable matter was found in the gizzarl of a single bird. On the contrary. insects in great variety, botly as to mumber and kind, as well as in every variety of condition as to growth and development, were the sole food.

But nine tenths of the aggregate mass of fool thus collected during this period eonsisted of one kind of larve, which, throngh the aid of Baron Ostensaclien, seeretary of the Russian legation at $\mathbb{W}^{r}$ ashington, I was cuabled to identify as the Bibio albipennis (Suy), and whose history and habits, by the airl of J)r. Asa Fitch, entomologrist of the New York State Agrienltural Society, I was cnabled to make out quite satistiuctorily.

Fom one to two hundred of these lavve were frequently taken from a single gizzand, all in a fresh, munacerated condition: and usually, when these larva were found, they were the only food in the stomach.

'lo quote from a communication reecived from Dr. Fitcl, he says: " $M[y$ attentiun was first lirected to this fly some twelve years ago, when I was occupied in investigating the wheat midge. I observed it to le so very common in fields of growing whertt tlat I suspected it of living at the expenso of that grain crop; but on looking aromul 1 found it was equally as common everywhere else-resting $u$ ron the grass, leaves, and flowers in my yard and grarlen, as well as in meadows, lastures, and forests. $* * * * *$ It comes abroarl abont the 20th of Mily, and contimues aliont a fortughtit. You will readily deengnize it ly its commonness, and its white transparent wings; its body heing black, elothed with solt, white hairs. It is rery slugersish, moving around but little, and is ensily picked up by tho fingers. * * * 
On page ret of the London Gardener's Chronicle of the year $15+t$, is a ralualule atricle of Ruricola, (J. O. Westwood), giving a finll histury of the Bibio llurci, the Luropean analogue of' the ene in question. 'It appears these insects (unlike most others of the family Tipulidie to which they pertain) are most pernicions, the larve feeding upon the roots of plants, sometimes to such an extent as to cause them to wither and dic. Ruricola states that the larve of the Merci, and other allied speeies of Bibio, ate frequently sent to him by graleners, who find them to be mischierons in their strawberry beds, vine borders, flower pots, and other sitnations where the soil remains undisturbed during the autumn and spring.' And another writer, Bouche, says 'that lis bed of ranunenluses was completely demolished, for several snccessire year's, by these worms eating the roots.' From these fircts erery one will perecive that the robin, consmung, as you fomm it to do, from one to two lundeed of these Bibio larve daily, during the months of Minch and $\Lambda$ pril, has probably been ribling our gardens of these vermin every year litherto; thus rendering us an important service, of which we lave been wholly maware. * $*$ * The larrie are gregarions; living together in swarms, and perforating the ground so that it resembles a honeycomb.

'This is probably camsed by the parent fly depositing her whole stock of egrgs in one spot, slie being too lazy and slothfnl to wander abont and distribute then in different places. Hence the robin, on finding one of these worms, knows that there is a host of others at the same place, and thus repairs to that spot, day after day, and gluts himself with then till the whole colony is cxterminated.'

To this extract I may be allowed to add, that my own observations, during the past year, confirm the conelusions of Dr. Fitch respecting this larra in erery particnlar, luaving found its colonies in Forember, and observed the fy in early summer. I may also here introduce an extract from a commnication of a lady friend, mder date of Oct. 7, 1555. She says: "On speaking of your remarls concerning the food of the robin, at the Teachers' Association at Bridgerater, in June last, to my father, he told me of a little circumstance which I thought just proved your statement. It was formerly the custom to have a shooting matel on election day in MLay. On such an occision in Nortl Bridgewater, about the year 1520, a great many birds were lilled, so many that a man bought them by the eart-load for the purpose of enriching lis land. In consequence, there was a great seareity of birds in that vicinity, and a great amount of grass land seemed to be injured, but from what camse no one knew. The grass withered and turned darkcolored, as thougl it liad been burnt, commencing in small tufts and spreading in large circles." It would seem that the insect nnder consideration would, growing undisturbed, produce precisely this result.

t. During the month of May, the Bibio larve entirely disappeared from the grizzarls, but up to the 21 st of June, was replaced by a variety of insects o: rorms only, including spiders, caterpillar's, and beetles of the family 
Elaterida, the palents of the well-known wire-worms, so destructive to corn and various other seeds when committed to the sromnd.

The carth-worn I fonnd to be a favorite food for the yomng bird, but eparingly employed by the adult for its own use.

5. From the date of June 21, I began to find strawberries, cherries, and pulpy fruit gencrally, but in a majority of the exaninations intermingled with inseets, which led me to conclude that they were not fond of an exelnsively vegetable diet, but lather adopted it as a dessert, and from the case of procuring it, particularly during the encrvating season of motting. At this season of the year, I discovered a marked difference in the food of the birds killed near or in the village, and those killed in the conntry at a distance from gardens and frut-trees, the latter liaving less stone frnit and more inseets in their gizzards, which led ne to conchude that the robin is not an extensive forager.

6. The mixed diet of the robin seems to continne from the ripening of the strawberries and cherries to October, the vegetablo portion consisting, during Lugust and September, in great part of elderberries (Sambucus canadensis) and pokeberries (Phytolacea decandra).

7. During the month of Octolser the vegretable diet is wholly discarded, and its place supplied by grasshoppers and orthopterous insects generally.

S. Early in November-the robin migrates sonthward-the fow remaining eking out a miserable existence, during the winter montls, on layberries (Myrica ceriferet), privet berries' (Ligustrum vulgare), and juniper berrics (Juniperus communis)."

Here is something further upon the food of robins: In the report of the proceedings of the Boston Society of Natural Ilistory in September, 1S58, we find an instruetive pajer from Prof. Treadwell, of Cambridge, giving a detailed aecount of the feeding aud crowth of tro ilueriean robins (Turdus migratorius, Limn.), during a period of 32 days, commencing from the 5th of June.

"When camglit, the two were quite young, their tail feathers being less than an inch long, and the weight of each abont 25 pennyweights-less than half the weight of the full-grown bird. Both were plump and rigorons, and had evidently been very recently tumed out of the nest. He began feeding then with eath-worms, giving three to cach bird that night; the second day, he grave them ten worms each, which they ate ravenously; thinking this heyond what their parents could naturally supply them with, he limited them to this allowance. On the third day, he gave them eight worns cach in the forenoon; but in the afternoon, the found one becoming feeble, and it soon lost its strength, lefused food, and died. On opening it, he fonnd the crop, gizzari, and intestines entirely enupty, and concluded, therefore, that it luad died from want of sullicient food, the eflect of lnunger heing perbaps increased by coll, as tho thermometer was about 60\%. 'Nhe other bird, still vigorous, lie put in a warmer place and increased its food, griving it the third dity 15 worns, on the fourth day 24 , on the fifth 25 , on the sixth 30 , and on 
the seventh 31 worms. They semed insuftieient, and the bird appenred to be lusing plumpness and weight. He began then to weigh both the bird and its food, and the results were given in a tabnlar form. On the fiftecnth lay, he tried as small quantity of raw meat, and finding it readily caten, increased it gralually, to the cxclusion of worms; with it the bird ate a large quantity of earth and gravel, and drank freely after eating. By the table, it appears that though the food was increased to 40 worms, weighing $20 \mathrm{dw}$. on the eleventh day the weight rather fell off; and it was not until the fonrteenth clay, when he ate $6 s$ worms, or it dwt., that lie began to increase. On this day the weight of the bird was 24 drt.; he therefore ate 41 per cent. more than his own weight in twelve honrs, weighing after it $29 \mathrm{dwt}$, or 15 per cent. less than the food he had eaten in that time. The length of these worms, if laid end to end, wonld be abont fourteen feet, or ten times the lengtly of the intestines. To meet the objection that the carth-worm contains but a small amount of nutritions matter, on the twenty-serenth day he was fed exclusively on clear beef, in quantity $23 \mathrm{dwt}$; at night, the bird weighel 52 dwt.-bnt little more than twice the amount of flesh consumed during the day, not taking into account the water and earth swallowed."

A man eating in the same proportion wonld consume 70lbs. of flesh and five gallons of water. Four young robins would require, according to the consumption of this bird, 250 worms, or their equivalent in insects or other food, daily. After the thirty-second day the bird was fed for eirgliteen days on an average of 15 dwt. of meat, tro or three carth-worms, and a small quantity of bread each day; the whole being erual to 18 dwt. of beef, or 36 dwt. of earth-worms; and it las continued to eat this amount to the present time. The fool was never passed nndigested; the excretions were made up of grarel and dirt, and a small quantity of white semi-solid urine.

Every admirer of trees may derive from these facts a lesson, slowing the immense power of birds to destroy the insects by which our trees, especially our apples, elms, and lindens, are crery few years stripped of their foliage, and often many of them killed. The food of the robin, while with us, consists principally of cartl-worms, various insects, tlecir larve and eggs, and a few cherries; of worms and cherries they ean procme but few, and those during but a short period, and they are obliged therefore to subsist prineipally upon the great destroyer's of leares, canker-worms, and some other kinds of caterpillars and bugs. If each robin, old and young, requires for its support an amount of these equal to the reight consumed by this bird, it is easy to see what a prodigions havoc a few hundreds of these must make "ipon the insects of an orchard or a park. Is it not, then, to om adrantage, to purchase the service of the robins at the price of a few cherries?

Speaking upon this paper, the editor of the Newark (N. J.) Advertiser says :

"There is so little knowledge of the habits of birls, and their ways and means of gaining a living in the world, that anything which promises to produce better aequaintance with them ought to be generally made known. 
"It will be seen by this account, that quite a young robin died from starvation, because it was allowed but eight or ten earth-worms a day. The surviror was afterward treated more generonsly, and his fare was increased from day to day, till he had for his dimer 69 worms, or $3 \pm$ dwt., though the robin himself weighed only $2 \pm d w t$, thus consuning in twelve hours 41 per cent. more than his own weight.

"After the birl was tully grown, he continued to eat one third of his own weight in clear flesh dally! A man with such voracity (inferior, howerer, we have secn to that of the young bird while growing) would liare some difliculty in fuding board in any of our cities. But nature is not obliged to go to market to sustain ler ehildren with comfortable food. This sane robin, if permitted to be free to satiate his prodigrious appetite, not eliefly on cherries or other fruits valued by man, but upon nan's enemies, wonld lange himself on the side of man, and slaughter the numberless insects of every variety which are destructive to his crops. Here we hare reason to be grateful for the prodigions appetite of the robin, and thank him for his extraordinary gormandism. This guest at the tible of nature is achlessed in very diflerent language from guests generally. She says to him, Will you take something further? pray don't spare, but help you'self to the spider, the canker-worn, the.measurer, the caterpillar, grub, slug, and bng, and help Jourself also to a score or two of eureulio's eggs. 'Thus, 'more the merrier'. is the sentiment of nature's feast. ITow the insect tribe, and all the wicked fry who infest our fruits and cereal erops, fall before the all-derouring robin! Even the ngly bug that is said to infest and feed upon the tubers and tops of the potatoes, producing thereby the blight or rot, might be exterminated, if the robin and other birds were not destroyed or frightened away by boys, or men as stupid or mischievous as boys.

"For what had been remarkel of the romeity of the robin, is probably true with respect to other birds. Men have but recently come to the knowledge that they are the most eflectual protectors they can have of their fruits and crops; but nobody till now has been awitre of the full extent of the obligation they are nnder to eren a few birls in eonsequence of their being such cnormous eaters. If their board costs them anything, they never could be able to stand it. But it does not-only now and then a life or two among them, taken ly some raseal or vagabond, who should be their true benclicetors, for they are busy in the service of man."

This birk, tho robin, is probably known to nearly erery one who will real this rolume; bnt we will add the following short description:

The robin measures nine inches and a halt in lenght. 1 lis bill, which is about an inch long, is strong, yellow, and dusky near the tip : the heat, hack of the neck, and tail are black; the back ind runp), ash color; the thront and upper part of tho bueast are hlack, the former streaked with white; tho whole of the rest of the breast down as fir ats the thighs is of a dark orange; belly and vent, white; legs, dark hrown; claws, black and strong.

It huilds a large nest, often on an apple-trec, which it plasters on the 
[Cirap. II.

inside with mud, and lines with hay or fine grass. The eggrs are from four to six, bluish green, unspotted. Thing feed on worms, insects, fruit, and berries, especially those of the sour gum-tree (Nyssa sylvatica). When fitt, the robin is in considerable esteem for the table.

These birds are among onl earliest songsters. Eren in March, while the snow yet mantles the fields and woodlands, he will mount a post or leafless tree, and make an attempt at a song.

They are ornamental to every firm, and should be eneonraged to bnild their nests in every garden.

23t. Birds Destroying Grasshoppers and Worms,-Last year, in the neighborhood of Philadelphia, there was a swarming pest of grasshoppers. Byand-by, when every one was at his wits' end to know what to do to get rid of this scomrge, there was a sudden appearanee of immense flocks of plover, which spread themselves orer the fields, and deroured with avidity the grasshoppers. Some of them lave been shot to test the matter, and their crops hare been fonnd full of grasshoppers. The rarages of the latter soon cease wherever the flocks of plover appear, as the great number and voracity of the birds render them more than a mateh for the insects. Up to this risit of plover, the only relief from this calamity was the eagerness with which the fowls devonred the grasshoppers. Turkeys, the most efficient adversaries of these insects-because the largest and most active-hare thriven wonderfully upon them. So have the ducks, geese, and chickens. If farmers prefer to be annully eaten up by insects, they will continue their insane warfare upon birds. On the contrary, let them be protected, and cncouraged to build their nests in the very windows of onr dwellings, and see what myriads of pests they will destroy!

In one of the years that I lired on the Western prairies, there was an irmption of greedy devourers of farn crops, known as the army worm, coming from no one knows where, nor when to look for its marcls. It is easy to trace it, however, after it has marehed over a comntry, for it consumes every leaf of grass and grain, whererer the army spreads itself.

lanmers sometimes plow a deep furrow around a field as the army approaches, and this furrow will soon fill up with worms, which are crushed by a $\log$ drawn over them; repeating the operation every day. This is troublesome, and not always effective. In the year allnded to, the army appronehed just at the time it wonld be destructive to the wheat erop, and the owners of the most exposed firms were in sore tronble at the prospect before them. For two days they looked on in dread. "One more day," they said, "and we slall be swept." One more day came, and with it one of man's best friends, the worm-eating birds. Looking out sonthward where the worms were at work on the prairie grass, a black clond was seen hovering close to the ground. It was a elond of blackbirds, coming "up from theip great nesting-place in the liankakee marshes, to feed on the worms. They anved the wheat crop. It is true that this variety of birds, when they come in great flocks into the grain-fields, are pests, but not lialf as bad as worms 
and bugs would be if not destroyed. Besides, birds can be watehed and driven away from fields, where no eflorts of man would serve to drive away an army of worms, mareling to destroy, uor prevent his firm from being devastated by such a fliglit of grasshoppers as swept every green thing from a portion of Minuesota a few yen's ago. Birds, then, in countless numbers, will be found to be man's best friends.

235. The sap-Suckers.-The name of "sap-sueker" has been griven to a very useful class of birds, under the erroneous impression that they sncked the sap from the fruit-trees, where they are often seen, hour after hour, clinging to the bole of an apple-pree, paticntly drilling, drilling, drilling their little bills through the bark, leaving it, sometimes, as full of holes as a honey-comb. It is a slander upon these beantiful, busy little birds to suppose their object is to suck ont the sap, and thus destroy the trecs. To say that the "sap-sucker" givlles apple-trees and destroys them, or taps the Austrian and Scoteh pines so as to eanse them to bleed to death, we must liave stronger proof than slipshod statements.

In argmment against the birds, it has been stated that they have been shot while in the very act of

$$
\text { "Tapping the hollow beech-tree," }
$$

and their claws examined without fudiug a worm, and nothing hut pieces of bark, thus proving their olyect to be eating the bark, if not sucking the ๕ap, and that they were therefore very injurious to trees. These unicroseopic examinations only prove what we lave lung belicred, that the bird can not always tell where the worm is that he wants, and so has to bore until he finds lim. It is not likely that lie goes far amiss, and probably lits him oftener with the first hole than he fails. It is thought by many persons that that tronblesome little destroyer of fruit, the curculio, deposits its erges in the bark of trees, and that that is what the salp-sucker is after. It is certain that when sap-suckers abounded in our orehards, there was no complaint of curemlio. In om opinion, a perfectly healthy tree, free from insects, is nerer attacked by any of the mut-hatch family-rulgarly called "sap-suckers." We helieve that, on the contrary, they are of essential service to man; and that it was one of the admirable provisions of nature, where ererything works on an eren balance, until one scalo is overloaded ly man, that the nut lateli shonld stand sentinel over the fruit-trees, and keep the pestiferous insects from getting the halanee of power.

236. Io Birls liat Rees ? -It has longg been a mooted question whether the birds known as "lingbirds" (the Muscicape tyrunnus) destroy bees? This hirel has obtaned his name from a spirit of boldness in attacking ant driving awaly birels of much larger size and power, enongh to kill him at at simgle stroke. ITe has obtained the name of a elestroyer of honey-lrees, and war to the death has been declared against him, on the evideuce of his bat name, and, as we think, without anything like a fair trial.

$\Lambda$ few years ago we eliciterl a great deal of testimony upon this question. One winess, Mr: Nathanicl M. 'Tobey, of Tomplius Connty, says he is an 
old famel, lias kept bees ten years, and always encourarged birts to make their homes upon his premises. One season, observing two kingbirds about his hives, he was curions to know what they were after, and ascertained to his satisfaction that they caught bees on their retum to the live, not to cat them bodily, but to disembowel them and despoil them of the "loney-sack."

Ie attributed the non-swarning of the bees to this pair of lingbirds, but says his bees hare nerer becn molested sinee.

That the kingbirds canght Mrr. Tobey's bees we have no doubt, since he says he saw the disemboweled eareasses muler the trees where they alighted, but that one single one of them was a worlier we do doubt, and that a single pair of kingbirds were the eause of the non-swarming of sereral hives of bees, we hare no doubt upon the subjeet-we know it was not the case-it rould be a preposterons absmrdity to beliere snch a wild tale. We do not believe that all the kingbirds in the world erer destroyed a hire of worlingbees, and a man who will lill the innocent birds withont better proof of their guilt, than all that we have heard, is at heart a-bird murderer.

Other persons deelared that they had often scen kingbirds cateh bees, on the wing, near the hire. This we do not doubt, because others have seen the same thing, and have killed and dissected them and found bees in their crats. But in erery case where they were examined by persons competent to decide, they have declared that none but drones were erer found. Upon this point the instinct or observation of the bird is perfect; and this may lave been one of nature's provisions, that these birds should be assistants of the workers, and not their destroyers. Certainly, until we have some better eridence against the birds, we shall adrocate their protection. Surely, if they eat bees, they also eat other flies, and if permitted to live and multiply around our dwellings, might keep us free of a great many pestiterous insects. If a bird can cat a stinging-bee with impunity, it can also cat a wasp or hornet, and so destroy that family.

237. Swallows, Swifts, and Martins.-In our boyhood, swallows were looked upon as pests of the farm, or yather the barn, and war was often waged upon them by the boys, with the comntenance of those who should liare been well enough informed to teach them better. We hope the day is past when any one ronld wantonly destroy these beantiful birds.

Ifirundo is the generie term applied to the class of birds comprised in the sereral species of barn swallows, bank swallows, chinney swallows, and a large, strong sort known as strifts, and the comnon martin, for which many New England people are careful to provide boxes, which are often attached to the drellings. Their first appcarance in spring is hailed with delight, and the time of their coming often noted, so as to compare one year with anotlier. Although "one swallow does not make it spring," people have learned to think that many nerer come mutil spring is fairly opened.

The Ilimundo family are all birds of passage. They go far south to winter, and return with great regularity to their old haunts, to build their nests, rear their young, and catch flies, till autmmn approaches, and then they are 
off. They cross the parallel of $40^{\circ}$, on their northern journey, about the first of May.

'The barn is often tenantless at night, and alive with the twitter of swallows the next morning. To talk abont their hybernating in the mud, or in hollow trees, is simply ridienlous. Fou might just as well expect wild greese to go down into the mud to winter, as for the swallows to do so.

'The following deseription of some of the rare varieties of the llirundo we fonnd in the Country Gentleman newspaper, and thought it interesting:

"The Cliff, or Republican Swallow, Irimnlo lunifrous, or $\Pi$. fulver, is a well-known swallow among farmers. Its crown and back are of stecl bise, belly white, length five inches, plus, and the stretel of the wines twelve inches, plus. They formerly ocenped the elifi's of the Rocky Mountains and the fur countries. One of the first records of their appeance in the states was at Ilenderson, and Newport, Ky., on the banks of the Ohio, in 1815. In 1817 they were observel at Whitchall, N. T., near Lake Champlain. These birds are of social habits, building thcir nests in clusters, or near ench oiher. Ficillot observed one at eca, oft Nova Scotia, long before this. They liare long been known in that province. In 181s, it is stated that they hegan to build at Crawford's, near the base of the White Momntains. General Dearborn saw their nest at Winthrop, Me., in 1S30; also in Gandiner. The writer first saw them in Worecster County, Mass., about 183s. Their nests are arranged frepuently along under the eares of a barn, in the form of a projecting retort, constructed of pellets ot earth, witl an internal lining of dried grass, in which are laicl four eggs. Their mote is not a twitter, but, aceording to Audubon, resembles in somnt the rubbing of a moistened cork in the neck of a glass bottle. Within a quarter of a century they luve become the furorites of many New Encrand furners.

"The Tiolet-green Swallow, Ifirundo thatassina, tail acutely emarginate; back a solit, relvety green, shaded with purplish viulet; length fire inclies, and the streteh of the wings twelre inches; is eommon in the lioeky Mlountain region. They are the associates of the eliff swallow, just described, their note being more like that of the ban swallow. Their nests resemble those of the eliff swallow, ranting, however, the pendulons neck. They sometimes ocenpy the deserted nests of their associate species. They are nut common east of the Mississippi River.

"The White-bellied Swallow, Mimendo biculor, is of a ghlossy, metallie green abore, and white below; hence its common name. Its length is six inclues. and the stretch of tho wings is twelve and a lialt inclies. It is not as contmon as the harn swallow, and is allied somewhat to the purple martin. Their note is a shrill, lively, wabline twitter. They are usually the tirst swallows llat appear in the spring. They hreed in some deserted honse or hollow tree. They use no mud in building their nests, which are lined with ferthers.

"The Rough-winged Swallow, Mirumlo semipennis of A udubon, and Cotyle serripenuis of Bonaparte; color alove a light, sooty brown, and bencath 
at whitish gray; length five and a half inches, and the stretch of the wings twolve inches.

"The Chinney Swift or Swallow, IIrundo pelasgia of Linnzus, and Cherture pelesyiu of stephens; color a sooty brown; lengti five inches; the streteh of wings twelve inches; the tail is sliort and mucronate. They build their nests tiequently in chimmeys, sometines in hollow trees. They are small and shallow, and are attached to the side of the chimucy or tree by an adhesire gmm or mucilige secreted in the stumach of the arehitect. They feed their young through the greater part of the night, as the writer has frequently obEerved. The noise they make in passing (lown and up the chinney resembles distant thunder.

"Vaux's Chimmey Swift, or the Oregon Swift, resembles the one described above; length three and a lialf' to four and a half inches; stretch of the wings ten inehes, plus. This speeies is not rare on the Western coast.

"The swallow tribe are remarkable for their social habits, living generally in colonies, constructing their nests together; and when the scason for migration arrives, they leave in large flocks. They usually ren two broods or more per pair during the summer. They frequent watery places or swampy lands, ponds, ete., in pursuit of winged inseets, which they take on the wiug. In far weather they usually fly high in the air. As the air becomes less dense, the insects fly nearer the earth, and the swallors skim near the surface of the earth or water, which prognosticates rain at hand. The number of thics, gnats, etc., anmually consumcd by swallows exceds all calculation. Hence the truth of the observation of a farmer', whose barn-cares had beneath them one connected line of cliff swallows' nests: 'I am very glad to have these birds here, for my cows and milkers a:e much less troubled with gnats and flies than before these swallows came in such numbers.'

"Some farmers try, mwisely, to exclude swallows from their premises, because, say they, 'these birds make dirty work.' Granted, but it is far less troublesome and annoying than the insects of the linds named, which greatly multiply in the absence of the swallows, swifts, and martins."

Barn swallows and martins are too widely known to make a deseription of them interesting in this place. Children, howerer, should always have an opportunity of seeing their prortraits and roading their history in Audubon or Wilson, as well as that of every other bird, and, by learning their habits, judge which is and which is not beneficial to the farmer. Swallows and martins would ecrtainly not then be doomed to destruction. D. WV. W Wrner, of Sharon Springs, N. T., says :

"My father repeatedly attempted wheat-growing, but as often failed, the weeril taking the whole crop, until a large colony of martins established themselves under the eaves of the barn, since which time he has raised good crops of spring wheat. The wheat has been growu within one hundred rods of the barn. Query-Had the nuartius anything to do in preventing the appearance of the wceril ?"

238. Skylarks and Imported Birds.--Several attempts have been made to 
introduee skylarks into this country. In February, 1853, John Gorgas, of Wilunington, Del., received a lot of twenty, which were kept confined until the 19th of March, when they were set at liberty. Another lot of twentytwo anrived April 1Sth, and were ect at liberty the next day. This was only twenty-two days from the time they were trapped in England. These birds propagated in the neighborhood that season, and strong hopes were entertained that the English skylark had been introduced permanently into this country; but these hopes have not been realized. A letter from Mr. Gorgas, in the summer of 1860 , indicates that the birds have all disappeared.

There was also another lot of sliylarks imported, and liberated in Greenwoorl Cenetery, on Long Island, in the spring of 1853 , and still another lot were set free in Washington eity, at a later period; but, so far as we ean learn, all of these birds have disappeared. This is greatly to be regretted ; for besides the interest of their curious flight and song, they are great insect destroyers. Their home is in the grass and grain fields, and their food in summer is entircly composed of insects and worms that are pests to the farmer. In Europe they inlablit a wide range of latitude, feeding in winter upon seeds of grass and weeds, and, if located too fiur north, making a sloort migration to a milder clime. It can mot be owing to the cold that they do not suceed here; but it is not improbable that the cold has prompted them to move sontluward, and they have not felt disposed to retmrn. We still hope the skylark will have its home with us, as eommon as in England, where it is so noted as a song-bird. Its flight skywarl is also rery curions. It ascends perpendicularly, as thongh it serewed itself through the air, until quite ont of sight, and after a little deseends in the same way. The skylark in Europe is a fine table luxury, notwitlrstanding they afford but half an onnce each of meat to the epienre. Vast numbers of just as diminutive lirds are sacrificed upon the epicurean tables of all our large eities in the United States.

To those who may take an interest in the importation of birds, the following account will be useful, as giren by Mr. Wr. Brodie, of his successtul transportation of English pheasants, gold plieasants, and partridges from England to New Zealand. IIe says:

"I left the St. Katherine's Dock with thirty-six pheasants and partridges on board, and after a long and most disagreeable voyage of 261 days, landed in Aneklanl, New Zealand, with the same number as I lad left England with. It is a pastime to eabin passengers going a long royage to lare some occupation to break the monotony of shipboard imprisonment. I thereforo looked after my own lirds, cleaned them ont every morning, gave them fresh red gravel (coarse) erery other day, supplied them bountifully with fresh rater (not water camght on leck after a heary rain, as there is a certain quantity of tar in it), never allowed them a fresh-water bath, fed them with buckwhent, wheat, canary-seed, and hemp-seed alternately, weck nud weck about, kept then in wicker eages made on purpose, three fect long, 
two fect wide, and one fort high, and praded the top inside the lids of the eages, to protect their heads.

"These birds were kept on deck the whole of the royage, with a painted canvas corer to proteet them from the salt water in bad weather. Hence my sucess. The increase of $m y$ birds has amomted to tens of thousands. In the northern part of $\mathrm{New}$ Zealand they breed twice a year, and they have stocked the province of Anckland, 200 miles distant from the point whero they were first sent ahrift, which was upon one of my estates, near the North Cape of New Zealand. In the carly part of 1559 I sent ont 400 house and helge sparrows and yellow-hammers to Auckland; and I hope in Seprember to send ont 400 singing birds to the same port gratuitously. Birds shonle not be sent ont between Mareh and September; those sent in April or May are sure to pine aray and die, it being their pairing senson."

By pursuing the course adopted ly Mr. Brodie, we might hare some of the most rare birls of Califurnia bronght to the Atlantic States, with un. doubted profit to the importer.

239. Laws for the Protection of Birls.-The State of New Fork has Had what is called a "game law" for a good many years; but it was a law for the protection of a class of men and boys who, withont any claim to the title, called themselres "sportsmen"-such sportsmen as would shoot a robin-red-breast on her nest, or an imported skylark in the nidst of lis song. The law was only incidentally beneficial to famers, so far as it protected game birds, the most of which are great insecteaters. There is not a farmer in all the old States that can affurd to have a quail killed npon his farm, if he ras prid a dollar a head. This species of wild bird wonld be semilomesticated, if man would allow it to be so. The have seen them so gentle that they often came around the barn for food in winter, and only walked slowly away at the approach of man. At such a time we wonld not kill one for ten times its value as food. All the past summer we had tho delight of knowing that a pair of these beautiful birds were safely rearing their young only a few rods from onr home. Often, as we walked about the little farm, they were secn dodging along some prath, or between the eorn-rows, or into the shelter of the grass or shrubluery. Then, with what sweet satisfaction we listened to "Bob White," sitting upon the wall, telling us almost merringly of the approach of "more wet!"

An Illinois farmer declares that a flock of quails made him a crop of corn, luaving voluntarily taken upon themselres to rid the field of cut-worms. "I never," says he, "can again consent to the destrnetion of these raluable hirds. I used to shoot and trap them, but I was ignorant of their value on tlee farm.

A ueighbor of ours, a true sportsman, said to us, the other day: "I have done shooting quails. I used to think it real sport to wing these beautitul birds; and the temptation to do so was enhanced by the delicious food they afford. I really think that I nerer shall shoot another quail in my life."

In answer to our "Why?" he said : 
"I hard never studied their history, and the nature of their habits, and eharacter of their tood, mutil this seatson. I was ineited to do this from mecting with a pair of the birls every time I walked over al ecttain portion of the firm. They were almost as gentle as the fowls in the door-yard, and frequently I noticed them so busily engaged picking up worms in the comfield, that it led me into a train of thonght and study that has taught me not to kill quails. $\Lambda$ few days ago I satw my pets-for ench I had come to regard them-with sixtecn young ones, each nearly as large as its parent. If I could grnard that flock from the depredation of idle boys, no money would buy them. Why, what uschul as well as interesting birls they are! We want stringent laws, well enforeed, to protect quails."

Yes, but, most of all, we want information for furmers of their walue.

The following are the penalties of the New York Gane Law, passed $A$ pril 14,1860 :

It is $\$ 25$ fine to kill a deer in the first seren montlis of the reas.

It is $\$ 2$ fine to kill a woodeock between Jamuary 1 and July 4 ; or a partridge (ruffied gronse) between Jamury 15 and September 1 ; or a quail between January 1 and October 15 ; or any wild duck between Febrnary 1 and Angust 1.

It is $\$ 10$ fine to kill a prairie fowl, or pinnated gronse, at any time within fire yerrs.

It is $\$ 10$ fine to trap or suare quail or mrouse.

It is 50 cents fine to kill, trilp, or suace a nightingale, night-liawk, lilucbird, yellow-bird, oriole, finch, thrush, lark, sparrow, wren, martin, swallow, woodpecker, or any other harmless birl, at any tine; and bobolinks and robins only between Februnry 1 and Octoher 1.

It is $\$ 5$ fine to catch brook or lake trout, or musealonge, betwecn Septenber 1 and March 1; and it is \$2 fine to catch them in any way but by a houk and line.

It is $\$ 5$ fine for any person to enter the premises of another with fire-arms, or other lunntiug or lishing implements, with the intent of using them; and if he enters upon a cultivated fick, orehard, w garden, or where crops are growing, in pursit of game, withont the eonsent of the owner, lie is finable $\$ 10$ for each oflense.

Such is the law now in force in this State. I.et all who are interested see that it is male effectual. The liflienly in the way of its enforcenent is an very lax state of morals anong the people, many of whom consider lideds free plunder; and they lave so lomer enjoged the privilege of rambling orer everybody's land, as freely as though they owned it, that it is hard to convince them that they do not. The contrary can never be taught in conts. nor ly funcs and prisons: it must he taught in our common schochs and arouml the finmer's fireside.

New Jersey has an good law upon her etatute hook for the protection of

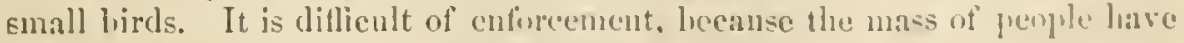
been educited to look upon all birds is noxions, or else wortly of destruce- 
tion for food, and of no other value. They do not even look npon poultry in any other ligint. lot the truth is, poultry is worth ten times as much to the farner for the work of destruction it does upon his pests, as it is for the food it affords him. It is just so with grame birels; and if the owners of land well situated for ganc preserves were able to preserse the birds, tho enltivated portions might be benetited, and the owners could make the keeping of wild birds as profitable as tame ones.

From time to time latrs have been devised and statutes enacted for the prescrintion of game; but until recently such leyislation las been originated by the wealthy men of eities, the men of the educated and leisure classes of the community, the consuners and killcrs, not the fecders and possessors, of the gume or the owners of the acres. This has generally given to these statutes the appearance, thongh in no degree the reality, of partaking of the odions character of class legislation; of being enacted for the benefit of the rich against the poor, the proud against the humble, the men of leisure against the men of labor. The farmers, who knew little and cared less for the game which ran wild in their woods, fluttered in their tangled swamps, or sercamed ored their boggy morasses, did not conccivo how it conld have any real value in the eyes of any rational being; regarded all legislation forbidding its slaughter, except at stated periods, as a derice cumningly framed for depriving them of their own natmal and indefeasible rights, and for giving amusement and gratification to finely-dressed, flashy strangers from the towns, who eame periodically into country places to break down fences, trample under foot growing crops, and kill the game reared on the farmer's land, which was, in its rery nature, and from the mode of killing it, useless to the farmer himself. In a word, they looked npon the Gamc Laws as an oftensive, aristocratic, unrepublican, European invention; a sort of scheme for making the rich richer, and the poor poorer-an idea sedulonsly eneouraged by all the brawliug foreigners and pot-louse rillage loafers, who, too lazy to work, found their own profit in poacling a few starveling parent birds on the nests, or half-grown fledgeling young fry on other men's lands, which they might trafic or truck away to railway conductors and stagc-coach drivers, fol transmission to the eating-honses of the cities.

Gradnally, howcver, they-the farmers, we mean-harc come to open their eyes on this question. The feaful juerease of insect life, the prodigions deterionation of the crops of all kinds, the threatened utter extinction of some of the most ralual, American staples in the rery localitics of which they were formerly the pride and hoast-as, for instance, the wheat crop of the famous Genesec Valley, where it is already questionable, from the yearly aserravated ravages of the Messian-fly and the weevil, whether it is any longer profitable, or perhaps prudent, to sow wheat-have forced then to perecirc that this growth and superabundance, daily and hourly aggravated and cxaggerated, of insect pests is to be attributed wholly to the unprecedented destruction of small birds. At the samo time, the rast and hourlyincreasing demaud for gane in the large eities, the immense freights and 
cargoes of wild animals sent down yearly, so soon as cold weather allows its safe transportation by express companies and railroad cars-imnense, yet still inadequate to meet the call of the markets, although the illimitablo West is fast suffering depletion, and is in some States legislating agrinst exportation-luave quickened the perecption of agrienlturists to the fact, that if game be wortl as much money in the market as poultry, or jnore, aud can be raised at no cost and less than no trouble, it is better to have the woods, which they necessarily keep up as timber lots, the lijll-sides, which are too clangry and sterile of soil to rear anything but brambles and ferns, and the morasses, which it wonld be too costly to d!ain, swarming with profitable wild animals, than waste and umprofitable; and to the other fict, that it money is to be made by killing game on their lands, it is as rell at least, if not better, to make it tluemselres, and to go on making it, year after year, by maintaining a sufieient brecding stock, as to suffer it to be made ont of their pockets by every landless, shiftless vatgibond who chooses to stanpede every head of game out of every furm, and who luas no eastlyly reason or inducements why he should not kill as speedily as possible the goose which lays the golden egres-secing that the goose, if slain by himselt, is clearly his, while the eggs, in futuro, muy fill to the lot of any other 'Tom, Dick, or Hary of his own jeputable or disreputable order.

The farmers and land-owners being thus convinced of the loss directly attributahle to the killing of small birds at all, at any season, and of the grent gain certainly attainable by the protection of the game during the brecling scasons, lave of late, in many States and connties of States, procured statutes to be passed for the preservation, absolutely and at all times, of certain innoxious and usefnl small birels. But all these statutes have defeets, besides the one alluded to-the lack of proper instruction to the children.

It is a defect in our State law that no penalty is provided suffieient to prevent limuting all the public highways, or other public grounds, and the penalty for entering your premises is quite inadequate to their protection, becanse you can not afford to mocure testimony, and hire attorneys to prosecule a fellow who will verify the arlage of "sue a begran and catch a lomse."

'I'lie statutes in question aro not asked on enacted for the defense of private rights of private individuals, thongh tlıey may defend them ineidentally, but for that of the community at large, to which the satioty of crops and the greatest possible supply of foul of alt limb in the market, at the lowest pussible rates, ane incontestably benetits. Therefore the community has mot only a riglit, but it is its especial dufy to enforee the same protection and preservation of the same animals on its own possessions-that is to say on the highways, wastes, commons, and all othel mocenjed lauds w waters of which the public aro the guardians and oecupants-as it comminds on the private lamls of individuals foum trespransers.

So convinced are the scientitic agriculturists of France of the importance of raising all thuse species of wild animals which are matmal, indigenous, or capable of being acelimated and natmealized to the waste lands, of which 
there are many humbrels of thousands of acres, utterly unsuited to any other Eort of culture or stocking, that there is an important lepartment in the Natimal Arricultural Socicty of that great and eulightened nation, the sole duty of which is to superintend the reproduetion on the waste lands and waters of liauce of the native speeies of game which have gradnally lecone extinct; to promote the introduction on the same lands of such foreign wild animals, valuable for food, as may appear to be suited, by their habits and the charucter of the climates to which they originally helouged, for naturalization in linec; and, lastly, to encourage and enforce, by means of premiums for success and stringent protective legislation, the mintenance of such stocks of game, both quadruped amel winged, as shall realize to the proprietnrs and to the state an abmdint return of nutritious and clicip food from lands untillable, unfitted for pasturage, aud in fact worthless for any purpose but that of raising game.

At the same time we, in Anerica, are suffering our infinitely larger number of unreclaimed-it not ireclaimable-aeres, which formerly swarmed with animal life, and afforded supplies, a few years ago supposed to be inexhitustible, of the choicest rarieties of game, to be stripped of the last fin, the last hoot or pad, the last feather of the wild tribes, mequaled elsewhere, both in quality and quantity, which at the time of its diseorery rendered America the paradice of Nimrods; so that the woods, the fens, the waters are inleed filst becoming utterly barren, useless, and unprofitable rastes.

It is certin that the filet of any tarm being well stocked with game is not, in any possible point of vier, a disadvantage, even if their ralue, whether as an article of food or as an olject of pleasurable and healthful pursuit be entirely ect aside, since the actual profit consequent on their subsistenee is meater than the loss from the grain which a few of the varieties consume. Besides the insects, many of the game birds are great consumers of weed seeds. The prairie-hens, where they exist in large numbers, do depredate upon corn-fields and stacks of grain; but even there, it is not a very severe tax to feed them; and we think that farmers could make the preservation of birds profitable.

It niay be assumed, as a reasonable arerage, that every farmer who owns and cultivates a liundred acres of arable land, with firom fifty to a hundred of meadow land and pasture, and an equal quantity of woodland, if he chonse to jrotect and preserve them, especially if lie takes the trouble to erect a few little shelter huts of brushwood and fern in his woodshirts, and to bait them in hard weather with a few bnshels of buckwheat, in a good game distriet where the winters are not too severe, may winter from ten to twenty brace of quail, which may be expected to raise from fifteen to thirty beries of birds. Each bery will probably average fifteen birds, which gives a yield of from serenty-five to one lumdred brace of quail, to be killed and Eent to market in the late autumn or early winter, with the butter, buckwheat, fit turkeys, and other produce of the farm. These birds will arerage twenty-fire cents a brace in ordinary seasons, and when game is scarce or 
for any reason there is an unusual demand, an increased priee. To this may be added, if it be a rufted gronse comntry, two or three broods of these larely, bold, and delieate birds, which rarely prodnce fewer than twelve and thence upwarl to sixteen poults, so that the landholder may reckon un lis fifteen to twenty brace of ruffed grouse at seventy-five cents a brace, and on his thirty or forty rabuits, at a dime a head. Here is a profit of perlapes fitty dollars per annum, arising from no expenditure, from no investment of capital, anl involving as a consequenee, several days or hours of pleasunt exercise and amusement in lien of labor, for the jurpose of renderiug it marketable. On snipe grounds and countries adapted to woodcock, the profits are yet more enormous.

The mmber of woodeck to be killed annually on any giren piece of ground is nerer so great as that of snipe, sinee the birds killed in the early. part of the season consist of those bred on the ground itself on which they are shot, which is of course a limited number, althongl the autummal flights, which come in sucessively, are those bred in the menltirated wastes tar to the northwad. Yet cren of tlese, there are mumerous localities, especially in parts of the States of New York, New Jersey, Pennsylvania, Delaware, Michigan, and other Western States, which iniglit be counted on as sure to furnish ten wondcoek to the acre in each season, at twenty-fire cents the bird.

It can harilly be doubted that by the system of game protecting, withont expending a dollar, every owner furming from 100 to 200 acres of land in a comntry we!l adapted for game-and there is but little country in any of the Nortliern, Western, or Niddle States which is not adapted to it-can add from $8 ., 0$ to $\$ 200$, and in some instances a much larger sum to his aunual income. If he liare trout-streams, and the facility of making a chain of small tront-ponds, as may be easily done in every deep glen watered by a rajid brook, insteal of suffering them to be weired and netted by all the ragabonds of the comntry side, lie might make thousands more easily than by his pouttry-yard or sheep-fold, and at far less cost.

With these fincts before them, it is for the farmers themselves to consiler whether game-laws are the obnoxious things that demagognes lave tanght them to believe. Is it not rather worth their while to insist upon the enactment, and strict obselvance of such liws as will protect their own interests, and aftord them such additions to their ineome as we have briclly linted at.

240. Scnding Wild Pigcons to .Market,-The Eagle, newspaper, printed at Grand Rapids, Michigan, published an article in the spring of 1560 , nhout the pigeon trade. There hat lieen at that time shipped from that villago $5 S S$ barrels of wild pigeons-equal to 105,555 lbs. The express freight on this quantity at three cents a pound, would be $\$ 3,25665$. If sold at twenty cents a poum, they would bring $\$ 21,711$. It was estimated that the west part of Michigan had sent two millions of wild pigeons to market in ono season. 'This great number can easily he muierstood by those who aro acpnainted with the manner in which these birds llock together. To ono 
who has never secn a pigeon-roost or a nesting-place, the trutl will seem almost as tubulons as the tales of Sinbad the sailor. I t it is fir within the bounds of truth to say that we hare seen many millions of wild pigcons at once, or at least as soon as we could direct our eyes upon them. We liare seen them on their erening flight toward the roosting-place, in one unbroken flock, two miles wide, and two hours' continuance. WT hare ridden two hours in a straight line through a pigreon-roost at least seven miles wide. We have secn upon a single beech-tree many wagon-loads. At one time a little section of the main flock got belated in reaching the roosting-place, and settled in a heary leech wood near onr house in Indiana, and the noise they made resembled a terrific tormado; and they piled on to the trees in such numbers that all the weak limbs were broken off, and hundreds of large trees, such as stood leaning, and were weak at the roots, were entirely broken down. We spent hours of the evening in that temporary roost, witnessing their operations, and trying to imagine the rastness of the multitude. There is great danger in risiting sneh a roost, from the falling timber. In one long oecupied, all that is liable to break lias been prostrated, and there is less danger, so there is less commotion. They often sit so low, and remain so quiet, that you may approach near enough to kill half a scorc at a blow. A charge of shot sent into a full tree brings down a great number. When they alight upon a tree that breaks maer the mass, they fly and light mpon the backs of others already loading a tree all it can bear, and so the additional weight perhaps produces a second crash, and sometimes crish after crash, almost without cessation. That was the case upon the erening mentioned. The breaking commenced at dusk, rhen they began alighting, and contimed until we left at midnight. In the morning about two hundred acres were literally corered with broken timber.

A pigeon nesting-place is a still greater curiosity than a pigeon-roost. It corers hundreds of acres of dense forest, and erery tree is corcred with nests almost as closely as the birds can build them, by laying a few loose twigs together among the branches. It is an casy matter to load a wagon with squabs. Often they fall out of the frail nests, and fall a prey to wild animals and rood logs. Audubon gives a rery truthful pieture of the immense numbers of wild pigeons in the great West. To us it is the more interesting, because we know it to be true.

Those who lare read Audubon, or others who hare written accounts of pigeon-roosts, and ean beliere the truth, will be able to realize the extent of the trade we liare sponken of.

Inving now, we hope, said enongl about birds to create an interest in their behalf, and induce a stndy of their character, and their value to the farmer, we shall leare the subject for another, which, thongh about smali things, is of great importance to all our readers. 


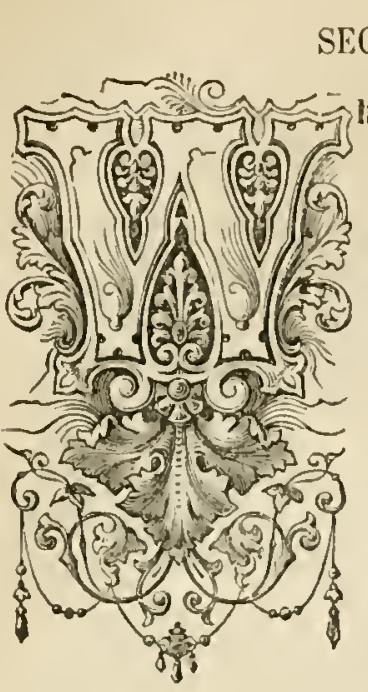

\section{SECTION XII.-ENTOMOLOGICAL.}

hat arc Insects ?-The term is applied to all, or nearly all, the fanily of bugs, worms, flies, wasps, moths, millers, and small creeping things that infest a firm, and all are generally ranked as pests, though erroneonsly, as we will show by-and-by, some of them being lighly beneficial.

The word insect comes from two Latin words, signifying cut into, or notched; and the body of a perfect insect, as a wasp, is cut into and clivided into three distinet segments-the lead, thorax, and abdomen, witls two or three pairs of legs, and one or two pairs of wings, and it lurathes throngh holes in the sides of the body. Insects commenee life in curgs, which hatch into worms or larve, such as maserots or caterpillars, and these, after doing immense mischicf, as in that state they are voracious gormandizers, muclergo transformation to the pupa or elirysalis state, and from that to the bug or butterfly form, during which the ergs are laid in such rast numbers, that the specius are propagated so rapidly that the art of man seems insufficient to stay their ravages, if of a ravagring breed, and hence he must look to natural aids. It is for this that wo liave adrocated protection to birds, because they are great insect destroyer's. Testiferous inseets also have several other natural cuemies, which must be studied and protected by farmers.

Tiesides what aro considered and treated of in natural history as perteet insects, there are a great many sorts that come moder the general name of insect that do not answer the above definition, such as some of the aphis, or plant-lice family, the striped and other bugs, and various woms. Some of the latter-for instance, the earth-worm, or ander's worn-are thought to be beneficial to soil. We think, rather, it could be made more beneficial in its death than in its life. Anything, such as salt, lime, potash, anmonia, that would lill all the earth-worms, would add all the animal matter of their body to the soil's fertility.

We can not go into a grencral examination of entomology, though we lo earnestly advise a study of the science by all furmers, who are, abore all other clisses of the community, nost in wint of linowledge of inseets, and how to distinguish between those that are pests and those that are harmless, or, perhaps, actual destroyers of those that are devastating our oreliarls, gardens, and gran-ficlds. Of' a few of these we shall give correct pietures, with brief hints about their eharacter, lepredations, and such preventives as have been tried and proverl valuable or useless.

The great difficulty with the numigenent of the greatest pests is their 
dimimutire sizc. The wreat destroyers of wheat, the midge, IIessian-fly, and jeint-worm, ale so minute that a mieroscope is needed for their exanination. it is the same with the aphis tribe, and what is called the "scale insect," which corel the limbs of fruit-trees like a second bark, mitil millions of months, althouerh very diminutive, suck away the life of the tree. Neithes. man nor birel notices these minute destroyers until it is too late to stop their. l'ansages.

Now let $n$ s look at what eome of these insect pests do to the farmer's crops. As cotton is considered the great Ameriean staple, and as America is, above all competition, the land of insects, we will first enumerate the cotton destrorers found upon that plant by that indefatigable student of entomology, Tornend Glorer, who was employed by the Patent Olite to collect information upon the subject.

242. Insects Infesting the Cotton-Plant.-A species of cantharides, similar to the striped potato 1 y, feeds upon the nectar or pollen, and sometimes eats the petals of the flowers. These are injurions, aud ecreral otliers found in the flowers did not appear to be so.

A leaf bectle cats holes in the petals, and, eome say, injures the bolls. A large, green, thoruy, poisonous caterpillar damagres the foliage in August and September. It also attacks Indian corn. If luandled incantiously, its spines inflict painful wounds. This large worn is in strong contrast witl the diminutive cotton-lonse, which destroys the young plant in wet seasons.

The boll-worm, however, is the great destroyer. Their presence in a cotton-field is indicated by the meat number of young bolls fallen to the ground, after the inside lias been eaten out. Before it falls, the rorm crawls out and attacks others, which in turn fall; and if the worns are numerous, all the bolls may be destroyed, just as all the plums of a tree are destroyed by curculio.

A small green caterpillar feeds upon and rolls itself in the leaves of the cotton plant; and a solitary liairy caterpillar, of a yellowish color, eats the leares; and a green, smooth-skimmed one feeds upon the blossoms; and also sereral rery slender, brownish span-worms. A small beetle, of a greenislı, metallic color, barred with dirty eream-color, often seen in the looles made ly boll-rorms, is not thought a destroyer. It only follows in the patlo of iuscets that do destroy.

Tarious other small insects are found on the plant, but it is not certain that they are destructire, while sereral are rell ascertained to be lighly beneficial to the cotton-planter. Anong these we enmmerate the lady-bird (Coccinella), which, both in the larra and perfect state, derours myriads of cotton-lice.

The planter and oversecr should learn to distinguish these from noxions insects, and instruct their liands to protect them.

The larva of the bee-winged 1 y also destroys lice, and ichneumon flies deposit egrs in their borlies.

Tiger beetles (Cicindella) are also destroyers of the noxious insects. Ants 
elimb the cotton-stalks to feed upon aphis, and not upon the plant. Spiders, too, eateh moths in their nets, and also scize and devour other insects. The grleat aim should be to learn which of all the insects found in the eotton-ficld are friends, and which focs.

'The boll-worm, and the one which is some seasons so destructive to Inrlian corn in the milk, aredeclared by enne, lipon pretty good authority, to be identical. The ehrysalis is of a bright eliestmut browu; the mothe, a tawny yellow eolor. The upper wings yellowish, shaded with green or led, in some, with a dark band, and crescent-shaped mark near the center of the wing. The under wings are lighter colored, bordered with black.

To provent depredations from the boll-worm, it is reenmmended to light fires around the field at night, to attract the moths when they begin to malie their appearance. Doubtless many will be attricted to the light and deptroyed. They liave also been destroyed hy placing plates upon stakes set among the cotton, in whicl about half a rill of vinegrar and molasses is placed, mixel, fonr of vinegrin to one of molases. 'This attracts the motl, which perislies in the mixture. This kind of moth-trap requires a good deal of labor, for the plates must be risited erery evening and replenislied, while the moths last. The same plan will be found a good one to enteh otler moths than those which infest cotton.

243. Iuscets Destructive to Indian ('ol'n aul Wheat. - The insect which eats into the grains of Indian eom is not only a destruetive one, but when it infests the cars that are wanted for cooking in their green state, it is troublesome and disgustingly offensive. It only feeds while the corn is in the "loasting car" condition. At first it is so small as to be almost impereptible, and lonbtless many a one gets between the teeth of the eater of carly green corn, even in this eity, for lere we have seen a great many marls of their ravages. It is, however, much worse at the South. Sheltered under the luusk, it eats roraciously, and inereases in size rapilly, nntil abont an incl long. Some are brown, some green, some striped. In fict, there is no unitormity in color. The body is sparingly elothed with short hairs, rising from black spots or wats. The worm leares the ear and goes into the ground to undergo its transformation.

If fimers, particularly Northern ones, would watch the first appearance of these insects, and try to destroy the moths, they might sare themselves much loss in the finture, for all insects of this kind are wonderfully prolific. There is an iclnemmon fly which preys mpon this inseet, and the liabits of that fly should be studied, and, it pussible, the family inereased. Birls, too, are fond of this speeies of worms; probably becanse the food it fattens upon makes sweet morsels for their palates.

The destruction of the grains of corn eaten by this worm is only a part of the damage that ensues. The grains eaten are upon the sumall end of the ear: and here grows n fungus, which often ilestroys the ear. It also oftentimes affurds a securo liarbor for other insects, which destroy what the worms have left. The corn-worm does more dumage in dry' seasons than wet ones, owing 
to the fact that the silk grows inegularly, or eontinues longer green, and the worms often eat off the silk before the kernel is fructified.

Another insect infesting Indian corn at the Sontl is ealled Sylvams quadricollis-a dimintive becte, which hides between the grains, and loosens them from the cob, devouring the germ first, and then the white starchy part of the kernel. These inseets sometimes exist in vast numbers, and are then rery destructive. Sometimes they destroy the grem in such a way that its absence is imperceptible, and that eanses disappointment when it is planted as seed. Kiln-lrying is recommended when the corn is to be used for food, but not for sced. Qnick-lime is recommended, strewed among the ears of eorn in the crib. If put up with husks on, salt lias proved beneficial.

There is another insect that troubles corn in the. Southern States-the com-horer. This is called a bill-bug, or corn-borer. It bores into the stalk just at the surface of the earth, and deposits its eggs. 'The grub cats the substance of the stalk, and the transformation takes place in the cavity eaten out, where the pupa remains till spring, and then comes forth a beetle, in its tmm to deposit eggs in the young corn.

These insects have been very destructive in Alabama and several other. Southern States, and, like many othel' pests, may gradually become aeclimated farther and farther north, till all the corn-growing region is infested. Farmers should be on the look-out for these "borers," and also bear in mind that the best remedy yet found is to pull up all corn-stalks, after harvest, and pilc and burn them. These insects are usually most tronblesome in swimp lands.

The larva of the angoumas moth is very destructive to corn, as well as wheat and other cereals, when stored; and in the Sonth, in the open field. The grub is one fourth inch long in corn, and less in whert. It spins a cocoon in the cavity eaten out when it gocs into the pupa state. From a small round liole previonsly made, it emerges a moth, with long, narrow wings, of a yellowish gray color, of satin-like luster, fringed with loug lairs. The insects grown in maize are larger, though identical with the whent inecets. This insect is not confined to warm latitndes, but is more troublesome there than farther north. We have seen the moths swarming in myriads about corn-lionses and around wheat-staclis. The female lays from sixty to ninety eggs, which hatch into minute white worms in four to six days, each one of which makes a lodgment in a grain of corn, where it eats, and matures in three weclis; so that two sets mature in one scason, the pupa of the second growth remaining in the grain till spring.

It is said that this insect was first observed in North Carolina, abont forty ycars ago. They will fly into a candle sometimes, in a granary, in such numbers as to extinguish the light, and doubtless conld be destroyed by firc to a great extent. Smear a cask with one head, on the inside, witl tar or molasses, and place a light in it, and you will catch quantities of the moths.

Where they abound, it is advisable to store corn unhusked; and salt is also useful, sprinkled in as the corn is put in the crib, just as hay is salted. 
We know places where this insect is so tronblesome to farmers, that it is only by great care that they can keep eorn or wheat over from onc erop to another. In west Tennessce and northrest Mississippi they are excessively annoying.

Several remedies bave been tried, witl snceess in some eases and fuiluro in other's, under apparently the same circunstances. We will name some of them. After the grain is thoronghly eleaned, spread it upon white sheets, of boards, or a tin roof, or, if convenient, a flat rock is better than either, and some nse a clay floor, and let it lie in the sun until it gets lot, and then put it up in tight casks. Kiln-drying at $176^{\circ} \mathrm{kills}$ the insect and the grermiuating power of the corn at the same time. If grain is placed in tight easks, and the gas arising from burning chareal conreyed to it by a tube, which may be iron next the fire, and flexible tube next the cask, for conrenience, so as to fumigate the grain, the insect is destroyed without injury to the germ. An infusion of the fumes of clilorotorm will kill these or any other insects in a close ressel. Eren a few drops put in a bottle with insects, corked up, deprives them of life directly. It will not, howerer, destroy erers, as the heating of the corn does. Heating it, by piling it up damp, has been practiced; but care must be taken, if this is practiced, that it does not orerheat and get musty. If it does, it shonld be washed before grinding.

Lime has been effectirely tried, entirely prerenting the rarages of the insect, by storing the grain, ready prepared for the mill, in tight casks or bins, and eorering by sifting orer the top an inch or two decp of finclypowdered lime. Whenever the grain is wanted for the mill, run it throughl the winnowing machine, and blow ont the lime. A trifle will adhere to the furze of the kernels, but it does no harm-it is rather bencticial to the flour or meal.

24t. The Rice Wecril,-This is another pestiferoms insect, which not only destroys rice, but attacks other grain upon the upland portion of a rice plantation. This weeril (Culandre orysex) resembles the one whose ravages we have noticed in 243, which is the Calandra granaria. All true weerils are beetles, with long snouts, and only depredate upon dry grain.

Many of us consumers of riee lave ecen the rice wecril, which has liatcherl out of egges deposited by the female parent, one in each grain, where it hatches, and the young larva eats ont all the substance, making food of its liabitation. By-and-by the weevil comes ont, and the sexes meet, and the female deposits its egres in sound grains, and so on until all aro destroyed.

When rery plenty in rice, it makes anything lojt a savory dish. It is the same with whent. We have eaten hread that tasted as though we had abont an even mixture of bread and meat. "Wecrilly flour," we have licard said, was not unwliolesome. T'erlaps not; to us it is most decidedly" nnalatuble, and no art of eooking wheat or rice will hide the weevil tlavor. It looks and tastes of weevil, even in the buttermilk and saleratus biscuit of the most liberal nser of that salt. 
The rice weevil has often been found in rice imported from China, and it way lare been introduced into this country from thence. It differs, both in appearance and liabits, a little from the grain weevil. It is said to attack rice in the ficld as well as after it is stored. It also attacks Indian eorn in the field, if left ont till late in the fall, or until it becomes quite dry, in those States at the Sonth where this insect most abounds.

The same remedies that will answer for one variety of weevil will anewer for all. We give a few more remedies.

2+5. To lestroy Weevil.-Grain subject to depredations from the weeril, which develops and matures in the heart of the seeds, and which imparts considerable heat to the bulk of the pile, equal to or above blood-heat, is ensily detected on thrusting the hand into the body of the grain, by means of the great heat of the mass.

In France, large quantities of grain are stored up against time of scarcity; and in order to protect it from the depredations of the insects that prey upon it, commissioners have been appointed to cxamine into the means of destroying them, who liave reported that a small quantity of chloroform or sulphuret of earhon put into the interior of the grain pit (which is nsually in the gromul), and then hermetically sealed up, will destroy all the pests. Abont Ecventy-fire grains of sulphuret of carbon are sufficient for about four bushels. Grain put up in rail pens, as is the cnstom in the West, may be treated with equal suecess with this agent, by corering the heap with a tarpaulin or close woren cloth.

A suecessful farmer in Broome Co., N. I., reeommends cutting wheat while in the milk, and the straw green, and salting it in the mow or stack. He says:

"About fourteen years ago the weevil appeared upon this farm, and quite seriously affected the wheat crop. We commenced also abont that time cutting our wheat very green, as soon as it was ont of the milk, no unatter how green the straw or heads; and in order to preserve it the better in the now ol stack, always applied salt liberally. For many years I have salted my grain mows and stacks, but put none upon ny liay. I am now eutting my wheat as green as nșual.

"From my own experience, I am satisfied that if the wheat is thus treated, and not thrashed until after it has been some time piled $u$, the insect will be destroyed in some of its transformations. At any rate, wlocerer tries the experiment will be well surprised in the value of his wheat and straw. Where straw is fed to stock-and all mine goes that way-it is sought for with keener relish, and makes hetter manure, while the wheat is much hearier and plunper than when not so treated.

"I ought to say, perhaps, that the weevil has not troubled the farm since that year, although wheat has been grown every year. Almost any year a tew may be found, but none to do any damage. My soil is a slaty, mravelly loam, and my secding is usually all done from the 1st to the 10th of September, and the best variety of wheat thus far has been the blue-stem, a beautiful variety of white whent." 
Another broome County farmer; who thonght the yellow-birds destroyed his whent, wished a neighluor "would get a gun and kill some yellow-birds, which farmers generally suppose destroy the wheat. Mr. R. declined, as he does not like to kill birds ot any lind. Ont of curiosity, however, he killed one of the birds and opened the crop, when he found that the Lird, instead of cating the wheat, ate the weevil-the great destroyer of the wheat. He found as many as two hundred reeril in the bird's crop, and but four grains of wheat, and these had the weevil in them. This is a very important discovery, and should be generally known. The bird resembles the canary, and sings beantifully."

246. Wheat Iuscet rs. Weevil.-There is a confusion of tongues in relation to the weevil that we hare described $(2 \pm t, 2 \pm 5)$, and the one that attacks the wlieat in the milk.

The insect that has injured the wheat erop so extensively in New Jork, Pemsylvania, and Ohio, is not the one generally known as the weevil. This insect, ealled "red weevil," "wheat-midge," "the insect," ete., differs very mueh from the Calandra granaria, as that only injures the ripened kenel of wheat or corn after it is stacked or housed, or eren after it is in the bin of the granary or grist-mill. The weevil exhibits in swarms aromel the burn, the female laying her erros on the grain, and the grubs as soon as hatehed work into the kernel, consuming all but the bran, without breaking that, so as to show that all is rottemess within. The rarages of this insect, as we lave alrealy stated, are so lestruetive at the Sonth, that it is difficult to keep wheat and corm. The latter is generally put up with the shueks on, which is damp or else heavily salted. Wheat is liept in close casks or tight bins by eovering with flom of line an incl deep over the surface.

"The insect that has destroyed so muel grin in past seasons is a yellow fly (with blue wings), abont one tenth of an inch in length; it deposits its eggs, while the whent is in blossom, within the chafiy scales of the flower, during the evening twilight and dark stomy days, in numbers from two to forty, which hatel in ten days and completely destroy the germ ot the berry. The maggot is reddish yellow, about one sixteenth of an inch long, or perliajs an eiglith when full-grown."

"It is supposed that it leaves the wheat and winters in the ground. That is the time to kill them. Salt is mulonbtedly the remedy. The tly is hardly ever secn; they never fly in the smohine. The weevil till the ar like musketoes in a swamp. This insect hide's on the stems and leaver, bhaded from the heat of the sun. This is a northern insect; the weevil is a sonthern nne."

"'lhis insect was first seen in America about the year 1525, in the northern part of Vermont and borders of Lower C'anala. It tirst male its apprearance in northern Ohio in the year 15.3, and its ravages lave rapilly increased from year to year."

Dr. Harris recommends brimstone funigation of the plants. That would be impossible, almost, on whole comnties. Flonr of lime sown on wet whent Lns appeared to prevent the work of destruction. Deep plowing the stubble, 
and not sowing any grain upon it next year, might eradicate the insect, if all who are atlected would unite in that course, as all must in any other that slionld be adopted.

The remedy recommended by our correspondent in Broome Co., of salting the cut wheat in the mow or stack, wonld not answer, for the maggots ahready burrowed in the ground for winter, but the salt must be applied to the land. in liberal quantities-say five to ten bushels per acre. We cut up the eutworns effectually npon oul" corn ground this season with a handful of salt to a liill. The coln fired a little at first, but it is growing beantifully now. Every bug or worm can be killed in the soil, with salt, and we hare no doulut that will be found the most sure way of jidding the country of this terrible pest of wheat-growers. The Cecilomyia tritici of Kirby is what we take to be the insect called the "red reevil."

$\Lambda$ "close observer" of the habits of the midge, says of one who had written of the insect's wintering in the ground:

"The writel" is mistaken in some of his faets as to the habits of the insect, as he can rery easily satisfy limself by getting a few heads of wheat in the proper season that are affected and putting them in a small glass jar. He will see that the worm does not go into the earth, but comes outside of the head after destroying the grain of wheat it hatched in, and worres itself up into a smug little cocoon on the under side of the outside chaff. If he examine that cocoon after a time, he will nind the wolm has clianged into a new shape, and will ultimatcly come ont a winged insect. I have never yet been able to find the worm seeking shelter in the earth. It is this knowledre of the habit of the insect that induees the belief that liberal salting of the arain in mow ol stack is fatal to it."

Townend Glorer, who is pretty good authority, says of this pest:

"The parent fly deposits her eggs in the beginning of July, and in the opening flowers of the grain, or when the wheat is still in the milky state. The eggs hatch in about eight days, when the little yellow maggots, or worms, may be found within the chaffy scales of the graiu. The seed scales of grass also sometimes serve as a shelter for these depredators. The worns, which are of a bright ycllow or orange color, do not exceed an eighth of an inch in length, and are often much smaller. I have seen as many as twelve within the chaff of one single grain, sent to the Patent Office from Ohio. These maggots prey upon the wheat when only in a milky state. When they begin their depredations, soon after the blossoming of the plant, they do the greatest injury, as the grains never fill out. Toward the last of July or beginning of Angust the full-grown maggots cease eating, and become sluggish and toppid, preparatory to shedding their skins, which takes place in the following manner: The body of the maggot gradually slirinks in leugth within its skin, and becomes more flattened and less pointed, as readily may be seen throngh its delicate transpareney. This torpid state lasts only a few days, after which the insect casts its skin, leaving the latter entire, except a little rent at one end of it. These empty eases, or skins, may be found in 
great abundance in the wheat-ears, after the molting process is completed. Mr. J. W. Dawson, of Pictou, Nova Seotial, says tlat sometimes the maggot descends from the plants and molts on the surface of the ground. After sledding the skin, it recover's its activity, and writhes about at first, but takes no food. It is shorter, somewhat flattened, and more obtuse than before, and is of a deeper yellow color, with an oblong greenish spot in the midlle of the body. Within two or three days after molting, the magrgots either descend of their own accord or are shaken out of the ear's by the wind, and fall to the ground. They do not let themselves down by threads, as has been supposed by some, for they are not able to spin. Nearly all of them disappear before the niddle of August, and they are rarely fonnd in the grain at the time of harvest. IIon. Willian D. Lindsley, of Sandusliy City, Ohio, howerer, sent me sereral specimens of wheat with this insect in it as late as the beginning of Angust. From observations and remarks made by intelligent farmers, it appears that the descent of these insects is facilitated by falling rain and heary dews. Having reaclied the ground, the maggots soon burow under the surface, sometimes to the depth of an inch, those which liave not molted eastiug their skins before entering the earth. Ilere they remain withont further ehange throngh the following winter. It is not usually before June that they are transformed to pupre, this change being eflected withont another molting of the skin. This pupa state lasts but a short time, a week or two at most, and in many cases only a few days. Under the most favorable ciremustances, the pupa works its way to the surface, before liberating the included fly, and when the insect las taken wing, the empty pupa shell, or skin, will be seen protruding from the grouml. In other eases, the fly issues from its pupa skin in the earth, and comes to the surface with flablyy wings, which soon expand and dry on exposmre to the air. This last change ocenrs mostly in the months of June and July, when great numbers of the flies lave been seen apparently coming from the fromnd in fields where grain was raised the year betore.

"The wheat-midge, or fly, "is a small orange-colored gnat, with long. slender, pale-yellow legs, and two transparent wings retlecting the tints of the rainbow, and fringed with delieate hairs. Its eyes are black and prom. incnt; its faee and feelers, yellow; its antemes, long and blackish. Those of the male are twiee as long as the body, and consist of only twelre joints, which, except at the base, an oblongr-oval, somewhat narowed in the midclle, are surrounded by two whorls of hairs. These insects rary much in size. The largest females do not exeeed one tenth of an inch in lengtl, and many are found toward the end of the season less than lialf this length. The males are usually smaller than the females, and somewhat paler in color.' Mr. Lindsley sent several of these inseets to the Patent Othice in August, 1855. and stated that they hare been extrenely destructive in sereral parts of lis district last year (1Süt), and that in some places the eattle were turnel into the field in order to eat the straw and what little was lett of the grain, the main crop not being wortl harvesting. These flies are likewise said to be 
much more numerous and destructive on the edges of fields than in the center, and in some cases when the edges were completely worthless, the center bore comparatively a gool erop.

"Fumigation with sulphni, and buming weeds on tho windward sicle of the field, when the grain is in blossom, have been reeommended. Air-slacked lime or wood-ashes, strewn orer the grain when in blossom, in the proportion of one bushel of lime or ashes per aere, to be scattered over the field when the plants are wet with dew or rain. Tro or three applications have sometimes been found necessary. Plowing up the ground, also, to destroy the maggots; and the dust-chaft, or refuse straw, if found to contain any of these inseets, should be immediately burned. In those parts of New England where these inseets hare done the greatest injury, necording to Dr. Harris, the eultivation of fall-sown or winter grain lias been giren $u$, and this for some year's to come will be the safest course."

247 . The Joint-Worm.-One of the greatest pests that Virginia farmers have laal to contend with in wheat-growing is the joint-worm. It has been more destructive than the weeril, and in some cases as great a pest in that State as the midrge bas in New York.

The following is Glover's deseription of this inseet:

"The joint-worm (Enrytoma harder), which has committed such ravages in the wheat-fields of Virginia, comes from a small, black, four-winged fiy, about an eighth of an inch in length. The female lays several egrgs in the outer slieath of the stalk above the joints. After they hatel, the worms commenee feeding within the sheath, and the constant irritation produced by them forms a woody gall, or rather succession of galls, in the carity of each of which lies a sinall, footless maggot, about the seventh or eighth of an inel in length, having a boly with thirteen segments, and of a pale, glossy, y ellowish color. The number of worms in each cluster of galls varies from four to ten, or eren more. The substanee of the stalk attrelied becomes brittle, and either partially or entirely fills its central carity, and frequently distorts it into various irregular sliapes. I have often observed young rootlets putting out immediately below a joint so affected. The worms on the stalks of wheat, when examined in February, were yet in the larva, but early in Mareh sereral had assumed the pupa state. They were about an eighth of an inch in length, of a pale yellow color, which as the pupa were near coming out, became afterward nearly black. These pupa had the rudiments of wings, legs, and antenne as in the perfeet fly, but were motionless. Late in April and the beginning of May the flies made their appearance through holes gnawed through the tough, woody covering of the galllike exerescence in which they had passed the winter. This transformation, howerer, took place in a warm room. These flies are about an eighth of an inch in length, of a black color, the knees, joints, and feet being tinged with yellow. The males, according to Dr. IIarris, vary from the females by being smaller, and in having no piercers. The joints of the antenne are likewise longer, and surrounded with whorls of little hairs. The hind body 
is shorter, less pointed at the extremity, and is connected with the thorax by a longer stem. He also says, that among fifteen females only one male was found. This corresponds with what I have observed, as out of sixty to eighty joint-worm tlies, produeed from diseased stalks of wheat, I only proaned one male answering to his deseription, and eight parasites, not fuite a tentls of an inch in lengtl, of a dark metnllic shade, with yellow legs, and the antenne much thicker at the end. These flies were furnished with four transparent, dotted wings. It is somewhat ineomprehensible how it happens that so many females appear at the same time without more males.

"Another fonr-winged fly also made its appearance from the same stalks, of abont an eighth of an inch in length, with an abdomen and legs of a bright yellow. The head and thorax were of a dark eolor, and somewhat metallic luster. The wings were transparent, dotted, and fringed with short hairs, and the piereer reached to the middle of the under part of the abdomen. Dr. Harris states that it lias been found in Massacliusetts, that plowing in the stubble lias no effect upon the insects, which remain alive and muiujured moder the slight covering of eath, and easily make their way to the surface, when they hare completed their trausformation. A free use of manure and thorough tillage, by promoting a rapid and rigorons growtl of the plant, may render it less liable to suffer from the attacks of the inseet. It lias been stated that this fly, like the whent-midge, does more injury on the edres of fields than in the middle.

"At the Joint-Worm Convention, lield at Warrentown, Virginia, in 1S5̆t, the following was recommended: Prepare well the land intended for wheat, and sow it in the beginning of autum with the earliest and most thrifty wud hady rarieties, and do nothing to retard the ripening of the erop by grazing or otherwise. Use guano or some other fertilizer liberally, particularly when secting eorn-land or stubble. Burn the stubble on every fichl of corn, rye, or oats, and all thiekets or other harbors of vegretable growth contiguous to the erop. Sow the wheat in as large bodies and in as compret forms as practicable; and if possible, neighbors shonld arrange among themselves to sow adjoining ficlds the same year. Feed all the wheat, or other straw, which may be infected, in raeks or pens, or on confined spots; anl on or before the first of May earefully burn all the straw which has not leen fed. The refinse of wheat, such as sereenings, ete., should also be destrojed, as the pupa case is hard and not easily softened by dampness or wet."

Tre can add nothing to this preventive, except a reenmmendation to cons. post the refuse of the eattle, instead of buming it. Make a herp that will undergo a lieating fermentation, and the egrgs will be destroyed, and the manure will be more valuable than the ashes.

245. The llessian-Fly, -This is the common name of an insect that at one time theatened to put a stop to whent-growing in all the Northern and Middle States. This inseet (Cecidomyil destructor) obtained its nanue frem the fiet of its (supposed) importation with the IIessian soldiers of the lievo. lution, though this fact has been strongly disputed. It miglit lav ro heen in 
the comntry before, and it might also liare been imported. It was first publicly noticul in 1776, at liatbush (L. 1.), and on Staten Island, in the viciuity of Sir William Inwe's debarkation of those mereenaries of King George, and it was quite in keeping with the fechings of the people that they should radily credit the charge, that they had brouglat this anoug the other evils of war. At any late, it multiplied and spread rapidy, and was for a time looked upon as a scourge almost as great as fire and sword. Of late jears, lowever, it appear's to be dyoing out. It is subject to the attack of parasites, which have done more than all the arts and strength of man to rid his land of this pest.

The greatest destroyer of the Hessian-fly is a shining black four-winged fly, abont the tenth of an ineh in length. Do not mistake this friend for y:mec, and compass its destruction. Many sensible men liave made this inistake, and rery aptly, too; for, as they will tell you, they have actually seen the fellow come ont of the dried skin of the Hessian. So they did; but not intil the destroyer of wheat had been destroyed by an insect that fed upon his ritals.

The parasite of the Cecidomyia destructor is the Ceraphron destructor of Say, and it is a question of vast eonsequenee to wheat-growers what they can do to promote the growth of this insect, which has already been of such rast benefit to them.

We have no doubt that the parasite of the wheat-midge will do the same kind of service, and perhaps exterminate that pest.

The IIessian-fly is a very small two-winged guat. The female deposits her egrs soon after the wheat begins to grow, say in October, for lat. $39^{\circ}$, $40^{\circ}, 41^{\circ}$, in the earities between the little ridges of the blades. In from foul to fifteen days the eggs hateh, and the diminutive maggots work down into the leaf-sicath and there spend the winter. The fly works from August to January, according to latitude and elimate influences, so that what would be a remerly in one place would not be in another. In fict, it is asserted that the fly sometimes works upon wheat in the spring; so the following recommendation wonld not be effectual. That is :

About the middle of August sow a strip of wheat adjoining where you intend to put your erop-say one or two acres. About the middle of September sow your field. When that has come up and shows eleverly, plow under the first somn; turn it under well. Tour fly is lieaded and your erop is safe.

In the partienlar locality of the man who says "that remedy wont fail," perhaps it will not.

The maggots within the leaf-sheath lie dormant through the winter, and do not stop the growtl of the wheat until just before it is ready to blossom, when if there are sereral on a stalk, it withers and dies. The worms do not eat the stalk, but suck up the sap and poison it. A full-sized maggot is three twentieths of an ineh long, with a liard skin, of a bright chestnut color, and looks as much like a flax-seed as anything it ean be compared to. This 
appearance remains, but the outside is a dried skin inclosing the pupa, which adrances to perfection in $A$ pril or May, and it is these carly flies that lay egrgs upon spring wheat. It is asserted that there are three broods in a year. The fly is abont the tentl of an inch long; the head, antenna, and thorax, black; the hind body tawny, the wings tawny at the base, and black and hairy at the ends, expanding about a quarter of an incl.. The legs are pisle, red, or brown, and feet black. The antenna are jointed, and surrounded with whorls of short hair's.

With the above short description and mieroseope in hand, it will not be diffienlt for any observing person to determine the eharacter of an insect foumd upon his wheat, so as to decide whether it is the Hessian-fly or the Hessian-fly destroyer.

24\%. Insects Injurious to Fruits.-Probably of all the tribe of pests that infest finit-trees, that known as curculio, or plum weeril (Rliynchunus nenup! $\left(a r^{\prime}\right)$, does the most damage. It las nearly driven the plum-trees away from every farm, and has in some seasons destroyed the peaches, and done incalculable damage to the apple crop. In fact, for many years pre. vious to 1860 , there was not a good apple crop in all the Eastern states, owing, in a great measure, to the curenlio. Small as this pest is, it is capable of doing reat misehicf to all the fruits, and its sting is death to plums, apricots, and nectarines, and very injurions to cherries and pears. The finer the finit, the greater the injury. A very haldy plum or cherey may snprive a sting from this insect, which leaves a pecnliar, elescent-shaped wound, and makes an ugly scar and a hard grnarl in the fairest fruit.

This insect is found in nearly all the States of the Union; it is worst in the Middle ones, or between latitudes $39^{\circ}$ and $\pm 1^{\circ}$.

By the following minute deseription by Glorer, the little rillain may be known by any one, though not previously acquainted with lim:

"The perfect curenlio is abont two tenths of an inch in length, of a clark brown color, with a spot of yellowish white on the hind part of each wingcase. The head is furnished with a long, eurved snout, or bill. with whels it is enabled to bore into the mripe fruit by means of jaws placed at the end of the bill. The wing-eases, which are rigid, nneven, and humper, corel two transparent wings, hy which the perfect wecril is enabled to thy from tree to tree; but when these wing-eases are closed, the back appleats withont any suture, ol division, which has led to the very erroneous ide:a among furmers that the inseet can not fly. When disturlyed, or shalien firum the tree, it is so similar in appearince to a fried bud, that it can scarcely be distinguished, especially when feigning death, which it always does when alamed. As soon as the plums are of the size of peas, the weeril (ommences the work of destruetion by making a semi-circular cut thromeh the skin with lec long, eurvel snout, in the apex of which she deposits a singre egrg. She then goes to another plum, which is treated in a similar manner, until she has exhansted her whole stock of eggs. The grubs. which aro hatched by the hent of the sum, immediately eat their way tu the stone in an 
oblique direction, where they remain, guawing the interior, mil the fruit is weakened and discased, and by this treatment falls from the tree. The crul, which is a small, yellowish, footless, white maggot, then leares the fillen fruit, cnter's the earth, changes into a pupa, and in the first brood comes to the surface again, in about three weeks, as a perfect reeril, to 1"oparate its species and destroy more frnit. It has not yet been decided whether the latest gencration of the weeril remains in the ground all winter in the grub or in the pupa state. Dr. L. Sanborn, of Andover, Mass., asserts, however, that the grubs, after liaving entered the earth, return to the surface in about six weeks as perfect weevils, which must remain hidden in crevices matil spring. 'The most popnlar opinion is that they remain in the larva or pupa state in the earth during the winter, and only reappear in the spring in the perfect state. The worm, or grub, is often found in the knots or exerescences which disfigure and destroy plum-trees, and has been rrongfully acensed of being the canse of these swellings; but it is highly probable that the weevil, finding in the young knots an aeid somewhat similar to that of the unripe fruit, merely deposits its eggs therein, as the nearest substitute for the real plum.

"Some of the remedies recommended for preventing the ravages of these insects are actually absurd, such as tying cotton romul the trees in order to prevent them from ascending, when it is known that they are furnished with wings, and fly from tree to tree witl perfeet case. Among the remedies at present in use, one is to cover the fruit with a coating of whitewash mixed with a little glue, applied by means of a syinge. Another is to spread a shect mpon the gromd under the tree, and then jar the principal branches suddenly with a mallet covered with cloth, so as not to bruise the bark, when the perfect insects will fill into the sheet and feign death, and may be gathered and destroyed. Hogs are sometimes turned into plum orehards, where, by eating the fillen and diseased fruit, they materially lessen the eril. Coops of ehickens, placed under the trees, have also been recommended. Then shake the trees often, and the chickens will catch and devour the insects. All fallen fruit shonld be gathered up several times in the course of the scason, and burnt, or griven to hogs, or destroyed in some other way."

Wre slall now give, besides the above remedies; a few more, "infallible," of course, that float anmally throngl the newspapers.

250. Curculio Romedics.-To one pound of whale-oil soap add four ounces of flom of sulphur. Mix thoroughly, and dissolve in twelre gallons of water. To one half peck of quick-lime add four gallons of water, and stir well together. When fully settled, pour off the transparent lime-water, and add to the soap-and-sulphin mixture. Add to the same, also, say four gallons of tolerably strong tobacco-water. Apply this mixture, when thus incorporated, with a garden-syringe, to your plmm or other frnit trees, so that the foliage shall be well drenched. If no rains suceed for three weeks, one application will be sufticient. Should frequent rains ocem, the mixture should be agrain applied mitil the stone of the frnit becomes hardened. 
The person who used and recommended this remedy says: "The trees that received the application ripened an abmudant crop of as perfect and beantiful plums as ever grew, while not a single plum was ripened on those trees to which the wasl was not applied."

IIe also recommends a little salt to be added to the mixture.

It lans been stated as an important fact, that plum-trees planted in snch a position that the fruit will hang over water, will never be stung by cureulio: so that nothing is more easy than growing this delieious fint wherever the trees can be so planted. Dr. Underhill, of Croton Point Vineyard notoriety, states that he is never troubled, not laving seen an insect upon one of 150 trees in six years. IIe formed an artificial pond, with banks constructed on purpose to set the trees slanting over the water. IIe gathers the fruit in a hoat. He has mauy of the best rarietics of plums so planted, and never saw finer fruit than he thus produces. It is an experiment that should be tried by every man who has the necessary coureniences. 'The rarages of the eurenlio have been so great for many years that we have lad but fer plums, and those inferior and high priced, in this marlict.

We have the following account from James Taylor, of St. Catherine's, C. W., a few miles from Xingara Falls, of a pretty uffectual remedy for the great pest of the plum-grower-the enrenlio. He says :

"Our locality being mueh infested with the curculio, and observing in one paper issue, last spuing, what had been pronounced by a Mr. Jos. II. MIather, of Goshen, twenty miles southenst of the place where the writer resided, an effectual remedy against its ravages, allow me, for the benefit of your readers, to state my caperince of its efficucy. The proposed remedy was a mixture of sulphnu, lard, and Scotch snuff, to be rubbed freely on the trunk and branches. This I applied according to the directions, and it is true that I had a splendid crop of plums, some of the ehoicest varietics, always most subject to the attaclis of this insect, viz., the Bolmar, ITuling's Superb, ete., being perfectly loaded; but math the result. On cxamining my trees last till, I found all that I had applied the mixture to in a dying stute, and I have lost them all, with the exeeption of one or two young nees. The operation being rather a tronblesome one, I did not apply it to at many as I should otherwise liave done, or I slould have lost more. So much for quack nostrums. The remely puoved worse than the disease. Perhaps my experience will be useful to others."

li. G. Pardee gives the following remedy for the eureulio, which lias been snecessfully practied by a person of his aequaintanee. Take tresh cowdroppings, and a little wood-ashes, some lime, and a little sulphur, and malic all into a thin decoction, and thow it orer the trees with a land-basin. This lasts mutil it rains; it is then put on again. A half pound of sulphur to a half barel is snflicient, and of the other sulstances it is not very inportant as to the proportions.

We think the lator of this appliention wonld be too great.

D!̣: Trimble, of New Jersey, says that he has tried all sorts of offensive 
odors to keep off curculio, withont effect. "I have found no remedy equal to that of manmal labor in catching and destroying the insect. It is a fatet that some plum-trees are not infested by the cureulio."

The following is a conversation of some experieneed fruit-growers upon curculio remedies, and the cliaracter of the inscet:

Hnvir Steele, a New Jersey nurseryman, said that he had prevented eureulio by the use of black soap from the tallow-elandler's, dissolved in water and much diluted, with which the trees are syringed directly after the blossoms fall, after a rain, and repeated, if necessary, in eonsequenec of being washed off.

T. G. PArDeE-A person puesent assures me that a neighbor of his yarded his logs aromin his plum-trees, and that saved them from the eurenlio. Mr. Pardee said that he thonght that fresh cow or pig manure, dissolved, and the water sprinkled orer plum-trees, would prevent eureulio. They dislilic any stroug-smelling substances.

Wir. Lawtox-You may apply cow or pig manure raw to all fruits and berries, but not horse manure; that never should be used fresh-make it first into compost.

Dr. TrubLe-The eurculio has alpeady commeneed its ravages this spring. I am also satisfied that tle cureulio stings the bark of plum-trees and produces the disease known as the black knot. I have made a great many experiments to prove the insect identical with that which destroys all of our smooth-skimed fruit. The jarring of trees to sliake oft the curculio is effectmal, but it is an immense labor, as it must be attended to erery day, and some sumy days several times a day. I think that, unless some remedy for this insect can be discovered, we shall be muble to raise any fine fruit. It is the enrenlio that canses the discase in apples linown as guarly. We get no good apples in Jersey, and it is out of the question to zaise plums, ajuicots, or fine peaches. The import prunes from Germany elicaper than we can make boxes to pack them in-tlic plums grow to such perfection in that country.

WM. LAwтox-I have remored bushels of black knots from my cherry-trees and burned them. I found in all these knots a living worm. I destroy the common caterpillar by collecting them in the nests and destroying them.

Mr. O. Wr. Brewster, of Freeport, Ill., gare a statement of his success in repelling the attacks of the curculio on his plums. Early in spring he scattered lime, which had been mixed for whitewashing, under his plum-trees onee a week, until the encenlio quitted the ficld. He also scattered soap-suds and clamber-lye under them in liberal quantity. He said, I have twice tried the same remedy, with complete success. I once applied it to a small tree, which matured its whole crop; sereral other trecs near it, which set full of fruit, did not ripen a specimen. If plum-trees suceeeded with us $\pi$ ell, I sliould have no fears of the eureulio.

P. H. Perne, of Collins Center, N. Y., says :

"A gentleman lately informed me that he had raised a good crop of plums 
simply by spreading a lieary coat of fiesh horse manure on the ground under lis trees. II e said it entirely prevented the rarages of the curenlio, when on their account lie had not been able to gather a erop of plums for years before."

Solos Robrsos read the following letter from Dobbs' Ferry. The man certainly can read, at least he says so, but we wonder how he can own a tree liable to the attacks of the curenlio, and know so little abont it. He says:

"I liave been mnel interested in the doings and sayings of the liarmers" Clnb, but in the various debates before that body, I have seen no statement adranced conecrning the habits of the cureulio. I hare also real sereral articles conceming its depredations, but I have yet to learn whether it is a flying insect, or simply erawls up the body of trees. I have seceral cherrytrees in $m y$ garden of choice varieties, and I can safely say that every elierry was punetured by the cureulio this spring.

"The trees are growing and have just eommenced bearing.

"The soil is sandy.

"My neighbor, less than a luudred feet from me, luas eseaped its rarages.

"Does it fly or crawl?

"Would a barrel or trongh similar to those used on the elms of New IIaren be of any service in staying its rarages?

"Are the worms in the common black elerry, which is universally inhabited, produeed by the enremlio?

"Is there any remedy for this pest?"

That questiou-" Is there any remedy for this pest?"-lias been answered in erery agricultural paper in the world, and so it has been stated that the insect lias wings, and yet the writer of this letter has not read of it.

Let me ask another question: "INow is it possible to enlighten people who will not read? or, reading, will unt understand ?"

Dr. Trmale-I am now trying several experiments to prove that the same insect that stings the fruit makes the knots on the limbs. No attachment to the bole of a tree can be any protection argainst a tlying insect like the curculio. The excrescence on the limb is no more remarkable than the insect that produces the halls upon aktrees. Dr. T. showed specinens of the cureulio of plums, that he liad liatehed ont in eartl covered to prevent eseape, to show that the insect becomes perfeet from the first laving of eggs in yomngr plnms, and, as lie thinks, these perfect insects lie dormant till spring. The question is, Where do they hinle themselres until the young fruit is realy for them to deposit their exrers?

Prof. Mldiss said that a preparation called l'ersian Powder is said to be rery effectual in lestroying insects.

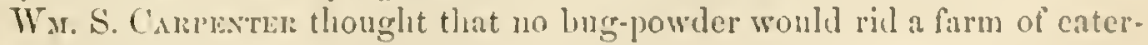
pillars. Something else must be done.

Wx. LawTws said that he had cleared his fam of tent caterpillars by pulling down the nests by land, with all the worms in them, when they are casily destroyed. 
Dr. Trunbe gare a history of the coclichafer, which remains in the gromud, like the locust, four years, and then comes forth in immense numbers, but in the flyiug state. They do not feed, and conseqnently do no damage to pliants.

In our opinion, the best remedy for curenlio is pigs, poultry, and birts. We hive seen fine crops of plums grown in a curculio neighborhood, in a season when these pests were active, in a small lot oceupied as a poultry-yard, in which several pigs l'un at large. The hens seratehed, and the pigrs rooted the ground, and the dore-cot also had something to do with the matter. At any late, the barn was inhabited by swallows, and they catch flies, and perhalps enrenlios.

251.-Apple and Peach Worms. - The codlin moth, or apple moth (Carpocapsa pomonella), is the riame of an injurions insect which deposits its eggs, in June or July erenings, in the calyx of the young apples, where they soon Latch, and the little worms eat their way to the lieart of the fruit, where they continue till ready to change into the chrysalis state. "Wormy apples" menerally ripen prematurely and fall. The worm is of a reddish color when linlly grown, and ready to leave the fruit and creep into crevices of the bark to spin a semi-transparent cocoon, where it changes into a small chestnntbrown chrysalid, and that produees a moth in a few days, measuring scren tenths of an inch across the wings, which are of a brownish-gray color, crossed by many dirk-colored lines, with a dark, oval spot on each wing. The muder wings are lighter colored, shaded near the margin. As a remedy against this pest, it has been recommended to wrap eloths loosely aromud the forks of the trees, for a shelter for the worms to form cocoous, and then destroy them. We fincy that this remedy will cure but a very small part of the evil. Picking up and putting all wind-falls where the rorms can never see daylight will kill more of them.

Perhaps the best remedy for this, and many other little pests, is the Scriptural one-"Dig about the tree and dung it." That is, give it greater vigor" of growth; make it more productive, so that a portion of the fruit will come to maturity in spite of all inscets. It is a well-known fact that the most rigorous-growing, thrifty trees exactly correspond with thrifty farmers-the more they have, the more tliey gain. Insects mostly attack the most nerglected trecs.

252. Peach-Tree Borers,-The peach-tree borer (Eyeria exitiosa) is one of the greatest pests of the farm, because it has almost blotted ont of existence this most raluable fruit in large districts of the conntry. It is believed by most careful observer's to be the canse of nearly all the discases which affeet the peach-trees, the most risible of which is "the ycllows," where the leaves gradually take on a yellow, sickly appearance in midsummer, and frequently at the age of three or four years show scarcely a green leaf, when they should be clothed in the richest green, and finally wither and gradnally perish. The epitaph of tens of thousands of peach-trees all over New Fugrland, New Tork, New Jersey, and Delaware, Maryland, and Pennsylvania, 
wonld be, "Died yonng-attacked by borers-the disease cxhibited in yellow leaves-speedy death followed."

This boring worm is produced from eggs deposited at the foot of the tree by a wasp-shaped moth, of a stecl-blne color, with an orange ring about tho abdomen. Sometimes the eggs are placed in wounds, or between forks, bi:t generally in the bark, close to the gronnd, where the worms eam ensily penetrate into and devour the inner bark and wood just below the surface.

Sometimes a vigorons tree will retain life ycar after year, with these worms gnawing at its vitals. Sometimes the tree is girdled and destroyed in a single summer. There appears to be a succession of broods in a single season. In the latitude of New York eity, the moths come ont in June and July. Nectarines and apricots are also attacked by the same insect. The plum wood appears too liard, and peaches engrafted on plum stocks sometimes snceed where, if upon their natnral roots, they would never bear finit. These borers, when finll-grown, are about an inch long, colored rellowish white, with an amber-brown head. The elirysalis is brown; it is formed in a case male of the gnawings of the rom, which it grmes together around its body. The moth expands wings an inch across, transparent and veined, and bordered blue in the male, and dark blue upon the fernale's upper wings, and her body is belted witli orange.

The remedies, as preventives or cures of the peach-tree borer, are numerous. Dr. Harris, the great $\Lambda$ merican entomologist, says:

"Remove the enth around the base of the tree, crush and destroy the coeoons and borers which may be found in it and nnder the bark, eover the wounded parts with the common clay composition, and surround the trunk with a strip of sheathing-paper nine or ten incless wille, which should extend two inches below the level of the soil, and be seenred by strings of matting above. Fresh mortar shonld then be placed aroumel the root, so as to confine the paper, and prevent aceess beneath it; and the remaining cavity may be filled with new or unexhansted loam. The operation should be performed in the spring, or during the month of Jume. In the winter the strings nuay be removed, and in the following spring the trees shonld again be examined for any borers that may have eseaped search before, and the protecting applications slonld be renewed. The ashes of anthrneite coal hare also been recommended to be put into the cavities mate when the earth has been remored from around the trunls when searching for the worm; and it the trunlis are thoroughly searehed three or four times a year, especially in the earth near the roots, and the grubs and chrysalids dug out and lestroyed, these insects would soon cease to be as injurious as they are at present."

The following conversation in the Farners' Club conveys some useful information upon this important sulyect:

Solon Rourson read a letter from the Rer. J. S. Weishnmpel, Sen., Baltimore, Mdd, upon the use of lot water to kill insects npon trees. IIe alludes to a letter read here some weeks since, about scaling whent, and then sars:

"This sealding process destroys the egg of the fly, and the sanne process 
lias beeu linown to destroy the eggrs as well as the grubs themselves, that injure the peach, plum, and other trees so greatly. Scald the stem of the tree well, letting the hot water get well into the ground around the tree, where the grubs do the most liaru, and a destruetion of both eggs and grub follows; and, in addition to this, the scalding appears to add to the rigor of the trees.

"An old lady in Berks County, Pa., had a plum-tree that for many years bloomed and brought forth erops of fivit till lialt ripe, and then shed them. She often besonght her lunsband to remore the tree, but he still pleaded, 'Let it stand another year.' At length, one spring, after she lial boiled her soap, she heated the kettle full of the refuse lye to a boiling legree, and poured it all down the stem of the tree, intending to 'scald it to death,' as slie said. It soon blossomed most abundantly, and bore a profuse crop of plums, which it brought to the greatest perfection, which greatly pleased the old lady.

"This same principle conld be applied to the destruction of erery kind of destructive insect upon the rarious ehoice fruit-trees, either by pouring boiling water upon the limbs and stems, or by conducting a stream of steam through a lose or pipe, from a movable boiler, to kill both eggs and insects.

"Chestunts, too, are very liable to be worm-eaten. If they were subjected to a momentary lieating (wet or dry leat), to a sufficient degree to scakl, it wonld lill the germ of the worm that destroys that sweet nut. And the same principle would also prevent all wood used in building and maelinery trom becoming worm-eaten."

Prof. MAres-I have used it on peach-trees, until I have satisfied myself that a peach-tree can not be injured by hot water.

M[1. CArpenter said that lime was the best thing he erer tried aronud peach-trees.

Mr. Wheeler said that lime will not kill the grubs in the wood.

Mr. Surtr, of Connecticnt-I have found no remedy exeept mannal labor, though wood-ashes are valuable, and so is lime. I lave an orchard in full bearing that is fonrteen years old.

Prof. MLApes-I have nerer found any remedy equal to lot water. It cooks the worms.

1 letter from East Wilson, Niagara Connty, N. Y., says :

"A large and interested community, comprising at least five thousand peach-growers in this county, ask for light. What ean be done to stay the ravages of the red-headed peach-grub? To dig him out and kill him will only insure an armistice for about ten dass. Fresh wood-ashes applied to the trees only seem to sharpen his appetite for destruetion. Hundreds of orehards and thousands of trees are dying from his operations. There are lialf a million of peach-trees in this ricinity suffering from this pest. Will tar prerent his operations? and will it injure the tree? Can you or any of your numerons readers or eorrespondents tell us of any specific which will kill 
the grub withont injuring the tree? If you ean do so, you will confer a substantial furor mon many lumbeds of your leaders."

ANuisw S. FulleI-The best remedy is to preserve the birds-the natural insect destroyer's. It is their decrease that has increased destructive insects.

Wr. LawTox stated that lie had taken great pains to preserve firds around his place, and was now reaping the benefit. As to any outward application to kill the peach-worm, he did not know of anything that would destroy it withont destroying the trees. If the worms are dug out, and a plaster of soft cow-mamure is applied, the tree may recorer. It is a rery tedious operation.

Trens. - The Secretary adrocated the cultivation, or rather protection, of wrens and insect destroyers.

Mr. Frlees said that the wren was a mischievous bird, and destroyed the eggrs of other birds.

A letter from P. M. Goodwin, Kingston, Luzerne County, Pa., says:

"I olserre in the transactions of the Club of July ?, it is thought that if a discussion ot the topic of the peach-grub rould elicit a remedy, it would be universally entertaining. My conclusion is, that trying to cure the peachgrub, unless where the soil is light and but few are found, is a humbug. I luave a preventive, which I will grive clicerfully:

"When I purchased my little place on Rose Hill, orerlooking a portion of ' Wyoming Valley,' there were one hundred neglected peach-trees thereon -budded, and of exeellent varieties-which were full of grubs. Early in A pril I commenced operations by carefully clearing away the grubs by means of the knife and wire. I then made a funnel-shaped hole aronnd the liase of each tree, which would hold three or four quarts of water. I filled the holes with boiling water, which eftectually destroged the juogeny. I then filled the holes with a tenacions clay, and tamped it laard, lurving the surface around the tree cone-shaped and hard compacted. I have examined these trees at rarions times during the intervening five years, and have foumd lut one tree affected, and that with but two grubs. This mode, with me, has acter as a perfect preventive, and, I have no donbt, will with all who alopt it and exercise the same care.

"These trees were three or four years old, and, at the time the experiment was made, much inferior to some fiom the same lot growing elscwhere, which were regulaly examined and cruefully cleared of grubs in the wsual way. My trees are somnd in wood, and look well, while the others have dizappeared.

"In planting peach-trees now, 1 would cut away the tap (not top) remt elose muler where the horizontal roots put ont. Having driven a statie fimbly fir each tree, I would plant it so shallow that after the heary rain the unjer sicle of the roots will become exjuserl. In this way the trees are not so liable to becone infested with the grub. I planted some trees so a year ago, and find the non-appearance of the grub satisfactory." 
R. G. PAnder-I have tried the hot water very often, and liave always found it effectnal; and I thonght that by this time everybody laad heard of it, but if they liave not, J. liope this letter will be read and remembered. Instead of clay I used leached ashes, as they were more conrenient, and they answered a good purpose.

The Chairman presented a new pest of the peacl-a dark-colored worm, about an inch loug, that fixes itself in the foot-stalks of the leares and destroys them.

WII. S. CARPENTER-This insect discussion is one of great importance to farmers. These little, insignifiennt things are great destroyers of our crops. What if we could discover a remedy for the bugs that cat up the potato rines, or a remedy for the eflect of cold upon fruit-trees; for I hare noticed, within a day or two, that the northerly sides of the pear-trees are blasted and turned dark by the cold wind. The cold of a day or two in spring often destroys many tender vegetables.

It was observed that cold niglits sometimes liave a beneficial effect upon frnits, by destroying some of the insects that usually prey upon them. It did in the spring of 1860 . That scason proved the most productive of fruit of any year in the memory of most young people. Of the hot-water remely for the peach-grub, we speak from experience, that it is the best of all we ever knew. Lime, too, has been tried with good results. IIon. Joln MI. Clayton, of Delaware, assured us once, at his honse, that the peach-trees we were then looking at, which were so vigorous, had been treated witl half a bushel of lime, placed in contact with the body and upper roots, and he believed it wonld continue to be a preventive of the peach-grub.

253. Insect Remedies.-Te give the following various remedies for insects, all of which are rouched for by good men; some beliering one infallible, and some another.

The following wash is recommended for" all sorts of trees, as a preventive remedy against caterpillars, etc.: Potash, 20 lbs.; air-slacked lime, half a bushel; sifted wood-ashes, half a bushel; fresh cow dung, half a busliel. Mix in water enough to be of the consistence of whitewash. Serape off the rough bark, and rub the wash in well with a bush.

Caustic soda wash is one of the best things we ever saw applied to a firuttree. It will make the bark as smooth as if wax-polished. It leares 110 larbor for insects under pieces of dead bark. It is made by heating the common sal-soda red hot in any old iron ressel, and then making a lye of it - say about one pound of the salts to a gallon of water-and washing the trees with a brush. It is best to put it on in the spring. A piece of old store-pipe, battered up at one end, and stuck into one of the store-holes, answers very well to heat the soda in. The wash should be too caustic to put your hands in, and, while putting it on, it will not be worth while to wear a fine broadelotl coat.

The Liquid Brimstone Remedy.-M. Letellier states in the Journal of the Paris Horticultural Society, that a liquid formed by boiling 63 grains of red 
American potash, and the same quantity each of flour of sulphur and soap, in $1 \frac{3}{4}$ pints of water, is most excellent and efficacious in destroying insects. If it requires to be stronger, the quantity of potash and sulphur may be doubled, but the soap must remain the same. Upon immersion, the insects -ants, caterpillars, cockchafers, grubs, etc.-are instantly killed, while the solution occasions no injury to plants. The liquid will destroy ants and grubs when poured into their places of resort.

I'reventive of Canlier-Worms from Apple-Trees.-A letter from M[alden, Mass, gives a most sensible plan for a cheap preventive of canker-worms, which climb the boles of apple-trees:

"Take pine boards of suitable width for four to box a tree. Cut them in pieces two feet long on one edge, and four feet long on the other edge. Nail them together in a box around the tree, with four sharp points up. This box is to be adjusted about the tree before the grubs come from the ground, and a peck of powdered lime or ashes thrown between the trunk of the tree and the inside of the box. The caustic lime or ashes will destroy the grubs near the tree, and the boxes will invite all the grubs near them to ascend and aleposit their eggs. I found the pinnacles covered with grubs and eggs, and the insects apparently contented with this highest point as a safe place, and there the eggs were deposited. I then removed the boxes to a considerable distance from the trees, and heard no more from canker-worms; they all diel for wint of propler food."

Another plan, lately patented, to prevent worms climbing trees, looks as thongh it would be effectual. A tin trough is made in two parts, large enough to encircle the tree and leare a space four or five inches between tho trough and bolc of the tree. From the outside edge of the trough a strip of cloth extends all around, wide enough to have its upper edge tacked to the tree, by which the trongh filled witl oil is sheltered from rain and sus. tained in its place, so that worms ereeping upward come first in contact with the eloth, and if they crawl down that to get around the edge and so up the tree, they are caught in the oil, which, being sheltered, remains in good condition longer than when cxposed. Now it is an experiment worth trying, and for which there is no patent, whether a strip of eloth nailed around the tree at one elge, and laving the other extended six inches from the bole hy a wire or limber rod, would not answer the purpose without the cil-trongli. The under side of the eloth conld be conted with some kind of pitch that would not larden soon, being protected from sun and rain, which would eflectually prevent the ascension of insects-certainly much more so than the belt of tar as it is usually applied.

Dr. 'Tumble, in answer to the question, what remedy to apply to this pest, said that the only remedy is the ichnemon parasites. These, in their proper time, will attack the worms and destroy then. In the mean time, while one section of the country is ravaged, another is extraordinarily funtful.

IIe introduced specimens of the eaterpillar that preys upon the grapevine, to show that it las its parasite, one of which laad just emerged from the 
body of the caterpillar. This, he loped, would prove a sufficient eheck to the ravages of this particular pest.

25t. Inother Conversation at the Club about Insects.-W W. S. C.smpenter:All classes of insects have their farorite plants, but if these farorite plants fail, the insects will take to others. Last year I saw ailanthus trees in this city completely covered with a worn known in the country as the cankerworm. The trees were wholly stripped of foliage. We are continually importing insects in various ways. I am told that erery banana stem contains a worm, and some of the same sort of worms liave been discovered preying upon the quince.

The rose-slug is easily killed by hand in the after part of the day, by an application of quassia decoction, sprinkled upon the leares, as the slugs are then on the upper surface.

Extra cultivation, by which the plants grow rapidly, is the best remedy for" squash bugs.

Mr. Pardes said that the best remedy is to expose the soil ding from a deep liole sereral days to the sun, and then put it back in the hole, patting it down solid, and then putting in the seed, and covering it lightly, and then spreading fine charconl orer the hill.

Mr. Fcller-I tried this charcoal remedy, last year, most thoroughly, without deriving a particle of benefit.

Mr. PArdeE-I have used charcoal, and ras not troubled witl bugs. Now it is possible that, without it, the plants would not have been tronbled. So, after all, it is uncertain whether the eharcoal was the preventive, or whether there were no bugs to be eradicated.

MIr. Garvex-I have tried a great many remedies, and liave nerer found anything so good as careful watering, and hand-killing the bugs.

T. G. Pardee-I wish every man would try the solution of aloes-two ounces to the gallon of water. It is such a bitter vegetable that it is offensive to all insects. It may be used just as strong as it ean be madefrom one fourth to a whole pound to the gallon.

Mrr. Carpenter-The canker-worm, in the northern part of Connecticut, is now ravaging the orchards to an extent that is destructive to all prospects of fruit. On some large orchards there are no applesin fact, nearly all the foliage of the trees has been destroyed. Can this be prevented?

Washing Insects from Fruit-Trees.-Mr. PardeE read a letter from Charles Lincoln, of North Bridgewater, Mass., which stated that he succeeded in saving his plum-trees, last spring, from insects, by washing them frequently with elear cold water, using for the purpose a little hand instrument ealled the "liydropult."

Dr. Trnmbe contended that all the rot in plums is caused by the sting of the eureulio.

Mr. Pardee thought that this statement was incorrect; that plums frequently rot where there are no curculio. He said, thirty years ago, at Seneca 
Falls, there was no curenlio to disturb the plum, and we grew great erops, and sometimes nearly all on a tree rotted, almost all at once.

Creisharst's Compound for Insects.-P. B. MEAD (editor of the IIorticulturist) said that he has tried the above compound upon several kinds of in. sects, and found it sure death to all he had applied it upon. The objection to it is its high price-too high for common use; if it wonld rid ns of the eurenlio, it would make the plums too costly.

Jonn G. BengeN-It is a fuct that we have a prospect this year of a larger erop of plums than we have had in many years, and therefore persons should be carefin of their hasty conclusions about this or that mostrum driving them off.

Mr. MEAD-The preparation I mentioned, dissolved in water and used as a syringe upon plum-trees, had the effect to drive ofl the curculio, even upon one side of a tree, while the other was still infested.

Remedy for Rose-Slugs.-GEo. II. IIts-I have found an effectual remedy against the depredations of these pests, in sifting lry dust upon the bushes. It is just as good as snuff, or any other bug-powder. Of course, it wants frequent renewal.

Bark-Lice.-Axorew S. Fulder-If a tree is properly eultivated, it will glow so vigorously that it will ontgrow all bad effects from attacks of plantlice.

Worms Destroying Gooscberry Bustes.-R. Dixic, of Painesville, Ohio, iuquires for a remely for a pest upon his gooseberry and curant bushes. He says "they have been stripped of their leaves entirely, in one summer, by hosts of green caterpillars or worms about an inch in length-a number of broods during the season. What shall we do to get rid of the pests? I have used lime in powder, and dry unleached ashes, without any apparent beneficial effect."

Soron Robinson-I would try the new preparation of "attenuated coaltar," which we have had exhibited here in the form of a dry powder. So far as ${ }^{\circ} I$ lave been able to try it, I have found it particularly offensire to all insects.

A. J3: Dickinson-If soft soap is plaeed in the eroteh of a tree, and left to work down by the rain, it will keep off all insects, eren the eurenlio. Many inseets are kept array by oflensive smells, which do not kill them. Sunoke, for instance, keeps off many insects.

P'ests of Grapevines and other Plants.-Dr. TrumbL-IIere is a specimen of the insect that curls the grape-leaf. Spring is the time to look after them, and pick them off by hand and destroy them, or they will destroy the vines. ITere is another curious insect that infests the currant bushes. It is what we call lice, and these lice furnish food for a colony of ants, hy their exudation of a sort of sweet substance. Here is the worn that curls the currant-leaf; and here is another emrous insect that binds itself up in a web and a leaf, and what is remarkable, this insect is itself full of other insects-parasites that live upon, and in a great measure destroy it. I wish that some pura. 
[Спат. II.

site could be found to destroy the cureulio. Perlaps it may be destroyed in time, as the IIessian-fly has been.

The Measuring Worm.- Solon Robrsson-If any one desires to extirpate the worms that infest the trees in our parks, now is the time to do it by destroying the eggs. Scraping and washing with potash is the best protection of the boles of the trees. If we had plenty of birds we shonld get rid of tho worms. It is only in cities, where there are so few birds, that theso pests are so tronblesome. Insects are the natural food of all birds. Even the domestic ones that we keep about our homestead destroy untold quantities of pestiferous insects that conld not be got rid of in any other way. The greatest profit in keeping poultry is the good the animals do in their ineessant pursuit of bugs and worms, which, if not destroyed, would in their turn destroy the food-plants that we cultivate. I know of no contrivance of man that will protect him from insects.

Mr. Pardee-In New Haven, trees have been protected by zinc troughs, filled witls oil, around the boles.

Destroying Trees to Get Rid of Worms.-ANDrew S. Fuller stated that the worms in Brooklyn were so bad that the eity councils were talking of cutting down all the trees in that city, to get rid of the worms.

Solon Robinson-They had better cut down the boys who destroy the birds.

Mrore than forty years ago, the "canker-worms" were terribly destruetive, for several years, of apple-trees in Connecticut, and attempts were made to prevent their rarages by making a band of tar, two or three inclies wide, aronnd the bole of the tree. It proved effectual while the tar was soft; but, unless renewed every day, and sometimes twice a day, the surface dried so that the worms crawled over; and I have seen them so thick that they erawled into the tar and stuck, and then others went orer them, and so on until they formed a bridge, and thus defeated their strong opponent.

Dr. Trimbe-The lindens of New Jersey, in former years, lave been very much affected, but this year they hase not been injured. I believe the insect has been destroyed by parasites, and I lope it will be in Brooklyn. I hope that no one will think of eutting down trees to get rid of the worms.

Origin of "Bug-Powder."-The Seeretary stated that Lyon, the great bug.powder man, has gone home to Europe, worth an immense sum, and it is now published that the powder is made of a common French field-plant of a species of the chamomile.

All the effective insect powders now offered for sale owe their efficiency to red chamomile. It is sold by some of the druggists. Rub it to a fine dust, nix it with some clieap divisor, and it is the best insect powder known. When dusted into the cracks and corners of ceilings, ete., out walk the cockroaches and all other intruders without fail. Dust the affected plants, and you may keep them clear of insects.

Mons. Radiguet states to the Society of Agriculture, Paris, that the plant known as "Whiteflower Margaret" (Chrysanthemum cuanthemum), used as 
a decoration, is very destructive to insect life. This plant is not a natire of this country, but is cultivated here, and can be casily multiplied.

Disease of the Coffee-Trce.-Dr. Montague stated, at a meeting of the Society, that a discase has attacked the coffee-trees of Ceylon, similar to the cidium of the grapevines. The same disease has been observed in the Wrest Indies. Olives and mulberies are attacked; inseets are observed upon them, something like the cochineal insect. There is also an exudation of a sweet gum that attracts insects. Milk of lime and purin-au extract of mammre-are used as a preventire.

Ailanthus, as a food for silk-worms, has been used in France with suecess.

Iierosene Oil for Insects.-Wm. G. Le Due, of IIastings, sends us a remedy for eaterpillars and other insects, easily applied. It is kerosene oil. He says:

"Finding some large nests of eaterpillars on my plum-trees, I took a can of illuminating oil, as it is called, and applying a few drops (suflicient to saturate the web of the nest), found that it worked like a charm. It is instint death to the vermin. Care should be taken not to apply it to the leares of the plant or tree, as they will be sealded at once. I have but little doubt that, in the hands of your carcful experimentalists, it will prove of value. The coarser oils of coal will no doubt be equally efficacious in many instances. I may as well mention here, also, that I have found kerosene oil a most excellent diluent of printer's' ink, which I use in my flouring-mill for steneil-plate marking. It would be a thorough cleanser of type, though, perliaps, not so cheap as potash."

Coal-Tar for Insects.-Prof. MAPES-Te are very free of destruetire tree insects, this year (1S60), in New Jersey, but have a fair sliow of other pests of the farm and garden, and we are obliged to resort to some remedy. We can not grow early turnips without using something to keep the insects off, and I am grad that the necessity stinulates invention to assist famers in the destruetion of these pests. I have lately tried one ealled "attemuated coaltar," and find it effectual. It is likely to be a very valuable aid to fruitgrowers and gardeners. It is in the form of powder, and wherever sprinkled upon insect-infested plants, the insects leave at once. It is coal-tar mixed with some substance so as to retain all its odor, and yet remain in the form of a dry powder.

Mr. LAwton-The Black Tartarian is a good solt of elierry, but I prefer the I3lack Eagle; it is a very hardy variety, and very productive. The English Morello is an acid clierry, and the tree very free from insects. We liave not had a rose-bug witl us this year.

Solon Rousson stated that, only five iniles from Mr. Lawton, the rosebugs infested his cherry-trees by inyriads, destroying more than lialf the fruit. Mr. IR. inquired of Mr. Iawton what it was that ate his eherry-leaven, if it was not rose-bugs, as they were evidently caten by some insect, and if coal-tar or anything else will prevent thcir ravages, it should be extensively known. 
Whisky for Ants.-Wm. Davis, of Marengo, Morrow County, Ohio, ofters the following plan for protecting fruit-trees from ants, which, he says, hare killed many trees for him. It is the same plan pursued in this eity to make loafers, and then get rid of them-that is, feed them with whisky and make them drunk, and then wipe them out. He says:

"Mix whisky, molasses, and water, in equal parts, and fill a tumbler about two thirds full, and set it partly in the ground at the foot of the tree infested by ants. When it gets full of the drunkards, scoop them out and kill them."

We suggest feeding them to fowls.

Do Worms Lain Down?-A person at Angola, Ind., who notices that the Club talks about all sorts of miscellaneous matters, wants us, in the absence of more important questions, to talk abont this: "Do fish, worms, and small toads, such as are often secn after a slower, in places where it appears they must have fallen with the rain, actually come from the elonds?"

Dr. Watendury replied-They do not; it is one of the popular errors which are so hard to eradicate.

The Locust Question.-A long disenssion ensned upon the locust question between Professor Mapes, Professor Nash, Wm. Lawton, Wn. R. Prince, Dr. Trimble, and Andrew S. Fuller, abont the habits of the seventeen-year locust, which appeared in great numbers in the summer of 1860 , in the vicinity of New York. Every sehoolboy of any pretension should read all about these locusts, and study their natural history. Wherever they appear, try to learn their habits, and whether they do injury to plants, either above or below the surface of the earth.

Prof. MAPEs exhibited the effects upon branches punetured by the females to lay their eggs, he still thought without permanent injury to the trees.

WM. R. Prince declared the whole theory of the seventeen-year locusts a humbig.

Prof. Nasn thought they return in some localities in thirteen years, and inquired if the nature of the soil had any effect upon their maturity.

Varieties of the Locust.-Andrew S. Follen-We hare many varieties of what are called locusts, among which are the Cicada Septemdecim, Cicade Canicularis, Cicada Iimosa, Cicada Marginata, Cicada Superba, Cicada Robertsonia, and perliaps several others. The habits of these are well known, and have been for many years. The seventeen-year locust has appeared regularly every seventeen years for more than a hundred years, as is well atiested by numerous writers upon natural history.

Dr. Trismbe, of New Jersey, gave a lengthy lecture upon the loeust, showing low the insect deposits its eggs in the limbs of alnost every variety of trees. A great number of these twigs were distributed among the company, to show the curious manner in which these eggs are deposited.

This peculiar insect appears once in seventeen years; bnt the year of its appearance differs in every part of the country. In 1555 it infested soutlern Illinois. In 1800,1817 , and 1834 the trees of Delaware and Maryland were literally covered by them; and in 1843 many of the river counties on 
the Ifudson were infested with the Cieada. The male insect has a pair of drums on each side of the head, and, when infesting an orchard or woods, the noise is frequently so great that no conversation can be heard in the vicinity. The insect appears about the 25 th of May, and remains six weeks. The female is armel with an ovipositor, with which she inserts her eggs in the smaller portions of limbs of fruit-trees, oaks, chestnuts, cte, always selecting new growth, of an eighth to a quarter of an incl in diameter. The incisions, about twelve in number, are nade at an angle of forty to fifty degrees, with an egg in each, and sometimes the twig is girlled near the eggs, so that when the end of the twig dies it falls to the ground, and the eggs are carried in by ders and rains. Miss Morris, of Germantown, Pa., a Well-known entomologist of close observation, claims that she found them attached to the roots of pear-trees.

"While plowing at our place, May 10, these inseets were thrown ont in large quantities. The holes through which they aseend in the soil may be traced to a depth of four fect or more. This locust is not to be dreaded, as they do but little harm; are not known to feed, and the sliortening-in of limbs by the depositing of their egges may give a useful hint to those who do not understand the benefits of the shortening-in process."

IIe also gave an aceount of a maple-tree in Newark, which appears to have a sort of bohun upas effect upon flies; they lay dead by thousands under this tree.

Prof. Mapes stated that, in plowing upon his farm nen Newark, in May, the seventecn-year loeusts were tumed $m$ in vast quantities.

Dr. Trisnde stated that this insect does not consume regetation. Ther are within a few inches of the surface, waiting for the right condition of the temperature to issne forth. Seventeen years ago these insects came forth on the 25th of May, and immediately conmeneed their musical notes. They remain about six weeks above ground, eating nothing. The injury they to regetation is by puneturing the limbs to deposit their eggs. This kills the ends of the branches. The apple-tree and elm-trees are farorite trees with these seventecn-year locusts. The time of their appearance varies in different localities. This is the year for all this vicinity and up the Indson River. My opinion is that the life of the insect is sustained under-ground by attaching to the roots of plants. The limb selected for puncture is always suall.

The Secretary stated that the size of the limb punctured is not usually over an eighth of an ineh.

Mr. Dobese stated that the locusts were very plentiful on Long Island five years ago, and that he has seen then every year in this city.

Prof. MLures thought that these fellows wonk be a littlo too much for "insect powder:" Still, he had receised great henefit from one callel the "Persian Powder." That will enable me to grow early turnips, anl it will kill caterpillars.

Mr. Gata:-In 1509, in Orange County, the loeusts rere plentiful enongh to allow me to gather bushels of them, and the apple-trees were coverent. 
[Criap. II.

The only injury was to the suall twigs. Wheat-fields were covered, but not injured.

ANmiEw S. Fuller-In 1855 the locusts were very abundant in Illinois, and eame forth out of heary cliny land, from more than four feet in depth, in oak folests. They appeared to prefer the oak-trees.

The Chairman stated that he had observed their preference for oak in some instanees, but npon the whole, he thought they had very little eare for any particular sort of trees.

Dr. Thimbs thought the chestnut was their favorite. I found, yesterday, the eggs of the locust are begiming to hateh, and the young inseet is as perfeet in shape as the old oves, of a pure white color, and no larger than one of the eggs.

IIabits of Grasshoppers. - $\Lambda$ Goliad correspondent of the Colorado (Texas) Citizen gives some eurious facts in relation to the grasshoppers which have recently swarmed in that region. He says:

"They have an especial foulness for wheat and cotton, but don't take so kindly to corn. The only regetable they spare is the pumpkin. The nost deadly poisons have had no effect upon them; fumes of sulpluur they rather like than otherwise; inusketo-nets they devour greedily; clothes hung out to dry they esteem a rarity; blankets and gunny-bags they don't appear to fancy. They swim the broadest creeks in safety, sun themselves a while, and then go on. The whole mass appear to start and move at the same time, traveling for an hour or two, derouring ererything in their way, and then suddenly cease, not moring perhaps for a weck, during which time no feeding is noticed ; and finally, they carefully aroid the sea-coast."

Grusshopper Parasites.-Solon Robmsox-I have a letter from I. B. Rice, Middlebnry, Vt., inelosing specimens of grasshoppers, showing a parasite that is preying upon them, which, it is to be hoped, will help to annihilate this pest. This parasite is a small red insect, which artaches itself to the grasshopper just under the wing.

255. Canker-Worm Preventives, - The following letter to the anthor, from a New York eity friend, is worthy of attention by all whose trees are eaten by wol'ms :

"Sir: Your recent discussions upon the canker-worm, which is so seriously devastating the foliage of the eity, stir me up to lay before your readers the intormation which some years of careful observation have enabled me to gain respecting this pest of our neighborhood. I do this the more beeause I notice some suggestions in your conversations which look to the adoption of remedies; and before any remedy is tried, it is essential that we have some assurance that it will be effectual.

"I was a student in New Haven at the time when the ravages of the insect were so severe in that eity, and witnessed the extreme desolation which the ereature produced. The magnificent elms which are the glory of tisat beautiful city, stood bare and wiutry at the end of June, with every restige of their foliage utterly consumed. I noticed, and have since repeatedly ob- 
served, how perfect a protection is afforded by the metallic girdle which you deseribe. Whether the plan of a Mr. Taylor, spoken of in the papers, is an improrement, I am not able to say.

"The whole merit of the plan, howerer, consists in its adaptation to the habits of the insect. The female-which deposits its eggs upon the body and branches of the tree before the opening of the spring-is wingless, apterous, as we say in Entomology; and being incapable of flying, is effectually arrested by the barrice which is presented by such an open tube encircling the tree. The protection is complete, the application is easy, and the remedy is effectual.

"One fact, however, is to be taken into view, which effectually alters the case witl us. After familia. study of our New York insect, for several years past, I an couvineed that it is an entirely different species, of different habits in many respects; and, abore all, different in the one particular which gires all its ralue to the New Ilaven remedy; our species fully possesses the power of flight. Its progress, therefore, to the body and limbs of the tree for the purpose of depositing its exgrs can never be in the least arrested by any such measure as your correspondent proposes to adopt. Protection agrinst the worm in our eity can be obtained only by the same method by which New Haren derived hers, viz., the thorough and careful study of the habits of our own species of insect.

"The very positive assurance of your correspondent, Mr. Webb, that 'it is a law of nature that all the millers which produce the measuring worm have no wings by which they can fly one inch,' is in the main true, though perliaps rather strongly stated; but it applies only to the canker-worm of New England. Our species may be seen flying abundantly, both males and females, ascending above the tops of our highest trees, and reaching the Jarge branches with absolute ease. After having observed the whole process very earefully, I am in a position to spenk confidently abont it; and I beg to assure your readers that any attempt blindly to imitate the New IIaven method will only prove a mistaken and mprofitable, becanse ignorant, attempt. In order to ascertain with greater certainty the trutl upon this point, I transmitted specimens of our New Fork miller, last summer, to $\mathrm{Mr}$. E. C. Iferrick, the accomplished librarian of Iale College, whose investigittions of the $\mathrm{New}$ lIaven eanker-rorm were published at length, somo years ago, in the American Joumal of Scicnce, and received from him the assurance that my impression that the two species were entirely distinct was no donbt correct. MI. II. also concurred with me in thinking that the power of flight possessed ly the New York moth would require entirely diflerent methods for the prevention of its ravages.

"The one methou which my observation has suggested as effectual, consists in thoroughly seraping the tree after the eggs of the moth have been deposited upon it. 'The worm with us does not, as in New IIaven, go into the ground and remain there till the winter, bnt goes through its changes in a very bricf period. After coming down from the tree, it lays itself up in a 
[Crisp. II.

cocoon, formed of a few thin fibers of silk, in the erevices of the bark of the trees which it frequents, ol upon posts and fences near the tree. There the insect may then be foumd, undergoing its change. After about a fortuight, it comes forth in the shape of a white moth, somewhat less than an inch long. At that period our parks and public squares are alive with these millers; the grass is studded, the paths corered, the air filled with them. Any one may casily satisfy himself of their power of flight by a careful observation of them. The antennx, or feclers, projecting from the head, are in the males feathered, or, entomologically, peetinated; a row of fine fibers, like the teeth of a comb, lines each antenna upon one side; the females have the antenna plain and straight; and they may also be distinguished by the larger size of the abdomen, which is distended by eggs. No difference, however, in the power of flight will he obscrved between the two scxes. On coming ont from the cocoon the sexes meet, and the impregnated egrgs ale at once laid upon the bark of the tree. They may be seen in patehes, varying from a dozen to fifty", or cren more-minute, green globules, which soon change to a dusky gray or brown, scarcely distinguishable in tint from the bark. They adhere by a glutinous secretion very firmly to the tree, and remain through the year until the warmth of another spring hatches them into life.

"At any time after the eggs are laid in the beginning of $\mathrm{July}$, aud before they are hatehed in the beginning of the following May, a careful scraping of the tree will remove most of them, and so prevent their rarages for the next smmmer.

"Ilaving frequent occasion to pass through Washington Parade Ground, I have pointed ont the eggs upon the bark to the persons intrusted with the care of that spot, and the trees have been sometimes seraped in the spring, with rery good results. This year it was omitted, and the deserted shclls of the eggs of last year may now be seen on the trunks of the trees so seriously injured by them this summer. No other method than this affords the least security ; but this, if faithfully carricd out under any competent supervision, can be made entirely effectual. The egrs remain for nearly a year before they are hatchel, quite obrious, and tolerably accessible. A couple of men would in two or three days elean any one of our parks of this destroying agent for the next summer; and careful attention for a few years throughout the city wonld nearly exterminate the pest."

256. Garden and Field Crop Pests.-The amount of damage done to farmers crery year by bugs and worms, if it could be exhibited in figures representing dollars and cents, would exceed the whole value of the wheat erop, or coln crop, or cotton crop, and it would not surprise me if it exceeded the value of all of them. If we could give certain prerentives of the ravages of any one of the pests, we could afford to devote much more space than we shall allot to this head. But we will urge farmers to give the subject more attention. Buy the best works upon entomology, and derote many a winter evening to the careful study of the appearance, character, and habits of all 
the insects that consume your crops. Give, we pray you, good attention to what we have already said and shall say in this section. You can not fail to find something that will repay you well. Iou certainly will find raluable information in the following paragraph, written by $\Lambda$. S. Hall, of Malden, Mass., in May, 1860 :

257. Salt for the 0nion Maggot.-Much has been said and written about the onion maggot, and I don't know that there is any cure for him; but I will tell you llow I treated mine last year, and with good success fol once, and slall try it again this year, and will tell it to you and the farmers free of eharge, for I don't think I could get " $\$ 60,000$ " for it if I shonld ask it.

I sowed last year in my garden, on good soil, three rows, abont thirty feet long each, to onion seeds. I expeeted the maggots, and watelied diligently their progress. When they were first np about one or two iuclies high, I put some strong salt and water on about three feet of one row, to see if it would kill the onious, and; in ease it did not, perhaps it might kill the maggots, if they came. The young onions stood it well, and it did not lunt them.

After the onions liad got abont is large as a pail-bail wire, there came a spell of warm, wet weather, and my onions began to be affected. I watehed them several days, and they grew worse, and were fast dying ont, for abont one in every eight or ten were wilting and dying, and I found a magrgot at the roots of erery one that appeared wilting, and souretimes the maggot was nearly as large as the little stock itself, and had eaten the bot. tom all away, and was making its way up the stem; at the rate of liavoe they were making, it appeared there would not be one onion left in the bed at the end of four weeks more. I took a pailful of strong piekle from my pork-barrel, and, with a watering-pot, put it all on to the three rows, as though I were watering them; the onions never faltered or cluangel. Tho salt killed all the grass, young clover, and weeds, exeept purslaue, which eame up later, and the maggots were entirely killed, and I never saw any after, though the flies continued to lay their eggs down the side of the little plant, and between it and the dirt, just as flies will blow a piece of fresh meat; but the salt prevented their maturing or latehing, and I raised a grood erop of fair-sized onions. I think they did not ripen as well as usual, but I am not convinced that the salt prevented them, for I hare often seen patelies remain as green as mino were at harvest-time.

I put on two or three slighter sprinklings of brine after the first, cluring the sunmer.

25S. Wssay on the Cut-Worm.-Read before the Chicago Gavelener's Socicty, August 6th, 1560, by Jxo. Prana.-I acknowledge my inability to do justice to this subject, from not having given it my attention, except in a general way. It is, nevertheless, one which interests agrienlturists, and particularly liorticulturists, as much, perhaps, as any other entomological sub. ject with which they liave to do. The farmers, working on a more extended seale, using larger fields, and planting fewer varieties of loed erops, do not 
notice, nor perlaps suffer as much from the ravages of these families of the Lepidoptera as the horticulturist proper. And the great order of inscets to which this class belongs are, perhaps, the greatest scourge with which the worker in the soil has to contend. According to Dr. Fiteh, the most of this species belong to the genus $A$ grotis, of the family Noctuidx, or Owlet-moths. In England, the inscets of this genus are naned Dart-moths, from a peeuliar Epot or streak which many of them have near the base of their fore wings, resembling the point of a dart or spear, and he says that much the most common species of this genus in the State of New York can be nothing else than the Gothic dart, Agrotis subgothica of the British entomologists. They are the sane which flit abont the lights in summer evenings, and are found hicl by day within crevices and shutters. To show still further the importance of this class of insects, I will quote from Dr. Harris, showing some of the families. Ite has divided them into three sections, called Butterflies, Hawk-noths, and moths corresponding to the genera Papilio, Sphinx, and Phalrua of Linnaus.

To the first of these orders belong the eaterpillars of our common butterflics, many of which are very destructive to regetation. To the second belongs that elass of caterpillars which infect the potato, the graperine, etc.; the Algerians, or, as they are commonly called, Borers, which latter name, howerer, is equally applicable to the larre of insects of many other orders. The third great section includes a vast number of insects, sometines called Millers, from their dusty covering, or Night Butterflies, but more frequently Moths. Among these are the Cut-worm, the Bee-moth, and all other insects belonging to the order Lepidoptera which can not be arranged among the butterflies and hawk-moths.

The most common of the Cut-trorm tribe which have come under my obserration the present season, are the Striped Cut-irorm, the Red-licaded Cut-worm, and the Black Worm.

The first is of a dirty whitish color, inclining to brown, with darker stripes. This worm works upon the surface of the ground, and may be found at any hour of the day, if damp and cloudy. The red-headed ent-rorm has, as its nanc implies, a red head, and is of a uniform pale brown color, and has this season been particularly destructive; and as it works under ground, it is death to whatever it attacks.

The Black, or (as it is sometimes called) Tiger worm may easily be known when seen by its dark, dull brown color and black head. It works under ground, just below the surface, drawing the stems and leaves after it into its hole.

There are a number of others, among which are the faintly-lined entworm and the wlite cut-worm. Of the latter, I have not found a single specimen this season, thougl last jear I found sereral. They are rare, and consequently do but little damage. In this day of patent discoreries, any one who has plenty of money and ample time to spend may furnish himself with a thousand-and-one nostrums which are said to be effectual extermi- 
nators. Snuff, strong liquid manure, powder, charcoal dust, etc., will protect, provided they can find plenty to cat elsewliere; if not, they care about as much for them as I should about wetting my feet in wading a brook for my dinner, if I conld not get it by any other means. I am satisfied that they might be, in a great measure, exterminated by neighbors joining, dneing the prevalence of the motlis, and seiting torches or building fires for them to lly into. I sared my tomato erop, the present season, by liaring my men go over the ground in the morning, soon atter daylight, and pick up tle worms by hand. The first morning we secnred orel two thousand by connt, and the next morning we gathered over a lialf peck of them on about an acre and a half. After that they began to diminish, and in a few days scareely one could be found. I protect dahlias, and other choiee plants, by wajping paper about the stems; vines, by planting plenty of seed, and killing the worms; vine shields, if set two or three inclies below the surface, will generally protect. I lare never sueceded in trapping them in holes, because, if they fall into them, they can dig out, if they can uot crawl out. The best way to protect against their ravages is to plant plenty of sced, protect the birds, and then lielp them kill the rorms.

The London Gardener's Chronicle says there is a prospect of a total destruction of the grass in the Iondon parks, by the grub of an insect known as "Daddy Longlegs," which eats the roots of the turf and totally destroys it. "Varions remedies hare been tried withont success." Have any of those remedies been a heary dressing of salt? If not, it should be trieci at once. And besides that, we shonld like to know what this "Daddy Longlegs" is. It can not be our cut-worm, that sometimes destroys the turf in old meadows; and certainly it can not be the "Daddy Longlegs" of our acquaintance, for that, so far as our youthful entomological rescarches went, was a very harmless Daddy, which had very loug, slim, crooked legs, attached to a round body, the size of a small pea.

259. Wire Worms. - "A Young Fumer" wants to know what he shall do to get rid of wire worms. IIe says :

"An old gentleman not far from me says: 'Soak the seed over niglit in copperas water, and the wire worm will not tronble it.' Who knows whether this is so or not?"

All! who knows? Does anybody know anything?

Another says soaking seed in a solution of niter will prevent destruction. If so, low easily practiced! Again, who knows?

Probably the best remedy agminst wire worms is not to grow them. licep no old mealows. Break them up. l'low all your god and stubble land in the fall. Either bury your worm seed ton deep to get out in time in the spring, or elsc freeze it to deatl in the winter. There is probably no remedy cqual to deep plowing in the fall of the year.

Perhaps we might all lcarn uscful lessons from uature if we would more carefully read her printed pages. For instance, one who does try to rual cucli lessons says: 
"So far as iny observation goes, the wire-worm is most troublesome in sensons after a mild winter, or when there has been a leary coat of snow on the ground during winter, thus preventing the frost penetrating the earth to any considerable depth. Consequently, the worms remain near the surface, and are not frozen te death or diven so fas below the surface that they must starve before they can return. Tro successire crops of buckwlieat will generally rid any soil of wire-worms."

And we add, so will ten bushels of salt per aere, and every worm that is killed by it will fertilize a whole handful of grass. Salt, alone, is an execl. lent manure; salt and lime still better, prepared according to the formula under the head of "salt and lime mixture." Thirty bushels of lime, in powder, sown broadeast, will destroy the forms in many a field that has been almost barren, and make it productive of fine crops of wlicat, clorer, corn.

"How to get rid of the worms," is one of the most important questions that a farmel can ask, and the want of a knowledge how, is not confined to young farmers. Henec, all we say upon the subject is worth treasuring up in the great store-house of knowledge, the hrman mind.

260. Worm-Killers, $-\Lambda$ reliable Sonth Carolina aequaintance, Col. $\Lambda$. G. Summer, of Pomaria, declares that China beries applied like manure to soil will expel ail grubs and worms. "China trees" are as common all ored the Sonth as locust or ailanthus here, and they are very fruitful, the berries resem. bliug suall cherries in size, and pulp surrounding a hard seed. Only a fow ycars ago, the fact was discovered, rather accidentally, that the wood of this tree wonld bear a high polish, and that furniture made of it was as strong and liandsome as that of some of our most expensive imported woods, and that its natural pleasant odor, like that of cedar or camplor wood, remains, and is a great preventive of moths. The botanical mame of the "China tree" is Melia azedaraeh; sometimes called the great Indian lilac. It is a lothouse slumb here; at Charleston, it grows fifty feet high, and is a beautiful shade-tree, its greatest objection being its abuidance of berries falling upon the ground, notwithstanding which it is a great farorite in all the most Southern States, and its berries, if of any ralue, conld be had here at a small price.

261. Tobacco-Worms,-These destructive pests of the tobaceo-planter, it is well known, ean be subdued with a flock of turkeys better than in any other way. As both turkers and worms are large, the operation can be seen and appreciated; yet we liave no doubt that a flock of wrens do just as much toward the destruction of some other family of worms, and really effect as much good to the farmer. And so of every other class of birds. - Cultivators of other crops onght to take lessons from the tobacco-growers. The first glut of worms, in July, is ensily subdued by the turkeys, while tobacco is small, and the wol'ms are doing but little damage. The trouble comes in August, but the destruction of the worms a month sooner may save the erop.

Mr. Wm. Sheppard, of Ann Arundel Co., Mrd., has been rery successful 
in poisoning the moth that produces the tobacco-worm, by the use of cobalt -a quarter of a pound to a half pint of water. This is made quite sweet with refued sugar, and the mixtmre is put into a small bottle, witl a quill in the cork, and two or three drops through the quill deposited in the blosson of the Jamestown weed, or in the blossom of the tobaeco-plants. The hornblower will suck the poison till he dies.

The trumpet blossoms of the Jamestown weed are favorite resorts of the moth, and are gathered fresh, and fastened to the tobacco-plants, or upon sticks set through the field. It may be worth while to grow the weed on purpose for trape.

The colualt is the same black powder often sold by druggists as "fly poisou." It should be redueed in a mortar to a fine powder before using. It is worth while to try it for other insects, plaeing it upon plates in their liaunts.

Mr. Sheppard thinks any planter may protect himself against the tobaceoworm with this poison.

Joln G. Bergen, of Long Island, stated to us, in the spring of 1560 , that he had been obliged to send all his laborers into his tomato-field to kill worms that are destroying the plants and young fruit. He thinks it identical with the tobaceo-worm, having grown tobacco a few years ago and been troubled with the same kind of worms. One of Mrr. B.'s neighbors told us afterward that the worms were not only very tronblesome on the tomato vines, but were cating the potato-vines ravenously.

The Now Haven Courier said the potato-vines in that State were being caten by worms, so as to destroy the prospect of a erop, and these worms, we judcre, are the same kind as those on Long Island.

In this eity, worms have been for yenrs destroying the trees; none but the ailanthus escapes them.

Is it not wortl while to try to poison the insects while on the wing, in the way indicated above, or some other way?

The Jamestown weed mentioned above, we take to be the same weed that grows along many New England waysides, called "Jimson wecd," or "stinkweed." It is the Datura stramonium.

262. Bur Remedies.-ITere is a good one! We liaven't a doubt as to its efficacy-not one! try it. A correspondent says: "I have secn many plans reeommended for removing and keeping bugs and other inseets from rines, and among them, smuff, soap, mustarl, ete., all or any of which arficles must, in my opinion, more or less injure the plant. I have found this the case from experience; and I have also found, by the same means, that the best preparation for this purpose is a cold and very strong docoction male with water and manure from the lien-roost and cow-yard, and applied morning and evening. The insects do not relish this preparation, while the plants to which it is aplied do."

Another one says: "I preserved my vines last year from the ravages of the striped bugs by placing little wads of cotton, saturated with spirits of 
turpentine among the vines near the roots, using care to live them not toneh the viues. The turpentine should be renered from to time."

Another says: "These prests of the vines maty be easily got rid of by building a fire of light wood that will blaze freely in the evening. All insects fly into a blaze, and are thus destroyed in myriads."

It is recommended by J. M. Dimond, of Eaton Co., Mich., to plant in the same lill with summer squashes or melons, ete, some seeds of the winter sfiuash, such as hare the largest sueculent leares. He says the bugs will not molest the smallel vines muder such ciremustances. When dauger from bugs has ceased, then the plants can be removed.

Another one gives the following as a sure specific for bugs on vines: "Hiving seen by your paper that many truckers in your section are anxious to ascertain a simple and sure remedy to destroy bugs on squaslies, cuenmbers, and the like, I will give you one which is almost a specific, and within the reach of every one, especially those living on the sea-board.

"Procure fresh fish-of any kind whatever, the commonest and cheapest just as good-a suffieient quantity according to circumstances, say one peck to a barrel of water. Let them stand therein a day or two, in order to commence decomposition and emit their necessarily unpleasant odor; then dampen the leaves with the liquid.

"In addition to driving away the bugs, your plants will become green and healthy, and soon grow beyond the reach of any future swarm of depredators. It may be necessary to use the water two or three times in the course of two weeks, but remember that every application is equivalent to a dressiug of manure, which will amply repay for the libor, which is rery trifling. Fresh fish offal is of equal value with the fish."

263. Potato Bugs, - It is quite as useful to report finilure as snccess in farming. We are therefore obliged to Horatio J. Cox, of Zamesville, Ohic, for telling us that he tried powdered lime, and also asles, sifted upon his potato-vines to prevent them from being eaten by the potato bugs, but he found them at work as usual, with their backs white with lime. I is conclusion, therefore, is, that that is no remedy against the depredations of these pests. He remarks that "there are two kinds working in concert, but, from iny obscrvation, keeping up separate breeds-the black shell and the striped shell ; the latter is more active than the ather, and not quite so plump."

A French paper gires an opinion that nearly all the diseases of plants, including potato-rot, are occasioned by insects. The insects, in many eases, are microscopic. The little aucaris, for instance, although so very minute, is a great destroyer. It canses little scabby pustules upon fruits, particnlarly fine pears.

Whether the potato bug always found on the diseased vines is the cause or effect of the disease, is a mooted question.

Althougl $M[1$. Cox did not stop their depredations, we still reeommend liberal dressings of ashes and plaster, and if these do not kill the bugs, they will give the vines a vigorous growth. So with lime and salt. 


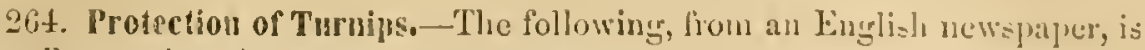
equally wortly of atention in America:

"In the list of patents for which povisional protection has been talien out is a machine of a novel and sonewhat curious charncter. The specification, as taken from the list, describes the machine as a 'blast drill,' the object of which is to protect the tmruij crop from the rarages of the fly and the slig, and its other numerous enemies, and secure, as tar als human ingenuity can accomplish it, this most valuable of all bulbons rooks. The cummon practice of protecting the tumip from the lly is ly dusting the row with lime during the night and while the dew is upon the plant. This operarion is diflicult, and imperfectly performed. Busides the slow process of doing this by laand, the difficulty of dusting the under side of the plant as well ats the top sicle offers an insuperable oljection to this mode of applying line, soot, or any ather compost, to the young tumiph-plant. This ditliculy is uow overcome, and the lime (a mixtme of one sixth of soot with it is reconnmended) is thrown, by means of a blast fan, upon evory part of the plant, both on the upper and under side. The fan is put in motion ly the traveling wheels of the drill, and receires its relocity in the usual mamucr by gearing wheels. The blast thus createrl by the fum is bromblit to ben upon the plant,-which, yiclding to its action, hems from the current, and as it icts upon a fulling stream of lime or other composition, the plant heconcs completely covered with the powler. Dit this is not the only object the bla-t. drill will aceomplish. The fly, disturbed by a simple contrivance, hops away, but is at that moment canght by a current of air cutering the lulast fin and instantly destroyed, and thrown on again with violence from the routex into which it had been drawn. This operation is simple, and the process of anuihilation is similar to that of a mouse or rat going down a thashing-nachine. The fly and the lime are so completely mixel and incorporated that the mischicrons jet delicate jusects are destroyed hy the atmospheric pressure thrown upon them, nud the plant is also scemed, by tire dusting of eompost, from all future attaclis of the encmy. All farmers can not fuil to know something about the insect which does so much ammil mischicf to the tumip crops. Sometimes a fallow, which in tillage amel labor

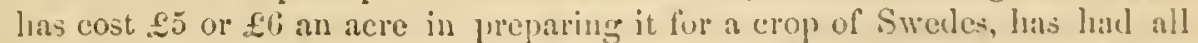
the labor and capital expended unde vain ly the fly. Can this evil be remediul: It seems possible; mel if this invention of a blast drill slonhl be the means of securing a turnip crop, or even improsing it, by the application of a top-dressing of soot or gruano, or auy oflier soluble manme, an grent grooul las Lecn accomplisher, not to farmers only, lut to tho community at larger."

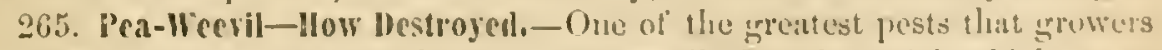
of peas lave to contend with is the pen-wervil, liruchus pisi, which some-

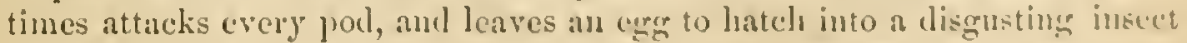
in every pea, so tlat, if intended lor foum, when dry, we shall find a mmile cum of meat ready mixed in our pea-soup. If intendel for suml, when we are ready to plant in the spring, we timb the life of our jeas eaicu out. 
Although several birels, of which the crow and Baltimore oriole are the chief, feed nfon the pea-weeril, they are very far from destroying it, and the evil is ammully increasing. IIow can this insect be destroyed, is a question wortl solving. Wu think it ean be, if furmers and gardeners wonld make a united ctfort, totally amnililated trom the comntry. The remerly is rery simple. It is to steim all the seel peas. This can be done in a small way in fimilies by taking the seed, so soon as gathered, shelled, and dried, and flaciug it in a cullender, coveren with a cloth or plate, and placed over it ketile of boiling water mutil the steam is thoroughly passed through the pens, when they are to be dried in the sun and put away in paper bags. Uprom as large seale, the peas may be steamed in bags or barrels, by inserting a steampipe from a boiler at so low a pressme that it will not eonk the peas, but it will the pupre of the pea-weevil. Let it be rencmbered that steam, properly applied, will totally eralicate the pen-weevil trom the land And if from peas, why not from wheat, corn, and rice, easier and better than by kiln-drying? It would be very ensy to dry the steaned grain. Passing it through a fanning-mill would probably be sufticient; or pouring it out of a baskct, where it womld full fifteen or twenty feet though the air.

266. Ireserving Insects.-Insect collectors will find the following method of killing the insects they wish to preserve one of the most convenient of any they have ever tried. Dissolve cyanile of potassa in water to saturation, and keep it tightly corked in a small vial, and it will alwatys remain in good order for nse. When you catch a fly, moth, insect of any kind, or a beantiful butterfly that would be injured in fluttering, dip a needlepoint in the solution, and prick your captive just under the wing, and see how quick and calmly they will lic down and dic. Some large or hard-to-kill insects may require more than one stab to make then die peaceably. This solution is used by seientific entomolorgists in making their collections.

267. Househo:d Insects.-Mall's Medical Joumal states that houseliold rermin may be got rid of as follows: Ilalt an onnee of soap boiled in a pint of water, and put on with a brush while boiling hot, infallibly destroys the bugs and their eggs. Flies are driven out of a room by lianging up a buncls of common piantain (fleawort) after it has been dipped in milk. Rats and mice speedily disappear by mixing equal quantities of strong clicese and powdered squills. They derour this mixture with greediness, while it is innocent to man. When it is remembered how many persons liave lost their lives by swallowing mixtures of stryclinine, ete., it becomes a matter of humanity to publish these items.

The Scientific American says: "Common red wafers scattered about the hamats of cockroaches will often drive away if not destros them." These wafers, like candies, are colored red by oxyd of lead, a most deadly poison; and so is the acetate of lead, or sugar of lead, as it is sometimes called, on visiting cards, which, being a little sweetisli, has been known to destroy young childreu, to whom they were hauded to be anused with. Fashion 
for onee acts sensibly in discarding glazed carls, using instead Bristol board, more pliant, less cumbersome, and really more delieate.

We have found that bugs cam not stamel hot alum water. Take two pounds of alum, bruise and reduce nearly to joweler, and dissolve in three quarts of boiling water, letting it remain in a warm place till the alum is dissolvel. The alun water is to be applied hot, by means of a brush, to every joint and erevice. Irusl the creviecs in the floor of the skirtine-board, if ther are suspected places. TWhitewash the ceiling, put in plenty of alum, and there will be an end to their dropping from thence.

To kill moths in carpets, spread a wet cloth on the earpet, and iron with a lot flat-iron round the elges and places where you suspeet them to be. Do this a tew times in the course of the summer, and you will save your carpet from the moths.

Silk-rcorms have been induced to work in France by electricity. II. Sauvageon reports to the Acadeny lis experienee in the matter. Finding the little things torpid and unwilling to work, the idea struck him to stip thenı up by clectricity. The results, us lie grives them, are really marrelous. IIe took fitty-three worms at random from among thousands belonging to a neirhbor, put them every day on a sheet-iron plate, through which a current of alectricity was passed, kejet them each time as long as they could stand it, and now has fifty.thee beautiful coconus, an amount wheh his neighbors will not olstin, to all appearuees, from Eeveral fhousand ungalranized worms. If these results may be relied on, he has made a very valuable discovery.

263. Mofh Protcctors.-Cumphor is one of the most useful moth protectors about the houschold. I trunk full of furs, witls an onnce of eamphor sum seatterel through them, will be safe from moths. Furs or woolene packed in a clest made of camphor-wood or cerlar will generally be safe. Sonce lousewives pack in a linen slieet, or lan of close texture. Others use tobacco. Others licep their furs or woolens in drawers or trums where they will be often exposed to the light, and where they ean frequently take them out to the air and smu, and beat them, which will effectually prevent the ravares of the moth. A very erood preventive is to earefully kill the miller that makes the worm which is eo destructive to woolens and furs. It is not a liurd unter to do so in a lomse not alrealy orermu with tlem. They may be attracted to a light blaze; and they may he eanght in plates with a little sweetened water and vinegrar of a piece of an old blanket may he used as a trap; or they all may be caught and elestroyed by hand, hy derofing lialf an lour to the work ench evening, in the proper season.

269. Ants in the House.-These troublesome pests may be orercome by various remedies. I'erhaps one of the lest things for the red ants is to mix a few graus of cormsive sublimate in a sponnliul of lard, with a liule sllatr, and then draw rongly strings of entton ol woolen yam llumerth the unixture, aud lay them in the eracks where the ants harbor, or in lle comers of relimet shelves. They may also be poisoned with cubalt, pulverized tine and mixed 
with something sweet that they like to feed upon. These and othel insects can be poisoned by arsenic. They may be kept from the sugar-bow] liy setting it in a plate coverel with powdered chalk. The whisky remedy reconmended in No. 25t, to protect trees from ants, may be adopted in the house. The buer-powder mentioned in the sane number, mate of red chanomile, can also be used in the house for ants and other pests. For the large black ant, the best rehicle for poison is old cheese. Dip a piece of it in a poisonous solution, or moisten it if dry, and dust it with corrosire sublimate or arsenic.

Be very careful, in the use of poisons, not to get them mixed with food. There is no more danger, with proper care, than there is in keeping gunpowerder in the house.

270. Insects Beneficial to Farmers.-It is not to be infered that becanse an animal is called an insect, it is pestiferous. The contraly should be tanght in all schools, as well as in home lessons. The false idea is prevalent that all sorts of insects, bees excepted, are mischicrous, hurtful, and lateful; so that every worm, bug, fly, moth, miller; or little crawling, crecping, flying thing is looked upon by almost every one with a feeling of desire to crush it. A contrary feeling must be cultirated. Cliildren must be taught to rliscriminate between good and evi] insects, as well as between good and eri] deeds. A cloud of moths might be seen horering around the wheat, and the farmer, under the supposition that they liad come to destroy the grain, 'might destroy them, and afterwarel find that he had killed lis best friendsthe parasites of the wheat destructors. Before we declare a war of annihilation, as many lave against the birds, upon any elass of animals, let us first inquire which are and which are not noxious. Te will here bricfly point out a few.

The common angle-worm, instead of being detrimental to the furmer, is actually a co-laborer, and often a better one than the biped owner of the soil. A scientific writer on Zoology says:

"The burrowing of earth-worms is a process exceedingly useful to the gardener and agriculturist; and these animals are far more useful to man in this way, than they are injurious by destroying vegetables. They give a lind of mider tillage to the land, performing the same below the ground that the spade does above for the garden, and the plow for arable land, loosening the earth so as to render it permeable to air and water. It has lately been shown that they will even add to the depth of soil; corering baren tracts with a layer of productive mold. Thus, in fields that luare been overspread with lime, burnt marl, or cinders, these substances are in time covered with finely divided soil, well adapted to the support of regetation.

"That this resnlt-wlich is most commonly attributed by farmers to the 'working down' of the material in question-is really due to the action of the earth-worm, appears from the fact that in the soil thus formed, large numbers of 'worm-casts' may' be distinguished. These are prodnced by the digestive process of the worms, which take into their intestiual canal a largo 
quantity of the soil through which they burow, extract from it a great part of the decaying regretable nutter it may contain, and cjeet the rest in a finely divided state. In this manner a field manured with manl has leceme covered, in the course of 50 years, with a bed of eartl atweraging 13 inches in thickness."

White, in lis " Natural Ilistory of Selborne," says:

"Worus secm to be great promoters of vergetation, which rould procecl but slowly without then, by boring, perforating, and loosening the soil aud rendering it pervions to rains and fibers of plants, by drawing straws and stalks of leaves and twigs into it, and most of all, by throwing up such infinite numbers of lumps of earth, called worn-casts, which, being their excrement, is a fine manme for grain and grass."

It is a part of the system of comminution spoken of under another head; and if all the eartl could he eaten by worms, it would serve as a manure fine crops, simply becanse it liad been julverized, and thereby fitted for their use.

Some time sinec, in company with several gentlemen, we listened to a conversation with referenee to the ralue of the earth-worm, one gentlentu claiming that they were a nnisance in the garden, and oflers aserting that they were a great blessing, as mole drainers, and always an index of the fertility of the soil. Here is a paragraph from the Encyclopedia Briturnice, riglit to the point:

"The common earth-rorm, though apt to be despised and trodden on, is really a useful creature in its way. Mr. Finapp describes it as the maturil manurer of the soil, consuming on the surfice the softel jart of decalyen vergetable matter, and conveying downward the more wooly filiers, which there molder and fertilize."

271. Plant-Lice Destroyers.-There is an ichnemon fly, a very small blackish insect with yellowish legs and ablomen, mot quite the twentietl of an inch long, which destroys myriads of aphides. The female lays an egren in each louse, and the grub from that clerours its nest. leaving only the skin attacher to the leaf, serving for a sledter for the larra in its pupa state. The fly comes out of a lole in the louse's hate, and repeats the operation. Careful examination will diselose a gleat many of these perforated empty

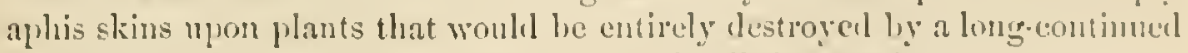
multiplieation of their consumers, hut for this litte parasite.

The Syryhes is the name of another destroyer of the aphlis that aboumb upon cotcon-plants. This is not a parnsike; the egegs heing laid on the leart among the aphis, the maggot, which is, when full grown, abont une fith of an inch long, makes its forl of the liee. The pup is formed on the leat, in

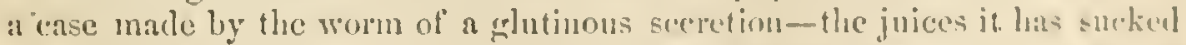
out of the lice it furl upon. "The fly is seven tenths of an inch meross the wings, which are double; the body appearing like a dininntive wast, handerl with brown, black, and yellow. It hovers much on the wine, willunt mush motion, nuless disturbed, when it shows its jower of nwift tlight. 'This 
lonse destroyer dues not confine its operations to the apluis of cotton-plants, thongly it seems to profer them. It is of immense servico to Sontlem furmers.

The Lady-birl (Coceinelli) is mother valuable assistant to the cottonplanter, in particulan. Where the lice most abound, there will be found the lady-lipul doing jts work. Fet there are numerous planters who, seeing this inscet lovering over the cotton, suppose it the parent of the pest they stand so much in fear of, and direct the negroes to destroy all they can. It was a negro who first discovered that the worms hatelied from their eggs, which are deposited on the leaf near the aphis, actually consume them, instead of the cotton-plant. The worns are a quarter of an inch long, bluish-black, and roracious as an alligator, to which they bear some slight resemblanee. They scize and eat the lice alive, until all upon the leaf are consumed, when the grub finstens itself by the tail to the leaf to arait its change. The insect while on the wing is also a louse-eater. $A$ disagrecable odor emitted by this inseet will serve to identify it.

The larra of the lace-wing fly is another cotton-aphis eater. These worms are hatehed from filaments of egres, which the fly attaches to the under sicle of the leaf near an aplis colony. This larra is not quite one fifth of an inch long. It may be known by the way it holds by the tail, while streteling out full length looking for its favorite food. It spins a little cocoon, out of which, in due time, comes a bright green fly, with brilliant eyes, and fon tramsparent greenish wings, delieately netted like fine lace-lience the nume. This insect also belongs to the fetid-odor family.

2־2. 0thar Insect Destroyers.-The Carolina tiger-beetle is a beantiful insect, seven tenths of an inch long, of metallic blue, violet, and green color, and savage propensities toward all other insects.

The II arpalus is another insect-consuming beetle, with very strong looked jaws adapted to a predatory hife. If it can not find living food, it will consume dead, putrescent substances.

The Mantis, an insect known in Maryland as the "rear horse," is a vorneious consumer of inseets. In fuet, it is said that they will sometimes consume one another. The largest are over two inches in length, of a rery awkwallooking form. The eggs attached to a limb look like an excrescence, and are often attaclied by an ichnemmon fly, as a place of deposit for its eggs. The young mantis comes ont in June, at first without wings, but with a strong appetite for aplides and other insects. It stands mpon four hind legs, with body elevated and forward feet elosed, and head constanty moving. It walks, or jumps, when alarmed, but is capable of donestication so as to come and take food ont of the hand, and is perfectly harmless except to things obnoxious to man, and for that it should be preserved. Its color is brownish gray to light gieen, and its form will be remembered from a picture of $\mathrm{it}$, or after being once seen or known.

The Reduvius novenarius measures an inch and a quarter in leugth, and destroys multitudes of insects in all their stages of transformation. The 
egras deposited in autumn hateh in May or June; the young worms are narked with a black head and thorax, and bright red abdomen, and black spots on the back. They afterward appear of a grayish color, with rudiments of wings, which at length cnable tlem to fly with strength. It approaches its prey cantionsly, and makes a dibl, and pierece it to death, and then suckis out the substance. It eats the common tree-caterpillar voracionsly, and it sometines wounds a person handling it incantiously with its slarp piereer.

There are numerous other parasites of noxious insects, and insects like those naned, which prey upon others, which are really beneficial to the farmer, as are many qualrupeds and other animals that are natmral jusectcatcrs, such as toads, moles, skmbs, etc. 'The most important of all, perluaps, we mention in the next paragraph.

273. The Wheat Milge l'arasite.-The only hope of relief from the blasting effects of the wheat-midge (323), with those who have thonght upon the sul,ject, has been a parasite that would work its destruction. That hope, we trust, is about to be realized. A correspondent of the Cunalliun Agriculturist, witiug to that paper in the autumn of 1860 , says:

"I am rejoiced that this weck I can ammonce the arrisal of a deadly enemy to the wheat midge or fly. In the neighborhood of Sparta, township of Iarmouth, the fumers have discovered some species of ichnemmons which deposit their exgs on the larva. One of these is rery small, black, and shining; the other is also black, with red feet and a blunt tail. These aro often mistaken for the wheat-1ly; but as it has only tuo wincrs, and they hare four, the distinction is obvious. To observe the proceclings of the ichnemons, place a number of the magernts or lavre of the wheatelly on a slecet of paper, and set a. female iehuemmon in the midst of them; slie som pounces upon her victim, and, intensely vilorating her antenne, hending heyself obliquely, phunges her ovipositor into the body of the larva, depositing in it a single erger. She will then pass to the second, and so on, deprositing a single egor in each. You will olserve the magent writhing in seening agony, when sometimes the fly stings them three times. These ielnemmons alplear in myrials on the ontside of the ear, but, as if impaticut of hright liglit, slieltering themselves from the smin's rays among the husks."

The same thing has been noticel in ofleg sections; and Dr. Fitch, the entomologist of the New lork State $\Lambda$ erricultural Society, is so much encomaged that a remedy has come at last, that lue writes confidently, in November of that yea": "The days of the wheat-midge pest are numbered. I fully believe that famers maty again sow wheat without fear of its destruetion by the Cicillomyia tritici." 


\section{SECTION XIII.MIISClLLANGOUS-WIID ANO TAME ANIMLALS OF TILE} FAlMI-IOOIESTIC FISII-BREEDIAG, ETC.

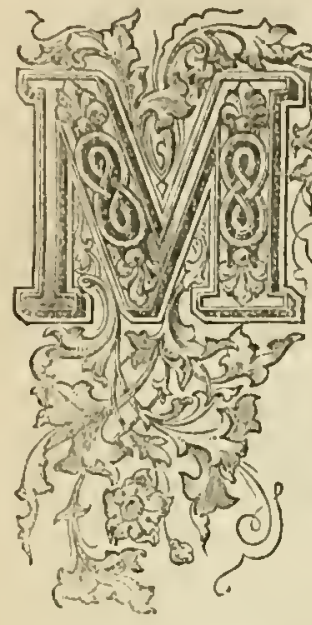

Gif oles. - We hare for fon years (1559-1562) ocenpierl on little fin in Westehester Countyone of the many sadly-abused pieces of land, some of that in mowiys, not planted for thirty years or more-and in this land we found the moles as thick as we erer saw them anywhere in onp life, and therefore lave a right to speak of then from experience. In some respects we liave suffered severely by them. They have killed many cloice things that we have planted, including several valuable grapevines; lut we are not yet willing to destroy the moles. We do not look upon them as pests, althongh they have pestered us. They undermine the plants, but do not eat them What for? It is not for eport, nor merely accidental in boring their suluterranean galleries. It is in pursuit of food. And as that food consists of inseets noxious to the farmer, this paragraph mpon moles eomes in conrse rery well after the section deroted to insects. In fact, we believe that the mole is one of man's best friends, and that it never ocenpies land that is not alrendy so picocenpied with destruetive woms as to render it unfit for cultiration. So impressed with this belief are some European people - all Prussia, we beliere-that ther lave enaeted laws to prohibit the killing of moles. As with the crow, opinions vary in this comntry whether the nole is benelicial or injurions to farmers. For onr own part, we must say that we never see an acconnt of a "new mole-trap" withont wishing the inventor might get his own fingers canghlt in it. It is a great pity that farmers can not leam that moles are one of the good things that Providenee lias bestowed upon them-that they do not destroy sceds and plants, but the insects that are great pests to the farm and garden. In this opinion we sluall continue untiI better informed upon this question. In the mean time we gire some opinions of others. The following is the sketeh of a report of a conversation at the New York Farners' Chul, about moles:

Solor Romissor read a letter upon the subject of moles, which elicited a lengthy discussion. The following portion of the letter we print:

"This animal, as you probably kuow, las a very suall apology for eyes, which ean not be discorered till the skin is removed, and it ean not be asecrtained that they are of any practical use. His sense of hearing and of smell is rery ante, and lie is criabled to elnde observation, and to aroid anything unnsual that may be placed in lis track. No device, howerer, with which I am aequainted will foree him to abandon a well-eultirated track, alounding with earth-rorms, which are lis chief attraction. IIe will pass from hill 
to hill, severing the corn, melon, or other seeds from the tender plant, thus mreatly impeding its progress; and in many instances wholly destroying it. In a seareity of earth-wolms he will prey upon beets, potitoes, and other roots witl voracity; still the dimage he thus does is of little aceount eomfrared with that produced by his relentless plowing or rooting. Wrere: the soil is fertile and not too wet, this intruder will be found undernining all vergetation, and is a source of discomfort to the atgriculturist, which must he realized to he appreciated.

"Irailures in field and garden, which are often attributed to drouth or in. eccts, are many times produeed in a great measure by moles. At morning, noon, and evening the mole groes finth on his depredations, making the no t rapil morements (for an mulerground pertomune(e), and in less than twenty minutes finishes lis repast, and returns agrin to his hiding-y lace deep in the earth, beyond the reach of all intruclers.

"The Ianke mole is too sluewd for the English trap, or, indeed, for any, with a single exception. I hare camined several traps, benutiful in theorr, but they are splendid practical failures.'

War. S. CAnpexter-I an satisfied about the injury of moles to the farme:, beines much more than all his henefit in cating worms. I had a bed ol" tulips destroyed by moles. I traced them hy their paths from root to root.

Irof. Maris - I have tried eareful experiments mith moles in confinement, and have never suceeded $\mathrm{j}$ getring them to eat any kind of verguable matter.

Mr. Mnony, of New Jersey-I liare found that moles do cut off the stems of thoms in my liedge. I cun not say that they ent thorns. I an sattisficil, ton, that they will cat potatoes.

Prof. MAPES-I find that protatoes are eaten in the vieinity of moles, but I am satisfied that they are caten by irmbs that the moles feed upon.

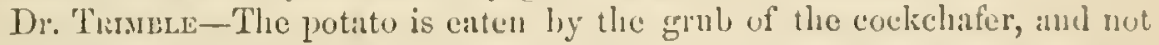
by the mule.

M[r. Futuli-I have known moles to gnaw potatoes, but not for foorl.

The Chaiman, Roblit L. P'bles, made the following remalks "pon this sulject:

Mole-Kills.-In rich alluvial snils, mole-hills are thrown up in immense numbers, because sueh soils usmally : abomul with the food thit these subterraneous ereatures seck for. "Thry destroy the roats of grass immediately contignons to their monnds, benides often impeling the free action wit tho seythe, for these reasoms. Sune think it well to exterminate them; still they no doubt ilo a vast deal of gool hy destroying obnoxions worms and grmuls.

In the spring of the year it is an easy matter to spreal nut these momms

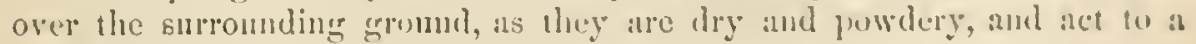
certuin extent as an chloching topretle eisiner.

The mole cau not lear acess to the atmosplucre, heing wholly subterabneous ly nature; they never drink, but live entirely upm worms, insects,

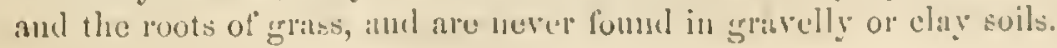


They breed in April and Nay, and generally produce four at a birth. The tumels that they make are invariably parallel to the surfice of the ground, and about six inches deep, unless they become alamed, when they inmediately sink to the deptls of fourtcen inclies, rarely deeper. They have cities muler ground, which consist of lonses, or nests, where they feed and numse their young ; communieating with these are wider and more frequented streets, made by the perpetual journeys of the fomale and male parents, as well as muny other less frequented streets, with direrging branches, which they extend daily to collect food for themselres and fumilies.

Moles are excedingly active in April and May, during the pairing senson, when the tumnels become very numerous, for the purpose of ineeting eacl other. I do not believe that they are bliud, from the fact that I have never olserved that the mole-hills increase exept in the day-time, showing that they do not work by night, which they would probably do if deprived of siglit. They eonmence very early in the morning, when you may often sce the mold or griss moving over them; you may then readily cut off their letreat hy thinsting in the gromed a spade direetly behind them, when they may be dug out very easily and killed by the attendant terrier. By plicing your ear ou a newly-laised hill you may hear them scrateling at a considerible distance, and thus be able to find them. Yon may always discover the locality of their young by observing the hills, which are larger and the color different, a portion of the subsoil being thrown upon top. If you desire to set traps in their tumels, it will be necessary to discover which are the frequented streets and which the by-roads.

This may be aceomplished by pressing the foot lightly on the hill, and if the nole passes that way he will nearly obliterate the mark. Fon may then set a subterrancan trap, and he will be canglit. These may be made fiom a piece of wood, in a hollow, semi-cylinder form, with grooved rings at each end, in which are plaeed the nooses of horse-hair, one at each end, fastened by a peg in the center, and stretehed abore-cround by a bent stick; when the mole has passed throngh one of the nooses, and remored the eentral peg, the bent stick, by its elasticity, rises and strangles the animal. The strueture of this quatluped adapts it admirably to the underground life that it leads. Its head is rery long, conical in shape, and tapers to the snout, which is much strengthened by a bone, gristle, and rery powertul nuscles. The body is eylindrieal, very thick on the back of the head, from which it diminishes to the tail. It does not appear to have any neck, but where it shonld be, there is a mass of museles, all of which appear to act mon the fore legs and head. These are the instruments with which he exearates the ground; they are harder, shorter, and stronger, in proportion to the size of the animal, than in any other of the mammiterons class. I have never destroyed one of these little animals, because I consider the damage they do to a few roots of grass is entirely counterbalanced by their immense destruction of wire-worms, slugs, etc., besides acrifying, disintegrating, and lightening the soil, and thus fitting it admirably for the purposes of top-dressing. 
I never permit the common crow to be destroyed, because he preserves my corn-ficlds from numerous enemies, lieeps ofî hawks, destroy's shugs, snats, grubs, and eats carrion. Nor the black snake, whose constant employment scems to be the destruction of fiekl-mice, and other encmics to the orchard. Nor the cherry birl, because he is always on hand ready to eat the first cherries that ripen prematurely, which invariably contan the worm. Nor the ling-bird, wren, or robin, all of which are employed from dawn to dusk in relieving ane from my enemies.

275. An English Opinion abont Moles.-The Royal $\Lambda$ grienltural Socicty's Transactions eontains the following opinion abont moles. The report atfirms that "in one year, and crery year, 60,000 bushels of seed-whent, worth $£ 30,000$, are destroyed by wire-worms! This prevents $\{20,000$ bushels from being grown, worth $\$ 300,000$. If ou farmers and others, instend of killing moles, partridges, and pheasants, would protect them, 720,000 bushels more wheat would go every year into the English market. But the ereature designed by a kinl Providence to perform the chief part of this immense rood is the inole! Some years since I hat two ficlds, one of which was full of wireworms, the other perhitps a third full. My erops failed on these fiells for the first two or three years, but afterward improved rapidly, for I bought all the live moles I coutd find at three shillings a dozen, aud then two shillingrs a dozen, and tumed them into these fields. I had eight quarters of har!cy per acre and seven of wheat whore the moles were at work all smmer, making the ground like a honey-comb. Next year, the wire-worms, being all eleared ont, my innocent little workmen, who had performed for me a service beyoul the powers of all the men in my parish, emigrated to my neighbor's lands to perform the same serviee, but of course they met death wherever they mored, so that my little colony was wholly destroyed. Nuw i will reccive all the unoles that the farmers will give ine, and tum them into my grlube."

276. An Ameriran opinion abont Moles, -An Ameriean writer mudertakes to criticise what is said above, and says: "This I know from everyday observation to be rery erroncons. I do not know that moles eat inserets; be that as it may, I have no douth their living is prineipally seeds, ant routs, and other regetables. In the winter time, when snow is deep and the ground not frozen, I have known then to destruy whole murserics of apple-trees, and eren young orehards that have conmenced bearing."

Now this man don't know what he is talleing about. Ho has confounded mice and moles together. It is the miee, and not the moles, that have heen runuing alont in this man's orchard eating his tres. But he helewen it is moles, and has a fixed prejuliee in lis mind against them, which no arewment perhaps ean remove. Wo beg of firmers to kentu tacts about things in which they are so much interested.

277. Mice and their llischief.-Miee, we willingly concente, are mischievons -in young orelards exeessively so. We seasons are furorable to the rapid incrense of field nice, and when fullowed by snowy winters and mfrozen 
turf, so they cin liave access to the elover roots, they hecome a scourge. The late dry smmers nearly externinated both rats and mice-probably more fiom thirst than lumger.

The variety of mice that does most damage to trees is known ats the "meadow monse," which always works under corer, grirlling the trecs most when the snow lies decpest, particularly if it lies lightly or is held up by weeds and grass, so as to allow the vermin easily to make their patlis from tree to tree, or from the tree to their resting-place.

27S. Remedies for Mice Lating frees, - Tramping the snow down aronnd the trees is a pretty smre remerly, and where the orchard or nursery is not extensive, will answer to be put in practice, lut it wonld he tronblesone on a large seale, as it may laxe to be repeated sereral times in the winter. Some persons have found it a good plan to tramp down the snow and wet it. It then forms ice, that often remains nearly all winter, keeping the ground warm, as well as kecping the mice of:

Downing, in his "Fruits and Frnit-Trees," says: "The following mixture will be found to be an effecturl prevention. Take one spadeful of hotslacked lime; one spadefnl of clean cows'-dung; half spadefnl of soot; nne handful of flour of sulphur-mix the whole together with the addition of suflicient water to bring it to the consistency of thick paint. At the approach of winter, paint the trunks of the trees sufficiently high to be seyond the reach of these remin. Experience has prover that it does no injury to the tree. A dry day should be chosen for the application."

Coal-tar has been recommendel, lut we advise great cantion in its use, since many persons have destroyed their trees hy it. We would sooner try a coating of strong alkaline soa]); that, at least, would not injure the trees.

279. Mice and Osage-orange--T. D. Cattell, of Salem, Colmmbiana Co., Ohio, says the ficld-mice are cating mp all the roots of Osanc-orange liedges in that region, so that they are ntterly destroyed, and their eultivation must be abandoned muless somebody can gire a remedy. II sars:

"It has been my understanding, lieretofore, that one of the greatest excellenees of this plant for fencing was its freedom from all animal destroyers. If no remedy against the ravages of the mice can be fond, it will be folly to set a plant of the kind in this part of the country. One of my neightbors has alieady giren up half of his for lost, and grubbel ont the balance. No donbt others are troubled in the same way. I have tried traps, terrier dogs, and poison, but all in vain. What shall I do?"

Who can tell?

We heard one nurseryman say that lıe shonld digr up an Osage-orange hedge, because it attracted mice, and also because it entircly exliausted the soil of a wide space, so that he lost the growtl of one row of trees.

290. Pats.-This specios of the renus $m u s$ is an almost intolerable nuisance in some portions of the United States. In fitet, we do not know of any portion now exempt. They follow man into the wilderness. When we 
located on the prairic, in 1894 , ahont 15 miles from neighbors, and 40 miles ont from what lias since crrown to be the city of Chicago, there was not a rat to seen or hear? of. For serelal years we were exempt from this pest. There came alundanee of shipping to Chicago, and with it aluundance of lats, and they soon spread orer the whole land, multiplying and derastating. Now they are great pests in the barns and stacks of prairic funcrs.

Our eommon breed is cailed "Norwy rats," from the supposition that they originated in that comntry. British naturalists, howerer, assert that they were introduced into the British Islands from India. If they are tropical animals, all we have to say is, that they easity adipt themselves to at rigolous climate, where they multiply at a most prolitic rate. What we are yet to do with them is a problem not easily solred. All the receipts to enre the nuisance are only preventive, not cradicative.

281. Rat Antidotes, - I correspondent of the Gurlener's Monthly sars: "I tried the effect of introducing into the entrance of their numerous holes, runs, or hiding-places, small portions of chloride of lime, or blenching powder, wrapped in ealico, and stufied into the entrance holes, and thrown loose by spoonfuls into the drain from the louse. This drove the rats away for a twelvemonth, when they returned to it. They were again treated in the same manner, with like effect. The eme was most complete. I presmme it was the chlorine gas, which did not agrec with their ollactories."

Another correspondent wites: "Some four or five years since, my cellar became musty, to orereome which my wife sprinkled a sulution of eopperas (1retty strong) ores the hottom. Since that time we have seen no sign of rats abont the house, notwithstanding there lave been plenty of them about the burn and other buildings on the premises."

Arsenic is considered, hy some who lave tried it, a failure, when nsel fir the purpose of clearing premises of rats, becanse they are too cmmonge to purtake of it after witnessing the death of two or three of the family. It is uflectual, if the verunin will take the bait.

Stryelenine we consider fin jureferable, and although so much more costly, It reguires lint a few ecents' worth to do the work of death npon a humbret 1'its. It is also the rery best thing to use upon a tronhlesome dog ol cat that comes jrowling about your premises. One grain tor a dose is sullicient. We hare killed mmerous wolves hy inserting one grain of strychniue in the ecriter of a piece of fresh meat, just large enough for a monthful for a walt. As rats do nut bolt their food, it is a little more diflienlt to get them to take strychune, it is so intensely bitter. If it is mixed with corn-neal, and a fow drops of oil of nuise alle added, it will at tract the rats.

Fitring and feathering rats, and then letting them run, has been furaticed. to grive the tribe a hint that it wull be well for them to leave. (Mne rather snat individual, not having tar, nsed spirits of turpentine. II was going to drive the rnts out of his house cellar. He was entirely suceestul; tor when he let tho rat loose in his kitehen, with a "Shoo!" to it to go down the cellan stairs, it took the kitchen fire in its comse, and then a pile of thax that 
lay in the cellar way. In two hours there was not a rat in the louse, unless it mierlit be a roasted one.

Plaster of I'uris has proved a snecessful poison for rats; and it las the advintage of being gnite harmless to have abont the house. $A$ tablespoonful of the flour of.plaster, mixed in a cup of Indian meal, and slightly swectened, will be eaten by rats, and kill them. A little grated eheese makes the food more attractive. Oil of anise wonld be still more so. In fact, by the use of it, rats may be coaxed ont of a louse to eat poison, and die where their dead bodies wonld not be a nuisance.

Phosphorus, powdered and mixed with meal, a few grains to a teacupful, has been often need sucessfully as a rat poison.

Poudcrel potash, strewn in the paths frequented by rats, has been known to drive them away from a house. The theory is, that it gives them very sore fect, and disgusts them with the place.

252. Diglish Rat-Catchers.-In England, rat-eatehing is a profession, sons often following it as the business of their fathers. The rat-catcher visits a farmer, and contraets with him at so much a head for all the rats lie destroys. His thap is a large bagr, which is set with the month open, baited with a piece of bread scented with oil of anise and oil of rhodium, the seent of which attracts the rats, and thus he bags enough to fill the contract. He docs not desire to rid the premises, as that would "spoil business." $\Lambda$ ratdestroyer would not be tolerated by the honorable company of rat-catehers.

253. Rat-Traps,-Among the many devices for trapping rats, we will mention a few of the best. A large wire cage-trap, where the second rat will go in because he sees the first in there, often proves successful. A Jarge brass kettle, half full of water, with a suall stone island in the center, just big enongh for one rat to rest upon, the top of the kettle being covered with parchment, similar to that of a drum-head, having a cross cut in the center, is a first-rate trap. Finsten a small bait upon the points of the cut, and the rat jumps down from a board arranged for the purpose, and through he goes into the water. He serambles on the island and squeals for help. Another hears him, and comes looking around, sees the bait, jumps for it, takes the plunge, and gocs down upon the other fellow's head. Then comes a scramble for place, the strongest pushing the weakest off to take his chance in the water. This muss, as with men, attracts others, and in they go. We have heard of twenty in a night thus inveigled to destruction.

A barrel, one third full of water, with an island, the surface eovered witl chaff, and a bait suspended over it, we lave been told, is an excellent trap.

Ferrets and weasels have been highly recommended to be kept about the barn, to drive away rats. The objection to them is, that they drive away the ponltry also. Ferrets have been trained so as to be obedient to the call of their inaster, and used not only to hint lats, but to drive rabbits ont of their burrows.

2St. Domestic Cats--Perhaps the best thing for a farmer to do, who is tronbled with rats, is to multiply his stock of cats. We knew one farmer 
who kept fourteen eats, keeping up that number for more than a yeat by which means he got rid of all annoyance from rats, and they also hunted the rabbits out of an adjoining grove.

The varicty of the felis tribe known as the donestic ent, once wild, casily gets wild aginin it neglected by man, and is then as great a pest as the lats, and is giren to the rery bad labit of eating eggs and chickens, and catching pigreons and other birds.

To prevent cats killing chickens, Marrict Martinean gives the following as a sure preventive both against the killing of ehickens and birds by the cats: "When a cat is secu to eateh a chicken, tic it lound hel neck, and make her wear it for two or three days. Fasten it seeurely, for she will make incred. ihle cflorts to get rid of it. Be firm for that time, and the cat is curcel-she will never again desire to tonch a bird. This is what we do witl on own cats, and what we recommend to our neighbors; and when they try the experiment, they and their pets are secure from reproach and danger hencefortl. Wild, homeless, hungry, latgred, savage cats are more difticult to catch; but they are outlaws, and may be shot, with the certainty that all the neighbors will be thankful:"

'The abundance of food and shelter obtained by the domestic eat makes them much more prolifie than in a wild stute. She is generally, thongh very tame and gentle, much more attached to the house than to its immates, which is quite the reverse with the dog. There are some demarkable singulaticis about cats. Gentle as they ajpear, they are very newons, ant catsily startled, and act for a moncht as wikly as though never tamed. They ale also accused of being very treacherous. 'Their affection for their own species or omrs is certainly doubtful. Their conduct at times, wen a menber of the funily dics, is singular. Their anxiety also to get at a curpie hats led to curions superstitions. In the opinion of the superstitions, the black cat has ever been attendant upon witclucraft. It is our opinion that a prortion of this black-cat superstition originated from the finct that the hairs of a black cat exhibit sparks of electricity to a remarkable degree, wholu the atmosphere is in the right condition. To see this, take suclu an cat intu at dark room, mon a cicar, cold November night, and stme the fin the wrong way, and if you never have seen it before, you will be surprised at the eflect.

Cats, particularly fenales, are gruerally very cleanly amimals to keep as honse jets. They are fond of watum quasters and soft heds, and their song of satisfuction, ealled purring, is very pleasant to all who have a fundues for cats. We have known this fondness becounc a eat mania.

We look upon cats as a necessary patt of fillu stock, and they should be properly treated as much as any other kiml of amimals.

285. Dogs.-If there is any more numitigated musance in a faming conmunity than dors, such dogrs as fummers gencrally keep, we are mulile (n) name it. In the country where we live, there are some lumblreds of foums hetter fitted for sheep hushambly than any other purjose, hut upon which no sheep are kept, becanse the conntry is so full of worthless logs. 'Thu 
country might be a hundred thousand dollars a year richer, if the people conld stock their farms with sleep. A man who keeps a worthless cur to prowl through a neigliborlood, is neither a good Christiau, moral man, nor grood neiglibor. He does not lo as lie would be done ly. A well-traned terrier is the only lind of a dog that is usetul to fumers in general. Of these there are several varieties; the best is the wire-haired terrier, an unglylooking brute, but a ferocious enemy to lats. The black-and-tan terrier is a luandsone and more agreeable-looking dog to have abont a place, and a grood ratter, when trained, but does not have such an apparent natural projensity to destroy rats as the wire-Iraired one. Ile is also, for lis size, a very strong dog, and linows nothing about fear of anything, and is therefore il very good house watcli-dog. Lint we do not beliere a farmer erer slonld keep a $\log$ for his services alone, as a watch or guard of his premises. $\Lambda$ dog to be worthy of a lome upon a farm should have sereral good qualitics combined. No conscientions man ean licep a dog when he knows that the Feeping of such dogs, whether his particular one or not, las a tendency to prevent the keeping of sheep; for shecp, of all animals, lave greater adaptation to the purpose of furnishing the poor with cheap food than any other donestic auimal in use in this comntry, and they are capable of converting the coarsest herbage of the furm into the most healthful meat of the shambles.

2S6. Slicpherd's Dogs.-Thenerer sheep are liept in such numbers as to constitute a considerable flock, the owner can well afford to liecp a good shepherd's dog. One who has nerer seen a well-trained shepherd's dog can form 10 jdea of their extraordinary sargacity and usefulness. Wre have ridilen leisurely across a wide prairic in a wagon, accompanied by a Scotch colley, half-breed slut, driring five hundred sheep better than three men conld have done withont a dog.

If there were none but such dogs in the country, there would be ten times as many sheep liept. One man would be entirely competent to manage a thousand. He should Inve two dogs, so that they monld be company for each other, and so that, in case of accident to one, the other would remain serviceable.

The Scotch colley rery much resembles a prairic-wolf, having a broad foreliead and pointed nose. The ears are short and upright, the flecee shaggy and slightly curly, with a bushy tail. These dogs are very intelligent, docile, and faithful, and possess an instinctive sagacity in ererrtling that relates to the care of shecp. In a pleasant little book called "Aneclotes of Dogs," some wonderful evidenees of the sagacity of Scottish shepher] dogs are to be found, and they should be read by all farmers' boys.

The English shepherd dogs vary considerably in appearance from the Scotel. The hair is smoother, and they do not appear so distinct a breed as the other. Both are of medium size, perhaps about fifteen inches ligh. The Irish shepherd $\log$ is larger and more ferocions; some of them would tear a unan sadly, if he interfered with the flock at night while in cluarge of 
the dog. The Scotch $\log$ is always gentle, and generally very affectionate. In France, the shepherd dogs are somewhat like the Scoteh, but smaller. The Spanish shepherds have al loreed of dogs peculiar to tlat country. 'They are the size of a full-grown wolf, with large heal, thick neck, mastifl-looking, ficree and strong, and are often armed with a spiked collal, to make thein more formidable to dogs, wolves, and bears, if they shoulel attack the flock. Their color is generally black and white-their daily rations two poumls of black bread, with milk and meat when it ean be had. In Spain, the great flocks of the country, always in charge of shepherds and dogs, matie long migrations every gear from their Jowland home to the mountain pastures, two or three hundred miles distant, feeding all the way in the roads and connunons.

Sheep are the wealtl of Spain, and withont the atd of shepherd logs, that wealth, under the present system of management, conld not be prodilecel.

2S7. Dog Laws.-In New Jersey there is a dog law which should be entitled, "An act to eneourage the kecping of the most orlinary breeds of sheep, and no others, and to induee owners to have them libled lyy dors." This act provirles that all sheep lilled by dogs shall be paic for ont of the jublic funds, at fire dollars a head. To improve your flock, it yon gut a buck worth a hundred dollars, and the dogs kill him, you get five dollars. It your neighbor las one killed that you would not liave on your farm, if paill five dollars for taking lim, he grets five dollars. It is not a law to encomage inprovement in sheep-brecing.

The number of sheep annually killed by dogs in Ohio has been ascertained by the assesiors. The number and ralue are astomding.

Therenpon a correspondent of the Ohio Furmer says: "Shall we have a dog law, or must we give up keeping sheep? That is the real question. There would be kept fifty per cent. more sheep in this comutry, but for dous: not that quite that amount are dogged, but most furmers lose some, and this, witl other risks, liscourages them, aud compels them to abandon the husiness. Now let every famer make this a test question in the elections this fall. Iet it be suris' 2's. Inons, and let all Republieans and Demoerats sec to it that erery man put in nomimation for tle Legislature is sombl on dogs. Iet the camblidate choose whom he will serve-sheep or dogr.s. I an in earnest. Mr. Eibiln. The sight of a few fine Leicester's, each worth more than all the logs in Ohio, mangled and tom by worliless curs, who aro ouly kejt heanse lleir owners are too lazy to lill them, has marle me in denel earnest: and wo to the Olio legislator, if he lepents nu my vote, whose fonr of dor constitnents shall induce him to oppose or dmolge a severe dog law! Now is the tiure, wool-growers of Ohio, to look to this matter, and sco that auti.dor men are fut in nomination ly your respective purties."

There is no use in talkingrentom taxing dogs. The dogs that really do the

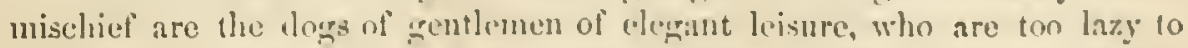
lumt with them, and of the llemeratic lnatir, who don't like to work. Jut arlories in the luxury of a house full of children and a doren elogs. Honest 
working people, who earn their bread, don't keep worthless dogs about them; it they keep a dog, they feed lim, and train him up properly; but your roaning wortliless vagabond will keep a seore, and expect them to take care of themselves. But these fellows have rotes, my dear sir; it will never do to tax their dogs. They would kick up such a dust about our ears that we conld never find our way into the State-house again.

2SS. A Trap for Catching sheep-killing Dogs.-Make a pen of fence rails, beginning with four, so as to hare it square, and as you build it, draw in ench rail as you would the sticks of a partridge-trap, untıl your pen is of sufficient lieight, say five feet. In this way you will construct a pen that, when finished, will permit a $\mathrm{log}_{\mathrm{g}}$ to enter at the top at plcasure, but out of which he will find it diflicult to estape, should he have the agility of an antelope. All that yon have to do to cateh the dog that has killed your slieep, is to construct the trap where the dead sheep is left, as directed, as soon as possible after an attack has been made on your flock; put a part or the whole of a sheep that has been killed in it, and remore the balance to some other field. In a majority of cases the rogne and muderer will return the succeding night, or perhaps the next, and you will have the gratification next morning of finding lim securely imprisoned. Some may object to the plan, perliaps, on the ground that you unight catch an innocent dog. If he is so, he can content himself with not trying it.

2S3. I Sermon on Dogs.-The Texas Christian Advocate gets off the following short sermon upon dogs, from a text to be found in Philippians iv. 2 "Beware of dogs!" Upon this the preacher says:

"The Apostle well knew the mischicrous and meddlesome spirit of dogs. Hence lis caution against them.

I. Dogs in general are a nuisance.

Because :

1. They excite fears of hydrophobia.

2. They worry and destroy sheep.

3. They disturb our slumber.-IIowling in horrid concert under our window, simultaneonsly baying at the moon.

4. They frighten us when ont at night. $-\Lambda$ snap or growl at a neighbor's gate, or when turning down a dark alley, has a wonderfully nervous tendency.

5. They are too familiar.-Will sleep on the front gallery, scatter fleas, come into the dising-room and parlor, and go to churel on Sunday mornings.

From these and other considerations I observe :

II. All dogs shonld be watehed.

1. To prevent their depredations.-Killing neighbors' cats, tearing pants, scaring children, and going mad.

2. To correct their bad manners.- Teach them they are only dogs, and not quite equal to "white follss."

3. Keep them in their places. - Wherever else they belong, I question as to the propriety of their getting between the sheets with gentlemen, or using the church as a dog-keninel. 
Application.-IIave you a dogr? Then keep him in a dog's place, and wateh him. If you admit him to undue familiarity, don't forget that other folks will still think lim to be but a dog. If he has a shaggy coat and turnnip nose, these will not entitle him to the privilege of following you to church and disturbing the worship of the entire congresation.

Though lie may be as nice and sensible as his fond master or foolish mistress, it is not very probable the preaching will do him any good. The intelligent fellow might be allowed the pleasure of trotting across the floor, and barking his approbation at the oceasional flights of the preacher's eloquence, were a dog's gratification more important than the people's edification.

IIenee, in conclusion, I would say, Beware of dogs! and what I say to one I say to all, Peware of dogs!

Finally, to the sexton, or that good brother who raises the tunes, I would say with emplasis, Beware of dogrs! and if those eanine interlopers persist in coming to the place of worship, just take them out and ent off their tails close to the ears."

290. Rabbits-To Prerent Gnawing Trecs,-The Ameriean IIare, commonly eallerl Rabbit, is common to all the Atlantie States and Canada. It is used for food by most people, but abhorred by others. Although clothed in a thick coat of soft, whitish-gray fur, the skin is not valmable, becanse it is too tender to be serviceable, and the fur is not much, if any, better than cotton, for such purposes as fur, separnted from the skin, is used for. These animals are prolific, and gencrally prefer to live in and about farms that lave been suffered to grow up bally to bushes. They do the most of their feeding at night, and farmers generally do not feel any dread of their misehief. Nurserymen do; and so do those who plant young orehards near where rabbits abound. When lunger presses them in winter, they will gnaw appletrees with tender bark so as to destroy them. Young nursery trees are often ent ofl by rabbits so smoothly that one not knowing how it was done would sulppose it was by a knife.

To prevent the depredations of rabbits, English nurserymen dip rags into melted brimstone, and fasten them abont anong the trecs. The renedy mentioned in 278 , to prevent miee, is reemmended to keep the rabbits away. Some persons have danbed their trees with grease seented witl some offensive odor, and found that rabbits would not tonch them. Some have plastered them with fresh eow-dung. A rery good remedy is to ofler a bounty for every jablit killed in the neighborhood.

Where trees lave been injured, it is a good plan to bind up the womnd with a plaster of elay and cow-dlung, made plastic enongh to adhere well; this, when firmly bounil on, will often save a valuable tree.

Domesticated rabbits, if suffered to run at large, are very ornamental, partienlarly if of the finest fancy sorts, but they are sometimes unpleasantly mischierons. Where they ean be conveniently kept under restraint, we have no donbt they ean be made as profitable as poultry or other small farm stock. In England, rabbit-breeding is quite a business, and men of wealth 
and good standing engage in it, and form rabbit elubs, and exhibit their stock for prizes. Some of the specimens imported from London, that we have seen, were very beantiful. Some years ago, Franeis Roteh, of Butternuts, Otsego Comnty, N. I., imported some of the best we have ever seen, and bred them to a considerable extent, finding ready sale for all he elose to dispose of in that way.

We do not know of any large establishment in this eountry where rabbits are lored for sale in market for food. The common American wild rabbit is often seen in the New York market.

Rabbits may be kept in very inexpensive hutehes, and in tolerably elose confinement. Their feed in summer is clover and various green things. In winter they will eat grain, sweet apples, parsneps, and other roots, cabbage, and a little sweet hay. A full-sizel rabbit wants about a gill of oats night and morning, with a picee of rutabaga or parsnep, or its equivalent, say a quarter of is pound a day, and a little handtul of hay. A doe, while suekling her young, which is most of the time, should be ted high, say three gills of oats a day, or wheat shorts, or pea meal, and roots and hay. Or in summer, upon almost anything that grows green, if giren fresh.

A dozen or fifteen years ago, we remember haring seen in "The Boy's Own Book" an elaborate treatise upon rabbit-breeding, and to that we refer the boy who reads this and desires to go into the business. They will also find frequent hints in agrieultural papers, and in several books devoted to fancy pouttry breeding. From what we hare said of the food which rabbits consume, it will be easy to calenlate whether kecping them will be profitable.

Newspapers bound aronnd trees, it is declared in an article before us, will wholly prevent depredations of rabbits, and also keep off the borers, and a wrapper well tied on will last for months. The writer says :

"I find no other remedy necessary for either rabbit or borer. The wrappers, if properly put on, keep whole through all the changes of our variable winters. The trees are thus seeure from damage by the rabbit. In the latter part of spring and early part of summer, when the beetles of the Sapesda and the Buprestis are about, a few eggs will bo deposited in the axils of the lower branches of trees, and at the tops of the paper wrappers. Eren these points of attack, however, can in general be suecessfully guarded, by simply depositing a small piece of brown soap in the main axils, after the season's growth is well started, to be dissolved and washed down the stem by subsequent rains.

"Bnt I do not find it necessary to resort to this preeantion; for if eggs are deposited at those points, I am certain to find the fact out, and make all right the latter part of August and first part of September, when I go among my young trees with a bueket of strong soap-suds and a hard scrubbingbrush, for the purpose of giving them a good hard wash, such as would make some people open their eyes with astonishment, and entting out suckers or small shoots that may have pushed through the papers, and renewing the wrappers." 
291. Squirrels and Gophers, - All of our Eastern and Fortheru readers will understand about squirels, and low mueh mischicf the smallest of the family does in the corn-field; but they know nothing of gophers-they belong to the West. In California they are almost intolerable, and it is about is hard to derise a plan to get rid of them as it is liere to get ric of the ". chipmucks" (Tamias tysteri). In our opinion, the best way to prevent lliem from digging up the sech-eom is to give them plenty to eat on the surfice. What is lialf a bushel of com sown hroalcast for the squirrels to pick np? It would save the seed of a liuge field lammless. Te would willingly grive that every year to see the dear little things around a farm. It is worth that to sec the old dog ehase them, and "barli at the loole" where one run through a stone wall. Tre have concluded never to kill a chipmuck. If others wish to do it, they may perform the work by poisoning corn, or they may frevent them from eating it by coating the secd"with tar, which is done by mixing a pint of tar in a pail of warm water, and putting the eorn in it ; then, to ruake it pleasant to haudle, roll it in dry plaster. If a little flour sulphur is spriukled on the wet seed, it will adhere and give it an odor that all little pests dislike.

At the West, in woody districts, gray, black, and fox squirels, partienlarly" the first named, are sometimes very destructive to the coln-fields in autmun. The gray and black squirrels increase so rapilly after one or tro seasons ot an abundant supply of beeli-nuts, that the regular squirrel-lumts to not appear to diminish their numbers. They are to some extent migratory. as their supplies eluange, from becel to oak lands. At such times the strung and liealthy will swin large rivers, and nuiformly talie one direction, leaving the young and feeble at home.

In Olio, about the year 1S35, squirrels beeame so mumerous over the whole conntry as to threaten the cntipe destruction of com-fichts while in the milk. The following year they were all starved. In the winter they ran desperately over the ficlds, indifferent of danger, sometimes feeding upon the bark of the beech.

The red and striped or ground squirel are not liable to sufter from these vieissitudes, as they lay np a store for winter. I think the flying squirrel does also, but this is a nocturnal creature, and less is known abont it. There are also several kinds of winter birds which deposit seculs in linots and loose bark of trees for winter use.

The fox squirrel is the largest of the Ameriean species. It is of a reddishgray color, and inlabits the prairie groves of northern Indiana, Michigin, Illinois, Wisconsin, and other States. It is very shy of mm, is liard to gret a sight of, and difficult to kill.

292. Striped Gophers (Spermophilus trilecemlineatus).-Perhaps, when you see the name griven to this animal by natural-listory writers, yon may imagine it is as big as its name. Int it is not lalf as formidable to look at. We give the scientifie name for identifieation, becanse the wort " (iopluer," in Florida, means a small land-turtle. In Wisconsin it means a squirrel somewhat like a ehipmuck. In California it represents a ditlerent aminal. 
The striped goplier abounds in the Northwestern prairic region. In the first settlement of the comntry a lundred miles around Chicago, it inluabited all the prailie groves and dry ravines. The following is its description: The ears are short and rounded; the tail slender and hairy, about half tho length of the body; the body is of a dark brown above, longitudinally marked with alternate rows and spots of a light fitwn-color, which correspond newrly with the belly and siles. The lighter lines on the upper part may be distingnished by the brown intervals between, which are oceupied by the single rows of light spots, which are generally indistinet on the anterior lialf of the body.

Altlough these animals are considered grain-eaters, and called misehievous, we believe they are among the many real friends of the farmer. Like the weasel, which oceasionally eats a chicken for lack of nore farorite food, the goplier sometimes eats the furmel's secd-corn, but he should not be condemned as an enemy for that act, without a fair hearing.

There may be some of the gopher family that are destruetive of firm crops. The evidence is rery strong to that effect against the Californian gopher, which lives in holes all throngh the enltivated ficlds, and does not scem to be very particular what it eats, whether corn, wheat, potatocs, beets, melons, pumplins, so that it is something which the farmer has grown for his own use.

It is not so with the small striped gopher. This beantiful little animal should be carefully preserved upon all farms where it now exists, and we liave no donbt it would prove a valuable addition to the stock of any farm where it is not found in a natural condition. It is a great destroyer of ficldmiec, and in onr opinion a whole troop of gophers do less damage in one season than the mice which one of them wonld kill in a single day. For they are real epieures, cating nothing lut the blood and brains, when the supply is abundant. These animals have such an appetite for flesh, that if deprived of it, a mother will eat her young. Such carnivorons animals must be better hunters than cats, and shonld be carefully prescrved, and not "drowned ont," as they often are, when their homes are discovered by the boys, just for the "sport" (cruclty) of killing them. These animals seem to have a natural instinct that man is their common enemy. We have seen thom often in situations where they could never have had any acquaintance witl man, at least civilized ones, who are the only ones who ever kill such small game for "sport", and we found them wild in the extreme. They utter a cry when discovered, and dart away into some shelter with great rapidity. In this respeet, quite unlike the elipmuek, which will play around a dog or man in the most tantalizing manner.

The striped gopher nerer gnaws trees, roots, fruits, nor green vegretables, and in fact does the farmer no damage except to cat a little sced-corn. For all that they eat in the harvest-field, they save twice as mueh in driving away mice and squirrels. Chipmucks, red squirrels, and mice can not inhabit the same locality with gophers; and yet there are persons who have offered bountics to have them destroyed. Let such learn this fact from this 
volume, if they learn no other, that the striped gopher is worth its weight in gold upon any farm where field-mice aro so abundant that they destroy fruit-trees.

293. Skunks. - We don't know that we can afford to stem the current of popular opinion so far as to recommend the protection instead of destruction of skunks (Tephitis Americana). Tre are aware that these animals are troublesone visitors to the poultry-yard, and on that account they are hunted and killed withont mercy, and without a thought about what they live upon all the time that they do not eat clickens. As they are llesh-eaters, they must find something of the flesh kind to eat, and that something is the very thing that the farmer is most anxious to get rid of-it is mice, and worns, and bugs. The quantity of these pests destroyed by a single skunk is enomons. It is very rare that they eome about a house, thongh we have known them to live for wecks in cellars, or store-rooms, or under a crib, withont producing any misance. They never enit their fetid odor unless attacked by man or dog; and it has been contended that it was practicable to domesticate a skunk so that he wonid be quite a harmless pet. We can not recommend making pets of these animals, but we do recommend famers to leam the important fact, that if they do him a little damage oceasionally, they also do him an incalculable amount of good. Generally speaking, there is not a farmer in all the region indabited by the Mephitis who could nbt well aflind to exchange logs for skunks, and pay ten dollars each for the barmain. There is one other thing that skmnks are grood for. As an article of fool we don't think there is any wild animal that makes a more dainty dish, and we hold that we are tolerably well qualified to julge. A fat skunk, nicely dressed and roasted, lung by a string betore an old-fashoned woul dire till beantifully browned, and then served upon a platter flanked with hoiled mealy potatocs, eorered with the brown gravy uade of the tait drip, is beyond dispute "a dish fit to set before the lingr."

294. Toads. - Aithough not among the quadrupeds, of which this chapter treats, toads are among the friends of the firmer, and as such should have a place in this connection. Every man who owns or culvivates a gauden or field, who linows anything about the matnral history of the toal, will never. allow one to be destroyed. There is 110 animal more hamless, and few that do the farmer more good than toads. Their whole fool is of insects injurious to the farmer. The prejudice against "the ugly llings" is a foolish one, and should be done away with. We once had a toad in the garlen which, by some particular mark, was known to the children, who called it "fitller"s pet toad," beenuse it really appenrel as though it knew that we wore its friend and protector. This tond eame year atter year to lend us its valualile aid in exterminating the insect pests of the fruden. We had another that made the milk-room its summer home, where it was constant!y engagenl in catehing flics and bugs. Toads and hats should both be protected from liam, and ehildren taught to encourage them to come about the lonse. Ihats aro great insect-eaters, and never visit the house of an crening for any ofler 
purpose than catching insects for food. It is eharged agrainst them, that they sustain bed-bugers as parasites.

295. famels-Their Introduction into the Cuited States. - It is a great jump from the back of a toad to that of a camel, but not so great as politicians sometines make. As we liave to make the leap somewhere, it may as well be done here as anywhere, and after a very slont ride we will jump down again upon the back of a goat. We lave introduced camels, because we want all, particularly the furmers' boys who read this book, to leam the fact that eamels hare already been introduced into the United States, and put to service as beasts of burden. The first imported were in 1557 , we beliere, under the auspices of the general govermment, since which time they have been in aetive government service, principally in Texas, and have male one or more trips to the Pacific with army oficers.

The Galveston News gires the following account of the strength of one of the camels. It says:

"There were near a dozen on the wharf, of all agres. The camel loaded was one of the largest. On the rord of command being given, the camel lay down, ready to receive his load, which consisted of five bales of hay, weighing in the aggregate over 1,400 pounds, which was firmly bound to the pannier placed upon the animal's hump. Upon the ntteranee of command by the native keeper, the luge animal arose, withont any apparent effort, to his feet, and walked off in a stately manner"along the whart and through the city. We were informed that the same camel had 1,600 pounds placed upon him, with which enormons weight he arose. The animils are all exeeclingly tractable, and seem to possess mnch affection for any one who treats them kindly, as an example of which Mrs. W. informs us that one of them, a pretty white one, which she had petted, would always kiss her when she ras within kissing distanee, which fact, we really thought, certainly proved the animal to possess an excellent taste as well as an affectionate disposition. In thein native country the average load for a full-grown camel is some 800 pounds, with which they perform their long journeys over deserts, with but little food or water."

It is to be loped that eamels will become one of the ordinary beasts of burlen in this country, where there are snch vast arid plains, as in northern Texas, New Mexico, western Kansas, and Utah, that no other animals can traverse tliem.

It is stated that the Emperor of Brazil is about to introduce dromedaries into that country. This ammal ean go long journeys without water, and therefore will be found valuable upon some of the deserts and plains of that comntry. A common load of an ordinary dromedary is 500 pounds. One of the camels in Texas has carried two bales of cotton, of 500 pounds each. One of the best kinds of dromedaries for riding can trarel 400 miles with. out stopping to eat, drink, or rest.

At the North, where liorses, mules, and oxen are in sucli common use, we do not think that camels will erer supersede them. 
296. Goats.-Introluction of the Cashmere Goats into the Iaited States,About the most unprofitable of all varieties of farm-stock is the common goat. It is known in some parts of the comntry as the Irish goat, probally becanse the people from Ireland in this country, particularly in cities, kcep more goats than all the rest of the inhabitants. 'These are of all colors, as much so as the common breed of horned cattle, and about the size of connmon sheep. The she-goats give a small quantity of milk, and the kicls afford some flesh food, at a small cost to the owners, as they torage their living, and frequently do more mischief in a neighborhood or upon a fum than their neeks are worth. The hair of the common groat is worth nothing for manufacturing purposes. It is quite the reverse with the Cashmere goat. The fleee of this rariety is eight times as valuable as tine wool; and, fortmately, it has been found that a cross upon the common goat. cren in the first progeny, prodnces a fleece abont halt as valuable as the full blood, so that the breeding of goats in this comntry for the fleece is likely soon to become quite common, and a profitable branch of husbandry, particularly in some of the roughest districts of conntry.

To Dr. James B. Daris, of South Carolina, the country is indebted for tho introduction of the pure Cashmere groats, which are now to be found in rarjous pants of the United States; and to IIon. Richard Peters, of Allanta, Ga., it is equally indebted for the interest he took at an early day in the propagation of the original stoek, which he pureliased of Dr. Davis. JIr. Peters, being a wealthy, public-spirited gentleman, spared no pains, even when suceess was doubtful, in gretting this breed established upon a firm basis, and proving that its crosses upon the common breed would be protitable, as well as upon several other varieties of fine-wooled goats.

We had the pleasure of an aequantance with Dr. Daris ant his stock at Charleston, in 18t9, shortly after his return from several years' residence at Constantinople. He bronght with him eeren females and two males of the Cashmere goats, besides several other eurions specimens of the livestuck of the East. IIe stated his belief to be that the Cashmere, Persian, Angor:I, and Circassian goats are all of one breed, and that they have heen slighly clianged by locality, principally by altitnde. These fine goats usually hreed two kids in the spring, and, unfortunately, where rapid propagation is an object, the males preponderate.

The progeng of these goats is now to be fomnd in all the States from Now York to Texas. In the latter State they have been established preity extensively. We saw a letter written ly John R. MreCall, at Anstin, in Augnst, 1860 , which estimated that two hundred head, principally bucks, had been introlneed into 'lexas.

The demand for the fleece of Cashmere goats may be calculated from the fict that it is stated that 4,000 Joons and 12.000 people are cmployed in the

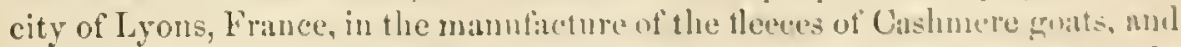
thiat they are worth from four to cightit hollars a poumb. As soon ats the supply is large enongh, we slath have manufictorics in operation in this comntry. 
Cashmere shawls were exhibited at the Crystal Palace, New York, valued at one thousand dollars each. These were all made by the needle. Fabrics malde of Caslumere goat's flecee, it is supposed, will ortwear those made of any fibrous material yet discorered.

The Thibet goat, one of which we saw at Dr. Daris's, differs from tho Cathmere materially. The outward appearance is that of a very coarschaired animal; but there is an under-coat of long, white, silky wool, which weigl!s alunt a pound when combed out. Dr. Daris thought this like the wild goat of the Rocky Momntains. Who knows if they are identical?

Dr: Davis imported, also, the Scinde goat, which comes from Scinde, at the month of the Indus. This was a remarkably large goat, with monstrous pendulous ears.

$\Delta$ goat used in Malta is the best milker of the family. A good ewe gives a gallon a day. Goats' milk, in all Eastern countries, particularly in malarious districts, is considered more healthy than the milk of cows; and some learned plysicians in this country declare that cows milk, in malarious districts, is the moring cause of many attachs of bilious fever. In this view of the subject, it may be well to inquire whether it would not be to the adrantage of the people, in a sanitary as well as pecuniary point of view, to introduce the improred breeds of goats into all sections reputed subject to malarious discases.

297. Brecling Fish for Food on the Farm.-Te do not feel willing to close the chapter upon animals on the farm, withont ealling attention to the subject heading this paragraph.

Fish are the least costly food that man can obtain; yet, owing to the scarcity, the labor of taking them out of the water-which is all the expense attending their production-lias become so great, that fish are sold in our market at nearly as high a price per pound as meat. Salmon are really higher than ehoice euts of either beef or mutton. And yet salmon can be grown at very trifling expense.

We have long been producing oysters by artificial means, without which our market could not be supplied; and yet, with that fact before our eyes, very few attempt to produee fish by an equally easy process. One fact of importance, in proof of the benefit of simply protecting fish from being taken in the spawning season, is the following:

"In the river Foyle, in the north of Ireland, by a steady perseverance in a proper system of protection, the amount of salmon taken was raised from an average of 43 tuns annually, in 1823 , to that of 300 tuns in 1812; while in the small river of Newport, in the connty of Mayo, in which the salmon was formerly unprotected by law, and consequently taken at all periods of the year, within three years after the introduction of parliamentary regulations enforcing their protection during the breeding season, the annual take was increased from half a tun of fish to eight tuns of salmon and three tums of white trout, with a certainty of a still higher increase.

"In view of the great augmentation in the price of all the articles of food 
and necessaries of life in this country, the small probability of any considerable reduction, and the actual sufferings of many of the laboring class from want of sufticient food, it appears to me that this subject is worthy of the closest consideration, and that any one who can suggest and effect the uneams of furnishing a new and ample supply of cheap, nutritious food, has sone small claim to be thought of as not an entirely useless nember of the community."

There is a little book, published by the Appletons, that gires in detail all the French plans for artificial fish-breeding, and any one who reads that rolume can go to work and stock his own waters with any kind of fish ho desires. That our natural supply has failed, there is not a shadow of doubt, and that it nerer will be replenished, except by artificial brecding, is equally indisputable. That a re-stocking of our waters with fish, so as to make them as plentiful as formerly, would prove one of the cheapest modes of lessening the price of human food, is just as certain.

In the West Indies, fish and turtle are constantly kept and stall-fed. At free running they never become fat, any more than our land stock. The ponds are constructed of stones, of irregnlar figure in wall, so as to retain three ol foul feet of water at the lowest tides. The water of the rising tide flows freely in. These ponds have a deck of plank orer them, iaid about two inches apart, for admission of air and light. A hatchway in the midelle of the floor is opened to throw in their food, which usually consists of fyy, or small fish, taken by east-nets in any required quantity. When this is scattered among them, the excessive eagerness of the fish is an interesting sight -their bright eyes, fine teeth, and sparkling colors showing beatufinly, as they leap ont of water to catch the falling bait.

The housckecpers send for a suitable fish for dinner shortly before the time to cook it. The person has a strong line and hook, with or withont bait; he lets it down, and the fish rnsh toward it, and he must be expert to let it drop to the mouth of the gromper, hamlet, snapper, white or blue band porgic, ete, which he wants. Such a fish uever appears on the tables of the Northcru States, and yet every town on our sea-coast ought to have them. Is it is now, when the poor fisherman has caught more than he can sell, the orerplus is a clead loss.

There is nothing more simple than the artificial breeding of fish. The entire mystery consists in taking the female chring her time, and by rumning the thumb with a gentle steady pressure down her back, forec ont her ora in a jar of pure fresh water. The male is then taken in the same way, and made to yield a few drops of the spermatic fluid in the same ressel, the two are then stired together for a few moments, and the contact of the fhich of the male has the eflect to vitalize the eggs at onee. The egrs ane then lat down in shallow tanks with wrivel hottoms, arranged in a serics of steps so that rumings water can continually pass over then. The whole trouble of the breeder is then to keep the egers free from any sediment or muddy deposit, and in due time each egg becomes a fish. Thus almost crery exog in an 
innumerable ova can be turned to account for the benetit of man. There is, however, something to do after the eggs have become fish, and that is, to confine then within certain limits by a dam, until they are old enough to be able to take care of themselves, and make fight agranst the larger fish which rondel eat them up. There are now three or four establishments in the country for the artificial bleeding of fish, and we see no renson why every lake and river may not be filled with life and food, and made to make an ample return for all investments.

The cultivation of fish in France and some other comntries of Europe has becone as much of a trade as any other ocenpation, and the results in supplying food and affording a handsome recompense to the owner have been equal to the most sanguine expectations. It is surprising that more attention is not paid to it in this country where the facilities are unsurpassed. Occasionally an indiridual makes a trial, but little howerer has yet been done in this line compared with what might be accomplished. I writer in a South Carolina papel gires a description of a domestic fisli-pond on the plantation of Mr. Freeman Ifoyt, Sumterville. Mr. Hoyt liad a small stream of water which ran through a low place in such a form as to enable lim, by a dam of some 50 yards long, to construet a pond of some 700 feet in length by 150 in width, with a deptl varying from the shores to 12 or 15 feet in the center. This gave him a pond of orer two and a half acres, where he conld raise nothing. He deposited in the pond cight good-sized trout, and about 300,000 eggs, with a larger amount of smaller fis! for the tront to feed upon, and in one yea the watel was literally swarming with the finny tribes. His tront one year old are some seren inches in length. The watel' running fiom the dan passes through a siere, so that the fish can not escape fiom the pont. The necessary apparatus for eultivating, feeding, and taking eare of the fislı costs but a small sum, and the proceeds of the poud will be a source of much pleasure and profit. And this is but one instance in thousands which might with equal facility be turned into a somee of revenue.

In many sections of the country numerous springs and streams abound, confined within narrow valleys, that may be conserted into permanent ponds and thns be made to yicld a profit in fish fir beyond the capacity of the same area of the best of land deroted to the most profitalle farm crops. These streams when supplied with living springs may be converted into nurseries of tront-the best of all fresh-watel fish. 'The streams or pouds more sluggish in tleir nature may be made equally productive in a supply of still-water fisl. This sulject has been bronght into extensive practice in Frauce and other portions of Emrope, and more recently a number of successful trials have been made in the United States to multiply domestic fislies, which may be as much at the command of the owner as the fowls in his barn-yard, affording an equal luxmy and at a much less cost.

Of artificial propagntion of fish in Scotland and Ireland, a late number of the Manchester (England) Guardican said: "As several reports have been circulated in the newspapers to the effect tlist the attempt to propagate 
salwon by artificial means in Ireland and elsewhere had extensively failed, we think it right to state that we lave obtained some information from the very best sources, which eonvinees us that these reports are wholly untounded. On the contrary, we are glad to say the suecess attending the first attenupt at propagation on an extensive seale in the country has surpasserl onr most sanguine expectations. It is reported from Perth, where about 350,000 ova are nearly liateled, that ererything has progressed most satisfactorily; the whole of the ora, with a trifling exception, seen in a lively state. The only difficulty appears to be that of providing sufficient ponds for such a multitude of fishes, when they are able to swim, as the feeding-ponds already provided will not contain one tentl of them; and such is the number, that there appears no other way, after having hatehed and protected them for twenty weelis, but that of committing them to the river to take their chance. It Galway about 260,000 ova are in a similar prosperous condition. Propagation on a smaller seale has also been earried into effect on the rivers Tweed, Louehard, the Foyle, Bush Mills, the Blackwater, the MLy, the Dee, near Chester, and other places. By the use of spring water the spawn has been entirely protected from injury by trost, luring the past serere winter; and of 2,500 eggs which were sent from Galway to Basle, a distance of nearly 1,000 miles, M. Lex states that a considerable portion are good, and in a state likely to live."

Tobert I. Pell, of Ulster County, N. I., has done a good deal to establish fish-pronds upon his farm; he says "that lie is trying to grow the noss-bunker for manure, and hopes for success in growing them, but thinks the nse of this fish the cause of disease in the districts where used. As many as 86.000 moss-bunkers have been taken in a seine at one hanl upon our coast. Mr. Pell also has in his ponds the black bass of the lakes-a fish that grows as large as sliad. Another fish from the lakes very much resenbles the black bass, and flourishes in artifieial water. Both do well, and are easily caunht with a hook. The dace is a good fish for ponds, as lie prefers still water. The rock bass is a common fish in Lake Champlain, and is much estcenued, and ean be enlivated witlout diflieulty. The musealonge, from the lakes, is an exeellent fish, and appears well caleulated for artificial water if pure. This fish grows large, and somewhat resembles the pickerel or pilie of the lakes. Mr. Pell has the stickleback, that eurious little fish that builds a nest something like a bird. Haddock he has tried, but failed of suceess, notwithstanding lie salted the pond. The laddlock is much inferior to the coul. fish, although frequently salted and sold as cod. IIe also gore necounts of experiments with several other varieties, and how to transport tish alive safely. Mr. Pell thinks it is possible to stock all the streams in the country with fish, and thereby increase the food of the people to a very great extent, without any expense."

A writer in The Homestead says:

"Tliree ycars ago I coustructel, in a ravine, a fish-pond covering a surfico of about three fourths of an acre. It is fed ly four small springs, and ro. 
ceives a large amount of surface-water from the slopes aronnd. It is fifteen feet deep at the greatest depth, and las shallow bays and inlets, where the small fish may breed and find protection from larger ones. It contains a small island, and the shores are embellished with flags (Iris), water-lilics (Nymphce odorata), and other water-plants. It was stocked with yellow bass, Oswego bass, white perch, and erery variety of sun-fish and minnows, also a dozen gold-fish (Cyprinus auratus). And now, at the end of three years, it is astonishing to note the vast inerease in my scaly family. They have multiplied by hundreds, and grown in size beyond all my calculations. The gold-fish number several hundred, some of them over a loot in length, and a few of them are beautifully marked with silvery sides and red fins, head, and tail; others with golden sides and black fins and tail. I had no idlea that they would thns sport in eolors, but certainly they are very beautiful. The other fish have grown so much that I intend to eommence using them for the table in autumn. I have not fed these fisl, except for amusement and to tame them, when a few erumbs of bread are thrown in from a sniall bridge connecting the island with the shore, and the fish called up like chickens. The sun-fisl, gold-fish, and sunaller fry soon learned to come at my call, and to follow me in great numbers, from one end of the bridge to the other, for their morning or erening meal.

"The young bass (the old ones hold back) and the sun-fish dart to the surface for their food, and have a lively seramble for it; the gold-fish pick up what sinks to the bottom. Their habits in this way are very much like a flock of ehickens, for some of the smaller fish take their position immediately under my feet, to piek up the small erumbs that fall, in breaking the larger ones to throw out. Some persons ring a small bell to bring their fish np, but I prefer calling mine. They do not appear to come from a greater distance than about forty feet to any one spot. I feed them in several places, to note the varieties and their growth. Now, as to the utility of this pond, it furnishes iee for my own use and three or four of my neighbors who have ice-liouses; it also affords excellent stock water, and will doubtless hereafter supply my table with fish. A small skiff on its surface gircs many a pleasant liour of recreation to the young who are fond of rowing.

"The constrnetion of this pond was very șimple. The earth was excarated across the ravine four feet deep and five feet wide for a foundation; then stiff clay filled in and well pounded, to prevent leakage at the bottom. The earth from the bottom and sides of the Javine was tlrown on the top of this foundation, to raise the embankment to the proper hight. A waste weil at one side, pared with flag-stones, and two feet lower than the top of the dam, sufficiently large to carry off the heaviest flow of water in rery lieary rains, guarded by a wire sereen to prevent the escape of the fish, completed the construction. It is now sodded orer, and planted with willows at the foot, and is considered safe. The expense of making such a pond is small, and it adds much to the value of a farm."

298. Trout Streams-Reasons for the Disappearance of Trout.-One of the 
rery best authorities in the country-Geo. Dawson, a great lover of piscatorial sports-gires, in the Albany Evening Joumal, the following reasons for the disappearance of trout from streans where they wero abundant. He says:

"Every one who has lived a score of years in the neighborhood of mountai: or spring brooks remembers when, in such and such a strean, trout were abmulant, where scareely one is now ever taken. "That has become of them?' is a question which every one has been asked, or has asked himself, a thousand times. Ono says, "They have been driven out by sawdust from mills erected upon the stream.' Another, who lives where tanneries liave been erected, thinks 'the tan bark has killed or disgusted them.' Another says, "Since the alders which used to border the creek have been cut down, and the forest cleared away, they hare sought greater solitude.' Others say, "They have gone because trout will not stay where there is a great deal of passing to and fro, as there necessarily is in a thickly populated locality ; and others still insist that 'they have all been fished out.' Now, in my opinion, not one of these reasons is real. Neither sawdust, nor tan bark, nor clearings, nor dense population, nor excessive fishing, is the cause of depopulation. Some of the rery best tront streans that I know of are full of sawdust and tan bark. The bottom of Caledonia Creck is not only a bed of sawdust, but the ereck lies in the midst of a dense population, and hus been fished, night and day, for thirty years. Nevertheless, in its coll, cristal-like water, trout are more plenty to-day, and more are taken, than ten years since. I have been more than once surfeited with snccess in a stream in Canada where the sawdust was so thick that it formed a compact covering upon its surface; and every year I take trout from a little brook in Connecticut which has been cleared and fished for almost a century. There are three great causes for the depopulation of trout streams: First, the erection of establishments upon them in which lime is largely used; second, the introduction into the streams of pike or pickerel, whose voracity is, sooner or later, fatal to all competitors; and thirdly, and principally, the gralual change of the temperature of the water. Tront will not live long in water which is not, at all seasons, of a temperature which may not, in comparisun with other water, be characterized as cold. Other eauses busides thuse I have named sometimes operate; but, in nincty-nine cascs ont of a lumelred, the changed temperature of the water is the canse of the abscuec of tront from streams where they were once abunlant."

Ile does not give the reason of this cliange of temperature, but we do: it is just the difference between a cool forest shade and a broal exp:me of liot sunshine. Where these mountain streams once were shaded from the first gushing spring to their months at some large river, they are now exposed to the full force of the noonday sun, nntil the water is heated to a deyree as fatnl to the brook trout as ice would be to a tropical plant. The streams that still retain tront are those which are so largely supplied with cold spring water that the temperature is kept at a healthy point, notwithstanding the dennded 
state of the land. Sawdust has no more effect upon the fish than rotting leaves and rood in the forest streans. The washing of cultivated fields, by which the water is made impure, has more effect upon fish of all sorts than sawdusi, or, in our opinion, lime, in sueh quantities as result from any mantfacturing establishnent. This fact nust be kept always in view in establish. ing artificial ponds for fish-breeding. Make them where the water will not be roiled by every shower.

299. Lel Streams aud Eel-Fishing,-In all parts of the country where ecls abound, they may be male an essential part of the food of the family in the autumn months, if the streams are such as easily admit the construction of weirs and placing traps or eel-pots. In some parts of the country the eel business affords no mean item of income to farmers who have riparian rights, the work not interfering materially with ordinary farm labor.

We find the following interesting account of the cel fishery on the Susquehamna in the Lancaster (Penm.) Ilerald:

"About the middle of August the water of the stream becomes rely low, and usually by September that in the chamel is only a few feet deep, leaving the stony bottom, for a wide space on either side, in some places nearly bare, with oceasional deeper furrows which pass along it. At this stage of water, the instinct which gorems the fish to descend the rivers previous to the advent of eold weather becomes the means of their destruction. For many miles of the river's length, therefore, north and south of us, the people orning the shore adjoining erect their fish-dams and gins, by deepening the channel somewhat, and building an elongated V-shaped wall, at the lower point of which is fixed a box, from which the fish, when once eaught, can not extrieate themselves. Obeying this instinet in their descent of the strean, they find themselves borne pleasantly in this chamel, and, wrigryling themselves checrily, they Jet the current, pent in by the walls, earry them along until they tumble plump into the box at the termination of the $V$. The tish taken in this manner are for the most part ecls, of which almost incredible quantities are eaptured during the fall season. Their 'rmi' only takes place during the night. In daytime they remain quiet in the comparatively deep pools of the river. The work of eatching them, however, is no sinecure, not so much on account of the labor as of the wakcfulness and exposure which it involves. In some of the dark and showery nights of the season the game will come into the box so fast that the wateher, who is often stationed there with a boat, can scarcely remove them into it with suficient celerity. At other times there will be scarcely spoil enough in the boxes to repay the trouble in watehing them. It is only the larger apparatus and dams, howerer, that are thins cared for, the smaller being rarely tilled to orerflowing. Fishermen secure and salt down some five or ten barrels of eels during the season, besides living entirely upon them during the catch. The larger operators make the business pay, as a single man alone can perform all the labor required in taking and salting the fish. We have seen various illustrations of digital dexterity, and also Ole Bull's manipu- 
lation of the riolin, bnt conlel any rapid manipulator once behold the marvelous rapility with which some of the fishermen divest the ecels ot their slippery epicleruis or intermuents, they would stand abashed, and, like the Eable individual in the sung, 'Lay down the fiddle and the hoe' forerel' atterwarl. We are at a loss to see how it is possible for any fish whaterer to ilescend to the montl of the rive:, excepting it be a few belated ones, who delay their retmon until a rise in the river grives them security from the low-water traps. From Marietta to a point perhaps 100 miles up, exceptiner in a few plates, these eel-grins are so mumeróns that they must entirely empry the river of eels, the run continuing enstantly mutil frost, and the fishinge being terninated only, as we have alrealy said, by the fall ratins. When theec ocenr, the hoxes are talien up. The watls which remain under the water are rery seldon disturbed, and the next year, with very lictle repairs, are just as good as ever. The eels are packed in full-sized barels, and many are sent to baltimore. Quantities are purchased by sea-going ressels, whose Elippers are aware of the delicions flavor of this lather anomaluns anticle: of provision."

The kind alluded to in this extract is the "silver eel," which is also taken all along the sea-coast by hooks and spears, and sold in great abundance in all the city marlets, at as high a price per pound as beef or mutton.

Now will farmers please to think that cels can be artilieially bred as well as any ofler fish, and that there are a great many strecms and pouds, particularly in the W' West, where there are no eels, which might be mule to furnish a vast amount of fool, as well for home use as for sale.

There is another kind of eels called lamprey, or lamper-eels, much estecmul in some places. This kind have no grills, but have sueker months, and breatling holes mpon each side of the neck. These are found sometines in great abumlance in the streams of the Eastern States, in the spring of the year, atul are casily caught by haud, by walling the shallows of thr etream, where they are tound elinging by their months to the roeks or large pethlile stones.

The silver ecls are also canght by wather streams at night, with lorehez and spears, during low water, atter larvest. 'This used to he accombul

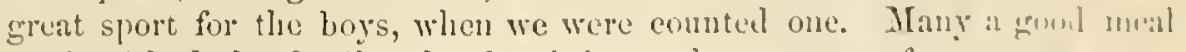
we fumished the fanily, also, by sitting an lionr or two of a sumnel even. ing hy the side of the mill-pond, whith a linok hated with a small fish. This we mention to encomrage funners to take steps towarl re-stocking llueir streams and pouds, as well als maling artificinl ones.

300. Ancient Fish-Brecding.-Jost our resulers should suppose artiticial

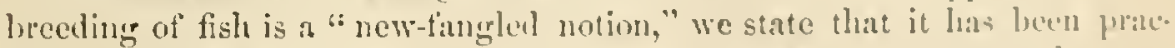
ticed in China many centuries; and it is probably a century since the mat ter attrated attention in Germany.

In that eomtry fish-brecling has now hecomo an extensive and profitalile business. In linue, also, there are many estahlishments, in some of which it has been demonstmed that salunon can luesucesstully bred in fresh-water 
ponds, from exrs obtaned thom salmon that come from the sea into freshwiter stleams to deposit theil egress at the spawning season, without allowing the fish erel to swim in seatwater. Lnd these young fish, it is fomnd, will reproduce their species.

If what we have witten should incite any one to undertalie to make artificial pouds, ol stock the natural waters of his farm with that kind of living animals which will gire lim the cheapest animal food that can be produced, he should first procure and earefully study the bools already published upon this question, and, it' possible, visit those who have had experience, suel as Dr. Grurlick, of Cleveland, Olio, Tobert I. Pell, of Ulster Co., N. Y., Messrs. Treat \& Son, Eastpolt, Maine, E. C. Kellogg, Hartford, Conn., and many other's.

As an artiele of diet, there is no mistaking the fact, gained by rending and oberration, that it is eonducive to health, and particularly that those who nse fish as their principal food are exempt from serofulons and tuberenlous diseases. 'This alone should prompt artificial breeding of fish in this country. 



\section{PLATE XIII.}

(Yage 275.)

TuIs picture in its two parts is allegorical, though drawn from an original. It is intended to teach. It should be studied with that object. Then it will convey its own lesson. If the residence of farmer Sung is most attractive, let every farmer strive to make his so, and keep it in that order. If the residence of farmer Slack is repulsive, let it be a lesson to erery farmer's son.

After looking at this pieture, placed as a frontispiece to Chapter III.-The Farmery-let him carefully read that chapter. It is full of instruction. This pieture is not designed as an index to the contents of that chapter, but to tell its own story-a story of good and bad management. As you read, you will see how such a residence as this dilapidated one produces a debasing influence upon the mindr of ehildren, and what inducements you have to beautify home. 
303. Reasons why a IJelling shonld be Light,-There is a mania for dirk looms. People do not appear to be aware of the fict, that dark roouss are deleterious to health. IIear what Florence Nightingale says upon this subject :

" $\Lambda$ dark house is almost always an mnliealthy house, always an ill-aired house, always a dirty honse. Want of light stops growtl, and promotes scrofula, rickets, ete, among the children. People lose their health in a dark house, and if they get ill, they cammot get well again in it. Three, ons of many 'negligences and ignorances' in managing the liealth of louses generally: I will here mention as specimens. First, that the fomale in charge of any building does not think it necessary to visit ereny hole, and corner of it erery day. How can she expect those who are under her to be more careful to maintain lier louse in a liealthy condition than she who is in elumege of it? Second, that it is not considered essential to air, to Enn, and to clean rooms while uninhabited; which is simply ignoring the first clementary notion of sanitary things, and laying the ground ready for all kinds of disease. Third, that the window, and one window is considered enough to air a room. Don't imagine that if you are in clarge, and dun't look to all these things yourself, those under you will be more careful than you are. It appears as if the part of the mistress was to complain of her servants, and to accept their excuse-not to show them how there need lue neitler complaints nor excuses."

We beg of all who build lionses, as well as those who keep them, in become aware of the fact, that there is a rencrous abundance of sunlight in the country, yet the observer is often convineed that a majority of conntry houses are but seantily provided with this first requisite of health am comfort.

In reference to admitting light frecly into our houses, the words of a writcu on the subject are pertincut. IIe says: "l'pun several years' olservintions in rooms of rarious sizes, nsed as mannficturing rooms, and ocenpied hy females for twelve lours each day, I found that the workers who ocenpiel those rooms which had large windows, with laroe panes of erlass, in the four sides of the room, so that the rays of the run penetrated throngle the whole room during the whole day, were nuch more healely than those who oecupied rooms lighted from one side only. or roums lighted through very sunall panes of glass." Notwitlstanding tle chestpuess and fincility with which glass can he obtained, there is a deficiency of windows ceren in what is usually considered the better class of American dwellings. Siting roons. cliecriess enough in having one or two small windows, alnost exinumblinel bencatl heary drapery of paper and cloth, ate execedingly common. Fin ordinary rooms, white cotton cloth fastented on rollers, als praper is usually hung for wiudow shades, is sufficient for the purjose of sereen-aduituing at the same time a diffused and softened light.

Dark colors upon the walls, alsorbing mure or less of the prismatio rays, are also unfavorable in their cffects. The writer just quoted tunnd that in 
looms of equil ventilation, lisht and drainage, some of which had white wills, and others yellow or buff-colored, the occupies were not equally checrful and healthy. Tlie workers in roous with colored walls were all incline? to melancholy, and complained of pains in the torehead and eyes, and were often ill and unable to work. By laving the color removed and l'eplaced hy whitewash, uniform lealth and cheerfuhess were ever after secured. In arehitecture, a course of progress is distinctly marked from the care, the winw wn and hut of the savage, who rudely supplies his few wants; from the tent and mosque of the $\Lambda \mathrm{rab}$; from the eots beneath the eastle and beside the palace; from the negro quarters to the mansion-house; and we wish we could say, progressing upward to comfortable, light, cheerful, elegant homes for every American farmer.

Let them learn that they cannot live rightly in dark dwellings. The nother who, in the fulfillment of her office, preëminently receives and appropriates from all the lite sustaining elements, suffers a twofold wong, in the injury to herself and offspring, by dwelling in darksome apartments; and childhood in such homes is pale and puny-often worse-is squalid and most pitiably diseased. The predominanee of the chemieal rays in Spring-time is undoubtedly one of the adaptations of this season to the young of animals which then begin their existence, and it also exerts a deeided inthence upon our own physical health. The invalid desises the return of Spring, for he instinctively feels that nature without will then come to the aid of nature within; and who, after the cold and lifeless Winter, does not love to seek the wind-sheltered nook, there to drink in the warm sunlight, and to receive upon the brow its life-giving blessing? Who las not felt the glorious influence of "bathing in the sunshine?" Then, we conjure you, let the sunshine into your lionse, and do not be afraid of letting in the air, day or niglit.

An extraoudinary fallacy is the dread of night air. What but night air can we breathe at night? The choice is between pure night air from without and fonl night air from within. Most people prefer the latter. An unaccomntable choice. What will they say, if it is prored to be true, that fully one-half of all the disease we suffer from, is oecasioned by people sleeping with their windows shnt? An open window, most nights in the year, can nerer hurt any one. In siekness, air and light are both necessary for lecovery. In great cities, night air is often the best and purest air to be had in the twenty-four hours. I could better understand shutting the windows in towns, during the day, than during the night, for the sake of the sick. The absenee of smoke, the quiet, all tend to make night the best tine for alring the patient. One of onr highest medical authorities on consumption and climate, has declared that the air in London is never so good as after ten oclock at night. Always air your room, then, from the outside air, if pussible. Windows are made to open, doors are inade to shut-a truth whieh seems cxtremely diffienlt of application.

304. The Location of a Farm-house.--Adaptability is the word that farmer's should study, above all others, when about to build a house. It is the 
word that they stuly least, if we may julge from what may le secn in a majority of the farm-lionses where we have travelled-that is, from Qucbec to New Orleans, and from Floricla to Mackinaw. Everywhere is seen the lack of arliptability to the purpose, eitler in size, form or location. Nut one farm-lionse in ten is located upon the farm as well as it could have been. In all the castern, western and northern States, the farmery is fond, nine times out of ten, upon some public roul, withont referenee to the convenience of farming operations; and frequently, in all respects, is rery inconvenient.

The location of the farm-house, and the arrangement of all the buildings comnected with the tirmery, reguire the exercise of grood judgment, fine tiste, curefnlly exereised slill, all combined, more than any other single operation of a whole lifetime, beeause it is not only for the lifetime of the builder, but sneceeding generations.

In the first place, the top of the hill, or highest point of a hilly firm, never shomld be selected for the dwelling of the firmer; such a site is only fit for the resilence of the lord of the manor, who intends to carry on furming ly" a tenant, or hired farmer, who will ocenpy the honse of the farmery proper. His residenee is not the farm-honse; it is the mansion of the propricter, and may be bnit to suit the owner's taste, if he has any. Onr remarks ale intendel to apply to farm-honses-the dwellings of that numerous class in America who own the soil they till, partly with their own liands, and partly with those of hirelings.

305. Size and Form of a Farm-honse. - It is not size that makes a dwelling-house attractive, beantiful, or conrenicnt. It is adaptability to the purpose for which it was designed. Indeed, a honse often luas an miplaasant ajpear:ance on aceount of its size, beeanse it gives the mind an imuntession that it is munecessarily large for the pnrpose for which it is designed.

It is necessary that some farm-honses should be large-that is, affuril a great deal of room; but they never should appear large, for if they du they alnost inevitably appear uncouth.

Make just as much of the room as possible, on the Eane level. I firmllouse with twelre rooms, should hare eight of them on the luwer fluor. Never have a basement kitchen.

No wonan, during the years of elilk-hearing, who does much of her own work, or oversees it when done ly erviuts, should be compellerl to an up and down stairs every hour of the day. Iler sitting, or family-romm, leelroon, dining-room, kitclıen, wash-room, wood-room, well and cistern, should all be on the same level, or with a variation of not more than two wr there steps. You eannot be a good man if you compel yome wite to run mp and down stairs to do her crery-day louscwork. Lon are not a good num, nur a

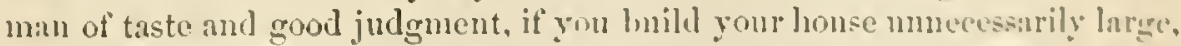
because it will cause your wito many weary, extra steps to kerel it lidy amel always swept and garnished as you should he proud to lave it alpu:ar to strangers. Yon are unworthy tho nane of man it yon kecly youl wite toil. ing in a homse entirely too small for the necessities of your finmily, ur in one 
wretehedly ill-adapted to their wants, one single year after you are able to provide a better one.

306. What constitntes a convenient Farm-house.-We can only speak in general terms of the plans of firm-lionses, because every plan is modified by location and the wants of the proprietor; but we ean give an opinion that. will be some guide to the new beginner in farm life, or one about to construet a farm-lionse.

We will suppose a farm of one or two lunudred acres, and a family of four adults and four ehildren, besides the necessary hirelings, which in most of the Northern States, are domieiled in the family dwelling. It should, therefore, liave a family-room located in the most pleasant part of the house, where the evenings, and all other leisure hours, are, or shonld be, spent; where the young mother devotes many days and nights of toil to her children; where all the fumily feel "at lome," more than in any other room.

Adjoining this room there should be a large fanily bed-room, with conveniences for warming it, so that it ean be used as a sick-room when necessary. There shonld also be a parlor, or spare-room; for it is not always desirable to introduce company into the family-room. There should be a dining-room, large enough not only to accommodate the family, but, if necessary, a dozen gnests. This room shonld be so arranged that mpon occasion, particnlarly in Winter, it ean be used for a part of the cooking. This would often save the necessity of kindling a fire in the kitehen in a cold Winter morning, to get an early breakfast. The farm-house kitehen, where so much of wonan's work inust be done, should be a large, cheerful, light apartment, with all the conrenienees that modern ingenuity has made to fireilitate labor. It shonld also, abore all other considerations, be so rentilated that there rould be no necessity for opening a door or window to let ont the smoke of a broiling steak, or that of the buckwheat cake griddle. The best cooking apparatus is a good range, permanently set in the chimney. One of suitable size for such a family as we have indicated, will cost about thirty dollars withont cooking utensils. The two ovens of a range obriate the necessity of a brick oren in the kitchen chimney. It will be convenient to have such an oren in the wash-room, which should be attached to every farm-house kitehen. This slould have an open fire-place, a kettle set in an arel, a brick floor, a large sink, and a pump which draws soft water from the well or cistern. Divided off from this wash-room, there sliould be a large store-room, for such coarse things as barrels of flour, fruit, fresh meat, and articles of kitchen furniture not in every-day use. Beyond the wash-room, there should be a room for fuel: and the best of all, when it can be had at a moderate cost, is antluracite coal. Opening out of the kitchen there should be a pantry, large enough, and with conveniences to store all the groceries and food in every-day use. In this, or some other convenient place, be sure to liave a refrigerator; and adjoining the kitehen, there shonld be a milk and butter room, wliere nothing else is ever kept. If cheese is made, it must have a separate room. Butter 
and eheese must not be stored together. The way to the eellar should open out of the kitchen. We do not advocate large cellars under the house, because they are apt to become the storehouses of a rast amount of stunfl that wonld be more fittingly stored in some ont-building, or an out-cellar. Cellars are generally kept in a way that seriously endangers the health of the lamily. If the house is set as it should be, well up from the gronnd, and rentilated under the floor, it is better calculated to promote health than a cellar. If the nature of the soil is very dry, the space under the wash-room may be used for a store-room, or even milk-room, properly ventilated. Every kitehen shonld have one or more closets, upon the shelves of which the many little things ean be kept, each in its plaee, and all in order. In the diningroom there shonld be two closets: one for dishes in erery-day use, and one in which anything not always, but oceasionally, wanted upon the table, and anything desirable to be locked up, can be safely stored.

There shonld be a large eloset for the use of the sitting-room; and there must be such a one in the fimily bed-room. In fact, this should be a donble room, a smaller one attached to the larger for the small children; and this should have its eloset, or clothes-press, that children might be carly taught to put every article of elothing in its proper place.

The larger children, and other adults, should have large, airy becl-rouns up stairs; and no farm-house will be complete without two, at least, "Epine bed-rooms."

307. How to Build a Convenient House, - A pleasant-looking, unostentistions farm-house, to contain the rooms indicated, may be of the following dimensions. A two-story portion, 34 by 24 feet, wonld give half of the parlor 16 by 16 feet, and a spare bect-room 10 by 10 fect, and a hall 6 ly 16 feet; a stairway $3 \frac{1}{2}$ by 10 feet ; a space for pantry, or closets, $2 \frac{1}{2}$ by 10 feet : a futuily, or sitting-room, 13 by $1 \mathrm{~s}$ feet, and two bed-rooms, 10 by 11 and 8 by 11 fect. This building may be roofed to piteh either way. The other half of the parlor, not comprised in this space, is to be gained by an attachment, $S$ by 16 feet, one story high, attached to that side to balance the jiazza, griving the house more of a cottage look, as well as being less expensive, and making better rooms on the second floor.

Aitached to the main building, a wing or $\mathrm{L}$ part, a story und a half high. will grive a dining-room 12 by 15 feet, a kitchen 16 hy 15 feet, a wasli-room 12 by 12 fect, a store-room 6 by 12 feet, a pantry 6 ly 5 feet, a milk-rom 6 by 6 fect, and passage and stairway to the half stury, which will make grood lodgring-rooms for hirclings.

The fuel-roon may lie a epparate bnilding, and althongls used for such is zurpose, may be male with a finish to correspond with the honse, and sut forwarel flush with the piazza, which is to extend along the front of this wing, and will form a grood termination to the walk, besides leing convenient mul approachable from all parts of the honse muder corer. This piazz:1, which is 6 hy $t 6$ feet, and one $S$ by 16 feet adjoining, should, if possil, le, lave a sontheastern exposure, which will make it pleasant to all the rooms must used. 
We do not give this as a superlatively excellent plan of a finm-lionse but one that would be convenient, comfortable, inexpensire, and capable of being erected in two or three parts, if necessary, at different periods, and npon the clieap plan described in No. 350.

The advantage that we elaim for this orer some other plans is, that if built in parts, at different periods, according to the circunstances of the proprietor, each portion ma be made to appear, and serve the purpose of, a complete louse. Thus, the part 24 by $3 t$ feet, with the little wings, one forming lialf the parlor, and the other the piazz, will be a neat looking louse, and a comfortable one for a small funily; using the sitting-room as a kitchen, and one bed-room as a pantry. Then the dining-room, kitchen, wash-room, etc., might be added, one at a timc, as ability or necessity prompts. Or, the part containing the kitehen, could be built first, and roould make a tolerable liouse by itself.

Another advantage of the plan is, that the rooms are all light and airy; erery room, except one small bedroom, has windows upon two or more sides, and the whole house will appear to every passer-by, as thongh built for use, lather than show. It is a great convenience to have a house so construeted that strangers ean find some other than the front door entrance.

The space in front of the piazza should be a plat of shrubbery, which wonld form a partial sereen, and in front of that the flower garden. There may be a door out of the dining-room into a garden upon that side.

In arranging the plan of this louse, the object has been to place the least used rooms in the house, the parlor and spare bed-rooms, upon the right and left-liand side of the hall, as you enter the front door from the portico. It the other end of the hall is the family room, and large and small bed-room. The stairway is situated, not for show in the liall, but convenient to all parts of the louse, running up at a right angle from the hall, between the sittingroom and spare bed-room. The sitting-room is situated in the centre of the louse, convenient to all the rooms, warm in winter, airy in summer, and easy of approach. If the ground suits, yon may drop the $L$ floor two feet below the main part, and set projecting beyond that part six feet, it allows a window there, and breaks the force of the wind upon that end of the sittingloom, and also grives room at the otlier end for a window and glass door out upon the large piazza. The common entrance to the house will be upon that piazza, and from that into the sitting-room, dining-room, or kitehen.

There was a plan, published by G. C. Honse, of Lowville, N. Y., in the Country Gentleman, so novel in its form, and apparently so conrenient, that we consider it worthy a notice in this conneetion. The following is what he says of lis plan.

"In the plan submitted, we flatter ourselves that some improrements have been reached, when we take into consideration convenience, space, accessibility, the ease with which the hot air passages from the furmace can be arranged for so many rooms, all within a few feet of the body of the furnace; and each door within a few steps of the main stair-case. From the 
peculiar form the centre of the house is at onee reached on entering the front door. The second story is quite similar to the first, closets occupying the spaces over the library and pantry, and a fine balcony over the reranda, reached through glass doors.

"To meet the full requirements which were had in ricw, in this arrangement, a site shonld be selected having a sotatlern or eastern cxposure if in the country, and the building set with both full fronts to the street, so that the veranda or frout door will luwe a direct front aspect. If, however, the location be in eity or village, it wonld be desirable to procure a lot having two fronts, if possible looking easterly and sontherly, and place the building with a front to each road, the front door looking toward the angle of the strect."

3(1S. Ventilation of I) wellings,-In whaterer form, or upon whatever plan you bnild, do not forget the necessity of ventilation. Onr drellings are viten charnel louses. The very first necessity of crery human being-pure airis rarely regarded in their construction. The air actually inhaled steals in at crevices and crannies, felon-like, becanse it cannot be shut ont. Only the defects of our architecture prevent our dying of a vitiated, poisoned, mephitic atuosphere, from which the vital element lias been exhilusted. IIust men, including alchitects, seem ignorant of the fact that the atmosphere is a combination of difierent gases, only one of which is wholesome and life-griving, and that this is consumed in the lnngs upon inhalation, lenving the residue to be cxpelled as a poison. 'The church, lecture-room or other structure, with doors and windows elosed, with no provision for ventilation, soon lecomes a slanghter-pen, and ought to be closed by the public anthulities.

Onr manufuctoriss and school-houses are nearly all disgraceful to their owncrs and arehitects in regard to rentilation. They are often divided intu rooms loss than ten feet high, each thickly stowed wih human beings, wh breathe and work and sweat in an atmosphere overheatel and filled with glease, wool or cotton waste, leatler or cloth, and the poisonous relinse expellerl from human lungs, which together are enough to incite a flaghr. and are, in fiact, the primary cause of nearly all the tevers, dysenteries, consumptions, etc., ly which so many graves are peopled. No factory shouhl be permitted to commence uperations, nor sclowol opened, nutil it shall have been inspecter by some competent public oflicer, and certified to In. thuronghly provided with ventilators-not windows, which may be oprenenl. but in a cold or stormy day very certainly will not be-but npertures fin the ingress of fresh air, and others for the egress of ritiated air, both wht of the reach of ignorance and defying the efforts of cunfirmed depravity of the Echises to close them.

Onr hed-roons are generally fit only to die in. The best are those of a fow of the intelligent and nftuent, which are carefully ventilated: next to these cone those of the eabins and ludest farm-houses, with an inch or two of vacaney between the chimmey mul the root, and with cracks mevery side. through which the stars may be seen. Tho ceiled mol plistered bed-romms, 
where too many of the middle class are lodged, with no apertures for the ingress or egress of air but the door and windows, are horrible. Nine-tenths of their oceupants rarely open a window unless compelled by excessire lieat, and very few are carcfil even to leave the door ajar. To sleep in a tiglt six-by-ten bed-room, with no aperture admitting air, is to court the ravige: of pestilence and speedy death.

Our railroad cars and steamboat berths are atrocionsly devoid of rentilation. A joumey is taken with far less fatigne, and more expeditionsly now than it was thirty years ago, but with far greater risk and liam to liealtl. There are probably ten thousand passenger cars now running in the Uniter States, whereof not more than one hundred are decently supplied with fresh air. Most of these, wherein forty or fitty persons are cxpected to sit all day and dose all night, ought to be indicted as nuisances-they are tit only for coffins. The men who make them probably know no better; but those who buy and run them have not even that poor excuse. They know that they are undermining constitutions and destroying lives; they know that ample means of aresting these frightful woes are at command; yet they will not adopt them because they cost something.

If people only knew how many thousands of lires are annually sacrifieing, how many hundreds of thousands are now suffering from ferers and otliel maladies whieh have their origin in the inhaling of noxions air, the excitement and alarm on this subject would work a revolution in our style of buileling.

Whlen we lived in old-style honses, with large open fire-plaees, like the one mentioned in the next paragraph, there was no need of being carefinl to builul air-passages in the walls of the house for rentilation, for the "fire-place, big enough to roast an ox," gare the most complete lind of rentilation.

It is of the utmost importance, partieularly in malarious districts, that houses should be so construeted that a frec circulation of air ean be liad through all the rooms. In the plan described in 305 this fact has been liept in view. Witl sliglit modifieations, the plan will answer for a house esther at the nortli or the sontl. At the south the rooms would be made larger, and the fuel-room would probably be substituted for the kitchen. Frequently, the litehen of a planter's house is placed several rods distant, without any covered way between.

309. An Old-Style Farm-house Kitchen in New England.-A pieture of one of these scenes of comfort has lately fallen under ny observation. What can be more eheerful and pleasant than the view of a farmer's kitchen, taken during the evening meal of a eold Autumn day? It is a picture of the ealm happiness of rural life.

The kitchen of the old-style farm-lıonse of New England is not the seullery, or mere cooking-place of some modern house-a dirty hole or comfortless ont-room or sort of human bake-oven, where the cook is almost as much cooked as the food. No, it is a room perhaps 24 fect long and 16 wide, well lighted, warm, neat, and every-way comfortable. Upon one side there is a 
fire-place large cnomght to roast a whole ox, in which a great firo of logs ecends ii] a cheerful blaze, lighting up the whole room so its brightness might be Eecu through its great mucurtaned winlows, like a beneon light to the travellel as he comes down the slope of yonder hill two miles away, and makes hin involuntarily thank God, in anticipation, for the good things spreal out upon the great table standing between the window and the fire.

Let wis take note of the old-fishioned meal. At the head of the tirlile sits al matron we some sixty smmuers-though in appenrance there is nothing of the winter of old age about her. Iler dress is a gown of home-spm worsterl, Well tortified witl flannels from the sane manufactory, that lid definee to the dutumn winds of a rigorons climate. The small, neat eap of white ganze, and the shoes and stockings of this woman, were made in pursuanee of the best medical recipe ever written: "Teep the head cool, and the feet ary and warm;" tor the stockings are the product of busy fingers at moments ille with many housewives, am the shoes of stout leather were made for service, and the cap is a mere ornament-a snow-wreath anong raven locks-and her face is the indieation of health aud happiness.

Lpon her right hand sits the farmer, dressed in a butternnt-colorel coat, hue junts, buff rest, white linen shirt-every artiele home male-stout brots and black silk cravat-for he has been to town, and this is his holiday snit. Below lim sit. Jededial, Ehenezer, Abram, and Solonon, all econonicil numes, for they can be shortened in common use to Jell, lib, $\Delta l$, and sul. Two of these wear the cheek woollen winter frocks of New England farmers -the others are in round jackets; they are schoulbors. Upon the left sit Mary, Adeline, and Mehitable, pietures of real beanty and health. The eldest is "dressed "1]";" she has been to town with her father; she has a gown of "boughten stuff";" around her meck is a bow of colored lamb"s woul, linitted by her own hands, fastened in the throat we grandmother's silver hrouch. The other two are in check woolen, which was spm, woven, and colored, and male np under the same root.

Further down the table are three athletic young men, day lahorers on the tam-sons of neighlouring farmers-one of whom is eveing the charms of sweet Mary with an dexpession easily real ly" a rood physiognomist. 'The aronp is completed by the seloolmaster, a young man with a glowing eye which speaks of intellect that will tell wpon the world some day with as much force as though le hat not beem obliged to uhtain his eduntion hy summer labor and winter teaching. Ile is one of New linglumbl's rising sons.

The meal is for men who toil. At one rud of the table stands a put, of anuple dimensions, sumbing from the uren thuking tho tire-place, ot ilu musi

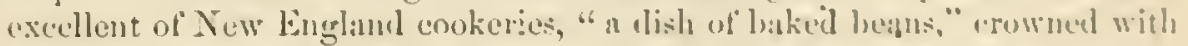
a pewter platter holds the remains of the "boiled vietmals" that firmed the

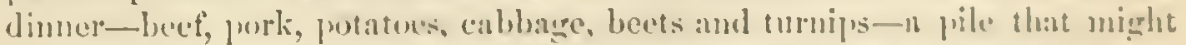
rival a sumall lay-cock in sime and shape-a phate of rye and inlian breal, 
coll, and another male of rye flour are untouched, for a great loat, just drawn from the oven, nieely lrowned and lot, is offered in great broken preces to tempt the appetite to one of the richest repasts ever given to an epicure. By the side of the old lady stands a black earthern teapot, the contents of which are freely offered, but only accepted by two of the men. as the rich ncw milk, or the liearty old cider is preferred as a beverage, morning, noon and night, by those old-fishioned, hearty laborers. ive nust not forget the nerer-fuiling accompaniment of the evening neal at this scason of the year in New England, for it is New England's proudest dish, the golnen pumpkin, sweetest pie.

God being thanked for his great bounties after the close of the happy meal, all are drawn into a circle around the great fire-place. Father is finishing ofl' an axehelve; Jed is mending a pair of boots; and one of the hired men, upon the other side of the same benel, is repairing a wagon harness-botl using the same tools. The other two are employed, one shelling consu and the other helping Mary to peel punplins, which are ent in slices and lume upon poles overlicad. This is Mary's aecepted lover. Happy hearts amd blessed industry! Ab and Sol are engaged with the seloolmaster around the big table, lighted by a home-made candle; they are studying geograply, writing, spelling, and arithmetie-fitting themselves for future statesmen. Mother is making a new coat for one of the boys, Ada is ironing at a silletable, and IIety is washing the supper dishes at another. There are two other members of this family group-the cat occupies the top of the blue dyc-tub which stands in one corner of the fire-place, and old Bose sleeps quictly under the table.

Directly, and before any sound is audible to human ear, Bose gets 1 p, wallis ont into the long entry, and gives a lond, sharp bark at the ontsille door, and stands waiting the approaching step. Soon satisfied that the new comer is a friend, he retires again to his repose, and three or four boys, who look as though they might be brothers to those already described, so muel are they dressed alike, enter and draw around the table with the otliers and the schoolmaster. These are from a neighboring farm, sons of a widow, who have till now been so much engaged with the labors of the furm that they liare been unable to attend the school in the daytime, but are determined to lose none of the evening opportunities to kepp along with the class. They will make honest, intelligent, industrious farmers.

The old folks weleome them heartily, and the young ones are all rejoicerl at their arrival. The old lady inquires why in the world their mother dicl not come along; and Mary, the lind-hearted Mary, is so sorry to hear that it is beense Sarah is not so well, and mother is rery busy getting their new clothes done so that they can go to school as soon as they finish pieking apples. "John," says she, "let us hurry and get through our stent and we will go over to the willow's; and I will help her with her sewing; you will leat for the anusement of pool Sarah, for an liour or two." "It that is the case," says father, laying down his axe handle, "my good children, you shall 
go now; I will finish your work." "And Mary, ny dear girl, don t go empty lauded," says mother; "yon know from experienee low sweet little delicaeies, bronght hy friendly lands to the side of a sick-bed, are tu a froor invalic]."

"Iletty, my dear, if you have done your dislses, you must get your cards mul make a fow lolls, for I am quite ont of grey yarn, and we must have some wore stockings in the work. Old man, don't ent that pumpkin too thick.- - Irla, daugliter, get a plate of doughnuts and some of those uice fill pippins and set on the table; I guess these boys can eat a few while they are ryphering. I do wonler if you have got light enough. Sol, get another candle, I am sure such industrious boys ought to linve all the light they willt:"

'Thus, my readers, I hare given you a sliglit outline of a farmer's house, such as it used to be, such as it might be, and such as it always should be, and such as, I :m prond to say, many an American furmer can bonst of cren in these degenurate days of "boughten stuft" gowns" and lack-n-daisical lounging of firmer's girls, who are nuiserable and tired of nothing to do. How do you like the pieture? If well, imitate it. It is a happincss caril! acquired.

It is easy to imagine the sumoundings of such a home as the one describerl above. And as there is probably no better exponent of the farmer's life thau the farmer's home, we projose to present the portrait of a home yuite in contrast to the preceding one. We are sorry that such in this are altugether two commun. IIere is the sketch:

A square brown house; a chimney coming out of the midllle of a rouf; not a tree nearer than the orchard, and not a fluwer at the door. At une cul projects a kitchen; from the kitehen projects a wool-shed and watgon-corer, ocenpied at night by hens; beyond the wood-shed a log-pen, firigrant and musieal. Procecding no further in this direction, we look directly ateros the road, to where the barn stands, like the hull of agreat lalack ship of the line, witl its portholes spread threateningly upon the fort opposite, ont of une of which a horse las thrust his head for the jurpose of examining the strength of the work:. An old ox-sled is turned up against the wall cluse by, where it will hate the privilege of rotting. This whole establislment wats contriverl with a single eye to utility. The barn was huilt in sueh u mannel that is depusits might be convenient to the roal whill divides the farm, while the sty was made an attachment of the house for conrenience in feeding its oceuplunits.

We cuter the house at the back door, and find the fanily at dimed in the kitchen. A kettle of soap-grense is stowing upon the stove, mul the funus of this, ningled with those that were generated hy boiling the cablume which we sec upon the table, and by perspiring men in shirt-sheres, mul by

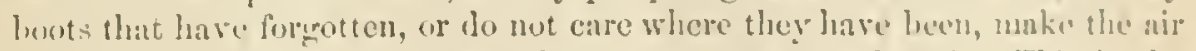
anything but agreesble to those who are not ncemstomed to it. "This is the place where the fomily live. They cook everything here fur themselves and 
theil hogs. They eat every meal here. They sit here every evening, and here they receive their friends. The women in this kitehen toil incessintly, from the time they rise in the morning, until they go to bed at night. Here man and woman, sons and daughters, live in the belief that work is the great thing, that effieicney in work is the crowning exeellence of manhood and womanhood, and willingly go so far into essential self-debasement sometimes as to contemn beauty, and those who love it, and to glory abore all thiners in lunte strength, aud brute enduranee.

IFe do not expect to see every farn-honse a domestie paradise; but we do contend that one contrived upon the moderate plan described in No. 305 will be likely to prodnee a better race of men and women than such a home as the ore last mentioned in this paragraph.

Having oceupied as much space as we ean afford to gire to the dwellings, let us now look at some of the surroundings neecssary to make up a complete firmery.

\section{SECTION XV.-CELLARS, CHININEYS, AND ICE-HOUSES.}

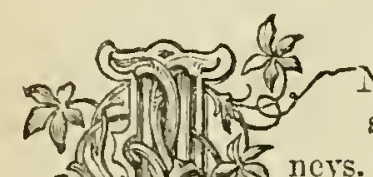

I a cold climate, two of the most important requisites of a farm-house are good ccllars and good chimneys. In all the great firming region north of Lat. $40^{\circ}$, there are nights almost every Winter in which the thermoneter falls $10^{\circ}$ below $0^{\circ}$ of Farenheit; and in some of the elevated portions of New England it sometimes falls $40^{\circ}$ below zero. There warm cellars are a neecssity. Everywhere climneys are so, for there is not a greater souree of rexation abont a farm-louse than a smoky climuey. Formerly, ice was looked upon as a lnxury merely; it is so no longer. IIenee we derote space to give the best information we can obtain, how to build an ice-house and preserve its coutents.

310. Cellars-Where and how to Build them.-As we have already intimated, we do not approre of cxtensive cellars under dwellings. Is a general thing, in all damp soils, like millions of acres of the western prairie linds, cellars, even when kept with the utmost eare, are not healthy; and when kept as we have often scen them, dripping with moisture, and frequently with water standing several inches decp, they are positive contagrion lureeders. In all such situations we recommend cave cellars, built on the level of the surface. An excellent one which we built near the kitchen door, 8 by 20 feet, was made of cight-inch brick walls, seven feet high, with an entry and double doors at one end, and double windows at the other. At first our design was to areh this over and make a grassy mound; but upon 
sccond thought, we earthed it up as high as the top of the wall and then put on a building for a smoke-house, the fire for which was built at the bottom and carried up in a flue. There there is a hillside, a cave cellar may be made more easily, thongh we did not fiud it a serious job to heap up the earth from the level ground, taking caro to slope it oft so as not to leave any noticcable depression. Such a cellar is rery convenient, dry, pleasant, and not unhealthy. It built where a building over it would be unsightly, or not neeled, it may be arehed and covered with earth and made quite an ornament of the housa surroundings.

Wherever a cellar is it should have as uniform a temperature as possible, the year through; it should never sink much below $35^{\circ}$ Fahrenheit, nor rise above $50^{\circ}$, and it should be always moist, yet never wet. It should be also well rentilated, and that should be by a flne of the chimney, constructed specially for that object, when the cellar is under the dwelling.

311.-Chimeysventilator has been patented by a Thiladelphian (Mr. Leeds), and is very strongly recommended by many who have tried it in that city. The brick wall of this chimmey is without flnes, no matter how large the house, but the smoke is carried up, say lualf the height of the bnildiug, throngh a calst-metal box or square flue in the centre of the stack, while pure, cold air is introdnced at the bottom of the building into the chimmey outside of the flue. The heat of the flue eanses this air to aseend with great rapidity and force, carrying the smoke with it from their juncture at the top of the bos, and renclering it wholly impossible that the chimuey shonld ever smoke. Ventilation is eflected by valves opening from the external or ail-elnimney into the rooms, so as to throw out a colmmm of air, warmed by its contact with the flue, in to the room near its floor, while another valve near the ceiling snclis in and carries off the impure air-the dranght of the heated flue being aided ly the influx of leated air through the lower valve into the room. This arrangement, it is claimed, saves the expense of brick flues, saves heat, which otherwise passes oft uselessly through the chimncy, insures a thorongh rentilation without trouble or cost, and aflords a perfeet sceurity agaiust fires from defective or urerheated chimneys, through the gradual charring of the wooden beans or other timbers imbeddert or ending against the chimucy. $A$ connection with the cellar, by an opening into such a fluc, would draw wit all the foul air that would be generated in any but a very bally kept cenllall: lhesides proving a valuable satternard anainst the curelessnuss of carpenters. who do sometines place wool in featinlly daugerous places. If all sturesleated houses land such menus of ventilation, it womld do sometling tuwarel bringing back the eame state of health that existed in connection with open fire-places.

The comfort of a dwelling depends in a great degree upon its having good climmeys, always maintaining a eurrent of air upward vithin, and sucurecl externally against the entranee of water. Form, size, lecation and workmanslip, all unitc in producing a good or bad article. 
The ridge or lighhest part of the roof is the best place for the exit of the chimney, for it is less liable to those sudden gusts of "blowing down chinney" than when in proximity to higher objects. In this place too, the roof is more easily rendered tiglit and sceure against wet. In small houses with but one chinuey we need not seck any other place for it. In buildings larger, where sereral chimmeys are necded, keep the same object in view, and aplroach as nea to it as possible. In brick honses, if the chimney is built into an exteriol wall, it will sometimes fail to draw well, becanse the air outside of the house cools the warm ascending current within the fluc. If the flue is in a south wall, the lieat of the sum sometimes aids the draught.

The size of the chimney is also important. The modern fashion is quite too small for utility. Economy of space and a desire to conceul entirely an object merely of utility, have caused its dimensions to be contracted until a few months' deposit of soot entirely chokes the passage. While we no longer need the lunge "good old-fashioned chimneys" of former days, the flues should not be contracted so as to hinder the current of smoke, which needs a channel as smooth as for the flow of water. We often find the curves, where the most room is needed, half filled with mortar carelessly dropped and loosely aldhering to the bricks. By making a proper table abore the roof, it can be made water-proof; but this, if not well done at first, always proves a vexatious and difficult matter to accomplish. Mortar, putty, eement, and paint, in all their variations, have been tried with various success. An old grafter recommends for this purpose "grafting wax," as the cheapest, surest, and most durable application. But we say, build so that they will all be unnecessary.

Always begin your chimneys from a good foundation on the earth. He who builds a small "stem" in the garret, builds a large nuisance for limself. The soot tea, black and penetrating, will leak out to discolor the walls, the gathered soot and ashes cannot be removed, and the thing proves a chimney only in name and in its appearance on the roof.

All unused stove-pipe holes and fire-places should be closed to secure the best draught.

Where there are two chimneys in the same building one will sometimes overpower the other, with the most provoking results. This is a contingency to be regarded in forming the plan.

The top of the chimney may be full size and open where there is no danger of down eurrents; otherwise it should be arched or provided with some cap or rentilator of sheet iron. Those who have built will see the importance of these hints; those who are to build, will do well to regased them.

312. Ice-Houses, - Next to a good cellar, an ice-house is a necessity of a farm-house. Here we can do withont an iec-house, aud north of latitude $40^{\circ}$ we cannot do withont a cellar-at least, not comfortably; and, in our opinion, any family who have once enjoyed the comforts of an ice-honse, 
will ever after think that they eamot live quite comfortably withunt onc.

We hare often witnessed in good furm-houses the neeessity of a supply uf ice, in the eharacter of the butter placed upon the table-even anong finse who know how to make good butter, we find a quality far interior to the samples made where there are cool spring louses or an abundant supply of ice. We give a few other reasons in farur of every farmer's having an ice-house, and we beg furmers to read and consider them well, and then we will tell them how to bnild one.

313. Ieasons why Farmers should have Ice-llonses,-It is Ancrust; hot, fitint and exhausted, the farmer comes from the field so thirsty that he cannot satisfy himself with water from a well so shallow that the hurning rays of the sun have reached the surface and penetrated into the water, warming it almost hot enongh for dish-water. Sume draw their water from springs, and others from cisterns. It is only here and there that we find a spring that comes gnshing to the smrtice, or that feeds a deep well with water, cool enongh to satisfy the over-lieated, thirsty harvester. How refreshing snch water is, not only to drink, but to lave the face and hands and breast, lefore sitting duwn to a meal, or lying down to repose to reculerate tired nature. We have no dombt that the laving is far better than lie drinking, and it should always be the first step taken to quench thirst.

Again, how refreshing is a cool drink with the luneh in the field, but low diffienlt to have it there, at only lanlf a mile from the coldest spring or well. How easy it would be if there was an ice-house on the farm. A piece that could be earried in one hand, wrapled in a blanket, would be harge enongh to cool the drink of a dozen men all the forenoon, and it would invigorate them more than a bottle of rum. Ice, taken in moderate quantity, is a tonic, and serves to keep the system in such healthy condition, that food gives it more strength. Simply, then, upon economic principles, crery furmer should have an ice-honse. il hmane man should lave an ice-house. It adds to the health and comfort of his smmmer laborem. I.et him think of it now-think of it in Angust, think of it while sighing, Oh, for a cens drink! Olı, for a eup of ice-water !

The stingy man, the veriest old hunks, who is never quite satisfiel with the amount of labor that lie gots out of lis workmen in the harvest-fichl. slonkl have an ice-honse; it will enuble him to get more wrot ont of thems. Now is the very time to think of this; particularly in the heat of the harrest-fiell.

The man that knows that fresle meat is not only more palatalle in the heat of Summer, but that there is a positive economy in fechling his fimnily and extra laborers upon sweet grass-fed bed and mntion, and upon enld milk and sweet, hard butter; and that a man who does feed his day-Iaburcrs so ean always get better men and more work for his money than his neighbor wh lives upon salt junk and rum, will have an ice-hunse: and if lu has not got one he will make up his mind, before the present Summer is viel, that us 
soon as there is a lull in the work of haying and harvest he will set about building an ice-house, which he can do with his own hands and common farm-laborers; and with less than the work of one hand and team during a week in winter, lie can lay up such a store of iee that he need never drink warm water, nor eat soft butter, nor fear to kill a sheep lest the meat should spoil before it conld be eaten.

Let all remember this fact: Iee is not a luxury; that is, one that ean be dispensed witl, and may be indulged in only by the wealthy; but one of the most ecomomical things that can be provided for family use. It is an article that no farmer can afford to do withont.

Now, having given arguments enough to convinee any man that he shonld build an ice-house, we proceed to tell him how to do it.

31t. How to lluild an Ice-Honse.-An iee-house is not the complieated, costly structure that some people appear to think it is. Quite the contrary, it is one of the easiest and most simple things to build, needing rery little nechanical skill, and being quite inexpensive. All of the work about an ice-liouse can be done by any farmer of ordinary Yankee eapacity in the use of such a set of earpenter's' tools as every famer should keep. In the first plaee, it is not necessary to build an iee-house under ground, although in ll'y, gravelly soil it may be built so at less expense than on the surface, and it is easier filled. A lill-side is the most convenient location, with the gable of one end abore the surface, in which have an opening to put in iee-tlie other end, to a lerel with the floor, being exposed-through which we would have the ordinary entrance by donble doors. In such a situation we would use broken stone, making a hollow, gronted wall; and the same kind of wall might be built on level ground; and a rery good, cheap, durable wall it is. Brick or stone may also be used for the walls, aceording to the fancy of the builder, always making them hollow, and the onter and inner part of the wall absolutely as air-tight as conld be made with brick and mortar.

The eherpest, easiest and quickest construeted ice-house, and one all-sufficient for the purpose, is built of wood; and the money differenee in cost placed at intelest will more than keep the wooden house in repair and good as brick ol stone. So we will give directions for building a plain, cheap, common, rough-board, farm ice-house, large enough for all ordinary private families.

Seleet a spot of ground eonvenient to the kitehen door, and remove the soil and put coarse gravel or sand in its place, with drains leading away from the eares, so construeted that it will be absolutely impossible for water to stand under or around the building. Lay down two-inch plank six inches wide, bedded their thickness in the sand, for sills; the end ones eight feet long and side ones thirteen feet. Cut your studs off square, eight feet long, of any size or width that you can get in the refuse heap at the nearest sawwill or lumber-yard, so that you can get one straight side, and set them "up fince side in, and toe-nail them to the sill, with an inch-board on top for a plate, upon which rest the joist; nail up through the plate to hold them 
in place. Now board these studs on the inside, and batten the cracks with rough boards, and serve the nnder side of the joists in the same way. This makes a tight boarded room, eight feet wide, eight feet high, and twelve feet loner. The floor must be laid npon timber bedded in gravel or charcoal. to eut off any curjents of air, but so that all waicr from melted ice will drain off immediately. Divide off four fect of the end in which you intend to have the door, for a cooling-room, and you will have room for a cube of ice cight feet, less the straw or sawdust all around between the ice and boards, and this will last any family through the hot weather, with most liberal use of it for all needed purposes.

Now for the protection of the ice to prevent its melting. Set up another "balloon frame" outside of the first, from one to two feet off, the widest Epace being the best, boarded perpendicularly with rough boards battenel. The top of the onter frame must be tied firmly to the inner one by strips of boards nailed from plate to plate, and the space between the walls compactly filled with cliarcoal, sawdust, or straw, provision being marle tor a narrow doorway in one end, to be closed with shutters inside and ont, which must be made to slut tight, and will be rreatly improved by lining them with a coat of straw two incles thick, fustened on by lath nailed across. Abont the roof. This must be made in the sane way is the sides, with two sets of rafters, boarded and filled between with straw, with good shingling cutside, or some other tight roofing. It will be necessary to make a trap in the roof, or a door in the gable end, opposite the usual cutrance, with a slide leading to the interior, for the conrenicnce of filling, and there must be al suitable rentilating climucy, six inches square, from the ice up through the roof, which at times may be partially closed by a wisp of straw. The space between the joists and the rafters, if filled with struw, will assist in the preservation of the ice, and need nerer be removed, except the portion arome the door made for putting in ice.

The expense of such an ice-house it will be easy to calculate non the local cost of limber.

Such a building as we hare described will take forty-ciglat studs s fect long, $2 \mathrm{by}+$ inches in size, which is quite strongr enongh, and sixtecn insile rafters of same size, s feet long; twenty rafters of same size, 9 feet long, for ontsile; two sills $2 \mathrm{by} 6$ inches, $S$ feet long each; two ditto 18 fect hong each for inside franc; two ditto 16 fect and two ditto 12 ficet for ontside sills, and some short pieces of etuft tor gable-cud studs; tor plilfes two boards 6 inches wide, 13 feet long; two dito 5 teet long; two diten 1:z tue and two ditto 16 feet each; and this constimtes the timber of the frame, and will not excecd 700 feet, board uncasure. In fach, this whole frane could lu made of straight poles, or split stuff, which would cost but a trifle on sume fitrus. The honding of sides, roots, floors, partition, measures in all, we he-

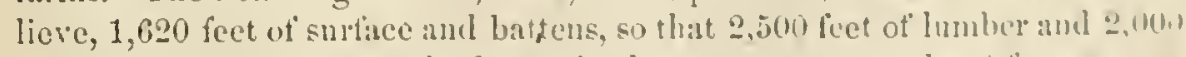
shingles appear to be ample for an ice-lionse to stow a cube s tect syllitre. with a cooling-room 4 by $S$; and $t$ wo men can build it in fonr days. Xow 
count the lumber at $\$ 12$ a thousand, slingles at $\$ 4$ a thousand, work at $\$ 2$ a dily, nails, linges, ete., $\$ 2$, team work $\$ 2$, and we liave a total of $\$ 50$ for the cost of a bnilding that is worth $\$ 50$ to any farmer erery year. Who wonld do without an ice-liouse?

Ilaving given the above as our own plan, we will add the plans of several others. One witer says:

"Instead of one hollow wall for a non-conductor of heat, as in ordinary ice-honses, I lave two, with a space between them for confined air. The site is on a gravel slope. The fomdation, for convenience in storing ice, is dug two feet below the surface of the ground. The ontside wall, for non-eonducting material, is six inches in the clear. The insile wall is four inches. The doors for entrance correspond perfectly with the hollow walls in thickness, and are filled in the same manner-beiug shaped to shut with a berel edge, like the door to safes used by merchants and bankers. At the lower side of the plates is a ceiling, upon which I put spent tan one foot thick, which tan is in direct eonnection with the side-walls, so that any settling in of the walls may be supplied from orerhead. From the under side of the ceiling runs a ventilator, with a hole of one and a lialt inch bore, up throngh the roof, which is finished with an ornamental cap.

"The room for ice is eight by ten feet in the elear, and eight feet high. About all the waste of ice that I observed during the smumer was at the bottom, and this was so slow that we used the ice without regard to economy for a large family, and in a dairy of thirty-five cows, besides giving freely to our neighbors.

"I put sticks four inclies thick in the bottom to put ice on, aud silso somo straw about the sides as well as underneath the ice."

At a discussion about ice-lıonses, by the American Institute Farmers' CImb, the following faets were elicited:

Mr. PARoev read an extraet from a paper upon the ventilation and drainage of ice-houses. It states that an morground ice-lionse is ealenlated to melt ice much faster than above, because the earth gets lieated and melts the ice.

WilliAs S. CARPENTER-It is a question of great moment to farmers liow small a cube of ice can be kept well. I have not, in my experience, found that one less than ten feet will keep. I have a floor orer my ice, which I licep covered with straw, and find it an excellent thing to prevent thawing. I find the bottom layer of my house, which is an mdergronud one, keeps better than the layer's abore. Some of my neighbors think the ice lieeps the best if the eakes are set on edge.

Jous G. Bengev-The great iee-packers I have seen put in their cakes flat, aud rely compact. Some of my neighbors break up the blocks of ice, but I prefer the solid blocks. My opinion is that straw is better than salt hay to pack ice in. I should prefer to have a very heary coat of straw on the ice, and then I don't care about the ventilation abore. I will say, hor- 
ever, that my neighbors' ice-houses that have wo upper lloor, and are a good deal open at the top, do keep the ice well.

Prot. NAsu-TWe are too mneh inelined to be innorators in all our buildings, and in iec-houses particulary. We must look at the rue plitosophy of keeping ice, or we shall fail; for the philosoplyy of it is to put it als much away from the air as possible, and that is why we pack it in slduw or sawdust, etc. As to giving some rentilation to the laft, or space orer the ice, it may be of service. I think that an iec-honse should not have any provision for rentilation-the tighter the better.

Soron lionswow-There is a misunderstanding about this term rentilation. As one of the advocates of it for an ice-lonse, as well as all wher liouses, I do not mean open exposure, but simply to allow an cienpe of lle heated air that will acemmunte in the spaec between the straw and the lont. Make it as tight all rome the body of the ice as possible, by using noncondueting substanees from the exterior, and eoser the top of the ice as elosely as you please with sawdust or straw, but dou't make the upper part - too close; at least, leave the cracks in the gable ends open. As fol the Eiles, the best of all substances to fill with is fine charconl ; the next best, sawdust; next, tan-bark, straw, leares from the forest, or salt liay, or al:y other fibrous substance. It is not neessary to have a Jouble wall if your ice is sufficiently packed around with any of the abore substances. The air, at any rate, must not come in contact with the ice, nor with a board that tonehes it. And a stone or the gromul will melt ice much quickel thin wood. What I luve been most anxious for in bringing up this discu-sion upon ice-houses, is to divest the subject of all sciumtitic nonsense abont making buildings to keep ice of so expeusire a character that no common farmer would undertake it. Yet there are thousands of men who nught enjoy the comforts of a full supply of ice, and some of them wonld do it if they only knew that they conid build a house at almost no eost. A lon cabin, as leseribed by Mr. Pell, or a cellar lined with fence-rails and a board roof, with plenty of sawdust, leaves, or straw, will keep it lungert than a stone or brick building, put up at a cost of sov. I want to encourige people to build eheap ice-liouses.

A correspondent says: "I live on Staten Island. where neitler charcual. sawdust, nor tan-bark ean be had, except at great expense, but diry forestleaves and salt hay cost but a trifle. Will eitlier of the latter answer a crood purpose for an ice-house out of the ground, and, if so, which is the best? (1.) I propose to make two boxes of rough liculock boards-llie outer onc twelve feet square by ten feet high, the inner one ten feet syuare hy the sames hight-so as to leare a continuous space of twelse inches all round betwern the boxes, this space to be filled with leares or hay pressed down light. (2.) The loof to be corered with tongued and gromed bonds, and set at an angle of 35 degrees, with a projection of wo fect. The donble denrs will be in the peak of the roof, the outside frnue to he supported lige chestnut posts, lined on one side, and set iuto the ground four fece apsurt; the 
inside box, or frame, to be supported by joists, $2 x t$-inch, set elyewise, three foet apart, secured arganst tho imner eide. Chestmut sleepers will be iaid on the ground, eovered with loose boards, from which there will be good drainage. Will it be necessary to make the roof double, and have an opening on the top for rentilation? (3.) Can you suggest any improrement on this: flan, withont increasing the eost? (4.) One of my neighbors, for the want of tan-bark or sawdust, luilt an expensive iec-house on the ground, walled up with stone, but it fials to keep the ice. (5.)"

I will briefly answer these inquiries:

1. Either salt hay or leaves will answer a good purpose, and I should use whicherer is the cheapest.

2. This plan will make an ice-house that will keep the eontents safe in any place.

3. There is the same neeessity for a double roof that there is for double sides, and more, for that is not necessary if there is a good thiek lining of straw between the ice and boards. I double my roof by a thateh of straw, first laid and then boarded over.

4. The improvement I should suggest would be a cheaper frame. Make the outside just like the inside. It is cheaper, and will answer just as well as the cliestnut-posts.

5. This is probably owing to defieient rentilation; that is, openings in the gable ends far abore the ice, to allow the hot air and foul gases that accumulate there to pass off. If the stone walls of an iee-honse onee get lieated from the sun, they retain the heat both day and night, and communiente it to the atmosphere within. Stome is the worst material for an ice-house that ean be nsed.

Rosert L. Pell said that he built an ice-house just like a log-eabin, in the ground, with a board roof, that keeps ice first-rate. IIe built one of stone and one of brick, laid in cement, neither of which would kecp ice. He fills on a eold day, and leares the house open to allow the ice to freeze. He packs broken iee into all the spaees between the cakes, and puts straw at the bottom eight inches thiek, and packs the ice up to the wood on the sides, and leaves it until June or July, when there is a space melted away all round, and that is then packed tight with straw. IIis ice-house is most thoroughly ventilated in the upper portion of it. A full set of iee-tools eosts about $\$ 50$, but be did not think it neeesary for a farmer to go to that expense; a saw is nearly as good as an ice-plow to cut ice on a small seale, when great haste is not very necessary, as is the ease with the great jeegatherers for market.

Jonn G. Bergex-1[y ice-house is a cellar, about twelve feet square at the top and ten feet at the bottom, and this is fitted with a double-boarded frame, the hollow filled with eawdust. The earth is so porons that it gives a natural drainage. There is a building, used for other purposes, over the icehonse, which is rentilated, but the iee part has no ventilation; and I corer the ice with sawdust, and also around the sides, and it keeps well. I pack 
the cakes close, and they come out as equare as they went in. There is a free circulation of air in the upper part of my jec-house, and nothing but straw to cxclude the air from the ice. The great Indson Rirer ice-houses are rery large, and al ways built above ground, with donble walls, filled with Eawdust. The ice is packed close, and broken ice filled in to all the cructis. Some single icc-houses hold 3,000 tuns; and most of the ice used in the city is cut upon the rivei, and not upon lakes.

MIr. Quns-I notieed that some of these icc-houses use salt liay. The roofs and sides are double, and the best of them are filled with fine charcoal, making the walls eighteen inches thick. I know one person who hal an undergromel ice-house, and now has one above, which he prefers; the ice keeps in this the best.

J. P. Treeder-I made my icc-lıouse by digging a lole ten or twelve fect square, and lined it with boards as a double wall, filled in with tan-bark. My roof is a straw thatch. My ice keeps perfectly well. I lave good drainage, and I put ahout six inches of straw around the ice on bottom, sides, and top. The house is only four feet below the surface, and the reat above. I pack about twelve or fourteen tuns of ice, being carefil to fill all the crevices with broken ice.

Joms G. Bergen said that he did not think a double roof necesary. None of the ice-houses in his neighborhood had them.

Prof. Mneks-The point settled in building ice-houses is, that the whole icchonse should be above ground. This is the practice in Massachuscts. There is no substance equal to a confined space of air for the walls of icehouses. Build of whaterer snbstance you please, so that you have a double wall, and tight enongh to hold air, and you will have a perfect protector of icc. As to ventilation, Jenuer, who first construeted ventilated iec-boses, found that iee melted faster in rentilated than in unventilated boxes. Ventilation is necessary when you desire to keep food sweet. If there is no rentilation, the confined air soon becomes rery foul thom animal subsiances on ice. IIe then gave some interesting particulars of lhe large refrigerators in some of the city packing-honses. Some are so large that they nse up a mumber of tuns of ice a day. The temperature is lept at 42 degrees, and in large ronms thus cooled hundreds of animals can be killed and cooled erery day. If your object is to kecp ice without use, shut up close-it needs no ventilation.

315. How to Make and store Ice.-IJ. Irsax, of Johnstown, Wis., tells how to malic ice for putting up in ice-honses, where there is no convenient pond or stream, and how to storc it withont an expensive house built on purpose. Mr. Lymm says:

"I live on the prairic. On tho coldest day of Jamary I draw water from the well and pour it into sruare tin pans, two fect long, nino incleses wide at the bottom, and nine and an eighth at the top, and abont nine inches deep. While I have been drawing water, Dick has heen gaflucring clean snow and putting it into tho water. The compound is fromen immediately. I now 
apply lot water with clotlis to the sides of the tin containere, which enables me to empty ont the blocks of ice.

"A cube of ice of four feet is all I need. No separate building need be erected to keep it in. The barm, the wood-house, or the tool-house ean funish an ample corner. The conditions of its safe lieeping are-the walls of a building aroumd, and two feet of compact straw on every side of the relid mass. In packiug, I lay loose boards on a bed of straw, and on this jlattorm I lay the ice. I take care to expose the ice to the lowest temperature of the year, and lay it up in the coldest state. If every alternate block of ice is inverted, the mass is thereby made compact; if not, there will be a little space open at the bottom between the respective blocks. When the cube is complete, cover the whole with straw. This work can be eftected with unilk pans or other ressels, and if straw or ice be carefully filled into the intervals in packing it will answer a good purpose, thongl square pans are preferable. I use snow for the sake of hastening the process of freezing. The pans are flured a little toward the top to facilitate turning ont."

This excellent plan should be earefully lieeded by all the dwellers upon prairics, and by a great many other people.

316. How to Carry Ice to the Field-Lucius Beach, of Port Huron, Mich., says: "Many farmers do not put up iec from the supposed difficulty of using it on the farm away from the house. I lare used ice-watel fol constant drink two summers on my farm. I lappened to carry water with ice in it into the field in a six-cuart tin pail with a corer to it. We used the water, and the ice was left in the pail about six hours in a hot day, and some of it still remained. I then procured a twelve-quart tin pail with cover, put in a large piece of ice, took a jug of water into the field, and turned it on to the ice as we wanted to use it. In this way it will last from six to ten hours for the use of six men, and is a luxury indeed."

317. How to Keep Ice in Summer.-If you have no ice-house, and buy ice, or eren if you liave an ice-house, and do not want to open it except at evening or morning, or if it is inconvenient to the honse, and you wish to have ice always handy, this is how you can do it. Have a bushel of clean, dry sawdust, put a peck of it in the bottom of a tight barrel, having one hole for drainage, then put in a layer of lumps of ice and another. peek of sawdust, and so on, covering the top tiglitly with sawdust, and over all a folded blimliet. Do not let the ice touch the stares, and do not set the barel in a warn place, and you will have iee all day, with searcely any perceptible waste. Provide sawdust enough, so that you can shift the wet for dry every day. This is a much better plan than wrapping ice in a blanket or kecping it in a refrigerator, because the lest of these useful articles of household furniture do not preserve ice, but rather waste it, and in so doing preserve the food placed in them.

318. Refrigerators.-No family can afford to keep house withont a refrigerator-a food-preserver. We do not mean an ice-box, which, like the one above described, will kecp ice, but nothing else-that is, not to any ad. 
vantage. A piece of meat, placed upon ice, will keep a longer time than in the open warm air, but it does not keep as good as in dry air of ice temperiture, and it spoils very quickly after it is taken off the ice. 1 custard pie kept three days on the iee will be slimy and not toothsone: lut when liept in a good refrigerntor, the pic will be as sweet and dry as it is in a pantry in cool weather; a piece of meat will kecp in July as well as in January. Such a refrigerato! has the jee at the top, and the ar cooled hy it falls upon the food below, or on a shelf alongside of the ice, and is as dry as any other cold air. A box of fine chareonl, kept in the refrigerato:, and clunged every month, will absorb all the unpleasint odors and keep the air sweet. Such refrigerators are common now in New York in families, and some of the butchers have them large enough to store the quarters of a bullock and several sheep and ealves. And some of the packing-lionses liare them large cnongh to store and eut and pack, in a winter atmosphere, sereral lundred lıogs a day. Without such "cooling-rooms," the summer slanghtering of butchers' animals could never be carried on to the great extent it is in all the large sea-board cities. This is one of the great inventions of the present age. These improved refrigerators, of suitable size for fimilics, cost fiom $\$ 15$ to $\$ 50$ cach. Ours, which cost $\$ 25$, is worth $\$ 10$ a ycar-lus bucu in nse five yeurs, and is just as good as erer, and we see no reason why it will not be so ten years hence. It is better than none, cren withont ice, as it preserves an even condition of temperature. Every firmer slould have ice, and no one should be without a refigerator in some rery convenient locality near the kitchen cr store-room.

\section{SECTION XYI-THE B.ARY AND ITS APPURTENANCES.}

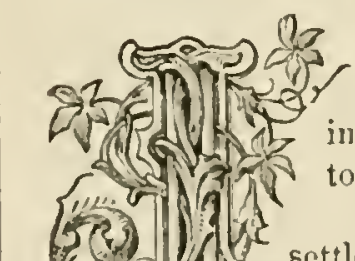

F all that might be profitably said unler the title of this section.were griven, we should require a whule volumse instead of a few pages, which is all the space we can allot to the important subject.

A farm willont a barn is only to be tolerated in a new settlement, as in some cases on the grent prairics, where the land can lie got under cultivation before the owner can crect the necessary buildinga. liven there, we have always noticed that the most thrifty fumers were those who ererted the best harns, at the earliest monent practicable.

The barn amel its appurtenances, treated of in this section,

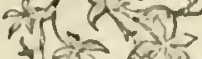
4 iv contains information that will he found valuable to erery one who owss, or crer cxpects to own, a firm.

319. The Ise and Value of Barus, and their Location.-Oi $-3$ conrse, a good barn is one of the great essentials of a timrnery-une that can 
not bo dispensed witl. Grain and hay may be preserved in stacks or barracks, but the one ean not be threshed and cleaned out-door without waste, and the othe: can not be fed to the stock to good adrantage anywliere but in the barn. A grood liouse and convenient out-buildings are comtortable; it good barn is one of the grand neecsities of good firming.

No furmer can afford to do without one of sufficient size to accommodate all the purposes for which a barn is appropriate. We lave rarely, if erer, seen upon a well-eultirated fal'un a barn that was too large. In nine ont of ten cases the barn is too small. After it is too late, tlie famer regrets that lie had not built it larger. But lack of size is not so great a fault as wrong location, for you can build to the original, by a lean-to mpon one side, and open shed or stable on the other, or an entire ner building adjoining, so as to make the whole quite as convenient as thougl all built together in one building. But if the location is wrong, it nerel can be righted. So, in building anew, make this a question for eareful consideration: "Where shall I place my barn?" And do not place it until you know that you are right.

We will point ont a fer essential things abont location, which we think may be of service to those about to build barms.

First, a barn never slionld be ect np-lill from the house, where by any possibility the drainage either on the surface, or under it, shonld come down about the rloor, or into the cellar or well. Wherever the situation will admit of it, place the barn on a lower level than the lonse, and northerly or westerly from it, and do not he afraid to gire a good distance between. Tou had better walk an extra limndred feet all your life than lave a hundred fonl smells ereeping into erery room in your dwelling.

Secondly, never build your barn upon the roadside. Upon the road, only a mile long, which we daily travel between our own home and the railroad station, there are four barns, located upon just snch situations as are rely eommon in all hilly regions, the face of a lill, which gires most excellent natural drainage-but unfortunately for good economy, the drainage is directly into the public road.

Another thing in the location of a barn should be had in riew, and that is conrenience of aceess. For a large farm, a hillside barn, that can liare a drive-way into the sccond or third story, affords a great conrenience abont unloading hay, and hanling away manure from-the lower side.

A loention should be chosen for a barn, so far as it can be, with reference to other important considerations, where it will not occupy half an acre, or more, perhaps, of the rery best soil, about the center adopted for the farmery establishment. If you are about to make a new location for tle whole of the buildings to constitute a farmery, it will be easy to have them arranged relatively right, if you first make a complete map of the whole farm, and tlien make your locations to suit peculiar circumstanees. On a rough, rocky farm you may often save an ace of good land by placing your buildings upon ground or rock fit only to build upon, and much better for that than a rich soil. 
Above all things, in selecting a site for the famery, of which the barn, with its appurtenances, forms such a conspicuous portion, aroid locating directly upon both sides of the road, and all locations upon brook or river banks, which allow so much fertility to be washed away. And do not gru to the botton of the hill because there is a natural spring there, or because you can dig a well so easily. You can hawe a cistern anywhere near a root, if you can not get a well. Do not locate on the very pinuacle of the hillit is too bleak, even in quite wam latitndes. It you place the house on the hill, you need not put the barn, like one I see almost daily, on the top of the highest pile of rocks in the vicinity-a spot bleak enongh to blow the hair off a cow's back.

Having said this much of the most important question, we will now introdnce some deseriptions of a few of the best barns in this comntry.

320. Bara built by the Slakers, Canterbury, $\boldsymbol{X}$. H.-The location of this Shaker society is about fifteen miles north of Concord, N. II., and nine miles east of Merrimac River. The society is composed of three fanilies, and owns about 2,500 acres, lying in wearly a square form, in the center of which are their substantially built and commodions dwelling-houses and numerons other buildings, all of which are painted of lightish colors, and kept in the most complete repair and neatness.

The main body of the barn is 200 feet in length by 45 in width, with 34 fuet posts (three stories high). The roof is ncarly flat, donble boarded, then corered with three layers of stont sheathing pajer, saturated with conl tar, "pon which is spread a thick coat of coal tar aud screened gravel. There is a projection at each end of the bam, 25 feet in length and about 16 in width, so that the whole length is 250 fect. "The whole structure is well boarded. The sides and ends are corered with 16 -juch pine shingles, laid forr inches to the weather. There are thee floors, extending the whole length of the main body of the barı. The grouncl upou which the barn was ereeted was nearly level, but at great expense a drive-way has been graded, of easy ascent, so that the loals of hay are driven on to the upper floor, over the high beams, so that, in unloaling, the hay is pitched down, instead of up. This makes a material ditlerence in torking orer 200 tons of liay cach hay season. The floors, ceilings, partitions, etc., are all plancel and finished off as handsomely as farm-lonses formerly were. There are two hovels on the lowel floor, extending the whole length of the main barn, the eastem portions of which are aranged for tying up 23 cows in ench, with slicling stanchions. The cors have been so trined, as they pass in the hovel each one takes its own jlace with the redularity of well-traned soldiers, and by a simple contrivance-the turn of a short lever-the lieads of all the cows are fastened or loosened, quicker than any one could he tied hy a rope. Each cow is named, and, like the "world"s people," they select fancy names for their cows, buch as Rosa, Latly Grace, Julin, Bustle, and Crinoline, each of which is printed in large type on slips of pastebosral, and tacked upon the joists over each one. Upon the roof are three large, hand- 
somely fiuished rentilators, with Venetian blinds. The cellar, 200 by 45 teet, is of good depth; the walls are of split granite, pointed with cement. Large wooden tubes pass from the cellar through the roof; which effectually carry off the heated foul air of the manure. From the south side of the center of the barn deseribed, a two-story building extends, sonth, 100 feet by 27. The upper part is used for storing hay, grain, straw, cte. ; the lower, for calf-pens, store-rooms, and hospital for sick animals, with a nicely fitted up room for the herdsman. The roof of this, like that of the large harn, is nearly flat, tarred and graveled, and shingled mpon the sides and ends, as is, also, a new sheep-barn, built adjoining. This runs from the southeast corner of the large barn, 108 feet long by 43 wide. The drive-way floor of this is 17 feet wide, so that two teams can stand abreast, and at the south end the floor is wide enough to allow the turning about of the team, so that the oxen passing out go before the eart, instend of the cart going ont firstfor the south end is not graded up so as to admit of driving througl, as in. the large barn.

Another addition was planned, that is, a long shed, extending from the southrest corner of the barn 100 feet. This will give two barn-yards of about 100 feet square each, well sheltered, all but the south, with both yards well supplied with water.

As the Shakers are famous for good barns, we shall gire the deseription of another one of theirs. We have great confidence in the economy of the form of the one next deseribed, as well as its great convenienee.

321. A Circular Barn.-The Shakers of Berkshire County, Mass., have a barn that is worthy the attention of farmers who are contemplating the erection of barns upon a large scale. We should think that on some aceounts it would be a good form to erect upon large prairie farms. We recommend its form for adobe buildings and eonerete walls, as one best adapted to withstand the force of hard storms, as well as the form most economical for the room inelosed. The barn owned hy the Shakers is 100 feet in diameter, built of stone-a material that is rery abundant in that part of Massachusetts. It is two stories ligh, the first one being only seren and a laalf feet between floors, and containing stalls for serenty liead of cattle, and tiro calf stables. These stalls are situated in a cirele next the onter wall, with the heads of the animals pointing inward, looking into an alley in which the feeder passes around in front of and looking into the face of every animal. The circle forming the stable and alley-rray is fourteen fect wide, inside of which is the great bay. Orer the stable and alley is the threshing-floor, whieh is fourteen feet wide and about three hundred feet long on the onter eide, into which a dozen loads of hay may be hauled, and all be mnloaded at the same time into the bay in the center: There shonld be a large ehimney formed of timbers open in the eenter of such a mass of hay, connecting with air tubes under the stable floor, extending out to the outside of the bnilding, and with a large ventilator in the peak of the roof. We should also recommend an extension of the eares beyond the 
outer wall, by means of brackets, so as to form a shed over the doors, and the manure thrown out of the stable and piled against the wall.

In the barn mentioned there is a granay projecting into the circle of the bay, which we do not exacty approve, preferring the granary in a ecparate building, to which grain may be conveyed throngh sponts, if the barn is located upon the lillside, which is proforable on account of entering the threshing-floor on a level, thongh that is not indispensable, ns a wagrou-my ean be craded up from a level plat.

322. Baru Foumdations. - The stone foundation of a barn shonld nerer be laid in mortar. This is an error that sliould be avoided, as unnecessary and mprofitable. It would be even better to place the sills upon pillars, leaving a fiec circulation, and space high enough to furnish shelter for all the poultry in winter, and thus lieep them ont of the inside of the barn, where they are a nuisauce. The main object, lowever, is to give free cireulation of lie air, to drive out all foul grases, and promote the health of animals. 'The surface must be so graded that no water will stand under the barn.

323. 0pinions of Practical Farmers about Barus, -1 t a Farmers' Club in Trest Springfield, Mass., after consultation and debate, it was decided that a large bau was better than two or more small ones; that a tight barn was betier, cren for badly-enred hay, than an open one; that a brick barn and a slate roof were the best and elicapest for a man who has all his materials to buy"; that a good connection between a house and barn is a covered walk, orerhung with grapevines; that economy of roof and convenience for work were of the first importance in any building; that warm water and warm stables were essential to the confort of animals; that the lousing of mannes was judicions; that liquid manures are largely lost, cren by those who have cellars and sheds for storing them; and that the best absorbents of liquid mannre are buckwheat hnlls, lcaf mold, sawdust, fine eand, dricd peat, turt, and straw.

The mecting was held at the lonse of one of the members-an old-fisllioned two-story building-with modern furniture and fixtures, where the well-spread tables were bountifully loaded with fat chickens, mealy potatoes, lighlit bread, yellow butter, melting cheese, with pies and eake to match, all larishly bestowed, and such conversation ensued as ronld, if it contl be initated in every neighborhool, prove of great benefit to the people. Let the plan be imitated. If not the plan of the barn, certainly the plan of meeting with your nejghbors, and talking over the subject, as to whether you shall build a large or small baru, ond of what materials. It is also very important to every one about to bnild, to go about, far und near, and look at all the barns of rnrions sizes, forms, and fishions, and talk about their conveniences and the reverse.

324. Barus Boarden Tight or 0pen. - Whether harns should be tight is one of the most important questions that $n$ farmer ean consiler; for it may" involve tle healeh and lives of all his farm stock. It is contended ly some writers, witl a good deal of renson, that open harns are moro healdy fur 
[Cinap. III.

stock, particularly the bovine portion, than closely boarded ones. A communication from a farmer in Mainc says:

"Screral years ago, I learned by experience that tiglit barns were not lealthy for cattle, and a little reasoning upon the subject will cxplain why this is so. It is a well-known fact, that the droppings of cattle, both solid and liquid, exhale a vast amount of gases of different kinds, and these gases are untit for respiration; if eattle are deprived of air, and breathe these gases, they die instantly, and if they breathe air impregnated witl a large proportion of these gases, they sicken immediately; the disease most likely to be produced is pnemnonia, or inflammation of the lungs, as the poison is applied directly to them.

"Now what provision is made in modern tight barns to get rid of these gases? Why, there is a rentilator on the top of the bam, but how are these gases to get to the top of the barn, since a lar'ge proportion of them are heavier than atmospheric air? The carbonic and sulphurous gases, which are more abundant than all others, are heavier than air, and conscquently will not ascend; ammonia is light and rould fly away, but the carbonic and sulphurous gases, having a strong aftinity for ammonia, seizc the fugitive, and by a chemical action a new compound is forned hearier than air, which, of course, must remain, unless there is some underground passage by which it can eseape. If there is no place for its escape, these gases accumulate until the barn becomes filled witl them, the hay is infregnated, and the stock lias to eat as well as breathe this noxious matter, and the tronble is worse if the stock is ligh fed. First, because ligh-fed animals have a greater amount of blood, the blood-ressels are fuller, and conscquently a greater tendeney to congestion. Secondly, becanse the exerements of lighl-fed animals crolve a muel greater amount of gases than those of others, and the difficulty of ventilation is increased by the fact that these gases are so nearly of the weight of air. If they were all light, like carbureted hydrogen, they would soon escape at the top; or if they were leary like water, or cven pure earbonic acid gas, they would, in most barns, find cracks snfficiently large to dun ont near the bottom; but as the facts prove that the gases are nearly of the same weight of air, I am led to the following conclusions :

"First, that the walls of barns should never be clapboarded; then there will be a gentle current constantly passing throngh the barn, and the gases passing out of the cracks on the lecward side; second, that the stable for horses and cattle should cxtend from one end of the barn to the other, with a door at each end, both of which should generally be open excepting in severe cold weather, and in storms. I lave fomd by expericnce that a horse kept in a small, tiglit stable, will commence cougling in a very few days. Cattle do not suffer with the cold (unless the cold is extreme) if they are in good health, are well fed, and have a dry, clean stall, and plenty of good air to breathe. The lnngs of an ox will manufacture a vast amount of animal heat. I have known a cow to be wintered with no other shelter 
than an open shed, more than two hudred uniles tarther north than Mrassachusets, and she gave milk all winter, and eame ont woll in the spring."

There is something worth a thought in this matce abont airy barns. We know them to be the best tor hay and grais; and we know that in olden time in New England, all of the barns, covered with upright boards, put on green, had wide erocks fiom top io bottom, and in such stables, althongh rery cold, the enttle wintered well and kept healthy. It is slieler froul storms, and not shelter from eold, that all of our stock needs.

325. Fentilating Ilay-mows.-One of the worst puetices of fimers, in $\mathrm{Yew}$ England particularly, is storing lay in large bays, without a sign of atuy rentilation under the bulk, which nsually rests upon a few loose poles or boards on the damp ground. A biy should have ventilation, not only under jt, but up through it, by means of a chimney made of tonr poles fistencel together by rounds like a ladder. A loose stone foundation eonld be lail for the hay lotton, with an air-chamber trom the ontside leading th the chimney, directly over which there should be a ventilator in the rout. This simple cantrirance would not only sare many a tun of lay from unstiness, but it would enable the owner io put in lis laty in a much greener state, and that which is next the chimney would al wiss come ont rery sweet.

326 . Slables-how to fonstruct linen,- I stable shomd be built witla a view to sereral points, among which we may mention economy of space consistent with comfont, convenience of feeling and milking the animals, consenicuce of tethering them so that they may lave the largest measure of liberty of motion, but be muble to injure one another; convenicnee of getting liag firm the lott and grain from the-lin to the stalls; and convenience of removing the liquid and solid exeretions, so as to preserve their quality, and Jemove them so specdily that the eflurium may not be breathed by the enws.

The floor of a cow-stall of a well-constructerl stable is fonr teet to four feet six inches longr, rased two or three inches for a dry platform. Behind the flattorm the floor is made of white-oak slats set aptart so that the urine may drop through to the cellar beneath. The floor-beams are lail four fiet apart. On the sides stont cleets are nailed, and on these the $2 \times 3 \frac{1}{2}$ whiteoak slats are doretalled and firmly nailed. The slats are beveled to a sharp elge beneath, so that the manue will not elog the open spaces. but drop clear as soon as it siuks below the upper edges of the slats. The slathed space is a foot and a half in width. Juelind that the first plank of the floor is male to litt like a talpeloor, turning on hinges, to secure an opren spaco through whieh to hoe the dropplings, litter, ofe., that would not readily piss between the slats. lig this simple contrivance tho droppings of thirty cow ean be remored in a tiew minntes.

327. Stables should always be buill high-that is, high between flnos. Most stables are built low, "because they are wamer." liut tho lunilders forgut that warmath is olutained at a sacritice of pure air and the health of the anjmal. Shut a man up in a tight, small box: the nir may he warner, hue it will soon lay him ont deal and cold it he continnes to lucenthe it. It siables 
are tiglit, they should have lighl ceilings; if they are not tiglit, but open to the admission of cold curents of air from all directions, they will be too unch ventilated, or, rather, rentilated in the wrong place. One of the clienpest modes of rentilation is to build the stable ligh, so is to grive room for the light air to rise above the heads of animals. The grand rule that must be observed is not to confiue a beast in a loom so suall that its breathing will soon poison all the air unless the foul portion can eseape aud fiesh ail cutcr.

32S. Cattle Sheds that Cost Yothing,-It is an act of wanton cruelty to expose stock to the blasts of winter without sliclter. In a comitry of sawmills, how eheaply a shed cau be built of slabs mailed to rougl posts, set in the ground, and roofed by laying one eourse of slabs round side down, and the upper conree round side up! The cracks of the sides can be battened with thin strips of slabs or refuse boards.

In a wooded conntry, where sawed stuff can not be had, how elieaply a side of round $\log s$ ear be built and craclis daubed with mud. Then an excellent roof can be made of split stuff, called shakes in some places and elap-boards in others, being split $2 \frac{1}{2}$ to 5 feet long, and 4 to 6 inches wide, according to the quality of the timber for riving. These laid upon round ribs, and held in place by weiglit-poles, make a roof, though rougl in appearance, as tight as a slingled one. If bark is peeled at the proper time aud laid at onee, or piled and dried flat, it makes a pretty good roof, still eheaper thau one of sliakes, though not so durable. We have seen a rely good cattle-shed roof unde of liemlock boughs, laid on in courses, butts up.

Cheap sheds on the prairie, where cattle are exposed to winter blasts more than in any other loeality, can be made so easily that it seems worse thau crucl-it is wicked-to leave the poor hrutes exposed.

Where rails are to be had, lay up a louble wall of rails a foot apart, by using eross-pieces at the end, and fill up the space with sods, or with earth and leaves, or brush, or witl coarse manure, or moldy liay aud straw, sucl as eattle will not eat ont, and you have a good wind-breaker. Extend from this wall, to the south, rails or poles to rest upon a girder on posts, and stack liay or straw on top, and there is a shed. It costs but little more to stack liay in this way than it does to make a suitable stack-bottom, and then fence the stack. As the hay is fed of in winter, fill up the space with refuse hay and straw, so as to break the wind, if it does not stop all the rain. Such slieds for sheep are very valuable.

Where rails are scarce, a good wall can be made of prairie sods laid up in courses, with hazel brush or small limbs to bind the sods together, to gire strength and prerent cattle from hooking the wall down. On this wall lay a plate to support the floor of the stack or roof. Such eattle shelter pays its cost every winter. There is straw enough burned or wasted every fall, upon the Western prairies, to shelter all the stock every winter, if it were put up in some such cheap form as we liave indicated.

829. A Valuable, Cheap Feed-Trough.-One of the puzzles in building harse 
stables has been how to make the feed-troughs. Tre can solve that difficuits. The have learned how to make a horse feed-though. Ol', Jatler, ves have learned how to purchase a re!y good and rery cheap onc. The leamen it of a progressive poung finmer. The tarm of Josiah Macy, a Wusteldester Connty tamer of the old school, is conducied by his grandson, who has granel knowledge from books, and goos alıcad with jmprovements, one of which is a now fecd-trongh. It is simply an iron pot-just such an one ats onr dimner nsed to be boiled in betore the age of cooking stoves. One ut about tour gallons is a gool size, and it is set in the comer of the manger, in a calsing of boards that inclose the rim, just up eren witl the top. It is superiol to any wooden, iron, or stone feed-bos we ever saw; is not expensive, and, barring aecidents, it will last torever, and be a good pot afterward.

330. Earthen Stable Floors, - One of the hest substances that can be found for flooring for horses is clean eand. It is superior to wood, as it does not heat and injure hoofs. Some English veterinary surgeons use nothing else for bedding but sund. We have always found stables witle dint floors preferable to plank ones.

331. The Stable Vard.-Tlie stable, or barn-yard, is one of the most important appurtenanees of the farmery. Two grand oljects inust be kept ju view in its construction-the confort of the animals and the prescrvation of the mamme. If it is on soft soil, and tolerably level, as such yards are upon nine ont of every ten of the Western pratric firms, they are most meomfortable places for stock, although good for preservation of manure, hut that is little or no object where it is of so little value. The only help that we ean sec for a ban-yarel upon such soil, where the tramping of cattle makes it into a quagmire, is thorough melerdrainage, and sedaping the earth from around into a low momd, and eovering the most of that with shels. It may be so constructed that all the draingge of the mamure will concentrate in one spot, to be ausorbed by straw or other manture-making substance. We liare found paring a garl with common fence-rails, where stones conld not le procured, paid the cost every year, and such a pavenent will last halt at dozen yours.

In a rocky comntry, like castern New York, Pennsylvania, and the New England States, if eare and somel julpment are nsed in the location of at firmery, the yard can be fixed on the somtherly side of the barn anel flieds, where it will always be lry, and rery comfortable for stock, aml yet not wasteful of manurc. Onr own is locited monn a rock, sloping sumthenst. Just ontside the fence, at the lowest conere, an excavition is malde, to be lept full of muck, sods, or other absorbents, so that while the yall is enastautly drained, tle drainage is not lost. Some very good yalels we lare Ecen constructed with a deep basin in the center. 'The great uljection to this form in a small yard is that the basin sometines grets so full that there is not dry space cnomoh aromel the edges for the cattle. Sometimes, tow, it free\%es orer ynite fnll, and strong cattle push the weaker ones upon the ice to their injury. We prefor the absorbing hasin ombile of the yart. 
332. The Heu-Roost.-Every furmery unst lave a hen-roost, if it does not have a poultry-yad; and this should not be an open shed, nor a cold open room, but one so arranged that it will be well sheltered from cold winds and storms, and lighted by a rrlass window upon the smny side or in the roof. It will also be found a most execllent provision to gire hens access in wister to a cellar, where they can scuatch gravel and wallow in dust. The hen-roost, too, should be arranged with special reference to saving all the Jroppings of the fowls, because it is the most valuable manure that is made about a farmery.

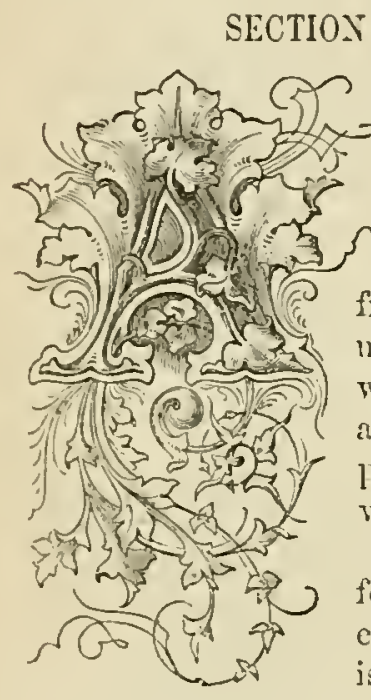

\section{SECTION IVII-WITER FOI THE FAlMERY.}

BOUT half of the firms in the United States are deficient in water-that is, the water is not convenient for stock; and in many situations cattle can only be watered by pumping, or by the still more tedious process of drawing water in a bucket from a well. This is a serious piece of labor, and a useless one, beeause the wind can be made to do the work a great deal hetter, cheaper, and more certain; and the whole expense of a wind-nill, pump, and putting into operation, in a well twenty feet deep, would not probably exceed $\$ 50$.

Yon may use any one of a dozen iron pumps, to be found in almost every hardware store. Our own choice would be West's Anti-Freezing Pump, which is male of iron, and is rery lurable. The wind-mill for the motive porrer is simplicity simplified. The wind-wheel is four feet in diameter, dirided into eight parts, eurved from the center, just as we used to whittle out wind-mills from a pine shingle forty years ago. The wheel may be made of mood or iron. If of wood, fix the points of the sails in a wooden hnb and seemre the outer ends by a rim, just like that of a large spiming-wheel. Fix this wheel firmly upon an inch iron-bar, say two feet long, with two bearings to run in iron or hard wood, and a crank in the center suited to the stroke of your pump. If the valve works four inches, make your erank short two inches. Now make a frame of three pieces, three quarters of a square, with bearings for the wind-wheel shaft upon tro, and an inch and a quarter hole in the eenter of the other piece. Upon this frame attach a vane of strong, thin wood, about three fect long and one foot wide at the onter end. Now ereet a gallows-frame seven feet wide and fifteen feet high orer the pump, fixed with a pipe in the well. No matter whether that pipe is straight or not. Now put a bolt, with a big head and washer, through the hole in the frame that holds the shaft, and 
through the center of the eross-picec of the gallows, so that the suall frame will be held firmly hy the head of that bolt, yet will turn freely in the winl. From the pistnn-rod of the pump, extend a rou with a swivel-joint in the center to the crank, and, let the wind blow high or low, you will have the satisfaction of knowing that your caltle are supplied with water. It is a good flan to make a cistern to hold a supply in case the pump stops at any time for repairs or want of wind; the latter will not be apt to ocents ats it will rum with a rery slight breeze. From your watering-tnb or trongh, conduct a pije back to the well, and you need not fear frost mules the pump stops. By making use of a force-pump you may get a supply from a well in the valley up to your honse and harn on the hill, or to imigate your garden. Sec \ов. 369, 370.

Ilow to get water most convenient to all parts of the fumery should he the leading consideration; beenuse water is indispensable-meither man nor heast can do without it a single day. All else may be inconvenient-marel should never be. It should be brought in pijes from a higher level, whenerer it is practicable at any reasomable expense, becanse that is the most convenient of all forms in which water can be hat at the farmery: und no farmer can afford to neglect to supply his jlace witl water, if he owns ir spring or stream that would afford such a suphly, because it is the greates labol-saving fixtme that lie ('an make.

If aqueduct water can not be had, then convenient wells amol jumpls should be; and if water can not be lad by easy, shallow digring, in well:. it can and should be in cisterns: and nyon this guestion we will give some useful information.

33:). Economy of Aqueducts, - Some farmers neglect to make provision fur watering domestic animals until dronght actually arrires, and then they can not. Te well knew one who, luring a droughth, drove his caltele an mile tu water, at the same time that he had roof enough on his lange ham to grive them all the drink they needed, if a cistem of proper capacily lad been pure pared to retain it. The barn cost $\$ 1,000$-the cistern might be built tor \$50-yet every animal of his large herd nust travel miles erery weck fir necessary drink. Ite might construct a cistern now, hut it will he annther year belore he can derive benefit trom it, and so he juts witl the labol.

There are many others who do the sane. We know anothel furmer, who las lived till past eighty years of age upon a furn where there is a gru-hing spring of excellent water within sixty gouls of his louse aml harn, himb enough to run through pipes over the top of ererg lmilding, pet this man dratws water with a bucket from a well, which sometimes fatils, when he hats to gro to a more distant and inconvenient well, or haul water in hanels fiom the river; and his stock, all the lone winter, go down the roal to the riverside for drink, wasting time (and that is money) and manure, to rejlice which he buys fertilizers. Saving the first cost of an aqueduct, in $=u e_{1}$ cases, is not saving money. Neither is the neglect to construct cisterns a good piece of economy. 
33t. Valuc of Cisterns- lucir Size and Contents - To man, whose only sup* ply of water is in a lecp well, ol where the well or spring water, howevel convenient, is harl-that is, like all the watel of limestone comntries, unfit for washisg, or making lutter-can afiord to do withont a cistern. If the aath where the cistern is to be built is compact clay, it can be dug out in the form of a jug, with only a man-liole at the top; and in all ground but caring sand it can be dung and plastered without any brick walls, and the top corered with durable timber, which shomld be placed at least fonl fect from the surtace to its muler side, as it will, when thus covered, last enongh longer to pay for the extral work. Wherever flat stones aboumd, a moderatesized cistern should be corered with them, laid slelving over each way, if not large enongh to reach clear across. The earth-bottom and walls are casily inade tight by cement (water-lime mortar), made with three parts of clean, coarse, sharp sand to one of lime, which has to be wet up only as it is wanted for use, or it will set whererer it las a chance to dry upon the bed where mixed. It should be very thoronghly worked in, mixing while prety wet, and plastered on the bottom first and then up the sides, one coat after another as fist as one is dry-two or three coats-taking eare that no defect is made in the joining of the sides and bottom together. The bottom should be dlug hollowing, and comers full ; and to sare cement, any little inequalities in the walls may be filled witl elay or line-mortar before putting on the cement plaster. In situations where cement can not be obtained, a good cistern can be made as follows, which will last a dozen years certain. Wre linow one grood at twenty years old. Take one and a half-inch plank, six or eight feet long, six inches wide at one end and six and a quarter at the other; joint and dowel the edges, and fit the ends witl a croze upon lieads six or eight feet across, and hoop just enough to keep together to roll into the hole, biggest end down, upon a soft mortar bed of clay, fonr inches deep; then fill the space between the tub and walls, which slionld be four or six inches wide, with clay just moist enongh to tamp in the most compact mamner, and the cistern will never leak, and will give great satisfaction for its small cost. The top shonld be eorered orer with timber and earth, deep enough to lieep warm in winter and cool in summer.

Upon the roof of a barn $35 \mathrm{by} 70$ feet-if three feet of rain fall annually - three cubic fect of water will be afforded by every square foot of surfacemore than 7,000 cubic feet from the whole roof-which would be about 1,700 barrels. This would be enongh to water daily, the year through, thirteen head of eattle, each mimal drinling four twelve-quart pails full per day. But if the water were reservel for the dry season only, or when small streams are dry, thirty or forty head might be watered from one roof.

People are apt to make their cisterns too sinall, so that often they do not hold a tenth part of the water from the eaves. In the above-mentioned instance it would not be necessary to construct one large enough to hold the entire 1,700 barrels. If the cattle were watered from it the year ronnd, and its contents thus constantly drawn as it fills, one large cnough to hold 400 
barrels would do; but it needed for the dry season only, it slould be more than double. A cistern fourtecn feet in dianeter and twelve feet deep would hold about 450 barrels - twenty feet in dianeter, and the sane depith, would be suflicient for 900 barrels. If built under ground, and contracted toward the top, it would require to be a little larger in dimensions, to alluw for the contracted spaec. Sucls a contraction would be alsolutely necesary in admit of convenient and safe covering at the top, and conld be effected without any diffienly if built of masonry. The pressure of the water oniwarl would be connterbalaneed by the pressure of the earth against the exterior, especially if well yammed in as the wall is huilt.

There are some portions of the conutry where the subsoil is mderlain by slate or other rock which may be exeavated. In such ease's, it sometimes happens that with a little care in cutting, the water-line muriar may be ap. plied immediately to the rocky walls, a shoulder above being made on which to build the contracted part of the wall.

ITe lave such a eistern, dug in tolerably compact carth, and plasteresl with cement, put on in two or three coats, using about two and a lalt harmels for a cistern eight feet wide and six feet deep. It was designed to he decper, which would have made a better proporfion, hut the exculvaturs came upou a ledge that could sot be lubsted, and was very ditlicult to pick

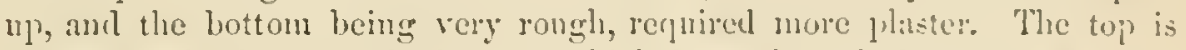
covered with chestnut plank, over which is earth, and the water is let in through a pipe beneath the surfice, and taken out by another that learls to the pump in the litehen. There is also an ontlet pipe under the corering for surplus water, so that when full, there is a body of watcr five fece decp by eight wide, and this gives abont sixty barels; and leing smpulied ly 1,600 superficial feet of roof, is not likely to firil for tamily usc. The warel" is perfectly filtered ly the mest combenient filtering arangement for a cistern that we ever saw.

This is by Peirec's patent porons cement pipes, which are laid in a sort of net-work in the bottom of the cistern, and the pump-pipe attached to them, so that no water can reach the jump that hats uot passed thromegle the substance of the pipes, which are in appearance much like soli] stone, and more than an inch thick, which cortaninly forms a very pertect straner to fres the rain water ot all jupurities. A writer in has recommendation to ererybody to luilel eisterns, says:

"I lave one in my houso cellar, cntirely below the bottom of the cellar.

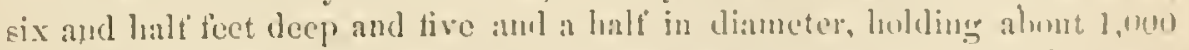
gatlons. It was dug six feet eight inches deep and scren tiet ju lianefor.

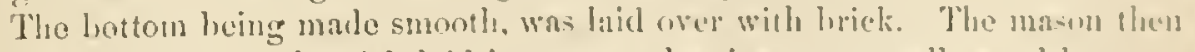
hegan the side with brick laid in cencut, leaving a space all rombl befwers the lrock and carth ahnut five incles. Atheraising the work ahout cighteren

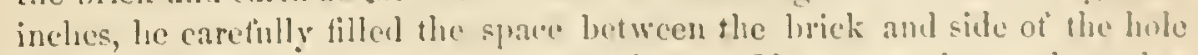
with carth, well aud earefully juessed lown. It you wet the carth or clay

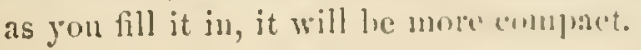


"When you get witlin about two feet of the top, enmuenee gradually to draw in the work towarl the center, leaving, when fulshed, a space open alont two feet icross. The next thing is to plaster the inside with cement; also the (nj) on the outside, commeneing where you began to draw in. About two cnurses of brick are laid round the month of the cistern, forming a neck, which adds to the strength of the toj). Now cover the whole with earth, except the neck. The water is conducted to my cistern througl a small brick drain laid in cement. I also have a drain near the top to let off the smpulus water. It a cistern is made out of doors, it must be below the reach of frost. Leal pipe would probably be cheaper than brick to eonduct water to arid finm the cistern.

"I lave $n$ o doulit but that a cistern marle this way of hard brick would lasi a century. Mine, loolding 1,000 gallous, cost $\$ 1 \mathrm{~s}$. The larger the size, the less the cost in proportion to the capacity. If the earth is firm and hard, you may lay the brick close against it, thus saving the trouble of filling in and digging so large. I lave known them made by cementing directly on the earth, nsing no brick, and covering the top with timbers or plank. One marle with brick will cost more, but I think it best and cheapest, taling into consicleration safety and dumbility."

Tables of Contents of Circolar Cisterns. - The following tables of the size and contents of circular cisterus may be conrenient to those about to build them. For each foot of depth, the number of barrels answering to the different diameters is as fullows:

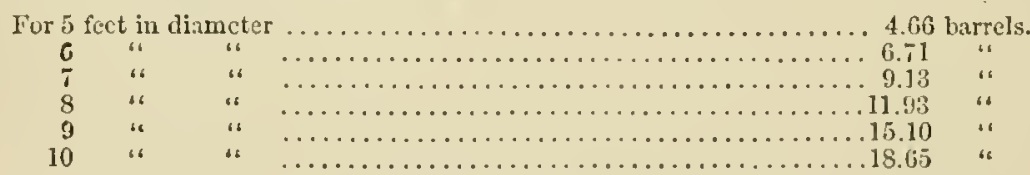

A cistern 31 feet diameter will hohl for crery 10 inches in depth ...... 59 gallons.

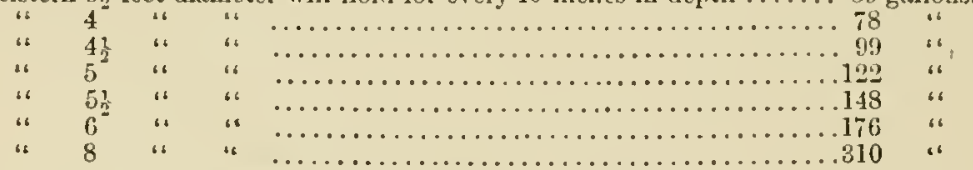

Yon will find by this table that a cistern six feet deep and six in diameter will hold 1,260 gallons, and each foot yon add in depth will lold 210 gallons. Therefore, one ten feet deep and six in diameter will contain 2,100 gallons.

To tind the contents of any cistern in wine gallons, the diameter and deptlı being known:

1. Multiply one half the diameter (in fect) by itself.

2. Multiply the above product by $3 \frac{1}{8}$, which will grive the area of the bottom of the cistern nearly.

3. Multiply this by the number of feet in deptlı; this will grive the cubic contents in feet.

4. Multiply the last produet by $1,72 \mathrm{~S}$ (the number of enbic inclies in a foot), which gives the number of cubic inclies. 
5. Divide the whole result by 231 (the umber of cubie inclies in the wine gallon), and the result will be the number of gallons in the cistern.

Divicle the gallons by 30 , and you will have the munber of barrels, and thus you can calculate low large to make a cistern for the use of house or barn; and be sure not to neglect so important and so incrpensise an inn provenent as making a cistern.

33.. Digging Welis.-There is no better improsement put upon at fium than wells, either in their erery-day convenicnee or ralue in estimating the price of a firmn. In some localities it will pay to dig a well at the lonse, at the barn, in the stableyad, and in almost every field. In compact eartl, a well can be dug without curbing to support the carth sides during the excavation.

Where curbing is necessary, the hest way to do it is to luill the wanl upon a wooden or iron ring, and let that down as the excavation proceeds, adding brick or stone at the top as fist as may be necessary to keep the wall even with the surfice.

336. Horizontal Wells.-IIere is a new idea for dwellers in mountainons, or eren moderately hilly districts to think of. Mining after coal in Promcylrania, and gold in California, has clearly illustrated the fact, that viclls may be dug into liblsirles, or banks, or lhutlis, as well level or horizontal:y. as down perpendicularly, which would save dangerous and severe labor. Water, so tronblesome in digrging common wells, has not to be bailed in the horjzontal, as it takes care of itseli. The certainty of discoveriug ur cutting ofl reins of water is greater with the horizontal well than the perpendicular, if it siarts in near the base of a hill, or anywliere as mucl below the surline as a common slaft wonld be likely to he smik. Jy laying down wooden rails, all the dirt can be brought out in a litte railway ear, and the stonc or linek carried in to builal the well as fist as the digging progresses. It will not le necessary to make a horizontal shaft any larerer than a perpendiculat one, though it should be of a different shipe. We would make it in the form of the figure we call a nanglit or cipher in numerals. "Two feet wide and four fect higrt will be large cnongh, with a gentle descent for the water to run to the outlet; and in many sitnations it can be inade to rum throngh a short pipe into the honse; or it it will not run, it can be drawn ly a pump through a lorizontal pipe any distance.

There is another atvantage in ench a well. It wonld not he constantly liable to have things falling, or being thrown into it, and the water would remain jurel.

There ale a great many pastures where water for stock has to lo drawn from wells, which might hare a natural flow from hillsides, with an expenditure of no more time and money than is required for a perpendienlan well.

There are some dairy tarms that conld habe valuable spring-lnuses smp plicel by such a lorizontal well, and such at supply of cold runuing water would ald to the ralue of the falm ahmost as much, in some cases, as its whole value is now. 
Such wells have been constructed in California, and we earnestly commend them to the attention of all the fumers in the hilly portions of tho Atlantic States. In rocky hills a horizontal slaft can be drifted in much easier thau it can lo bored perpendienlarly ; and the work either in rock or earth digrging can be much better done in winter in a lorizontal than in a jerpendicular well. We lope to see them extensively adopted.

33T. Wells on Hils.-Wo hare seen a great many wells on the tops of liills afforling a large supply of water, while the bottom was above the plain or valley in which the farmstead was situated. IIow easy to obtain this water by a siphon, or a pipe inserted on a level, which ean be done withont digging a ditch the whole depth aurl distance. Ascertain where the level of the bottom of the well will strike on the fince of the hill, and dige in there, and set up a frame to support an earth-boring auger, and drive a bore straight through to the well, which can be easily done one or two lundred feet, if artesian wells can be bored one or two thousand feet perpendicular. Where the distance is too great, or the lill is rocky, put in a siphon pipe, with a little land-pmmp to start it, and you can always have duming water in your yad or garden at the foot of the hill.

39s. Causes of Impare Water in Wels.-It sometimes occurs that the water of a well, noted for its purity and delicions drinking quality, becomes offensive to the taste and smell withont any apparent cause. Sometimes it is occusioned by surfice water from an impure somec finding its way to tho well, after many years of exemption; and sometimes it comes from joots of trees growing into the water and lecaying; and sometimes worms work their way in and decay; and occasionally lats, mice, ol other jests burrow in the wall and injure the water. And not unfrequently a new vein of water finds its way into an old well and materially clanges the character of the water. Generally a well is improved by cleaning, but we hare known the contrary. In a well of our own, in the trap-rock district nortl of New York city, the quality of the water was materially injured by sub. stituting a pump in place of a bueket. The reason was obvious. The water was seren or eight fect deep, and the bucket drew it from the surface and the pump from the bottom, and in the water drawn from the bottom we found a strong sulphne taste and smell. Clcaning it out did no good; the water at the bottom was decidedly different from the top. The only remedy, if we continued to use the pump, which was iron, and costly, and extremely comvenient (it is one of Gay if West's foree-pumps-rery valnable for farm use), was to attach a grutta-pereha pipe to the bottom of tho imn pipc, and to a float, so that it would always draw the water from the surface, at whatever hight it might be in the well by the fluctuations of the seasons.

Where wells are injured by surface water, resort should be had at once to the most thorough draining. Lay tile or stone drains fire or six fect deep, so as to eut off all leaking into the well. If injured by trees-rhich, by-the-by, should nerer be set near a well-dig a deep trench so as to cut 
off all the roots, and fill that trench with cuarse gravel, or a stifl mates of clay, that will not be attractive to the roots. Iiemove all that ron can frum the wall and earth near the well, and time will cure the watcr. Sunctines, to get ricl of roots, insects, or other pests, it will pay cost to umwall the well and build it anew. Fill in eharcual, cinder's, or other sweet substances; and sometines it will be well to lay a portion of the top wall in cencent mortal.

It is recommended in all cases, where well-watel beeomes unpalatiblule, tu argitate it frecly, and very often. If drawn with a bucket, set a man at work pushing the bueket down deep and drawing it np tull, and pourine it back again, so as to fall in the water till it is all thoroughly mixed ant all the stones washed, and then when it settles clear again it will probably be found as good as erer.

This plan of agitating the water may also be applied to cisterns to goud advantacre.

Looking into a well, so as to see anything at the hottom, (am be camily done any sumuy day (the moming is the lest time), by nsing a lookingerntas so as to reflect the rays of lingt and throw them quite in the botton of in deep well. We have nsed this means to hiscover the position of a lunclect that hat broken leose and fallen to the botom, and then with the stect. yarls linng to a rope hare been able to look on to the bucket and draw i: up at onee. We once recorered a tin pail of butter in the same way.

839. Self-limptying Well-Buchet. If the water is clrawn frou a well hy a bucket and windlass, two ropes are better than one. Fisten ly a staple to the center of the windlass and wind each way toward the ends, so that the ropes will be widest apart when the bucket is up. Instear of a bail, attach a short chain or piece of iron roul to each ear of the lucket, and sec the ears low down, so that the bucket will tip easily. Cut a hole in the bottom, fonr inches across, and cover it with a block coatcel with soft sole leatler, like the valve of a fump-bucket, which will open to let in the water as the bucket descends, and elose as soon as it starts upwarl. 'Tu cmpty the water casily, there are two ways-tirst, and best, lyy a llat iron lonok ibunt cight inches long, fastened to the well-spont in such a way that it may eatch the erlge of the lucket as it is drawn up, and tip and empty. The other way is to have a pin in the spout that will strike the valre and open it when the bucket is plated upon the spout. "lwo buckets with two ropes will work much stealier and casicr, and in the long rm cost less than with one, and the valve to till, and hook to empry tho hucket, are great laborsaving tistures.

It is almost as important to keep water pure for steck as tor tamily nse. Pure water is a great luxiry to the palate of a thissty horae, and every man who is fortunate enough to be the owner of so noble an animal, shunlit see that the wants of the sanc are properly jurvilent for.

Unfortunately, very few persons realize the impurtance of supplying domestic animals with pure water; yet they stand in need of it whenever 
thirsty, and as $\varepsilon$ matter of profit to ourselves and lumanity to them, we should see that their wants are well supplied.

I'ure water is very nutritious, and as a nutritions agent its value is injaired when of inferior quality, or when mixed with indigestible foreign substunces, such as are often found in watering-trouglis located by the waysicle.

Some rely interesting experiments lave lately been made on liorses belonging to the French arny, in view of testing their endurance as regrards the deplivation of water, and it was fouml that some of them lived twentyfive days on water alone; it is a singular fuet that screnty-five per cent. of the weiglit of a horse's hody is composed of fiuid.

Strange water, as it is called, often has a had efieet on the digestive organs when first used, and in order to suard against its conscrpucuces, English grooms always provide for the wants of their horses, when away from home at the race-course, by furmishing them with an abundant supply of pure water to which they have been acenstomed, which is transported from place to place in logsheads.

3:0. The Ilydranlic PaE.-To those who have no spring above the level of the louse, but have one below, we press the subject of a water-ram-a simple, little, inexpensive machine that can be made to throw about one eighth or a tenth of the rivater that flows throngly it up a stecp hill and along a pipe lialf a mile or more, discharging it in a cistern in the garret of a lionse or loft of the barn, whenee it is drawn as it is wanted in auy apartment, while the overflow or surplus of water will give you a constant litlle strean in the cattle water-trough. IIndreds of these rams are in ne all over the country; but there are thousands of places where they are not in nse, where equal matural facilities exist. Our object here is only to call attention to the fact, that every farmer who las a spring in a valley where he can get three or four feet fall from it to work the ran, can gret a portion of that water on top of a hill; and in many places where no ruming springs naturally cxisi, snfficient water can be ohtained by digging. We have seen a strean discharged at the outlet of an underdrain suffieient to drive a ram--water obtained withont any expectation of obtaining it; because the objeet was to drain the land of its surplus water, and prevent it from oozing ont of the surface of the hillside.

The house of the late John C. Sterens, at South Amboy, is 120 feet above the level of a spring, near the bay shore. At this spring he set a water-ram, with a two-inch drive-pipe, abont sixty fect long, laid upon an inclination of fire feet. About one eighth of the water which runs through this pipe is sent, by the action of the ram-a little affair, about as big as a teakettleup through a small lead pipe into the louse, nearly half a mile distant. Perhaps the whole may lave cost $\$ 100$. We know a good many places where $\$ 50$ has secured a full and constant supply of water from the bottom of a lill alnost impossible to elimb, yet which had been climber from the first settlement of the conntry till the little water-ram was set to work. We lnow 
a great many other places where it is worth a dollar a day to twe the water up the slippery rocks in buckets, where all that labor conkl he saved by an expenditue of $\$ 50$, and an anmmal expense for repail's of a slilling a year. let those who own such places do not improve tliem, becanse they do nut linow they crus.

3\$1. Datrability of Wooden Vipes fur Ifinc:acis.-Charles Stcurns, of Springfield, Mass., lias proved ly a somewhat lengtly experience that worden pipes ane nenly indestructible, il Zaid deep-deep enough to prevent atmusplicric action upon the wood. Ilis rule is six feet decp in sandy or prorous earth; four feet deep in compact, clayey eurth, and three fect decp in Ewampy earth, where the jeaty condition of the soil, which is antiscptic, jueserves wood from decay. Thus laid, Mr. Steams thinks wood will ontatut iron or lead; and the wooden pijes are cleaper than any material that can be used, where a bore of two to six inches is repuired. In one instance, an aquednct lad by Mr. Stearus of three fourths-incle caliber lead fipe, corroded and failed in filtecn years, and hat to be leplaced. Another one, made with very heary lead pipe of two-inch ealiber, laid throngh a wet meadow, in the rey lind of soil that preserves wool the most perfectly; firiled so is to reed repairs wifhin three or four years, and at the cull of ten years had to be replace! with new jipe, whicll he then made of wood, and which, after twenty yeals of use, is still in good order. The aqueduct pijes supplying springticld with spring water, that comes to the surfuce on the eandy plains above the town, lawe been in use fourtecu ycurs, and bid fuil to last many rears longer. The bore of the logs is from one and a lualf to seren inches, charred on the inner surfice by forcing flanc through the bore, or by the insertion of a lieated rod, to prevent the timber from griving any mpleasant taste to the water. Mr. Stearns thinks, tron cxperiments made, that lead pipe will last enough longer to pay fur the expense ot burying it deep, or lacking it elosely ju chy. Ile also thinks that the interest rjou the difference in cost between well-mate and properly Inid woorlen pipes and those of a more costly matcrial, ealled inelestructille, will licep the wooken pijes ju repair forever. For the lizanch pipes leading into the houses, Mr. Stearus used lend pipes in all the houscs supplied from the Springfiedd Water-Worls, and las never lnown any injury to ocenr to any one using the water; and his own fanily labe nsed water passed tirongh lead pipe a long distance for many years, without suttering any of the cllects tirequently ascribed to snch water; nor has he ever heard of a care based upon any letter testimony than "they say so." The water that supplics Springficld comes from several springs, improved ly direging, and we liave no dunlut that there are lumdreds of other villages that might lie watered in the sane way, grently to the comfort and health of the inhubitants. There is anotler alvantage hesides eleapness in woolen pipes. It is the ease with which they are tapjed, wherever and whenever a hranch is to be takcn oft, and they are also casily repaired. Wu hope that not only vil. lages, but finmers, wherever a spring exists ahore the level of the fimstemel, 
will arail themselves of its henefits. Many limmers lave cliestunt or cedar, the best of timber, which they conld have jrepared at very small expense liy their own lunds, and gret an aquelnet that would, in case of sale of the farm, pay ten times its cost; and it womlel he worth still more to the owner, for it would aflord him a constant enjoyment.

There is a very curious mannfactory of wooden artueduct pipes at Elmira, N. I. A large pine $\log$ is cut up into a series of pijes, from an incl lore to ten or twelve inches, taking one ont of the other, leaving the sides from one to two inches thick. These pipes are then banded with hoop-ilon, drawn by a powerful macline througl lot coal-tar, and being huried helow the action of the atmosphere, are expected to last for an indefinite period.

\section{SECTION XVIJ.-STACLING ANI) STORING GRAIN ; CORX-CRHBS, PIG-} GERIES, AND PIG-FEEDING; SHOKE-HOUSES, AND CURING BACON.

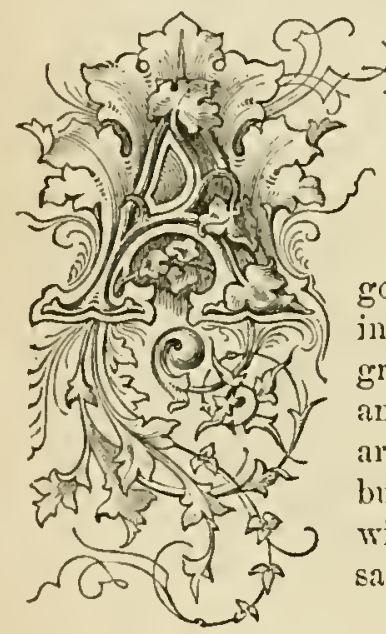

LTHOUGH, like most of our suljects, these are treated liricfly, each is worthy of notice, and must have enongh, if nothing more, to attract attention, so as to incite the reader to look further into the matter.

One of the indispensable huildings of a farmery is a good storehouse for grain. Upon a small tin'm, a room in the barn can be set apart for the storage of small grain, but it is more liable to the depredations of rats and mice than in a building made purposely for a gramary. Every firmer who annually raises a humdred bushels of cars of Indian corn can not afford to do without a corn-crib, because com can not be stored safely except in a room with very open sides.

342. Corn-Cribs, - The best lind of a corn-crib is a building twenty feet wide, and of such length as will give sufficient capacity - say thirty feet long- for a farm where ten to twenty acres of corn are usually grown. The sides should not be less than ten feet hight, and boarded up and down with strips two inches wide, one inch apart. Six feet from the sides, partitions are made in the same way. This leares a drive-way eight fect wide, so that yon can drive in a wagon-load of corn and throw it right and left over the beam into the crib. This drive-way should be made to close at both ends with slat-gates, or lattice-work gates, so as to allow a free circulation of air.

343. Rail-Pen Corn-Cribs,-Cribbing corn, after the Western fashion, in open rail-pens, is considered down East a very slovenly method. Iet it is one of the best ways in which it can be stored. It is true it wastes a little 
by slıclling if it remains till spring, lut not much if the jens are so located that the pigs and poultry ean he let in to pick up, the seatterenl grains. The way to make a rail-pen corn-crils is to talie straight fence-rails, as near of a size as possible, and saw part of then into halves of equal leugth, su that you cam lay up a pen half as wide as it is long, notehing the corners sut that the rails will come close enongh together to prevent the ears falling wht. If this can not he done with all of the eracks, they must he stopped lye "chinking" from the inside, or ly hoards nailed orer. It is usnal to build the pen mpon a floor of rails, which are sometimes laid on the gromel, and sometimes mised mpon logs, stones, or blocks. The pen stionld not he orer eight feet high, and when full is covered with boards held on ly a heary rail or pole. In woodland regions the covering is usually made of " shakes" -split clap-boards, such as log-eabin roofs are generally made of. On the prairics, we have frequently scen straw used for a covering: and we lave also scen many thousands ot bushels of wheat, hoth in the chatl and after it is wimowed, stored in the same rude way, loy simply calking the cracks with straw.

Nor is it a very wastetul way of storing wheat, if the pen is luilt upon a hard-beaten spot, where all the grain ean he swept ul when the pen is emptied.

We have also secn eorn put up in rail-pens without any corering, and kept through the winter without damage, the cars leing simply romed up on top. We lave often been told ly those who have had a grood deal of cxperience in storing corn in this way, that rain does not lurt it-all that does not run through dries out the first windy day. Wheat in the clatf will not injure in a long rain-storm, when simply piled in a conical heap, it it does nut wet at the bottum.

Great boat-loals of l3lack Sea wheat are hronght down loner rivers, heingr many wecks on the passage, withont any covering. The wheat is rounderl up in the center, somewhat in the form of a root, and the ontsile gects wet and grows into a mat, sometimes two inches thick, and that sheletrs the ma-s below. It does not strike us as an economical method, hut that depends upon eireumstances, as it does in cribbing Indian-corn. It certainly never would pay to huild expensive cribs to store some of the great crops of the West; and it lans been found grool economy, for want of better storige, tor let the corn remain where it grew until wanted tor nee. Eiven with snaller crops, it may not always be eridence of bad farming where we see the com stand in shocks until wanted. It certainly keeps hetter there than it woukl in a bally ventilated store-room.

84t. Stathels for sitack Bottoms, - In Fingland, it is not eonsidered gnool cconomy to luild bams enongh to store all the grain, and it is therefore stacked ont. In this country, if economy warmed the practice of storinge

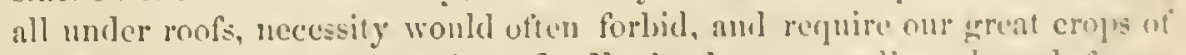
wheat to be put up in stacks. In Eugland, upon well-conducted firms, where the practice of stacking prevails, the stathels for the stackis to res: 
upon are permanent structures. Some of them are male witl stone pillars and caps; and some with a wooden frume on stone pillars; and in some instances iron lias been substituted for wool. The stack being elevited a foot or two, allows a circulation of air, and very much assists the euring of the min. We recommend farmers, wherever they are in the regular practice of stacking hay and grain, to have a permanent stack yard, provided witl stack bottoms, after the Finglish fashion. Even for temporary stacking, bnilding the stack mpon the ground is a very wasteful practice. We have seen stacks upon the Western praire built in a spot, dry at the time, beenne saturated with water, and lialf rotted two fect above the ground, before they were used up in winter. For a temporary stack bottom, there is notling more convenient than fence-rails. We have built long wheat-picks on the prairic in this way. We took fencerails and laid them up as though bnilding a worm fence, pretty straight, in two lines abont two seet apart at the bottom, and about four rails high, leaning inward so that the two lines of fence touch. Against this upon each side the sheares were set with butts on the ground, leaning townd the center until a sufficient bottom for the rick was formed. This leares an air-pipe tlrough the bottom, and keeps all the lieads from the ground, and although the water stood some inches deep' in a wet time orer the spongy soil, all the wheat came out bright and sound. The butis of the lower sheaves only were rotted. The fence sustained the greatest weight of the rick, besides gring it air.

345. The liggery.-No famery is complete withont a well-armanged piggery, which consists of a grain-l'oon, a root cellar, a cooking-room, a fuedingroom, a sleepingroom-all under corer. All this is requisite mpon a furm where only two or thee pigs are fattel annually. It is still more requisite where a dozen or more pigs are kept-where the leading object of the farmer is to convert coarse farm products into pork; execpt where pirs are wiolly fatted in cornfields, as at the West. Upon all other firms a well-arrunged piggery is indispensable, and, as we have shown in Section 11, that cooking tood for pigs is advantageons, the greater the conveniences for cooking, the more profitable will be the feeding.

The best arranged piggery we erer saw for convenience and saving of labol was built "pon the side of a Vermont hill, where potatoes were a leading article in the manufacture of porls. The potatoes were stored in a care cellar, from which they were shoveled upon a sereen, over which they rolled to the large potash-kettle set in an areh some twenty or thirty feet distant. Gencrally the potatoes thins sereened needed no washing; if they did, provision was made for doing it by a copions stream of water let on as they triwersed the sereen. The water was let into the kettle from the source supplying the wasling water. The floor where the kettle stood contained bins for meal, which were filled from the bags emptied into a spont on the outside. The eooked food was shoveled from the liettle into a hopper that condueted it into a cooling-trough on the floor below, which stood lighl enough to allow the swill to run throngh a long conductor to the feed. 
troughs. The objection to this last arrangement was, that the swill had to be made thin enough to llow fiecly. The arrangement, howerer, was a very perfect onc, and worthy of imitutum npon all simblarly sitnated farms.

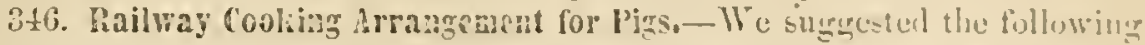
arrangement, more than twenty years ago, for couking fuod for pigs or an other stock, and we afterward lial a model made and cxhibited at the lair of the American Institute, whish awarled it a silver netal.

This is the plan: arrange a stem ehamber of any giren dimensions-say three feet by six feet, and threc feet high-ovel a tumace lictile, or anywhere that steam conld be conveyed into it from a boilcr. This chamber luas a door at one cud, made stean-tight, and rails in the bottom upon which a car travels, and these rails should extend ontsicle to the rout-lin, or multubs, or reservoirs of food to be eunked. The ear being loalded, is rulled iuto the chamber, and door elosed. When the foor is cookerl. shut uff stean and open an escape-ralve, and then the door, and roll out the cat cre: conling vats, and npen a trup in the bottom of the ear, and let the contents drup. These cooling rats may be placed near enongh to dip the swill into the tiedtroughs, or it may be carricd in another car along an alley, and thence dippel into the feed-tronghs, or made to run into then throngh contuetors. Survel an arrangement would, without dombt, save a great deal of hard lahur, and it would not be very cxpensive. Whatever the arrangenent of the pigigery. lecp this fact constaitly in riew, that in some sections of the comntry the mamure whel you can make while fatting your pork, it your pigrery is well arranged, will prove to be the most profitable part ot the pork-making plocess.

There is another neessary farm-lnilding which we may ats woll speak wo here, particularly as it is one that may, whenever the situation will almit. very properly be located in the immediate vieinity ut the pigerery, and it is equally valuable to the farmer as a mine of manurial wealth. It is-

3t7. The Temple of Cloacina. - Every fum-honse must have a temple sut aj)at for this heahenish deily, but no farm-lonse slould have such a nexer. sary appendage a disgrace to cirilization, as 100 many of them are. Surlu a building should be placed convenient to the honse. but s.ever in sight. It slonld be located in a clump of shmblers, mosty evergecens, out of sight from the house, or else it should be mule part and pared nt ande nt the outbuildings, so als never to be a prominum uljuet. We have ofien secen thesis buillings so placed that they wele the most conspitinous things alunt the

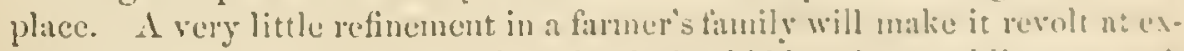
posing the part of a farmery that shomld be hidelen form fublic gaze. I

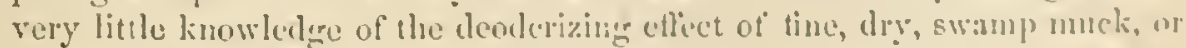
charcoal, or plaster. of copperas will serve h keep a jlace lhat mus be visited every day, hy every mentuer of the fimily, so swert that it never will he offensive: and the raluahl. coutents of the rnult, which shenlel he always shallow and engy to clean, will then heenme a somec of profit, iustexl of a musance both disignecable and distracetul. 
315. Smoke-Honses-llow to Build ans how to Tse Them.-ITe lay it down as an axiom, that the best smoke-louse crer built is a log cabin, with the craclis all open. In such a building you can not confine the smoke so as to smother the meat and spoil it, as it easily can be and often is in a rery tight room. It is not generally understood how much the execllenee of bacon depends on the manner in which it may be smoked. Indeed, we look upon this part of the process as more important than a good receipt for pickling. A han that is well pickled nay be spoiled in smoking it, and then no skill in enokery will take away its clark color and strong, rancid tilste. To make good hams, there must be a free circulation of atmosphere, to that the smole nerer shall become lieated. A smoke nerer should be made in a damp, fogery, ol rany day.

In building a suoke-house the furmer is more apt to regard external appearanees than the object for which it is intended. It may be very strong and neat, but if it be built on wrong principles, it will never give satisfac. tion, and the good wife will be always wondering how it is that her bacon is not equal to that which she eats away fiom home. Now, there is no bacon in this country superiol to that produced in Marylund, where the suroke-houses are celtainly ratlrer primitive in their construction. They are usually made of logs, rudely phastered with clay on the ontside, and thatched with straw. The hams are lnug upon liooks driven into the rafiers. The fire of chips-eovered with saw-dust in order to prevent a blaze-is in the middle of the floor-gromd floor, generally; and the smolic, after laving done its dufy, escapes through the innumerable cracks and openings in the wall and thatel. Such a building is not very ornamental, but it is muel more eflicient than those we frequently see construeted of briek or stone, witl tiglit roof, a close-fitting door, and but one small aperture for the escape of the smoke. The great secret in the art of smoking hams is to dry them in smoke, but not by leat. When they are kept close to the fire, they invariably acquire a disagrecable flavor, and often beconse soft and greasy. The smole should not be allowed to reach them until nearly or quite cool, and to effect this some famers have the fire ontside of the building, perhaps twenty or thirty feet distant, and conduct the smoke to the interior thlongly a narrow covered trencl. By its passage through the trench, it is cooled and purified, and there is no danger of its giving an umpleasant taste to the meat. $\Lambda$ still better plan is practiced lyy the people of Testphalia, which, as all the world knows, is eelebrated for its bacon. The smoking is performed in extensive clambers, in the uppermost stories of high bufldings. Some are four or fire stories above the grome, and the smoke is conveyed to them by tubes from pipes in the cellars. The vapo: is condensed, and the lieat absorbed by the tubes, so that the smoke is both dry and enol when it comes in contact with the meat. Many of the fumlouses in Pennsylrania lare a somewhat similar arrangement. A room is partitioned off in the garet, next to the kitclien chimney, and the liams are lung from the rafters overhead. Near the floor is a small opening in the 
chimney, by which the smoke enters the apartment ; and insteal of returning to the flue, it finds its way into the open air through the innumeralte creviecs in the roof. The meat is thus kejt frerfectly dry, and it will he found to hare a color and flavor unknown in that treated in the common unethod.

A smoke-honse can hardly he too open; where the walls and roof are tighth, or nearly so, the smoke condenses on the hacon, rendering it flably. and ill-colored. To be sure, when there is grood ventilation it talkes nnucis longer to complete the process, but this delay we helieve to be rather henficial than otherwise. Some people hare the fanlt of alwas being in a lurry, and their lacon is never well smoked. It should he cured gradnally and slorrly, and this is another reason why the Germans are so sncecstinl in the business. In Virginia, two months is not considered a long time fur the operation.

Green sugar-maple chips are the hest for the fire, and after maple are ranked hickory, sweet birch, and white ash or heech. Some think welldried corn-cobs superior to everything else; and they certainly furnish in swect, penetrating smolic. San-dnst from hard wood is also excellent for the purpose, lut rotten wood shonld nerer he uscd; and it is said that locust batk will actnally spoil the flavor of hams; and we doulte not that there are many other sulstances which will produce the sante result.

Some persons are always rery particular ahout hanging their hams with the leg end down. They should never be allowed to tonch each other, mir tonch any flat sulistance. In hanging large nmmbers of hans in a cromed room, we have often kept them apart lyy a small picce of a corn-col.

No finmery is complete withont a smoke-house, and where the amount of ment to be ammually emoked is insuficient to make it an object to erect a bnilding specially for that purpose, it will be found very easy to set apart a small room in some of the outhuildings, and convey the smoke to it throngh a long flue. As the building mentioned in No. 349 never will be wanted fur the punpose for which it was constructed, when bacon should be smoked, it could, perhaps, be made so as to answer both purposes.

349. A Fruit-Drying Ilonse-In some ecetions renote from citics, and upon some farms, fruit-drying is quite an olject, and is relied upon by the female portion of the family ats a means of replenishing their wardrobe, independent of the general products of the furm. Upon fruit farms it is also mate n considerable itcu of the regular business. All such farms should have a fruit-drying house, built upon seicntitic principles, to accomplish the olyeet in the most expeditions manner, at the least expense. The true principle of drying fruit would be to place it on open-work hurdles, in the flue of at heated air furnace, so that there would he a continnal iratit of hot air pal aing through the finit, earrying ofl the moisture into the upper air. The hest one we ever saw, heated the air in the basenent of a threestory luniling. In the thited story, one side of the large brick flue was arranged like the drawers of a burean, the bottom of the drawers being hasket-work. In thesc, ench of 
which held about a bushel of apples or peaches cut in quarters, the fruit dried with wonderful rapidity. It needed no other attention than changing lle drawers once from top to bottom, to equalize the drying, so as to finish all at once. Other things besides fruit were dried in this flue, such as sweet com, okra, pease, tomators, ete.

The following, taken from the Fulley Furmer, is the description of a drying-lionse in nse in 1 iseonsin:

"It consists of a building of logs, brick, or stone, of any conrenient size. say ten feet wide by twelve or fourteen long, and one story ligh, liaving an orlinary roof, with a rentilator to admit of the escape of tho heat and vapor arising fiom the fruit.

"The furnace should open on the outside of the luilding, at the end. It should be about two feet square. The sides should be of brick, and as thin as may be to sustain the top. The flue shonld be extended to near the cutire length of the building, and then return, forming a parallel flue, which may be reduced to two thirds the size of the furmace or main flue, terminating in a elimmey near the loor of the furnace. The top of the furnace and fine slionld be covered with plates of thin boiler iron; thicker iron, or a covering of lrick or stone, will not admit of a sufficient escape of heat to facilitate the drying process. The fruit is dried on trays or hurdles, arranged in three tiers, one above another, with a space of twelre or fifteen inches between them. The luurdles may be two and a half feet wicle, six or seren feet long, and three inclies deep. These are made of common boards, with a lath bo:tom, made thin; the laths should be made of hickory, as the fruit is found to dry much more leadily on hard wood lath than it does on poplar or other soft wool. Through the lengtl of the building frames are put up to support the hurclles of fruit. These frames or rails extend through openings made in the end of the building opposite the furnace, and corresponding with each pair of rails are wooden shutter's. The rails extend on the ontside abont six feet; upon these the hurdles are placed crosswise; upon each of the lundles are rollers corresponding with the rails; being filled with the fruit to be dried, the lurdles are run in like cars upon a railyoad. 'Thus arunged, with the three tiers of rails filled with trays of firut, about one and a lalf barels can le dried at once, requiring about twenty-fonr hours to complete the operation. The trays nearest the fire will, of course, dry the fastest, and, with the convenience of the railroad and the shutters in the end of the building, they may be drawn ont and changed to the upper rails, when the whole may be finished within the twenty-four hours in the most perfect and uniform manner, and withont the least burning. The fire shonld be made withont grates, on the bottom of the furnace, which consumes less fuel, and lieeps up a more uniform lieat than if placed above the draft.

"In some instances we have seen pieces of old steam-boilers substituted in the place of luick walls for a furnace; to the boiler is connected and returned a pipe of somerthat smaller dimensions, a sheet-iron pipe, which ad. mits of the free escape of heat and speedy drying of the fruit. 
"The ordinary method of drying peaches and apples in lientuckr and Temuesse is to constme a kiln of stone, will a luoul Hat top, upun which the

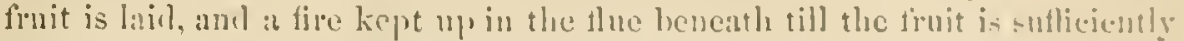
dricel. This is more cxpelitions than dryme in the sun, and the frut is mo so liable to be soiled ly llies, ret it is oljectionable on account of liability to burn the finit in contact with the over-heated stone."

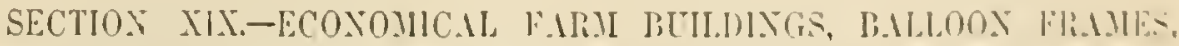

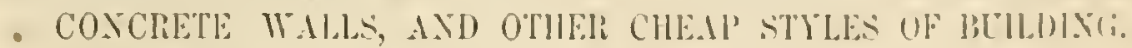

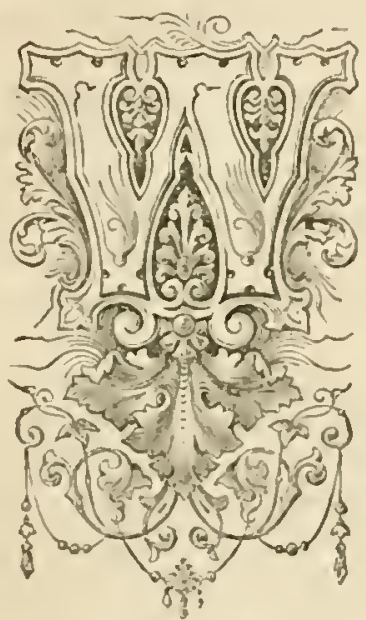

E are satistied that we can do those who desire in build no greatel favor than making then acepuninirel with the molern style of huildiug. known at " batlloon franco"-2 nane that was at first conflumeal mpon thes in ridicnle on accoms of their lierlatnes amd mombstantialility. This mame is only true as it applicel to their lightuess. Iballown trames atre not ridiculous from any lack of sufficient strengrth. There is need of nu stronger buikeling than one marle " this plan, except where it is necessary to have streng h of timler to snstain weieluty storage or ponlerous madincry. For all ordinary farm lonillines, we earnestly jecommend billon frames. And we are not alone in one recommendations, fhough, su far as we know, we were the first in recommending them to famers in the lasturem States. Of late, Geo. E. Woom warl, an architect and luilder of New louk city, has written some cxceedingly valualsle articles upon this sulyect, ant published them in the Country Gimtlomen, with illustrations, and to hint or then we respectinlly refer realers, who may he incited from what we s?y here, to make further inquiries.

Anong the sensille things said hy Mre. Woodwatl, are the following:

"Econnmy in the constriction of all huldings anlapted to the larlitation or convenience of man has been a sturly of much interest to those whe enn-

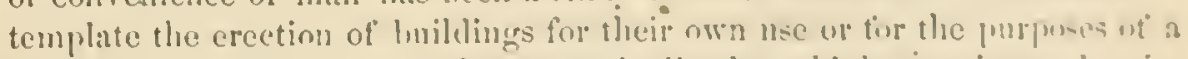
protitable investment; though we are inclined to think cixpentumental or in. rentire talent has applied itself more to produce some new and eldeap luihl. ing material than to derelop the full resonres of such materials as are tumi best arlapted to om wants.

"Necessty las Jone much for the huilding public ly intrombone

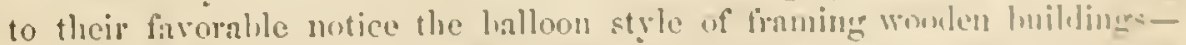
a style which is not well understond in the olil settled and well-timlerent

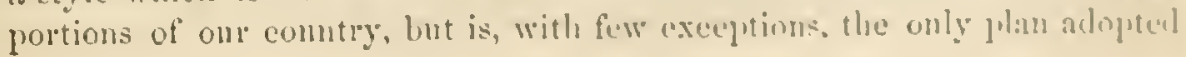


throughont the magnificent agricultural districts west of our great inland seas.

"The increasing ralue of lumber and labor must turn the attention of men of moderate means to those successful plans which have demonstrated economy in both, and at the same time preserved the full qualities of strength aml security so generally accorded to the old fogy principles of franing, but which, we presume to say, is inferior in all the true requisites of cheap and substantial lunilding.

"Any intelligent man who can lay out a right angle and adjust a plumb line may do his own hulding, for it is without a mortice, a tenon, or lrace, and a nuan and boy can do all the work. This principle is the one applied to the construction of what are technically as well as sarcastically terued badloon frames, which, instend of proving a failure, stands with more than 30,000 examples of erery conceivable size and form, a perfect sucecs."

350. Low to build Balloon Frames. The following remarks upon the snlject we printed some years ago, not only to show that much labor and much timber may be sared, but that sawed timber may be dispensed with where it is rery expensive. We know that this article enabled many persons to build cheap frames, and as it onee did good, we reprint it that it may do much more good in future. The remarks were an answer to the inquiry how to lunild lualloon liouses.

"I would saw all wy timber for a frame house, or ordinary frame ontbuilding, of the following dimensions : two inches by eight, two by fonr, two by one. I lave sometimes built them, when I lived on the grand prairic of Indiana, many miles from saw-mills, nearly all of split and hewed stuft, making use of rails or round poles, reduced to straight lines and even thickness on two sides, for studs and rafters. But sawed stuff is easiest wrouglit, though in a timber country the other is far the cheapest. First, level your fomdation, and lay down two of the two-by-eight pieces, flatwise, for sidesills. Upon these set the floor-slecpers on edge, 32 inches apart. Fisten one at each end, and, perlaps, one or two in the middle, if the building is large, witl a rooden pin. These end-sleepers are the end-sills. Now lay the floor, muless yon design to lase one that would be likely to be injured by the weatlier before you get the roof on. It is a great saving, though, of labor to begin at the bottom of a house and build up. In laying the floor first, you liave no studs to cut and fit around, and can let your boards rum out over the ende, just as it happens, and afterward saw them off smooth by the sill. Now set up a corner post, which is nothing but one of the two-byfour studs, fastening the bottom by four nails; make it plumb, and stay it ench way. Set another at the other corner, and then mark off your door and window places, and set up the side-stnds and put in the frames. Fill up witl studs between, 16 inclies apart, supporting the top by a line or strip of board from corner to corner, or staid studs between. Now cover that side with rongh sheeting-boards, nuless you intend to side up witl clapboards on the studs, which I never would do, except for a small, common 
building. Make no calculation ahont the top of your semb; wait till you get to that hight. You may nse them of any lengih, with hroken or s'ulssliot ends, no matter. Whon you have this sido boarled ats high as you can resch, proced to set uy another. In the mean tine, ofher workinen can he lathing the first side. When you have got the sides all up, fix upon the light of your upper floor, and strike a line upos the studs for the muder sile of the joist, and cut a gain four inches wide, half-inch deep, and nuil on timly one of the inch strips. Upon these strips rest the chamber-1loor joist. Cunt a notch in the joist one inch dece in the lower edere, and lock it on the strip, and nail each joist to each stud. Now hay this floor and go on to lutilu the upper story as you did the lower one, splicing on and lengthening out sinds wherever needed, until you get high enongh for the plate. Splice studs or joist by simply butting the ends fugether, and maling strips on cach sile. Strike a line and saw off the top of the studs eren upon each side of the building-not the ends-and mal on one of the inch strips. That is the plate. Cut the ends of the upper joist the berel of the piteh of the ront, and nail them fast to the plate, placing the end ones inside the studs, which you will let run up promiscuonsly, to be cut of alongside of the ralter. Ẍw lay the garret floor ly all menus betore rou jut on tho roof, amb you will find that you have saved 50 per cent. of lard labos. The rafters, it supperted so is not to be orer ten feet long, will be strong enougly of the twohy-fon stufï. Bevel the ends and nail fist to the joist. Then there is no stran upon the sides ly the weithl of the roof, which may be coverul wils shingles or other materials, the cheapest being compositivn or cenent ruts. To make one of this lind, take solt, spongy, thick paper, and tack it upon the boards in comses like shingles. Commence at the top with lot tar aml saturate the paper, upon which sift tine gravel erenly, pre-sing it in while lot-that is, while tar and gravel are both hot. One coat will nalie a tights: roof; two coats will make it nuore durable. P'at my jour partitions of stuth one hy four, muless where you wnet to support the uppar joist; then un stuff two hy four, with strips nailed on top for the joist to rest upon, tis :essing altogether ly mails wherever timbers tonch. 'Thus you will hare a frane

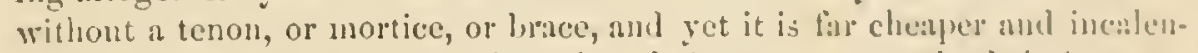
lably stronger when finished than thongh it was composed of timbers ton inches square, with a thousand anger-holes and a humbed days work witl the chisel and alze, making lioles and pins to fill them. To lay ont and frame a luilding so that all its jarts will come togethes, requires dhe skill of a inaster mechanic, and a lost of men, ame a deal of liaed work wo liti the great sticlis of timber into position. To erect a halloon huilding reynires

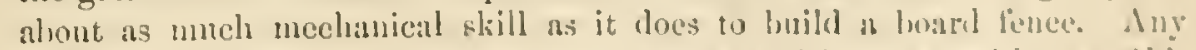
famer who is handy with the saw, iron square, and hammer, with one of his hoys or a common laborer to assist him, enu go to work amel put up a frame for an outbuilding, and finish it wh with his own lalwo just as weil ns tu hire a carpenter to seore and hew grest oak sticks and till then full of mortices, all by tho science of the 'sunure rule.' It is a waste of labor that 
we should all lend our aid to put a stop to. Besides, it will cuable many a fumer to improve his place with new buldings, who, thongh lie has long meeded them, has shuddered at the thought of cotting down half of the hest tieces in his wood-lot, and then griving halt a ycar's work to hauling it home and paying for what $I$ do know is the wholly nseless labor of framing. It it had not been for the knowledge of ballon frames, Chicago and San Francisco conld nerer lave arisen, as they did, from little villages to great cities in a single ycar. It is not alone city buldings, which are snpported by one another, that may be thus erected, but those upon the open prairie, where the wind has a swcep from Mackinaw to the Irississipyi-for there

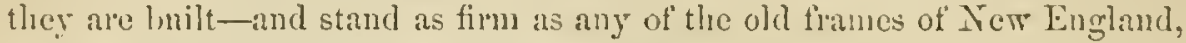
with posts and beams sixtecu inches square."

To this we add something more from MIl. Woodward. He says :

"Wre hear and read vely much ahout the policy of enting mortices, tenons, gains, etc., in the varions pieces which go to make up the balloon framic. Fow it is om opinion, based npon a long and thoroughly practical cxperience, that lic who does much of this will hare some misspent time to accomt for hereafter, besides weakening his bnilding and liastening the decry of the frame. A gain must be cut in the studding for the side grirt, mbless the dwelling be lined. Gains are sometimes cut in floor joists for the purpose of locking them orer partitions that run through the lighlit. of the building. Rafters projecting over the sides should be notehed, to grive then a foothold on the plate. These causes would, as a gencral thing, constitute all the eutting neccsary.

"In huilding houses onc-and-a-lialf-story high, never cut a gain for the side girt on which to rest the upper-story floor joists, unless the thrust of the root he well guarded agranst ly secure collar heams. We prefer, when we cut this grain, to use studding one inch wider for the sides. Where the lnilding is lined, the side grint rests on top of the lining, and no cutting is necessary.

“ Lmplastered lonildiugs, of a moderate size, are snfficiently strong if the girt be nailed directly to the studding without eutting the gain or recess.

"We lave recommended, in the construction of a bain $2+$ by 40 , alternate sincts on the sides, $2 \mathrm{by} 4$ and 2 by 5 , the side girt to be nailed to the narrow stud and let one inch into the wide stud. This wonld not answer for a plastered building, as the surface is not flush for lathing.

"Two full story luildings are abundantly strong with 2 by 4 studding and gains cut into them for side girt; the third floor ties the top of the studding, so there is no yield. The joists of the third floor should be placel upon the ilate, the ends bereled to the same pitch of the rafters, and each joist nailed at loth ends to each rafter.

"We prefer to bnild the second story full for a dwellingrhouse, as me get more strength, more convenient room, and the real difference in expense is practically nothing. Where the studding is more than fire fect high above the second floor of a barn, two or three tic-strips across the foot of the rafters will make all snug. There should be tic or collar beams on all rafters. 
"In story-and-a-half buildinge, it is very desiralle that collars be put on sceurely, so as to prevent any thrust of the retfers; where the side rirt is not erained in, as in emall mulastered huildings, the collars may be nailert or spiked to the rafter. If the side girt is set into the stmdeling, ats it should lue in a plastered building not lined inside, it makes a weak point in the stulling, redueing them from 2 ly 4 to 2 by $: 3$, and the collars should lue put on in such a manner as to gramel against any thrust whaterer. "The $=$ izo of the luilding and the judgment of its constructor will indicate the luest course to pursuc. Buillings of one, two, or more full stories have no collars: the joists of the upper floor tic the top of the luthling, and talie the thrust of the rafters. In the usmal morle of inside liniug, one sile lings the stud. The cuds of the lining of the adjoining side are nailed to a strip lastencel fo the stud to receive them.

"Wre have built balloon frames with green oak studding, loasswond siding, and butternut rimmings, that hare never yiclded. 'There is al system of compensation among the lighlit sticks of a balloon frame by which the seasoning process goes on without injury to it. We liave secu warped surtiuces prodneed ly using green oak siding and ly eareless bulling, but there is no gooul reason why a balloon-frome building should not be always șuaro and plumb, and the ontsile boneling reman secure.

"The subject of tajering rafters his been pretty thoroughly discused heretofore. The same amount of strengrte can be hat with a less amonnt of lumber. There is an alditional lalor in sawing such ratters, as well as a different calenlation to be made in using up a long to the best anlonntige. It is necessury always to order this special bill of unter's direct from the mill. and the result will be that the extra cost will, nine inues out of ten, unelbalance tlıe amonnt sared."

351. The Cost of We Author's Balloon llonse and Barn,-There is not only a saving in first cost of lumber, lut a very large item will be satred in tho bill of curriage, particularly where it has to lie hanled a long distance on a wagon. The saring in the caplenter's hill is very large, becanse so muth of the work may be done by persons less skilltul than a well-hred carpenter. Aur then there is a total saving of all that tromblesome, dangerons, latrd work attendant "pon an oll-fishioned "raising."

We have hately huilt (that is, we were on own architect) a louse and larn. a few miles ont of the city of New lork, upon the plan we are alvocntinge. and therefore ean speak from actual experience of the benchits of the plan in an oly as well as in a new country. The louse, or rather the andition to an old one, is 15 by 2 fect, with an nttachment eight fect square "pron ono sille, and a piazza six feet wide on the other. It is one story wi lint fect, and lias nine wimlows amel seren dours. Both floors are deadened lye a courso of hoards aml heary coat of clay mortar. The siding is nailed upou studs 2 by 4 inches, ambl there are $t$ wo courses of lath and plastering-one halt way hetween the sidling nud inside lath. The root projects, and is ornamented, and the garret is lathed and phastered, and tho lower part divided 
into four rooms, and a!l is of goorl materials and workmansluple at a total cost, except painting and papering, of $\$+50$. The sills and slecpers are pine, i hy $T$, and the joist $:$ ly $(i$, spluce, and all would have heen just as good, if procurable, 2 by 6 inches; and there is not an upright stick larger than 2 by 4 of henlock. This honse, notwithstunding its elieapness, is strong, durable, warn, and good-looking. What more could we hare of a pouderolts, cxpensive firme?

Our lorse barn is 22 by $2+$ fect, and 13 feet high, and has but one upright stick in it larger than $2 \mathrm{by} \pm$ inclies. As the hay-loft is a high half story, it was thought best to have a eenter-post, which is 3 by 7 , to support the ridge pole in the middle. The stnds are corered with smooth pine siding, and the lower story is lined with rough boards, and the building is as strong as we desire, and cost, completely finished, with good floors, stalls, mangers, doors, and windows, $\$ 300$. The earpenter's work was only $\$ 50$.

We have dwelt more fully upon this subject of balloon frames than upou many others, because we look upon it as one of very great importance. It is one that, if fully understood, would induce and euable farmers to lave better dwellings and other farm buildings.

5\%2. Coucrete Walls. - The best advice that we ean give one who asks for information about making concrete walls, or how to build houses of grarel, or broken stones and lime and sand, is that lie buy a little book called a "Ilome for All," published by Fowler of Wells, which gives all the details of this mole of building. Mir. Fowler directs mixing a large mortal-bed of lime and sand togetler, with twice as much sand as slacked lime, made quite thin, and well worked. Into this mixture of lime and sand and water the gravel or broken stone is put and evenly mixed, and then shoreled ont into a barrow or hoisting tub, and from that dumped into a smaller mortarbed on the scaftold, where it gets another good mixing, and wetting if needed, and is then shoveled into the box that forms the mold to grive shape to the walls. In thi. mold it hardens in one lay so that the mold can be remored, but it takes a longer time to dry hard enough to put on the next course. Sucl walls, if well made, are almost as solid as hewn stone, and much cheaper where lime is not eostly, aud where sand and gravel or broken stone can he had for hauling.

The proportion of materials given in the book referred to for a conerete wall are eight wheellarrows full of lime, mixed with sixteen barrows of sand into a thin mortar, to which add sixty or eighty barrows of pebbles or rubblestone. The lime may be of the corrsest kind, and not over one bushel of stone lime to thirty bushels of sand and stones. A wall three stories lighl is reeommended-iwelve inches thick for the first, ten inches for the second, and eight inches for the third. To protect the outside plastering, the roof should be a projecting one.

Wedo notknow how far this plan of building ean be recommended upon the score of economy. We think that will depend very much upon eirenmstances. If broken stone or pebbles are very convenient to the building site, 
and lime to be had for the burning on the place, ol at a sinall cost, the building will be a cheap one, and not otherwise. ILrace Greeles bnilt a large barn of concrete mpon his farm in Westchester County, of sueh stunes as are spread over the endiace of these granitic hills. Mlthomenl it is a rely substantial building, our opinion is that we could bnill a good frome, sud put the supplus money into other improvements, to a better frotit.

353. Builling with Billets of Woot.-A new style of bnilding lus heen adopted in several places at the West, where lricls and stones are inconvenient, and sawed lumber and earpenter's work are expensire. The plan is to saw billets of wood of an even length, say one foot long, from limbs of trees; or split stuf1; slabs, we suppose, would answel a good purpose, if split up into frre-wood size. These billets must be straight enongh to pile up well. 'The wall is made by laying them in lime mortar, and, we belicre, in some cases, in good clay mortar, where lime and sand are scarec, and then plastering the wall ontside and in. The great objection seems to be that the oulsile plastering cleaves off, as it does from all plastered buildings exposed to rain, frost, and heat. A friend writes us inquiring whether there is any compo-ition for ontside plaster that will stand the weather. $W^{r}$ answer, none tha: can be wholly depended upon. A mortar made of lyydraulic cement (water lime), of good quality, mixed with elean, coarse, sharp sand-two parts of sand to one of cenent-wonll stand until some crack ocenried. and water and frost get in hehind. Perhaps the mortar described in No. 3.i? mill answer the purpose. But as it is cheaper, and perlaps cyually gooul, we wonld recommend an oldinary cont of plaster, and then take cencut and auy cheap oil, and mix a pretty thick paint, and put on thoromerly two op three coats. Another good paint may be made as fullows: Take tom pomnds of rosin and one pint of linsect oil, and boil together, adding about an ounce of red lead, and put it on lot, and afterwarl paint any color yon lilie. If a crack ever ocenrs, stop it at onee with the rosin and oil misture. Ite lave no doubt that these billets-of-wood honses can be built in many places cheaper thin any other, and that they can bo made neat, comfortable, aud durable. 


\section{SECTION XX.-ROOHS AND ROOFING-l'ALTS AND WHTEWASII FOR

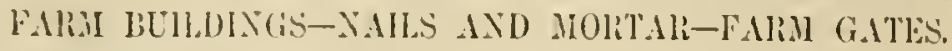

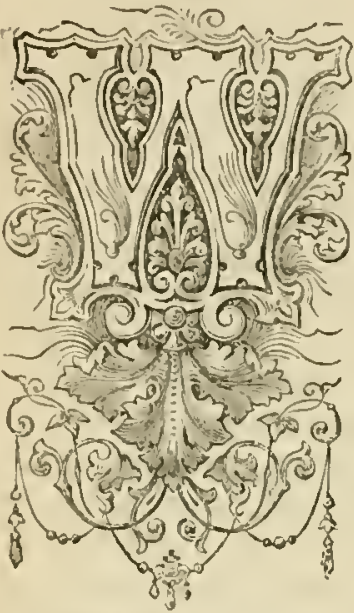

IL TTEVER the style of building aropted for any of the fumery structures, a good root never sliould be lost sight of, for upon that, much of the farm economy depends. A leaky roof on a dwelling destroys comfort and property, and is the source of many muleasant days and nights to the family, and sometimes prodnetive of sickness, as well as injury to funiture. A leaky roof upon a lan will destroy every year a greater value of hay and grain than it would cost to make it tight. It is for this that we give special attention to this part of the farm buildings. Whe also give some valuable hints mpon painting and whitewashing, becanse both beauty and economy may be thus promoted.

35t. Sawed Shingles. Of all the inventions erer contrived, that of sawed slingles lias proved to be one of the least value to the country. The only profit is to the patentee and manufacturer. To every one who lias used then, sawed shingles have jurod a loss, no matter.what the saving lias leen in first cost, mless the shingles, previons to laying on the roof, were prepared so as to prevent their saturation with water every time the rain fell upon them. It is this repeated saturation of sawed shingles that rots them, and gires us leaky roofs in one fourth the time that split shingles remain sound. It is true that good shingle timber is becoming scarce, and more and more so erery year, and that farmers must have something as a substitute. What that something is we know not, but are quite sure, where ceonomy is studied, that it will not be sawed shingles. If they must be nsed, let the roof have a rery steep pitch. On a flat roof we have known them rot entirely throngh in five years. Another roof, ten years old, both slingles and roof-boards, when taken off, crumbled into a mass of rotten wood, that scarcely bore any resemblance to boards and shingles.

"A retired mechanie" writes us that he followed building eighteen years, and prefers sawed shingles if they are planed on the upper sicle, and says that a smart hand can plane from two to three thonsand a day. We think a macline miglit be constrneted to plane one side of sawed slingles without adding mueh to the cost. Withont planing or dipping in boiling oil or tar, we ro not believe sawed shingles should erer be used by any one who wants a good roof, or who cares for economy. The writer of a letter now before us spentis in very severe terms of the mannfacturers of sawed shingles. IIe says they are often made of small cross-grained, sapling spruce, and that 
the bark of the tree will last about as long as such shingles on a root. The carelessuess of persons empluyed to lay shingles is notorions, and it cruss. granined shingle is just as apt to be laid wrong side up as right. Then ilse surfince wears rongh, and water soals into the wood and rots it throngh so as to leak in a few months. This writer thinks the funlt of sibred shingles is mueh more in the timber than in the bitumficture: that is, flnt sawed slingles from good, soumd, straght-gmaned timber will last as long as split ones.

Another letter writer suggests that sawed slingles slonld nerer lie ıaid upon a boarded roof, but upon narrow laths, one to each course. He says:

"I know of a building wlere the shingles were pint on boards and the boarls put close torether, which liare been on but a few years and are very leaky; the shingles and bourls have rotted throngh in places, while otlour parts are sound and good. I think the reason in, the shingles lie so cluse to the hoards ldat when they get wet they never dry through; while if laid upon latlis, sawed shingrles will last as long as split ones from the same timber."

Another writer, speaking of the absolnte necessity of using something as a substitute for split shingles on aceonnt of the scarcity of timber, wants to know why we can not lave tile mamufactured that will be a better Eubstitute for shingles than anything else that we lave, both for conomy and certainty of laving a gool root.

A comespondent speaks of shingles cut by a machine patented by J. L. Brown, of Indianapolis, Ind., at the rate of 50,000 a day, that are aluegether superior to sawed shingles, eren shondd the latter be plancel. This may be so, but we lase no faith in the economy of using shingles male by any kind of machinery that cuts wood across the graiu. No shingles thus made will be as durable as split ones, mless satmated witl oils or resins, w liyanizul, and then they wonld be as expensive as those male by riving and shaving, or perhaps as much so in the long run as slate or tin. Depund upon it, using poor slingles upon fium buildiugs is very pool ceonomy.

355. Prescrving shingles on Roofs.- "Some paint root slungles after they are hail. This malies them rot sooner than they wherwise would. Some paint the courses as they are laid ; this is a great prescrvative if each slingle is paintel its full lengtl, mul not ly courzes."

Mr. Ed. Emerson, of Ilollis, Mass, thus grives, in the Fere Fingluml Farmer, some hints that are worthy of preservation upon shingling roots. II says:

"Twenty-three years ago I lial quite a lot of refuse slingles on limul, hoth sappy and shaky, and I labl then on the lack kitelien and woml-sher]. I lave just examined them, and think they will last at least seven years longere. The building has not leaked, to my knowledge. I soaked these shingles in a very thin whitewash, made with brine insteat of clear water. 'lhere lins been mothing done to then since, althomgh I liave no doube that to have whitew ashed or served a coat of elry-slaked lins of tiue salt one in tro or three years on them, would liave been of great anvantage to then. 
"As I shingle differently from almost erery one else, I will gire you my method, and my reasons for it. Ilowever wide the shingles may be, I do not allow the nails to be put more than two inches apart. Reuson-If your shingles are wet or green, and the wide ones are nailed at the edges, the shingles must split or one of the nails must draw when the shingle shrinlis If the shingle is dry, it must huff or crowd the nail ont when it swells. Thus your mails are kept in constant motion by erery slurink or swell of the shingle till they are broken, pulled out, or the shingle is split. I do not want the nails driven quite in, $01^{\circ}$ so as to siuk the lead. Jeason-The heads of the nails hold up the butts of the next row of shingles, and give the air a free circulation.

"I lay all my shingles in whitewash. I prefer brine for making it. I line with red elalk. I then whitewash the last course laid down to the line, and after the building is shiugled I whitewash the whole of the roof. Reason-To make the shingles last twice as long as they would without the whitewash, and I consider it mueh better than just whitewashing the roof after shingling."

"Whitewashed shingles are never mossy. If slaked line is sprinkled upon wet roofs, it will prevent moss from growing, and if the shingles are covcred erer so thick with moss, putting the lime on twies will take all the moss off and leare the roof white and clean, and it will look alnost as well as if it had heen painted. It ought to be done once a year, and, in my opin. ion, the shingles will last almost twice as long as they will to let the root all grow over to moss." One who has tried this plan says:

"I tried it on the back part of iny house ten years ago, when the slingles wcre all corered over with moss, and appeared to be nearly roticn. I then gave rlic roof a beary eoat of line, and have followed it nearly erery year since, and the roof is better now than at first."

356. Roofs-their Form-Shingled and Composition.-It is a scrious defect in our roof architecture that the roofs of most buildings are so flat that the rain finds its way under the shingles. Sharp roofs lecp ont rain and last longer, and although the first cost is a trifle greater, they are eheaper in the end. We know of no composition we can recommend to cure leaky shingled roofs, though several are advertised as sure cures. We are afraid they are like the Indian's gun- "cost more than he worth." There is a patent asphalt roofing felt that ean be casily put on by any person. It reighs only about forty-two pounds to the square one hundred feet. It must be stretehed tight and smooth, orerlapping full one inch at the joinings, and closely nailed througly the overlap. It shonld then receive a coating of coal-tar and lime-two gallons of the former to six jounds of the latter-well boiled together and kept constantly stirred while boiling, and put on with a swab, and while it is soft some coarse sand may be sifted over it. This coating needs renewing once in fire or six years.

There is also roofing-paper-a soft, spongy substance, saturated with tar, which comes in rolls, and is sold for about four cents a pound. It is un- 
rolled upon a flat boarded roof, and taeked sufliciently to loold it in place, and then saturated with tar, which grlues it to the boards, and it is corcicul with sand; then more tar and anviher coat of sand.

Another receipe for composition roots is given as follows: Take conl-tar, 300 pounds; hydrautic lime, 150 poumds; ocher, 75 pounds; and whiting, 40 pounds. Mix these substanees together thoronghly, and they will malie a snflicient quantity of cement to cover 1,000 square feet of rooting. It Elould be laid down npon strong cotton sliecting naited to the ruof-hoards, and on the top of all a cont of dry sand or gravel is to be laid and juressed firmly down. The cost of smeh roofing is nbout $\$ 230$ per ten feet sinuare. It answors very well for sheds and other outlionses.

357. Protecting Roofs from Pire.-In a country where wood is used a.s fuel, and where roots are made of pine shingles, and.where droughts are among the things oceurring erery smmmer, there is constant danger of contlagration of the dwelling from sparks on the roof. This may be gruarded against in a very great uncasure in a very inexpensive manner. A roof earefully washed with three coats of either composition mentioned in Nos. 360 or :ili, onee in three years, wonld be a hundred times less liable to take fire from sparks than :n unwashed root:

Such a wash wonld be a very cheap preventive of danger from fire. So is the print mentioned in the following extract:

"A wash composed of lime, salt, and fine sand or wood ashes, put on in the ordinary way of whitewashing, renclers the roof fifty-fold more sate algainst taking tire from falling cinders or otherwise, in eases of tire in the vicinity. It pays the expense a hundred-fold in its preserving influence against the eflect of the weather. The older and more weather-beaten the shingles, the more benefit derived. Such shingles generally become more or less warpel, rough, and cracked ; the application of the wash, by wetting the mpler surface, restores them at onee to their original form, thereby elosing the epace between the shingles, and the lime and sand, by filling ip the cracks and pores in the shingle itself, prevent its warping for years."

3is. (heap kails, - The cheapest mails are not the lowest pricel onces. Cut mails, made of iron of good quality, will outlast such as ean le bonght at the lowest rates about two to one. Xerer use mails for siding or elaingles that hreak rery easily; and he sure not to allow your carpenter to 11 se nails of very light weight. Firstrate ent nails of snitalsle size may cout twenty-tive jer eent. more than the poorest and lightest, but in the eme they are a hundred per cent. the best. Niails made of pros iron will rust cunt al arreat deal quicker than nails made of good tough malleable irou, like that known as old sable. It is about on a par with sawed slingles to use the eheapest or lowest priecd nails, particularly for shingling. In lunilling balloon frames none but the rery best quality of nails should he nect. Those known as "funce nails" nre fur the best, being male of thicker iren than the ordinary mails of the eame number.

Weather-1'roof S'ails-are described in the Okio Cultivator. It says: 
"Everybody knows what a difficult thing it is to nail roof-boards and weather-boarls so that they will holel tor a good length of time. 'There are many other places in which it is netrly impossible to make nails do the attice for which they are intended. A renedy-and the only one I ever saw-I discovered a few years ago; it is rery simple and never fails. Talie terpenny, malleable nails, and place the lucad in a vice, and with a pair of pincers grip the nail near the point, and twist it half-way rond, minding to malie the trist somewhat elongated. In driving, the nail becomes a screw, and nejther sun nol hammer can willd'aw it."

359. To make Dortar Impervious to Wet.-" Provide a square wooden trough, say $S$ by 4 feet, and 2 feet decp: jut in a quantity of fresh lump lime, and add water quickly. When the lime is well boiled, liaving assisted that operation by frequent stirring, add tar (the heat of boiling lime melts the tar), stir it well, taking care that erery part of the lime is intimately mixed with the tar; then adel sharp sand or crushed clinker, and stir it well as before; after which, in about twenty lours, it will be fit for nse."

360. Chrap Paints for Farm Buildings.-Tar and lime may be used, in order to make cither wood or mason-work waterproof. The best way to prepare gas or coal tar for coating wood-rork with, is to get some of the best stone lime, aroiding chalk lime, and slake it to a fine powder; boil the tar for about lialf an hom, and then add abont one pint of lot lime-poweler to a gallon of tar, and boil it about laalf an hour longer, stireing it coniinually, and using it lot.

We rive the above as we find it, but prefer the following: Take the common "Rosendale cement" (rater-lime), sift it, and nix the fine powder with coal-tar, or any kind of oil, and it will make an excellent paint, of a drab or brown-stone color.

361. Permaneint Whitewash Paint-Another excellent paint is made of the following ingredients: that is, one bushel of well-bunt white lime mslalied, 20 lbs. Spanish mhiting, 17 lbs. rock-salt, 12 Ibs. brown sngar. Slake the lime, and sift out any lumps.or stones, and mix it into a good whitewash, say with 40 gallons of water, and then add the oilier ingredients, ancl stir all well together, and put on two or three thin coats with a common whitewash hrusli. Five dollars' worth of this eheap white paint will gire the firmery such an improved appearmee that it would sell readily for $\$ 100$ more than it would in its old wood-colored coat and neglected-looking condition. This mixture makes a paint that is rery clyenp, and makes a coat that loes not wash off or rub off, and looks well-that is, makes the rough boards of a barm, shed, outbuilding, or fence look much better than in their natural wood-colored condition; and it rill, ly its antiseptic qualities, tend bencficially toward the preservation of the wood. It can be tinted by auy of the articles mentioned in 362. This is intended for the outside of buildings, or where it is exposed to the reather. In order to gire a gooul color, three coats are necessary on brick and two on wood.

Another cheap and good paint may be made of any pure clay; such as 
potters use is the right sort; or that known its "bluc clay" will answer is grood purprose in its natural condition. Even such as brick-makers ntse can:1 be washed of all its impuritics, by thoronghly mixing it with a large hulk of water, and letting it settle and then draw otf the water, and also roject the bottom of the mass, which will contan all the sanml.

To prepare clay for paint, first dry it, eitler in the sum or ly fire, mot then pulverize it fine, which may he lone with a ('anon-bull in is swinging iron pot. Then sift it, and mix with boiled linseed oil, pretty thick, and you will hare just as good a fire-proof paint, or a weather-protecting paint, als any that are sold as such in the sliops.

In some localities soft slate, or slate-lust from a manufuctory, can lo lıal, and that will make a good "mineral patint."

362. Riuc and Lime Whitewasls Paint. - Take a clean barrel that will huld water. Put into it half a bared of quicklime, and slake it hy ponring orer it boiling water sufficient to cover it fou or fire incless deep, and stirring it mtil slaked. When quite slaked, dissulve it in water, and ald two funmls of sulphate of zine and one of common salt, which in a few ditys will conse the whitewash to harden on the wood-rork. Add sufticient water fo hring it to the consistency of thick whitewish.

To make the above wasls of a pleasant crean color, ald three pounds of yellow ocher.

For fawn color, add four pounds of umber, one pound of Indian red, anc onc pound of lamplack.

For gray or stone color, add tour pounds of raw umber and two pumuls of lamplack.

The color may be put on with a common whitewasle brusle, and wiil he found mucl more dumble than common whitewash.

363. Stuce Whitewash.-To malic a brilliant stueco whitewsh for all buildings, inside and out, take a bushel of clean lmups of well-burnt lims. slaked; adil one fourth pound of whiting or burnt almm pulverized, one found of loaf sugar, three quarts of rye flour, mate into a thin mul wellboiled paste, and one pound of the cleanent grlue, disiolverl. This mily le put on cold within doors, bnt shonlel be inplierl hot untsile.

The following is another recejpt fol stueen whitewa-la: "Take halt a bushl of nice molaked lime, slake it with hoilug water, everims it during the process, to lieep in the steam. Strain the liquid throngh a finc sieve or strainer, and add to it a peck of salt, purbonsly well disolved in wilfer: three poumls gromul rice, fwiled to a thin paste, and stirmen in luiling lut ;

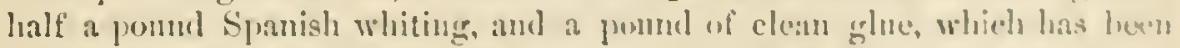

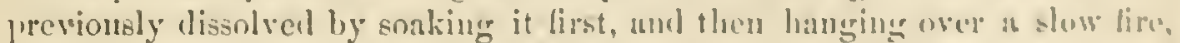

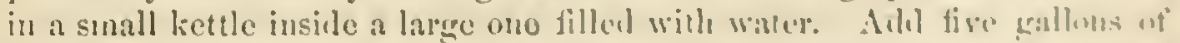

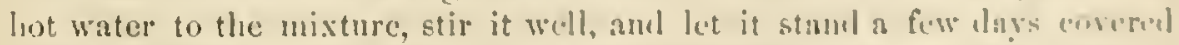

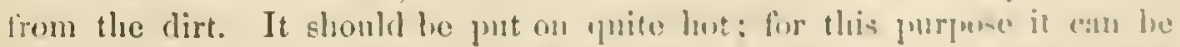
kept in a kettle on a tumace. It is said that nlumt a pint of this mixturu

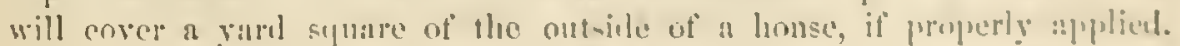


The size of the bruslies usel should be adapted to the work required. This cumposilion answers as well ats oil paint on wood or stone, and is clieaper. It retains its lirilliancy for many years.

Coloring nay be put in, and made of any slade you like. Spanish brown stired in will make red pink, more or less deep to the quantity. A delicate tinge of this is rery pretty for inside walls. Fincly pulrerized eommon clay, well mixed with Spanish brown, makes a reddish stone color. Yellow ocher stirred in makes yellow wash, but elrome goes further, and makes a color generally esteencel pretticr. In a!l these eases the darliness of the shades is determined of comre by the quantity of coloriug used. It is dificult to make rules, because tastes are different; it would be best to try experinents on a shingle, and let it dry. We have been told that green must not be mixed with lime. The lime destroys the color, and the eolor luas an effect on the whitewash, which makes it erack and peel. When walls have been badly smoked, and you wish to have them a clean white, it is well to squeeze indigo plentifully through a bag into the water you use, before it is stirred into the mixture. It a larger quantity than five gallons be wanted, the same proportion shonld be observed.

The above is the receipt that has been so long in circulation as that which gave the original whiteness to the "White House" at Washington.

In oil paintiurs, never suffer a painter to use unboiled oil mpon any of your buildings or farm implenents, and certainly never suffer yonrself io leave any of them unpainted. Tilke care that the painter is not too liberal in the nse of his "driers" in your paint. Tint is to please the eye. Oil preserves the wood, and one cont of boiled oil is worth three of unboiled.

All firm buildings slould be oil-painted or whitewashed. Whitewash tends to preserve wooden buildings more than any ordinary eoat of paint, particularly such a one as would be given to unplaned boards, which is a better condition for whitewashing than when smootl. The ice-house should be whitewashed on the outside as often as it is necessary to keep it perfectly white, as that is an important aicl toward keeping it cool.

36t. Farmery Gates-No famery can be eonsidered at all complete that is not amply furnished with gates, constructed with partienlar adaptation to their sereril sitnations, and aranged in the most perfeet mamner with linges, latelies, and fastenings. There is to us no greater evidence of a slovenly firmer than is furnished by half-dilapidated, or at best inconrenient, bars. These bar-ways may answer in field fenees, where they are seldom to be opened, but they are a nuisance abont the farmery. Most of the farmery gates slould be self-closing, and made to swing so that an animal could not push against and open the gate. In some places a gate can not be made to wwing eitliel way; then it must be made to open upon some one of the several plans that have been made for convenient opening iu a straiglit line. One of the sort patented by some one in Oneida County, N. I., is a very easy working gate. It is made of very liglit stuff, and for a wagon-way a pail, each five fect long, are set between posts nine feet 
apart, and held against the posts ly guides, which allow of their easy worliing. Attached by bolts to the upler outwarl corner are two light strips of boarls, one on each side, and two others in the center. 'These strips are lingel to posts at the bottom in the same way they are at the top to tho gate, and when the grate is shut they stand at an angle with the grate life braes, and when the gate is to be opened it litts upon these centers, aud passes orer and stands alongsile of the fence in a straight line. such grites are very convenient in ease of snow, as they lift up right ont of ho drift, so as to allow a passage withont shoreling. When closed, the two gates are fastened together by hooks or bolts, or any convenient fastening. Is they are not hinged to the posts, these may be male ruite lightut.

Another plan of a gate, to open withont swinging, is to suspend it nun: rolkers running upon a rail overheal. Some one has improvel upm this plan to make the gate openable by a person driving up in a watron. "This is done by lifting the gate at the front end by a lever, which clianges the level of the railway-bar upon which the gate hangs, so that it rolls back ly. its own gravity. The principle will be understoon ly looking at any gate made to run off on rollers upon a bar above the top, by supposing one emi of the har raised, when the gate rolls lown. A tonch of another lever, als the wagon passes, reverses the position of the bar, and the gate rolls back agiain to its closel position.

The great objection to this, and almost all the plans for opening gates from: the wagon, without alighting, is the musightly appearance of the gallowsfrane necessary to support the levers, ropes, and pullers.

We have ecen gates which opened lyy the weight of the wagon passing orer a bar, and shinting it by another tonch of a bar on the other sicle. There is a good deal of machinery to this plan, as well as to nearly all of the contrivanees to open and shut gates without labur, and the most of them are very liable to fail of working easily.

The most simple one of the kind, and, so far as we could julge from a single examination, the least liable to ret out of working orler, was one exlibited at the New York State Fair of 1860 by Jasper Johnsos, of Genesce County. One of the greatest advantages of this invention is, that it can lie applied to gates alrealy in use, so that one can be opencel by a person in at wagon and shut as he passes throught withont stopuing.

Any crection that will sustain a single corl upon each side, aud a bar of jron about four fect long, of the size of an ordinary crowbar, and one or two small rods, comprises all that need be alded to any gate to fix it for this eonvenient way of opening. This lar of iron is made in a peculiar form, and attached to the grate-post ly a loose joint at one end, while the other works in a long staple attacherl to the gate. Its position is nover! ly julling the cord, and its specific gravity heing thus changer?, throws the gate open, and shuts it ly another pull at the same coml, or the other one, as the person drives throngli. The attachunent certainly is a very che:t] one, and its operation was cutirely satisfactory. 
Robinson's Farm Gate is the name given to one inrented, and not patented, hy Dr. D. A. Robinson, Union Springs, N. Y., of which we think pretty highly. One of its good points is the eheapness of the hinges. These are figured and fully deseribed in that excellent poeket manual, the "Rural Register," published by Luther Tuelier, from which we copy the following (lescription:

"This gate may be male of any light, tough, and durable wood, but answers a good purpose when made of pine, with the npright or eross-bars of white oak. The upper horizontal bar is 11 feet long, 3 inches wide horizontally, and 5 inches deep at the hinge, and $2 \frac{1}{2}$ at the lateh. The mortises are only two thirds throngh, to shnt ont rain, and $\frac{5}{8}$ by 3 juches-exeept in the heel-piece they are an inch and quarter. The heel-piece is 3 by 5 inches, and the fon lower bars are boards 1 by 5 inches. The cross-bars, the lrace, and the two pieces forming the head-piece are 1 by 3 inches. They are secured at each crossing by wought or anncaled uails. The head-piece consists merely of two boards, nailed on each side of the horizontal boards. The hinge is made by driving an iron rod, at least three fourths of an inch in diameter, into the top of the post, which turns in a hole seven eighth of an inch, bored two thirds of the distance through the large end of the npper bar. A short iron plug driven into this hole makes a hard resting point that will not wear, for the gate to turn mpon. The lower linge is a wooden block, attached to the lowel part of the gate, and hollowed ont so as to fit npon the round post. The latch is not attached to the gate, but to the post, so that it catches over the top rail, which is made to project beyond the end of the gate for that purpose. If it is preferred to have the lateh fastened on the gate lower down, a pin ean be fixed in or one of the slats projected forward. This gate is not liablo to sag much, bccause there is no wcight what. iver straining the linges, except white the gate is open. A pin or spike is driven into the post on which the linges turn, just above the lower linge, to prevent hogs or other animals from lifting the gate, but which does not prevent it from being placed on its hinges while open. The past holding the lateh may be rough, except the face, and the other need be rounded only where the hinge turns.

"The whole cost of the hinges need not exceed ten cents, and the gate itselt may be made at no greater expense than a common set of bars."

An excellent gate-fastening is one in common use in Mississippi and some other Sonthern States, which we have never secn in any of the Northern oncs. A gain is cut in the corner of the post, say three by four inches, and in that is hung a piece of flat bar iron, say one inch wide and one fourth of an inch thick, bent in somewhat the form and of the length of half a horse-shoe, the "uper end hammered thin and bent over a staple which is driven in the npper part of the gain, so that the lower end of the bar rests on the bottom, near the outer edge. An iron pin in the upright of the gate strikes against this little bar and lifts it up and passes beyond the end of it, when it falls back, and no power but a man's haud can open the gate-but 
for that it is reryeasy. It is me of the liest latehes we ever saw tu prevent unruly animals from getting the gate open, and it is very cheaply made, and would be a very safe one for all the gates about the firmery liable to le opened by the hogs and cattle.

The following is a good plan of a new gate-hinge or plan of fustening the upper hook or eye of a gate-linge into the post, which we have secil deseribed lately, and like it so much that we wish all farmers to kunw it. Instead of driving the hook into the post, a hole is bored quite through it just at the top of the upper rail of the fence, aurl the slank is marle long cuming to reacl some inches beyond the post, and has several notches on its ujuet. side. Bore a hole through the rail and put a small bolt with a looploble at one end, to bite into a notel of the hinge, and unt at the other. Of course. when screwed np, the sag of the gate can not draw the hook; but if neressary it ean be made shorter by slifting a notel or two.

The following dimensions of a good strong farm gatic, and the timber for it, may be taken as pretty near correct:

Space between posts, 12 feet; light of posts abore ground, is $\frac{1}{2}$ fect : slats, 12 feet long, 5 inches wide, $1 \frac{1}{4}$ inches thick for the hottom one, and 8 incles wide for the other six; light of gate, $4 \frac{1}{3}$ fect. The cuds into which the slats are tenoned are $2 \frac{1}{3}$ by 3 inclies, 5 feet long. Some prefer to have the top rail double the strength of the midlle slats. There are two hraces and a center upright fastened with small serew bolts or rivets. If a strip hinge is used, they should he riveted to the slats. If straps are not used, the jrom slionld be made to clasp the upright, and not go through it.

In soft land, like that of the W' estern prairics, it is clifticnlt to make gatteposts stand firm, and they are often formed with a galluws-looking cruss-lint overliead.

A better way is to put this cross-bar and braces at the botom. Frame the posts and braces into a sill, and lury that three feet dere, ind it will eflectually prevent the posts from sagging, and then you may use them ot much smaller timber.

A good ligrit gate is made as follows: Tuke strips of hoards tluree inclies wide, half an inch thick, of any etrong wool; pinc, thec of knots and weak Epots, will answer, and cut them suitable lengrths for the length, and others for the width of the gate. Lay down upou at smooth surfice sereral of the short strips not over three feet apart, and then ling the long strips un for a close gate tluee inclies apart at the bottom, gradually wilening to (he top); then lay down slort strips directy orer the others, and nail throun these witl clinel nails. Wre lave sometiues reversed the order, and used two hun strips opposite, instead of two short ones, which makes a stronger lunt henvien

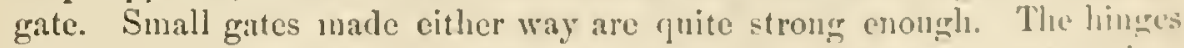
should be of a peculiar form, with long strajs to clasp the gate so as to rivet througl and hold the wood hetween the irom.

In Section I.II., in an article upon farm fences, something will lue fonnd about how to make grate and fence posts durable. 


\section{SECTION XXI-LIGHTNING CONDUCTORS-PROTECTION OF FARII BULLDINGS FROM FIRE.}

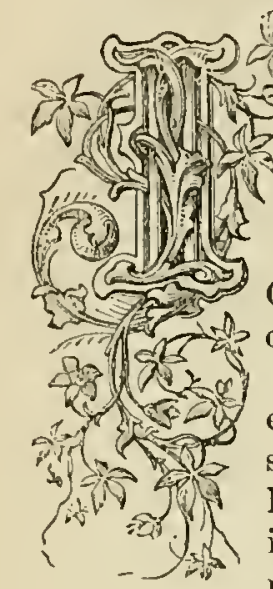

$\mathrm{T}$ is a great question for the owner of farm buildings whether he can protect them from destruction by lightning-rods. Being almost faithless ourselres, jet not quite sure that lightning-rods are all useless, we will give the opinions of several who have investigated tho question.

365. 0pinious of the Valmo of Lightning Conductors.-MTr. Quinby, a practical electrician, gave the following riew of the subject in an article in the Working Farmer:

"There can be few subjects of equal importance less generally understood, or perhaps more nniversally misunderstood, than the seience of electricity in its application to lightuing-rods. The errors of the past are very slow of eradieation, although it must be admitted that progress has been made since the famons discussion in George III.'s time as to whether lightning-rods should be pointed or blunt at the top. So little is lnown of electricity itself, and so largely is it a purely speculative science, that it is no wonder that doctors disagree.

"It is clear that the most valuable opinion on this subject is to be looked for from those who have made the study of eleotricity and thunder-storms a specialty, with the practical result in view of ascertaining the most effectnal means of protection, and it is to be remarked that those who have done this have arrived at similar conclusions.

"It is a common error to suppose that lightning-rods should be insulated, and a very natural one, arising from a superficial view of the subject. It should be remembered that currents of electricity in a rarefied state are continually cireulating through masses of matter silently and without producing any manifest effects ; the effect of insulation is to interrupt the flow of these currents, whereas the lightning-rod onght rather to be so contrived as to facilitate their free passage from the building to the rod, and thenee to the atmosphere, and vice versa.

"During that disturbed, electrified condition of the atmosphere, which we call a thunder-storm, these currents circulate in greater volume and rapidity, and a sufficient interruption of them brings about a discharge of lightning.

"At such times the insulation of the rod from the building is a most excellent derice for causing an explosion of accumulated electricity either from or into the building, as the ease may be. The rod, on the contrary, ought to act somewhat as a safety-ralve, as regards any electrical disturbance within the house, ncutralizing it gradually, and thus preventing an explosion. 
"Shonld the rod be struck by lightuing, its eflicacy in carrying ofl" the shock will depend on whether it presents a coutinuous chain of condueting matter, in the line or direction of the discharge, which is superior to anything within the building. If it does not, all the glass in the world will not prevent fluid from leaving the rod and passing through the luilding on such conductors as it may find there.

"The true theory or purposes of the lightning-rod is to facilitite electricity in following out its natural laws and tendencies, and nothing can le more truly unscientific or practically absurd than the idca of presenting a barricr or obstruction to lightning."

This theory fully accords with all our information upon this subject.

The following are the views of another practical dectrician, S. D. Cushman, of South Bend, Ind. Ite says:

"A conductor for the protection of life and property from the efiects of lightning shonld be so constructed and applied that it will ads to the cundueting power of the building so as to admit of the most intense dischatlos being securely transmitted, without explosion or dimage to the bnilding ur structure.

"A attracting power.

"Isstuatiox.-The conducting power of a lightning-rod is rergnently" "diminished by insulation, and never is increased; it should never be insulated. It may be fastened to the building with brackets of rood or staples.

"Porsts. -The attaching to the upper" end of a lighruing-rod a copper, silver, gold, or any hind of a point, does not add to the utility of the rod. but when attached always diminishes, more on less. the conducting power of the rod, by breaking up the perfect continuity that a rod should possess, and interrupting its polarity.

"Stze- - An iron lightning-rod should never have less than three inche's conducting surface, vossessing solidity sufficient to have strengrth and duritbility.

"Coxstrectrox.-A lighlning-rod should not possess in its constmuction sharp edges, neither should it be in sections nor piees (the sections or pieces being hooked or serewed together), lout it should be all in one piece, justesing an equal, eren unbroken surface in its whole length.

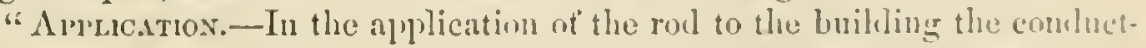
ing power of the building shonld be bronght into the general line of conduction; that is, the rod should come in good metallie contuce with all the important metallic snbstances upon the ontside of the building, snch as gutters, sponts, etc. That part of the rod that cones in contaet with the earth should be increased in its surfice and conducting power, so that there will not be less conducting surtide in contacet with the earth than is cxprocel to the building and atmosphere, and care shonld be taken thas the earth around and in contuct with the rod is ulways noist.

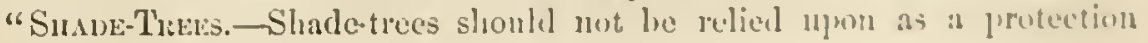


from lightning, because their conducting power varies so much, and very olten, when in their best conducting condition, they are dumaged by the lightning passing orel them. The conducting power of sharle-trees, then, shonld be increased and made permanent by the application of an iron or copper wire.

"Enrons.-One of the errors committed in protecting from lightuing is an improper estimate placed mon the conducting power of the building, compared with the material used for protection. When a lightning-conductor terminates or ends in a substance of inperfect or less condneting power, it is relueed to the conducting power of the body in which it ends.

"Dry earth is a non or imperfect conductor. Earth owes its condueting power to water. According to Cavendisls, the condncting power of iron, as compared to the conducting power of water, is as four hundred millions to one. The electrical size of the mass of lightningrods is not as large as a common knitting-needle, being reduced by so small a portion of the rod's surface coning in contact with damp earth.

"Another error is in constructing the rod in sections. Rods properly applied, of perfeet continnity, being all ju one piece, without conpling or looking, liave never failed to carry the quantity of electricity that may have passed upon them safely and suceessfully to the ground, while the sectioned, or the rods hooked or serewed together by burs or nuts, have frequently failed to do their duty. Searcely a day or a week passes during the summer months but we hear of the failure of the coupled lightning-rods.

"However" well the firet of electrical conduction may be known-liowever" well scientific men may be agreed that lyy the judicions employment of metallic bodies we may increase protection against lightning, certain it is that they have taken too much upon trust, and neglected the investigation of the fiacts.

"Men ignorant of every electrical prineiple have professed to furnish security against lightning, mntil the scientific electrician who attempts to sell lightning-rods is received with jeers and.contempt as a designing swindler; his story is listened to with impatience, and his presence considered an intrusion."

The rod recommended by $\mathrm{Mr}$. Cusluman is made of four copper and four iron wires laid together, with a pointed cap on the top, and some metal plates at the bottom. There must nerer be a splice in the wire, but several wires carried up from the ground, in the main body, may be talien off and connected with the metal roof of a building, or witl other points.

The following language we used upon a discussion of this subject before the Anerican Institute Farmer's' Clnb :

"As lightning-rods are most commonly constructed, they are not what they are generally conceived to be-that is, attractors of an approaching thunderbolt, picking it up on the sharp points, and condneting it down a carefully insulated rod to a safe deposit in the eartl. If a lightning-rod ever performed such a service, I should like to be assured of the fact. At 
present I liave no faitl. I believe that, when the atmospliere is sureliargel with electricity, any metallic substance will absorb it just in proportion to its natural aftuity, and if there is an excess of flud in the air arome the top of a rod, it will rum down it to the cart], just as it rums along telempraph wires; and experience has proved that a bright, sharm voint is more attract. ive than a blunt one.

"Still, a blunt rod will become charged, and so will a metal ronf, and, more than all, an iron building, and the water-conductor, or whaterer wilser metallic substances reach from the top to the earth, will tend to dissipate the execss of electricity in the air above and around the building, and prevernt an accumulation of it sufticient to produce an explosion. Int I lave not one particle of faith that any building that happened to be situated in the jatly of what we eall a thunderbolt, ever was saved by the best lightining. rod ever erected. And if in its course the discharge from the elnul, comming like a rifle-ball from the muzzle of the grum, liappens to strike the sharp point of the rod, it is, to my mind, a preposterons idlea to suppose that perfect jusulation of that rool from the building can be of am possible advantage."

This opinion we still abide by. The rorll is full of theories upon the Eubject. We wish we could eluciclate them. We want all these lingtumg theories reduced to two or three fitets. It is clamed hy some that im is the best, and by others that copper is hest. One confenils that blunt iron is just as good as shap gold or platiun. One says that insulation is necessary, and the other that it is not. Now it is facts that we want. larmers want to know whether they can protect their buildings from danger of heing struck by lightuing.

A. 13. Dickenson, a practical and close observing farmer of Stenlen County, N. Y., is of opinion that no lightning-loul will protect a harn while giving oft' steam arising from newly storel lay and grain. 'Then, of what advantage to erect one? for that is the very time it is most needrel to save the furmers' barns from destruction, which are much more likely to be destroyed than any other buildings, and the loss is unch greater.

Adrian Bergen, of Long Islane, relates one case of a barn apparently saved by the conductor. The foree of the shock was so great that a man in, the barn wats knocked down. The rod was a small, ronmel one, fastened to the barn by wooden supports. After the explosion a hole was found at the foot of the rod.

So we have read of many cases where there was au apparent grond cflevet fiom liaving conductors upon buillings. A very licary erash till upon or over a house and barn in New Ilampshire, which melted the points of mew conductors sud apparently dissipated the flutil so as to prevent damnge. though the barn appeared to be filled with alectricity.

The Tenple at .Jerusalem stood ten centuries without neing injurerl: lunt this huilding had a great deal of metal alout it, aud perhaps conductors for water that carried the electricity from the ront to the ground. Fiet we hatve many instances in this country where bulldings have been struck ibat wero 
fully provided with lightning-rods. This may be owing to bad construction of tho rods. In the case of a great cxplosion, like the one in New IIampshire, it is not likely that a single rod conld convey all the charge to the ground. If a rod was full of points along its lengtl, it would serve to dissipate the cliarge, and a square rod is better than a round one.

Wm. S. Carpenter, of the eastem part of Westchester Cominty, N. I., says:

"The farmers in my' section hare no faith in lightning-rods, because tlie proportion of barus that liave been struck with rods upon them is greater than those withont conductors. A scientific work states that a copper rod one inch in diameter is bettel than an iron rod four inches in cliameter, and nothing less than that seems to be suffieient. This rod, too, must be continnous, and well connected at the bottom with damp earth."

Cases have oceurred where a tin roof appeared to act as a great absorbent of the electricity, which it conducted down the tin water-sponts, and in one case into a water-cask, which it burst, and passed on into tlie wet enrth.

Single rods are apparently not al ways reliable. It is not doubted tiat an extensive spread of metal diffuses lightning. Then, are buildings safe with metal roofs? Flagstaffs have been tnrn to pieces on their tops, and no mark of injury left about the dwelling. Would it not answer the purpose and be also ceonomical to place a stout rod on the center of a wooden roof, and attach to the bottom, where it tonches the roof, a ummber of telegraph wires, carried in many directions to the ground? Would the stroke on the center rod be calried safely off by such radii? It so, the plan is vastly clieaper than an entire metal roof. Faraday experimented on iron cages suspended in air-in one of them a man; in another small cylindrical one, a monse. The cages powerfully cliarged with electricity, produced no effect on the man or monse. The plan of one central rod, with many wires corering the building, may produce like results.

It is wortl a trial. It is also worthy of obselvation how many more barns than louses are struck by lighlning. $\Lambda$ calculation of an average of seven persons to a dwelling in the United States, basing the population at $30,000,000$, would give $4,200,000$ drellings. And assuming that there are $5,000,000$ of farmers, we may say there are 700,000 barns. Now, greatly as the number of dwellings execeds that of barus, our opinion is that there are two barns to one dwelling destroyed by lightning.

The impression is common, that barns when first filled with the harrest are attractive of the fluid by the medium of the ascending gas of their contents. This is probably true, and it is our opinion that a rod to scrie as a conductor, so as to be a sure protection, must reach higher than this column of rapor. Some barns need sereral rods; others may need but one. It depends upon the location very mneh, whether on a damp or dry soil, etc.

Prof. Renwick, of New York, says :

"I doubt whether a barn was ever struck by lightning which was properly protected by a conductor."

Ah! but what is that proper protection? That is what we mould gladly 
tell the farmers. We linow of a fict that two barns were burned the last ecason in Westehester County, which were provided with conductors, which the owners thought as perfect as it is possible to make them. Sereral cases have come within our knowledge where green trees were tom to slivers near buildings, which saved the buildings trom destruction, while liphtuingrods on the buildings touched by the trees did not attract or conduct ilic fluid.

Then, as trees certainly are protectors, let every famer plant irees atronnd all the furmery. That they are the very best conductors we helieve, hut they are never tall enough to protect the ham when giving off its tuwering column of steam.

366. Haterial of Conductors atul Instlators.-It" a farmer lins determined to erect a lightning-rod, the first and most important thing for him to be anssured of is, what constitutes the best conducting naterial. As there are hut two materiuls, copper and iron, and ats both are good conductors, and will vary in power according to size, the choice may be regulated ly the curt. M. Ponlet, a French scientific writer, grives the conducting nower of enperer as five and a half to six and a half times (barying witl the specinens lrieul) greater than jron. Then, if iron is six cents a pound and copler thirty-aix cents, the cost would be equal for a given length of rod. 'This is probably a fair average of the differenec in the condueting power, as Dr. I'riesily maliea copper five times greater than iron, and Prof. Faralay six and two-fithl tinces greater. As seientific men have ealculated that a copper rod, to possess sulficient condneting power, should be, for short rods, half an incli dianceter, and for very long ones, three fourths of an inch, it follows that none of the iron rods in use are large enough, for they are generally under one inch diameter. We believe that that is large enongh, and we do not belicre that insulators are neessary, but that the rod slould be in one eontinuous prece, and if it can not be welded tomether an the grroumd where it is to be erectul, it slould be firmly serewed torether, so as to be as nearly solid as possible.

If the rod is continnous, it may be safuly fistencel to the building wisl ordinary iron staples. If it is inserted deep in the earth, so as al ways to he moist, there is no danger ahout the lightning leaving it while passing from the clond to the earth, shonld it be attucted by the ever hright point which the rod should, and must, possess, to be of any practical value as an attractor of electricity.

Instend of insulating a rod from the house, it would add to its eflicieney, if the house has a tin root, to conneet it with the conductor. It wumlel also be beneficinl, we believe, to connect the conductor with the tin mater-spruts of a woolen building.

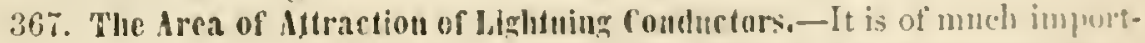
ance to a farmer, if he intemls to protect his buillings ly lightning ruds, to know low fitr a single rod will aflorel protection; that is, the area of intraction ovel which the single bright point of the rod is smplesed to exereise m influence-so as to attract or bend a stresm of electricity from its cunrse-so 
as to carry it down the conductor to the earth without harm to the bnikling. My own opinion is, that the area is much smaller than is generally supposed. If a rod is erected at one gable of a biln forty feet long, projecting ten feet above the peak, we do not believe it rould afford the least jurotection to the other end.

If a conductor is erected upon a dwelling, it should have a point ten feet above each gable and each chimmer, and then it is donbtful whether the steam and smolie arising from a wood fire wonld not prove a better conductor than a rod.

Wre should not feel any protection from the very best lightuing conductor projecting ten feet above the roof, at over ten feet from it. Probably this fact, that the area is rery small over which ]rotection extends, may account for buildings being stunck and destroyed which were furnished with wellaranged lightning conductors. The area exposed was too great for the attractive power of the rod.

36s. Protection from Fire.-There is no mistalie about the matter of protecting buildings from danger of fire, whatever there may be about protecting them from lightning.

In the first place, have a carefu] supervisory care in building that no wood is allowed to be placed where it can be heated to a point of ignition. Ilere is a case in point. In building a chimney upon the soft, damp soil of the Western prairic, where brick was too expensive to encourage excarating down to a solid foundation, the mason suggested placing hewed timber on the gromud, to which I readily assented, as it would save brick, and being two feet below the hearth there ras no thought of danger from the fire. So upon this foundation the chimney was built, and as it was built right end up, it afforded the opportunity of having large fires, though the fireplace was but a small one.

After keeping a hot fire throngh sereral extremely cold days and nights in midwinter, we began to be annoyed by the smell of wood burning in a confined situation. This contimued sereral days, and legan to be alarming, yet no one would belicre it conld be possible that those solid oak timbers under the chimmey were being consumed by subterranean fire. Yet it was so, and it was fonnd impossible to extinguish the fire withont digging up the hearth, and with great labor working out the most exposed timber; and as the other conld not be taken ont without danger of throwing down the whole chimmey, we saturated it with salt, alum, and lime, to prevent it from taking fire again.

This case we have introduced solely to prove how dangerous it is to allow any wood to come near enough to the fire to be heated rery hot, for wood will ignite from heat, withont any possible contact with the fire. Another case :

A gentleman in this city set a store in a lower room, and conducted the pipe through the room abore, used as a nursery. For conrenicnee of warming food he had a hole made in a slab of stone, just large enough for the 
pipe to fit closely. This stone was neatly set in the floor, forming, as the owner and the mason thonglit, arery safe way to conduct the storepipe, which did not stand within a toot of any of the wood-work. It was fo: at long time a great convenience, and rery sate; but one day the stove below: was heated pretty lot, and commmicated its lieat to the stune, and the wooden beans it rested upon, which had been long sensoning, ignited, and the honse was within a very narrow elance of destruction. Five minutes more of absence from that room, and it would have been too late.

We conld name unany instunees like these which luwe come within our own observation, but we hope theso are sullicient to put all who read them on their.guard against similar dangerons practices in huilding.

Stove-pipes may be safely passed through floors and woodeu walls by inserting an earthen pipe, at least one inch in dimeter larger than the storepipe, which should not be allowed to tonch the earthen pipe, but should bo wedged off from it by little piees of stone, brick, or broken carthenware. This allows a eurent of air continually to circulate, and renders it impossible to become heated so mueh ats to convey fire throngh the eartheu pipe to the wood-work. If the stove-pipe thts tightly in the earthen one it will be liable to become hot, like the stone mentioned, and set fire to the house.

369. Winsmills and their lise in a Farmery,-There is one more building, or an arlunct of some of the buildings of the fiumery, that slould be men. tioned, before closing this chajter, more fully than it is in the commenecment of Sec. XVII. We allude to the windmill. liesides pumping water, which, by-the-loy, would be a great help in the way of protection agrainst fre, a windmill attaelsed to a barn could be male serviceable tor a great many purposes, such as threshing, corn-sliclling, eutting straw, grinding fect, sawing wood, and tumiug the grindstone.

Wind is undoubtedly the cheapest power that a furmer ean use, and, notwithstanding its inconstanc5, the improvenent mentionel below operates well, and las been often ayplied to many valuable uses. By wiudmills, swamps may le draned aud mpland irrigated. What an advantage in a dronght in many parts of the country, besides the economy of nsing a great amount of fertilizing matter iu water at all tiues!

We have often suggested the idea of using wind-power to pump up water into a reservoir, or wind up a weight, to bo huld as a reserved pover, that could be used when the wind dil not hlow.

There is no doubt in our unind that such a cheap power conhl ho economically established to do a great teal of work that requires a motor "ypu almost every large farm. It the seat of the jower is at the ban, it cun lu carried to the loonse by a couple of wires, to do the chuming. We hare seen power carried thus from a water-whed, nearly lastf a mile firom the dairy, and it was used not only to drive the chum, but the washing mathine, the sausage-enttel, a small griudstone, mul the cotliee-mill. To obtain the puwer from the wind-wheel, all that would he necessary for tho darywomn to de wonld be to pull a cort or wire at the honse, which wouhl throw into gens- 
ing a driving-wheel, and that would, by means of the wires, convey a crank motion from the windmill to the churn, no matter how distant; and the motion can be stopped and startel as easily as thongh churning by hand.

The objection to wind-power is want of constancy. This e:m only he obviated by accmulating power. If the situation is sucl that a water "eservoir ean be filled upon high ground, to he used in a calm, the aceumu?ation of power wonld not be expensive.

The method of conveying power by wires a long distance, from the waterwheel to the chum, may be seen in several places along the Chenango Canal.

370. Se!f-regalating Windmills,-One of the best contrivances for a selfregulating windmill was invented by Danicl IIalliday, of Ellington, Tolland Co., Ct. The size mostly built by him has fire-feet wings, that is, the diameter of the wind-wheel is ten feet, and the first one was in operation for six months without a hand being touched to it to regulate the sails. It rim fifteen days at one time without stopping day or night, and it stood through some hard gales. The benuty of the improrement is, that it stands still when the wind rages hardest, with the edge of the wings to the wind, and as it lulls they gradually resume their position for a gentle breeze. It is so contrived that nothing but a squall of great severity falling upon it without a moment's warning ean produce damage.

The mill mentioned has drawn water from a well 28 feet deep, 100 feot distant, and forced it into a small reservoir in the upper part of the barn, sufficient for all farm purposes, garden irrigation, and "lots to spare." The cost of sueh a mill will be $\$ 50$, and the pumps and pipes about $\$ 25$. It is elerated on a single oak post a foot square, the turn eircle being supported by iron braces. The wings are made of one longitudiual iron bar, through which run small rods; upon these rods, narrow boards, half an inch thick, are fitted, holes being bored through from edge to edge, and screwed together by nuts on the ends of the rods. This makes strong, light sails, which, it will be scen, are fixtures not to be furled or elewed up; but they are thrown up edgewise to the wind by a rery ingenious and simple arrangement of the machinery, which obviates the great objection to windmills for fam use-the necessity of constant sur errision of the sails to suit the strength of the wind.

With this much food for reflection, we will close the chapter upon the farmery. 


\section{CII $\Lambda$ P'TER IV.}

\section{DOMESTIC ECONOMY.}

SECTION XXH.-THE FOOD QUESTION-QUANTTTY, QU.ILTTY, VARIETY, ADAPTATION, ADULTERATION, AND CILAGES PRODUCED ISY COOKING, BRIEFLY CONSIDERED.

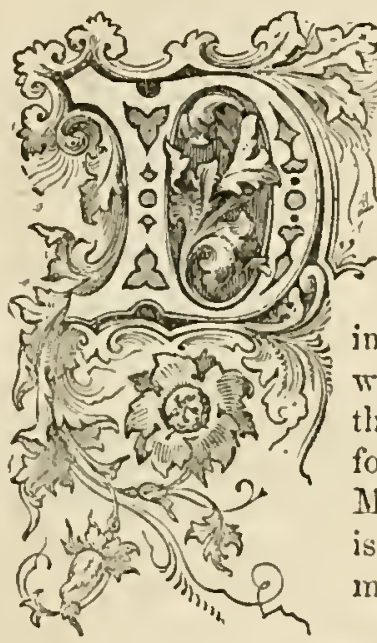

OMESTIC ECONOMY! That is it? "Domestic, belonging to the house or home; Fionomy, from two Greck words, signifying a house or fannily law-that which relates to the fanily conceris of a houschold, and the disposition or arrangement of any honschold work."

Such is the eharacter of this chapter. It is full of information useful to every houschold. Without it. we should have fallen short of our object in rriting this book. It was never our intention to make a work for the sole henefit of the male portion of farmers. Much of the preceding chapter, and nearly all of this, is intended to promote the eomfort of those who anminister all of our liome comforts.

We shall also say sometling that will be valuable upon the sulject of the dairy, at least to new begimers in the various arts and mysteries of domestic conomy.

No question can be discussed between the master and mistress of ulue house, nor between parents and a fitmily of growing children, that is of greater importance than the one that heads this section. "T'o the employelo and his hirelings, to the master and his slave, it is a question not only" of interest, but of health, and it is all concentrated in four words : quantity, quality, variety, adaptation.

There is only one thing more requisite, and that is, that each of these words should be fully understood and properly acted upon. liclicring that they are not so, we shall treat upon each hrielly in its order. And first-

:i1. What imount of Food is Repuired by a llard-working Man ? -This depends on the quality of the foorl, the matme of the elimate, and on such : raricty of circumstances that it is impossible to grive a sati-fictory answer. The arerage allowance to British saliors in active service is 302 ounces of solid food per week, and a pint and $n$ hulf of rum. Dr. l'ercy, nu linglish author, mentions the diet of a prize fighter during a contie of rigorous training, who ate one promd of mutton at each menl three times udiy"; nt dimer 
lic ate in addition two onnees of bread, and at each meal drank laalf a pint of ale. IIe walked regularly 17 miles per day. The total solid fool contained in this diet is 350 ommees weckly. We suppose abont three pumds of solid food per diy in temperate climates may be taken as the arerage consumed by hard-working men. But in the Aretic and Antaretic regions the amount of food that can he disposed of is truly immense. Thus Ross tells us that the Esquimaux cat 10 lbs. of neat at a moal, accompanied by the same quantity of oil. Parry weighed the food of nu Esquimanx lad, scarcely full grown, and found that he consumed, daring the day-sealorse flesh, $8 \frac{1}{3}$ lbs.; bread, $1 \frac{3}{4}$ lbs. ; ricl grary soup, $1 \frac{1}{4}$ pint; raw spirits, 3 glasses; strong grog, 1 tumbler; water, 1 gallon 1 pint. Cochrauc deseribes a Takut or Tongonse as eating 40 lbs. of flesh in a day, saying that a gool calf, weighing 200 lbs., "may serve four or five good Takuts for" a single meal," aud that lie has seen three of them "consmme a jeindeer at ono meal." Admiral Saritcheff says he knew a Iakut who consumed "the hind quarter's of a large ox, 20 lbs. of fat, and a proportionate quantity of melted butter for his drink" in a dar. The admiral tried an experiment with him by giring him "a thick porridge of rice, boiled down with 3 lbs. of butter, weighing together 28 lbs.; and althongl the glutton had already break: fasted, yet did he sit down to it with great eagerness, and consumed the whole without stirring from the spot; and, except that his stomach betrayed more than an ordinary fullness, lie showed no signs of inconvenience ol injury." Barrow states that three Hottentots ate one sheep in a day, and that ten of them ate an ox all but the hind legs in three days. The Samoyedes are stated to consume $S$ or 10 lbs. of meat at a meal, flavored with a dozen tallow candles, and washed down with a quart or two of train-oil. Extraragant as these statements appear to be, nost of them liave been verified by numerons observations.

We need not go to savage lands to find gliutons. We hare the well-anthenticated fact of one who lired in Connectieut, about seventy years ago, who ate three shad a day, upon a wager, thirty days in succession. The same man repeatedly ate a goose or a turkey at a meal. These were acts of gluttony, and we look upon gluttony as a great sin. There is just as much wrong in feeding too much to those who labor for us, who may happen to possess gluttonous natures, as there is in feeding others too little. Every laboring man requires a sufficiency of sonnd, nutritious food to enable lim to perform a fair task of labol. The question is, What is sufficient?

372. Rations of Southern Slares.-The arerage ration of negro slares in our Sonthern States is $3 \frac{1}{2}$ lbs. of bacon and a peck of corn-meal per week to each adult. The meal will weigh $14 \frac{1}{2} \mathrm{lbs}$, making $15 \mathrm{lbs}$. of the strongest lind of solid food. Then they al ways eat potatoes, turnips, greens, pindars, green corm, and other things in their season, enougl to make up an average of three pounds of solid food a day.

As it is the policy of plantel's to give the slares all the food that is neces- 
sary to give them strength, and as it is against the rules of good cconumy to give more, we may safely calculate that thee pounds a day is all that is l::horing man reepires.

373. Soldiers' Rations,-The Englisl are proverbially henry eaters, and the Englisl government hare not only studied ecomomy, but the watus of their licalthy, strong men in fixing their lations so as to give all that is neeessary, and this is tomel to consist of the following articles. While the men are in barmeks, $1 \mathrm{lb}$. of breal and $\frac{3}{3}$ of a lb. of meat per day. In camp of actual service, $1 \frac{1}{2}$ lls. of treal and $\frac{3}{3}$ of a lb. of meat. On foreign scevice, $1 \mathrm{lb}$. of bread or $\frac{3}{4} \mathrm{lb}$. of hisenit and $1 \mathrm{lb}$. of meat. When lilleted for board, the allowance is $1 \mathrm{lb}$. of bread, $1 \frac{1}{4} \mathrm{ll}$. of meat, $1 \mathrm{ll}$. of potatoes, and 1 quart of beer.

This was mainly followed in the Amerien army until the smmmer of is 61 , when in consequence of grmblings among the soldiers about insulicient food, the rations were incrensed, and are now as follows:

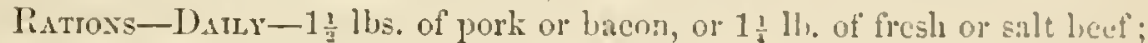
$220 \%$ of breal or flomr, or $1 \mathrm{lb}$. of pilot brest.

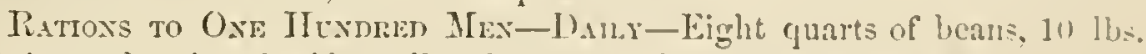
of rice or hominy, besides $1 \mathrm{ll}$, of potatoes three times a week to calch man, or a substitute therefor; 10 lbs. of cofiec; 1.j lbs. of sugar ; + quarts wi vinegar; 13 lbs. of adamantine candles; + lus. of soitp; 2 quarts of salt. Extra issues of molasses occasionally mate.

Iiations may be commuted at forty eents per day when stationed in cities. or when there is no opportunity of messing, or when in regular eamp, at the cost of the rations.

37. Variety of Food-Xan crares a clange of fond, that is, a raliety of substances, either one of which would subiain life, but would not be siltis. factory. Nature demands the variation, and the mixing tomether of the Eeveral substances. Why? Simply lecause no one will give all the c!ements that go to make up the animal economy. One articlo furnishes phosphizte for bones, which another article is destitnte of, ret it may cont:uin matter that will elothe the boue with inuscle. Fool that contained ueitler fat nor sugar would he insuflicient to lieep uj, the animal heat. food that contained all the elements of hone, muscle, fiber, fat, and liea-jroducing qualities, might he so coneentrated as to bo unwholesome.

A man fed upon pemmican would lisve a disprosition io eat strnw, lusks, and twigs, or grnaw the bark from trees to get something to disteml the stomach, and enalile it to perform its functions healthily. I.et this bo thought of in feeding domestic animals as woll as men. It will furnish su easy rule for your gudance. Julge them ly yurselt, and aet necorlingly. Yon will find it an easy und sure rond an success. Whe do not for animals. quadruper or biped, recomment, a variety of froul at the same meal-ming a change from time to time, so ats to reire variety, and consequently all the clements necessury to produce growell.

And neither man nor beast will reanel a high point in the seale of perfec- 
tion who is confined to one single article, or to two or three articles of fool. Lonk, for example, at the rice-cating nations; also to those who, like the lisquimaux, live principally upon the fat of seals and whales; or to savage sations, confined to an almost exchsive diet of meat. Each shows a lack of some quality that we consider essential in civilized nam. The continenent of a larere" portion of a nation of people to a diet of potatoes is rapidly working a deteriontion in the race.

"The profusions of nature lempt the appetite of man. Tise productions of all the carth are at his command. But, for the control of his appetites, man is endowed with reason and conseience. Tho brute is governed in reard botls to the quantity and lind of its food by an justinct from which it duely deviates, unless when domesticated, and consequently corrupted.

"There are three practical laws to be observed in the taking of food. One regrards the time, another the quality, and the third the quantity.

"An interval of" at least five hom's shonld elapse between meals for alults, muless some extraordiuary exertion has exhausted the system, or soncthing lias intermpted or prevented the reception of a full meal at the stated hour. The stated hours sliould be resular."

375. Quality of Food suited to a Farmer's Wamily.- " $\Lambda$ s to the quality of the food, there is no doubt that the more simply it is cooked the more easily it is digested.

"Chemical analysis should be the guicle for the cookery book.

"No one wonkl think of eating raw potash, a substance, that dissolves metals, but we do not hesitate to cat salerntus, which is a modified preparation of $i$, and has the same, though a more gradual eftect, upon the orginic tissues and the blood. Soda, it is well nuderstood, rots eloth and takes the skiu flom the hands when it is put into soap, or' even when used to 'break harel water', as the washerwomen term it; yet we put it into bread and calies. Our stomachs were not made to digest metuls, and when we powder them and eat them, we try to cheat nature.

"Spices were undonbtedly made for nse in those climates where they grow, but the natires of those climates use them nuch more sparingly than we do. We may reasomably suppose that they are more adapted to the wants of hot climates than of cold ones, as mature has placed them in the former, and yet we saturate our food with them, mix them together, destroy the flavors of each by so doing, and make a stimuhs to appetite by a conglomeration, which is a most unmatural one, and gradually injures the very jower of digestion. We thus conceal, also, that fine aroma of vegetables and meats which distinguishes one from the other, and deprive ourselves of the pleasure God designed we should feel in partaking of thein. There is a delicate fruit of the tropics resembling a muskmelon, which grows, however, not upon a vine, but upon a tree, the taste of which is so tinely delicate, that a foreigner can not even perceive it at first; but if he does not cover it with pepper and salt, as we have seen many foreigners do, to 'give it a taste,' he will, after partaking of it a few days or weeks (aceording to 
the simplicity or sophistication of his apjetite), appreciate its flaror, which is that of the most delicate anomatic nut. In on climate we lose the flavor

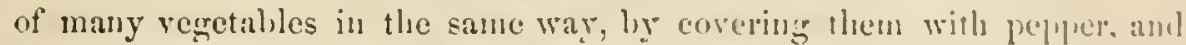
also by putting them into water helow the boilingrepoint when we couk then Every one who is so haply as to live in the comtry, and can gather rewetables daily from his own garden, knows the diflerence between them when gathered thus and properly cooked, ant those which have been picked and kept for market even one nighlit.

"When substances like rice, eorn-starch, and furma are usch, which have rery little taste (rice, beeause it has been sn long exposed to the air after it is gatlered, and corn-stareh and farina, becanse, from the morle of their preparation, they lose a great part of the untritions ingredients of the (curn), a delicate flavoring of spice maty be used withont injuy to licalth.

"Science may at last bring us to the conchusion, that cach climate and region produces those articles of food which it is most Inculthful tu eat in their respectire localities.

"The quality of chiblren's food should differ from that of alults, so liur as that it shonld consist of more substances containing sturch, grum, and sugar.

"It is not the most costly or most luxurious living that we would arlvocate, but it is a rariefy of food. The difliculty is, that we are tempted sometimes by a great variety of dishes at one meal to eat too much. 'This is no argument against rariety of tood.

"It is important that we should study to inerease carth's prodncts, and improre their quality, to produce the highest condition of pertection in 1 man. $\Lambda$ man, it is true, may be a glutton, and consme mountains of fleslo and rich, dishes, but that is not the pinint. It is that wo all should consume the lest food possible to be produced, and in suthicient varicty to give healtlyy results."

376. How Food affects the system.- "The presalent idea that soup which sets into strong jelly is most mutritions, is altngetler a mistake. The soup eets because it contains the gelatin of the sinews, tlesh, and bones; it has been fully proved that no animal can live upon this imagined richus: alone. In fact, such jelly is unwholesome, for it hats the blood with useless substances; hence what are telued rich somps, being loaded with gedaltiu, are not ranked among the articles of wholesome food. Minked results of the eflects of cooking upon food miy he secn in the eontrast between civilized and savage nations. In ererg mation on carth, those who rule the masses are invariably better fed than the masses themeclves. This is ure denced in the power exereised by the beefenting British over the riecenting liast Iudian nations." It is further evidenced ly the condition of the preople of this conntry, where the masses are hetter feil than in any nther on earth, and where there are greater numbers of men fit to be rulers than in any other. And this proportion will increase as the laws of lygencun are heter understood, for then, those who control the preparistion it foul fol ihuse 
masses will understand how cooking affects the raw material of food, so as to make it wholesome and mutritions, or otherwise.

Next to the knowledge of the diflerences in the luman constitution and the nature of food proper for min, the art of eooking so as to make the food most agreeable to the palate shonld be studied by erery good lronsekeeper. Bear in mind that in preparing food three things are to be mited-the promotion of liealle, the stndy of cconomy, and the gratification of taste.

Pie-eating is an Americanism that we can not approve nor recommend to the extent it is practiced. Though pie be nearly allied to piety, this does not save it from condemnation. Pies are caten for breakfast, for lunch, for diuner, supper, and many go to bed on pies. "Oh, pies sare a great deal of cooking!" says the frugal housewife, "and are so convenient for the childien to take to school, and then they are not so hungry when they have pie to eat." Pies are New England's farorite refection; bnt tlat does not prove them, as a general thing, well adapted to the wants of the luman srstem. Pies of erery deseription, as nsed in almost every New England farm-lionse, may safely be classed "unwluolesome food." The worst of the fimily is the one most prized-the rich, sweet, highly spiced mince-pie. It is one of the prolific parents of dyspepsia.

377. Alaptation of Food to Circumstances.-One of the great mistakes of many families is in not adapting the food to the season, the elimate, and circumstanees. A liard-rorking negro slare may eat fint bacon and cornbread in August, and bask in the sm in Mississippi. . It would not be good diet for a sedentary white man.

Fruit is an essential article of food for the preservation of health, in bilious loealities. It seems particularly adapted by nature to that cnd.

A sensible man always adapts his eating to his labor. The following remarks upon this subject we adopt, because they are pertinent:

"I have been asked sometimes how I could perform so large an anount of work with apparently so little diminution of strength. I attribute my power of endurance to a long-formed habit of observing, erery day of my life, the simple laws of health, and none more than the laws of eating. It ceases any longer to be a matter of self-denial. It is almost like an instinct. If I liave a serere tax on my brain in the morning, I ean not eat licartily at breakfast. If the whole day is to be one of exertion, I eat very little till the excrtion is over. I know that two forces can not be concentrated in activity at the same time in the body. I know that when the stomach works, the brain must rest-and that when the brain works, the stomach must. rest.

"If I am going to be moving abont out of doors a good deal, I can grive a fuller swing to my appetite, which is never exceedingly bad. But if I am engaged actively, and necessarily in mental labor, I can not eat inuch. And I have made eating with regularity and with a reference to what I have to do, a habit so long that it ceases any longer to be a subject of thought. It almost takes care of itself. I attribute mucli of my ability to 
endure work to good liabits of calting, constant attention to the litws of slecep, physical exereise, and generol cheerfulucs.

"There is one thing more to be salul in this comnertion. It is not a matur

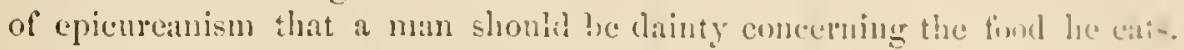
On the contring, I hold thit a civilized man onght to he civilized in lis cookery. I suppose one of the infillible signs of the millemunum will be it better regulated litchen-a lifchen that seuds out food that will hel] to promote health and increase Cluristinity."

878. The Fobd and Clothing a Man bay consume in a lifetime.- Hox. Soyer"s "Modern IIonsewife" grives the fullowing calculation as the probulale anomt of food that an epicure of seventy years might liave consmund. "Supposing lis gastronomic performances to commence at wu yeur. lue will make 65,700 breakfasts, dimers, and suppers, to say nothing of lunchuns and extru fuastings. To supply the epicures tal le for sixty ycars suy sur cal.

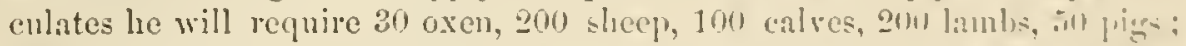

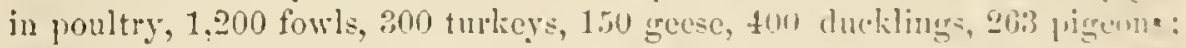
1,400 partridges, pheasants, and grouse; foo wondcucks am snipur: linl wild ducks, widgeon, and teal; fisl plorers, luffs, and reces: sull yuail-,

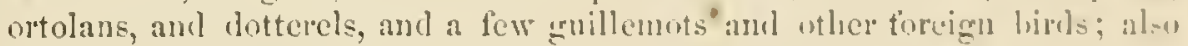
500 hares and rabbits, 40 deer, 120 Guinca-fowl, 11 peacocks, aml 3til vilul. fowls. In the way of fish, 120 tmphot, 140 saluon, 120 coul, 2hin tront, fun mackerel, 300 whitings, S00 soles and slips, too flumblers, fint recl mullet,

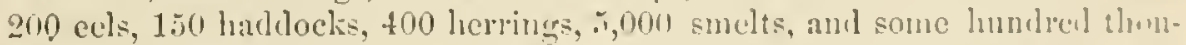
sand of those delicious, silvery whitehat, hesides a few hundred species ut

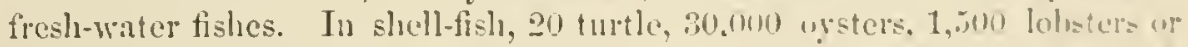
crabs, 300,000 prawns, slumps, sardines, ant ancluries. In the way of

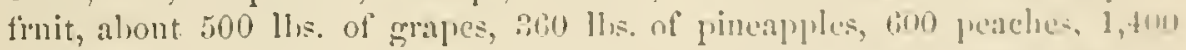

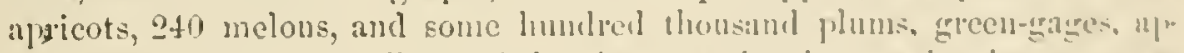
ples, pears, aud some millions of cherrics, strawherres, rasplecrics, currumb. mulberries, and an almudance of other small fruit, viz, wahnts, chestumts.

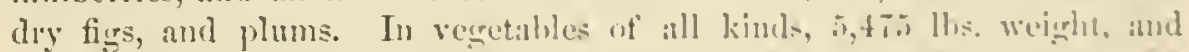

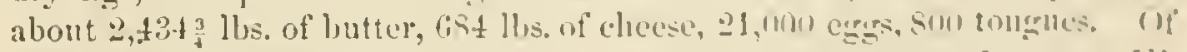

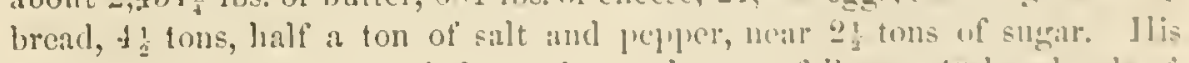

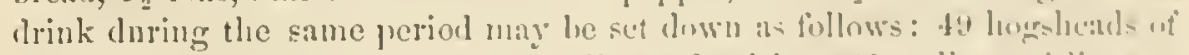

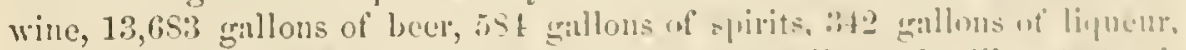

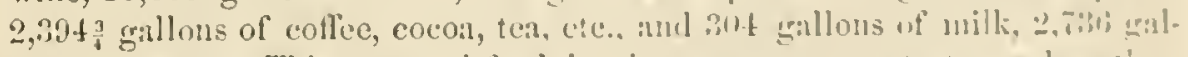

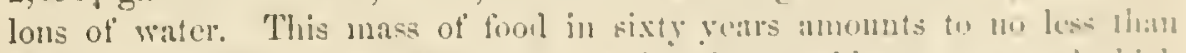

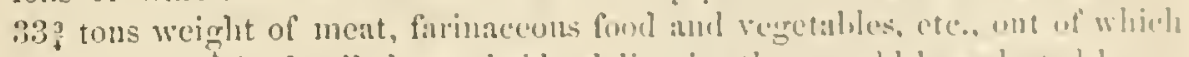

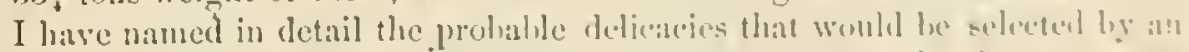

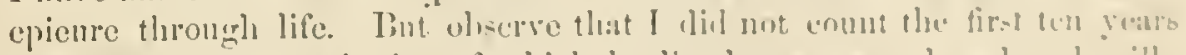

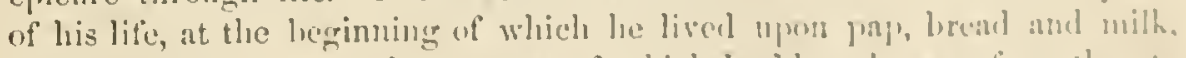
etc., also a little mest, the expense of which I athel to the are from then tw

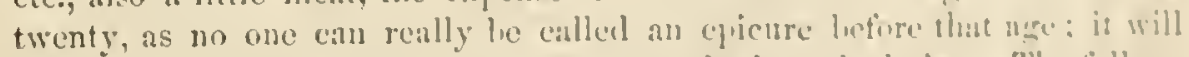
thus make the expenses moro equal as reande the cublenlation. The fullows. ing is the list of what I consider his ditily me:ll-: 
"Breskrast.-Three quarter's of a pint of eofiee, four ounces of liread, one onnce of hutter, two egras, or fon onnees of meat, or four onnees of fish.

- Ixxcn.--Two nunces of hreal, two ounces of meat, or poultry, or game, two onness of recretables, and a half pint of heer, or a glass of wine.

"Disxisi.- Ialf a pint of soup, a quarter" of a pound of fish, half" a pound of meat, a yuarter of a pound of ponltry, a quarter of a pound of sarory rlishes or erame, two ounees of regetables, two onnces of bread, two onnees of pastry or roasts, half an onnee of cheese, a quarter of a pound of fruit, one pint of wine, one glass of liquenr, one cup of cottee or tea; at night one glass of spirits and water."

To this we lave added the following calculation of the clothing the same man may have used. We estimate that a full-nlbessed man carries about fitty yards of cloth upon his body, or at least it las taken so many square yarks of cloth to make the following garments: one under and one orer shirt and drawers, eight yarls: rest, with all its inside and ont, four yaris; coat, orercoat, and cloak, 32 yards; the landkerchicfs in the coat and cloak pockets, two yards; pants, lined, four yards. Then we may add a nightshirt, four yarls, and norning wrapper, 10 yards, and we liave $6 \pm$ yards for a single snit. Allow six of these snits a year-of some gaments he will want more, and some less than six, but take that as an arerage, and we hare $34 t$ yards for the gentleman's wardrobe one rear. Multiply that by sixty years, and we have 23,040 yards of cloth, which appears a fair allowance, as we throw unt the ten year's of elildhoor. With these garments he will want each year two pair of boots, two pair of shoes, two pair of slippers, two pair of mbbers or overshoes-450 parirs. Tith these lie will wear sixty dozen yairs of stockings and (four hats a year) 240 hats. I will say nothing about the yards of eloth that he will want abont his toilet and table, his carpets and eurtains, and his bed, with its daily cluange of bedding; but yon can imagine it wonld make a large spread. The great question for consideration, in an arricultural point of vier, is this: Could such a consumer of earth's prodnets produce as much as he consumed, with all industry applied during lite, or wonld he be dependent mpon the labor of others?

37\%. How cooking Changes lood.- We are not going to make a cook-book, but simply to attract attention to some of the leading seientific prineiples of the effect of fire upon articles of tood.

Meat, for instance, often loses more than lualf its sulstance, which is rasted and lost in the process of cooking, because the cook did not understand some of the simple elcments of the chemistry of cooking, and the eficet of water and heat upon flesh.

If meat is to be boiled for cating, particularly fresh lean beef or mutton, never soak it in cold water. IIave your water boiling over a brisk fire, and plunge the meat into it, and see that the heat is kept up. If soup is to be inade, then the meat should soak a long time in cold rater, because it extracts the substance that is wanted in the soup, learing the fibrous portion of the meat almost worthless. If the meat is to be boiled for eating, plung- 
ing it in hot water has the smme eflect that is produced mpon an cger-ilue albunen is coagulated, and remains in the meat, anl couts with it, anrl becomes the most mutritive porrion of it. Theretione remember it ats unc of the most important items of knowledge abrut coulking. never to put a pieces of meat into water to boil, muless the water is builing lout and never put at piece of meat to roast until your fire is rery hot; aud it it geos into an weren to bake, see that the oren is hot enough to couk fle untside alunust instantly. If you let it simmer slowly, it will onze ont the riehest portion of its projert!" for food. "The first effect of applying a strong heat to a piece of fresit meat, is to cause the fibers to contrict, to squecee ont at portion of the juice, and partially to close the pores so as to prevent the eseape of more. 1leat is applied to meat chiefly in three ways-boiling. roasting, and biking. During these operations, fresh beet and mution, when moderately fat, lose, on an arerage, about as follows:

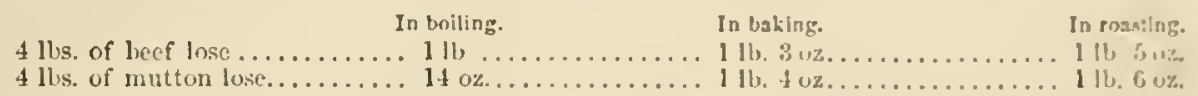

The greater loss in baking and roasting andises chicfly from the erreater quantity of water evaporated, and of tat which is melted ont by ceither of these two methods of cooking.

"In preparing meat for the table, we disenver that it is most desiruhle to retain all the ingredients of its juice; low this is to be done will depend much upon the method of eulinary procedure. It the piese of meat be introuneed into the water when brislily boiling, the alhunen it its surfice, and to a certain depth inward, is immediately coagulated, llum; inclosing the unass in a crust or shell, which ncitlel permits its juiee to How ont, nor the external water to penetrate within, to dissolve, dilnte, aml wealien it. The greater pat of the sapid constitnents of the meat are thus retained, jendering it juicy and well-thaverel. It shonld he hoiled fur osly a few minutes, and then liept for sume time at a temperature fiom lis io 165 lenrees. Meat is undertone op bloody when it has been licated throughnut only to the temperature of congulating albumen (1 fll dergress): it is quite elone or evoked when it has heen lecatent throngh its whole ma-s

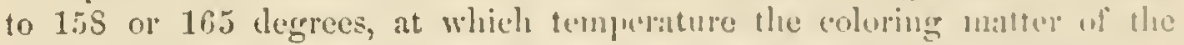
blood coagrulates. As in boiling, su in haling or roasling for whether t!n

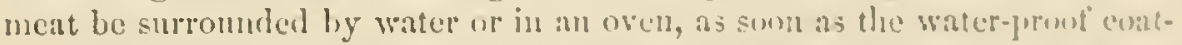
ing is forned aroum it, the furthor changes are eftected alike in both catses, by intemal vapor or steam. In roasting or haking, therefore, the tire slinulal

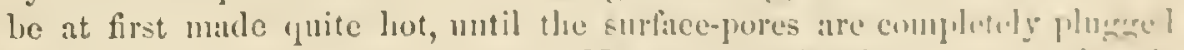

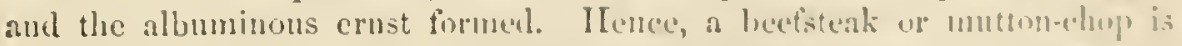
done quickly over a smitrt fire, that the richly-flatured matural juices may be retrincel."

The above is estracted from a most raluable bonk-one that mo lonke

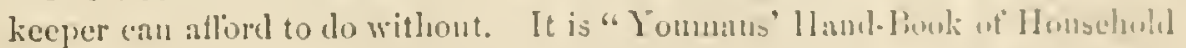
Science." It is seicnee in such an attractive form that nll may leabl it with 
pleasure and protit. Treshall draw upon its waluable store-honse of knowledge for other facts in confirmation of what we have to say upon the food question.

380. How the Albumen of Weat is lixtracted.-When we wish to dissolve ont the albumen, and not the gelatin of meat, for soup or for beef-tea, which is much used as nutritive food for the sick, the meat should be cut fine-ilue finer the better-and soaked a few miuntes in an equal reight of cold watter, then slowly leated to boiling, and so continned a few minutes more, and when strained yon will have as much weight of pure extract as you had of meat, and it will aftord equal nutriment. It would not do so if hoiled for hours, in a linge mass. IIence, ment for somps should be finely divided. The effect of long boiling of meat for $s 0 m$ is to thicken the soup, and mako it apparently richer; but it is so ouly apparently. The albumen is extracted by coll water. It is cooked in the wite' in as short a time as an egro would cook. The substance extracted by long boiling, making the soup appear thick when cold, is gelatin. Still further boiling would malie glue, which would harden by drying, like the glue of commeree. It is not considered a untritious kind of food.

3\$1. French Experiments with Gelatinons Food.-"The French attempted to feed the inmates of their hospitals on gelatinous extract of hones: murmurs arose, and a commission was appointed, with Magendie at its heal, to investigate the matter, the conclusion of which was, that giving grelatin to the poor was just equiralent to giving them nothing at all. The use of gelatin as a mutritive or invigorating substance may be regarded as griren up. The utmost elain uow put fortl for it is that, mixed with other food, it makes it go further; but at the same time we must be eareful not to use it to cxcess, as it is apt not only to wealien the individual by its insufficiency as an article of diet, but causes also diarhea, whether by acting as a foreign body, or by some spontancous decomposition. Ileuce the um holesoneness, to healthy stomachs, of dishes containing a great quantity of gelatin, such as mock-turtle soup, calves'-foot jelly, etc."

The healthiness of any kind of strong meat soup is not a matter of doubt in the minds of those who have given the subject a thought. It may be taken in small quantities at the beginning of a meal, when it will be immediately followed with fibrous food; but the appetite nerer should be satisfied upon soup alone, unless it is soup-maigre, ol soup made almost entirely of regetables.

352. Relative Valines of Food for giving Warmth or making Flesh.-The following table shows Liebig's estimate of the proportion of warmth-giving substances to the flesh-producing sulbstances in various articles. Basing the flesh-producing porrer at 10 , cach of the following articles gires the proportion of warmth-producing power set opposite.

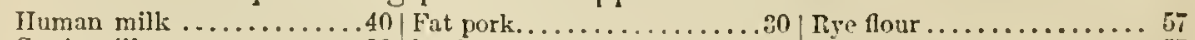

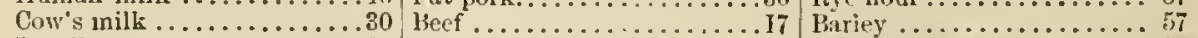

Lentils ...................21 | Hare..................... 2 white potatoes......... 86

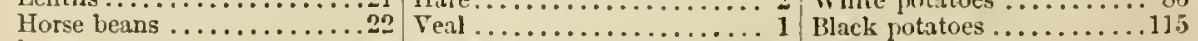

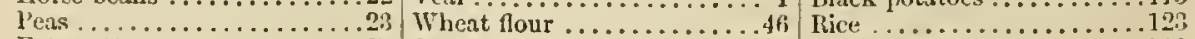

Fit mutton.............. 
This tahle gives a suffieient explanation of the reason why luckwheat is always used as winter food. The reason is still more apparent when we know that butter and syrup, which are eaten with hurkwhent eakus, are also producers of heat. It sliows that veal is a very fit fond for children and very mufit for aged people. In cold climates, particularly, whele men are much in the open air, they instinctively crave fat meat. At the tropino, instinct tenches man to consune an abmondance of thits and vergetalles. In temperate regions, where we may indulge with impunity in in viriuly ot fool, instinct is not so strong, or at least does not point ont so merringly what we should eat, and therefore the juestion should be more fully dincussed; for among all the arts of civilized life there are none iu which all are more interested than the preparation of nur daily fond.

3S3. Changes produced in Cooking Vegetables,- Inay vergetalles, for instance the potato, in a raw state, are wholly unfit for food. Every homsekeeper knows that couling renders them palat able and wholesome, but covery one does not know how they are allected hy heat, nor wh one mode of cooking makes them aceptable to the taste, while they may he nearly Eloiled by a different appliention of heat. IIcuce it is not always alpulicul in the right manner to produce the lest effect.

It is often stiul of potatoes, "they were spoiled in the eooking." Louk at the reason. I pound of potatoes contains on an average abont three "fuarters of a pound of water and two to two and a lialf omuces of starcli. It a! contains about one fourth as much sugur and gum as it does starch, and about one sixth as much woody fiber.

If a good, sommel potato is plunged whole into hoiling water and licpt hoiling until soffened throughout to such a degree that it eonld he rearlily mashul, the starch-grains lumst and alisorl, the water, so that the mass nppears more like meal than like starch boiled in water, and is then in a condition to atforl its untritious properties realily to the system. If potatios are maturally bad, cooking will not make them grood, lut lad cooking will make the lust gotatous quite unfit for human food. If they are put into rolu water amel sinmered slowly till soft, they will generally lecome so waxy that they ate quite imligestible.

If potatoes are roasterl or baked, they should be put into a hot neen or burierl in hot embers, and hept hot mut taken ont, which slionlul le as soon as sufficicntly cooked_otherwine a new change takes place, the water herrins to evaporate, and the ontside hurns, while the interior sonn lecomes worthless.

In frying potatoes, the starch and fibrin aro often turned to charmal, which is just as nutritions and digestilne as clanreoal male of womb. As it is with potatoes, so it is with many other vegetables-they may he spoiled by improper cooking. As a gencoul rule, put all into loiling water mul keep it hoiling briskly till the artioles are sullicicutly conked. Never at tempt to conk green regetables in what is termed lonril walor: it will sometimes render green peas wholly unfit lor fool. The diflenlty is often rem. 
edied by putting a little lump of potash, saleratus, or soda in the water. If too much is used, it causes the regretaliles to fill to pieces.

¿St. Reasons for Improved C'ookery.-Erasmus says : " Barl fecling unakes the rulgar selitions and quarrelsome." Perlaps this will aceount for the "luarelsome character of some fintilies. We serionsly think erery young "loman shonld have some linowledge of cooking. Ignorance upon this sulject ought to be a reproach. Inew nations have the wealth of matcrial for fine cookery that we possess. Fish, tlesh, and fowl are abundant ; fruits and vegetables unsurpassuble, and can be rinised withont great labor or expense, and it is owing to our own culpable carelessness in all that pertains to health that wo are not the healthiest, best fed, and best trained people in the world. Iet Anericans generally undervalue preparations for eating. Dislaining gluttony, despising pampering to fancies, they run into the opposite extreme of neglecting that which is of real value to their bodies. This inattention proceels not from inability to comprehend the science of caokery, nor real dislike to good things, for their appleciative power of such is on a par with that of other nations; but they grow up with the idea that it is mbecoming to be dainty, and beneath their dignity and independence of cluaracter to think too much of their stomachs. Aneriean mothers too seldom instruet their danghters in the culinary art.

In early times necessities were stronger than comforts; kitehens were unfurnishel with conreniences; cooking nteusils were clumsy and scaree; pots and liettles did donble duty; iron skillets were used instead of saucepans. This is rot and need not be the case now. Erery farm-louse shonld have all the modem improvenents for cooking, and then as a greneral thing onr cooking should be better; and as necessities are no longer strongen than conforts, the reason that we lack the comforts is because on young Anerican housckeepers lack the linowledge, and, for a certainty, their Irish cooks do not possess much of the seience of the useful art of cookery.

Every beginner thinks it an easy thing to learn, and, without any linowledge of the necessary rudiments, expects t $\Omega$ blunder into some sort of proficiency, so that in time the mistakes come to be regarded as the rule, and they abide by their own experience, rather than accept of rules that science teaches.

Another, and perhaps to most peoplc the most important reason for improved cookery is, the econony of food. "What shall we eat?" and "IIow shall it be coolied?" should be made a part of the houschold economy of erery family, particularly every one who purchases food by the wages of daily labor. This question is not an idle one, and only interesting to those who live in cicies. It is equally so to those who fumish the eity with food. Let us glance at the prices which the consumers in the eity have to pay.

Of late years, the price of butchers' meats in Now York, at retail, have been frequently at the following rates:

For roasting picees of locef and beef-stealss, the nominal price per pound 
is trom 15 to 25 cents, while the real price, owing to the cheating in weight, is often 25 per cent. higher. I piece only fit tor somp is changerl at albut 12 or 15 cents, and a shin-bone, with rery little nueat, rates at 10 cents it pound. Plates, navels, necks, briskets, and rounds are rillely sold fre-h, and one of the strongest reasons griven by lutelicrs for selling the portions universally ealled for at such high prices is, that they can nut retail the coarser parts at any price, exept the small portion taken as councd bect, and for this the price is sometimes from 12 to 1 s cents a pound. I leg ol loin of mutton is sold at 16 to 20 cents it pouml, and all the coarser jairts at 12 to 16 eents, and some of them are course and poor enough. Teal that is fit to eat, is sold at about the same price per pound as mutton. Lamb is fifty per cent. higher. Frush pork-miserably pror, too-sells it 12 to 15 cenis. Salt pork and smoked lincon sell for 15 io 15 cents, and smoked bect the same.

When the greatest meat-cating people in the world pay such jrices, it would he reasonalule to expeet that they would he willing to leam and practice improved cookery. We are sorry to say that they du not. A scliunl that teaches the art is rare. It should, ats a miversal rule, he tamght in all schools. In many families, with all the economy of the hest honseliecping, it certanly is a question of scrious import as to what we shall cat, that will afford suflicient nourishment and raricty of food for health, and sill cmalde thuse whose income is linited to keep expenses below that linit. Insuch fimilies it is important that they should learn how to conk butchers uneat more economically than it is generally in Autrien. In some mensure alrintage can be taken, thongh it seldom is, in luying fresh meat. The price by the piece or by the quarter, of heef and mutton, often raries fit? per ecent., and a fore-quarter always sells the lowest; yot, to the consumer. it is absolutely the most valuable.

The trucst economy is to eut less expensive meat and more vergetable's, and learn how to componnd them as the firench do, so as to make wholesome, mutritious, conomical foorl hy iunpureul conkery.

385. Hater for Cooking, - One reison why we lave treated so largely" upon

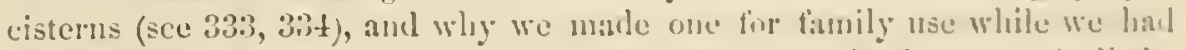
a never-tailing well of water, is becumse rantwater is the hest of all fin culinaly purposes. What is termed hard-water is untit for conking soms kinds of regetables, and is nurer good for teat. We lawe alrealy stated that Watel is sometimes so Jatul that green peat cunlel not be cooked soti in it. On the otluer hand, care muat be taken in the use of ran-water, or the fender vergetables will be brolien down ly a litle over-boiling. In such water always le careful to throw as much salt as will serve to sealom the beare tables for the palate. Oniun; lose nearly all their peenliar thanr what oiled in soft rater withont salt. 'lhis mater of sultulle waser for the hifclen lus quite as much importance to the coule as it has to the lamedres.

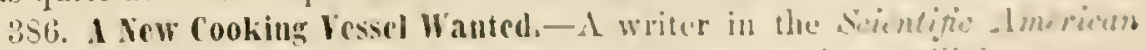
suggests an improvement in cooking vessids that wo hope will lue at ance 
actel upon. It is to coat the inside with silver or platimum, which could he done ly the galranie hattery, so that the expense would not be too great for ombinary use in the louses of those who are able to live iu war suited to a high order of civilization. This would be al particularly desirable improvement in kettles for heating water for tea. So it would for such cookery as requires poreclain-linel liettles. From the greatly increased supply of silver flom Washoc, Arizona, and other silver mincs, we may yet be able to improve our domestic utensils. Iron, copper, brass, zine, are all ohjectionable for many purposes, and porcelain lining is soon destroyed by careless coolss.

:B⿱. Hour-llow to Select Good.-Farmers of all the Eastern States luy flom, and some of them are not very good judges of what they luy. There are a few plain rules to observe in buying flour ly whicl you can tell its quality, and seleet that which is good. The best flour is not suowy white, lnt lias a yellowish tint when a handful is squeezed together and lien broken open. Lay a little in the palm of your hand and smootle it with a knife or your finger, and see that it is free from specks, and of eren fineness, but not an inpalpalsle powder. To prove this, tlurow a little lump agninst a perpendicular board or smooth wall, upon which the most of it, it good, chonlel stick. Good flom, squeezed in the hand, will retain its sliape. If you wet a little in your hand, see that it does not work soft and sticky, or you may get spring-wheat instead of winter-wheat flom. Flour that works sticky is not grood. If it has a bluish tint it is not good. If it falls in d!y powder when thrown, or if it falls apart, dry and powdery, when squeezed, it is not good. We commend to all families who buy flon the trial of these tesis with the flour now on hand, the quality of which is known.

3SS. Adulterations of Foos.-The first object of a liouseliceper sliould be to procure madulterated articles. This is very diffienlt for eity people to clo, owing to the adulteration of almost every article of food prepared for sille. But this is not the case with most of the food used by farmers, hecause it is made of lome products.

Many of the adulteratious of sinch articles as are usually purehased may be detected by simple tests. The microseope reveals the adulterations of" flowr, sugar, farina, arrow-root, stareh, salt, etc.

Bread, that most important article of food, is always more healthful in a farmer's family, because it is free from adulterations, or at least mueh more free than baker's bread.

389. Wow Eating Affects the Health.-To meet at the breakfast-table, fatlice, mother, clildien, all well, onglit to be a happiness to any heart; it slould be a source of humble gratitude, and should walie up the warmest feelings of our nature. Make it a lule nerer to come to the table in a chmplish mood. I.ct joy pervade your meals.

"The tables of the rieh and the nobles of England are centers of mirth, wit, and bonhomie, and they live long. It talies lours to get through a repast. Tlie negroes of a well-to-do family in Kentucky, while at their 
meals, abandon themselves to jabber and minth, and they enjoy life. At tho family-table all slould nect to make a common interehange of high-bred courtesies; of warm aftections; of checring mirthfuluess, and that gernerosity of nature which lifts us above the butes whel perish; for such thines jurumote good digestion, health, and loug life. Children in good healuh, if left to themselves at the table, become, after a few monthiuls, grarulous and noisy; but if within bounls at all renconable or bearable, it is better to let then alone; they eat less, because they do not cut so rapidly as it connelleal to kecp silent, while the very exhilaration of spirits quickens the cireulation of the vital flude, and energizes digestion and issimilation."

Let this excellent adrice of IIall's Journul of Healle be followed unirersally, and we shall hear less about dyspepsia.

390. Farly Breakfast-its Effect on Health.-" Treakfast sliould he caten before leaving the honse in the morning for exereise or any deseription of labol: Those who practice this will be able to perform nore work, and witl sreater confort and alacrity, than those who work an hour or two lufuro breakfiast. Besides this, the average duration of the lite of those who tako breakfast before exereise or work will be a number of years greater than those who do otherwise.

"If early breakfast were taken in regions where chill and fever aud ferer and ague prevail, and if in addition a brisl: fire were kindled in the linnily room for the hours including sunset and sumrise, these troublesome mallalics would diminsh in any one year, not tenfold, but a thousand-fold: becinse miasm is more solid, more concentrated, and lence nove malignant about sumrise and sumset than at any other lour of the twenty-four."

This, and much more said upon the sane sulject by Dr. Mall, acrees fully with our long experience in a miasmatic region of the West. The nust industrious people who eome from New England, where they laul always lecn aceustomed to early rising and working before breakfist, were the ones most liable to attacks in autumn of bilious lever and argue. leet ns therefore urge erery resident in such a reginn, never to gen to work, wor go much out of doors before breakfasting, nul let no expense or troulile about the work deter you from having your dwellings purified by fire. ln sume parts of South Carolina men have lost their lives from a single night's cxposure to miasm, withont fire. Ilence, whenerer persons are compellen to spend a night in such a situntion, their first eare is to build a lange tire and, withont sleeping, liecp near it, even in the smoke, and thus they escape the danger of the poisonous af umosplicere. 
SECTION XXIH.-TIIE BREAD QUESTION-VARIETIES AND QU.ALITI OF BREAD, AND IIOW IT IS MADL-CYLAST, AND HOW TO MIAKE IT FOR FAMILY USE.

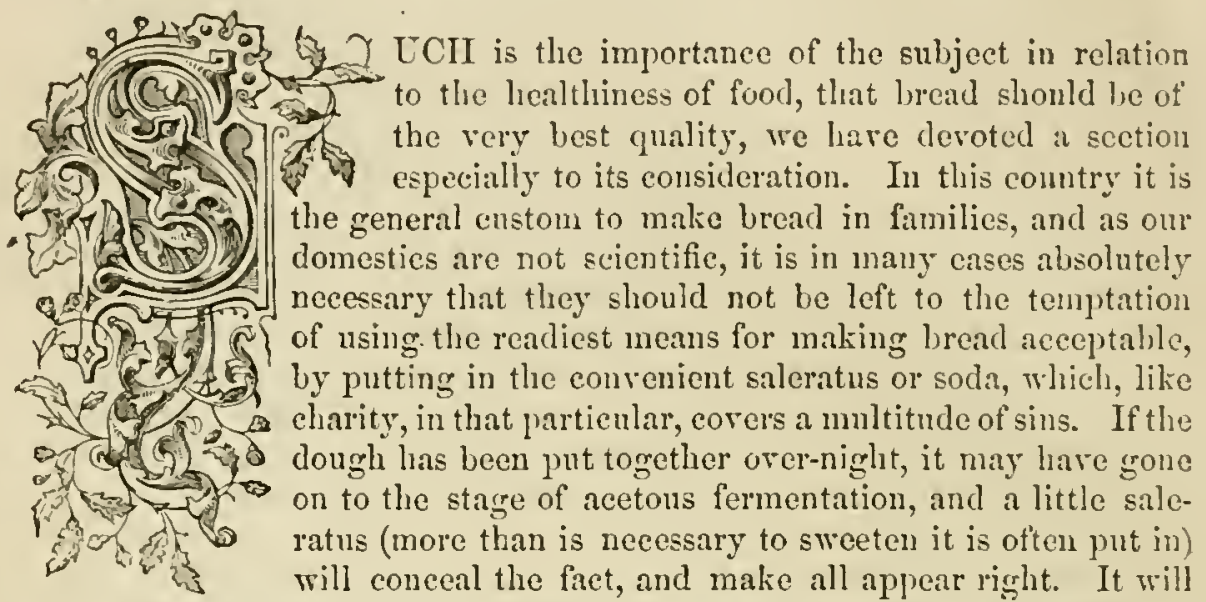
also save the trouble of kneading well. Let the mistress, then, if she do not actually mix the bread, overlook the process; and it wonld be a goou custom if all the ladies in a family would take their turn at bread-makin!r, and thus insure its good qualities by effieient kneading. It ean not be kiseaded too much. But of that hereafter, and in all that pertains to the subject, we hope to give some useful information to all who are not already good lread-makers. Not only in bread, but in erery article consumed upon the farmer's table, we beg of lim and the mistress of the family never to lose sight of the importance of quality. The proper consideration of this question will save many a doctor's bill, as well as the misery attendant mpon sickness.

There is nothing that the good housekeeper so much desires abont her cooking as to have good bread, and as all have not had the advantages of the daughters mentioned in the following extract of a letter to the author, we shall gire as much information as we can erowd into a brief space upor this subject.

391. Good Wheaten Bread, and How to Make it,-The letter alluded to is front a sensible, practical woman, who says:

"I have been a housekeeper thirty years, and I have reared a family of six damghters, and we have always made onr own bread, and it is a very rare thing for us to make poor liread.

"Now, the first thing I strive to teach my girls is cooking, and making bread is one of the first items of cookery. I know that good bread ean be made by the different kinds of yeast, but the recipe that is the most simple is the best. 
"Here is my way of making good head: Take one pint of warm water, one teaspoonful of salt, jut it in a dish sulliciently large to admit of stirring in flom until it is a thick batter, and keep it warn, quite wam, and in tive loms it will rise or become fit for use. If it does not rise sufficiently, dis. solve a piece of common soda as litrge as two kernels of corn and stir intc the batter.

"Yon can make three common-sized lonves of bread with this yeast, which will be nice and tender. The soda is only necessary when the flun" is of an inferior quality."

The following directions for making bread we grivo in the language of another good housekeeper. She says :

"To have grood, wholesome bread, it is absolutely necessary to pay attention to the making of it, aud to belicre that making bread, like learning to reat, does not come by nature; that it is indispensable to learn every little fact comected with the fermenting or raising of the dough; absolntely neeessary to understand the diflerence between vinous and acetous furmentation, and when an alkali, such as saleratus or bicarbonate of soda, is requirerl.

"Of course, good flow" is the first requisite. The finer the flour the greater the labor in kneading it; and the finest flour dues not always matie the sweetest and healthicst bread, yet the best flour is the elenpest; though I must confess I can mot adrise abont using interior flour, for I have never had any.

"The next important thing is the yeast, and I give the preterence to tha male of potatoes. I have tried brewer"s yeast, baker's yeast, yeast cakes, lop yeast; learen, which is a bit of sour donerh, and needs saleratus to mitke the bread sweet; in tact, all the various linds of yeast, and aftor orer two years of constant use, I am content with potato yeast.

"The rule of making it is this: 'Take ten potatoes of nearly equal sizewash and boil them; when cooked, peel and mash them perfectly smooth: pour on to this a quart of boiling-hot water ; stir in a cothee-cup of gnod. pure sugar, and after standing a few minntes, pour in a quart of boiling water wanting a gill; when lukewarm, add a pint of yeast to raise it, put it in a tirfuly-cotered vessel to ferment, and set it away in a moderately warm place mutil sufficiently risen, which may be known hy the potsto appearine" upon the top of the liquid, and light, formy spots bursting "up thromen it. The temperature of the place where this is set to rise or work slomlil lwe from 65 to it derrees; too much heat is as bid ns ton much culd. When this is risen, put it into a stone jur mul cork it; tie in the eork and herp it in a cool place. A gill and a half, or common-sized teacuptul, is sullichent

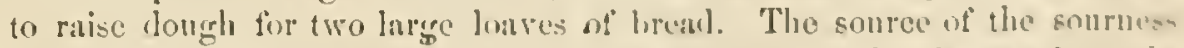
which supervenes in hreal, under careless or muskilliul hamls, wh formerly aseriber to each of all the ronstituents of 1 lour; to its ghtucn, which is in parts; its starch, which is 70 prirts; and its sugar, t litls; the other lei parts are water-but erroneons?y for it is merely the result of the secomel fermentation, which alwas suceceds the vinous when pushed improperly 
too far. There are extremely simple and effectual methods for enabling the baker to adopt measures either to prevent or correct tle evil of aceseence, and these are to neutralize the acid by the use of an alkali, sucle as solla, or an allialine earth, such as magnesia or ehall.

"If proper" care be taken of the yeast, there is no danger of having sour dough ; and if the yeast be remored to a lower temperature after the signs pointed ont, the acetic fermentation never sets $i$.

"To malie bread I set a sponge over-night. To a half pint of lukewarm water, put in a gill and a lialf of yeast and a pint of flour (atter measiring, sift the flomr), and stir this all well together, strew a little flom orer the top, and cover the dish and put it in the same temperature that the yeast was in. In the morning, warm lalf a tea-cup of milk (if water is used, add half a tablespoonful of butter), add two tablespoonfuls of lime-water after it is warm, and stip this into the sponge; lave ready a piut and a half of flomr, and linead this with half a teaspoonful of salt into the sponge. Divide this into two portions, and put each into a buttered pan to rise, and when the dough rises to the top and bursts into little cracks, it is reacly to bahe. These loares will bake in a common store or rangeroven, heated with conl, in thirty or thirty-fire minutes. The adrantages of lime-water are these: The dougl requires less kneading, the loaves bake in less time, and the bread lieeps soft and moist longer, and is less liable to mold, and it is healthy bread. After the bread is baked, it shonld be turned npside down from the pans upon a folded cloth, and left there until cool. Then it may be put into a eovered tin. By following this plan, I never lose any bread from mold. In cool weatler, the pans containing the dongh should be placed orer a vessel containing hot wates, or each pan orer a bowl or pitcher with hot water in it, and covered with a eloth. These loares are geuerally ready to bake in two or two and a half hours.

"To make biscuit, I warm a tablespoonful of butter in half a teacupful of milk, and stir it hot on a quart of flour, let it stand and cool, and when lukewarm add a gill of yeast, a spoonful of lime-water, and a little salt, and lukewarm water to knead the whole into a smooth lump of dough; sprinkle a liftle flour into the bottom of the dish, lay in the dough, cover it, and when risen (which may be known by the dongh's cracking and its spongy look when cut witl a knife), divide the dough into equal portions and put in pans, and let them stand twenty minutes before purting to bake.

"I never use tin or metal ware of any kind to mix bread in. I prefer" a wooden bowl and spoon, becanse they can always be kept clean and sweet. A still better thing is a yellow nappy, as it can be dipped into hot water before setting the dough in it.

"As to the use of saleratus and soda, it is only tolerated by the grossest ignorance. It is the received impression that an alkali makes the bread tender, and it is indiscriminately used, and hence so mel yollow-looking bread. These alkalies are only of service when an acid is to be neutralized, and then they should be used very sparingly. It is rery difficult to enligliten 
an ignorant eook, wlose obstinaey is in proportiom to her ignorance, and whose threat of leaving if not left undisturbed in her kitchen, friglitens ler timid, delieate mistress into silence and absenee. How few mistresses there are who are able to eontend with these kitchen antocrats, or are couplutut to prove their ability to exeeute what they have undertaken to eucls.

"If an old housekeeper reads what bas been witten, she will cry out: - La, what a fuss about bread-making, which any niuny can do!' ind if she lias a batch of good bread once in a fortnight, and that lyy good lnck, as she would call it, she thinks she knows all about it, and disdaims to rive attention to sueh a trifling matter. Tet, if you ask her why her breal was not invariably good, she can not explain otherwise than that the leaven was orerworked, the yeast not good, the water too hot, or the flour was bad. No wonder this question continues to agitate the world, siuce the world is daily doomed to dough and burnt erusts. Good bread is the cexception and not the rule in more than half the families of the world."

For this reason we think that some furlser rules for breal-making, which come from those who almays liave good bread, will be acceptalile. The first is from Waldo, Ohio. The writer says:

"I soak about a pint of dry lops two or three lours, or until the water foams, by which time I have boiled seren medium-sized potatoes, whicls I then mash, boiling hot, with a sancertul of flom, leaving the skins on; then add a quart of cold water, little at a time, masling and mixing thoromghly. after each addition of water. When lukwarm, I stir in the lonprests, and let it stand until morning; then I rum it through a enllender, with iwo quarts of lukcwarm water, which I add part at at timc, that the lerment may be rinsed from the potato-skins. Then add two rounding tahlesununfuls of salt, and then flour until jt can only" he stimed with diflienly. Then I set it over a liettle of warm water in winter, or in a conl place in summer. until it is very light, when I mix it and kneal it thoronghly nntil it will mot adhere to the table or bread-bowl. When rery light, knewl into luares and put it in the pans, this time kneading as little and handling ns lighty as possible. When it is again light, I put it in a hot oven, bate an hurr. taking eare by watelung not to let it hurn. When done, rub the emit with a little lard, and wrap up till cold. It the youst sours, ald sola tu correct acidity."

Another woman, Iyndat Ball, of Clevit, Liton Comm, Mich., grives her method, as follows:

"Pare and slice four common-sized potatoes, and hoil them in wne pluart

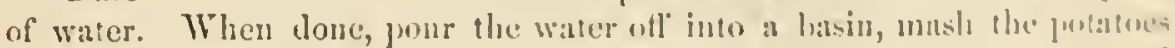
and put them in the water, and when abont milk-wam mbl one iearopful of grood lop-yeast; stir in tlome chomght to make at thick lostter, and loo it stand abont two hours in a warn place. Then jut flour emomglo ing your bread-bowl to make three loaves of hreal: ald three pints of wan waler to the yeast, and stir it in the llour, sml set in :t wam vlace till it loas sponged nieely; then mold, and hativ mu honr." 
The two following are from the Granite State Health Institute:

"Ixulas Sxow-Cake-Witl one quart of meal mix two tablespoonfuls of fine diy sugar and one teaspoontul of salt. Stir into this quiclily two quarts of light, clean snow. When it is well mixed, put it in a decp cakedish, sprinkle a little snow over the top, and bake half an hour in a lrot ovell.

"Potato Roll.-Boil one dozen mealy potatoes, nicely peeled, covered elosely in just water enough to cook them. As soon as they are tender, drain off the water if any remain, and leave them over the fire a few minutes uneorered. This is the best manner of cooking potatoes for the table, also. Mash them fine witl one eup of sweet cream or new milk; rub them through a cullender iuto a quart of flour; then add lalf a tea-cup of fresh yeast, and sufficicnt sweet milk to make a stiff dough; keep it in a warm place until light; mold into rolls, and let it stand fifteen minutes; bake in a quick oren for half an lour."

We gire another practical rule for potato bread: "The evening before you wisl to bake, take six or eight potatoes, more or less, medium size, pare, boil in water till done; mash very fine, then put back into the water they were boiled in, and, when they come to a boil, liare ready a pan; I prefer earthen, as that lieeps warm longer, with, say, a pint of flour: pour on the sealding potatoes and water, beat well, cool with water, if thicker than buckwheat-cake batter; add, when a little more than milk-warm, lalf a pint or less of your bottled yeast, stir well, cover elose, and set in a warm place till morning, when the mass will be perfectly light, if all the materials are good and put rightly together. Then mold out iuto small loaves, put in pans, corer, and set aside till they rise again; be very careful not to let them orer-rise this time, or all your care is thrown away; liave your oren of a moderate heat, and while baking wateh carefully; the loares onglit to bake in 40 minutes or an liour, according to the size. When done, they shonld be a light brown; cover them up on a board kept on purpose, and by evening you will have bread that is rieh and wholesome."

Another direction, from an oll housekceper, snys: "Take two handfuls of hops, three pints of water, six potatoes; boil all till the potatoes are soft; pare them, mash through a eullender, strain the liquid; then put it in your preserving kettle, orer the fire, with the potatoes added; also, one cup of sugar, one table-spoon of salt, one table-spoon of ginger; then add flour enough to gire it the consistency of paste; let it boil five minutes, stirring it all the time. Tum ont, and when partially eool, add half a pint of good yeast. Let this stand until fermentation takes place. In the winter I keep the yeast in a stone pot in the cellar, but in summer I dry it by mixing it with corn-meal, and spreading it on a table and exposing it to the ail (not sun). Now we have good yeast, we will proeeed immediately to make good bread. Wash and pare two dozen good-sized potatoes; boil them, with a large handful of salt, till reduced to a fine pulp; strain through a cullender, add three pints of sweet milk, and when sufficiently cool to bear your hand in it, 
stir in as much flour as will make it into a thick batter; to this sponge add a coflec-cup of the yeast. I always make my slumere at night. In the morning I add six quarts of sweet milk and thec gills of lime-water, and kneal into a stiff dough.

"Some housckeprers use alum, as it makes the brend firirer, but I prefer lime-water, as that congulates the gluten; and it requires less baking: and retaius its moistme longer-and I think it much healthier tlan alum, and liealth is the great desideratum. In two or three hours after you kncald your bread, it will be as light and porous as a loncycomb; knearl it down, and when it has again risen, mold, and put it into pans. Ict it stand till it Jises again, then wash the lowves over with eoll water; this prevents the formation of too hard a crust; hake in a well-heaicl oren. When lakerd, wash again, wrapping it up closely in your breal-clotls. Wraplung the breal "p in the steam till cold, prevents it from becoming lard and dry. If your flou" is rood, bread made in this way will be equal in appearance to the hest baker's' locad, and in point of sweetness anl economy, fir superior. The quantities I have named make twelve good-sized loaves, and my fumily requires such a baking twice a week. For many years this plan has grivan me good liread, and I hope others will try it."

392. liow to make (iool "Bakers' Breal."-To those who wonld like to know how to have such bread as the city bakers make, we recomment the following formula of one that we know makes groorl bread, and we believe uses first-rate flonr, and no deleterious mineral substauces:

Tikers' Yesst.-The following is the formula for making a tub of yeast: Four pailfuls of hot water, two quarts of malt, half a pound of hops, six jounds of flour, four quats of reast. The hops are hoiled abont five minntes, and strained. The flom is made into a paste, with hot water, before mixing in the tub. The malt and yeast are added when the water ju the tub is milliwarm, and stirred briskly. It must stand from $1 \pm$ to 15 hours before $i t$ is in order to use.

Fensext.-The tollowing is the preparation for mixing a barrel of flowr: Boil one half peck of potatoes, which are to he masced, strained, and mixul thin in water, with four pounds of flour and four "guats of yeast, and left to stand eight liours.

Setrive tus: Srosgli- I pailful of this ferment is poured into the flour in one end of the luesel-trough, and mixed, with an aldition of some hot water, into a soft dougl, and lett to stand threo lours, when more water is aclded, and the whole mass mixed into a still breal-dongh, and leit two lours to rise, when it is realy to make out into loaves for the oven.

S.ut Uswn.-The quantity of salt used in a barrel of flour is four guarts, and no other mineral ineredient is ever adeded by an lonest baker. Cire must be taken to nse plenty of yeast, but not an rexcess, and that the fongh

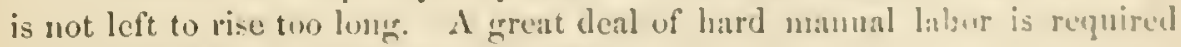
in kneading rough, to hase grood loread.

393. Brown Bread, or "Buston Bread."- In old lanke honscwife gives 
us the following valuable directions for making home-made or family bread, sonctimes called-

"Whit and Ixuna Bread.-To two quarts of sifted Indian meal add lot water enongls to wet the same; when sufliciently cooled, add one torspoonful or more of salt, half a pint of yeast, and one lialf teneupful of nolasses. Then add wheat flom enongh to make it into lo:kes (it shonld be well kneaded), and when well risen, bake or steam it three or more hours; if this should get son while rising, add a teaspoonful of sugar and a littlo saleratus dissolved in water.

"Rre asid Irdan Bread.-Take equal quantities of Indian meal and rye flour; seald the meal, and when lukewarm add the flour, with one haif piut of good yeast to four quarts of the mixture, an even tablespoonful of salt, and half a cup of molasses, kneading the mixture well. This kind of bread shonld be softer than wheat flour bread; all the water added after scalding the meal shonld be lukewarm. When it has risen suffieiently, put it to bake in a brick oven or stove-the former slonld be hotter than for flourbread; if in a stove oven, it shonld be steamed two hours, then baked one hom or more; when done, it is a dark brown. The best article for baking this kind of bread in is brown eartlenware-say pans eiglit or ten inches in hight, and diameter abont the same-grease or butter the pans, put in the mixture, then dip your hand in cold water, and smooth the loaf; after this, slash the loaf both ways with a knife, quite deep. Some let it rise a little 1mo:e before they put it to bake. Many people prefer this bread made of one third rye flour, instead of one half. When it is difficult to get rye, wheat flour will answer as a substitute. It adds very muel to the riehness and flavor of this kind of bread to let it remain in the oven over-uightst."

INdiAN on FANKeE Brown Bread.-Another old bread-maker gires tho following information abont Yankee brown bread:

"Brown breal, kneaded and made into loaves in the common way of mixing white bread, dries more quickly than the white. I obviate this difficulty thus: Take a quantity of meal, sufficient for as much bread as you wish to make at once, put it in the mixing-pan with a bowl of rising, and add sufficient lnkewarm water to bring it to the consisteney usually required in making johmny-cake, mixing in the same manner with a spoon, but do not stir too longr, or it will not have that liveliness so desirable in good meal. It is also a much neater method, as you are not obliged to immerse your hands in the dough.

"Grease your pans, and fill not quite half full, and set it as usnal to rise, which it will not be long in doing if the temperature is right. Bake one lom in a slow but steady oren. It injures a large loaf to ent while warm, though my family are very fond of it in this state, and I generally bake a loaf in a small pan to be eaten warm.

"I ean assure you that bread made in this manner will keep moist for Eereral days, and even when it does become rather dry, owing to its being 
light and porous, it is immediately restored by simply warming the slices slightly in the oven of your store hefore cating."

We reprorluee here, from a usetul little book ealled "How to Iive," which we wrote a tew years since, for those who will try the economy is well as palatableness of a lonf of wheat and Indian bread, the following good receipt, long in use by our good motler and grandmother:

"To two quarts of Indian meal adl boiling water enough to wet the sane; when sutficiently cooled, add one teaspoonful of salt, half a pint of yenst, one teaspoonful of Ealeratus, one half teacupful of molasses, aurl Hour enough to form it into a loaf (it should not be kneaded liard); when light, bake two hours in a well-heated oven. (It should be baked until brown.)"

And here is another good receipt from the same book for making rye and Indian bread, which is both cheay and wholesone:

"Stir and mix most thoroughly two quarts of Indian corn meal with a tablespoonful of salt and a quart of hoiling water, or enongh to wet crery grain of meal. When the mush cools to milli-warm, stir iu one quart of ryc meal and a teacupful of good yeast, which you will first mix with halt a pint of warm water, so that the yeast will be more erenly diffused. With the rye meal adel water enough to malic the mass a stitl dough, but not as laal or tough as flour. It must be kueaded with the liands. [Lememher-rye mal is not rye flour. It is the mulublted produet of the whole grain.] Put the dough in a fran, and pat it smooih with a wet hand. It will rise enough to bale in an hour, in a waru place, and slould be put in a hot oren, and remain three lours; or if during the nights, all the better. If white flour was not fushomable, or if people did not think that brown breal has a lonk of poverty, we should have the brown breal upon erery table, for it is not only more economical, it is more muritions and more hicalthy, particularly for children.

" $\mathrm{V}^{\top} \mathrm{C}$ do not eat oatmeal in this country to any extent, and yet it is the most mutritious breadstuft ever nsed hy man."

39t. Potatoes Csed in Bread-Making,-Mhen potatoes hear such a price to wheat flour that, when coolied, they are shout half the price per pouml of the flour, it is good cconomy in adul of potatoes about ons fourth the weright that is used of tlonr, for a batch of breal. IBreal so male is plensanter to the taste, and equaliy untritions. The potatoes should be boilud with the skins on, and then pecled, maslicel, and stired iuto a pulp with warm water, and rubbed through a wire sicve, and then nised with the flonr, and yenst added as for otler bread. The hakers of Xew lork understaml the ecomenny"

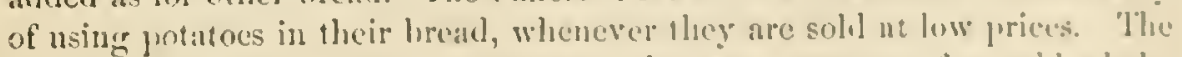
small potatoes, which are msalable fir nflece purvoses, we often suld wholve sale to trakers, and ardel to the flumr.

The potatoes make the breal molster than it would be if composenl cutirely of flour, so that for those who sell their loares hy weight, the more water they ean be made to contain the greater will be their prolits. When 
about one third of the weight is composed of potatoes, it makes first-rate bread. Many persons prefer the potato-bread beeanse it is noist, and nerer think how much water they are buying at sixpence a pound.

There is another nse of potatoes in brenc-they make it nppear light, notwithstanding its specific gravity. P'otatoes take on the vinous furmentation quicker than flour, and sometimes that passes into the acetons state, which the baliers correet with biearbonate of sola, or line-water, still adding weight withont any addition of nomrishment. Lime-mater is not objectionable; it is only so that we should be indueed to buy it at sixpence a pound, becanse the baker puts it in lis sour flomr or potato-blead, to make ns think it is sweet.

Prof. Licbig advises the use of one pint of lime-water to every fire pounds of flour. The lime-water should be prepared by dissolving lime in water to a point of saturation, and letting it settle and then bottling for futura use. With this lime-water, use pure yeast, and you will liave light, healthy bread. With saleratus, largely used, yon will not have wholesome bread, disguise it as you will. In using lime-water, add it first to the flour, then add pure water and yeast, and you will have better bread than you can obtain from any preparation of carbonate of soda or cream of tartar.

Wheat, divested of all its bran, does not contain enongh of all the healthgiving ingredients, partienlarly of phosplate of lime, to satisfy the demands of natme. Tith such flomr, potatoes are beneficial.

Bread should be more thoronglily baked than it is usually, and not eaten warm from the oren.

Dry bread shonld never be thrown away. By soaking and reconverting it into dough, it ean be again baked into excellent breal. It is of snch materials that the delicious tea-rushs are made. Dry bread also malies inost delicious puddings. Bread of fine flour is too much eaten. We recommend farmers to have their wheat ground more coarsely, and only take out a portion of the bran. They may also add corn or rye meal, witl adrantage to economy and health. It will be also economical in the country to add potatoes. It is not always so in the eity. And it is not quite lonest either to sell them at the price of superfine flom. bread.

For potato bisenit, grate one half dozen potatoes; add one quart of water; one cupful of hop-yeast at night; and in the morning, when light, add three teaspoontuls of sugar, and flour to form a dough. Let it rise; when light put in tins; let it rise again, and bake one hall hour.

395. Spronted Wheat Flour-its Effect on Bread.-Sprouted wheat flour makes what lousewires eall runny dough, and that is apt to make clammy bread. To remedy this, it has been recommended to ald half a gill of whisky to flour enough to make four molerate-sized lonves. But many object to the use of whisky to make bread, and ask if sonething else will not answer as well. We think it will. We think if abont the sane quantity of shortening is added to the flour that is commonly used in making the old-fashion Iankee light biscuit, that the bread will be light, fine-grained, 
and free from all the diffieulties usually attributed a grown wlost. The addition of a littlo butter or lard to any flumr will nut do any labrn. Try it.

396. Yeast-llow to Make it.-The chemists hare proved that beat is it plant, as much so as molel or any other fumgus. As we gret it fresli fiom the brewer, yeast appears to be a yellowish gray or fiwn-colored, frothy lipuid. It Eoon settles down and appears dend, but is still active. The taste is liiter, and it emits a rather disagrecalle odor. Its effect upon all muist sub. stanees is to camse them to ferment, by a rapid increase of its growth, amb at generation and diffusion through the mass of enrbonic achl gabs, which matics the dough puff up and assume the condition called light.

The great secret of bread-making is to use just the right quantity of yeutst to produce a light louf withont having any of the flavor or oulor of the yeast imparted to it, as it will if too much is user, or it the action of the yeast is not arrested at exactly the right time.

We give in No. 397 the most convenient form for preserring yeast ready: for use. If liquid yeast is preferred, it can be made ly mixing wh weat flutir and water into a paste and letting it stand wro or threc days in a mud. erately wam place, when it will hegin to emit a disargreable sour odos, which afterward passes off or changes to a vinous odor at the end of six days. Then if you lave the opportunity to get malt from a brewery-amel if not, you ean make it ly sprouting barley or Judian corn, which must then be dred and crushed-you will male an infusion of malt and buil it in water with a handful of hops, and cool it till lukewam, and add it to the paste previonsly thinned into a soft batter with tepid watter. This mistme kept in a warm place a few hours, begins to show activity. I'ementation lats commeneed, and will work the mass nutil there is a clear liquid wh the surface, which pour off, and the opaque liquid at the botrom is good genst, which you may keep as long ats you like in winter, and in summer mpon ice: or hemetically sealed in bottles till wanted fur use.

A good yeast can be made, when you have the seed-lhat is, active goat: -from four pounds of peeled potatoes hoiled in four quarts of watele and a lare hamlful of hops in a hag. The potutues are mashed and thorminhly mixed with the water and a little salt, moluss's, and flour to matie a huefer, to which a couple of spoonfuls of gond yeast are alderl, and this will ferment the whole and make it fit for use ats leaven for breal; it may be bept a long time in a cool place.

Yeast is sometimes preserver by dipping clean twigs in it and drying them and preserving them dry till needen, when they are soaked and the liquor adcled to the spount.

It lias also been dried by spucaling it with n brush upon a hoard and re peating it as fast as cach layer is driend until of consinlerable thickness, when it is sealed otl, broken "p and hottled, and sealed nir-tight; it will then keep for years.

A yeast-plant has been fund in California enpolve of reprotuction to an 
indefinite degree when plaeed in a bottle with a little sweetened water. Tinese plants appear somewhat like small grains of white-hulled corn soaked in water, or like the lumps of wleat tlour which form in boiling, if not sufficiently stinerl. A spoonful of this substance put into a quart of flom mixed for a sponge will cause it to ferment, just as an addition of ordinary yeast would. The difienly in its use is, that it is rather liable to becone too acid, but it is a pretty good substitute for common yeast in a new comtry where baker's and brewers are not convenient.

397. Veast-Cakes, or Rcady-malc i cast.-Take three ounces of good ficsis lops, three and in half pounds of rye tlour, seren pounds of Indiau corn meal, and one gallon of water; rub the hops so as to separate them; put them into boiling water and boil half an hour; strain the liquor through a fine sieve into an carthen vessel. While hot, put in the rye flour, and when lnkewarm add a pint of yeast. Next day put in the Indian meal, stirring it well, and the mess will be stiff dongh. Kinead it thoronghly, and roll it out to the thickness of about a third of an inch, and cut np in cakes three inches square, and dry them on as clean board or a tin in the sun. Turn them every day, let them receive no wet, and they will become as hard as ship biscuit. Store them in a bag or box, perfectly free from damp. When you bake, take two cakes for three loares, and put them into a quart of tepid water with half a pint of flour in a ressel near the fire-place orernight, where they will dissolve by moming, and then use them in setting your sponge as you would the yeast of beer. These yeast-cakes may be kept just as long as yon desire.

Rye flour is better than wheaten, but not absolutely essential. Some use potatoes, but a lady writes us that she finds the addition of the potatoes of no benefit and no injury, and for years las used Indian meal only-which, being simpler, makes the work easier.

To make yeast powder, take one pound of saleratus and two pounds of cream of tartar, mix them thoroughly together by passing them two or three times through a sicve. To each quart of flour add two heaping teaspoonfuls of this yeast of baking powder; wet with sweet milk or water, as usual, and bake at once in a quick oren. The bread should be in small loaresbiscuit in the same way.

398. Saleratus-Rising for Bread,_- "In discussing this I aim at the health stand-point, and reject whatever inpairs the nutritive qualities of the flour, injures its flaror, or discolors $i t$. The excellenec of bread and its lightness depend upon the disengagement of carbonic acid gas during the process of fermentation, which is the netion of yeast upon the saccharine matter of the flom. Ferment or yeast is an organized matter, and its essentially operative constituent is a peculiar azotized matter, which, in the wine-vat, is mixed with some tartar and other salts, and in the beer-tun with gum and starch. Azcte is found in animal bodies, and certain vegetables contain an azotized principle; indigo, enperine, gluten, and many others contain an abundance of azote. All bread-making which dispenses with kneading and 
true yeast fermentation may be distrusterl. The compositions of what may be termed bread compounds, even if palatable, differ greatly from true, good bread.

"It is not of what kind of eatable things bread ean be made, but how" to best make grood, wholesome bread that is as sweet when a day or two uld as when first made, or better even than when new, that has no taste of peast, none of the litter of hops, nor the disingreable flavor of alkali, aud that will licep good a week, ji" necessary.

"The preference should be given to that yeast that will make the lightest, swectest hread, without aid from cxtrancons substances, that is least likely to run into the acctons fermentation without infusing the bitter of hops.

"The itlea that alkalies make the bread tender is an error, the dongh before their introduction hising run into the mucilaginous or putrefactive fer. mentation."

But as many do and will continue to nse alkalies, we will give some of the inost approved methods

"For making prepared flour that can be used at leisure, to each quart of flont add one teaspoonful of saleratus and two of puro cream of tartar, nut what salt is required; mix them thorombly together while dry, and set aside for use. Flour prepared in this way will last three months, fur the reason, the flowr lieeps the chemienls separate from each other; it can then be wet up in the usnal way and baked at once. Use this prepared flumr for bread, biscuit, or any hind of sweet cake or pan-eakes, but do not mix tle pan-cakes until you want to use them.

"The best method for miling loreal with somr milk anul saleratus is to add to each pound or quart of flour one heaping teaspoonful of saleratus and what salt is required; mix them well together; which is hest done ly jassing it all throngh a siere. Then add as much sonr milk as will matic the dongh the usmal thickness. Mold it in small loaves, and bake at once. It the bread slionld be a little yellow, put in less saleratns next time. four biscunit, it slonld be molded quite thin. Tery liete shortening is repurimed; it shonld be balied in a hot oren; and, if balied (puick, the stean will lie]p' to raise the biscuit."

It is contended by the adrocates for this breat, that "locing free from all yeasty particles, it is more digestible and not so likely to ereate tlatuleme or tum acid on weak stomaclis as femmentent loread; and when of the tinest quality, it is bencfieial to those who suller luealache, acidity, flanulence, ernetations, a sense of sinking in the pit w' the stomach, dietention, or pains after uncals, and to all who are sulject to gont or gravel. It is nlso uscoul in many aflections of the skin.

"These remarks apply to hoth varicties of the breal, lut especially to the lown, which is further invalualile to all who are lialle to constipation

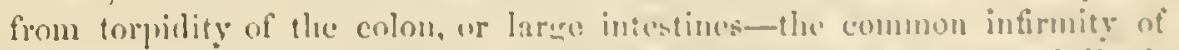
the sedentary-and of those who latre leen acenstomed to vatnueal diet in their youth. 
"Lut the adrantarges of the process are not limited to matter's relating to health. It is valuable hecause bread ean be prepared by it in the short Epace of halt an hour, thus saving much time and labor. It is valuable, also, becanse the materials are not perishable, and may be rendered available in places and at times when yeast and other ferment is not within reach-ns at sea, for example, or in country retirements; and it is still more raluable as regards ceonomy. The cost of the chemicals is connterbalaneed by that of the yeast, salt, and alum, otherwise employed; but were it not so, they would form an altogether unimportant item in the prico of bread; while by their use a saving is effected in the flour of not less than 13 per cent. In the common process muel of the saceharine part of the flour is lost by being converted into carbonic acid and spirit, and thus waste is incurred solely for the purpose of getting carbonic acid to raise the dough. By the new method waste is avoided, and the gas obtained in a manner cqually eflieacious. And it is a striking instance of the successful application of ehemical philosopliy to the common arts of life, for fermentation destroys a part of the flour or meal, so that 280 lbs., which make $360 \mathrm{Jbs}$. of bread by fermentation, give 380 lbs. by the new process."

399. Sosla rs. Yeast, and Bread without Veast.-Withont taking any part in the controversy aliont the healthiness of unhealthiness of soda bread, wc will give extracts from the opinions of its adrocates as follows :

"Soda is a caustic alkali in its nucombined state. It is the base of common salt. In this form it is daily taken into our stomachs with food, and also administered regularly to domestic animals by the carcful husbandman. Let us remember that notwithstanding the ehlorid of sodium has been used from time immemorial by man, and always eagerly sought after by wild animals, it has also met opposers among nlira lydropathists. It is therefore not so astonishing that the bicarbonate, which is what is used in eookery and of recent introduction, slould find many opposers.

"Potash is an alkali extracted from wood ashes by percolation, and for culinary purposes is combined with two equivalents of carbonic acid, and sold under the name of saleratus. The chemieal natures and plysiological efiects of the two biearbonates are so nearly identical that I shall not liecp up the distinction in treating of them, though from the fact that the bicabonate of soda is dryer and more easily redueed to powder, it is preferable.

"To secure the desired effeet of bicarbonate of soda, it is necessary to use it in connection with some aeid which, by combining with the alkali, sets free the earbonic acid, in form of gas, at the time of baking. Sour milk, which contains lactic acid, is best. The lactic acid, having a stronger affinity for the soda than the earbonic acid has, combincs with it, forming lactate of soda, a nentral salt, possessed of no caustic property whatever; while the gas, disengaged, fills the bread with minnte cells and thus renders it light and palatable.

"In the absence of sour mill, tartaric acid or crcam of tartar should be used. If tartaric acid is used, tartrate of soda results; a harmless substance 
even in considerable quantities, and by no mesus unpleasant to take in warm days in the form of an cffervescing dranght. If crean of tartal is used, the product is tartrate of soda and potassa, or liochelle sults, which, in ounce doses, is known to be one of om mildest saline puremtives.

"A henty cater will take only a few grans of any of these salts at a meal, and these readily yass off through the excretions of the bonly, or cuter upon their physiological oflices in the gastric fluids-the bile or blinel.

"These biearbonates, used without an acid, render breal unjalatable; nn! this of itself would prevent persons from using then to a hurtul extent.

"Instead of being a curse to the world, the introduction of the bicallonate of soda has been a great blessing in banishing lard, in a great measurc, from our biscnit. That the large quantity of grease necessary to make geoml short biscuit of superfine flowr renders bread in a high degreo indigutible, will be universally admitted. Make hiscuit according to the following formula, and you liave an article altogether superior in point of digestibility and flivor to those in which lard is used as the only shortening.

"Luke 1. Flour, two pounds; fino Indian meal, a tencupful; bicarbonate of soda, a heaping teasjoonful. Thoroughly mix these dry. and make up with new buttermilk, or if the milk is very sour, add water sufliciently to inake it about like new buttermilk. The soda must he nentralized, and, in using milk, judgment on this point must he exereised.

"Rule 2. Flour and meal as above; rub together dry a teaspoonful oi cocta and two thirds as unch tartaric acid. Mix this dry with the uncal anul flone, and make n], witl water.

" liule 3. Same as No. 2, except use a teasvoonful of eream of tartar instead of the tartaric acid.

"A rery small quantity of lard or butter may be used with advantage to the taste, but it is not essential. These ingredients alded to corn breal make a wouderful improvement on the old-fashioned hoe-cake. That this bead is healthier than yeast hread there is no doubt.

"I healthy stomach, especially in winter, when the syestem is in a vignorous condition, may take yeast in considerable guantity mud digest the meal before the process of fermentation has time to take pluec. lint not so with weak stomachs, or henlthy ones in the heat of summer, becauso yeust is the deposit formed in fermenting liquids, and las the property, when ahled w solutions of starch or sugar, even in excedingly small quantitics, of cxcop ing the vinons fermentation in the whole mass, and mas, and often does, fo it, in the stomach as well as in lireal."

But lle sweetest, most mutritions, most wholesome baters' breal, wo helieve, that crer was male, is that first brought into general use in $\mathcal{D}_{\text {ew }}$ Fork: in 1811 , ly the estahlishment of "large mumtactory for its probluction, wlic's usel over forty larrels a lay, when working in full furce. This bread is called "unfermented," yet it is as light as ang goud humbunals bread, which it very much resembles.

Tho following is the process by which it is made light without yeast: 
"The best superfine flour, with a due proportion of pure water, passes from the bin, through a large iron pipe, into a huge, hollow globe of castiron, lined with tin, in which revolves an iron shaft with polished steel arms, which mix and knead the dougit.

"During this operation pure carbonic acid gats is conveyed from the gasoneter into the globe by a powerful foree-pump, and is incorporated uniformly into the whole mass. Every ingredient is in definite proportion, and the most perfeet aceuracy is thus insured. By the pressure of the gas the dongh is then foreed through a valve into baking-tins, and in an hour and a half, from flour in the bin, it is beantifully baked bread. No hand of man touches it in the whole process. All is done by the iron hands of machinery and the power of stean. No chemical change whatever oceurs in the flour. All its elements-the stareh, the grhten, and sugar-are retained in their original proportions and purity, and the result is the best and sweetest bread in existenee. By the old process a little of the stareh is always converted into dextrine-n speeişs of glue-giving the bread a dark color, and sometimes sodden texture. To remedy this, alum is generally used, and the bread thereby further vitiated. Perfect eleanliness in the manufacture of bread has not been possible lieretofore. It is by this process.

"Bread made at home has been the purest that conld be had, for the vessels were carefully looked after, and the air was generally free from dust and decomposing particles, but none conld tell what impurities contaninated the yeast, which, whether it came from baker or brewer, was necessarily more or less mixed with foreign substanees. Home-made bread was the eleanest we could hare, but was not perfectly pure; while with the most watehful supervision and most careful cleanliness, bakers' bread, made in the ordinary way, can not possibly be entirely elean."

Another adrantage unfermented bread has orer all other bakers' bread, is its remarkable kecping quality. It has been eaten with great satisfaction when twelve dirys old.

William Lonnsberry, commissary of the 20th Regiment, New York State, which lad been served with this bread while in the eity and on the mareh to Washington, speaks of it in the following terms:

"The bread has been on our table every day since we left, and is eonsidered ly all a great delicacy. It loses none of its flaror by its age, but, for me, it really seems to improve.

"It is sweet, light, and rery palatable. I consider it, in many respeets, the best bread I ever tasted, in addition to its power of retaining its exeellenee so long, the virtue which gives it its inestimable valne. I wish I could be the means of informing a much larger number than $I$ am able of its inestimable merits."

We Lare spoken of this metlod of making bread, not becanse it will help families to make better bread, but to show what improvements have been devised to make bread upon a large seale. The process wonld be a good one for the army and nary, and in all large towus. It is proper to say, 
howerer, that the breal is not a universal fiworite. II taste, that there are people who love sour herel, and also biead that smells and tasies rank of yeast. 'To ns it is not agreeable nor liealthy. This "mufermented bread" is patented by Elisha Fitzgerald and Janes Perry, Nuw Tork.

400. Other Substitutes for Yeast- Chamica?s in Brpad-1 substitute for eream of tartar has been discovered by Prof. IA. L. I Iorsford, which he thinks far preferible to use with fola in breal. IIe says of it:

"All these considerations led me to the conviction that, if it were possible to prepare phosphoric acid in some form of acid phosphate of line, such that, alter its action with moist carbonate of soda, it would leave plospliate of sorla (a constituent of the blood) and phosphate of lime (an essential constituent of fool), and confer upon it the necessary gualities of a dry, pulver. ulent acid, the end would be so far attaned as to justify a practical experiment in domestic use.

"I suceceded in plodneing an article in enndition to meet the wants of the problem. I then introdneed it into my fiunily for nse in ull forms, as a sulstitute for crean of tartur for eulinary purposes. When many mouths of daily use had assured un that my theoretical views were sustained by practical application, I gave it into the hands of friends, whose prulongerl experience fully confirmed my own. It has been in constant use in my family now for more tlan funr years; and in the form of yeasi powder, during this tine, it has been produced and cousumed in all parts of the comtry to a very large extent, settling, in the most satisfactory manner, all questious as to its serviceability and healthtulness.

"The article is prepared according to instructions furnishal by myself, as the result of long-continued experiment, and it will be prodncel of invarable purity and strength equal to that of crean of tartar."

Of the same purport, and liaving a direct reference to this case, are the views of Dr. Sammel Jachson, professor of the institute of nedicine in the University of Penusylvania:

"Your substitute for cream of turtar for the rasing of lireal is a leciled improvement. The tartaric acil is not a constiment of the grams from which flour is made; it is not a mutritive principle, and often disanrees with the alinentary organs. The phospluate of lime, which is the princigal ingredient of your preparation, is an essential constituent of all grans. It is further an iuportant untrive principle; and recent experiments lase lurored it is an indispensable element in the formation, not of bunes only. but of all the animal tissues. A deficiency of the pluspluate of lime in find is a common cause of ill-heulth, of detective development, und retariled growth in chillren. In the consersion of whent into flume, the phosphate of lime is rejected with the bran; ant, in consepuenee, this necensary ule uent of untrition, contrary to the arrangement of nature, is not obtaineal from our tine whent breal. lour preparation, while it makes a light, swee?, and palatable bread, restores to it the phosphinte of lime which has been 
separated from the flonr, and thus alipts it as an aliment for the maintenance of a healthy state of the organization."

Other chemists and physicians of acknowledged high elaracter aud standing have given similar opinions.

If raising bread by yeast is properly condncted, it is quite mobjectionable; but if, as is often the case, fermentation is allowed to proceed too long, acetic and lactic acids are formed, and some of the complex nitrogenons substances arise from the decomposition of the plastic bodies of the flour, and are incorporated in the hread.

Teast bread is never good mnless the fermentation is arrested by baking at just the right time. Ordinarily, this right time is a period of short duration, and probably not one loaf in one lundred is raised and baked when it shonld be. The circumstances which modify the time in which the fermentation may take place are so varions, that it may ocenr in thirty miuntes or twelre lionrs. The sponge requires constant watching, and this, in the multitudinous duties of the kitchen, it is not always possible to secure. Then suleratus or soda, to sweeten the sour sponge, is the resort of the cook; and the result is an unpalatable and unwholesome loaf, unwortiy the name of bread, and is really unwholesome food.

$\Lambda$ correspondent of the Country Gontleman recommends the following formula for unfermented bread:

"Take of flour 3 lbs, bicarbonate of soda 9 dracluns, hydrochloric acid, specitic gravity $1.16,11$ drachms. About $25 \mathrm{oz}$. of water will be required to form the dongh. First mix the soda and flonr as thoronghly as possible; which is best done by shaking the soda in fine powder from a sieve over the flom with one hand, while the flour is stired with the other, and then passing the mixture once or more through the sieve. Next ponr the acid into the water and diffuse it by stirring them well together, aroiding the nse of any metallic utensil that the soda might come in contact with. Then mix the dough and water so prepared as speedily as possible. The dongh slould be speedily put into a quick oren. This manner of making bread is a great improvement, and will prove advantageous, compared with the ferunenting method, and the quality also will be fonnd vastly superior to the antique 'learened bread,' particularly for dyspepties, as it has this adrantage, that it never sours on the stomach. By this method bread ean be made in two hours, and it sares both time and labor. The ingredients are simple, and cost little. Fermentation always destroys more or less of the flour, besides otherwise injuring it for the purposes of assimilation.

"A large proportion of the bread used in some families is scarcely nore than an active form of yeast, which prodnces in the stomach a new fermentation and a liost of disorders. And then we witness, of course, the blue vapors, which under different aspects are as ruinous to the welfare and peace of a family as are those of a distillery. If the proportions of acid and baking soda directed to be used are thought to be too great, they may be varied at discretion. 
"In bread-making the only purpose served ly fernentation is the enencration of carbonic acid to raise the dungh, and to ceflect his a ruantity of yeatst is mixed with the flom. But the fanc purpose is gancel ly unixing at quantity of earbonate of soda with the thom, with a corresponding propurtion of hydrochloric or muriatic acid, and breal so formed is more nutri tious and cconomical."

Common salt always shonld he adeled, not only locense it is pallatable, but because it has a chemical eftect upon the flour, so that that of interiur quality assumes an appearance abore the reality. "This is proved in what is called "salt-rising bread," which always looks whiter than the same flour nade with yeast. Salt also has the eflect to make flonr take mp and retain more water in the breal. Alnm has the Eane effect as salt in at stronger degrec, and its nse by bakers is lishonest, becanse it is much more deleterious than salt to the luman stomach.

Sulplute of copper is amother deleterious article in hreal, but it can only be usel in small quantitics, without great danger, and produces the sanic results as alum in a still grpeater degree.

Carbonate of magnesia, 1 sed at the rate of 20 to 40 grs. to the pomul of flom, prolnecs effects similar to the alum or sulphate of copper, and cemol seientific authority has pronouncel it harmless, or at least preferable wn =oula. Other anthority says its inaptitude to become entirely solnble matics it hicplily objectionable.

Probably the eafest mincral substance that ean be used in breal is line, as recommented by Liebig $(39 t)$.

f'o prepare this lime-water, mix a quater of a pounel of slakel lime in a gallon of pure, Eoft watce or filterent ratin-water, and curk it tight in butelus. The water will dissolve $\frac{1}{4}$ th of its weight of the lime, and the balance will settle to the bottom, learing the water transparent, which may he used at the rate of 5 lbs. to $19 \mathrm{lls}$. of flour, and then fresh water mat le alded tu the lime until all that is soluble is used up. The quantity of lime taken into the system is so minute that it is believed that it is not on! not deleteriuns, lut positively bencticial.

401. Prof. Youmans Opinion of Chemicals in Breas.-S peaking of the nee of varions chemical substances tor yeabl, P'rot. loumans salys:

"The class of snlestances thus introlnced in the breal are not muritive

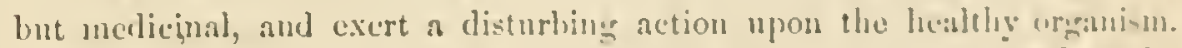
And although their oceasional and cantions employment may probaj s lex tolerated on the around of conventener, yet we consiller their habitual use as highly injulicions an muwise. This is the best that can ho satil uf the chemical substances nsed to raise bread, eben when pure; but the corn monly obtandel, they aro apt to he contaminated wish impurities more ohjectionable still. For example, the commerein murintic nevil which is commonly cuployed aloner with liearbunate of follt, is ulwys puite impure. often contaning chlorine, chlorid af iron, smlphurons meil, and eyen arfenc, so that the chemist mever uses it without a tedions process of juritien. 
tion for his purposes, which are of far less importance than its employment in diet. While common lydroclloric acid sells for three cents per pound wholesale, the purified article is sold for thirty-five. Tartaric ated is apt to contain lime, and is frequently adulterated with cream of tartar, which is solk at half the price, and greatly reduces its eflicare; while cream of tartar is rariously mixed witl alum, clnalk, bisulphate of potasl, tartrate of lime, and even sand. Sesquicarbonate of ammonia is lialble by exposure to the air to lose a portion of its ammonia. It is hence seen that the substances wo cmploy are not only liable to injure by ingredients which they may conceal, but that their irregular composition must often, more or less, defeat the end for which they are intended. We may suggest that in the alsence of tests, the best practical defense is to purchase these materials of the dinggist rather than the grocer. If soda is desired, call for the bicarbonate of soda; it contains a double charge of carbonic acid, and is purest. Sodasaleratus is only the crude, impure carbonate-soda ash. The cream of turtar should appear white and pure, and not of a yellowish tinge. Carbonate of potash in its erude state appears as pearlash; in its more purified form it is saleratus. Crude soda is known as sal-soda or soda-saleratus; refined and cleared of its clief impurities, it forms carbonate and bicarbonate of sola. All these compounds have the common alkaline or burning property, wlich belongs to free potash and soda, which is lowered or weakened by the calbonic acid united with them. The potash compounds are the strongest, those of soda being of the same natnre, but weaker. Tet the system, as we have just seen, recognizes essential differences between them; one jertains to the blood and the other to the flesh. Aceording to the theory of their general use for aising bread, they onght to he nentralized by an acid, muriatic, tartaric, acetic, or lactic, thus losing their peculiar properties and becoming salts. These changes do take place to a certain extent, and the saline componnds formed are much less powerful and noxious than the unnentralized alkalies; their effects are moderately laxatire. Iet, in the common use of these substances, as we have stated, the alkali is not all extinguished; much of it enters the system in its active form. Pure, strong potash is a powerful corrosive poison, disorganizing the stomach and dissolving its way through its coats quicker, perlaps, than any other poisonous agent. When the alkalies are taken in small quantities, as when there is an cxcess in bread, they disturb healthy digestion in the stomach by nentralizing its necessary acids. They are sometimes fonnd agrecable as palliatives when there is undue acidity of the stomach; and, on the other liand, they may be of service in the digestion and absorption of fatiy substances. It is alleged that their continued use tends to rednce the proportion of fibrin in the blood. Cases are stated where families have been poisoned by the excessive employment of saleratus."

402. Baking Bread-Ileat of the 0ven-Quality of Flour-The heat of the oren, besides being equa!ly diffused, should continne regular. The heat is right when flour sprinkled on the oven-bottom turus brown gradually, and 
too lot if the flonr chars black directly; for then it will pruduce a thick clust, often burnt, while the interion of the loat is underilone. The ermmb) is cooked at the boiling-point-21: degrees-and uniglat be done in a bleanchamber as well as an oven, but for whe crust, which we all lore su well that we are not willing to dispense wirle it for any more economical moele of cooking than the oren.

The heat of the oven swells a well-raised lump of lough to alont inuble the size by the cxpansion of carbonic acid cas, and by stun arinim from the moisture in the loat, and by the vaporizing of alcoliol, distilled ont in the process of baking, to an anomnt equal to abont one quirter of one per cent. of the weight of bread. A well-raised loaf of breal is more than halt" carities. The loss of weight in haking depends upon the quality w the flom and size of the loaf. A one-pound hat will generally require $1 \mathrm{lb}$. fi uz. of dough. A three-ponnd loaf requires \& lus. $120 z$ of llongh. A rix-ponnul loaf requires 7 lbs. of dough. This sluws that it is the must economical to bake lumge loaves.

If you wisl to prevent baking a liand crust, you can do so hy rubhing the lonf, after it is slaped for the oven, with a littlo lard, just enough to varnish the surface. The erust, howerer, if not burnt, is always centen with saltisfitction, its agrecable bitter tnste being preferrel hy many persons.

'The crust, which is dry and erisp upon new luneal, grows sott and noi-t after a day or two. Sonne housewives always wrap theip lines in wet elotlas when taken from the oren, to prevent the crust from continumg to get dryer. There is no need of this, because the noisture of the (crumb suon soffens the erust, and frequently leaves the crumb too dry. When this is the case, d' turu the stale loat to the oren in company with a dish of hot water.

The average quantity of water in well-baked whaten luabes is ubunt forty-fire per cent. The best flour enmains six to ten per cent. of water. The reason that spring wheat flour makes moister bread than winter whent, is because it contains more gluten, and that heing once flownghly wet in mixing the dough, is retentive of the water, even after it has lost its tomeh, adhesive qualities, in passing from domgly into well-baked breat crmml. I portion of the starch of the dongle also lentins water hy heing converterl ly. the baking process into gum. "The lont will retain much more sunisture, and consequently le better hreal, if it crusts wer immediately upun its being placed in the oren, as $\mathrm{jt}$ is then in ancusure impervions to wher, and sluts in all that the interior of the lont contains.

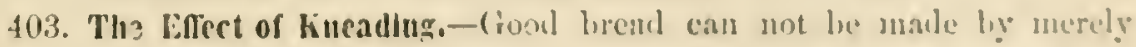
mixing tlonr and water and yeast. 'The mass must he knemlenl so as to be sure to bring every grain of llour in contact with its equivalente gran of water, and to as to cliffise the yenst miformly thromghunt the man. or else the resulting gas will be liberuted in exeess in one spot and not at all

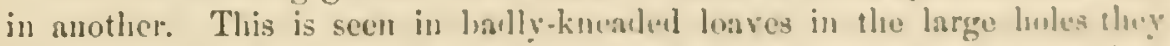
contain, and in a crust that ensily detuches from the crumb, us thomels it hat been lifted np by internal force. Tle nir-cells in n well-knended lont aro 
fine and uniform throngliout the nuss, and all will be formed at about tho same time. If the flour and yenst are deeidedly good, and the lineading decidedly bad, the bread will not give satisfaction. On the other hand, goorl kneadintr, grood molding, and good baking, will make a second or third-rate quality of flom pass almost equal to the best.

104. Preparations of Wheat and 0ther substances for Bread,-There are many things which may be used to mix with white wheat flour, or as substitutes for it. A baker in Paris has tried a successful experiment to reduce the cost of bread by mixing riee flour with that of wheat. He puts in one part of rice to five of wheat flowr, and the economy effected reaches the rery considerable fignre of one sou in the two-pound loaf. "The goverment lias had the bread exanined ly competent persons, and has authorized the sale of it at a less rate than fixed by the police. The demand is snch that the balier can not supply it. Neither the nutriment nor the taste of the bread would appear to be affected by the presence of the new ingredient.

The greatest advantage of mixing rice flour with wheat flour is to enable the loaf to retain more water, and make a moister bread.

Bread made of wheat meal, as is proved by the chemical experiments of Prof. Jolnston, affords much more nutriment than that made from superfine flour. These experiments show us that 1,000 lbs. of wheat meal, or the wheat ground coarsely, and the lunlls or bran portion sifted ont by using a common meal-sieve, eontain the elements of-Musenlar matter, 156 lbs: fitt, 28 lbs.; bone material, 170-35+ lbs.

Whereas in fine flour are found only of-M[usenlar matter, 130 lbs; fat, 20 llus.; bone material, 60-210 lbs. Leaving a balance in faror of the former of 144 lbs. in 1,000 lbs. of the real elements of food convertible by assimilation into musenlar flesh, fat, and bone.

Now, as bread ranks among the elief, if not as the ehief substance designed for the nutrition and support of the liuman frame, the above facts onght to have weight, in a pecuniary point of view, as an argument against - the exclnsive use of superfine flom.

Unbolted wheat meal for bread is in high faror with many, and we think every family shonld use it a portion of the time. In mixing the dongh of this meal, do not make it quite as stiff as yon would white flour, and you must be eareful that it does not sour in rising, as it will do so sooner thun bolted flour. It also requires a lotter oven and longer baking, and the erust is more apt to burn.

Rye flour mixed with wheat flour enables the loaf to hold more water. The objection to it is its darker color and rye taste.

Indian corn meal is also mixed with wheat flonr, for the same purpose as rye flour, and if pure white corn is used, it does not affect the eolor of the loaf, and makes very sweet bread.

Of mixing potatoes we have fully treated (394), and recommend farmers to grow some of the very white fleshed, dry sorts, for this purpose.

A French process uses ninety per cent. of the wheat making white bread. 
The whent is grome into fine wheat flom, eventy-four per cent.; brown meal, sixteen per cent.; lran, ten per cent. The meal is then mixed furite thin will water and the necessay yeast alded, and this is necl to mix the white flour into a doughl, which is baked as usual when light. The lirear? is declared to be greatly improved, being less likely to somr, and is light, sweet, and untijtious,

405. Corn Brcad--Although Indian corn is a more universal crop than wheat, corn bread is by no menus in universal use. The reason is in some measure to be acconted for in the inborn love of fermented bread which the meal of this grain will not make. The use of "leavened breal" la: been thought by some to come in part from the early notion that it ereated a distinetion hetween Christians and Jews. The former alwars use luvened bread-at least the Protestants do, in their sachuments-and the Jews lave their holy "feasts of unleavened liread;" go that eating unlearened lipeal as a constant practice has heen said to he an unchristian act. It wats also the daily food of the henthen, and in early times, when the first sctulers of the comnery were rely poor, corn breal was the only kind; and the ute of it now may eall up reminiscences of painful poverty. It is alsu the only hread of slaves, and it may be looked upon ats a landge of servitule. It any rate, the poorest classes of the Northeru States make the luast use of corn hread. Yet it is the rery thiog that they should eat, leceanse it is nutritions, healuful, and economical. In Northeru cities, corn unal furnishes ecareely one per cent. of the hreal food. and not one per cent. of that is made into bread. In the farming regions of the northensturn sintes pure

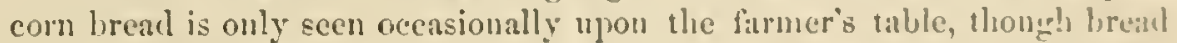
made of a misture of about two parts of corn meal nul cone of me meal, fumiliarly luown as "ry"n'-injun," is still extensively used. (Liec 3it?.)

A much better mixture is nue part rye meal, two parts eorm meal, and four parts fine whent flour. I'le rye and corn are mixed with yan-t, quite soft, aut sct to rise, and after getting very spongy, the wheat dlour is worked in, and the mass allowed to get light betore it is put to halie.

At the Soutl, com lireal is almost the only sort ever seen upon the tables of many families who rank upon a par with the mass of Northern firmers. All eat it there and are content, hoth waster und slave, and those who are

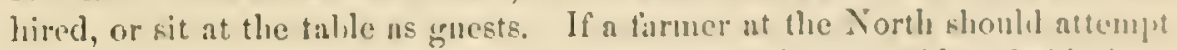
to feed his halorers eschisively upon con head, there would jubahly be as revolt, particularly if a majorify of them were Irish, whose only lirest in their own romintry wis jotntoes.

Such laborers have yet to learn that enru breal gives moro working forco than lureal of fine whenten flonr. The latter grives the most brain funh, ambl is best for growing children; but Indian corm, either in the furm nt breul, ur many of the nther forms in which it comes to the tables of those whe hnow low to conk it, furnishes the laborer with a greater proporticn of prower than any other grain, and its value slowlit be better known, and it thou vould be more used as an article of fuvd. 
Perhaps the reason why the nse of com hreal is going out of fashion in this region, which is in the very center of the great eorn belt, may he found in the fact that so many lonseholds are now served by cooks who were not born in a corn-growing comutry, and who seem incapable of leuruing that corn meal is not fit to cat in a seni-raw state. If they malie it into mus, they only scald it. If they mix it into breal, they insist upon its being dono as soon as it is heated through. Learn, then, that corn meal can not he cooker too much-it seldom is enough. The best eorn bread we erer ate was from meal well lineaded with nothing but water and a little salt, and then made intolumps abont the size and somewhat the sliape of a man's foot, and raked in the embers just like potatoes to roast, and there allowed to remain and cook all night. The next best corn hreal is the old-style johnnycake, mixer in the same way, and patted about three-quarters of an inch thick upon a board, and roasted before an exceedingly liot fire.

The wext best are the "corn-dodgers" of the Southwest, mixed lilie the first, and baked in an iron bake-pan, standing on hot coals, with hot coals on the lid. These dodgers are usually of two to four pounds weight, and when brought liot to the table are certainly good bread. They are much eaten eold, but we can not recommend them in that eondition, only as being infinitely better than the half-baked corn bread common at the North:

All the improvements of corn bread ever attempted by adding other ingredients have failed, to our taste, to produce an article equal to a well. baked ash-cake or corn-dodger.

Remember the three grand secrets about making good corn hread: never to grind your neal rery fine, always to lave it fiesh gromd, and never fear baking it too much. All corn bread should be cooked a long time. The negroes often bury the dough in the hot embers all night.

One of the most common objections to the use of corn bread is its supposed indigestibility. On acconnt of this eharacter, which it has obtained, as we think, unjustly, it is avoided by many people who are of a dyspeptic halsit. We think there is a mistake in ascribing this eharacter to corn bread indiscriminately. If Indian corn meal is not thoroughly cooked, it is indigrestible-more so, perhaps, than any other grain. But such bread as that ahore described as ash-eakes or corn-dodgers, we do not believe indigestible. We have often eaten corn-eakes, made purposely for a severe aftliction of indigestion, and found them better than any other kind of bread. These were made of meal and water and salt only, and patted out into the size and thickness of Boston crackers, and most thoroughly baked in a quick oven. See Section IXIV. 


\section{SECTION XXIV.-SUBSTITUTES FOR BREAD, IX GREEX A.TI) MlII:H}

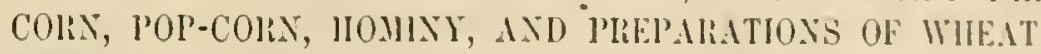

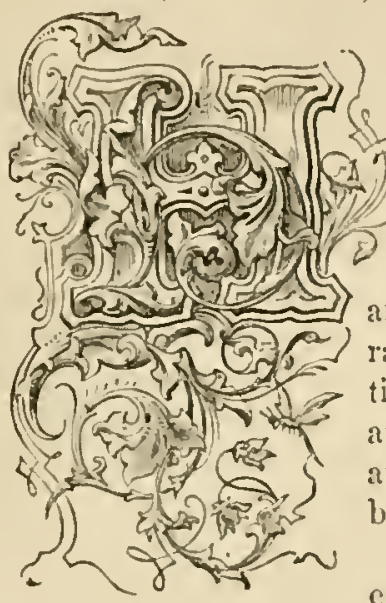

OW truly has lireal heen denominated "the statf" of life!" For it there is no sulstituse; thomigh some of the excellent preparations of form treated of in this section may le considered substiute. lut they are only partially so; yet fluey are worthy of our especial attention, becanser, ita articles of food, all orer Auscrica, they loold at high rank; and a notice of them seems fitting in conncetion with the hreal question. Ealch one of the articles named in this ecetion furnishes whelescrume and economical food, and some of them sluuhl be better known in every farmer's family:

406. Green fortu, or Boastiug lars-lionsting the ears, is the printive way of using ludian corn. It is the first use that the early settlers of $A$ merica inale of it, lecanse tlant was the mode in whieh they found the Indians preprang it. The puality of the corn grown for enting while in its milky siate, has been much improverl since Captain Suith took his first meal with P'ocahontas, on the lamks of Janses River, in 1607. Certainly there ean lo 110 richer vectotalles food than the best quality of sugar corn, such as crerg farmer slonlel grow, when simply boiled, or when made up in that Indian dish callew sheco-tash. And if any finmer donhts the ralue of this green com, ns winter food, whon carcfully preserved ly drying. or in sealew eans, we think he wonld be convineer, it he could dine at our table for a munth in midwinter, where lie would find it was one of the rexplat distes. We have just make a hearty meal of this and another preparation of enrti, directly to be molicel.

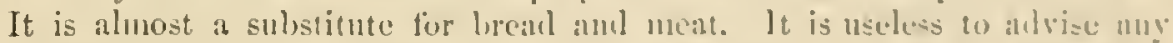

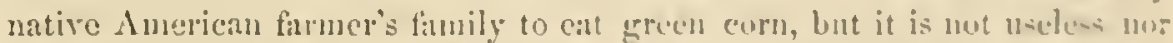
improper to urge nine temtlis of them to wse a hetter variegy. And we de most earnestly ask every family to juenere enongh ly drying the grive the

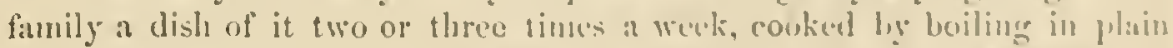
soft water two or three hours, nut until nearly all the walter is ab-orduel ur evaporated, and then sentson with salt and linter. It a little salerntus is

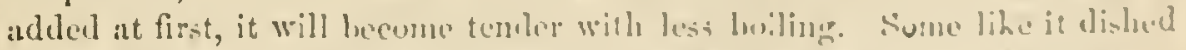

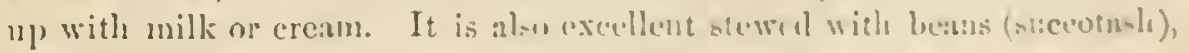
seasoncel with a piere of meat, and it is very gonod in Fonpls.

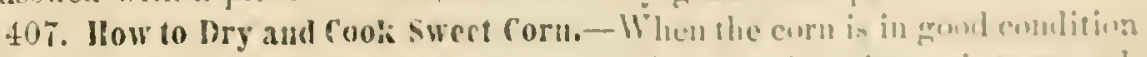

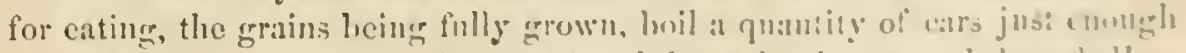

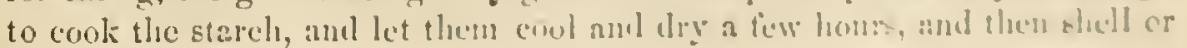


cut off the grains and spread them in the sum till dried. The best way to dry the corn is to mail a piece of cloth of very open texture on a frame; say two feet wide and five feet long, will lie a convenient size to handle. If the corn is spread thinly upon this cloth it will dry quickly withont souring. It should be covered with a piece of musprito netling to keep off the flics. - Another person gives the following directions for drying smeet coln.

"As soon as the corn is fit for the table, husk and spread the cars in an open oven or some quiek drying-place. When the kermels loosen, shell the corm as soon as you can, and spread it mpon a clotlı to dry in the sum, or on papel in a mam oven; stir it often that it may dry quickly and not overheat. Dried in this way, the kernels remain whole, are sweeter, and retain more of the natural flavor by drying faster. When all clried, expose it to the wind by tming it slowly from dish to dish; the wind blows oft all that troublesome wlite chaff."

Anotlser plan has been highly recommended and a machine invented to facilitate the operation; this is to bore ont the pith of the cob and then completely dry the eom on the cob and keep it there till manted for the table, when it nay be slielled first or boiled as it grew.

Directions for cooking dried street corn are very simple. Wasl and put it in warm water to soak several hours; then in the same water boil it for a half hour. Just before taking it up, add some sweet milk or cream, pepper and salt to the taste, and a little sugar if it is not as sweet as wonld bo agreeable. Sometimes a bit of soda as large as a pea in a half pint of corn, while soaking, makes it more tender, and corrects any stale taste which it has aequired by long keeping.

This is a good dish with meat, dressed with grary, or it may be eaten with sauce as a dessert dish. It is good enongh, eaten any way, to be, and it should be, upon every American farmer's table.

40S. llwlled Corn, or lye llominy, is mother primitive form of preparing an excellent substitute for bread. In the form of "tortillas," it is the almost universal bread of Central America. We look upon hulled corn as one of the lnxuries of American farm life, yet not one in ten of farmers families ever enjoy it. It is particnlarly acceptable in the spring of the year, when old regetables are on the deeline, and new ones hare not yet come into use. When the farmer burns wood, a white lye may be made in a few minutes, or cobs may be burued and ashes used to make a lye, into which put the corn to be hulled, which should he large, white-flint corn, and let it remain until the hull will slip easily, and then rinse it thoronghly in cold water, rubbing it with the hands or stirring it with a stick till all the linlls are washed oft. Feed the luuls and chits which come ont to the pigs or hens, and boil the corn for yourself until it swells to three times its original size, and is as soft as lireal. You may prepare and boil a gallon at once for six persons, and what is not eaten at first may be warmed orer just as you would potatoes. Those who have no wood ashes or cobs to make weak lye of, may luull corn by lusing a teaspoonful of saleratus to a quart of corn. in water enough to 
cover it. In either case the lye mnst be male lot after the com is put in to loosen the hull; and if the lye is not carcfully whlied from the corr, it will taste umpleasantly.

409. Samp, or Iry Homing.-This is anotler and most valuable preparation of corn, and an excellent, wholesome, economicul sulstitnte for bread. It is an aticle that no family, desirous of proticing economy, cun do without. It is a rery cheap, healthy, mutritious food. It usually costs only halt the price per pound of flour, and contains no moisture, while the best of thur holds from twelve to sixtecn pounds of water in a harel. In point of cenony as luman food, one bushel of homing is eytal to ren of potatoes, fon which it is an excellent substitute, and is almost as mirersally liked as pur. tatoes, and at the Sonth it is more freely cuten; while at the North it is seldom seen, cxept by a few persons in cities. Jy hominy, we do not nem a sort of conse meal, but grains of white corn from which the luth and chit or oye have been removel by moistening and ponnding in a worlen mortar, or patent hulling machine, leaving the grains almost whole, ant composed of little else but starch.

410. How to Cook Hominy, - The process is very simple to those who knnw how. As but few do, we give the formula of practice in our awn tamily: Wasl slightly in cold water, and soak twelve hours in tepicl, soft water; then hoil slowly from three to six hours in the sane watler, will plenty mente added from time to time, taking eare to prevent burning. Do not salt while cooking, as salt or liard water will harden the colu ; su it will peas or beans, green or dry, and rice also. When done, add butfer and salt: or at better way is to let each one season to suit the taste. It may be waten with meat in lieu of regetubles, or with sugar or syrup. It is grood, hot or colld: it is grood frequently warmed over, for it is like the old-fashioned pot of -

\section{" Jean porrishe hot, or besn porrillge cold,}

Iken jurrilge best at nine day's ollt."

So is lomriny ; it is good always, and very wholesone, and like tomatues, only reguires to be enten once or twice to fix the taste in irs fitvor.

In New York this article is called samp, and the name homing is priren fu corn cracked in a mill, and winnowed, and sifted, and mumbered aceorling to its fineness. We add a few of the was in which homimy may he nsol.

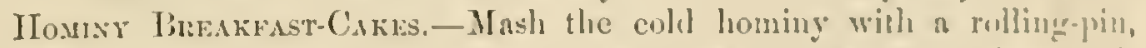
and add a little flom-and-milk hatter, so as to make the wholo thick contegh to form into little eales in the hamel, or it may he put upon the erridelle with a spoon. Iakke brown, cat lot, and you will declare you never ate anthethin!s better of the batter-calie kimb.

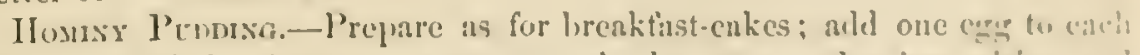

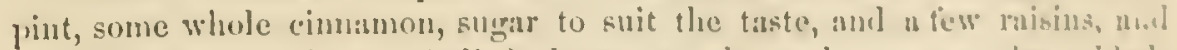
hake like rice-pulding. A linte luther or chopred suet may be mifled. Serve liot or cold, with or withunt fance.

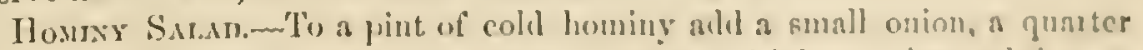
of a boiled chicken, or ubout tho same quantity of lolsicr, chopperl time, to 
which some add a small pickle. To he dressed with sweet oil, mustard, nepper, and rinegar. It is a rery good substitute for green salads at seasons when the lattel can not he obtained.

Ifosuxy axd Mick, hot or cold, is as much better than mush-and-milk as that is better than rye-meal porridge.

Homwy Axn Briss. - Mix equal parts of cold baked beans and homing together, and heat up, and you will have an exeellent dish.

Sort Howny lirenn.-One spoonful of hoiled lominy, cooled; a small lump of butter, one egra, lialf a pint of wheat flom-mixed with milk to the consistency of cream. Bake a lialf hour in a lot oven.

Homix WafFlis.-Two spoonfuls of hominy, a small lump of lutter, two egrs, one quart of wheat flome. Thin with milk to the consistency of very thick cream. Bake in waftle-irons.

411. How llominy is Malc.-The primitive way of making lominy was beating the corn in a mortar, in a considerable mass togetier, so as to rub off the liuls by attrition of the grains, without breaking them. Nearly forty years ago, in floating down the Ohio River of a still evening, we first heard the music of the hominy mortars, which filled the air, as the roices of the negroes liept time to the strokes of the pestles, preparing a farorite fool for their masters as well as themselves. Put of late years the gromd hominy, or cracked corn, luas in a great measure driven the old houniny mortar out of use. Negro hominy is cooked by soaking and boiling until it becones gelatinous, and then, when eoll, if cut in slices and fried in a little fat, is often eaten in preference to any other bread. Honiny is also made ly mechanieal means, one of which is a shaft armed with files, revolving in a case with the corn, which makes a rey nice article.

At the South, negroes prefer hominy or corn meal to wheat flour, pound for pound. Com is ground very conse, and frequently eaten, lubls and all, in preference to sifting. Few would be willing to live upon that alone. It rould not be good economy to do so. It would be good economy for us all to nse more Indian corn meal, and it would not only be economical, but healthy, to eat more hominy.

Wewill add here sereral good receipts for cooking corn meal, as substitutes for wheaten breacl:

412. Virrinia Corn Bread--Dissolve one tablespoonful of butter in three and a half pints of boiling milk; in this seald one quart of Indian meal; when cool, add a half pint of wheat flour, a little sugar, a teaspoonful of salt, and two eggs well heaten; mix well together, and bake in two caketins well greased or buttered.

413. The St. Charles Hotel Indian Bread.-Beat two eggs rery light, mix them with ove pint of som milk (or butter with sweet milk will do), then add a teaspoonftil of soda or saleratus, then stir in slowly oue pint of Indian meal and one tablespoonful of melted butter; beat these well together; bake in a common cake-pan, in a quick oven. The bread can be made rery good witliont eggs. 
414. Mush, or Lasty P'udding, - Stir into a laslf pint of cold water enough Indian meal to make a tlick hatter; put this into threc or four quarts of boiling water orer the fire; after this has boiled ten minutes, stir in a dessert-spoonful of salt, and sifted meal until it is quite thick; let it buil from one to two hours, stirring it often to prevent its burning.

415. Fricd Mush.-Mush to be fried sliould boil a little stiffer, with a hali pint of flour, say, to two quarts of mush; put the rnush in an carthen dish dipped in cold water; let it stund until perfectly cold; then cut it in slices halt an inch thick, and fry them brown on both sides in a little butter or pork fat-lard will do with a little salt.

416. Indian cakes.-To a pint of mush add milk or warm water to unake a batter, and flour enough to make the calke hold togethur; two or three cinfs, two spoonfuls ot molasses or sugrar, a listle mutueg or lemon, to suit iles taste; bake on a griddle or in an oren.

417. Baked Inlian Pudding.-Into one quart of lwiling milk seall iun tablespoonfuls of Indian meal; when cold, ald a teacuptul of molnses, a piece of butter the size of an eseg, a teaspoontul of Ealt, also of gringer and cinnamon; bake in a pudding-dish from one to two lonrs, in a cuck-stove, of longer if in a brick oven. When done it has the nppenrance of brows bread.

415. Pop-Corn-Its Cses as Food-It makes Delicious Puddiugs- II cu can not close this section upon substitutes for breal without bringing to the nutive of fumers a new preparation of Indian corn, original with lie author, lut lighly approved by a rery large number of persons to whom the mew alicovery lias heen made known. It is as mnch a plensure as it is a duty to tell fumers how they cun grow and prepare upon their own farms a substitute for rice, farina, tapioca, sago, etc., for culinary purposes-ouncthing, in short, that shall he as good as either of the abore sulstinces for the uer of the grood honsewite, to make a pudding - a pudeling that is not a mere adjunct of a dinuer, but a real 'substantial allition to it; as hearey ats one of corn meal; more wholesome than that, more toothsome, amel equally clienp : so that it is within the reach of all, lwth rich and poor: and as l think it in valuable discovery in the preprastion of fool, I am anxions that evergbenty shoull enjoy the benctit of my diecurery.

"Necessity is the mother of invention." It was 80 in this ense. It was discovered that a pudeling could he got np in an impromplt: mamer, upon an emergency, in a farm-lonse, when the ingredisnts in most common nse were cxliausted.

For years popped corn hat heen an almost dnily dish, all the family ant all visitors liking it very much; lun we liad never thomght of reducing it to meal, and npplying it to culinary purposes, until one winter clay, when as pudding was wanted, and it was not convenient to olotain any ot the orlinary substances usel for that purpose. "To the couk's stregestim that corn meal might be horrowel, the mistres of the house replicel: "No, nu-1ny" father would rather go hungry than live ly borruwing besides, I dusit 
think there is time to make a corn-meal pudding; it requires fonr good hours to cook it sufliciently, othorwise it always has a raw taste; tor corn meal is never good mnless cooked a great deal. I think you will have to give up the pudding, but I will ask my father."

So she did, and he said: "Let us have a pop-corn pudding."

"Oh, it will, I fear, be a waste of time and material, and prove a great failure."

"No matter: there is as much to be learned by failure as success. Let ns try."

So we did. A pint of pop-corn was put through the operation, and it made sixteen pints of popped corn, which was first ernshed with a rollingpin on the kitelien-table, and then gronnd in the coffee-mill into a coaree meal, which measured eiglnt pints. It is easiest crushed by putting it in a bag." We have sinee procured a large-sized coffee-mill, that grinds the eorn without first mashing it. The difficulty was, that it was so light it wonld not feed regularly into the grinding-plates of the mill. The grow the corn for popring; it is a small, white, flint grain, upon small cobs, and quite prolifie in its yield. It is popped in a small popper made of woren wire, and takes perhaps half an honr to pop and grind a pint.

419. Now to make a Pop-Cora Pudling.-Mlix five pints of the pop-eorn meal with full four pints of sweet milk, and set it where it will wirm slightly, and soak an hour or two. Then let it cool, and and two eggs, sugar, raisins, spiec, as you would to a rice-pudding. Let it be set on a hot store and boiled a few minutes, stirring it sereral times to get the meal well mixed with the milk, because it inclines, from its great lightuess, to flont, and if baked withont stirring there will be a brown erust on top and custard at the bottom. It should be baked about an hour, and served hot, and will be eaten with great satisfaction-satisfaction that a new ingredient for a delicions, rich, wholesome pudding has been diseorered-one always at hand, easily prepared, and one that has nerer failed to gratify the taste of all who have tried it.

The cost of sueh a pudding to a farmer is the cost of the sugar, raisins, and spice-the milk and com I connt at nothing. What slonld I count the cost of five eighths of a pint of corn and four pints of milk, which, if not caten upon the table, would go to the prigs? The eggs would sell possibly for four cents, and the things bonglit cost as much more, in a pudding that fed eight hearty people. Let us then eat pndding-good, riol pudding-as mneh as we can at a meal, at a cost of one eent each. It is cheap; try it, and your will say it is good.

420. Pop-Corn Griddle Cakes--Another use for this pop-corn meal is for griddle cakes. To my taste, they are quite equal to rice cakes, coolied in any way that riee is, and are much henrtier. In fact, there is no strouger food for a laboring man than any of the preparations of corn in the way I have indicated. At the same time, its digestibility is unquestioned.

421. The Pbilosophy of Popping Cort.-The philosoplyy of the advantage 
of thus preparing corm is wortly of our attention. Of all the ceruals, Indian corn requires the greatest action of fire to fit it for foou. It is full of e-senttial wil, and that needs to be cooked, aud it cau only be done by a rerey high licat or a long-continued moderate one. If lung continuen, the ailier (a)n. stituents of the corn are sometimes injured, and so are the indredients arlderl to the meal. If not well coolied, any article of foud prepareil frum corn, howerer palatable, is not so digestible as wheaten bread. Now, in prop ping coln, it is subjected to a rery ligh heat, which thoronghly exulis the oil, and fits the corn at onee for fool-a food that almost evirybody lores, and so will everybody love the various preprations of tool from meal made of popped com, for it may be eaten withont fear by the dyspeptic, and it will be eaten with satisfuetion to appease lunger.

As we know that com and con meal, properly kiln-dricd, will keep a long time, we may safely argue that meal prepared hy a still mole purfuet system of fire-dlying, will keep an judefinite lengrll of time, or just ats long ats we wisl. If ground and packed in barels, the prop-corn menl will keup beter than corn meal or flour, or even whole grain.

422. Hulled Wheat, Wheaten Groats, atid Boiled Wheat,-Jhllul wheat is another exellent substitute for bread. It can be lullerl ly lye, or ly am of the mechanical means nsed for lublling corn of rice, onc of which is in run it through millstones, set just fur enough apart to gub ofl the lumk-. It is cooked by simply boiling, and is eaten in the various was that we labe mentionel for lioming.

Illeaten Groats, or "grits," as they are usually called, are coarsely" groumd wheat-as conse as it can well be groumd. This is also a subtitute for bread. It is cooked by boiling in plain wates, as honiny or hulled corn and wheat should always be, until all the water is alsorbed. It is catcen lweth hot and cold, or warmel orer, and it does not repuite as much cooking as any preparation of Indian corn, and it is hoth palitable and healthin.

Every fanily, whether rich or poor, or in town or country, should matic it a religious duty to use more corn uncal, oatmend, Gralnan tlum, huminy, aud eracked whent for breast, in preference to fine wheat flour, buth for lealth and ceonomy. Look at the relative retail prices jer poumel of these articles, and see which will grive the most mutriunt for the lenst money; not which will afford gou the most fashionable hread.

Boiled wheut is amother simple form of preparing an excellent substitute for bread, particularly at labvest-time, whilo tho grabins are not as larel as afterwarls. It shonlel be catefully selected, and cleaned, aud washed, amel then soaked several hours, and boiled in the fume water mot snue of the grnius crack open. It may be eaten witl meat, or as u dessert, with syrup, sauce, or milk. 


\section{SECTION STT.-EXCERPTA OF USEFUL KIOWLEDGE FOR IIOUSEWIYES.}

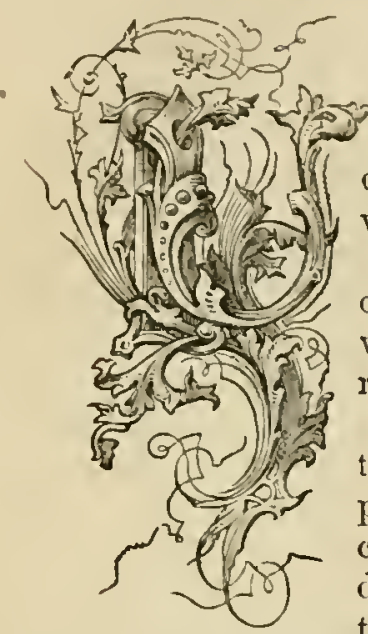

NDER this heal, which really means selecting choice extracts from books that we read, we intend to gather up a great muber of useful things, and concentrate them liere for easy reference in a somewhat miscellaneous order.

We will open the section with a most valuable line of adrice, selected from a letter of an exeellent lionsewifi to her danghter, when about undertaking the responsibilitics of housckecping. She says:

423. "Always Buy Good Articles, notwithstanding the first cost is more, in preference to cheap or lowpriced sorts, which are generally the most unecononical; and sometimes low-pliced articles of foor prove detrimental to health. Malie it a point to read ererything that eomes in your way about domestic economy. Fon ean not learn too much. Keep a little memorandum-book, with alphabet pages, and make it a rule to store up excerpta from all you read, for future use. It will prove to you a lasting somee of useful linowledge. Frequently you need only make a referenee in your memorandum where to look for what yon want. No head is large enongh for a storehonse of all that a good housewife will at some time want to linow."

424. Econony of Farm-house Lights,-This is a rery important question for the consideration of farmer's' wives, who may find that it will not always be good economy to bum their own tallow. Certainly not, if it ean be exchanged for a light-producing substanee which will save the hasd, unpleasant labor of eandle-making, and at the same time afford a unucl better and a pleasanter light. Unfortunately, we hare no standard of comparative enst of tallow-the almost miversal somree of farm-honse light-with fluid substances. E. N. Kent, of the United States Assay Oftice, tells ns, in the following table, which is the most economical as regards cost of olenginons substances for light.

\section{Cost of 0ils for Light Compared:}

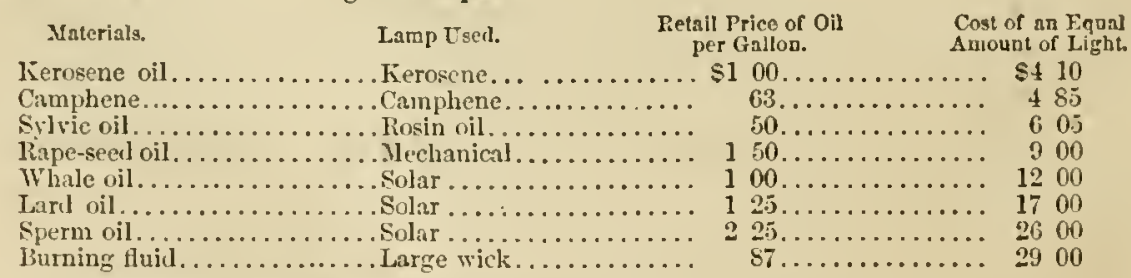

426. Cost of 0il and Candles Compared.-Dr. Ure gires tlre comparative cost of an equal amonnt of light per hour from tho following substances: 
"Careel lamp, with sperm oil, $1 \frac{1}{6}$ l. ; wax candles, fill. ; spermaceti cambles, $5 \frac{1}{4}$ l. ; stearic acid eantles, $4 \frac{1}{4}\left(1\right.$. ; molled tallow candles, $2 \frac{1}{2} 1$."

427. licomony of licrosene 0il.-From the foregning it will be seen that kerosene oil is the least expensive of all thuid lighteproducing substances; and as it is now refined, and burnt in improverl lanps, we letieve it to loo a very agreeable substitute for tallow candles, but whether cheaper or not ean only be determined by actual experiments ju dillerent lonscholls, comparing the cost per gallon with the value per pround of tallow, and the light prodneed or the light required. As a gencral thing, farm-louse lights are very inferior, and many a bright pair of eyes has leen chinmed in conse. quenee. It is on this aceonnt that this question of light should be more diseussed and experimented upon. Do not eontinue to use candles; or any particular form of lamp or kind of oil, bectuse you have long been in that practice, if there really is something better.

42S. How to Improve C'andes. - If you to use lioune-male cantles, pray purify the tallow, and to not mix lard with it, thougl yon may adil a limle alun, and never use your canelles any sooner than you would soap-unt they are at least six months old. Pack them in hram, and sct timen away in a cool, dry place, and see how much they improse ly ape.

It is well to mix beef and mutton tallow, but the proportion of the latter should be small, becanse it sometimes grives oll' a disngreeslule olor. All grood tallow is white, firul, and brittle, and dipperl canclles can only be mato of it in mild weather. Be careful to use nothing but fine, white, clean cutton yarn for wicking.

409. Ladd-llow to Make and Keep it Swect.-The lard of a hog of athont a year old, fattened upon con, and caretully rendered and packed in stures pois or sound oaken firkins, and kept covered elose, will kicep in a cool cellas just as long as any furmer's wife wants to keep it. Iard nust he thoronghly cooked in rendering, to keep sweet.

$A$ cooling-room attached to the ice-louse is an exceslent plnee to kiep lard in summer. But rementier that larel will never kecp well in any place it' it has been insulficiently cooked.

130. Rice and sago slonld hoth have a clear, fresh, white apjearanse when you purehase. Rice with the largest whole gratus is the hest. lice is remarkahle for being the richest in stareh, ant most leficient in vil, of all the cultivited grains. Old rice is ajt to be infectenl with weevil.

The sinall, white saro, culled pearl sago, is the best. The large, lrom kind has an eartly taste. "lhese arlicles, nut gromul rice, tapioca, etcon should be kept in hoxes or jars elosely corvereal.

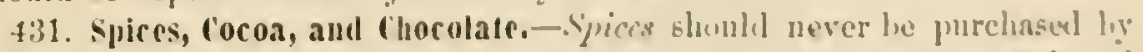

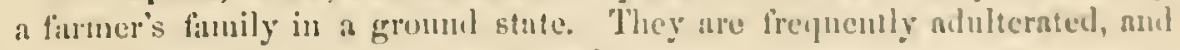
nlways luse strength as soon ns opened.

Nufmegs sometines ure kepe in store until stale. l'resh ones can he fro sected by pricking with a pin at the stem end, when, it good, a dropl of oil will ooze ont. 
Cocoa shells are apt to be inusty from long kecping. Never purcliase a large quantity until you have tried a sample and proved it fresll and sweet. Cracked cocoa is generally the best. Some that is carefully put up in papers keeps rell. Chocolate is often adulterated so that it makes a nauseous beverage. Do not buy lut a single cake until you prove it good. Both these articles are male from the cocoa heans, which grow upon small trees, cultirated for the purpose in Central America and otlier tropical latitudes. The beans are bitter and astringent, and are roasted like coffee to prepare tliew for use. They contain nuch more oil or fatty matter than coffee berries. It is rater in an analysis by Lampadius orer 59 per cent. of the substance. The substance containing the aroma of the bean is giren at 16.70 per cent. The shells are the dried fleshy pulp that surrounds the beans in the pods.

The cracked eoeon is the broken roasted heans. Chocolate is made of the beans, ground witl hot rollers, and made into a paste witl sugar, and seasoued with ranilla and spices, and if not adulterated, makes a wholesome bererage, but it is next to impossible to find chocolate that is pure.

432. Coffee, as it comes to ns, is the half of a dried bean which was inclosed in a pulpy berry that grew somewhat like a cherry upon a tree naturally ten to thirty feet high, but kept pruned low in coffee plantations, which are to be found in most tropical comntries. The best variety of coffee comes from Mocha, in Aralia. The berry is small and round, and the odor and flavor rery agreeable; it bears a high price. And next to it is the Jara coffee, a large, pale yellow berry. The Brazilian, commonly ealled Rio coffec, is the sort in most common use. The berry is of medium size, greenish color, and appears rusted with specks of gray. It is not a fine flarored coffec, liaring a good deal of acridness, but it is in faror witl farmers generally, becauso "it goes fartlier than mild coffee." All coffec improres by age if kept dry. It should be roasted very erenly, of a light brown color, and used very soon afterward, as it loses value every day after it is roasted, and after it is ground it will become almost worthless by a few days' exposure to the air. Roasted coffec should always be carefully kept in a closed canister, separate from all food, as it rapidly absorls odors. Roasting coffee in a room will always disinfect it of bad eftluvia. It also imparts its own odor to other things, such as tea, butter, and bread.

In roasting coffee, first dry it gently in an open pan until it changes color, and then cover the pan and scorch it rapidly without cliarring a grain. The term, "burning coffee," implies a great error in its preparation, or ignorance of its cliaracter. Roasting renders the grains of coffec brittle, and makes the matter that it is desirable to extract more soluble in hot water, and produces as great a chemical change as fire does upon corn meal or any other article of food.

The peculiar aroma of eoffec as it comes to the table, which gives it the flaror and stimulating effect ascribed to it, is nerer found in coffee grains before they are roasted. But if it is burnt, this flaror is destroyed, and 
in its place we lave a bitter, acrid, tannic acid taste, which produces pyrosis in the stomachs of those who use it lingely.

Nerer allow pepper and coffee to come in contact. The two should not he lept in the same pantry.

The best water for a decoction of enflec is that with a slight alkuline tinc: tmre, and it lias been recommended to and 40 grs. of rly soda to a poumel of coffec. It is certainly true that some of the springs of the Rocky Mount. ains, which are so alkaline as not to he drinkable. unake good coffec. So du wells that will not make grood tea.

Never buy ground coffec. Besides the fact that it loses strength, it is almost miversally adulterated. Pens are largely used for this pmpose, and beans, com, dried carrots, turnips, chiccory, and several other substances ure also employed.

433. Tca-its Valne as Food.-That tea lins a value as food, we can not doubt. Long betore its nse among European nutions, the Chinese haul suttled this question to their satistnction. It it is not of itselt food, it secms to help us to assimilate other things. It certainly is a farorite beveragu wirl all who are aceustomed to its $u s e$, and so fur as licalth is concerned, wo heslieve it is ecrtainly harmless, if pure, as the best blach teas generally are. The green teas, either from the uatire of the article, or from something added in curing, luave a much greater clicet upon the nervons system than the black teas. Pekoe and Oolong are the numes of two of the liest varieties of black tea. Gunpowder and Inuerial are the two best rereen teas.

434. Wow to Bake Black Tea.-lilack tea must be loiled some minutes -thirty is bettel than less-in a eluse vessel, to get the fragraul aroma and all the vergetable extract that ackls valie to the delicious leverage we get from a well-inade eup of good black tea.

Nerer nse liard water for tea. Filtered rain-water makes good ten. Never stecp it in lukewam water, and never let it cunc to tho tablo at that temperature. The true aroma of te: is never obtained uxeept when it is boiling lot. Ten shonld never bo exposed to the nit. Keep all ground 6jices, and also gromel coflce, earefully exchuled from the air.

43J̃. sugar and Molasses.-For most jurposes retined Engars aro the most ceonomical. In buying raw sugar, select nono hut ilic clenuest surta, such as the lest New Orleans, or Suntal Cruz, of a linglit straw colór, cuarsel! crystallized. White Havana sugat is unt as clenn as white Hruzil sugar. Select bright, light-colored molasses. Never buy the thick, dark-culored, 6riga-house syrup. Its thickness does not indiento sweetness. For the table, the real "golicn syrup" of the sugir-refivers is uot anly the hest, hut most conomicnl. We make an excellent tablo syrup every year of maple. sugur dissolvel in hoiling wrer.

436. Kuowledge for the Kildien.- Iere are a few eimple rules for the kitclien that may be usetinlly remembered:

Oranges and lemons kecp best wrapped close in eoft proper, and laid in s drawer with lincu. 
Bread and eakes slould be kept in a tin box or stone jar.

Salt codfish should be kept in a dry place, where the odor of it will not affect the house. The best kind is that which is ealled dun, from its peculiar color. Fish skin, for elearing coffee, should be washed, dried, cut small, and kept in a box or paper bag.

Soft soap shonld be kept in a dry place in the cellar, and should not be used till three months old.

Bar soap should be cut into pieces of a convenient size, and left where it will become dry. It is well to keep it serernl weeks before using, as it spends fast when it is new.

Cranberries will keep all winter in a firkin of water in the cellar.

Potatoes should be put juto the cellar as soon as they are dug. Lying exposed in the sun turns them green and makes them watery. Some good housekeepers have sods laid over barrels of potatoes not in immediate nse. To prerent them from sprouting in the spring, thrn them ont on the ecllar bottom.

To thaw frozen potatoes, put them in hot water. To thaw frozen apples, put them in cold water. Neither will lieep well after being frozen.

437. Storing Butter and Cheesc.-The most economical, and, to our taste, the best table butter is that which is paeked in September and October for the next winter's use. If well made, in a soft-water region, there is no difficulty about keeping butter sweet in a temperate elimate, it properly made. Never keep bntter and cheese together, except it is in a rery cool room, and then not in close contact.

If cleese is rich and good, it always feels soft muder the pressure of the fingers. Eren if kept until quite old, it does not become lorny. Be careful not to select a horny cheese. That which is rery strong is reither good nor healthy. To keep one that is cut, tie it np in a bag that will not admit tlies, and hang it in a cool, dry place. If mold appears on it, wipe it off with a dry elotl.

435. Keeping Sweet Potatoes,-One who is a successful grower of sweet potatoes in quite a northern latitude-near 42 degrees-gires the following as his method of keeping them orer winter. He says:

"I nse dry sand to put them up in; it does not matter low the sand was dried-in a kiln, a $\log$ heap, or in the sun-if it is dry, that is all that is required. I prefer drying it in a $\log$ heap, as it costs at least four times less, and is just as good. And a family that has a little room with a store in it, may keep a box or two, with eight or ten bushels in them, without any inconvenience of consequence. The boxes must be raised a fer inches from the floor, and they must not be less than four inehes from the wall. Fill the boxes with potatoes, and then put in $d r y$ sand until they are corered.

"I hare known them kept well in buckwheat ehaff. In order to keep potatoes with snceess, there must be a thermometer kept in the room. The mercury must not sink below 40 degrees; if it does, the potatoes will chill and rot; and it must not rise above 60 degrees, or they will grow." (See 565.) 
439. Preserving Eggs. - The following receipt is of such casy applicatiun that all houscwives should try it, and satisty thenselves whether it is all that its anthor claims for it:

"Dissolve some gum slellac in a sullicient quantity of alcohul to malic " thin rarnish, give each eger a coat, and after liey become thoronghly dry, pack them in bran or sawdnst, with their prouts downwed, in such an manner that they can not slift about. After you hitro liept them as loug as you desire, wash the rarnish earefully ofl, and they will be in the sume sance ats they were before packing, deady citler for eating or hatching."

440. Beans-llow to Cook llicm,- "Few people know the luxury of baker? beans, simply because fer cooks properly prepare theus. Leans guncrally are not eooked half long enough. This is a sure mothod: Two yuarts if middling-sized wlite beans, two poumls of salt pork, and one spoontul of molasses. Pick the beans over carefully, wn-h them, and add a gallon of boiling-hot soft water; let then soak in it all night ; in the morning. punt then in fresh water, alding a teasponnful of saleratus, and boil gemely, will the slin is rery tender and about fubresk. Talic then up dry, put ilsus in your dish, so as to have the henus fill the dish newrly to the upper edere; turn in hoiling water till the top is just conered; bake with a stealy fire four or five homs. Watch then and all nure water from time to time, as

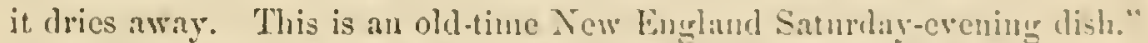

44. Tomatoes-Varions Nethots of Preservin? ant Vsing them.-There is no way to preserve tomatoes for winter nse su gnod as drying then. It is casily done thus: Scald, anci pect, and sicw 10 at golatinons mass, and splund upon earthen plates, and dry in the smmshine or in a slow oren. It will then lescomble dried stewed pumplin, or the julput penches dricd in the sane way. When wanted for use in wiuter, a portiun ut this dribl tomato is sunked tive in cold water, and that is gratually warmed till the whole becomes a homogeneons mass, moro or less thick, aceorling to the quantity of watcr wnet. It may be eaten as a sauce with uteats, on, ly alling sugar, as at swetmeat, or in place of currant jelly with venison and mutton, or as a sulsirtute for cramberrics with least turkey. It is an escellent and a cheajp Eance.

Tomato Crowden.-To one busluel of green inmatoes add nue d zen errecu

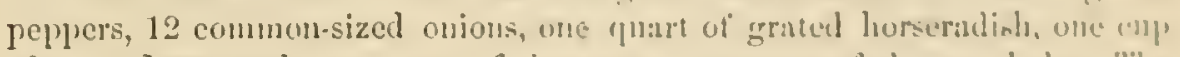
of ground mustard, one ounce of cimminm, one nunce of cloves, whole. "lhe

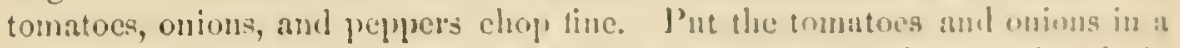
ressel over-night, sprinkle a lible salt over them, and in tho mornimg dran off the water, jut all together and boil them in clear water until tender, then

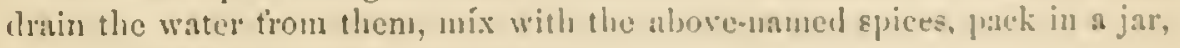
and pour senlded vinegar orer iliem.

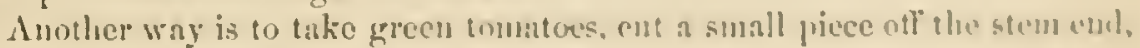
and also from the other sile: then lity them in a pan. Sprinkle with nult. pour hoiling water on them, and let them stand sen minuters. L'unr tho

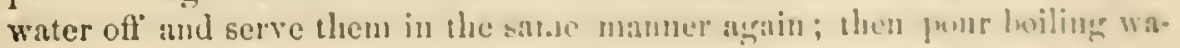


ter on them without salt, and let them stand a few minntes. Chop them np fine, putting in some cabbage, lorseradish, and peppers; and when all chopped, put on salt, pepper, and vinegar, and they are ready to pickle in crocks. This makes an excellent relish with meat.

Tomato Citcrice.-Scald ripe tomatoes just sufficiently to allow you to take oft the skins; let them stand for a day, covered with salt; strain ther, to thorouglily remore the seeds; then to every two quarts add three ounces of eloves, two of black pepper, two nutmegs, and a rery little Cayenne pepper and salt; boil the liquor for an loour; let it cool and settle; add a pint of the best cider vinegar : bottle, cork, and seal tight, and lieep it always in a cool place.

Axotuer WAY.-Take a bushel of tomatoes and boil them till soft; squeeze them through a fine wire siere, and add half a gallon of vinegar, one pint and a half of salt, two ounces of clores, quarter of a pound of allspice, tro ounces of Cayenne pepper, five lieads of garlie, skinned and separated; mix together and boil about three hours, or until reduced to about one lıalf; then bottle, withont straining.

Tomato SAdCE.-One peck of tomatoes, one ounce of clores, one onncc of cinnamon, one quart of rinegar, four pounds of brown sugar, two tablespooufuls of salt, and the same of ground black pepper. Peel the tomatoes, and boil until very tender. Drain them from the juice. Now boil the sugar, spices, ete., in the liquid until it is thick as syrup; return the fruif into this syrup, and stew until the mass is a jam, and it keeps well any length of time. This may be used to flaror the following sauce:

442. Picnic Sauce--Beat the yelks of four eggs perfectly; mix with the crgs a tumbler of jelly, four large tablespoonfuls of brown sugur, four large tablespoonfuls of mustard stirred into a batter with rinegar; to tluese ingredients add a teacupful of butter and two tumblers of best rinegar. Stir all together carefully; set the vessel in which you liave mixed the sauce in a pot of boiling watel and cook until it thickens and the egg is done; stir in a little salt and half a teaspoonful of Cayenme pepper and as much tomato sance as will give it a pleasant flaror.

443. Muslorooms, and their Tses and Probuction.-It has been published that some of the great producers of mushrooms near Paris, who grow them in artificial caves, can produce at the rate of eighty quarts a day upon an acre of surface, which would give an annual crop of 29,200 quarts. Allowing the actual erop only one fourtl of this quantity, it wonld be a very ralwable one, as the average market price in New York is 25 cents a quart. Say 7,300 quarts for the prodnet of an acre, at 25 cents, this would be $\$ 1,525$ a year. The construction of artificial cares, lowever, is so expensire, that mushrooms are not likely to be much eultivated by farmers for finily use, though many of them will continue to collect such as are produced spontaneously about the homestead; and to enable them to do so without danger of getting lold of other plants of the agaric family that are poisonous, we gire the following rules to distinguish the edible mushrooms 
from toadstools. Without giving the hoianical characters, we notice sonde of the marks by which they maty be distinguished:

First. The mushroom his no hat smell. The skin on the tor of the mushroom will readily peel off. "The grills or plites on the under sinle of the mushrom are of a white and pinkish or rosy lue, and thongh turning brownish lyy age, yet never of that lurid brown of the toadstool. When sprinkled witl salt and allowed to stand a few lours, the mushroom gives out juice, but the toadstool becomes dry ind leathery. If all these charac. ters are mited in the specimen it may be safely eaten, otherwise it flomld be rejected, as it would be better to throw away acres of grood muslirooms than to eat one of the poisonous toalstools.

Sccondly. Mushrooms which grow in marshy, shady places, and in thick forests where the sun lias no aceess, are in general to be rewarled as possessing dangerous qualitics; their substance is softer, moister, and more porous than that of mushrooms used for the table. They liave likewize a more disagreable and dirty-looking appearance. Those which have a dusky luc, aud cluange color when eut, or slow a gandy or many very dis. tinct colors, particularly if they latye been originally covered lyy skin or exhale a strong and mupleasant orlor, ought not to be eaten. Those which hare sliort bulbous stalks, or fragnents of skin alhering to the surface, or which grow rapidly aul corrupt quickly, slould also be rejecter. It las been generally supposed that poisonous mushrooms loso their teleterions qualitice, hut this is a lule to which there are many exceptions, and which onglit therefore to he very cantionsly admitted.

It you wish to grow nushrooms, procure some of the spaw from a gardener, and make a hed of light lommy soil, mixed with manure from horses fed upon urrin; it will produce these plants when the temperature is rimlt, which is ahout 50 or 55 degrees Faluenlueit, in dry, calm, smmmer weather. $\Lambda$ cave cellar, or natural cave, or reces in the rocks, is a good place to matic a mushroom bed.

4t4. Drying Rhuharb.-Tiluharb, when well prepared, will keep good for an indefinite period. The stalks shomld he lroken ofl while they are erisp and tencler, and cut into preces about an inch in length. These pieces shoull then le strung on a thin twine, nud hung up to diy. Thubarb shrinks in drying more than any other plunt, and when dry strongly resembles pieces of sotit.wool. When wanted for use, it slould bo sonked in water nll night, and the next day stewed orel a slow fire. Nume of its properties appear to bo lost in drying, and it is equally as good in winter as mu ofluer dried fruit.

Anotlier plan is to cook it first; for this get tho I,inunus rlubarl. It is larger, more tender, and bettel tlavorel thun any other, requires less sugar by one fourtls, and has no skin to be taken ofl. Do not attemper to preel it, but ent in pieces as long ns the thickness of the stalk, nul funt them with your sugar in an earthen dish without water; ever it to retuin the flavor. and place it in an oven and cook till quite tender, withont stirring or break. 
ing the pieces. If too much cooked, it assumes a disgusting stringy appearance, and loses all fruity charncter. The rosy color of the stallis will give your dish an attractive appearance, and the dyspeptic will find in it a porrepful aid to digestion.

This, if thinly spread upon plates, and dried in the sum or a slow oven, just as the pulp of peaches or stewed pumplin is sometimes prepared, will keep as well as pumpkin, if packed away in thick paper bags or boxes, and kept in a dry place.

Thlubarb has within a brief period, quite within our memory, become generally diffused, and is now looked upon as a family necessity rather than a luxmy. There are several varieties: Cahoon's seedling is the largest, but is rather coarse and not so high flavored as some others, of which we may have more to say under the head of the garden. We will only speak here of one or two methods of preserving the good qualities of the stalk by drying. For drying whole, the Victoria is one of the best varieties. Other sorts contain too much woody fiber.

4t5. Facts about Pork and Bacon-Ilow to Cure and Keep llams,-The best and most solid pork is made by rapid feeding of pigs in autumn, which havo been kept growing, but not fat, all smmmer. Hogs that are kept fat through the summer are most apt to afford soft pork, which shrinks in the pot.

One writer says that-" Pigs shonld be wintered upon two ears of corn a day, fed very regularly, one at night and one in the rnorning, keeping them in a warm, elose pen, withont water, and they will hibernate in good condition upon this small amount of feed. If watered or fed with liquid food, and liept in the cold, much of the food is expended in keeping up animal heat. The pigs slonld be in good condition when put up, and must be well bedded to enable them to keep warm."

446. Dry-Salting Bacon,-Hams, or any part of the pig designed for bacon, we think, should never be put in pickle; they are decidedly better salted dry.

Our practice has been to weigh both pork and salt, giving six pounds of fine salt to one hundred pounds of pork. First sprinlile about one fourth ot an ounce of saltpeter, finely pulverized, upon a ham or shoulder, and then rub it well orer with salt, and pile up the pieces in some dry room, just as you would pile up a lot of stove-wood. It should be overhanlel onee, and the spare salt rubbed on fresh-looking spots, and the pile reconstrncted so as to allow the air to come to all parts. It will completely salt in as many days as a ham weighs pounds.

For pickled pork, it is adrantageons to salt it in bulk, before packing in barrels. Nothing will drain off from meat thus salted, but just what should drain away. When your pork is ready to go into the barrel, pack it as tight as you can force it in, and then fill the barrel with brine; not salted water, but brine, which is water saturated with salt. Pork thus cured will keep longer than we can calculate.

447. English and Irish Mode of Curing Bacon.-The Irish Farmer's Gazette 
gives the following directions: "Singe oft" the hasir, and seraje thoronglyly clean; when cut ul, rub the flesh side well with conmon salt, aud pack the pices on top of each otler on a triy with a gutter round it to caticls the briue; once erery four or five days the salt should be changeel, and the fitches moved, placing those on toj at the botton; five or six weeks of this treatment will suflice to cure the bacen, when it may be lumer uy to dry,

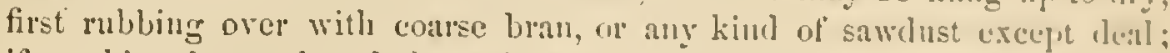
if smoking be prefurred, hang in a climney; if not, in a dry, airy part of the kitchen, not too near the firc. We are not acpuainfed with the Limerick mereantile process; the Wicklow is similar to that given above, and priticed by fimuers there."

An English recipe says: "For foul hams, tuke two ounces of salppeter. two quarts of inolasses, one quarter of a poumel of pepper, latle an unnece of cochincal, and about thece pints of tine salt. If the hams liave becu in salt pickle, the salt will not be needed. Pouml the sal!petco aml couluneal, then put all these iugredients together, and rub the hams thoroughly with the pickle, turuing them every tay."

145. A Good l'ickle for bams.-It dejends partly upon low hogz are ful. but more upon the mannel of curing than anything clse as to the yublity uf lanme. They can be made almost as delicite as tender chicken. lin curing hams in pickle we lave tried and applrove the following compunm of articles: To 100 llos. of lams use $S$ or $y$ lbs. w rock-silt, 2 oz. of salipueter.

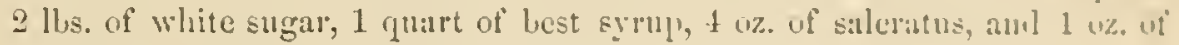
allspice.

These materials are hoiled and scummed, in ten or twolve callons ot watier, and the hams packed in a batrel, anl the brine put on coml, alling water it necessary to cover the hams. None hut a new onk batrel smuld lue u-enl.

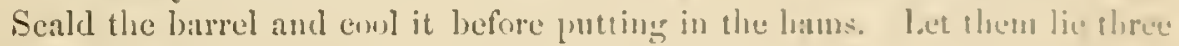
weeks, and then take them out and air them twenty-tion lours; put them

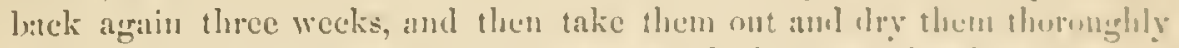
before smoking, which is done in an atry smulse-lunsec, with cobs and maple or hickory elipis. It is then a most deliefons arriche of foul. In smoking. be careful to keep your hams coul: never allow tire enongh io heate the meat.

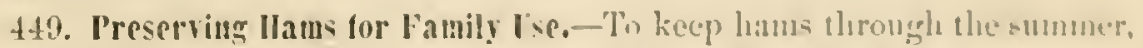

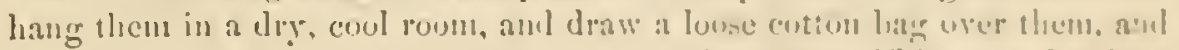
tic it tightly around the string that holels the meat. "lolis must lue alone

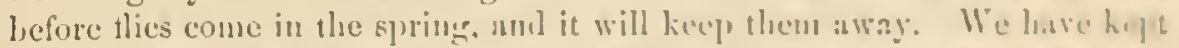

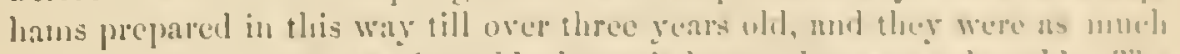

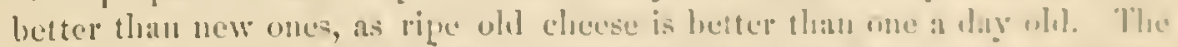

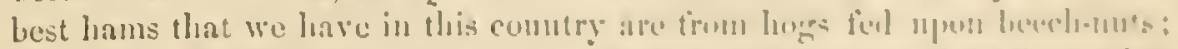

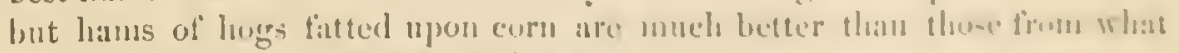
are generally known ms matofud hegrs.

450. How to cook a Ilam.-Nevede jut a ham iuto at kettle of colal water.

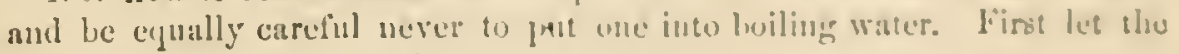


water become lnkewarm; then put in the ham. Let it simmer or boil lightly for fonr or five hours-fire is better than four-then take it out and shave off the rind. Iunb granulated sugar into the whole surfuce of the ham, so long as it can be made to receive it. Place the ham in a bakingdish, with a bottle of champagne or prime cider. Baste occasionally witl the juice, and let it luke an howr in a gentle heat. A slice from a nicelycured ham, thus cooked, is enough to tempt a Jew.

451. Eansage-haling, - $\Delta l 1$ the lean scuaps of pork that accumulate in cutting up the pigs, whether for bacon or jickled pork, will be most economically nsed if made into sausage neat. But do not attempt this work unless you liave a good sausage-meat cutter ; and if you wish to stuff the meat into cases, you should have a combined entter and stuffer, so as to do the work at one operation. Cut the pork into small pieces, and divide it in parcels of about a quart, npon a clean table, to which the cutter slould be fastened. Mix your ecasoning of salt, sage, thyme, cloves, pepper, and a little sugar, it you like it, with your meat, and then put it through the cntting-machine, this nicely blending the seasoning with the meat, which passes directly into the cases, and finishes the job with great expedition.

452. The Value of Pork in Pacon.-If bacon sides should range at 13 cents per pound, shoulders at 10 cents, and hams at 15 cents; and prime piekled pork at $\$ 18$ per barrel, mixed pork at $\$ 16$, and rumps at $\$ 14$ per barrel, we would advise all small farmers, who liare a limited foree to feed, and a limited purse to empty, to buy the rumps; they are abont eight inches of the small end of the backbone, with the tail cut off, and consisting of a dne proportion of fint, lean, and bone, and are the cheapest meat diet that can possibly be purchased by planters for their people.

453. How to cure and Cook Comes] Bccf--Fol a pickle, to erery $100 \mathrm{lbs}$. of beef, take five lbs. of salt, a quarter of an onnce of saltpeter, and one pound of sugar; dissolve in sufficicnt water to cover the meat. Do not get your meat too salt, for it makes it tongh and tasteless. Do not allow it to remain orer two weeks in the first brine, for it takes ul' all the blood that was in the meat, and consequently ought to be drained off, as the meat will be much more likely to be injured than it will when separated and replaced with fresh-made brine: but more especially in warm weather. In this way it will leep with just sufficient salt to season it. In the second place, the cooking is of just as much importance as the corning; it should be boiled at least four hours, or until it can be cut and caten as readily as a piece of soft bread. Not one half of the domestics cook their meat long enough. Try it oince and you will see the difference. Neat prepared in this, way can be caten with a relish, and is casily digested, giving mourishment and strength to the body. Bnt fried meats, or meats lialf cooked, can not lue properly masticated or prepared for the action of the stomach, and are among the most indigestible articles of nomishment. Some persons are always in too much of a hurry or too lazy to chew. their food, thereby favoring their teeth and throwing the responsibility upon the stomach. Frequent abuses of this 
important organ develop disease, and the individual is eaid to latve drspepe sia with all its attendant evils. Therefore, spare not the cooking; you will have the less chewing, and greater advantage of the food.

454. Italian Mode of Cooking scrap, or Coarse l'ortions of Bect.-1 rery economical and unost savory and delicious dish can he male wirle two or three pounds of cluck steak, or chenp parts of bect, which infinitcly surpinses the tasteless, insipid, common cating-lionse stuft, called "licet il la moule." Cut the steak into pieces of less than two inclies Equare; senson with black pepper and salt, put them into a sancepan with a full hast pint of could water on the fire, and as soon as it boils up, remove it from the fire and ret it.where it would simmer for two hours and a lialt, until perticely temler. While simmering, tic up in muslin a bunch of sweet herbs, conposed of knotted marjoram, winter savory, and a little thyne, and take it ont jur-t before the dish is served. Of course, the stew must oceusionally lie shatien, as all others are; remember, llowever, the fat must not be skimined ofl": the more fat there is, the better the stew. 'I'he dish is of Italian orirrin, and is eaten by Italians with plain boiled macaroni and Pamesan chucee, or with a salad, and with cither is a dainty dish.

455. Pressed Bef.-This is another excellent way of using up the cheap parts of fresh beef, or even that which is corned by the receipt given in Xin. 453. Boil any ragrged scrap picces, with not too much fat, until tle lunes will freely separate from the meat, which prek off and pack in any strong dish, and add such scasoning as you wish of salt, peplyer, spice; some awll a tritle of molasses or sugar, and jiress the whole into a carke, just as these the who make "head-cheese" from that portion of pork that is betfer preprared in this way than any other.

456. Iseful Litte Things for Honsekepers,-"The truest econumy locrins in little things." And so we give a dozen of them in a bunch tu curnelme onr "execrpta of linowledge for the kitchen."

MLnogaxy Stan.-Tialie four ounces of red sanders, one pound of timite. and an ounce of logwood, and boil them in lialt a gallon uf wibter fur vice houl; then apply it warm with a hrush or sponge; when dry, apply rar. nish. With this you can renorate old furniture.

1 Curar Rrmiglator.- "Two tin prails, soldered one into the other, tho space between them filled with chnecoal, in small pieces (not necessirily dust), with the cover arranged in the same way, will keep a small 'puantis of ice a very long time. Three inverted tea-enps, or somedning mate dur the purpose, shonld support the ice to keep it ont of the watur. Siens on putting the ice in a tin pail and wrapping it in a blanket, whis is the simplest ice-kecper wo know of, and it is entirely philosuphical aud a fective."

To this we add the recommendation of putting this tin pail, with the rec in it, with a hole as big as a pin at the lottom and drippinge pan under it, in a cliest or close-shutting cluset, the air of which will he couled, with tho provision placed in it. 
This, of course, is only a substitute for in grood refrigerator, but will be found much better than none, and ean be male for almost nothing, by any man wh lankee gumption.

To Mane Tovan Meat or Fow Therer. - One or two tablesponfuls of sharp rinegar put into the water when set to cook will do this, and in no way impair the flavor of the stew or sonp. Veal to roast is much improved ly being rubbed all orer with vinegar and allowed to remain two or three hours before cooking. Fifteen minutes to the pound is the received rule for roasting and boiling meats, and ten for fish.

Ilow to UsE SALT, - Beef or mutton should not hare a bit of salt put upon either when first set to roast; just before serving, baste the meat, sprinkle fine salt slightly over it, dredge flour on, and let it brown up. Ponltry must be covered with sweet lard and salt - a teaspoonful of salt to two of lard -l,efore roasting.

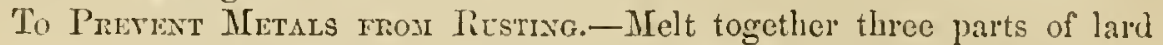
and one of rosin powder. A very thin coating gpplied with a brush will preserve Russia-iron stores and grates from rusting during summer, cren in damp situations. For this purpose, a portion. of black lead may be mixed with the lard. The effect is equally good on brass, copper, steel, etc. The same compound forms an excellent water-proot paste for leatlier. Boots, when treated with it, will thereafter take the usual polish when blackened, and the soles may be saturated with it without soiling the floor, as it does not rub off.

SeEDs and many other things are best kept in wooden boxes. By a new patent eontrirance, boards are eut about one eighth of an inch thick, of suitable length and width to bend into forms for the sides of a round box, the largest holding about a peck, and eight others, smaller and smaller, to form a nest. The ends are fastened together with some kincl of ghue, and the bottoms are fastened in by a rim of tin bent over the corner; and the lids are made in the same way, so that the ends may be of stuff but little thicker than the sides. The tin corners are great protectors against mice, as that is the only part of a circular box likely to be gnawed into, and this makes them quite safe for seeds and better as well as cheaper than tin boxes, and a decided improvement upon the old-style circular wooden boxes which have bottoms made of a half-inch board, so as to nail it in. We should think that half bushel and smaller measures, made up on the same plan, with iron instead of tin corners, rould be first-rate.

Uxpleasant Odors arising from boiling ham, eabbages, etc, are completely corrected by throwing whole red pepper's into the pot, and at the same time the flavor of the food is improved. Pieces of chareoal will produce the same effect.

A Good Way of Roastrag Aprles. - Select the largest apples; scoop out the core withont entting quite through ; fill the hollow with butter and fine, soft sugar; let them roast in a slow oren, and serve up with the syrup. Hodge-Podge.-Cut two pounds of mutton into small pieces, anú put them 
in a stewpan with three quarts of water and a tablespoonful of salt. Sct it on the fire and let it come to a boil; then set it where it will simmer an hour; keep it well skimmed; then add one carrot, two turnips, two large onions cut into small pieces, and half a dozen lettuce-heads, and let lice whole cook quite tender. Skim oft all the fiat, and serve cither with the meat in the soup or separately. A pint of green peas boiled in the sump will be found to be a great addition.

Il ani-Butsues are best cleaned by washing them in sal soda or Ealerutus water, which removes all the oily coating.

SAGE and all other herbs for fimily use should be ent when the plant is budding for blossom, and dried in the shade, and then storel in thick paper hags, and there is no better place for them than langing from the graret rafters.

To Curar Kives. - Take a potato, cut in halves, and dip the cut part in brick-dust and rub the knives, the potato aftording just enough moisture.

For Creasixg Taintin liarrils. - T'ut one peck of chareonl aud nne terenp of saleratus into each harrel, fill them "y with boiling water, eorev tight, and let them stand until cold.

457. Vernin-Memedies-Moths, birss, Atts,-Moths are driven away, it is generally licliered, or rather the miller that lays the egges is, by any etrong odor; so that furs or woolens, packed in a eliest of eamphor-woon, or of cedar, or Eassatras, or with the shavings of those woods, or with grum-camplior, or tobaceo, sunff, or pepper, are preserved from the ravages of thene pests. After moths commence cating, they pay no regart to the prescnec of camphor, cedar, or tobaceo; in fact, I think they enjoy the latter, if anything else than humanity can. The superiority of pepues to eamphor" as a preventive of moths eating furs, consists in the filct that, while the escos will hatch among camplior, there is something in the aroma of pepper which destroys their vitality. Woolens may be safely stored in a close linen bay if often louked after. And probably looking after is tho best of all the preventives, for moths never work where they are frequenty disturbed. Sint if articles are packed in linen bags, they shonld be taken ont and aired once a montl during sumuser.

lictore packing away fints, they should be well beaten, to distolge tho moths that, despite the most scrupuluns care, may he depositel in them. But the dreaded and incomenicut taking up und beating carpets will not" always insure suecess; but one who las iried it, says: "I compnerul then wholly in this way-1 touk a conrse crash towel and wrung it ont of clenu water, and spread it smoothly on the carpet, then ironed it dry with at gool liot iron, refenting the opelation ou all suspected ploces, mul thuse least used. It does nut injure the pijte of color of the earpet in tho least, us it is not neecsary to press hard, lient and stenu heing the nepents; and they do the work effectually on worms and cers. Then the camphor will donlo:less prevent future depredations ot the niiller. by placing a few litelo crunbs under the edges of the carpets withont moring them." 
Patcliouli is recommended as a preventive of moths. Sachets do patchouli are made of cotton-wool, among which a few grains of the powdered patehouli leaves are mised, and folded in paper. Placed among elothes, they are said to chrive away moths. In ILindostan, patchonli is used ly the women for scenting their hair, and it is also mixed with tobaceo for the lookah. In this country the patehonli leaves, it is said, will retain their seent if dried in tho dark by being pliced singly in a drawer, and tmoed daily for a fortnight. The Arabs diy the leaves and stuff pillow's and mattresses with them, beliering that they prevent contagion and prolong life; a belief which attaches annong the ignorant to sage and other odoriferons plants. As a scent, patchouli is used by perfumers chicfly for mixing with other aromaties.

Benzoin is used in the musenm of the Jardin des Plantes, at Paris, to keep the moths out of the skins of the animals.

Tallow packed with clothes is also a moth prerentive. But after all, frequent shakings are the best preventives of all injuries by moths or mold.

Bugs may be killed with almm. Make a solution of alum, as strong as water will dissolve, and apply that hot to places infested with bugs of any sort, in bedstends, closets, or trees and plants, taking care not to apply it so as to kill tender plants, and the bugs will take a strong dislike to the locality. You may brush it in cracks and crevices of floors, ceilings, or walls of a room, or in the holes and nesting-places of these small rermin in trees.

Corrosire sublimate is excellent for bugs and ants. For bedsteads it may be mixed with soap. For ants, with lard and sugar, throngh which draw woolen yarn, and fix it in cracks infested with ants.

458. Rat Remedies.-Chlorid of lime has frequently proved a sure thing to drive rats away from any place infested by then. An ounce of it, senttered in the place where they come to feed, or wrapped in a bit of musliu and put in their holes, where it aequires dampness, prodnees a gas that is not offensive to man, but is to the rats. If chlorid of line is moistened with muriatic acid, and placed in a drain, vault, or cellar, and closed from the air a little while, the rats will depart, because it will be death to remain. This is also a good clisinfectant, and will for a time remove the efluria of a dead rat. One application of dry chlorid of lime to rat holes has driven them array for a year. If they return, a renewal of it will start them again.

Cats are the best rat-traps that we have found after many years' experience, and next to cats, the chaff-trap. This is best made by partly filling a large, smooth kettle with water, and then eovering with a few inches of chaff. The first rat that gets in makes a great outery, which brings otbers to share his fate.

The best food with which to mix poison for killing rats is pumpkin seeds. Wet them, and sprinkle on a little arsenic, which will adhere to the reeds. They will be eaten by rats and miee, while cats, forls, etc., not being fond of such food, will not meddle with them. Wherever poison is put for these 
troublesome pests of the furm, water should be uear by, so that they may" eat, drink, and die ontside of their holes and hiding-places. Mustoruts, which are often troublesome pesis "yon some firms bordcring erecks or ponds, may be poisoned will ansenic upon pieces of parsnep or street apple. Gunpowder, flashed in rat-holes, is said to be grood to drive then away from the premises.

459. Disinfectants and the Valtae of Bisinfectiug, - Nothinge conduecs nure :o promote the health of a family than pure atmosphere. It cam be licp: eo only in dwellings properly construeted for ventilation. Front sittingrenom, dining-room, and bed-rooms we lave air flues that have a strong dratught ont of the top of the liouse, and the kitchen is latigely furnished with ventilation. In all unventilated rooms of the honse, and in sick chambers, odors at times accummlate so as to neel disinfecting, while cellars, sinks, onthouses, and stables often need it. Cofiee ronsted in a room, solutiun of copperas eprinkled about, or cloths wet in it and hung up; chlorid of lime moistened, each acts quickly as a disinfectant. The odor of a deal rut cest be allayed at once by moistening an ounce of chlorid of line with $n$ ters. spoontil of muratic acid. But no one should breathe muclu of the gins it engenders.

There is a considerable difference between a deodorizer aud a disintietant. The former cither merely reusores or discruises a tonl odur; the latter changeo the eharacter of the matter which ereates the etluvia, and prevents it frum sending forth disease. Fresh slaked lime and chareanl dust are very goud deodorizers, but their disintecting powers are not equal to some of the salts of manganese, which, when they combine with pestilentinl thids in sinks and darins, give ont at the same tiuse a considerable quantity of pure oxy.p.u to refiesh the atmosphere. The manganate of soda, or potash, hats recenty: been tried in London with much suceess in deodorizing and disintecting the water of the river Thanes, and its use in our citics during dro wenther way be of great benefit. It is applied by dissolving it in warm wider. and punring it into the sink or dran to be disinfected.

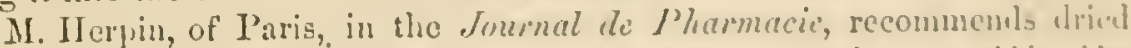
and pulrerizel plaster of l'aris, mised with rather more than une tifth wt is weight of powdered charenal, as a chesp and nust efliective disingecting mixtme. It cutirely remores the noxions emanations tium elecenpusing organic matters, fixing the ammonia, and forming a valmalate manure.

l'rof. Nish, of Amherst College, gives the following lormula fur 1:181kims what may be termed home-made chlorid of lime:

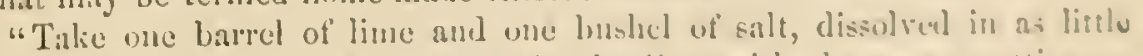
water as will dissolve the whole; slako the bine with the water. putting on more water than will deg-slake it, so much that it will form a verye ilick paste; this will not talie all the watere; jut ab, therefore, n little of the renainder daily until the line las taken lle whole. "Tho nale will le a

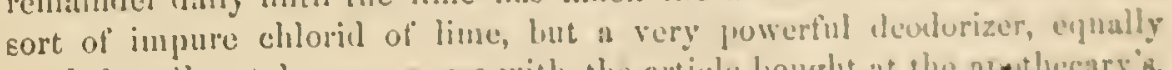
good for all out-door purposes with the article hought at the ap whecary 
[Crsp. IV.

and eosting not one twentieth part as much. This should be kept under a shed or some out-building. It should be kept moist, aud it may be applied whenerer offensive olors are gencrated, with the assurance that it will be eflective to purify the air, and will add to the ralne of the mamne much more than it costs. It would be well for crery farmer to prepare a quantity of this, and have it alwilys on hand."

IIow much more sensible it would be for the city anthorities to use this mixture, which concentrates efturia, insteal of quickline, which dissipates it through the air and into everybody's lungs!

To prove how quiekly the air of a sitting-room becomes impure, place in it a pitcher of iced water, and in a few hours it will have absorbed from the room nearly all the respired and perspired gases of the room, the air of which will have beeome purer, but the water utterly filthy. This clepends on the fact that the water has the faculty of condensing, and therely absorbing all the gases, which it does without inereasing its own bulk. The colder the water is, the greater its eapacity to eontain these gases. At ordinary temperatures a pint of water will alsorb a pint of carbonie aeid gas and several pints of ammonia. This capaeity is nearly doubled by reducing tho temperature to that of ice. IIence water kept in the room awhile is alwalys unfit for use, and should be often renewed, whether it has beeome warn or not. And for the same reason, the water in a pump-stock should all be pumped out in the morning before any is used. That which las stood in the pitcher during the night is not fit for coffee water in the morning. Inpure water is injurious to health as well as impure air, and every person should provide the means of obtaining it fresh and pure for all domestic uses.

460. Soap-Ilaking and Washing, - Wood ashes made from any liard wood will make soap. Pine ashes are nearly worthless. Beech, maple, birch, and hickory are among the best sorts for leaching. Put sticks and straw in the bottom of the leach-tub, packed close, and four quarts of lime to a barrel of ashes, which wet and ponnd down as you put in, and then put on water slowly tro days before you let the lye run, and it will come strong, but should be boiled still stronger before you put in grease. Bones, rinds, gristle, and hard seraps must go into rery strong lye, and will then soon be eaten up, all but the earthy part of bones, which skim out and sare for the graperines and pear-trees. Make the soap strong of grease as well as lye, and do not use it till very old, and it will be very good. It should be of a salvy consistence.

To make soap with potash : Use the best quality of "first sorts" of potash, in the proportion of six pounds of potash to seren pounds of grease, for" a barrel of 40 gallons. Break up the potash into small lumps and dissolve $24 \mathrm{lbs}$. in two pailfuls of hot water. It dissolves rather slowly when the potash is good. When dissolved, put the solution into the kettle, and add the grease quite warm, and stir the mixture together; allow it to stand all niglit, if convenient. In the morning apply a moderate heat until the mixture appears ropy; then fill up with cold water. Cost, say 6 lbs. of potash, 
36 cents ; 7 lls. grease, 25 cents-6t ceuts for a barrel of so:ip. Another re. coipt says:

"One hundred pounds of good soap for \$1 30 : Tilke six ponnds of po:nsh. 75 cents; four pounds of lurd, 50 cents; quarter of a jound of rosis, j cents. Beat up the rosin, mix all together well, and set aside fir tive dars; then put the whole into a twelve-gallon costi of wan water, and stir twice a day for ten days, at the expiration of which time rou will have abont one lumeled pounds of exeellent soap."

The following is considered a raluable aid to the washerwoman, ly one who has tried it. She says :

"Talie oue pound of sal soda and half a pound of unslaked line; put them in a gallon of water and boil trenty minutes; let it stund ill cool, then drain oft and put it in a stone jug or jar. Soak your dirty clothes all nightit, or until they are well wet through, then wring ilsem out and rub, on plenty of soap, and to one boiler of clothes well covered with water adil one teaspoonful of the washing flnid. Joil half an hour briskly, then wash them thoroughly through one suds, and rinse mell witl water, and your clothes will look better than the old way of washing twice betore boiling. 'This is an invaluable recipe, and I do want erery poor tired woman to try it."

Another one says: "Take two pounds of soda ash, two pounds of liard soap, and ten quarts of water; ent the eoap fine; add all together, put into a keteli: and bring to a boil, then take it off the fire and stir until nearly cool. P'nt your closhes to soak the evening before you wash. In the morning, wring out, boil them in water, to which is added nearly a pint of the compumil to erery pailful. Wash out in the same water and rinse, and your washing is donce."

46i. Washing Machines hare been contriberl, patenfed, male, and sold and discarderl almost as mumeronsly as "patent churus." IV e have tricel a pronel many. The churns have all heen griven up for the ohd dasher, and metwishstanding Washing was " made e:isy," the ohl wash-boaril still holds its place. though sone washing unchincs are worthy of connendation as assistants in the lanndry. None will do all the work. Perhaps enr lady realers will say that we onght to tell then which to buy. We can not do it. The later

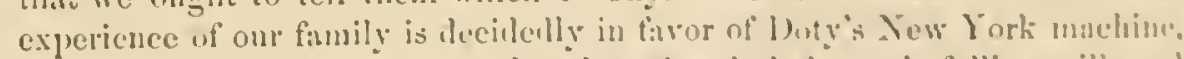

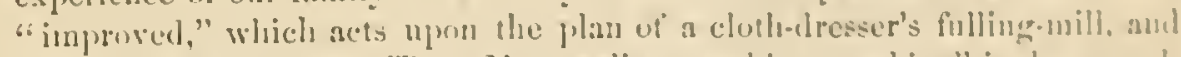

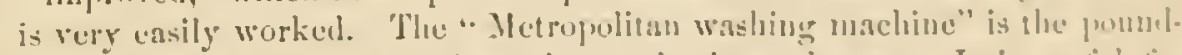
ing harel improsed by springs that mako it work casy. It is uncful fir

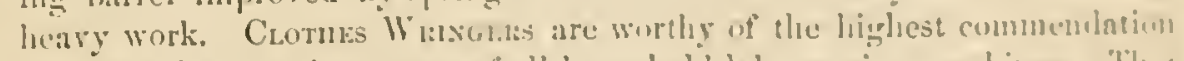

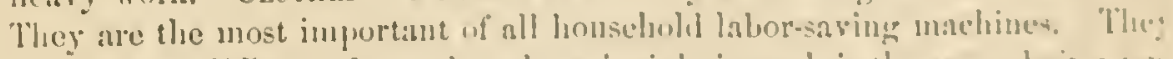
are male of diflerent forms, but ble principle in each is the same heing and strucfed to attach fo the culge of a whsh-tul, and routain two chatice rullers which are turned ly a crank with ono liand, while whils tho other the washer picks up one end of a garment and lohls it to the rollem, thrumgh which it fasses rapidly and fulls intu a cluthes-basket a great deal dryer thin n:!y 
moman could wring it with all her strength and ten-fold more time. These machines cost from $\$ 5$ to $\$ 10$, according to size, and are very simple in construction, very effective, and look as though they would be very darable, and are certainly very great labor-saving machines, and one should be in cvery family, and we are doing a public duty in maling them as extensively known as any other fact for farmers. With a Metropolitan washing machine and a clothes-wringer, or, rather, a clothes-squeczer, which has been sereral years in use in the author's fumily, washing-day is no longer one that is dreaded. With these, rashing is made easy.

462. Soft Water.-No woman can wash with any satisfaction unless she has soft water. It is for this that we lave treated so fully upou cisterns333, 334, 335. Hard well water can be softened witl lye, potasl, or soda. We have seen a statement that a well of hard water was permanently cured by putting four feet of coarse gravel in the bottom, where the water oozed iu through the blue clay. We recommend that a space at least a foot wide behind the wall should also be filled with grarel as ligh as the water comes in.

As Inoving follows washing, we say: If your flat-irons are rough, rub them well with fine salt, and it will make them smooth; so will jubbing them with a waxed rag. Be sure to use them hot.

463. Beds and Bedding,-There is no article of houschold furniture of so much importance as the bed. It is the place where exhausted nature enjoys recuperation, and all that art can do to make it comfortable at all seasons of the year, should be done, particularly in the farmer's home, where the nature of the labor is so exliausting. We are so much opposed to feather beds, that we have not had one in the louse for mans years, and we never sleep more comfortably than we do at home upon hard mattresses. We think that feather beds ought to be done aray with, especially in warm weather. For spring, summer, and fall, husk beds onght to be in use in every family, and would be if better known. There is no better time for proeuring huslis than when the corn is being harrested, and the husks will be much nicer and eleaner when corn is ent and shocked, and not become so dry and weather-beaten. $\Lambda$ good husk bed will last from twenty to thirty years. Erery farmer's daughter cau supply herself with such beds against time of need at a trifling expense.

No one who has not tried them lnows the ralue of luusk beds, which is Encli that some persons think that straw and mattresses would be entirely cione away with if lusk beds were once tried; that they are not only more pliable than mattresses, but are more durable, and the first cost is but little. To have husks nice they may be split after the manuer of splitting straw for braiding. The finer they are the softer will be the bed, although they will not be likely to last as long as when they are put in whole. Three barrels full, well stowed in, will fill a good-sized tick, that is, after they haro been split. The bed will always be light, the husks do not become matted down like feathers, and they are certainly more healthy to sleep on. 
461. Home-Made Maltresses of Hair and Wool,-Hair mat!resses con al-o l,o made in every famner's fumily of rely grood quality out of pign's hair, which slould be eleaned in the same way that fine wool is clenned of all its gmmony" dirt. See 129. Where sleep are liept, a great deal of good material for mattresses can he saved from targlocks and clippings of wool, which can ho cleansed with but little tromble by placing them some days in a basket in a running stream, or even ly soaking in still water. The filth disolves wirlsout injury to the wool. The cardings of liorses and bullocks, it sabed and cleansel, will soon acemmulate enough for a mattress; for one of twenty poumds on the top of a lusk one will malie a luxurious bed. There is in secret about making a mattress. I Iolster the edges upon one of the silles, and lay it flat on the floor or a broad talsle, and fill in the unterial evenly of an equal thickness all over, and then sew on the top and lift the unttress upon two or three narrow strips of bostris supported at the euds npon taliles, benches, or barrels, so that you can stitch through and thromgh with a long needle which you can buy for such work, using stroug, smooth linen twine, with a clotl button under the loop of each stitch.

Coiton makes a eoft, pleasant mattress when new, but it soon unats together, and we do not esteen it a healthy material for beds or bedhling, cexeept for sheets and light quilts. Beech leaves make a rery goo!l martress. clean, sweet, and wholesome; they are best when gathered by lamel from green trees. Straw, too, is always mnel better eut in a green state and dried in the sun, and rye straw is the best kind.

The hest vegretable material ever used for mattresses, and almost equal to hair, is the long moss which grows upon forest trees, eovering then ns with a gray bearl in several of the "Coufederated States." It repuires to bo macented in water until a thin enticle precls ofl by wasliug, or by drying and henting, leaving the black, hairy-looking theads of the interior, which are very tougl and durable.

465. Wow to Wake Bed Comforters, - The best betding ever used is linen slects and blankets for smmmer, nnd cotton slects and blunkets for wimer. lint as all ean not havo blinkets, we will tell them how to meske bed cum. forters. It may be new to some readers that nice, warm bel comforters can be made withont the labor of quilting.

Make two calico spreals, old or new, nml tack one in a quiltingrfinme, if you have onc, and if not, spread it on the lloor and lay on four jounds of cotfon liating, and then the ofher spreat, und tack through mul through with a darningrnecolle and tic tight over a piece of bright colorel cloth, ot ynrn, o! wool, in squares ol a foot, and you will have a neat-looking warm article of hechling. 'Two persons cm make five of them in a day.

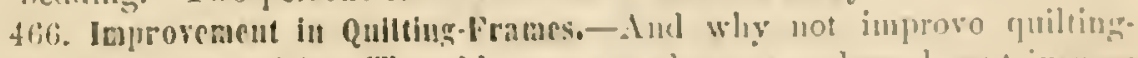
frnmes? They need it. The old ones wre ahout as nwhwrel contrivanees as ever were concerved-always in the way when in use, with their long ans sticking out all over the room lung nfel they lat ceased to ho usefut. What man ever looked upon these necessay implenuents of liusuliold eron 
omy with any satisfaction? He looks erery time he comes into the house with an anxious eye at the progress of the work, "loping the confounded long-armed quilting-frames will get ont of the way some time." Now, for the special benefit of such nervons gentlemen, some good sonl ont in Michigan has invented a quilting-machine that lias no arms to stick out in the way. "Necessity is the mother of invention," and this inventor, wo suppose, lired in a log-cabin only sixteen feet square, which, as it contained two beds and a cooking-store, had no spare room to set up the quilting-frames on four chairs; so lie eontrived a machine something like this, as near as we ean understand the deseription: Frame four legs together like the firame of a kitchen table, with side pieces nine feet long, dropped fire inches below the top of the legs, and end piees two and a lialt feet long. Now take some scantling, two or two and a half inches square, and round them with inch round tenons upon each end to work in sockets in the top of the lears. Upon one end of each of these rollers have a little ratchet wheel and catch, and mail a strip of cloth along one side of each to which to tack the edges of the quilt. When all ready, roll it all but tho two and a half feet wide strip upon one roller and tighten the eatch; now quilt that side and roll upon the other roller and so on till finished. The side pieces shonld be made to go in with a key, so that the frame can be taken down and packed away at any time, eren with the quilt half finished, as it can be rolled up suug. It is a simple piece of domestie machinery, but would add to the comfort of many a household.

467. Carpets and Carpet Sweepers.-Keep a broom exelusively for carpet sweeping. Never use it for any other purpose. Every one knows that the daily dust arising from sweeping carpets canses a permanent injury to furniture, books, pietures, and the lungs. It is an old but good way to sprinkle the floor first with damp tea-leaves, and then sweep with a bristle brush; but latterly we have found it much easier and more convenient to use oue of the new revolving carpet sweepers, which takes up the dust and puts it away in a box so it does not rise without using any moistening application. They are especially suited to libraries, oftices, cabiuets, and parlors.

The most economical carpet, probably, is a good, stont American ingrain, which will cost about two dollars a square yard. If jou are buying a carpet for durability, choose small figures. A farmer should never grudge the money to cover one room, at least, with a first-rate earpet, and eheaper ones for sitting-rooms, bed-rooms, and dining-room, if one is set apart for the latter purpose. There is no furniture that adds so much to the comfort of a house at the same cost as earpets. These is no labor better bestowed abont a house than giving the carpet a thorough shaking and beating in a lot, dry day, upon the elean grass, at least once a year.

You need not hesitate to wash a carpet with stroug soap-suds, with a brush, as it lies upon the floor, nsing clear water afterward, and drying it by ironing upon coarse towels spread orer the wet spots.

468. Remoring Stains-Becf-Gall.-There is no better substance than the 
very cheap article-mpon most farus-of beci-sall to take unt siaium mpun carpets, as well as inany other thinirs.

The clarified gall of the ox is also much usen by seourers for ronoviting

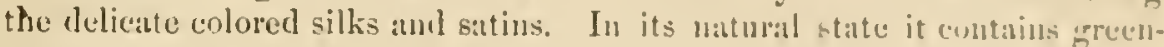

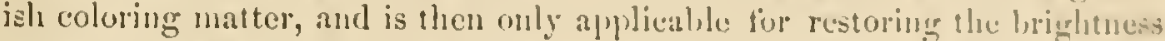
of dark materials. It is de-colored thus: "l'athe nue pint of anll, loil nul skim it, then divide into two parts; to vne lialf pint add lialt an onnce ut salt, to the other add lialf an omee of powdered alum; each part is iv lus heated till the ardditions are dissolved; then punr into separate bontes, anul allow them to stand in a quict place, and clear for a montl or cientat wectis, eren longer if not briglit. The clear portions of hoth stre then to le pun reel gently off the sediments and nixed together; the coloring matfer conthenlates and falls, from which the transparent gall is fiusally scoparated he filtering througl blotting-paper. In this state it will heep any lengell of time with its qualities unimpaired, and free from onlor.

If the stain npon silk or satin is produced hy an acid, suely as fon fruits, and that upon black or dark colurs, the best reanent is lipuicl ammonia (-trones hartshorn) rubtued in till it disappears. [For phan and fierured silk-, wi delicate colors, we ean not give at general rule, and thepefore leave them to be operated upon by the professional digreliseurs. To rubliterate enteas: spots from white silk or satin, we maty proceed as directed fiur culured silks; but thut, ink, and glove marks require at diflerent treatuent. These unatis are generally removed by dampening the pat with oxalic aced dissulven in watcr ; about the eiglith prat of an ounce in a winceglasiful of water is sirung enough. The common salts of lemon in water also answer well. (ivflece stains, mud.splashes, ete, will mostly give way to the wec of suap and water. Curd soap) should be applied for this purpose.

For grease spots upon eloth amel all kimels of woolen gools, soap and water may be used without fear, provided it is well wasted out atterward. finller's earth or powdered French clialk, male into a paste wirle water, and latid upon the part, is, howerer, the best application, to be brushed unt when diy.

Paint matrs are remored with turjentine, the smell of which may be quickly dissipated hy langing the atriche mpun a line in the air.

Silk articles slould not be kejet folded in white pajer, ats the whorid of lime used in bleaching the paper will probahly impare the color of the silh. Brown or blue paper is better" the yallowish, sumotle Indin paper is hest if

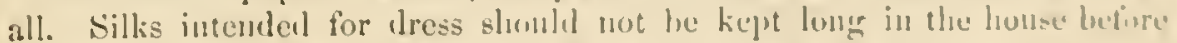
they are male un, as lying in the folds will hatres temelency to imprir ios durability ly cousing it to cont or split, garticular!y if the silk lis. luect

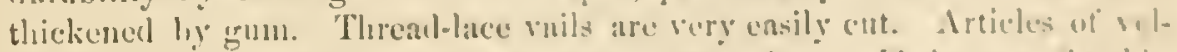

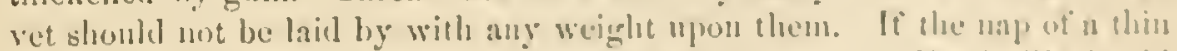

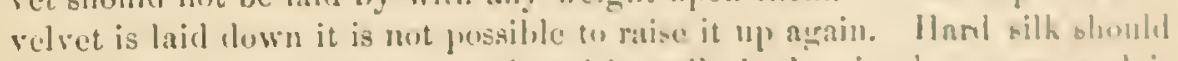

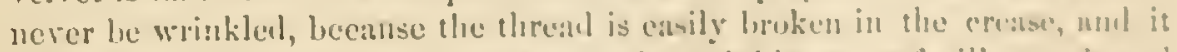

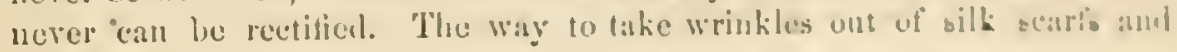


handkerchiefs is to moisten the surface erenly with a sponge and some weak glue, and then pin the silk with some toilet pins around the selredges on a mattress or feather-bed, taking pains to draw out the silk as tight as possible. When dry, all the wriukles will have disappeared. It is a nice job to dress light-colored silk, and few should try it. Some silk articles should be moistened with weak glne or gum-water, and the wrinkles ironed out by a lot flatiron on the wrong side.

To Take Grease Oct of Silk.-Rub a lump of wet magnesia orer the spot; when dry, brush off the powder, and no grease will be seen. It may be applied to other stuff's. This is an old and well-tried remedy; but there is a newer and better remedy, but not so thoroughly proved-this is benzine, the most complete substance to eleanse all fabries that we have ever seen.

Ox-gall and turpentine are both good to take out grease. If turpentine be employed, it should be distilled, and perfectly free from rosin. The preparation called scouring-drops is pure turpentine, perfumed with essence of lemon. Either of these substances may be applied with a piece of sponge, or with a remnant of the same material that is being cleaned. When the grease spot is large, the greater part may be removed, in the first instance, by the application of blotting-paper and a hot iron.

Use a piece of zine to stir your glue, or keep a small piece of zine in the bottom, and it will-so we rend-prevent it from acquiring that mpleasant odor common to glue. Where glue is always to be heated with steam, a zine glne-pot is recommended.

The presence of cotton in woolen fabrics may be easily recognized by the following tests:

When boiled for twenty minutes in a solution of nitrate of mercury, the woolen fibers acquire a red color, but the cotton fibers remain colorless. When the fabrie is boiled with caustic soda solution (sp. gr. 105), the wool dissolves, but the cotton is only slightly affected. Picric acid also stains wool yellow, but has no action on cotton.

There are five pounds of pure sulphur in erery 100 pounds of rool. IIenee silverware, wrapped np in flannel, or any other woolen stnff, will turn black.

A bit of glue, dissolved in skim-milk and water, will restore old crape. Ribbons of any kind should be washed in cold soap-suds, and not rinsed. A hot iron, held orer varnished furniture, will take out grease spots. 


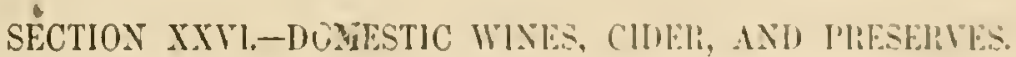

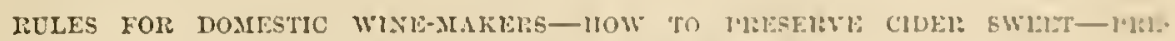
SHRVIAG liLUITS FOI: WTATEl:.

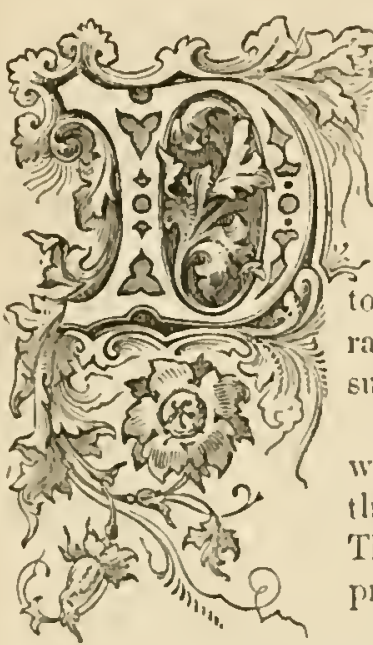

OMESTIC WINE, as usually inanufactureu, is rather a cordial than a wine, and is cutircly inferior to good srape wine; lut when properly male, it will be a very lealthinl heverage particularly for summer drink, when fully diluted with water.

We recommend to thuse who lave the means, to manufacture currant wine; nud let it le pure currant wine, using nothing but currants, wibter, and sugar, without alcolool.

There is no great dificulty in making growl courrat wine. White sugar only slienlel be usel. The better the quality of the sugar the betfer the wine will be. The idea that any surt of sugar will do fur wine is pretty well explocled.

It is now also sitil that white curromis inake at mutels nicer wine than the red enrants, but that is alceording to finley.

While we admit that the true wine mist be made from the grape, still, for the want of a more appropriate name for bererages made frem fruits other than the grape, we call then wines. These dunestic wines may be made from the enrant, rlubarb, strawberg, lhacklerry, rapperry, and gooseberry, of passule quality. Inferior lunt drinkable wines mus he mate from parsiejs and many other roots.

In the manufaeture of all domestie wines, the grent mistake is in the $11-\mathrm{e}$ of sugat of an inferior guality; double-petincel is nut sufliciently jure 1. mantacture either of theae wines of the lest yuality; trebleretined sugar should be used ; that of inferiur linul contains gam, and after the ferment:-

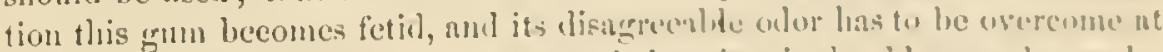
the expense of the odor of the fruit, am therefore it shonled never be uncl.

Brown sugar, no matter of low gonel a gluslity, will not make wime, fire

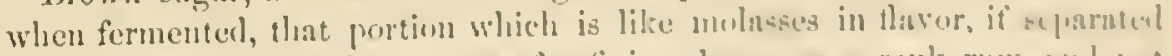
from the sug:tr, as in the process of refining. hecennes a rank rmm, mul mot sufliciently delieate us the preserving alcoliol of the result. Whene grapes are fermented, the sugar or kateharine mattere is not converted into rum, hut

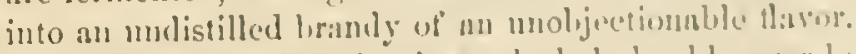

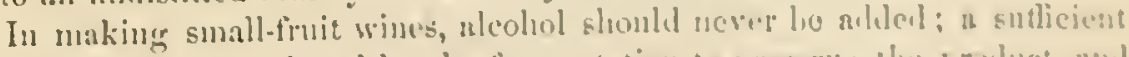
quantity will be produced by the fermentation in juestres the fromet, mul any furtlier adlition injures tho quality mol arrests the fermentation. When alcohol is added, these wines do not improve ut nll by nges. 
The common practice of racking cider has caused many to rack fruit wines, which some wine-makers tell us is all wrong. They say :

"When the proper amomnt of the juice of a fruit, amel treble-wefined sugar in solntion, is placed in in barrel with the bung loose, in a cellar of even temperature, fermentation will readily commence, and will proceed until the sugar, or a portion of it, is converted into alcohol, when it will cease. The bufiy coat which rises to the surface will then settle and attach itself to the cask; the bung shonld then be driven in, and in six mouths the wine may be drawn off and bottled. No alcohol will be necessary to keep it."

Let these general rules be obserred, and the following special directions pursued, and domestic wine may be made in any farmer's family of almost any kind of small fruits.

The directions given in 469 are from George H. Hite, of MIorrisania, near New York, who is one of the most successful domestic wine-nakers of our acquaintance.

469. Llow to Ilake Currant and olher Wines,-"The curants shonld be perfectly ripe when gathered; they should be stemmed and washed before pressing, which should be done as thoroughly as possible with a 12-inch cider press. Ascertain the amount of juice thus obtained, and then aid that amount of water to the punice, and incorporate the water, and pumice well together: let it stand a few lomrs, and press it again. By this process an additional quantity of juice, though mot so strong, is obtained; then mix the first pressing with the second, and weigh a gallon of it, and whatever it falls short of 10 pounds to the gallon, add encugh of good refined sugar to make it weigh 10 pounds, and so on of the rest. I wonld here remark that an additional amount of sugar added to the abore will make a sweeter wine, and perhaps more suitable to the taste of many.

"It would be rather an expensire business to those who have but few berries to make currant wine from the first pressing of the currant alone, as it lequires one bushel of currants to produce a little over three gallons of pure juice. The red enrrant pure juice weighs eight and a halt pounds to the gallon. The white currant juice comes almost within the wine-maker's rule, reigling nine and a quarter pounds to the gallon. The way in which I make chirant wine is, to use the pure juice alone or without much water, and I find that I can readily command three dollars per gallon for it, whereas the other would be dear at one dollar per gallon, and not much of a wine at that.

"Elderbery wine is made in the same way as first stated, adding about lualf water in the way of re-pressing the pumice, etc., as, if it is made withont the addition of too mueh sugar, it resembles claret very closely.

"Black currant wine is made in the same way as the elderberry, only the berries should be scalded before pressing, and if carefully managed in the fermentation, will resemble the Rhine wines.

"When the juice, sugar, and water are well incorporated by stirring to- 
grether until the sugin is dissolved, it is then placed in an opren tub in a tern-

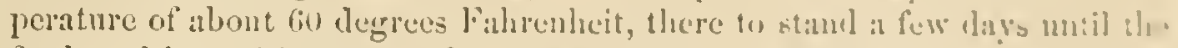

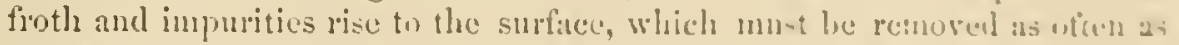
they aceumulate; and when the lipuid becones limpid and sonewhat arana. parent, then it is put in a clean lanel, filling to within fivenr eight inches wi the bung. I tube, somewhat in the shape of a siplon, or more in the slan?' of an ox-bow, male of griss, is inserted into the hnugr abont two inclues, and

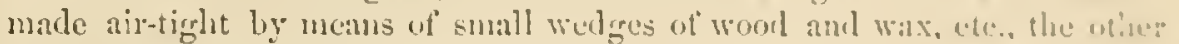

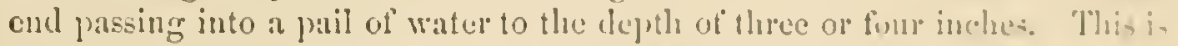
done to prevent the oxysen of the air jenetrating the furmenting man and

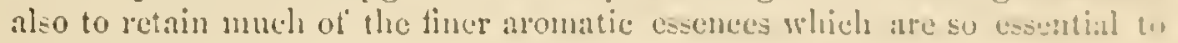
fine-flarored wines.

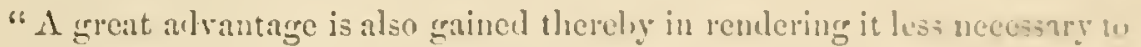
keep watch over the fermentation as jursuchl by some in kereping the loirfel bung full ly replenishing with some of the juice stamling ne:ar at hamb. which becomes pricked hefore fermentation las ended, renderinger it in 2lu" end little less than sweetened rinegar. So almixmre slondl be attempren] after fermentation has commencel, and if the fenterature of fermentation is kept at about 60 or 65 elegrees baluenheit for about six nechs or two monthe, it will be ready to remore the tuhe. 'Tlien fill the harel full uf the sort made in a scparate resscl for thist purpose, and put tho bung in moderately tight for a tew lays, amb after that drive it in tight until almu

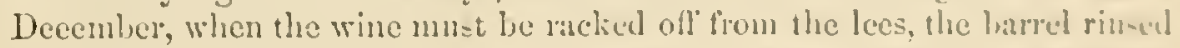
with lot and cold water, and when dranined gluite diy, insert into the lungehole a small cup, sllspended by a wire, containing onc untce ut ep irits ut wine or :!lcolwol, ignited, and kept there mut the barkel is well tunigated, during which the bung must not le elosed. Then rotnru the whe ningin mol

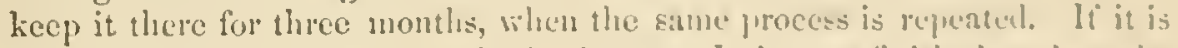
done a thind time it will be all the letter. It is new furishen, and can lie kept for any length of time, eitles i: hothles or wood, shm? improving by age.

"Grapes may be made into wine in the same way as first mention al alure",

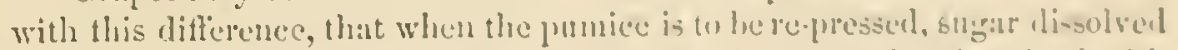
with grape-juice (by leat) mu-t be aldelet to the water that is mised with the pumice, and staud a few homs lectire the second premoing. It mm-t ens. tain the sance proportion of sugat and water as is fumbl in tho natural fulec of the first pressing, all of which is misul well tugether and fermenterl us abore. lint it the grapes are left on the vine mutil they are puite riju, saly

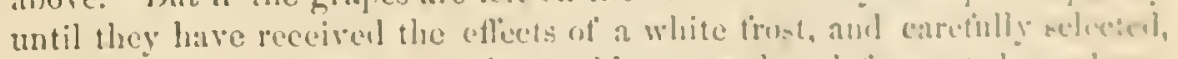

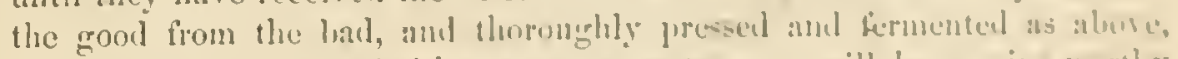

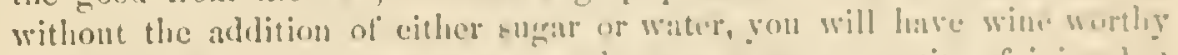

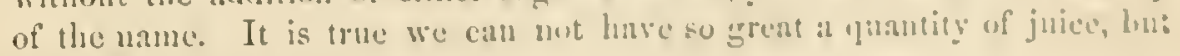
what we have is guml."

We ald several ofher formulas for making corrant wine, w- follows:

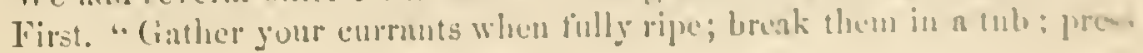


then through a sifter; strain througlı a flumel bag, and measure the juice. Add two gallons of water to one of juice, and three ponnds of New Orlens sngar; stir till dissolved. Strain through a hair sicve, then a close tow linen bag, and afterward a flamel one. The juice must not stand all night. The cask nust be sweet and clean, never used for beer nor cider, and if new, well seasoned. Do not fill your cask too full, otherwise it works out at the bung, which is injurious to the wine; make a quantity orer and above to fill up the cask. Iay the bung on the hole to prerent flies from creeping in. In tluree or fon weeks bung np, leaving only the rent-lole open till done working; rack off, if wanted for present use, but it is best to leare it on the lees till spring, or it may be left for two years without damage. When yon draw off the wine, bore a hole so it may run off clear of the lees. Some put in spirits, but I do not think it advisable. Do not put in more than one third juice, for that would render the wine hard and unpleasant; nor too much sngar, as that would deprive it of its pure vinous taste. It improves by age."

Second. A sample which was rery elear, and at two years old of a deliicate, fine flaror, was made by the following rule:

Take two quarts of juice, two quarts of water, and three pounds of refined sugar; mix and let it stand two or three days; skim every day, then strain through ganze, and pnt into the cask and let it stand one year; then bottle, and you have an exeellent wine.

Another sample, made with one quart of juice, three quarts of water and one pound of sngar, was a rery pleasant drink, but would not keep as long as the other.

Third. "Before pressing the juice from the currants, pass them between a pair of rollers to erush them, after which they may be placed in a strong bag, and they will part with the juice readily by light pressure, sneh as a common serew or heary weights. To each quart of juice add three pomis of double refined loaf sugar-single refined sugar is not sufficiently purethen.add as much water as will make one gallon. Or, in otlıcr words, suppose the cask intended to be used to be thirty gallons; in this put thirty quarts of enrrant juice, ninety pounds of double refined sugar, and fill the cask to the bung with water; roll it over nntil the sugar is all dissolved. This will be told by its eeasing to rattle in the barrel. Next day roll it again, and place it in a cellar where the temperature will be sure to be even. Leave the bung loose for the free admission of air. In the course of one or tro or three days, fermentation will commence. By plaeing the ear to the bung-hole a slight noise will be heard, such as may be observed when earbonic acid is eseaping from champagne or soda water. Fermentation will continue for a few weeks, converting the sugar into alcohol. As soon as this ceases, drive the bung in tiglitly, and leave the eask for six months, at the end of which time the mine may be drawn off perfectly clear, without any excess of sweetness."

Fourth. Take one quart of jnice, three pounds of sugar prepared as abore, 
and water enough to make a grallon; leave it in the celsk one year, 1lun draw oft and bottle.

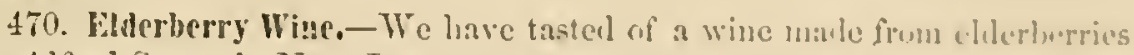
by Alfed Speer, in New Jersey, that certumly had some cexcellont punlitics. After preparing the juice, like that of curauts, he requires funr yoars to ripen it. His siatement is :

"First year, it is kept in large celsks, with valve lungs to allow the erats to escape, and at the sane time prevent the oxyeren of the atmosphele from coming in contact with the wine.

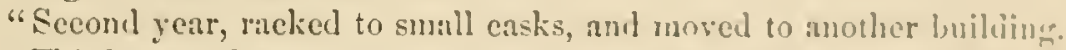

"Third year, drawn off in bottles and piled awsy in stacts, which stre then completely covered with sand, lept at one certilin tempernture the year roumel.

"Fourth year, they are dug out, the wine decunted in fresh int:les and laid away, being kept in amother temperature until the conl of this vear, when they are sealed, labeled, am packed ready for shipping.

"The principal part of the whole operation is the managemont of the temperature in the rooms and cellars. Farcls yent, as the wine in drawn ofl into other vessels, it is moverl to a mihling liegl at in difo ferent temperature from the previons year, where it is livglt miturm durime the whole time by means of cool vaults or stures, as the case amb ecasual repuire.

"So that after four years it becomes unchangeable, and rcudy fir unativ: in any climate.

"It is male from the juice of cultivated elderherrics, which are male "n grow nearly as large as the smallest-sized grapes, and pure without t!ue andition of alcolol or spirits in any form."

471. Winc from Rhubarb Stalks,-Iimbarb will yichl five times th math per acre as grapes, but care should he taken not to use the stalk fow whe to the leaf, as it will impart a peculiar thour (o the winc. Take at thirty-

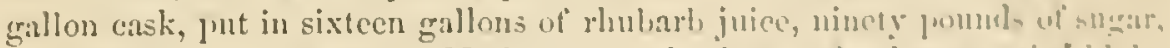

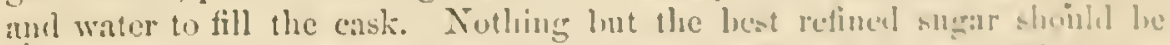
used if the best results are desired, and it is still better to disinlve the st sar

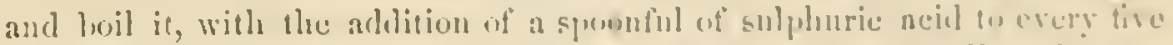
or six gallons, before mixing it with tho juice. This must be allowed in of ? colll beture nsingr.

Another formula says: "Trim ofl' the lenves, aml grimd amb jom the

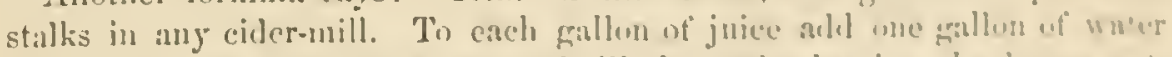

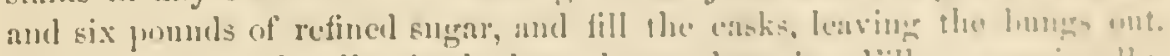

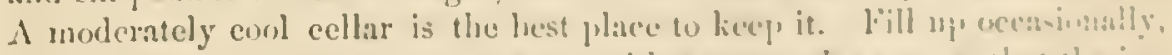

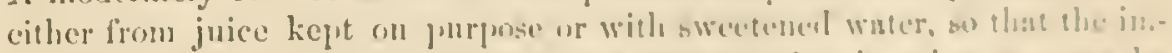

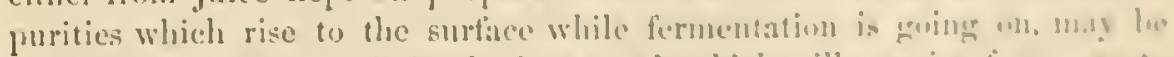

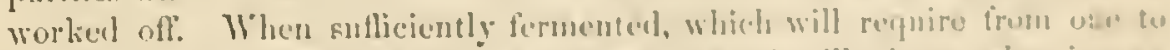

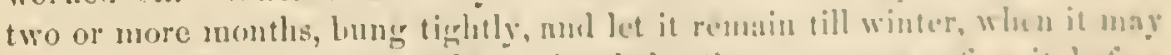

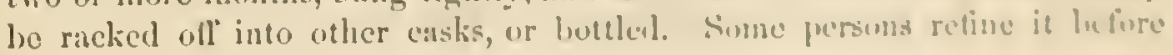


bottling, by putting into each barrel two onnees of isinglass, dissolved in a quart of wine."

Calroon's seelling yields the greatest quantity of juice. Mr. Cahoon's method of making wine is to mix equal quantities of water with the juice of the stalks, and to cach gallon thee and a half pounds fair quality of Nuw Orleans sugar, filling the barrels cuite finl, and refining with isinglass, and allowing the wine to remain till spring, when it is bottled. Jyy adding or diminishing the quantity of sugar, it will vary the strength of the wine in the same proportion. The jure juice, withont water, makes a very strong wine lyy using four poumls of sugar to cach gallon. Mr. Cahoon estimates that 2,500 gallons of wine can be made from an acre planted with lis scedling. Sold at from $\$ 2$ to $\$+4$ a gallon, this would yield a retnrn of $\$ 5,000$.

The fault of the above is the unefined quality of the sugat. Well-made rhubarb wine will cease to ferment in alont eight weeks, and then it slould be corked tiglitly, and liept one year undisturbed before bottling. In three years it will become like a dry sherry wine.

472. Botling and Corks.-Use none but strong, heary bottles, and look to your corks if you would have your wine keej. One of the grentest mistakes made by those who are new beginners in wine-making is the using of poor corks; they do not reflect that the common cork permits the air to reach and destroy the wine. Besides this, a poor one can not be drawn without breaking, and thus injuring the flaror of the wine. If wine-makers would desire to have their wine keep well and taste well on opening, let them never use any but the rery best relret eorks. The use of the best quality will more than doubly pay by securing the wine from spoiling, and retaining the flavor, which is often lost by a bad cork.

Bottles slould always be stored upon their sides, or in racks, with the corks down. If poor corks are used, they must be covered with sealing-wax.

473. Wine of Grapes.-Most of the wine made in this country is barely drinkable; what is called pure juice of the grape is often lut little, if any, better than rery poor som cider, and is not generally palatable to the com. mon taste. In a trial of wine that I attended, a number of first-rate judges of wine finally settled upon a specimen of eurrant wine, is superior to any of the sweetened specimens of grape juice; yet the concoctors of it label it "pure juice of the grape," "fit for sacramental purposes and for the sick." They insist that fermentation of sugar does not produce alcohol. They are mistaken; fermentation produees it, and distillation separates it. This sugared wine is not pure-it is one fourth alcohol. Much of the imported wine is sugared. Some of the best wine can not he imported; we can not move from place to place the rely best wines made of pure grape juice.

These sweetened bererages all lack one very essential clement of wine, and that is the göut, which all gennine grape wines possess. Unfortunately, with very few exceptions, American grapes have proved so defieient in grape-sugar, that they would not make wine without adding eane-sugar, which makes rmm instead of brandy, which is the true spirit of wine. Some 
of the best wine-maters of the country now believe that they have dis. eorered, ju the Delaware grape, one that will make wine erpual to flue herst Emopen varicties. Some Cincinnati Catawba is a gool substitute for Rline wine. Some grood wines are mate in Cillifornia.

tit. How to Make Grape Wine.-For the benefit of those who maty wish t: do a little in the way ot dunestic wine-making, we will gire a feib sim] le rules, sucle as are fullowed by wine-makers on a small scale:

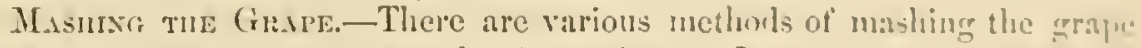
now used by the more carefinl wine-maters. Previons to the mathing, lowever, when first-rate wine is to be male, the bunches are carefully cox. anined, and all umripe and rotten berrics are plucked oft and thrown :way: then the grapes are thrown into a tul, and mashed lye tramping with tim feet, or bruised with a chb, or crushed by passing between two lareno wooden rollers, which are far cnough apart to allow the secels to frass withont being broken. The seeds, if mashed, would grire a litter ta-te (o) the wine. To tramp grapes, wear Inlialpublier louts.

Pressing tule Grards.-The pressing of the mashed herries is a simplo process, like the pressing of cheese, or aplles for cirler. The grape-pren is nsually male to hold about 150 lhs. of grapes at each pressing. li white wine is to be male, the grapes are pressed as soun as mashed; lut it rud wine is wanted, the whole mass is left to ferment for six or seren days in which time the juice takes the dark color of the skin.

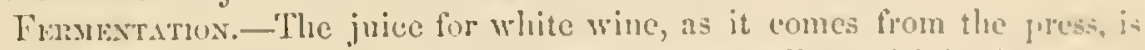
put into pipes measuring 1 to gallons, alout $11 \mathrm{~J}$ galluns of juice lueiug put into each eask, leaving one fourth of it empty. The lume-luble is luft unery, and in two or three days the fermentation herins, and its foree is oser in thee or four days. The wine-maker then pruecels to fill up the cateks, gradually pouring in six or eight gallons at at time, so that the eanh uro filled in the course of three or four days more. The easks should he tilled up before the strength of the fermentation is over, fo that the the or scmm may be horne up to the bung-hole and there thrown ont.

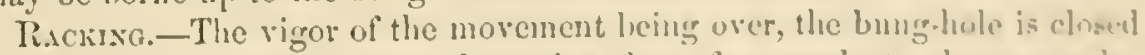
and the wine is left tor a period varying from four vecks to three mumts. It is then drawn oft" througls a cock placed a couple of inclus nluse the lustom of the pipe, taking eare not to disturh the senliment at the luterus. The elearer wine is poured into a clemu cask: that tilled with sediment is filtered through a doubled cotton clath, nul is then mixed agenin inte the first drawing, or it is used wilhont fillation in makine branly. Alunt

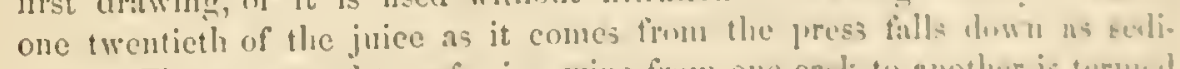
ment. The process of transferring wino from onc cant to mothes is termul "racking off."

After the first racking, the new eask is completely fillerl, she huner elomal,

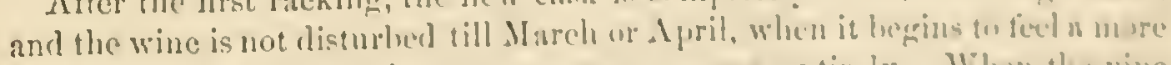
lively fimentation, for that process never consen chtiruly. When the vine sprouts in March or April, amel when it lilossums in Jume, nul the grape 
ripens in Septenber, the new wine ferments; and at those times the bungs nust be raised, and eare must be taken not to disturb the barrels. Between times, when there is no pereeptible fermentation, the wine shonld be racked off two or three times in a year, and at the end of a year and a half it is clear and good, but it continues to grow better witl age. The red wine is treated in precisely the same manner, exeept that it is allowed to ferment befire pressure. Immediately after the presstre the wine should be placed in as cool a cellar as can be obtained in the country, and should be kept there always. This cellar should liave no moldy matter about it, no regetables or salt meat in it, nor anything that can corrupt the natural sweetness of the air.

- Red and White Wine.-Brandr. - All the white wine made in this manner resembles liock or sauterne; the red wine may be made to resemble claret, burgundy, or port. When the berries are picked early, the red wine is like claret, but has more body; if the grapes are left upon the stem nntil they are nearly dry, they give less juice, but the wine has a much stronger body, and rivals port in strength.

The method of making champagne is held as a secret, and we shall not attempt to deseribe it fully. The main facts, howerer, are that the wine is bottled ahont. six months after pressing; it is again re-bottled in cight months more. The bottles are laid down upon their sides in racks, and a large per-centage of them are broken by the activity of the fermentation.

The refuse of the press and all the sediment of the new wine may be nsed in making brandy, which is obtained by distillation in the same manner is whisky is distilled from maize or potatoes. For erery lundred gallons of wine about twenty-five of brandy are obtained.

475. Wine of Tomatoes. - We have no experience of wine from this fruit, but a lady writes us from Iowa as follows:

"Are you aware what rery excellent wine can be made from tomatoes? I tried it on a small scale last year, and find it serves as good a purpose for using in sickness and in cooking as the compounds of nauseous drugs usually sold for wine. Many who have tasted it were unable to tell it from grape wine. If people will use wine, it is certainly well to have it free from poison, and tomatoes are so abundant that it could be afforded cheaply. If rinegar can be made from it, it will be a blessing to the West, where we liare such horrible compounds mnder that name. The recipe: One pound of white sugar to a quart of juice, and similar treatment to currant wine."

47. Blackberry Cordial.-This is not wine, thongh an article called blackberry wine is often made in the same way that wine of other small fruits is made, and is a rery good beverage; but this is what the name implies, blackberry cordial, and it should be provided in every family, particularly where there are growing children; it is such an excellent remedy for children troubled with diarrhea and all other diseases of the bowels gencrated 
in the spring scason. Th mizle it, to two quarts of hlackberry juice ahl one poum of loaf sugar, halt an ounee of mutmeg, lialf un ounce of cimmanon, pulverized fine, quarter of an oumee of cloves, quarter of an omuce of allspice, finely pulverized, and a handfol of raisins. Boil all togetler fur a short time, ant when cold, add one pint of fourth-proof French brancly. lialek curants also trested in the same way make an excellent cordial. Fice tï.

475. Cider-Preserving it Sweet.-The following is the flan recommended by Professor IIorsford, of Cambrielge, Mriss. :

"When the eider in the barel is undergoing a lively furmentation, ach] as mucli white sugar as will be equal to half or three quarters of a jouml to eaclu gallon of eider, and let the fermentation procech until the liquid antains the right taste to suit; then add an eighth to a quater of an ounce of sul. phite (not sulphate) of lime to each gallon of cider in the cast: first mixime the powder in about a quart of the cider, and then pouring it back into the cask and giving it a thorongli slaking or rolling. After standing lunperl up a few days for the matter added to become incorporated with the cider, it may be bottled or msed from the cask."

Do not mistake sulphate of lime-which is a natural production, amd known as plaster of Paris-for sulphite of lime, which is a manulacenrenl article, and is wortl by the barrel about thirty-three cents a pouml, and ly! the cwt. thinty-seven and a half eents, and by the single pomm tiry cents. It has lieen of late years much used ly sugar-makers to prevent fermentation of cane-juice, and in our opinion it will be fomml more eflective as a pre ventive of fermentation in eider than an arester of it after it has proceclent scarly to completion.

We kept cider on tap that was treated as alsove for six months, which appeared to possess exactly the samo degreo of acidity as it had when first treated, but it lind an mplensant sulplur taste.

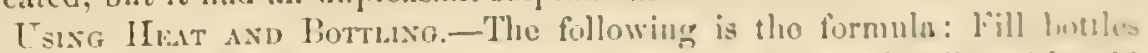

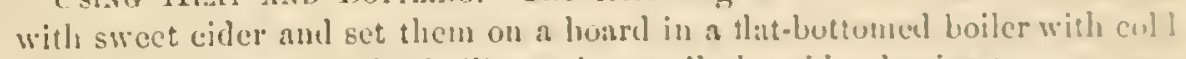
water, which heat to the builing-point until the cider begins to run over. lut not to boil so as to alter its lluror; then cork aud soal just as fruit are treated, and the eider will lecep equally woll.

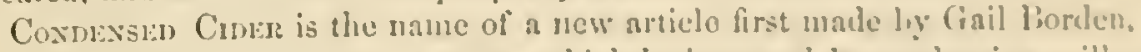
Jun, in 1S63, using the sume process whicl he inrented for comdensing milk: that is, boiling it in vacum with stean-pipes, roulncing the cicler dircet from the press to a stitl jelly, which will kecp as well as nuy fruit.jelly malo by domestic process. For transportation it is put up like the cendemed milk, In tin cans. It is reduced to its original comdition ly ahling $n$ s mueh water as it had parted with. It is, prublably, tho best plan ever devised for herpr ing cider sweet.

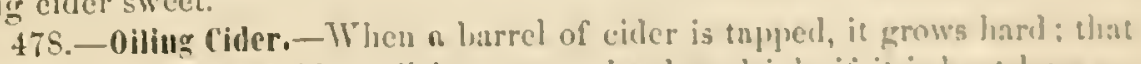
is, more and more acid, mntil it gets tom lined to drink, it it is kept long on tnp. This is oceasioned hy the nir, whels tills the cask above the cider us fast as it is drawn out. The air can not bo cecluded, eren if the cask were 
air-tight, beeause the cidel will not run from the tilp if there is no air to press it ont. If eiller is exposed long to air, it will become vinegar. In filet, the way to make rinegar of eider is to expose it to the air as much as possible. To prevent the cider on tap from lecoming acid, it is reconmended, as soon as onc or two gallons are drawn out, to ponp in the bnng-hole about half a pint of elear sperm oil, or sweet oil if it is preferred. It should be warm when poured in, and it will spreal in a thin coat over the surface, and leep spreading as the cider is drawn down, and thus exclude the air, without giving any taste of oil to the cider.

This plan of preserving eider is worthy of further attention. Te have fath in it from knowing that oil-casks are the best we know of for storing cider, imparting no flavor, and keeping it sonnd as bottled cider for years. Sperm-oil easks are more valuable for cider-caslis than for any otler purpose.

479. Filtering Ciacr.-Cider is very mueh improved by filtering. This should be done when the first fermentation is over, by racking it of into clean barrels. A good plan for a filter is the following:

"Take a square or round wooden box, made of inch pine plank, three feet in diameter, and one foot four inches deep. Make it with a bottom perforated with numerons one-quarter-inel angur holes, orer which slionld be laid coarse hemp bagging. Now fill in the box for eight inches with pieces of clareoal-animal chareoal is the best-about nut size, and on the top of this place a four-inch layer of clean wasled sand, and corer all with coarse hemp bagging, and you lave a cheap and good filter. Any numher of such filters may be nsed, according to the quantity of eider to be operated upon, and the eloth can be frequently washed without dis. turbing the sand and chareoal. Before any cider is filtered through, pass a stream of clear water into the filter for fiftecu minutes, so as to remore any fine, loose particles of elarcoal that otherwise wonld be mixed with the eider."

4S0. Aerifying Cider.-If eider, when it first comes from the press, could be filtered, and the clear liquid allowed to fall from an upper story in a thin stream into a large tub in the story below, or, if feasible, to continne falling from one to another through several stories of a building, it wonld become greatly improved, and we are assured by one who las tried it, that it may be bottled at once without any further fermentation, and it will remain in its sweet or slightly acidulated state, and when at a year old it is uncorked it will sparkle like champagne wine.

The grand secret of having a cider equal to pure wine is in checking any further fermentation. If the cider is left to itself, the acetons fermentation follows-the sedimentary mattel at the bottom of the cask rises, and the liquid becomes mnddy-this, acting as yeast, produces a second and more violent fermentation, resulting generally in hard cider.

By straining out the crude and nseless matter from the liqnor, the liability to excessive fermentation is greatly lessened, and so it is by fumigating casks with burning sulphur as well as aerifying. Remember, however, that 
this aring process must he confined to eider while quite new. If fernentel cider were treated in the same way, the result wonld be rinegar.

When eider is liept tightly bunged up, it changes lintu and very gradually: bottled, it changes none at all, except a certain improvenumt by age whic!l takes place.

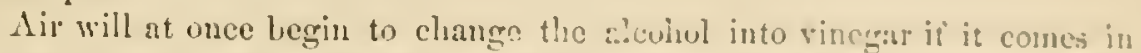
contact with it, and this will make the lest cider hatd and sour before long.

4S1. Vinegar-Kow to Bhake it.-If yon luave cider that "woùt tum (o) vinegar," just try the following plan: Jill a barrel, tul, bnx, or any vilser cleau vessel, with clcan shavings, or small twiors of any sweet woml, snch as maple, bireh, bech, cte., and wet them with rincerar, if rou have it, and if not, cides, or eren warm water will answer. "This barrel must be tull of looles, sides and bottom, and set over a larger vessel, to catel the drif as it leaches throngh. The cider is to be comregerl to the leach by any rone venicut methor. I good way is to put it in a pail, set on the harrel over the shavings, and carry it over the edge hy siphons, marle ot rases, or cottun lamp-wicking, or a hank of cotton yarn. Thase comluctors shombl be cut long enough to reach from the bottom of the gatil or fan used, up were the elge, and down an inch below the bottom. This sradual cunptying of the pail, and trickling down through the filter, exposes the liquid to the anus. phere, am that is what is wanted to make vinegan. If the first nleration is insuflicient, let it be repeated, and good strong vinegar will ho the result.

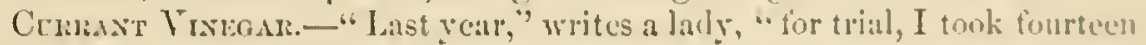
jounds of currats, mashed them as for winc, jut them imo a tul, with wo or three pails of water, stimping it two or three times a lay. After standing several days, I strained or pressed it, and with molases enowgh to matie it as sweet as new cider, I laal ten gallons. I put it info a lice, and alid not open it till December, when I found it to be as goud vinemar als was crer made."

Blackberry vincgar may be made in the samo wy or, if you aro making wine, do not thow away the seecls anc skins affer drawing ofl the must. Pour warm water over these mutil they aro cntirely cuvered, and lot tlem stand in an open vessel three or four days. Then draw ofl the lipuid nul let tlat stand until the acetous fermentation takes juace. A small pumtigy of coarse sugar or molasses will hasten the process. In this way a mot excellent article of wine vinerar may lie olitaincel by many wo liave not the means of making cider vinegar.

452. Preserviug Fruits for Winter Ise.-We hare alrealy given a julan in 337 of a fruit-drying honse, and lave recommended preserving various kinds of fruits by drying for winter use, nnd now wo give some directions for various other preparations for preserving fint, cooticel and uncouked.

Apples licep best in a diy, cool room, just alove the freminge print. If headed in barrels, apples will keep in th room where winter would freczo quite solid. 'Tley will not keep well in w warn ciellar where cablagen, 
turnips, or any strong-sinelling substances are stored, for they absorb the unpleasant odor. If packed in straw or cluafi that becomes damp and musty, they will spoil.

453. Grapesserve the purpose in some degree-that is, it will preserve them some weeks into the winter in a toleralule state of freshness. The first is to hang up the bunches separately by the stems in a dry room, barely warm enough to preselve fruit from freezing. The next is to pack the bunches, each separately, in absolutely dry sawdnst, of some sweet wood, in layers, in a box or eask. The other is to paek the bunches separately between layers of elean eotton fibel or batting. In each case the firuit should be kept in a dry, eool room, and, when packed in cotton, the room nay be so cold that it would freeze water, yet will not injure the grapes. Care must be taken that the fruit is dry and clean, and that there are no decayed, mashed, or imperfeet grapes on the bunches.

Another direction says:

"In gathering grapes for keeping fresh, they should be allowed to hang on the vines until finly ripe, and then gathered with eare to aroid bruising. The fairest bunches should be ehosen to put away, and with a pair of small scissors all defeetive and bruised berries should be cut off. They shonld then be placed in boxes well ventilated, and remain for a fow days, when they shonld be packed in boxes lolding six or eight pounds cach. It is not important that the box be tight; it is better that it should not be. These should be put in the coolest place in the house, where the air is dry. On the apploach of freezing weather they may be removed to upper shelves suspended in the eellar, or in any dry room where the temperature is as near the freezing-point as possible.

"While grapes may be grown in such profusion and with so little labor, it is a little remarkable that a supply for every household in the conntry is not seeured, not only in the regular season of them, but to last until spring. There is no trouble in keeping grapes through the winter as fresh as when they are first gathered."

4S4. Preserving Fruit in Air-Tight Cans and Rottles.-The modus operandi of putting up fruit so as to preserve it in a fresh state withont cooking, drying, or packing in sugar is not yet fully understood by all farmers' families, thongh largely manufactured for sale by many persons in cities; and many contrivances have been invented for sealing up eans, some of which are very convenient; but the same thing can be accomplished with bottles corked and sealed aceording to these directions.

It is a busincss that can not so well be done in families as in large manufactories, where everything is arranged for convenience; but still, with a little experienee and careful attention, every family ean save enough of the various fruits of the season to furnish their tables with a great delicacy during that portion of the year when they can get nothing of the kind. The whole secret consists in expelling the air from bottles or cans by heat, 
and then sealing up the contents hermetically. If the article to he preeerved is pesclies, select such as you would for sweenucuts, and pare am] cut then so that they can be put in the buttle, and you must do this with tho least possible delay, or they will be colored by the atmospliere. Some persons who want them to retain their matural whitences pecel slicm under wa ter. When the bottle is full, cork it tight and wire down the cork with very little projecting above the gluss. When you have bottles euough (n) fill a kettle, such as may be most convenicnt, jut them in and boil witl the water all around up to the nozale for about fiftecn or twenty minutes, or until the hotile appears to be full of steam, the atuosplicre having hech fored out through the cork. Is soun as the bottles are cool cronghl fo landle, dip the corks in sealing-wax, so as to cover then quite tierht. An additional precantion is usel by some in putting tintuil over the wax.

Another plan is to cook the fruit slightly in a kettle, and then put it into cans or bottles, and pour lot syrup of sugar in to fill up the inferstices, and then cork and seal, the lieat of the fruit and syrup answeriug to expel the air. But the less they are cooked or swecteucel, the mure natural will be the taste, like fresh fruit when opence. Wr have eaten peacles a year o'd that we conld not tell from those sugared ten hours hefore.

Tomatoes are very easily preserved, and retain tleir freslness better than aimost any other fruit. The small kind only are used. Scald and peed then witlout breaking the flesh. liottles slould hold abont a guart culy, beenuse when once opened, the contents must be nsed up at once. Buttles made on purpose, witl large throats and a ring on the insile, are the best, and hottles atre better than eans tor all acid frit. "lhe cans, howevel, are more casily secured by solder than the bottles by cortis and wax, als the nir is let out through a small puncture after the large opening is soldered up) and cans heated, and that lole stopped with a single drop of eoleler.

Every article of fruit will kecp fresh if the air is exhansted and the hotte scaled light. The least particle of air admitted thromgh nuy imperfection of the scaling will spoil the frut. It the air conld be driven out wistsont heat, there would he no need of any" cooking, and only just cuungh should be giben to expel the air and not chinge the taste. Many persuns prefier to add syrup made by about one pound of sugar to a ylunte of watter to ull suituble finits. Green corn, heans, peas, fomatos, piceplant, curmuta, gooseberries, cherrics, plums, risplerries, strawberries, peaches, are thu most common things put up in this was. They adil greatly to the pleasimes of the table and to the health of those who consume them-iu that renpect quite unlike the common preserves.

We lave known fruit for pies put up in tlrecquart eans ly partially conking in an open lettle in a syrup just sweet enough for nFe, and putimg the fruit in the cans lot and solilering iumedintely. It kept thua preffectly.

Some fruits kecp much better nul with less heating than others. l'ens nro anong the hardest urticles to keep, they contain so much fixed nir.

$\mathrm{T}_{\mathrm{e}}$ advise every funily in the country to try this plan of putsing up 
fruits for winter use on a small seale this year, and if snecessful, eularge upon it next year

A new mode, to us, of canning fruit is recommencled as follows:

"Take a common wide-monthed crock or jar of any size; preparo the fruit in the rsual way; fill the jar and tie two waxed cloths tightly over the nouth. The jar must not be very uarrow-monthed in proportion to its size. A common, straight, stone gallon jar is of good proportions. If the mouth is too small, the cloths can not follow the surface of the fruit down in a cold time. The cloth must tonch the firnit at all times, and if the mouth is wide it can riso and fall with the weather. In order to have the jar rery full, it is well to let the frnit cool down a little below 212 degrees; then fill mp with more fruit just before putting on the cloth. 'Tho cloths may be of the common muslin, but they must be soaked in melted wax. The wax should be beeswax chiefly; a little rosin and tallow will help it."

455. Dry Sugar-Preserving, -Strawberries, raspberries, blackberries, cherries, and peaches can be preserved in this manner: Lay the rije fruit in broad dishes, and sprinkle over it the same quantity of sugar used in coolsing it. Set it in the sun or a moderately heated oven until the jnico forms a thick syrup with the sugar. Pack the fruit in tumblers, and pour the syrup orer it. Paste writing-paper over the glasses, and set them in a cocl, dry place. Peaches must be pared and split, and cherries stoned. Preserved in this manner, the fruit retains much more of its natural flavor aid healthfulness than when cooked. The paper which is usually pasted orer jars of preserves is porons, and admits air. To render it perfectly impervious to air, apply the white of an egg with a brush to the praper betore corcring the jars, orerlapping the elges an inch or two.

4S6. Dry Pressure Preserving,-By snbmitting regetables to a powerful pressure, they hare been prepared in France so that they liare been kept in a dry state many months. Cabbages, beets, parsneps, peas, apples, etc., are dirested of all moistnre by a powerful hydraulic press, and thus are packed in small compass for nse of men on ship-board. They are a tolerable substitute for fresh regetables, but as unlike them as bull beef is to tender lamb. Upon such a voyage, however, as that of the Grimuell expedition, where the slips were frozen up nine months, a taste of such food as this would have been not only palatable, but extremely beneficial to health. We understand it is not expensire.

457. Currant Jelly,-As currant jelly is pleasant and useful to both the sick and the rell, we give the following directions for making it of excellent quality, which retains the beantiful crimson color of the currant much better thin that made by the old mode: "Squeeze the juice out of the currants, strain and measure it, put it in a poreelain or very well-cleanel copper or brass kettle, and boil it nntil the scum censes to rise; then, without taling the juice off the fire, stir in one pound of well-refined sugar to every pint of juice, and as soon as the sugar is fully dissolved-which will bo 
in less than a minute-take it off and pour it into the vessels prepared 10 receive it."

Cruer Jezcr.-Boil three quarts of ciller just from the press till it is re. dueed to one. Skim well, anl ald not yuite one quart of white sugar. lioil fifteen or twenty minutes, and strin throngh a coirse linen cloth nuto your jelly glasses.

4SS. Pickling Cucumbers, Melous, Touatoes, Peacbes,-The great art in making good pickles is to havo good vinegar. The best vincerar for jickling is made of somnd cider. As good vineurar is not aluags at hame, the best way is to preprare a brine strong enougly to bear an eigg. When the tub is full of piekles, allow the brine to cover them; then curer them over with eabbage-leaves, and a board and weight to keep them in the lrine. For use, freshen in wain water, and put them in a bright lirass kettle, with vinegar enougl to eover them, ant seald them fiften or twenty minnes: put them in jars, and pour hot vinegar over them; thor tlene wits rloves, mace, black nepper, an onion ur two, and a lible loncrulish and ringer.

For Pracur Pickids.-Stil two pounls of white sugar into two quarts of the best eider vinerar. Boil it ten minntes, skimming it well. Have resuly come large, fully-ripe peaches; rub them witl a clean thanel to tate oft ilio down, and stick fom cloves into cilch. I'ut them into grlas or whiteware fars, rather more than half full, amd pour on then the vinegar hoiling hot. Cover them elosely, set them in a cuol flace, and let them jest for a vink. Then pour off" the liquid, and give it anuller boiling. Afterward pour it agrin on the penclies; cover then closuly, corking the jars and tying leather over each, and put them away till wathel for nse. Insteal of cloves you may stick the peacles with blades of mate, six blates an cach peach. If you find a cont of mold on the top of a jin of pickles, remose it carefulls., and do not throw anay tho pickles, as they may still be quite gerorl heneatl.

459. Apples, how l'reserved, and their lse. - Where njples abound, as they do in a large portion of the Northern States, they slould be fommel in some form upon every farm-honse talile at nearly crey moal. Sevoral very choiec sorts can lo kept through the winter up to the time when mples come agaiu; ame where they abouml, there is really lunt litilo ncetsion fur prescrving small fruits, as indicatul in preceling paraprajls. Apples.

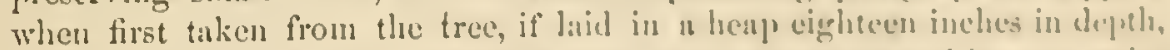
and corered with a cloth, or a little siram, will somn swent mul luconn yuite moist; then the cover or straw should he taken ofl. nuel the splules fuflireal to dry as smdlenly as posible. 'Then packed in harreds and kepe till they eweat again, and finally dried, repacked, aml stored in proper situntions, thy y will always te realy for furnishing somes uf the locst fuectucats at phort notiec that a farmer ean cojoy, for they furuish liealelyy inul.

Apples bronglat to the table raw should be ouly such simb as cau be eaten after sweet things, us pastry and custurals, lence all intensely sour alylios, 
however grateful at other times, are not fit for the dessert. There is almost an infinite number, and among them our best rarieties, which do not come witlin this stricture, though some of the choicest for culinary purposes are too som for the dessert meooked.

The effect of heat on many apples is quite noticeable. Baked apples are always liked. We are not surprised when a tender apple bakes soft and delicate, but when one tough and corky loses all these characteristics, and su:passes in delicacy eren the other, as is often the case, we appreciate better the ehemical action which heat induces. Sweet apples, free f:om decar, worms, or gnarly spots, scrupulously eleaned and placed in pans, and baked in a slow oven till fully done, are excellent. The apples shonld shrivel and dry away very much, and the skin should uot be broken so as to let the juice out. The sweetness is thus concentrated, and they are three times as good as if simply baked through.

Sour or tart apples may be baked much quicker; the juice, instead of becoming viscid and thick by heat, is apt to flow ont, or the steam splits the skin and lets it out, and it is likely to burn to the pan. Baked tart apples should be eaten with sugar, or they may be baked with sugar. Tart apples, washed, placed in a pan with a little water, and sprinkled orer well with sugar-or the same, cored and the holes filled with sugar-or pared as woll as cored, and spice added with the sugar, are delicions. Some use one or two cloves to each apple, or a bit of cinnamon with some lemon-peel; others grate nutmeg or sprinkle cinnamon over the apples in the pan.

To our taste, plain baked apples, or slightly sugared if very tart, is the very best preparation of this raluable fruit for the table.

APple Custard.- To make the cheapest and best every-day farmer's apple custard, take sweet apples that will cook eoft, pare, cut, and stew thein; when well done, stir till the pieces are broken; when cool, thin with milk to a proper consistency, and bake with one crust, like a pumpkin pie. Ergs may be prepared and added with milk, thongh it will do without. No sweetening is necessary. It may be seasoned with any kind of spice to snit the taste-the less the better.

Raw Apples and Mirk- A tender sub-acid, or sweet apple-the latter preferable-pared and sliced thin into a bowl of milk, for breakfast or supper, is a great luxury to some persons at any time of the year; and it is not less healthful.than grateful to the palate. 


\section{SECTION XXVII.-IIYGIEAIC.}

PREPARATION OF FOOD FOI TIE GICK-I:EMEHILS FOl: POISONS, BITES, AID srisigs.

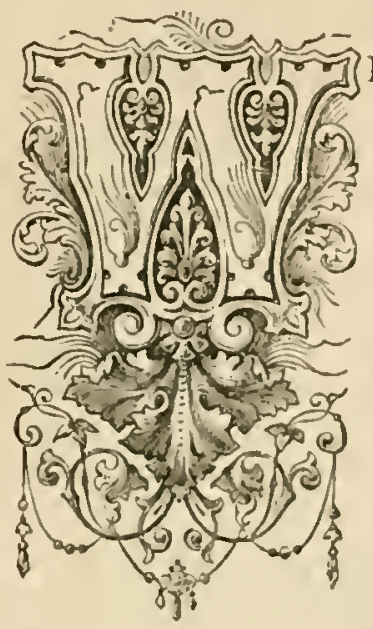

E will not tire the reader with nostrums under this title; we sinply ask attention to a very slourt sectiun "yon matters of great importance to those who are suftering, and which cont jrojerly under the lical of this chapter. All of oul realers whu have, while recorung from sickucss, uskerl, "What flall I eat?" will appreciate all that is said in the next paraglapli.

490. Food for the sick and Irspeptic.-Sickness occurs in crery fumily, and during ennvalescences the appetite is sometimes so delicate it needs al grenul deal of pampering. In some families there is ulwavs an invalid. who cin not eat the erery-tay fond of those whose appetites are strong. To such, some of the following lints may be very aceptable, and equally aecpitable to some who are not sick.

What shall I eat? How often this question is asked hy the sick, or thuse with delicate appetites! Nature demands food, but the apputite does rme crave it, and the nind of the fecble invalid cas nut fix upon anylhing that lie will relish.

It may relieve snch sufferers to point nut a few snitable articlos of forl. such as are casily prepared aud usmal!y tempt delicate appetites.

IIere is one peculiarly New Enmandish:

"Cut some codfish in bits the size of a pus, amb boil it a minnte in watur to fieslien it. Pour off all tho water, and all some cream nul a linle pepper.

"Split aud toast a lioston eracker, and put the abovo upon it. Milk and a little butter may be used instend of cleam.

"IIam or smoked beef may be prepared in the samo way. For u variety. beat up an eggrg and stip it in, insteasl of crean, or with the crenm.

"Tlicse preparations are also good for a relish for a tumily liruatian or tca."

Another excellent dish for sick or well, and cemonical withal, is mule by taking a few eakes of pilot-hreal and soaking flem sill partialls soff.

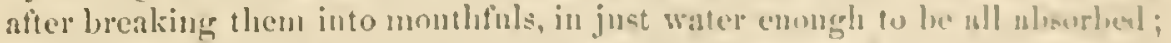
then cut a slico of fat sult prork into very small piceses, iry it crispl, puur it ores the bread, and heat the whulo in a sluse or uren, or in a spicher. 
Another plan is to pour over the bread a sweetened butter gravy, or wine sance, or the juice of stewed fruit or preserves. All are good.

A very excellent food for delicate stomachs may be made by swectening water, cold or hot, with refined sugar, and crumbling into it stale bread.

Bread and eider used to be a favorite food in Yankee land in old times. Sweeten the eider, and erumb into it toasted bread.

Sometimes a piece of codfish or a slice of fut salt pork, roasted upon live coals, will tempt a convaleseent appetite when nothing else will answer.

In making porridge of corn or oatmeal, be eareful to eook it well. Do not think it done till it lias boiled an hour.

Rice gruel does not need so much cooking. It slrould not be griven to a person of constipated habits. Simple boiled rice is a delicate food for the sick.

Arrowroot, tapioca, farina, and corn starch are all of the same characterhighly concentrated food. A good gruel may be made of either, and flavored with sugar, nutmeg, lemon, or whaterer would be agreeable. Stale bread, very dry, crumbed and made into a gruel, is perhaps the most digestible. Stale bread, toasted very dry and brown, and then steeped in water a long time, makes a good drink for the sick, and furnishes considerable nourishment.

In all cases of sicliness, when the appetite eraves fruit we would give it, ripe and fresh in its season, or preserved and cooled in the most simple manner. Apples for the sick should always be roasted. So should potatoes.

If the friends of the sick possess a little skill and neatness in the prepara. tion of dishes, the patient need nerer say, "What shall I eat?"

The following is well relished by some appetites, but we doubt its digestibility : Shave a good crisp head of cabbage as fine as possible; add a tablespoonful of lorseradish to each quart of shaved cabbage; let one pint of rinegar come to a boil; have ready three well-beaten eggs with a little salt; pour the eggs into the rinegar and stir until eooked; then pour it over the cabbage and set it away, as it is better when cold. This will keep some days, and is always ready.

Rolsting a Cincken may be thought a very simple operation, bnt, in our opinion, not one in ten of modern housekeepers can do it to perfection. First, because they have no conveniences. The abominable cooking-stove lias spoiled many a dish, and none more so than this of a roast chicken, which never has been and never will be roasted to perfection in any other way than tied up by the legs swinging by a string before a wood fire, dripping its grary into a pan in which there is a little crean and a lump of butter, witl which the roast is to be basted from time to time until the skin is brown and flesh thoroughly cooked. It is this cooking in the open air that gives it the peenliar richness. If a elicken must be roasted or baked in a stove-oven, it should be done with the oven door open. With some stoves it ean be much better done in an open pan set down before the 
grate. All holes in the boly of a fowl sliould be ecwed up as tight as jrigsible-not merely drawn torrether, lut tigrlat.

A badly cooked fow should never be set before an invaliu, or one whoee digestion is naturally weak. The following makes a nice dish for a delicaie appetite:

Lay half a dozen enackers in a tureen ; pour enough boiline water oser them to cover them. In a few minntes they will be swollen three ur four times their origrimal size. Now grate loat sugar and a littlo mutureg over them, and dip on cunngl, eream to urtke a nice sance, and roul latve a simple and delicions dessert that will rest lighty upou the stomach, am it is easily prepared. Leave ont the crean, and it is a valualle recipe tur "sick-room cookery."

LFmoxane-Three lemons to a pint of water unkes strong lemonale; sweeten to taste. This is a cool, refreshing: pleasant, and salubrions hev" eragre for invalids.

Mran.-Three pounds of sugar, five gills ot molasses. three piuts of water, three ounces of tartaric acicl, one ounce of sarsaparilla. Sir it owr the fire till at the hoiling-point. Whicu cols, bettle and cork tiglıt. Dild the superearbonate of suda when you drink it.

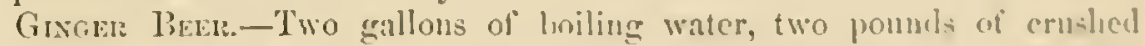
sugar, nue and a half ounces of lined gringer, one ounec of cream of hartur. one lemon, two tablesponfuls of yenst. Jix all together (execpt the yesn-l) and let it stand over-night; then adl the yenst; strail and bothle it: ic down the corks. In twolre hours it may he hank.

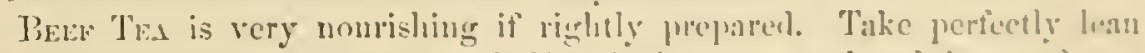
parts of fat heef, ent it into cubes half" an ineli sfuare, and soak it sume lours in cok] water, and then boil all together for an hour. Yum may impruse this by addling a tonsted cracker to cach lowlful.

The following fommla is given ly Lichige: Half a pound of frests, lean levef,

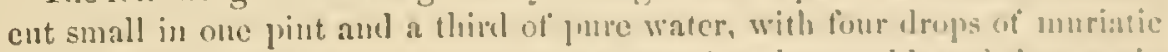
acid and half a sutall spmouful ol salt, to staml um linur coll, aul theu sirain withont sfuecziner. It may then be conked nud takeu lint or could

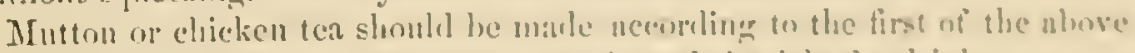

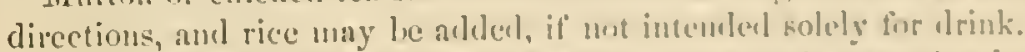

491. Candious about I'reserving Uralth, - The art nit pesurviug liealeh is of

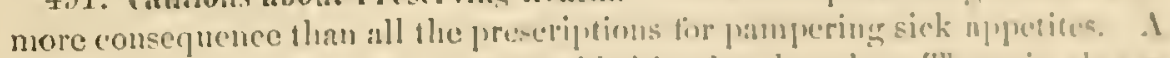

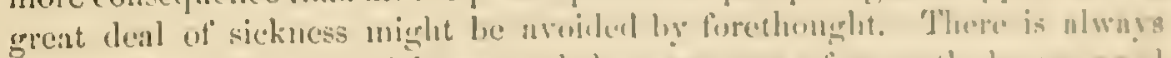

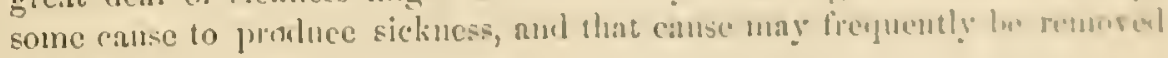
by a few lumess' lahor.

Stagnant water in the collar is a gereat lirecelor of disease. I, the the al.

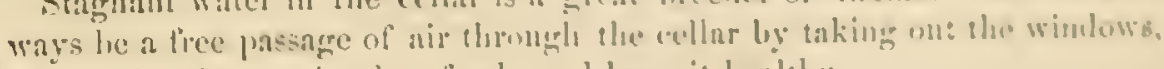

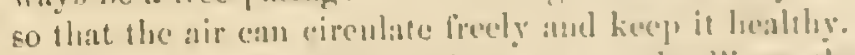

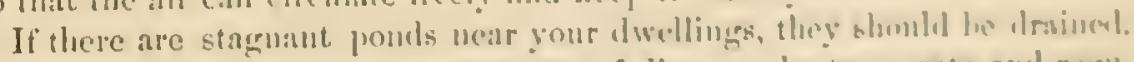

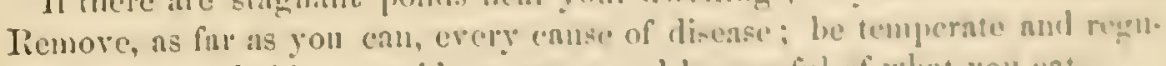
lar in all your habits; avoid exjosure, and lie careful of what you eat. 
422. Poisons, - There are numerous poisons lurking unsuspeeted about many drellings that tend to produce sickiness. Amoug other poisous, we entumerate-.

Oxalic acid used in solution for cleaning brass and remoring stains from linen, is a virulent poison. Lime forms an insoluble compound with it, and proves the best antidote when it has been taken into the stomach.

Among regretable poisons we find the mountain laurel (Ĺalmia latifolia),

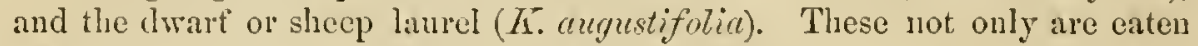
by animals, but the leaves are mistaken by ehildren for wintergreen, and we lave known serious cases of poisoning to result.

Poison sumach (R̂hus venenata) and poison vine or poison iry ( $R$. toxico(lendron) produce excessive irritation of the slin, and eren blistering from contact with most persons, and some are so sensitive that the odor only of the first or its smoke in burning produees most painful results. The wild or poison parsnep lias a similar effect upon some persons, and some very deljeate skins are affected by the garden parsnep. The effect is lightened when the leares are corered with dew; when dried, they may be handled witli safety.

Water hemlock (Cicuta maculata) is a virulent poison. From the form of its inflorescence and the aromatic odor of its seed and root, it is sometimes mistaken for sweet eicely (Myrrhis odorata) by clildren. Pains should be taken to extirpate it wherever found, as also to prevent the spread of a similar plant, a foreigner, poison hemlock (Conium maculatum).

Among poisonous garden flowers we have the larkspur, monkshood, and foxglove.

Opium, the product of the poppy, in some form, either as landaun or elixil, is a very frequent means of poisoning. These medicines are too powerful to be trusted in ignorant hands, as the ycarly record of fatal accidents sadly attests.

The green color on wall paper and on cards attached to various dry goods, often contains arsenie, a single square incl having eupongh to destroy a child. Green wall paper is unfit for use, especially for sleeping-rooms. The exhalation from such walls has been known to sicken the oceupants.

The frequent use of poisonous colors upon candy or clildren's playthings indicates the need of the utmost caution on the part of parents. The red, green, yellow, and blue colors may all be harmless, but fatal eases of poisoning and the examination of chemists prove that the grossest ignorance or the deepest depravity prevails with some makers and venders.

Copper in all its forms is poisonons. Acid or greasy food allowed to stand in copper or brass vessels, readily corrodes them, and proves their unfituess for snch uses. The metallic or brassy taste of the articles usually affords reasonable warniug.

Common black writing-ink, made of nutgalls and iron, is not poisonous, but the blue ink has a different composition, and is so in a greater or less degree. Indelible ink and also hair-dyes having nitrate of silver as the es- 
sential ingredient, are poisonous. Comosive sublimate used in alculuol 4 , $\mathrm{n}$ bedbng poison should never be kept in lamilies, as it has been the cante wi rery many accilents.

Phospliorus, an ingredient in friction matches, is a leadly poisu:ı. Tim much eation can not he nsed to kecp them away from suall children, wh will put anything in their mouths. 'The fiee bse of warn waer will mot only favor the romiting which may ensue from the action of the poinon itselt, bnt as a diluent it may serre to wealien its pourer me! remler it com* paratively harmless. Common table-mustard is a very jrompternetic. "Thu dose is a teaspoonful of elry mustarel; stir this in a tumbler of wafer um? drink at one dranght. It is quick, sure, and as agrecable as any curctic. If some does remain in the stomach, it does no harm. In a tew catses sume an. tidote may nentralize the poisonous substance in the stonach, but the man dependence must be in remoring immediately its confents cither ly" :u

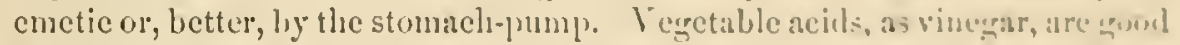
antidotes to many of the regetable poisons, yet ne rules can he given ujmu which it wonld be safe to rely without inedical assistance.

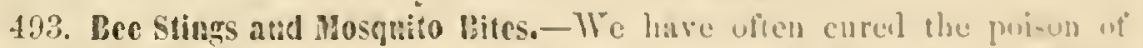
bec stings, and relicred the pain almost instanty by an application of" spiri's of hartshorn (liquid ammonia). It that is not convenicut, wet the shin und apply powdered saleratus or sal sola, which eflects stant relicf. The same things may be applied with suceess fo monpuifo bifer upon children or others, where they are particulandy poisuntus. Scumber body has published a statement that, if a piece of lam bect is placen in a room infested with mosquitocs, they will all suck the beet and het fultis alone.

494. Suake Bites and Rencelies. - The most virulent nul fitul of all proi-one, excepting always the poison of bal ventilatiun, comes from sualic hifen. which ocen occasionally in some of the new settlements of our century. We liare known death to supervene in several cances for wan of n linte

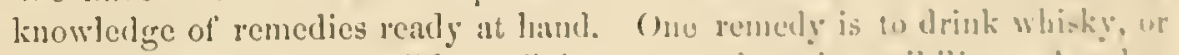
any spirit, as soon as possible, sutlicicut eo produco insusibility. Amosluer remely is to kill a elicken, or any osher nuimal, and ent it ojum nud apply

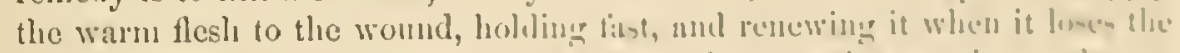

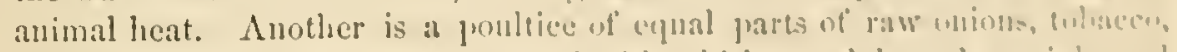
and salt, mashod together, moistened with whisky, amb humbl un fight atul frequently renewed. Sweet or olive cil, we know as a rery saludile

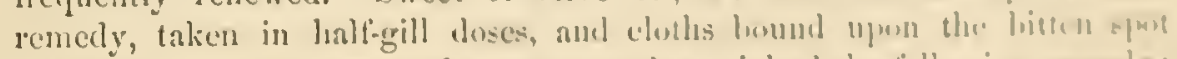
soaked in oil. We earnestly reconmend a trial of the fullowine remedr: Wet a hunch of lint with a teasponuful of chlorotorm, and lny is on the bite, and cover it with a watele crystal, a wincoglasen, or n munhler. pre ent down su as to exolute the air, and hold it there fiftedu to thireg mimms.

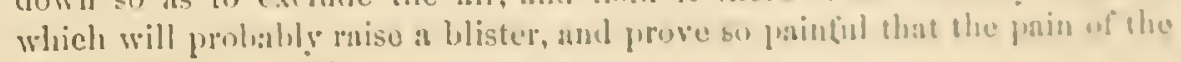
poison will not be felt.

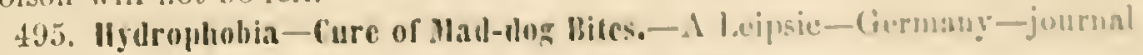


[CHAT. IT.

gires the following, said to have proved many times a sure remedy for the bite of a mad $\log$ :

"Take inmediately" warm rinegar or tepid water, wash the wound clean therewith, and then dry it; then pour upon the wound a few drops of hydmchlorie acid, because mineral acid destroys the poison of the saliva."

Brazilasx Mode or Crire- We have seen it stated that the bites of rattlesnakes and mad dogs and stings of seorpions are cured in Brazil by the use of spirits of hartshorn. It slould be applied immediately, if possible, and the wound kept wet by eloth application or eontinual sponging, and doses of the spirits diluted, taken into the stomach three or four times a day. It is said that the spirits of hartshom has a chemieal affinity for the poison virus, and absorbs and decomposes it, and thus renders it harmless. If this is the ease, then ammonia in any form wonld have the same effect. At any rate the remedy is simple and easily tried, and should be tested. We have faith in it, knoring it to be an exeellent remedy for a bee sting.

490. Remedies for Lockjaw, Felons, and Clcers. - We have heard a great deal about the medieinal value of a ponltiee made of grated bect-roots, and now we find the following statement, which we eonsider worthy of attention, the remedy is so easily applied:

"A young lady ran a nail into her foot, which prodneed lockjaw of such a maliguant elaracter that her physicians pronounced her recorery hopeless. An old nurse applied a ponltice of pounded beet-roots, renewing it often, and the result was a complute cure." •

$A$ good remedy for a felou is made of eommon soft sonp and air-slaked lime, stirred till it is of the consisteney of glazier's putty. Make a leather thimble, fill it with this composition, and insert the finger therein, and our informant says a cure is certain. This is a domestic application that erery lionsckeeper can apply promptly.

$A$ figr heated as wim as it ean be borne, and cut open and applied to almost any uleerated sore, and renewed as it cools, is recommended for boils and similar affeetions as one of the best remedies. It may be applied to an ulecrated tooth.

497. Remedy for a Tight Finger-Ring, - If it can not be remored by such mechanical appliances as inserting a stout thread under it and pulling upon it, nor by thin strips of metal, then ehemistry must be resorted to, and the strength of the ring destroyed, so that it ean be easily broken. "This is done by rubbing it with quicksilver, which has an affinity for pure gold, and makes it brittle. 


\section{SECTION XIYIII-THE D.MIRY.}

\section{BCTTER-MLAKING, AS PFACTICYN IYY FIRST-CLASS DAIFYMEX-CILESE ANT} CILESE-JIKING.

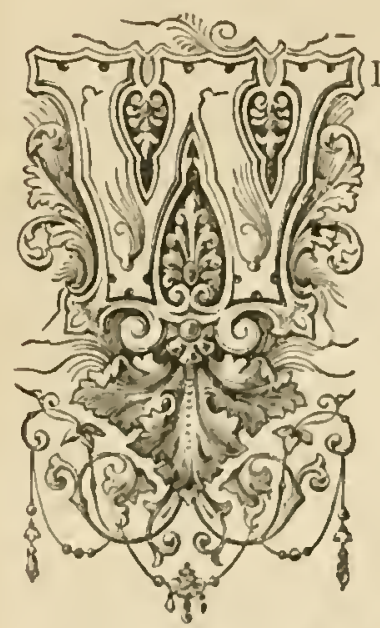

E can not teach all who neel to le tamelyt the perfect art of butter-Inaking, which is one wit the uscful ants that but few lonscholils prossess. In ihc great butter market of New lork, we fim! that not one tentl is really first-1ate; and probably more than one half is solel from one to lliree cents a pound loclow the first price, while toms are solil erery year at lhe prico of soft erease, and nicol fur other purposes than foorl. What a loss to the jroduccrs! In hopes to nill this class, we lave ruhodial in this scetion lircetions for malinge huter, as practicel ly sume of the best butcr-makers in the eountry dmong these, we may nane A. l;

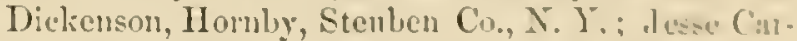
penter, of Elmira, X. Y.; John 'T. Nortun, of Farnington, Ce, and others.

19S. First Requisites in Intfer-Making.-1. B. Dickenson Eays: "One uf the first requisites in butter-making is care that all the ntemsils of the thiry are kept diy and swect; that the milk-ruom is well rentilated, of a proper temperature, frec from dimpuess and the mupleasant smell generalud by moisture; that the cream is not allowed to stand ton long npon the milh, nor after it is slimmed; that it he churned at n proper tempernenre, tho.

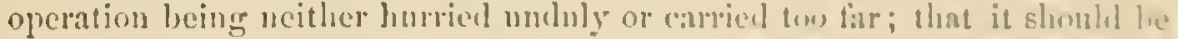
salted with the nicest salt obtamable, not injurenl by the mblision of surar or saltpeter, and that all the butternilk he joperly abd cdliectunly remored.

"The ntmost moisture which should be fumed in thoronghly workil hup ter is a rery sliente dew, and it slonlel be of such firm consistency as to slice down, hardly dimming the hrightuess of a huite-blade. To hutcer is propro erly male unless it will hoar these test.

"For tlepositing the milk, when strumen, the tin jail rif the enpacis" of abont twelve quarts is preferablo to any uther kind of res-el. It is sulli. cienly large to fulfill all ale repuirenents in that parteular, while its snperiority over the shallow pau-which is cousilcrably 1 sed-is 100 palpablo to almit of doubt.

"No first quality of hutfer cau be made cither in Nowember or dukne. While the one is too colil with frost-hitten grus, the other is yulfe foo warm, and withont ice it is imposinilile to muke first yuslity of lumber. Ho careful in washing butter to handle it with a lalle, no sis not to ntlect the 
grain; then put it away in some sweet, cool place out of the reach of any bad odor which it miglit absorb. When it lias stood long enough to get its proper rich color, work it over and lay it down and lieep it with the same degree of care. It would spoil in sixty days in a common farm cellar, where meats, fish, and regetables are kept.

"It would be a much easicl task to teach a man to make a watch than how to make the first quality of butter, as it is the most sensitire and the most liable to injury of all the eatables extracted fiom the regetable kingdom. It is so sensitive as to partake of ererything that can affect it that it comes in contact witl_-as onions, carrots, parsneps, turnips, fish, or anything else that would rake it unpalatable, either in the butter or the milk before churning. Not only so, but the butter partakes of erelything the cow eats or drinks, and the longer it stands after being made, the more perceptibly will the unpalatable things on which she fed make themsel res manifest. By this it will be seen that the most important thing for first quality of butter is the food for the cow. Neither from roots of any sort or kind, nor grain of any description, can first quality of butter be extracted. It must be from something that inparts a sweeter and finer flaror. The cow mot give good ricl milk, as first quality of butter can not be made from poor pale milk, for it lacks the essential quality of good butter."

Rest and quict are as important to a butter-producing cow as good food. She should nerer be logged, beaten, driren on a run, nor liare her quiet in any way disturbed.

499. Churning, Washing, and Coloriag Butter,-In spite of all the patented improrements, the old dasher churn still lolds its position, not only in families, but among dairymen. The following are $A$. B. Dickenson's directions for churning milk and working butter :

"The churm shonld be as nearly straight up and down as possible, as the dash should stir all the milk erery stroke it makes, so that the butter in the churn should all come at the same time. If the milk is too cold, the only safe way to warm it is to place a pail of milk in a large boiler of warm $\mathrm{ma}$ ter to bring it to the exact temperature, which is about 55 to 60 degrees-a fow degrees warmer in cold than warn weather. As soon as the butter has come and gatlered, tale it immediately from the churn in its warm state and put it in a large wooden bowl, which is the best ressel for the purpose; then put it in cold, soft water; then commence pulling the butter orer with the ladle in so gentle and careful a manner as not to affect the grain, for as sure as that is injured at the rashing or working, the butter becomes oily and can nerer be reclaimed. Erery particle of milk must be washed out, and then season with the best Liverpool salt. Set the bowl away until the next day, and when sufficiently cool, work the mass thoroughly, but not so as to malie it oily, and on the third day pack it away if it has assumed the right color. Examine it well before packing, and be sure that no milky water runs from it, for if packed with the least drop, you will hear from it next April. 
"If your spring or well is hard water, save ice from streams, as line nes er congeals with ice. Save ran-water, and then with ice yon will have suft. cool water to wash your butter, without which fon cail not get the milli out withont injuring the grain. Soft water is as indispensablo wo wals hutter as it is to wash fine linen. Washing buter is not positively necessary it" it is to be used within a few weeks.

"The idea of coloring butter with anything after it is made is as al-url as painting rye bread white, with the expectation of making it aste like wheat."

Jesse Carpenter says: "The unilk in the churu, when tit fur churning,

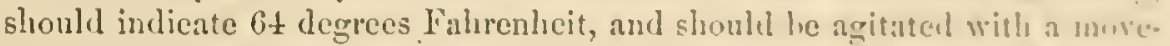
ment of the dash at not less than fifty strokes to the nninute. Io-s mo i n will fail to divide properly the butter from the milk. When hom, tho butter shonld be taken from the churn and thrown into a tub or a sonll

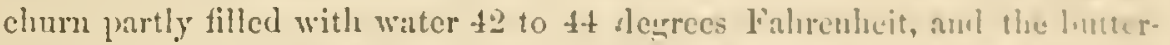
milk fureed out with a small dash. It should then be jut int, trays auel washed mutil the water used ecases to be the least discolored with hutier. wilk. It is then realy for salting, which donc, "ary the trays imundiatly to the cellar. Lse one and a yuarter cumees of sall to the poumel of worherl butter. 'Three or foul lours after the first Ealting, stir with a ladle mul furt it in the form of a honeycomb, in orler to grive it the greatcot pus-iblestrfice exposure to the air, which gives color ant fixes the high tlavor.

"Butter, when well manufuctured, while standing prepunto:y to prek. ing, is composed of gramulatel particles, between which atu my rimls of in-

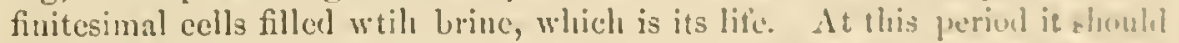
he touched with a light hamd, as too much and too careless working will de strug its gamular and cellular characer, and reduce the whole to n compace anel lifcless mass, with au inmediato loss of tlavor, sud a certatin mul roliahle. prospect, if packed, of a rapid change of its characere frum inditlerent!

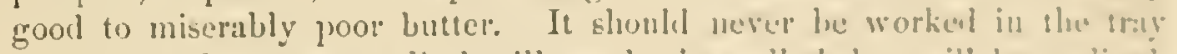
while in a diy state, or all the ill results just alluded to will he realizul.

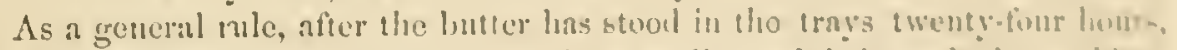
and hats hecu worked three or tour times as directed, it is realy fur puch in : After the firkin is filled, it flumlel stamel at flort time, mul then should

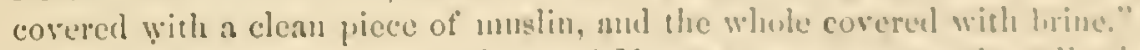

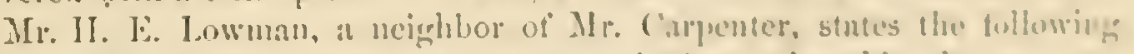

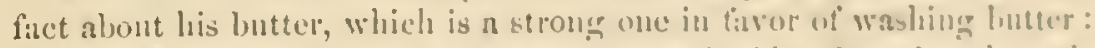

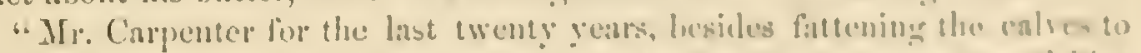

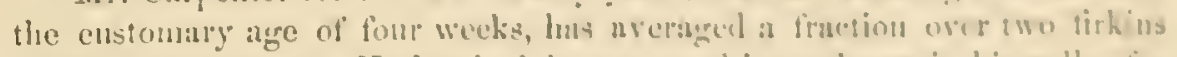

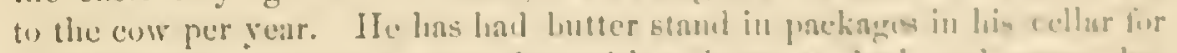

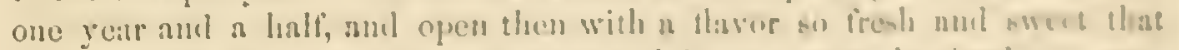

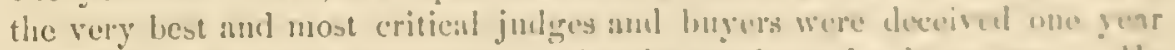

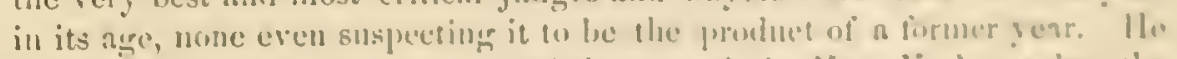

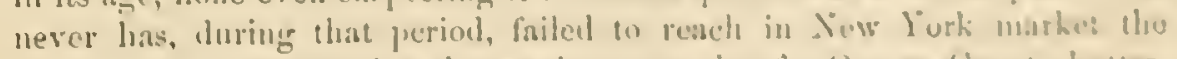
highest fignre representing tho maximmm market for Orango County humer, 
and latterly he has very often exeeeded the rery highest market from $\frac{1}{2}$ to $2 \frac{1}{2}$ cents per ponnd."

Butter is judged by its color, aroma, taste, and consistency. Its color should be a delieate pale straw, not approaching white, and yet perliaps that is better than the deep orange tint, almost always a sure indication of extraneous coloring matter. The peenliar smell of good butter is easily recognized. The better the quality the more delicate this aroma; while, as the inality degenerates, about in the same proportion does the smell vary, until it becomes positively offensive. This fragrance is dependent very much on the process of manutacture. Orange Comnty dairymaids make "Orange County butter" wherever they follow the same processes. The taste of the butter will betray any inattention to the proper care of either the mill, cream, or the vessels in which they are kept. So will the addition of any foreign matter, such is impure or too mnch or too little salt, sugar, or coloring matter. $\Lambda$ certain amount of salt is necessary to bring out the true flavor of butter in its greatest delicacy. In texture or consistency, a greater difference is seen than upon any other point. Some are firm, leaving no mark npon a knife after being thrust into a lump, with hardly enough moisture to dim its brightness, while other lots are soft, leaving greasy streaks upon the blade, and large drops of an opaque liquid oozing from the newly cut surface. The existence of either of these signs gives sure indication of an imperfect, if not bad, process of making.

500. Number of Quarts of Nilk for a Pound of Butter,-The number of quints of mill required to make a pound of butter varies very widely. By many trials in England, it is found that one pound of butter requires from fourteen to sixteen quarts of milk; that is about one onnce from a quart, varying with the feed and the season. Although it may be true that the milk of a majority of the cows in this country would require an equal number of quarts to make a pound of butter, yet there are cows that will give a pound to four quarts of milk. Col. Jaques, of Massachusetts, and Maj. John Jones, of Delawne, both had a "cream-pot" breed of cows which we saw a few years ago produce this result. But we believe that it requires an arerage of fourteen quarts to a pound, and that is why farmers prefer to sell their milk where it brings over two cents a quart. At that rate a milkdairyman ean not even afford to make his own family bntter; he ean buy it from a farmer, who can not scll his milk, at a rate more economical.

William Buckminster, of Franingham, Mass, in 1555, exhibited a Devon cow for premium, as the best butter-maker, with satisfactory proof of the following yield of mills:

"In June and July last she filled a common milk-pail, at night, as full as any dairy maid would wish to carry. And on June 17 her milk weighed, morningr and night, each $34 \frac{1}{4}$ pounds; June 10 , morning and night, $34 \frac{3}{4}$ pounds; June 19, morning and night 134 ponnds; June 20, morning and night, $32 \frac{3}{3}$ pounds; June 21, morning and night, $32 \frac{3}{4}$ pounds; June 22, morning aud night, $30 \frac{1}{4}$ pounds ; June 23 , morning and night, $30 \frac{1}{2}$ pounds." 
He also certified at the time she was offered, in Oetober, that fonr quarts of lyer milk, when fed on grass only, and that of an ordinary pasture, jrudueed one pound of the finest yellow butter. "This cow," he sars, " is onc of the six cows owned and bred by ne, whose milk has repeaticily viclded onc pound of butter from four beer quarts. Iler keep throngh the antumn of the three years of her milking lias becu grass feed unly, no grain, or roots, or corn stover having been given her."

This is the richest anilk of any but Allemeys, and aluove their arerage.

William S. Lincoln, of Worester, Mass., produced frum one cow, owned by lim, in the spring of 1858 , eightecn pounds of hutter a week ; and cons that produce fiticen or sixteen jounds a weck are nut uncommon in ilsi State. The "Oaks cow" yiclded lier owner nineteen pounds a weck at the best, and uearly 500 pounds in the course of the scason. These are cxiraordinary cases, it is truc; but if onc cow can do it, others curn.

Now, if these are facts-and who ean dispute them:-what are we to think of the quality of judgment, sense, or economy of unen who will kiepl cows on their furms tor the sole jurpose of making butter, at an average of one pound to fourteen quarts, when they conlil have eows that would give a pound from less than laalt that quantity? I.et this fiet be thought ot, ahat it does take fourteen guarts of milk for a pound of butter, which mightit be made from four quarts. While this is a fitet, it is not to be womleres nt that Or:uge Comnty firmers have quit making butter, notwithstanding the high reputation it lad attained, and prefer to send their milk to New York from every farm within reach ot the river or yilrual. If the milk arerage's two and a lialf cents a quart when sold, and it wonlel take funrteen yuarts to make a pound of butter, it would make the first cost of tho butter thirts:five cents a pound, besides all the labor of its muntacenre.

The Homestead says: "Mr. Coit, of Norwich, kecps wo eows which, in the best ot the season, furmish four quarts of milk ditily for nse, and matio niuctecn pounds of Lutter a week. 'lle writer also thinks that un improvent style of milk-room would be quite als likely to increase the yielel of buter

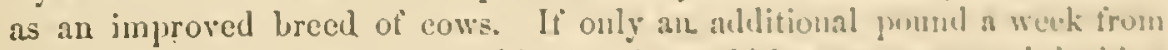
each cow could be secumed in this wisy, it wonld be a matter worth luoking into by our furmers, and would grealy iucrease the yolit ut butter in thestate."

Think of it, farmers, ju erery State. An allitional pound of lumer at week to each cow! What would be tho aggregente? Cau anybuty idl! Can anybody think of the vast amoment, med that it would be ull clear jrotis: And it is just as easy as it is tu lo right instead of wrong.

Good cows, sweet feed, and puro watter are the first of all requisites to the manufacture of good linter. Good cows, that proper color amel right consistency be secured; sweet feed and juro wreter, that ne flavor be int parted to the milk which would rember the huter mupalable. Dependent, however, as the quality of the articls is upon the cow mol the genodisess of the foot, a proper degree ot care aud skill on tho part of the dairywunan is of much greater cunscuucuce. 
Undoubtedly butter can be worked so as to keep sweet without washing; so can wheat be eut with a sickle, and thrashed witl a flail, but they are not great labor-saving machines.

With snecessful butter-malsers the churning occupies about half an hour. By increasing the temperature of the crean, it conld be done in one half the time, but the quality of the butter wonld be much reduced. In winter, to facilitate the rising of the eream, the earthen pans for holding the milk are rinsed in lot water before use, and warm water is applied around them, not to heat the milk, but for a time to maintain its original temperature.

When the temperature of the dairy is less than fifty degrees Falirenlieit, the millk will not ripen for chmrning, and in such case should be remored for a time to a temperature of fifty-five degrees. The sudden waming of the milk will not always enable it to yield up its butter readily.

One butter-maker says: "Carefully conducted experiments prove tlat more butter is obtained from a giren quantity of milk, when set in pans partly filled, than when full." This is in opposition to the theory of A. B. Dickenson.

A French chemist declares that butter may be made without clumning, by the use of a filter, made of white felt, in the form of a bag, in the four corners of which are inserted porous strings, like candlewick, to liasten off the fluid portion of the milk. The bag being suspended by the four corners, from twenty-four to thirty hours, the contents of the filter will be found to be of the consistence of "smear case" (soft cheese). This soliclified cream is then placed in a linen bag, tied tight, and the bag kneaded like a roll of dough. In a few minutes the mass grows liquid, and the butter and buttermilk are separated.

One large butter-maker says: "I use a horse-power churn, of a capacitysufficiently great to make one hundred and twenty pounds of butter. I always try the temperature of my churn before putting in the cream. If below fifty-fire degrees, I raise it to that point with warm water, and keep the cream as near that point as possible. As soon as the cream is in the churn I start the horse, and keep hin moving at a steady gait until the butter is broken, or begins to gatlier in small lumps. Opposite the opening throngh which the cream is poured into the chum is an inch hole, which is stopped with a plug. When the butter is formed as above stated, I open this hole and draw off all the buttermilk, then start the horse again, and keep him going until I gather the butter into a solid mass. This accomplished, it is taken from the chum and put into a tub prepared for it. I then weigh the whole mass, and transfer it to the butter-worker, when it is worked over twice, after which I add one dessert tablespoonful of the rery best dairy salt to every ponnd. I again work it well, so as to ineorporate the salt thoroughly. It is again weighed into pound lumps and printed. The human hand is never allowed to touch the butter, nor is water ever used to wash it." 
Of course it is sold immediately; if it is to be kejt, we think it must be waslied.

501. Batter Arrected by Foos of Cows.-The quality of all buter is so greatly atlected by the food of the eows, that no one can make goonl butter, although he has good cows, if their food is poor. In smmmer, there is muthing hetter than clover pasture. At any rate, the pasture must atiord swect gra-.; runuing water, and trees for shade and rest. A cow should be selected for hel quict disposition, as much as any otlel quality, for a butter-anaking cow; for milk alone, this is not so important. It she has vicious propensities, slıe ean mot be eured by viciousness. In winter, clover lay, cured in the most perfect manner, is better for butter tlan auy oflicr lay. To this add slops once or twice every day, composed of loran, Elorts, cut potatoes, corn meal partially cooked, and salt, and an occasional handful of hono meal, lime, ashes, of elıareoal-dust, will be found advantageons. C'arrots are always good for a butter cow. Nothing slould ever he given her that is not sweet enough for you to eat yourself. And eren that is not always good food for a cow, ns turups, eabbages, and onions are considercd goud food for the table-they are not for the stable, if sweet milk is an olject.

Then she must be kept in a clean, sweet-smelling stalie, wann and dry. but ventilated. The same stable slould he usel in summer for milking after which the cows may he allowed to slecp ont, it it is such weather that

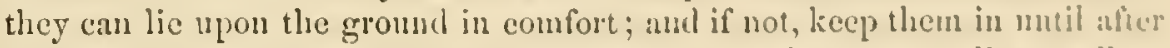
milking in the morning. Every cow should know her uwn stall as well ns a man knows his own bed, and they will soon learu to be nuwilling to ent or be milked anywhere else. Food and care of the cow, and perfice yujet and comfort for her in every respect, are the first repuisites in making gened butter.

A stable ean be kept sweet enough to loclge in hy the daily use of plaster. chareal, prepared muck, or an vceasional sprinkling of dilute suluhuric acel or Eolution of copperas.

It is necessury tor a full flow of milk on maintain a comtinual supply of albminous food, while in the latter period of fattening, sucle kinels of tount are superfluous, and only tend to enrich the manure heap "There is one leadiug feature in his puratice. to which the utmost importuce is antacherl by Mr. Horsefull-an English dairyuan-tho manteasme of the condition

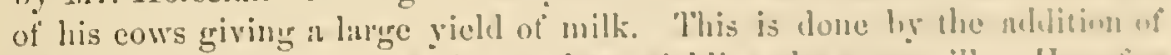
bean meal in greater quantity lo these yiclding tho most milk Ile refur also to the chlect of clover npon the supply of milk as known to nll elairy. men, the dry material of which is searly as rich in allumen as herus, smbl

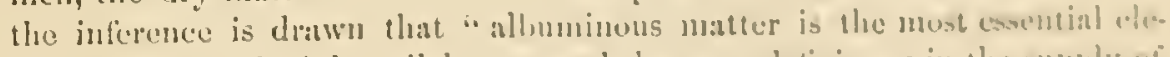
ment in the fool whe milch cow, and that my deticiency in the sujpl! of this will he attemlerl with loss of comlition, mal a consequent dimimntion in the puality of her milk." He is of the opinion that "you enu increm-e the propurtion of lutter in milk mere than that of cusein or other suliel prerts." liaje-cako scems more eflicient for this purpose than liusced-cake, tho cilly 
matter in this seed more nearly resembling that in butter than that of flaxseed. He also says: "It scens worthy of remark that a cow can yield a far greater weight of butter thun she can store up in solid fat. Numerous instances oceur where a cow gives off two pounds of butter per day-fourteen ponuds per week-while half that quantity probably would not be laid on in fat if she was fed for that purpose."

These "Euglish notions" are worthy of American attention.

502. Butter Afected by the Packages.-It is one of the greatest mistakes that butter packers make, to put it up in bad packages. Let it be taken for an incontrovertible faet that, as a general thing, a dairy of butter of uniform quality may be packed, one half in rough, untily casks, and the other in neat, sweet-looking firkins, of suitable and uniform size, and that lialf will ontsell the other at least ten per cent. The purchasers of lutter, by the single package or by the hundred packages, are always influenced by the outside appearance. One of the reasons why Western bntter sells at a price generally under the market is becanse it comes in bad orter. IIow can jeople expect first prices for bntter in mottled rolls, packed in a dry-goods hox or a flour barrel? Sucl butter, when it arrives in New York, is denominated "Western grease," and sells at a price corresponding with its name.

503. When to Skim Milk.-The right time to skim milk is just as the milk begins to sour in the bottom of the pans. Then the cream is all at the surfaee, and shonld at ouce be removed, witl as little of the milk as possible. That lonsewife, or dairymaid, who thinks to obtain a greater quantity by allowing the milk to stand beyond that time, labors under a mistake. Any one who doubts can try it. Milk should be looked to at least tliree times a day.

504. Alderney Cows and Alderney Butter.-It is our matured opinion that the Alderney eow is the only one for a family, where but one is kept, and where rich milk and sweet cream are a leading object. (See 47, 48, 49.) There is no donot of the fact, that this breed of eattle is superior to any other for making butter of rich flavor to the taste, and with a peenliar sweet aroma. We have thoroughly tested butter made from Alderney cows, by John T. Norton, of Farmington, Conn., and have snbmitted it to the sight, smell, and taste of some good judges of butter, who, withont hesitation, pronomneed it as unlike as it is richer than any other kind they liave ever tasted. We kept it some weeks exposed to an atmospliere that wonld soften ordinary lutter so that it could not easily be liandled, and yet this remained almost as firm as though just from a cool dairy-room. There can be no mistake in its natural superiority and good keepiug rualities over butter made from cows of other breeds. This fact is as well known in England as the fact that Southdown mutton is superior to that of other breeds of sheep. And the fact is beginning to be known here, for we have lieard of Alderney butter selling in market, in places where it is well known in this country, at double the price of good butter of common stock. This much for the in- 
formation and benefit of thuse who do not linow that there is a very gerene

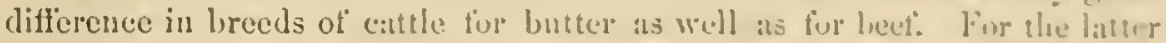
purposes the Aldernegs are ectatuly superiog to the lourhans. licreturda, Derons, Ayrshires, or natives.

Another good quality of the Alderneys is, that they will live upon hun-e.

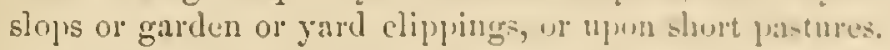

Mr. Nouton says: "I live on one of the old worn-ont farms ne Connere icut, which I an tryiner to iuprove," and we say. "1pun such u furm he finds

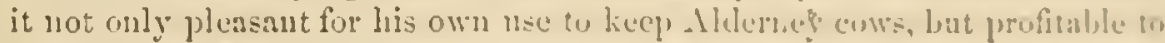
make buter from them for the Janttord market. (Mn recommendarion, lowerer, is not for dairy purpwses, unt strictly for privite fanily use, anm] for that we do consider this small beed of cows most valualile. "There are persons, howerer, of experience, who helieve the Allermegs valualie for dairy firms.

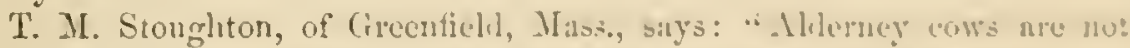
only good tor private faubly use, but actually the lust for a large dairy

"Ir experience has been with a herd of cows imported by Ilr. Jumathan

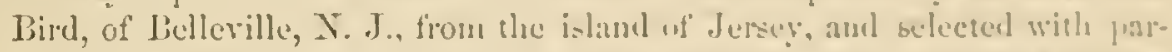

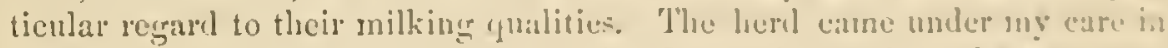

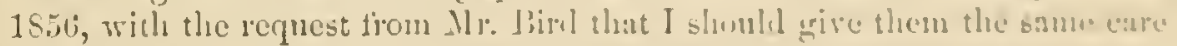

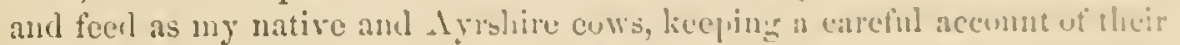
jroduct by measurement and weight, so ats th he ahle we deternine whether they are a protitable breed for butter-making. The following stanement is oflered as an answer to "What is at grood cow ?"

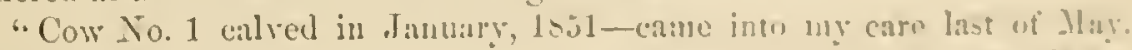

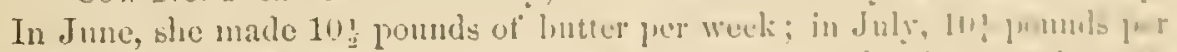

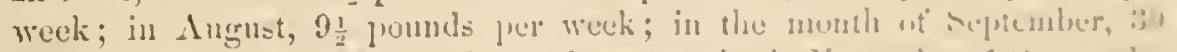

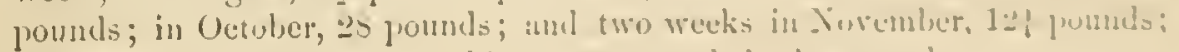

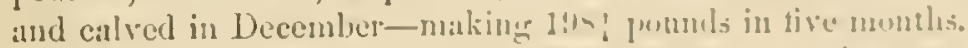

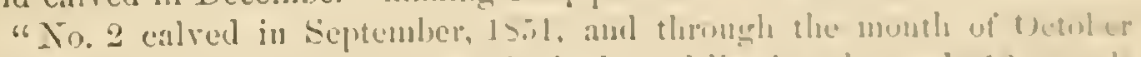
made $14 \frac{1}{2}$ ponnds of butter per week; in June fullowing she made $1: 2$ jumbers per weck; in Angust, 6 poumls per week; and colvenl carly in (denbermaking 317 jom of butter fint the gear.

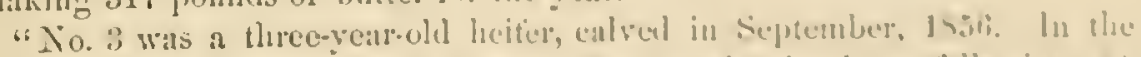

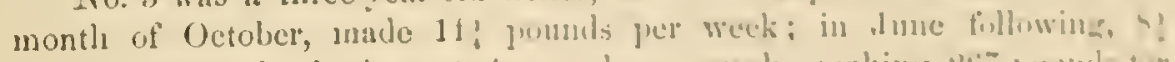

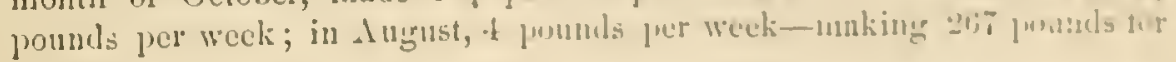
the jeas.

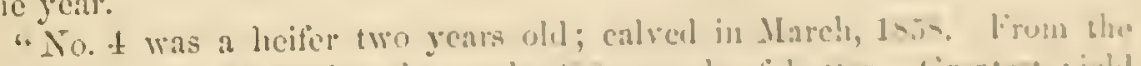

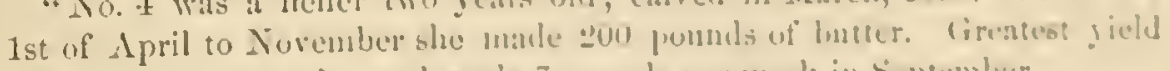

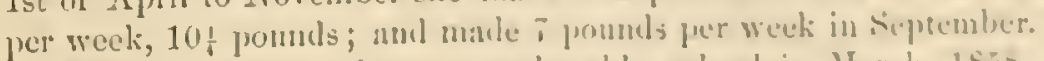

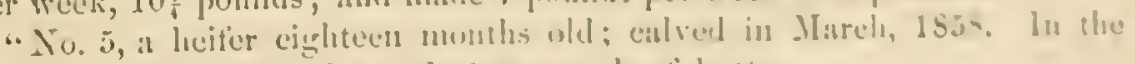
fire months fullowing she made lue pommls of lintere.

"The above live are an aredage of the ten milling cows. 'lheir liel has

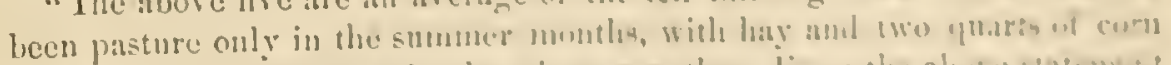

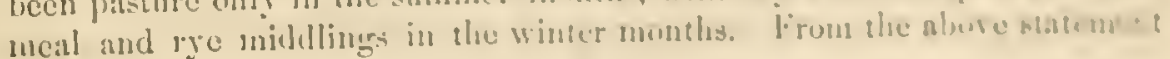


it will be seen that the eows which have come to maturity will malie 300 pounds of butter per year nuder favorable circumstances. Alderney butter sells in the different markets of the conntry for from forty to fifty ecnts per pound. The best dairies of New York and New England do not average over 200 pounds per cow (native and Durham). The arerage price of their butter is not over twenty-fire cents per pound.

"One of the most important peculiarities of the Alderney cow is her miformity of quantity, making nearly as much butter at the end of eight months after calving as at four. The objections urged against the Alderney eow are, that she is a voracions feeder, lean, awkward in appearanee, and will make but little beef when old.

"Admitting the Alderney cow to be a pretty sharp feeder, it can hardly be expected that a cow will make from ten to fourteen ponnds of first-rate butter by simply standing in a cold stable, and looking at a haymow, of by shirking round a stack of swamp hay. That she is inclined to be lean is an evidence that she is a good miller; for a cow that secretes fatty matter can not secrete good milk at the same time, witliout being fed too ligh for the permanent good of the cow. If she is ugly to look at she is a good one to go, for she will be worth $\$ 100$ when six months, especially if a heifer. And atter being millied twelve or thirteen years, producing orer 3,000 pounds of butter, it is of no great consequence whether she makes 600 or 900 pounds of beef."

505. Heating New Milk.-The Dairyman's Record gives the opinion that the heating of new milk to near the boiling-point just after it is drawn from the cow, is preferable to allowing it to stand for a time before heating, and thinks both butter and cheese are improved in flaror by so doing, "beeause the animal odors which are oljeetionable wonld be expelled," and goes on to say that "tasteless and leathery" cheese is cansed by manufacturing under too ligh a temperature rather than from high heating before mannfacturing.

506. Bust and Fiy Covers for Milk-Pans.-To keep dust out of millk-pans, make hoops of ratans, or ash wood, a little larger than the tops of the pans, and stretch orer and sew on them some thin cotton stuff that will not stop the circulation of the air, but will keep out the flies and mites, and when the milk is cool, lay these eorers over the pans. To keep ont flies, use mosquito netting ol wire ganze instead of clotll. The wire gauze is a fine thing to cover all windows in fly-time.

Some inventive Connecticnt genius has contrived a portable, ventilated milk-closet, which, frou the deseription, we should think a very good thing, but presnme that any ingenious wood-worker could get up one a little different in form to answer the same purpose; and we recominend all families who keep but one eow, to provide themselves with such a convenient ventilated mill-closet; or one that will let fresh air in and foul air out, and keep the milk safe from pestiferous inseets and vermin.

The following item shows the benefit of kecping milk cool: "In seading 
milk to marliet, thongh it left the daily pertectly sweet, it wh often fomml curdled on delivery to customers. To remedy this, the cass were coverent with thick cotton clolh, and this was wet with salt water. In this way the dificulty wis entirely olviated."

507. Necessity and Value of a Namity bary Room.-Erery farm-lum-e shonld have a room for milk, solely devoted to that, and nothing des. In very dry soils this ean be made easiest and best in the cellar, providenl it lus a chimney ventilator of ample dimensions ruming to the top of ilu honse, which ean be easily made when bulding, and mo nilk-lon is perteret without such rentilation, and in ont opinion the eanse of bal butier is a much in the want of a suitable place to stand the milk, ant a coul, sweet rooin to store the butter, as in the process of manufuchuc. It is all impurtant, also, that the milk-room should he of an unvarying temperatner, so far as it can he kept so without extra expenditure over the profitable advantage. An attachunent to the ice-house is the best plate for storing butter. "Ilue fol. loring is a good plin for a family dairy-room :

Build rery convenient to the kitchen, but not adjoining, an eight-inch wall brick luilding, eight feet by sixteen feet inside, with a door in one end nul a window in the ofluer, and arch it over ten feet high in the center, and plaster it all over outside with water-proof ecment. The top shoull be enverel with a coat of asplaitum, if to he had, or clsc with sanel and tur. Give the inside a cont of hard-finished plaster, and praint that well, so that it con lue rashed. Where there is a good chance for dranage, the walls maly he dropped two fect below the surface, or the whole built into a hillside, in which case there can be no door nor window in one end, luat there can and must be a large chimney rentilator. Make the llool of ement or than ging-stones, and, if not too expensive, use stone shelves, luilt in the wril. The outside is to be bankel up with earth and eodiled orer so as fo furm a grassy monnd, forming, in fact, a sort of cave cellar. A rutaining wall must be huilt ench side of the loor-waty, and at shel orep it, with wirescreened windows in the door fur rentilation, the sash being hinged to swing down and fasten to the lower half of the dour. Such a roun will kecp milk sweet and of even temperature, and is not more expensive than a puorl frame builling.

The place where the milk is ect, clumniug done, or louter stored, should be absolntely sweet, elcan, and deolurizel of erery sucll. Wancr-enhl water, and its liberal application-is an essential abont the latiry lomse, n: ll outsile of it ; mpon ererything erer used, hut water, snap aul saul, mul hard hand-work, to make absolute purity, are the essential requisites to proluer good butter. Every wontu should nssmo all the "mentulks," aul when

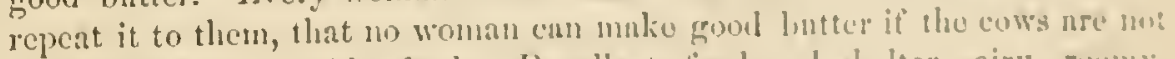
provided with suitable fond. Recullect, foul nul sholter-airy", renmy. clean stables, summer and wintel; none of your milling in the rond, amuln:

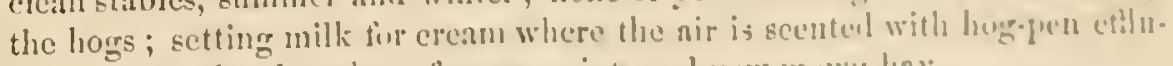
via, or any othe! but that of roses, mint, and now-mums lin!. 
Food is the first, purity the second, temperature the third requisite in making sweet yellow butter.

The lost way to make dairy shelres is to use strips sawed one by two inches, and set so that the pans will stand upon their edges, or else place them wide enough apart to receive the bottom of the pan, having crose strips nailed in to support the sides, so that the pans would only touch at four points, and so cause the milk to cool quickly, and save labor in keeping the shelves clean; for a pan of rarm milk set mpon a flat shelf in a room a little damp, or when the shelf las just been washed, will generate moldcertainly more than when set on strips, as here recommended.

A Mr. Motley, of MLassachnsetts, has a dairy-room in the cellar of his house, and arranged to be rentilated by an area window, which is covered with wire netting. The floor is cemented, and of course kept serupnlously clean. Plain, broad wooden shelves around the four sides of the room hold the prans of milk. A marble-top talle, standing in the center of the apartment, is used for working the bntter, and preparing it for market. The milk is chumed in one of the well-known Crowell "thermometer churns," of a capacity of thirty gallons. A small air-tight wood store is used to insure an equable temperature in winter. Abont 100 pounds of butter are made weekly, which is sold to gentlemen in Boston at fifty cents per pound. It is put up in neat quarter-pound rolls, prettily stamped, and sent to town in tin boxes, fittel with shelves inside to keep the layers of rolls separate. As to the delicions quality of the bntter, that is proved by the price.

50s. How to Make Winter Buttel:-If cows are fed with roots, meal, or cren whole com, which, by-the-ly, is only to be tolerated when corn is worth less than twenty-five cents a bushel, there will be no complaint of poor white butter, unless the fault is in the churning or the keeping of the milk. Milk, in winter, should be kept about the same temperature as in summer-time, and should not be allowed to stand unskimmed merely becanse "it is taking no harm." Take off the cream, and if not enough for an immediate chmrning, let it be kept cool and sweet till enough is accmmnlated, when, if it is necessary to son it, it may be put in a warm place and done all at onee. When put into the churn, it should be at a temperature of 62 degrees, and if kept at that, yellow butter will be got in thirty minutes by churning moderately, if your cows have had a little salt every day.

509. Buttcr Colored to Order.-Are the butter-eaters of New York aware that butter, so far as color is concerned, is made to order as much as their hoots, hats, and coats? We assure them that such is the fact, as is well known to all dealers, and should be known to all consumers, and by them wholly discountenanced. Onr present notice of the fact arises from hearing a woman bitterly denouncing the grocer who sent her "white butter." $\Lambda$ fter she had selected some "nice yellow" butter", at two cents higher price per pound, and retired, the grocer asked us to test the samples. We found the rejected white butter as sweet and fresh as conld be desired, and worth twenty per cent. more than the other, according to onr taste. The other, 
lowever, wats pretty to look at. It was of a llecp yellow line, lut we at once declaled that it was made so by anuatto. "Yes," Eaill the grucer, "you are dighth. That butter was maile to order for me for just sucla cus-

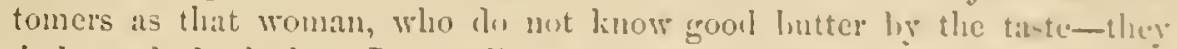
judge only by looks. It actuilly cost me two cents a poind less thun tlic other. You saw how I sold it."

1 butter-maker, writing to the author abont "coloring butter to order," says:

"We think you New Indkers possessed of remarkalle tastes, if you really jrefer lutter made yellow to orler instead of that of a uatural color, thoufy jerfectly swect. It it is the color instead of the quality that you care firr, we shajl have to Eolicit a sample of the sluale desired, and order mure drestufl. We shall have to make hutter for home use and for city use, as un one in the comntry will eat colored lutter in wiuter except ns the milk colors it. There is but rerg little in the conntry at this scatsun that myswers the order's from the eity, exceyt such as las been fixed uy to suit gour marliet."

Now, butter-eaters, you hear how yellow butter, is made "fresh from the cow" in winter, asd how much you pry for the privilege of eating "annatio and otlier dyestufts."

510. Rules for Salting Butler,-First, none lut tho very purest rock-salt, or manufactured salt, juepired especially for the dairy, should erer le used. An experienced Ĺcoteh dairman says:

"Talie the best erystal salt, wash it, lissolve, stran, sutile, aml turn oll: hoil it down in some perfecty clean iron vesecl, skim as loniling: when

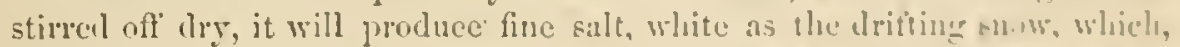
it stired up in a glass of water, will prodnec no seliment, aml will be di . tinct from any mincral or other possible impurity."

Three experieneed dairywomen in Inertiro Connty, Mass, give the fullowing rules for quantity:

"No. 1. A teacupful of salt to six promeds of hutter.

"No. 2. One pint of" salt to fifteen jumbs of lutter.

" Vo. 3. An ounce ot salt to a pound of lutter."

Salting the cresm before churning his lees alvenented ns a froml practice. To every quart of cream, as it is flimmerl nad put in the prot in

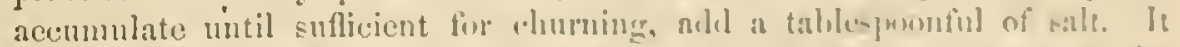
is stated that the time of churning is very much lessencel by saltimg the crean.

511. Pacling and Preserving butter. - I paicnt has lecen granbed to li.

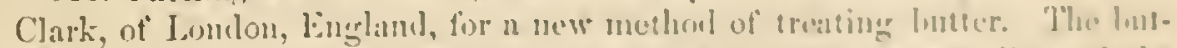

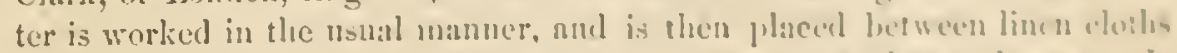
and submitted to serere pressure, whell remores the whey umb wher. It

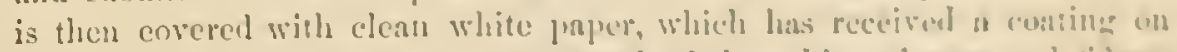

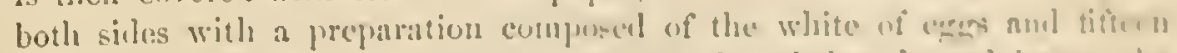

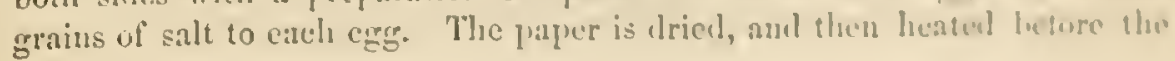


fire or with a lot iron just before it is applied to the lumps of butter. It is claimed that butter treated in this way will lieep two months withont salt in a cool cellar. Any ordinary cheese-press, or the presses accompanying the portalle cider-mills, now common, will answer the purpose. Pressing remores the water, and the prepared paper excludes the air.

Larthen jars, made of the size and shape of a fifty-pounds tub (not a frlin), and put in a wooden tub, made to fit, with a head in each end, are recommended as an improvement for packing butter. If desirable, the wooden tub may be made large enough to fill with salt between the two, or can be male close. The heads should be made elose to the butter-pot in. either case. Bntter packed in this way will keep sweet any length of time, if well male, while in the present mode of packing, in nine cases ont of ten, it will taste of the tub after being packed two months. The first cost of the two is about one dollar, and after being sent to market, they can be leturned a distance of 300 miles at a cost of abont thirty cents. Tre fear the expense of this improvement will prevent its general adoption, though we can perecive no reason to doubt its efficacy.

There is no doubt that if butter could be rendered absolutely pure, it would keep, if exeluded from the air, as well as sweet-oil. That it is hardly erer pure may be shown by a sample melted, and put in a bottle, to stand a fer hours in a warm place, when the oily parte will float upon the top of water or other impurities it may contain.

512. How to Cool Butter witheat Ice-The following plan of cooling butter is founded upon the scientific prineiple of cooling a body by evaporation. Fill a deep plate or flat dish with water, and in that set a trivet, such as are often used mpon the ironing-table, to hold a plate of butter above the water. . Cover the butter-plate with a porous, earthen flower-pot that must liare its edge immersed in water, and a cork in the hole in the bottom. Now dash water "pon the pot, and repeat several times as it evaporates during the day, keeping it in a cool place, and at supper-time you may bring your butter to the table as delightfully firm as you would from an iee-honse.

513. Muking by machiaery.-If anything has been or may be invented to reliere woman fom the tiresome labor of milking, it will be hailed with intense satisfiction. We therefore chronicle the faet of the recent invention of a milking machine. The manner of $\mathrm{jts}$ construction is simple enough. It consists of two diaphragm pumps made of tin and India rubber, so arranged as to be easily talsen apart for washing. The teat-cups are made tapering to fit any size, and attached by flexible joints, so as to be spread apart to suit wide-spreading teats, or those more contracted. It is possible that it will prore a very useful incention. If so, we presume that farmers will hear more of it.

The machine is attached to a pail, and set on a stool under the ndder, the fonr teats inserted in four tubes, and the pump operated, and the milk drawn and conreyed by a conductor into the pail, the inventor says in a marrel- 
ously short time-say three minutes for an orlinary (a)w ; milking entiruly clean, withont injury and to hel alrantige, as it is lrencticinl to have thi" work done quickly, and the machine is intended (1) 1h) it quiclien than it is possible by hand. It is said also that cows gent? stand this undhine milk. ing; the contrivance is ingenions, and will work. Its practical utility we can not rouch for.

514. How to Make Cows give Bown.- We have often liearl that onc man could lead a lorse to water, lut two conld not makc him diuk. Thic preat mistake of most people in the management of horses, cowa, anel cren Inen. is trying to make tirem do things ly force instcanl of miller me:ans. Thu best way to make a cow give lown is to cond her. l'aticuec and perece verance will generally orercome the dilliculty and eflect a cure. 16 e lave seen cows that had been trained to lecing fed when milked until they womlal only grive down when bribed to do so. Strappling up the fure lew in a cow with a strap slipped over the bent knee so that slie can nut walk mutil milked, will sometimes eure lier refractory disposition. If a cur will nu: grive down by geutle means, it is of no use to try to matie her lo it.

515. Milk Farms-P'roduct, Price, Profit,-Mlli for fitiss-f'oudemied Mish.

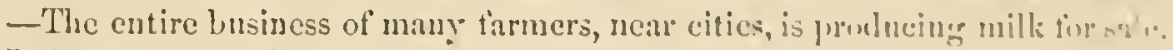
It is sent by railway more than 100 miles. The average value upun 1 la.

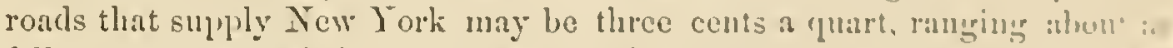
follows, as a general thing: for five months, at 2 conts: one monel, $2 \frac{1}{2}$ cents: two montlss, 3 cents; four montls, $8 \frac{1}{3}$ cents. liveinht will averater an cents a quart, besides a great loss of caus. It costs the furmer most in protduec milk in April. The cost of winfer feed, 5 lls. of mest and 15 11 s. e lay per day. The anmual arerage product of gool curs would be sati() anch. It eream only is sold, say 10 quarts per reek all 15 cents, and ! lhs. of

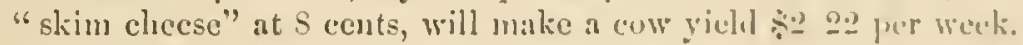

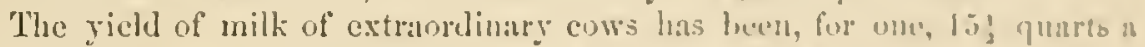

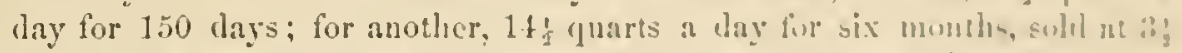
cents a quat, producing \$10

'The income of an Hllinois cheese and huther dairy, uwnel hy Mr. Sabory. of De Kalb Comnty, is griven as follorss, in a prour, dry seasum : io, jlll) pummils

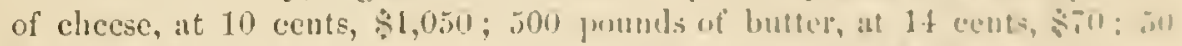

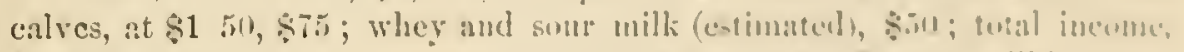

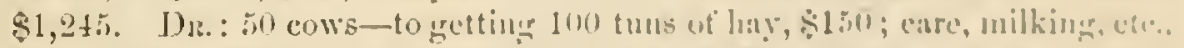

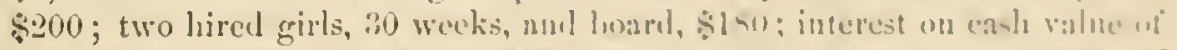

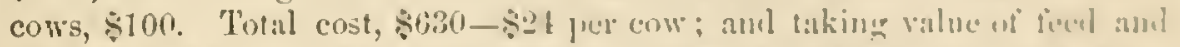
labor into account, was perlaps as protitalole as u Xew lurk milk liarn Sec $\%+1$, ctc.

Coxmexsten Muk.-There is nne methou of sending milk to the cities.

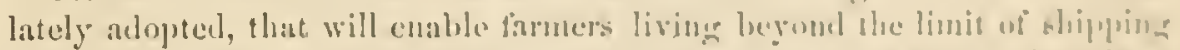

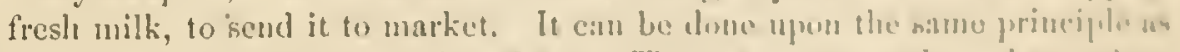

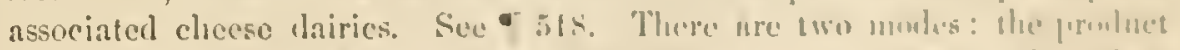

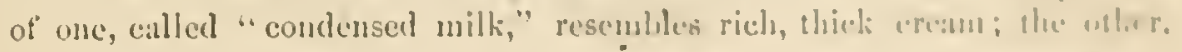


called "concentrated milk," resembles and is composed in part of dry, whito suckn: The former lias nothing added, lut much taken away.

The process of condensing mille was invented hy Gail Borden, Jun. (hin1self an octogenarian). The first manufictory was established at Burprille, Litchifiel Co., Conn., if we remember rightly, about $1854-5 \tilde{5}$, and is still in successiul operation, conducted by $1 \mathrm{Hm}$. Borden. Another establishment has since been started at Wassaic, Dutchess Co., N. F., on the Harlem Railroad, S5 miles nortle of New York. This is condneted hy the inventor limself. whose residence is at that place, where partics desirons to commence similar operations can obtain the necessary information. The product of this iuvention furnishes to residents in citics who have a taste for pure nilk all that they can reasonably desire. 'The process of condensation not only separates the water from the more solid elements of the milk, but absolutely frees it from all impurities, even including the mpleasant odor that is usually combined witl the milk of cows, and which sometimes, when they are nuhealthy, is exceedingly offensive. Samples of milk from all the dairics are constanty subjected to tests to indieate the quality and detect inpurity. As it is brought in trom the farms, it is emptied throngl fine strainers into tin cooling rats. These must be placed in ruming water or cooled with ice. The first process in the operation of condensing milk is to free the natural milk of all its animal lieat; and cluring this cooling, if there is any sediment that was not remored ly the strainers, it is found in the bottom of the rats and rejected. Tlie milk is then heated by steam nearly up to the boiling-point. This brings uj) a rery small per-centage of cream that makes butter. The milk is now ready to commence the process of condensation, and is drawn ly an exhaust-pipe into a stean-boiler heated by coils of pipe which raise the temperatme to a giren degree, converting the water into vapor which fills the npper part of the boiler from which it is pumped off; and as it is discharged into the air, it gives ont a fetid odor almost equal to the swill-milk of New Tork. This pumpmog is continued until this ndor is exhausted, and until so much of the water has been separated frum the milk, that when it is once cooled again it has the appearance of thick, smootl cream. It is then packed in cans for transportation; and we see no reason why milk comld not be put up in this way upon the prairies of Hllinois as well as the pastures of Dutchess Comuty.

For many purposes the condensed milk is used in the same eondition; for icc-creams, eating upon fruit, and many cnlinary pnrposes, it is delicions.

When milk is desired in its ordinary condition, add water until the condensed milk is thorougrlly combined with it, and it is like good, rich, fresh milk, except that it has lost a little of that pirnaney which is found in some "pure milk," and which some city people scem to relish.

The advantages to the farmer of this inverition he will readily understand. A milk-condensing factory established in any neighborlood, its it may be wherever there is a pure strean of water, wonld prore as great a convenience as a grist-mill, and more adrantageous, becanse he can sell his grain in the rough state, but can not dispose of his milk unless it is converted mto 
some condensed prodnet. The advintage of sulling milk insteal of converting it into butter or checse, crery farmer cum calculate for himself, upon the basis that it will require four ruarts of milk for one ponml of checec, wr fourteen quarts tor one pound of hutter, taking the average proxluct of (cous and arerage process of manufucture. If intended for a combensing factury" in the immediate neighborhood, the farmer would be cmabled to eary the milk directly from the stable.

Another advantage would be gainel in the saving of eans, many of which sent to cities are lost in spite of all the care of the owncrs. The estallish. ment of such factories will open up new tields of imlustry in many parts of the comntry, alding wealth, comtort, and happiness to timners' fumilies. We urge them all to consiller the sulject, and compare whth other prouluets of the dary this new one of eomlensed milk.

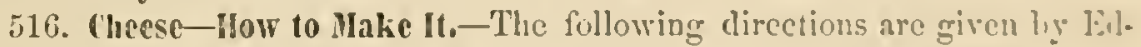
win Pitcher, of Martinsbure, N. I., a noted maker of grood cheese:

"The way to malic a mild, rich, egonl-1litrored, sound cheese is tw work the curd carefully, so as not to elatt the white whey, or, in uther woral, mork ont the cream; second, cook it well; salt even, and cunghls to malic it good flarored; press it well, and keep it cool anl try when male. I neglect in prit will spoil the whole. He set our milk et degrees, as mearly as we can, and put in rennet enongly to hring the curd in lati an hour.

"We use a cheese-cutter. Cut the eurl cilldully over ouce, and thu l, t it stand fifteen or twenty minutes, till the whey begins to rise; then worls $i=$ fine will a clsecsecntter; then jut liot water enongh muler the tin vat is ratise the heat 1090 degrees. Stir often, so as not to het it pacticlum. W" then dip oft about one third of the whey, and jucrease the hene to alunat

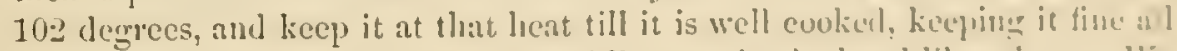
the tine. When it is done, it will fill apart in the lnanl like whents. We dip ont of the tin vat (when it is cooled down to gu degrees) into a sink, nenl when the curd is dry put in a teacupful of sale curd, combgh to make dificen

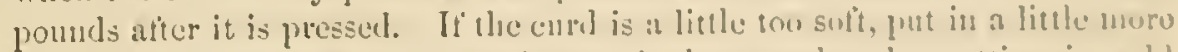
salt to haden it. We cool in the sat, in lot weatler, by lutting in eulel water under the vat, to 30 dergrees, before dipping out. I thiuk it hurts the cliecse very much to dip it out too lot.

"My" checseroom is plastered, and I led down my windows from the top ju hot weatler, and I have a ventilator in the center orerheru. The ther is matched and male tight, su as to slut wp the room in cool weneher, with seven tripledoors to let in the nir when necesenry. I think it rsecutial.

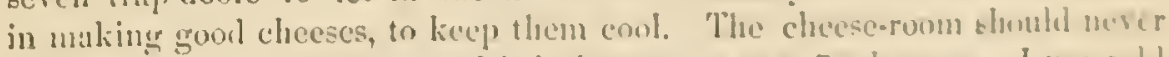

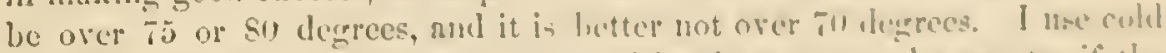
water on the floor, and a large piece of iee in a pan on the eomuter if the

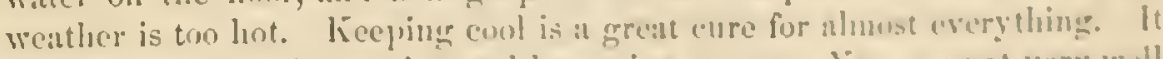
saves clecic from fermenting mul becoming strong. Jun can not very wefl

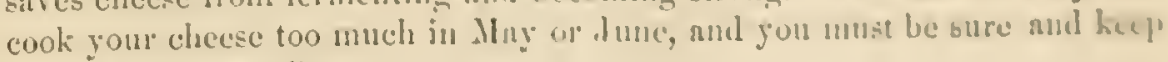
your renuct swoet." 
A first-rate checse-maker of Herkimer County, N. Y., gires the following as her practice:

"I set the milk at 90 degrees, in spring and fall, and 86 degrees in hot weather. Heat up three times-first 90 degrees, then 95 degrees, and last 100 degrres. I put about one teacupful of salt to sixteen pounds of curd, and nse much eare in breaking it up and working; cutting at first with a dariry-knife of four blades, and using the knife with one hand during the whole operation, taling particular care not to squeeze the curd in any way, but pass one hand under, and lifting gently, and letting it fall of the hand and betreen the fingers, and with the other keep the knife in motion in the curd, cutting it as fine as possible by the time it is ready for salting.

"Thought and care are essential in all the rarious operations. Intense interest and anxiety are neeessary in order to do all these things well, for they influence the textmre, flavor, and quality of the cheese.

"RExxer.- The stomach of the" ealf should be taken when empty (no curd in it)-eare taken not to get dirt on it-and, without rinsing or washing, salted inside and out with one teacupful of salt to a rennct, and placed in an earthen dish. It should lie in the salt two days, then be stretehed and dried upon a stick in the form of a hoop. When dried, take it off the stick, and place it in a tight sack for nse. Those prepared one season are not to be used till the next.

"When rennets are to be used, put three in an earthen ressel; then take tro gallons of water, put one quart of salt in it, boil and skim, and cool till mill-warm. Then pour it upon them, and in one week the liquor will be fit for nse. One teacnpful of it will enrdle the mills of two millings from fifteen cows, fit to break up in forty minutes."

An experienced cheese-maker of Warner, N. H., gives her method as follows:

"I first scald the tub, then strain the milk into it as soon as brought from milking. Next put in suficient remet, the quantity depending upon the quality to fetch the milk to a curd in from forty to sixty minutes. The curd is then dipped carefully into the baslet for draining until the next morning. The morning's milk is prepared in the same manner (after the thorough sealding of the tub). The curd, when formed, is dipped in with that of the previous erening; then left to drain, with an ocensional stirring with a knifo or slice. I prefer a knife, as it is not so likely to injure the curd. When sufficiently drained, which it will be ly nine or ten o'elock if properly attended to, I tie together the ends of the eloth, and hang in the cellar until the succeeding day, when the curl of that day is prepared in the manuer of the previons day's curel. It is now realy for sealding. I' pour boiling lot water, at the rate of one gallon for ten ponnds of eurd, into the tub; next slice in the curd from the basket, handling it carefully, so as not to disturb the white whey. The curd is next brought from the cellar and sliced in the same manner. It is put in lastly, for being older it does not require as much scalding as the newer curd. I now let it stand from five to ten minutes, 
from the tine the last sliee is lropped in, then dip hack into the lasket, curel and water together, to dran. I check and stir it up with the knitic four w fiye times, when it is ready for grimling. 'The mill is placerl npun tlic cheese tongs over the tub; the enrel is then slicel into the mill and armuml. when it is rearly for the sensoning, which consists of a commun-sized [encur ful of rock-salt aud one teaspoontin of saltpeter for erery twenty poumels of curd. It is thoroughly nixel-not squeczed-with the lumes. It is lown realy for pressing, whels is done gently until night, when the cheen is turuci, cloth changed, and put back to juessing witl suficicnt wciuht, where it remains until the next elieese is realy for the press."

We find in the best large cheese-dairies of this country, that where the curd is sealded by steam, that the riglit temperntmo varies among ditlierent cheese manufieturers; thus Mr. O. S. Cumiugrs, of Trenton lialls, I. I.. scaldls to $10 t$ degrees; Mr. L. Coan, of Russin, from 105 to 110 derrees: Mr W. Buck, 102 to 104 degrees; and Mr. S. N. Andrews, 100 to 1112 dengreés.

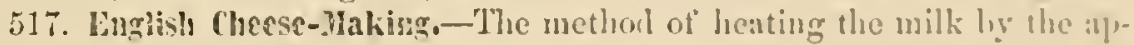
plication of stean to the cheese-rat, is a great inprovement orer the lingli-h method. So is the method of separating the curd fon the whey loy a ratining it through a cloth much more expeditions. In Cheshire the whey is removed by pressing lown a flat-bottoned pran gently on tho curl in the checsetub and allowing it to fill. When the curl is thas fratially frend

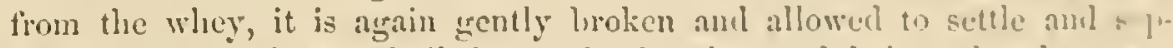
arate and the whey is boiled ont slowly, the curel being plated on one side of the tub, which is slightly rased, and a bomel is placell on the curd with heary weights on top to pless ont the whey.

The curd is then ent into pieces six or eight inches stuare, aml aptin pressed with hearier weights. When as much whey ats pu-sihle is remment

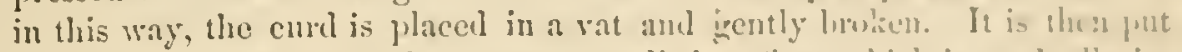
muder the press and a slight pressure applieul at tirst, which is enplublly in-

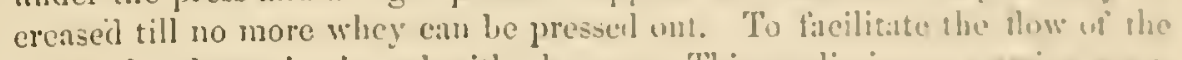
whey, the clieese is pierced with stewers. This prelininary jresing we onpies four or five hours. The cheese is then taken out ot the pre..., hruben

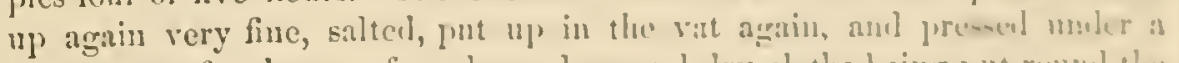

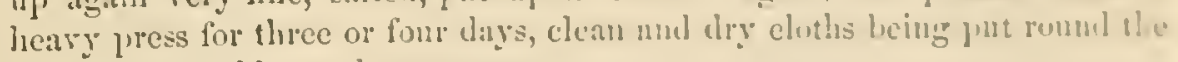
cliecse as the old ones become wet.

This is a tedious process, smd we think some of the operations ut the

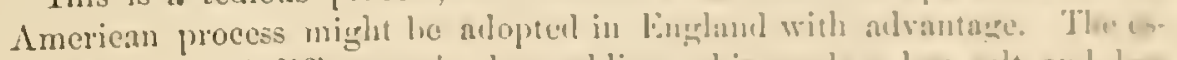

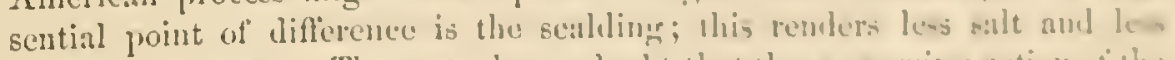
pressing necessary. There ean be no donht that alu prenerving action wh the

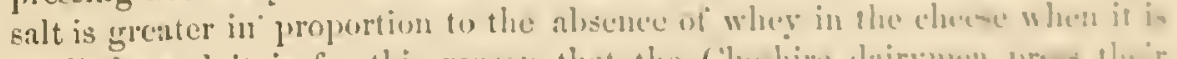

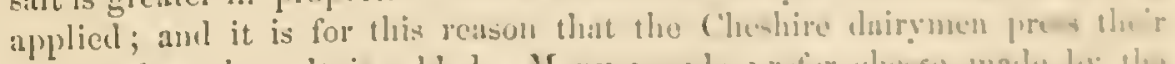

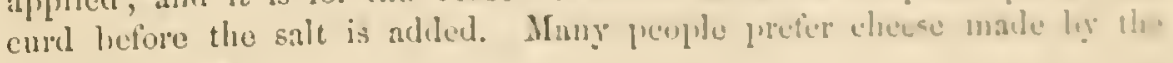
linglish process.

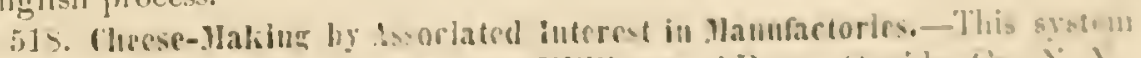

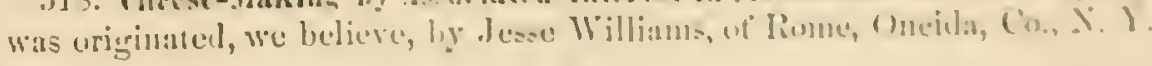


somewhere about the year 1850 . Since that time it has been greatly extended in Central and Northern New Iork, and consiclerably in Northern Ohio. It is like the mannfacturing of any other farm produce, exeept that this is usually carried on upon joint account of the producers of the raw material. The success of this mode of cheese-making has now become fully established. It not only lessens the expense of manufacture, but improves the quality of the cheese. The establishments vary greatly in size, using the milk of from one lumudred to fourteen lundred cows. The business has beeome so important that regular organizations have been effected, both in New York and Olio. To enable our readers to eonsult with those already engaged in the business we give the following list, naming the owner or superintendent and location of a number of establishments represented in a convention lield at Tome in Janmary, 1S64. This list, though representing only a portion of the dairy interest, shows how the subject lias affected the minds of farmers in the central part of New Tork.

\begin{tabular}{|c|c|}
\hline Factories located. Cows. & Factories located. \\
\hline . Oneida Co..... 527 & ..Lewis Co....... 800 \\
\hline Villiams, Adams \& Dewey. Onej la Co...... 350 & Asel Burnham, Jr... \\
\hline 7. WV. Davis........... Oneida Co.. & Hanck, Wilcox \& Co... \\
\hline Oneida Co.... 350 & Clear Spring Factory...... Chautauque Co. \\
\hline Chenango Co... 500 & A. L. Fish. . . . . . . . . . . Ilerkimer Co.... \\
\hline Oneida Co.....707 & .....Fulton Co...... \\
\hline liarles Iiathburn.... & aydatta Cheese Factory. . MIo \\
\hline J. IV. Brooks & West Eatou Factory........ Iad \\
\hline (F. E. Morse........... Mladison Co. . . 650 & Hiller, Fowler \& Co...... Oneida Co..... 800 \\
\hline. Oneida Co..... 300 & I. U. Sherman ....... \\
\hline n, MIass. . . 500 & Jerome Bush .... \\
\hline er Co... . 600 & 200 \\
\hline & 500 \\
\hline G. Coa & Buck. \\
\hline lenry llill.. & n \& Co. \\
\hline W. WVI & Norton. \\
\hline $\mathrm{rCo} \ldots \mathrm{600}$ & .. 600 \\
\hline$\ldots \ldots \ldots \mathrm{E}$ & .. 600 \\
\hline Factory... & $\therefore 800$ \\
\hline & . 300 \\
\hline igton.. & Factory. \\
\hline i. B. I & Jarvey Far \\
\hline $.1,000$ & J. H. IJubbard..... \\
\hline ......Le & Oneida Co.. \\
\hline & .. 220 \\
\hline$\ldots 1,4$ & . 270 \\
\hline If. Ass.. C & 897 \\
\hline right \& Williams........ On & David W. Wilcox.... \\
\hline Whittaker \& Curry...... On & Levi Tanner........ \\
\hline D. Thomas ............. Oncida Co. . & . Oswego Co ... \\
\hline
\end{tabular}





\section{PLATE XIV.}

(Page 461.)

Turs picture illustrates the subject upon which the chapter treats, where it is placed as a sign is sometimes shown, to indicate the things within. It is the sign of the garden. In it were grown the cabbage, com, cucumbers, turnips, tomatoes, pumpkins, potatocs, beets, carrots, parsneps, egg-plants, ornamental gourds, onions, and so on of all the rest. It indicates some of the subjects of this chapter, but not all. It would require a large picture to do that. So, after taking a glance at this, look well at every one of the nest hundred pages. Every paragraph about "The Garden and its Fruits" has a deep interest to erery reader. The picture is only a sort of wayside resting-place for the weary reader's eye. It is to amuse and lead the traveler on to more substantial fare. 

VII

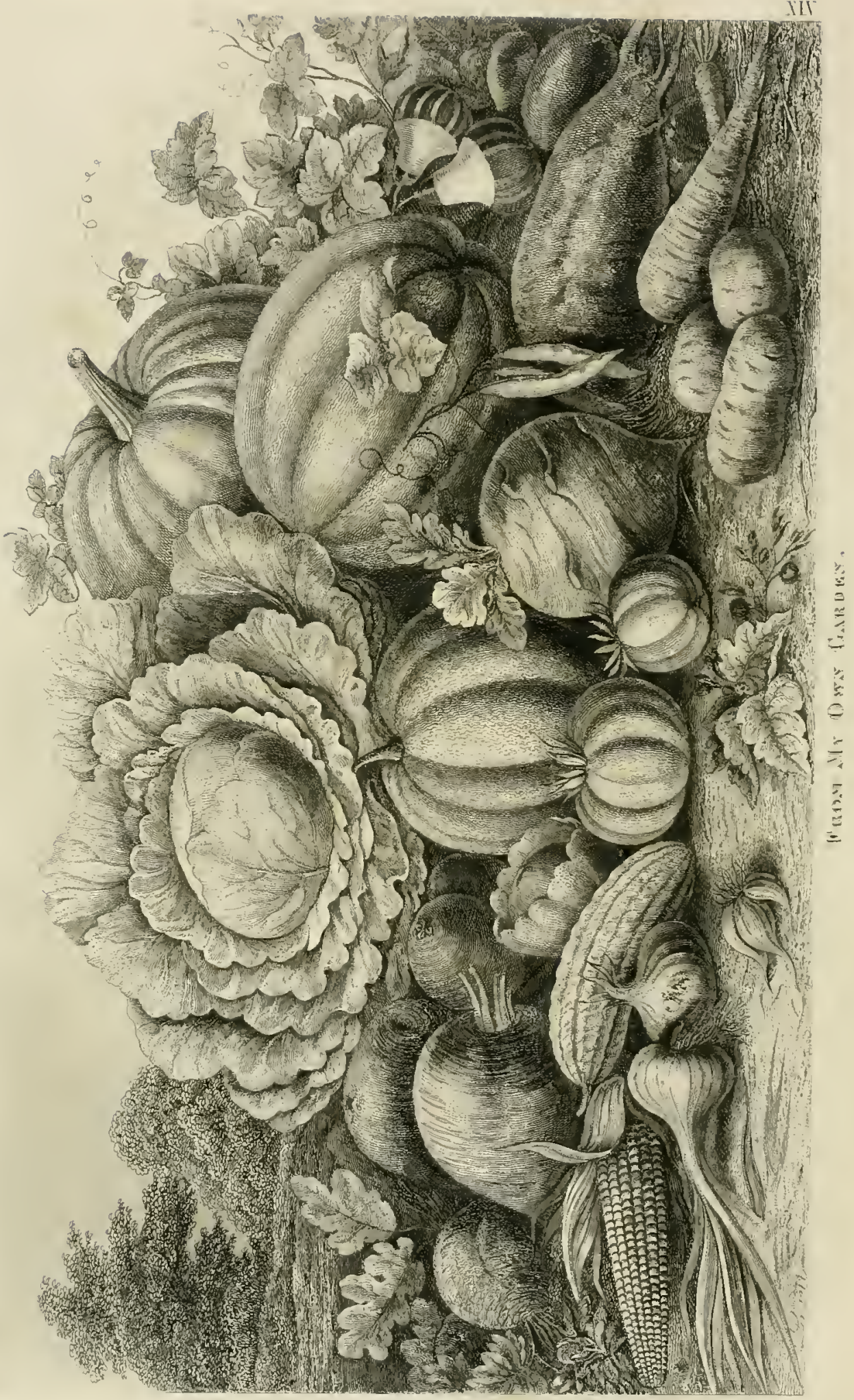




\section{CHAP'TER V.}

\section{THE GARDEN AND ITS FRUITS.}

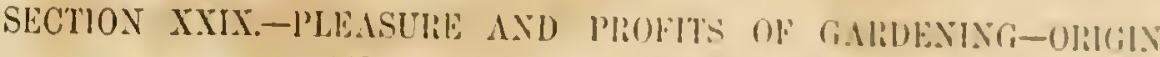 AND HISTOLY of VBGLTHAL:}

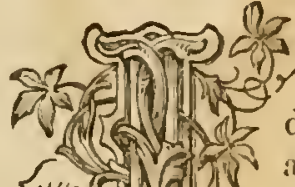

$\mathrm{T}$ is an error, and one that prevails to a consillerablo extent, to suppose that all lablue bertowed upun a garden is so much "labor lust." Many firmers pinss throbegh a long lite without crer having anything worthy of the name of garclen-a nane which sirnities: "1. A pifece of ground appropriated to the cultivation of horls or flants. fruits and flowers. 2. A rich, well-cultivated sput or tracet of country; is delightful spot."

And colloguially, in the Northeastern States, in crarden is a spot not always delightinl-where all the potatous, levets,

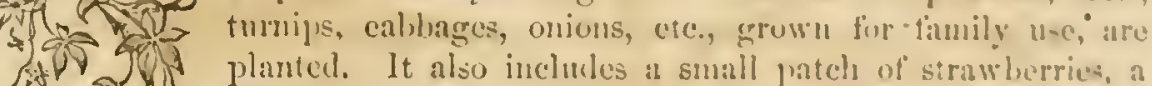
at 50 planted. It also inclules at small patch of strawberries, a

Often, however, it is as deatitute of the latter as it in wit all

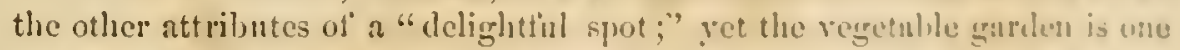

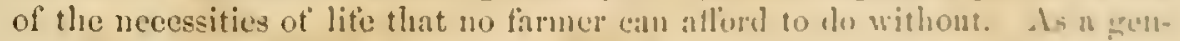
eral rule, the garden of a farm should be in the form of " pantlelurram, rumning north and sonth, with orchard trees and shrulwery at the nurth end and a grass-plat at the south cul, and ererything should ine planted in tong rows. This admits of plowing the gromul, with at flace to turn at enche emt. both in breaking up the soil early in the spring and in after enltivation. It is just as well to have a row of hects twenty rods long as lo hatre twenty rows of one rad-inded, much hetter, hacanse gon can de more in one hur in deepening the soil suthiciently for hects with a stome hose than at wan can

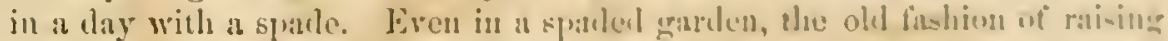

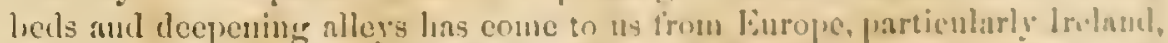

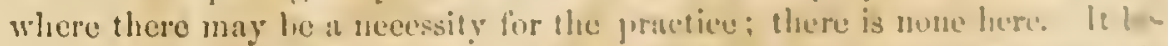
longs to the sane fimily of antigunted notions as hilling "up Imlian curn. It is a foolish notion.

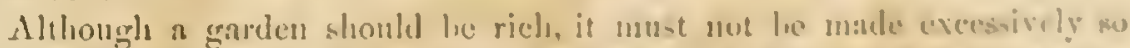
with stable manure. We beliere at continmane of any one hint of mbure

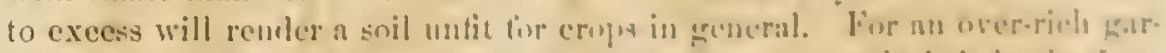
den soil the lrest remely is limu, and the best way to sply it is in the form of "lime and Ealt mixture," which is mald ly dissolving nalt in water moril 
[Crar. V.

it will dissolve no more, and then using that brine to slake lime. $A$ bushel of salt may thus be mixed with three bushels of unslaked lime and the mirture applied at the rate of 30 to 100 bushels of the slaked lime per ace. If the lime atter slaking is liept in a pile under a sher, the outward portion efloresecs, and it may be raked ofl and put away in barrels as it accunnlates. The lime is then in the best possible condition for' nse.

Of the profits of gardens there can be no doubt. Any one who is familiar with the operations of the market gardeners near large cities, knows that the business is more profitable than ordinary farming. There is no reason why many other persons shonld not enjoy similar profits.

There is not one village in ten in all the Eastern States that is rarge enongh to support a locomotive butcher that would not support a goor market garden from the first year of its establishment, the produce leing sent around to the lionses in the same way that the butcher sends his meat. Of course, all the waste or refuse of the garden must be fed to the cow, pig, and poultry, and of eourse the owner wonld grow wealthy faster than the owner of a large farm eultirated in the ordinary way.

The great secret of suecess in market gardening lies in the succession of crops. Heavy manming, thorongh cnltivation, and a good market are of conrse important adjuncts, but all of these will not gire maximum results without the gardener's skill in keeping the ground fully ocenpied; and in that, more than in all other things, is where not only gardeners, but farmers, fail. They keep too much unoceupied land, allowing a grain crop, onts, for instance, to be followed by a erop of miscrable weeds more worthless than it is easy to imagine, for they are more exlanusting than the grain, and of no use to man, animal, or soil. Land shonld nerer be left idle. In a nell-arranged market garden one thing sneceeds another so rapidly that one row of the first crop is off to day and its sncessor growing in its place to-morrow. The owner can not afford to wait till all is off, because by planting one after the other, he has the ripening crop for sale in the same order, and thus secures the whole valne of the manure.

The work in a market garden properly begins in autmmn. There are several regetables that mnst be started at this season, and all the ground should be manured either then or during the winter. Mnch of the snecess of the garden peemniarily depends upon laving its products a little anticipate the nsual season. Potatoes early in the season are worth two dollars a bushel. Three wetks later they are down to a dollar or less. There is a like falling off from most other articles, though hardly anything fails to return a paying price.

Spinach is sown in September and October to furnish cuttings in April and Nay. Cabbage is sown abont the same time to furnish plants for the cold frame; which are kept throngh the winter, transplanted in April, and furnish heads in Jnne. They are put into the frame in rows rery near together in November, and when the winter sets in, are covered with boards, removing only in mild weather and increasing light and heat as spring ad- 
vances, muil the open ground is in condition (1) receive then. These are called cold-fiame plants, and furnislı lieads about two weelis carlicr thun the lot-bed plants started in March. 'The lest variceics for this rarly (ero]) aru the Jarly lork and the Winnigstadt, which makes a very eulid lical ot ex. celleut quality.

Iettuce is also sown in the fall, and with a little protcetion kereps well through the winter. About the first of Mareh operations commence wirle the lut-beds. These are preparenl with rarious quantities of mamure, uce cording to the lieat required. The heds are grencmlly from four to six fect wide, for convenience in attending to the plints. They are coverexl with a sash alyout three feet wide, the gliss being not more than ecen hy ninc. In these beds a great variety of plants are furwarded-cabbage, tuinutues, peppers, ergroplants, and other carly plants.

The whole ground is covered as eon as it is suficiently warm, and arranged so ss to allow a succession erop. In the first course come dalisher, spinach, lettnec, cabbane, potatnes, peas, turnips, corn, kolıl-rabi.

Eurly potatoes are ofl" in time for late eabbage; carly radishes in timo fur elery, swect corn, or cabbage. Early jeas are always folluwed hy a crop of something that will ripen before frost. Early com nny be fullowed lye menips, of by spinach for spring, which will be ofi in time for tomanes. Jiecis are fullowed by celery, and peppers are transplanted anong the lieats ot heptwee a weck or two hefore they go tu marlet; or squashes or cueumbers are planted. Quassia chips, stecped in loot water, and that fprinkled upun the vince, are found to be efticient protection agaiust bugs. Carrots form a guen] snecession (rop to the onions. They are sowed between the ruws nhent the midlle of June. Two crops, and cometimes three, are always frombu from the same plot of ground in a senson. Nothing but ignoranco of these taces jrerents a great many small owners of land in the viejnity of suall fuwns from establishing market gardens fur the supply of thoec who can not, or at least do not, grow a supply for themselves of the most commun forts of erarden regetalsles. It is a firct but little appreciatch, that a very large purtinen of those who lave lived all their lives upon a farm, amel male its enltis.1. tion their only busines, are ntterly incompetent to mamere a garelen-ihat is, a frarden intended for supplying ang market with yeuctables.

Illustrative of the pleasures and profits of fardening, we innert a me pert of a visit of the anthor to the gurelen of an artist, to fhow what an 111 .

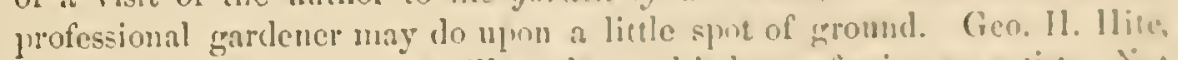
of Morrisania, lives upon a villagro lut, nut is ly professinn an artioi. Xut an artist in grardening-not one who protesses or pretend a to practice horticulture upon a scientific or artistic plan. Nor do I nemtion lis parile $n$ on 2 molel of taste and ekill which may be imitated ly the wealihy at freat a. jeuse. I mention it ratler ats the givrlen of a mechanic, nud just fuch a was. as a great mavy mechnues or professional men minglit have if they wouldif they only knew how. I mention it full of hope then is mag he the moving canse towarl inducing otlier men who have daily euplugnent. as this on. 
has, at some trade or profession, to derote a little time, some moner, and a great deal of sound common sense in the enltivation of the little lialf-acre plats that we often see surounding village resilences, which re mere examples of the utter uselessuess of land except to cnable the owner to show how barren and worthless he can make it. There is no need of this idle use of land. There is no reason why every owner of a village lot shonld not revel in all the lnseions frnits of the senson, and treat himself and his friends to an occasional bottle of wine, equal to any that he could purcliase for a couple of dollars, just as Geo. II. Itite is now able to do, free of expense; for his garden pays its own way, and a little more, of all cost of cultivation, learing him in the enjoyment of its delicious fruits, fresh from the earth, or their products preserved to continue almost as fresh throughont the winter. And he is not by profession nor early edncation a gardener, being a mative of a State less noted for its horticnltural skill and fruits than for its productions of great corn crops, great bulloeks, great men-physically and intellectually. Mr. Ilite is a Kentuckian, and some of his early years were spent in painting portraits in Lonisiana. Then he came to New York, and during other years aequired fame as an artist upon irors. Then, some years ago, like a sensible man, he began to create a home for his old age, when it comes; it is only in the blossom now; and that lome I have visited, and I wish I could take every one who hears or leads of it with me to learn what an artist has done, and what a mechanic, a lawyer, a doetor, or any body else might do in a garden upon a village lot. Will the sluggards who sigh after an abmdance of frnit, and enry those who hare, yet take no steps to have it themselves, believe me rhen I tell them that in this garden there are graperines of such extent, lusuriance, and finitfulness, that sereral baurels are required to hold the juice of the surplus of the crop? The fruitful arbor that extends some fifty feet from the rear of the louse, affords a delightful shady spot, which, independent of the frnit, is well worth its cost. Isabella grape wine, five years old, with no addition whatever to the juice of the grape, is excellent. Strawberries grow to perfection in this garlen; and as a cultirator of currants, Mr. Hite excels. Not merely a few basket. tuls for family use, but bushel after bushel, red, white, and black. The berries of the true red Duteh variety are upou the average as large as the cherry curants under ordinary cultivation; and as for productiveness, no statement can conrey an idea. To believe, yon must see. And this is the result of pruniug. True, Mr. Hite follows the Scriptural injunction about a barren tree, to "dig about and dung it," with all of his trees, and rines, and shrubs, and flowers, and table vegetables; but with the currant the secret of success is pruning. "Keep no old wood," is his injunction. Erery branch that has borne three crops must be ent array at the ground, having been twice shortened in, by which the short fruit-spurs on the new wood are always loaded, and the bunches growing close to the canes, so that they look like ropes of red berries. To commence witl a single plant, cut it away close to the ground, to induce several vigorous shoots, instead of one, 
mowing trec-shaped. Next sjring slurien all thue canes. and let thu frnit

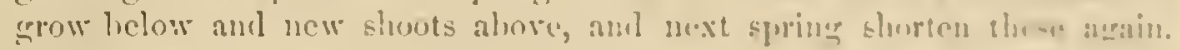

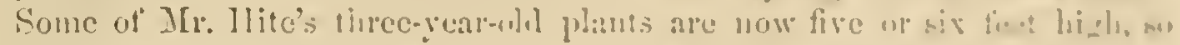

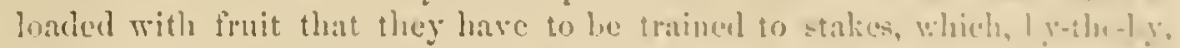

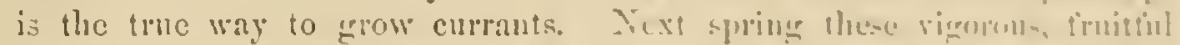
branclics, all that are thre years old, will be wusparingly cut awny. It is

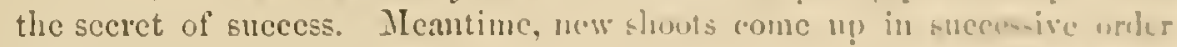
in take their place. I hase $n 0$ loulit sif the fact that currant hushes thus

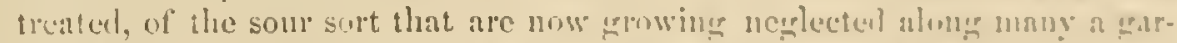

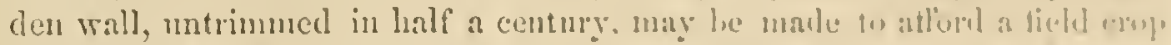

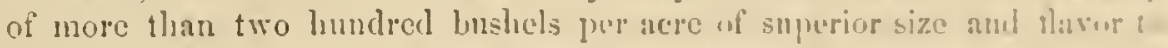
these grown in the ordiuary way, and that the cost ot production will he tur

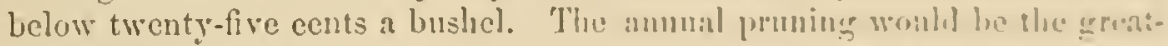
est part of the labor, and, in the vicinity us this city, the woml cut awa! would he wortl nearly the cost of colthing; and in the cunntry, where ranc

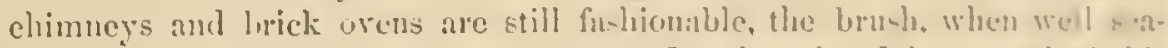
soned, would make superior oren woml. liesiles what I lave sa il it this garden, there is much more to be learmel from it, ant that whern is lifos.

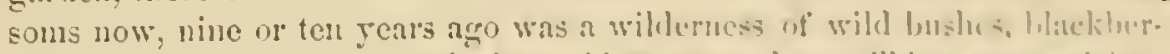

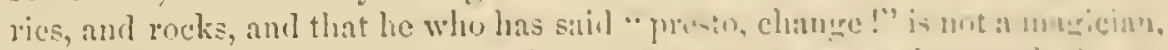

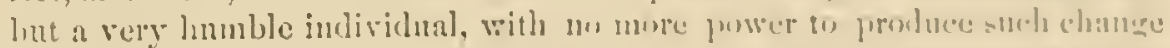
than the most lumble one of the migh?y mulimde who hase an i.lou atmo the gutter, with a will to work that idea ont in the rich prostuctions wi na ture improval.

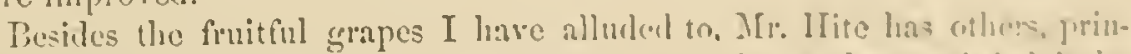
cipally of the Delawares, now growing leantitully a and so sati-tind in loo

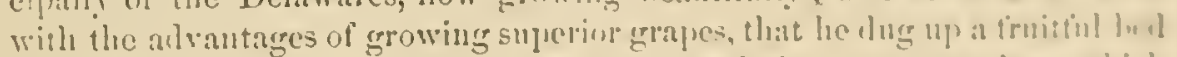

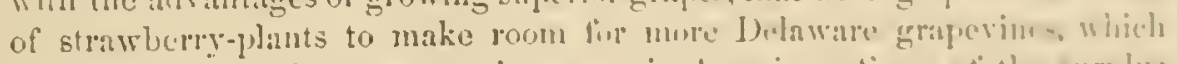

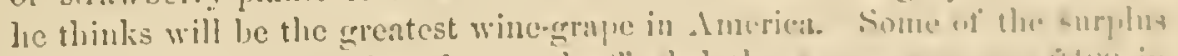
products of his little plot of gromed afliopled the owner one years:

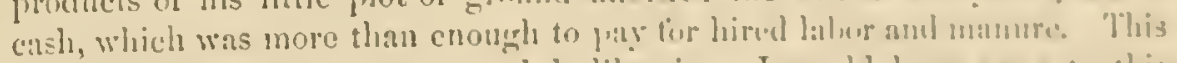

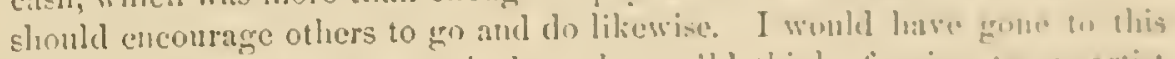
man for my miniature portrat, but whe wonld think of guing on an orri-b

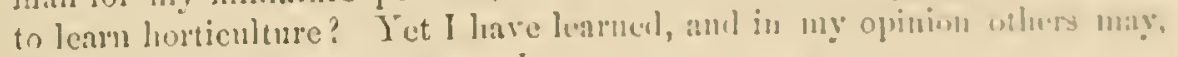
from very mexpected soureces. Lect us $11 \%$.

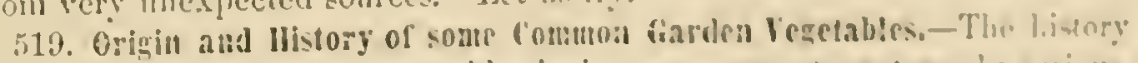

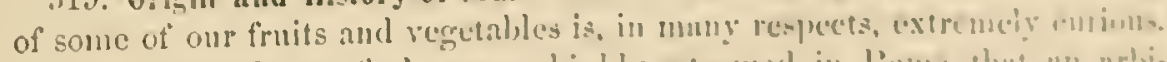

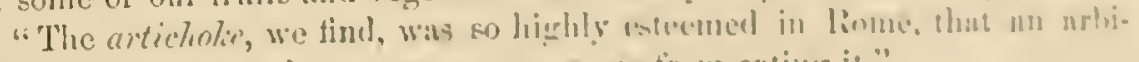

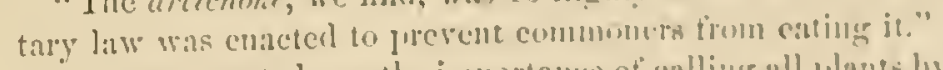

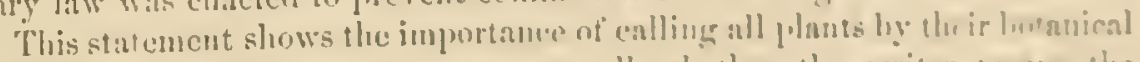
or scientific nanc, since we can but tell whether the writer masum tho

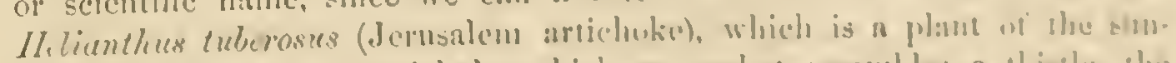
thower species, or the artichoke which smowhat resembles a thi-ile, the

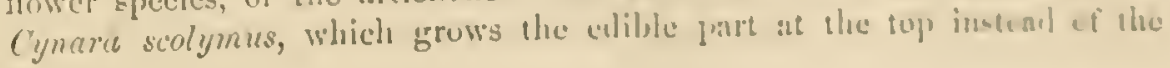
botton. 
[Cirs]. T.

The plant used for flavoring, called basil, which now stands so higli that a Ionklon alcleruan wonld spurn a basin of mrtle made withont it, was, 200 years hefore Christ, condement ly Chrysippus as an enemy to the sight and a robber of the wits. Pliny says they sowed the seels with maledictions and ill words, believing that the more it was eursed the better it rould prosper.

Letfuce appears, fiom an aneedote related by IIerodotus, to liare been scrved at the royal tables of the Persian lings, five or six litundred years before the Christian era, but they ouly knew one sort, which was a black variety. This esculent lias been greatly improved by eultivation as well as cabbage. The ean remember when a head of lettnce rould have been a great curiosity, and the louds of "eabbage fifty jears agro were rery unlike merchantable cabbage-lieads of the present day.

Mint appears to liave been used formerly for other purposes besides making mint-juleps, which produce a disease which, in ancient times, mint was used to cure; fol Pliny says, at a consultation of plyysicians in lis chamber, it was decided that a chaplet of pennyroyal was better for giddiness and swimming in the head than one of roses.

According to Ovid, mint was used by the ancients to perfume their tables, by rulbing the leaves upon them before serving the supper; and mushrooms, loth edible and poisonous, were known to the ancients. They were cousilered, when good, a great dainty with the roluptuous Romans; and one of the poisonous sorts was used by Agrippina to destroy her husband Tiberius Claudius.

Mustard, it will be recollected by Bible-readers, was cultirated in Syria at the time of our Saviour, as it is mentioned in one of his beantiful parables as being the least seed that was sown in the field.

Garlic and onions must have been in high faror as food.at a rery carly day, since it appears that the Egyptians worshiped garlic, and were said to wish that they might enjoy it in Paradise; though the Grecks held it in such ablorrence, that they regarded those who ate it as profane. The Romans gare it to their laborer's and soldier's to strengthen them, and to their game-cocks previously to fighting them; and the Israelites, wlile in the wilderness, lamented the depriration of these stimulating roots, to which they had become so necustomed in Egypt. In this country, onions are eaten by all classes, and in New York city, we have noticed, are greatly esteemed in winter by the rery poorest classes, particularly the dissipated. They are not generally considered unhealthy, thongh no dyspeptic should erer touch garlic or onions in any shape, particularly raw.

Parsneps were held in high esteem by the Emperor Tiberius, who imported them annually into Rome from Germany, probably beeause they grew much better in that colder climate, as they are greatly improved here by remaining in the ground to freeze during winter.

Parsneps contain a large proportion of sugar; beer is made from them in the north of Ireland, and wine, closely approaching the malmsey of Dadeira, 
is inade from the roots. Marmalade, male witl parsmeps mol a small quantity of sugar, is said to excite appetion, and to lie a very goml forml firl convalescents.

l'arsley was cultivated, as it is now in gardens, in the time of ]'fins. an! appears to have becu highly estecuned ans a scasuning of foul.

Ráulishes were so highly esteenued by the Greeks, that they matu: Ihent of gold to offer at the slurine of Apolh. It these were male wi the riec that ladishes are uepreecnted as growing in those tays, we certainly should protir the counterfeits to the real; for it is stated that they grew to the meight of forty or fifty pounds. P'robably they were an entircly diflerent nuticle frum our leadishes, and perlaps were a culinary venctable.

Beets were made for the sane purposc of silver, which shows the enme parative estination in which they wese hele. With us is is plufe the reverse.

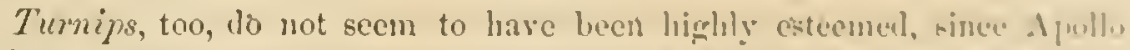

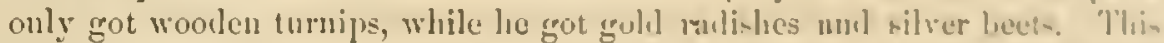
was somewhat owing to climate, umlonhtelly, for wo linvo ohiervel that

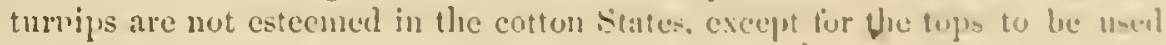
as grecus.

Thyme was planted in Grecer, and thenece imported into the liomsun Stater on aceount of its value as pasture for the lomese-ueres.

Theter-cress was esteemed as a stimulating article of uliet, as well in olden time as at present, and was often eaten with salat to counteract if etliect. which were thought to be clilly. An chll wrifer says:

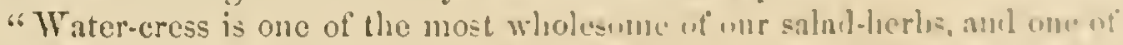

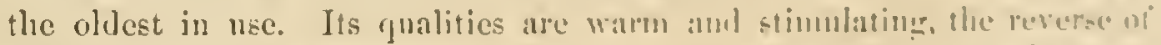

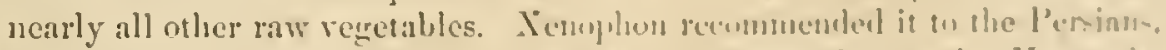

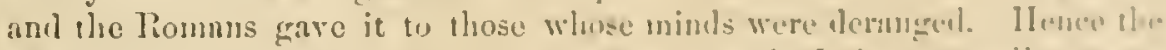

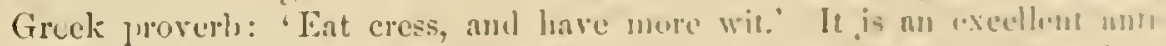

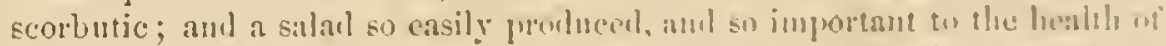

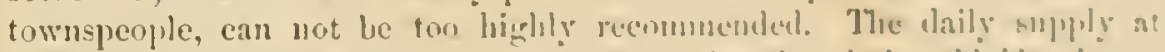

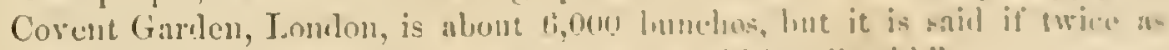
many nore bunclies were brought in they would he all wold."

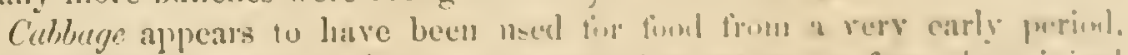

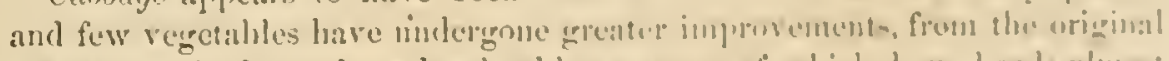

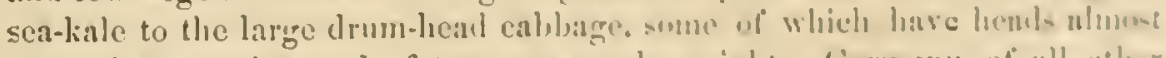

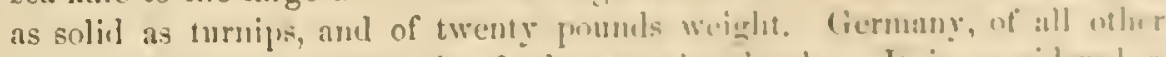

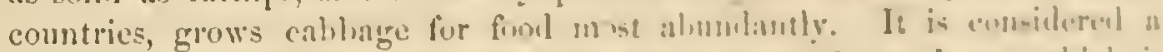

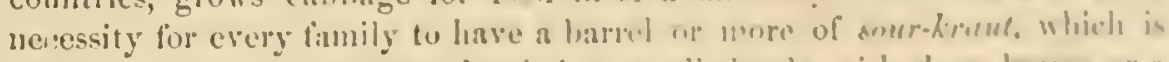

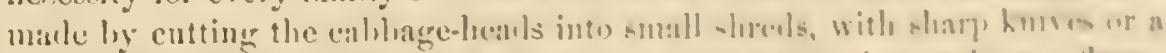

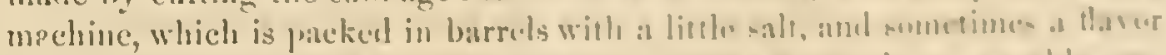

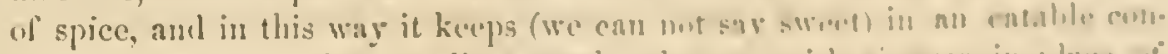
dition ull winter, and is usually stewed aml esten wish vimegr, in fluon of uther vergetables, with inent.

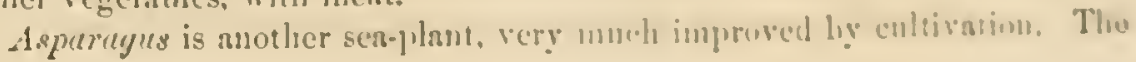


first time we lear of this regetable is in the time of Cato the Elder, two hundred years.before Christ. The Emperol Augustus was very partial to it; and at Rarenna it grew to such a size that three heads weighed a pound. Mrr. Griyson, of Mortlake, near London, lias produced one luundred heads that weighed forty-two pounds, perhins the largest ever known in Great Britain; and hundreds of acres around the metropolis are deroted to its eultivation. The small heads are sometimes ent into pieces and boiled, as a substitute for green peas. Medicinally, it is considered diuretic, and is said to promote the appetite. It is considered antiscorbutic, and rery good in dropsical cases, but is aroided by those having the gout. The most extraordinary virtue is that ascribed to it by Antoine Mizold, who says: "If the loot is put npon a tooth that aches violently, it eauses it to come ont without pain." Our modern dentists will, we are sure, thank us for this infornation, if it is true.

Asparagus and cabbage are both benefited by the use of salt for manure. For asparagus, there is no danger of using too much salt. It may be used in a clude state, or dissolvel, or in compost.

Carots, we are told, originated, or at least, were first enltirated for food, in Holland. They are not only mutritions, but the peetie aeid which they eontain luas the effect to grelatinize oflier food, hence they are used in soups, making them rieher. There is no root grown by farmers of quite as much value tor stock as carrots. They are very nutritious food for our tables, simply boiled, and only require a little practice to be much liked. The white carrot is sometimes boiled, and mashed, and used in bread. The foliage of carrots is truly beatiful, and we read that, in the time of Queen Elizabeth, it was common for ladies to use the fresh, green leares as ornanuents of their liead-dresses.

Potatoes liave a history so wrapped in obseurity, that no one can tell for a certainty where they originated. Their adoption, as a general artiele of food, dates back only to a comparatively reeent period; that is, sinee the settlement of America, yet they are now considered an indispensable article upon almost all the tables of rich and poor in all countries where the potato flourishes, as it does in the northern United States and England and Ireland.

The potato-plant (Solanum tuberosum) is said to belong to a family of poisonous plants, and an extract, powerfully narcotic, may be made from the leares and stalks, and a weak spirit is often distilled from the loots; and a pretty good stareh is made, both in a domestic way and in large manufietories, from potatoes, with which sago is often adulterated.

Potatocs make good yeast, and they are often used for making sizing; and the water in which potatoes are boiled is good to wash any fabrics in that are liable to fade.

Excellent as potatoes are for food, sad experience has proved that it will not do for any nation to rely upon them. This reliance brought famine, 


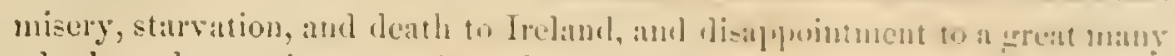
who have lost entire crops from the putatu-dlisca-ce

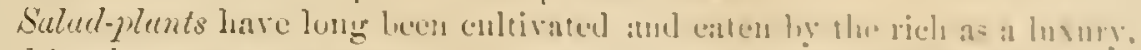

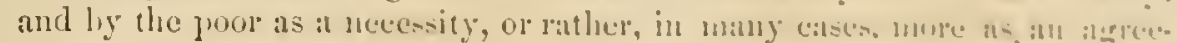

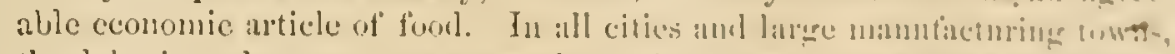

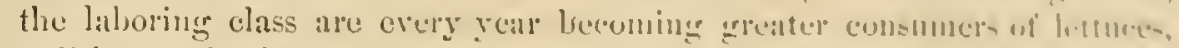

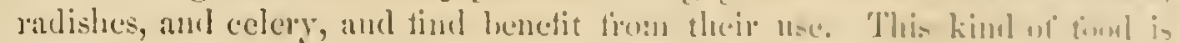

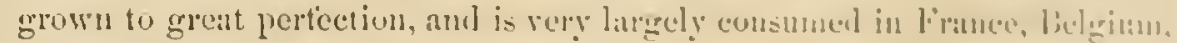
and Inolland-more so than in this comntry.

Salsify is a plant that should he lonown more extensirely than it i-, lu=

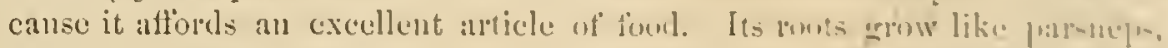
and the cultiration is similar, hut they lase quite a thitlerent flatror, and a

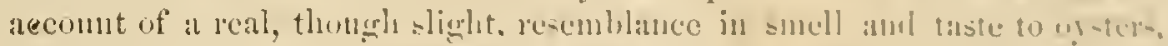
it is often called vergetable cyseter plant.

The greatest resemblance to opsters is, when the roots, which linve - - woul all winter in the gromed, are dne in the cally spring. loiled and mathed ambl

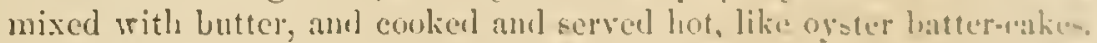

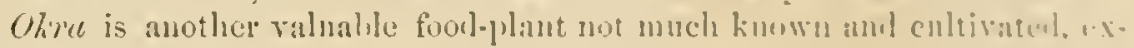

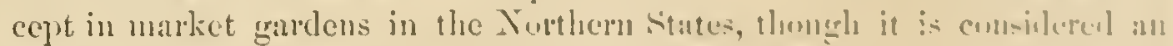

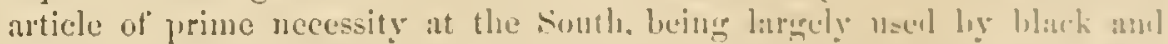
white. The negroes make a rery titwrite dish, with ckia and liacost, adlod

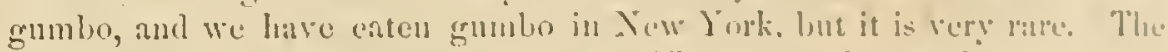

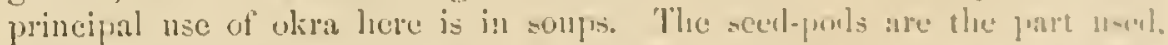

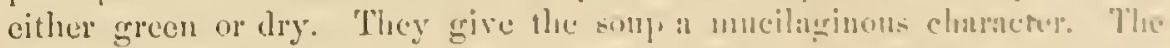

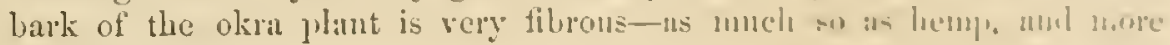
toligli.

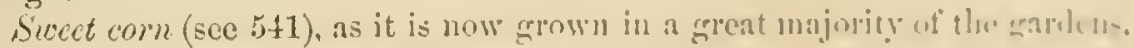

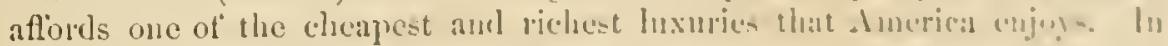

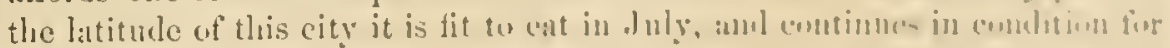

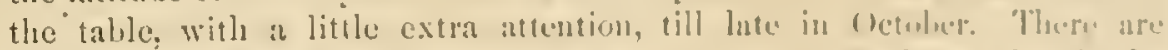

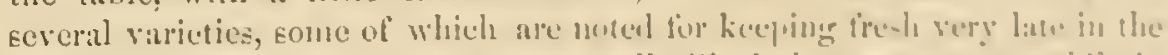
season. 'Ihere is mo dish more muiversally liked that swere corn while in

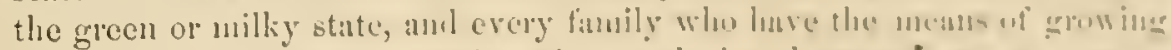

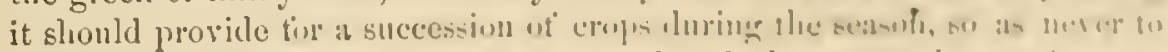

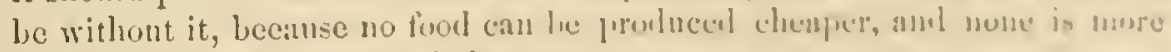
nutritious, jalatable, and whulcsimuc.

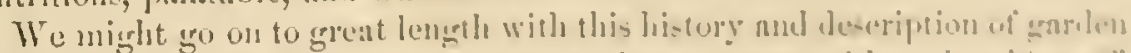

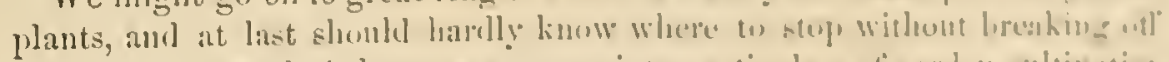
abruptly; go we do it here, to gro more inte particulurs of garden cultivition of proper vegretables, yla!sts, fruits, und fluwers. 


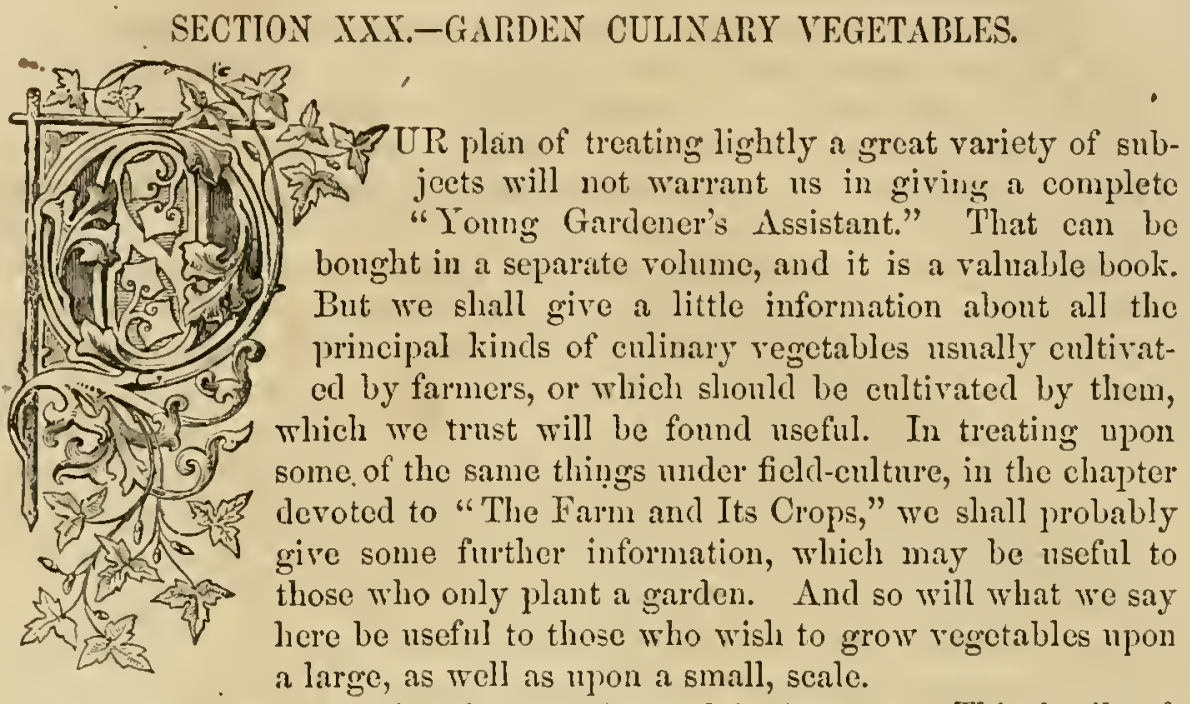

520. The Brassica Family-Propagating and Saving Seed.-This family of plants, which includes all that are near enough related to the calsbage to lybridize with it, is the most universally cultivated of any rariety of enlinary vegetables. In planting out cablage, cauliflower, broccoli, turnips for seed, great care should be taken to set each lind by itself, at considerable distances apart, to prevent hybridization, and no seedsman mnst keep hees, for they are the greatest hybridizers in nature, carrying the pollen from one blosson to another, and mixing the two together indiseriminately. All the different rarieties of calbage, such as Flat Dutch, Savoy, Drumhead, mix rery readily and spoil each rariety, or else by one chance in a score of millions, prodnce a new variety which may be worth cultivation. $\Lambda$ s a general rule, however, all farmers who raise their own seed should try to lieep the rarieties separatc. This may loe done in most eases by setting ont the seed-stalks in different fields. It is not necessary to confine them to the gaiden. Where there is any great inconvenience about kecping the sorts apart, you had better plant only one sort for seed, and buy seed for all other sorts you may wish to cultivate. Do not try to grow your own secel, if it will cost jou twice as much as it would to buy a small paper of a professional seedsman. The principal advantage in growing your own seed is to sclect carefully the very best and throw away all others, and unless yon tho that, you had better not grow any. To grow good cabbage and tmmip seed, select the very best roots to plant, and then select the best seed branches.

A correspondent wants to know if turnip seed, harrestea from roots that were left ont orer winter, will produce good turnips if sown for a 
crop. "My neighluore," says the writer, "tell me it will not produce tur. nips, but cliarlock."

We lo not beliere that it will clange in a sinele season, lunt we les furm

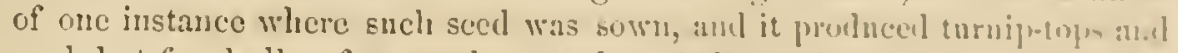
seed, but few bulbs of any value; and we helicre that if the feeel of the-1e

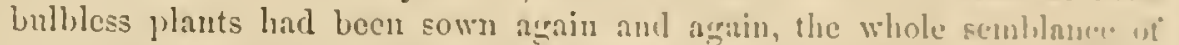
tumips except the tops would have becn lost. An this being thu finct. wing may we not belicve that the reverse will be the case, where the most perfect bulbs are selected for propagation?

521. Cultiration and Value of the Turnip cro\%, - The value of the ra:? baga turnip for stock-focling (sce $S S(0)$ secms to he almost univer-ally (un. ceded, while the common flat tumip appears to lic under a clond of jiriju. dice in this country. We liare, howerer, stmug fitith, from jersonal evpu-

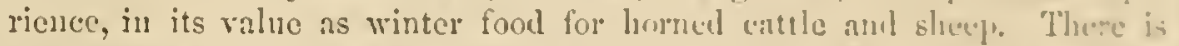
great difference in the ralue of the sereral rarietice. (Ine of the lese is ino Red Strap, which erows well up ont of the enouml, and all the upuer pro of the bulb is of a rich plum red. 'This sort, it sown mpon gooul lame, groms rapidly and solid, and sncle turnips always licelp the liest amd ationd the most mutriment when fed to stock, and erery vacant sput in tho garalen may thus be profitalily occupicu.

For garelen culture, turnips should be sown at three periouls: firet. .

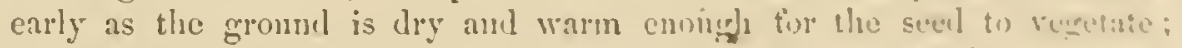
second, abont the first of Juno; and the thirel, after the jeas liave riper 1. and in all other vacant spots from which a fir-t erop lias hecen remored. Ii

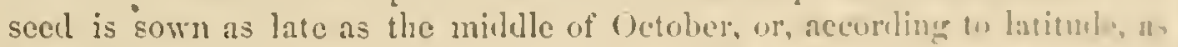
late as it will grow bulbs the size of pigeons eyses, and thene are combrel orel with a mulch of coarse manure, strat, or leares, amb the muleh raticl

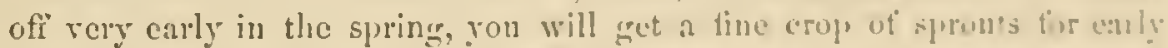
grecns, and Eometimes the bulls will grow again to as (1) he groul ealing. Tiemember, nerer sare sech from such ronts.

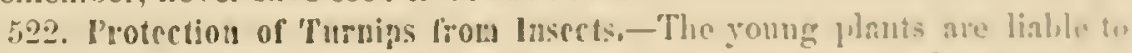
suffer from the attack of certain insects, (spectally the turuip drat, or lue the

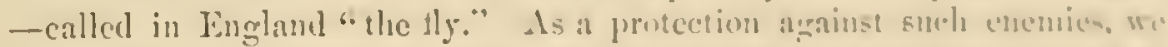

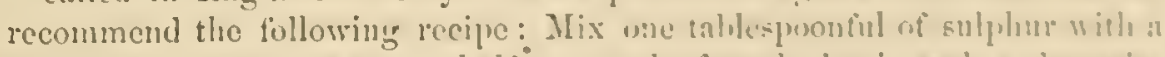

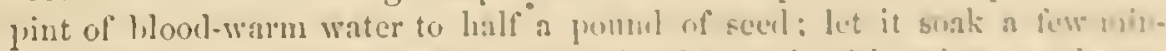
utes, then pour oft the water ant mix the seed with astue or fulwer.

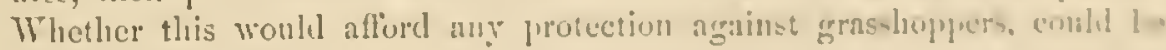
deternincel by trial.

There las becn lately ntlercel in market a uew preparation of " attemante coal-tar," that is, coal-tar mixed with u dryer, making a granulate l tral m

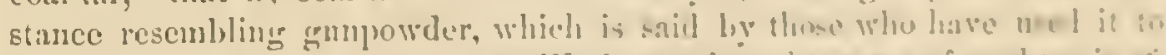

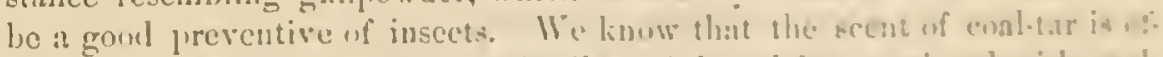

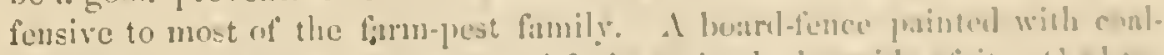

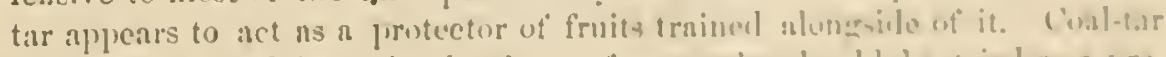

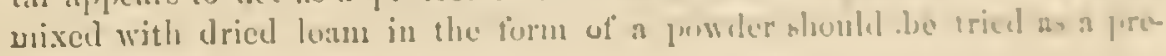


ventive of insects on the young turnips. In this form the expense would be rery trifling. It may answer for all other garden plants just as well as the more expensire preparations solul for the same purposes.

523. The RoullRabi-lts Character and Eso-This relative of the turnip and eabbage is comparatively a new garden plant, but one much approved lyy all who are acquainted with it, and extensively grown for the New Yorls markets. It appear's to be a cross hetween the cabbage and turnip, growing with a bulb like the latter, which has the outwarl appearance of a calbbagestalk, with leaves like ruta bana. These bulbs, cooked, lave more of the flaror anil general clariter of eabuage than turnips. Those who are not aequainted with them should procure seed and gire them a trial. They are largely grown in England as a field-crop for stock, the seed heing plinted by drills, four pounds per acre, and produce twenty-five tuns. F'or garden culture, pursue exactiy the same course as with cabbage.

5:4. Cabbage Cultivation, and Value as Food-Almost every family cultivates cabbage in the garden as an article of fool, for which purpose we look upon it as of very little aceount. We know it is relished liy a very large portion of the laboring class, amel that class alone should eat it, as it is, particularly when cooked, one of the most indigestible artieles of food crer taken into the luman stomach. Eaten raw, in small quantities, it is more digestible, and serves very well as a relish in place of other green food at seasons when the garden does not afford a supply.

We recommend the cultiration of cabbage in all garlens, even where the family do not care to grow it for the taljle, becanse a plant can be stuck in here and there to fill up waste plices, and if the plants are not wanted by the family when grown, the cow's will he rery glad of then after the grass is frosted in autumn. If eabbage is winted for very early use, the plants must be started in cold frames in autumn, and kept corerel up all winter. Such plants are much more hardy than hot-bed plants started in spring. Seed may be sown, as soon as the ground is warn enough, in garden beds, for early calbage, but for such as are wanted for winter use, seed sown late in May or June, or even in July, will be early enough to set where peas and early potatoes hare been harrested. Cablage requires a strong soil, and will bear heary nnuming, except with hor-pen manure. That, it is pretty well settled, causes the disease known as "chub-foot" in cabbage. This whole order of plants delights in bone-dust as a fertilizer" and bones prepared as superphosphates are still letter.

The distance between the plants when set out varies from one and a nalf to three feet. A moist, cloudy day is the best time for transplanting, and it is well to dip the roots before planting in a composition of black mold and a little soot, made into thin mud with the addition of liquid manure.

Cabbages may be headed in winter by setting them with their roots in good rich earth, just as they grew, and covering the tops so that they will not freeze. This may be done with a roof of boards, hay, or dirt, or brush and raits and straw corered with dirt, with little air-holes. Cabbage grown in 
this way is blanchal, sweet, and tender, and will pay much more than the cost of thus arrngring the late stalks which fitiled to form lreads in the fill]. The work sliould be done just lucture the ground freczes, aud at tirot unly elientity corer the tops.

The heals cum be liept very sound and clean, and convenient for duily noc

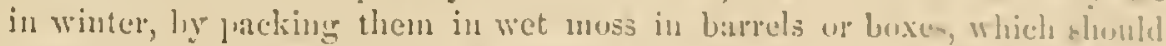
be kept in a room where the temperature is just abovo the frecring punt.

'The casicst way that we erer put up cabbuges fur winter use wats as fill. lows: Ialy two common fence rails, or two poles on lle frionme, side ly sicle, about six inches apart, and as you pull up the cabbages, lay thein down, with the liculs resting upon the poles and the ruots on the grromm on carch side, at right angles with the poles. It you take afl the lumec leaves for feed, lay in thin cunt of struw oren the liculs, and then throw up the dirt from each sille, so as to cover the hearls about six inches deel, aml furm is smootl mouncl, shinped like a winrorr of liny.

Of the kinds of cabbare, we recumnemel the "licrgen," fir its large size

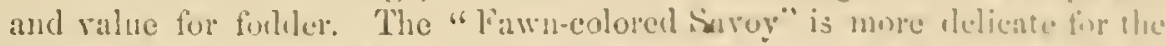

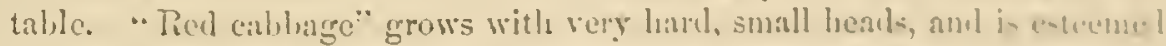

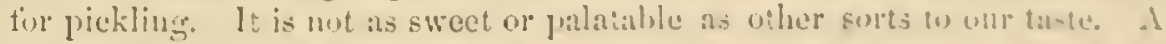

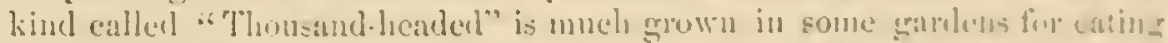
green. It is a cuarse variety. The " Cireen curled liale" is al-u gromen lor

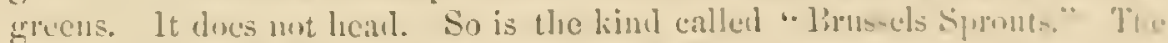

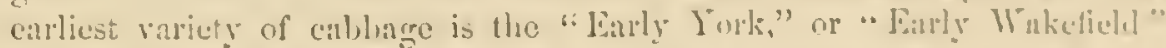

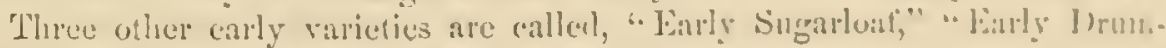
bead or Battersea," and "Birrly Lomdon."

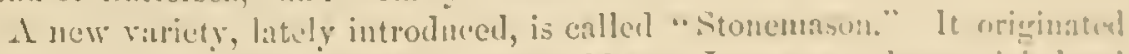

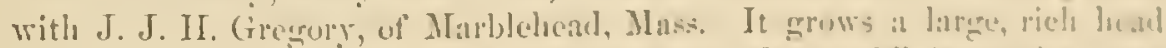

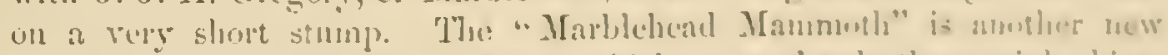

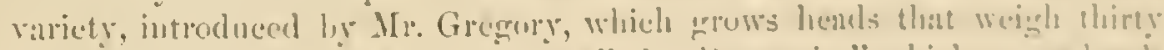

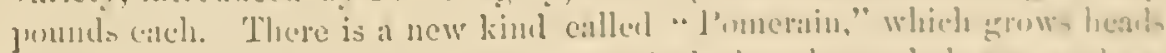
shaped like the licel Duteli, that is, conical, though much lngetr, mal re. matrisbly sulicl.

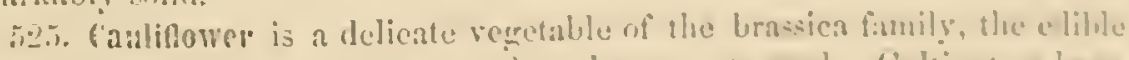

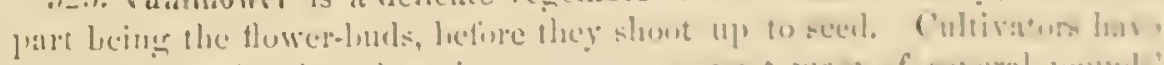

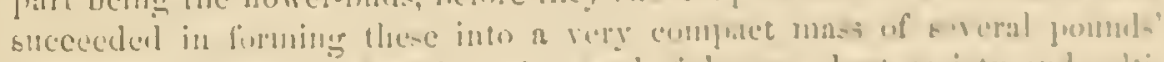

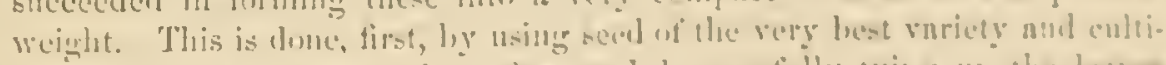

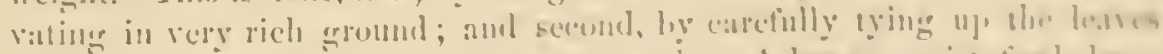

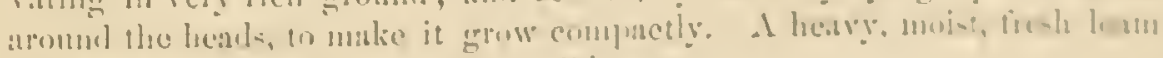

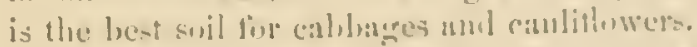

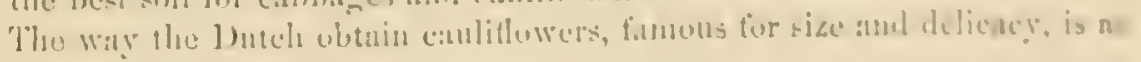
fillows:

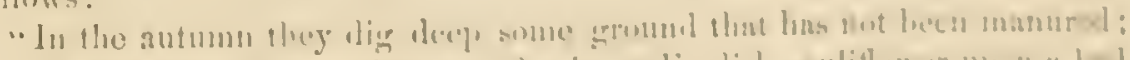

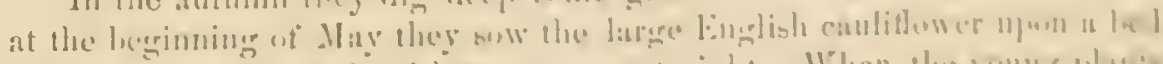

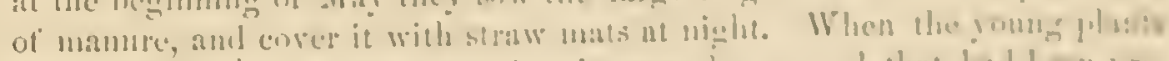

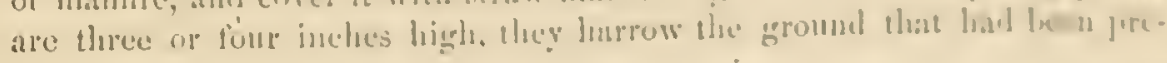


pared the antumn before, and with a wooken dibble, eiglsteen inehes long, they unake looles about ten inches deep, at proper distances apart, and cnlarge them by worling the dibble round till the loole at the top is about three inches in dianeter. 'They immediately fill these holes with water, and repeat this three times the same day. In the evening they fill them with sheep-dung, leaving only room cnough for the young plant, which they rery earefully xemore from the bed of manne and place un the hole with a litile carth. Directly afterwards they give them a good watering, and als som as the sun begins to diy them, water them agrin. Furthemore, as the plants grow, they dig round them, and earth them up in rows. When the head is forming, they pinch ofi' some of the lorer leares of the plant, and use them to corer the young head."

526. Eroccoli is nearly allied to cauliflower, and though inferior in quality is much cultivated. One of the secrets of growing cabbage is frechent lopeing, and in case of dronght, watering. The ground can not be stirred too frequently, and it is well to hoe when the dew is on, if you are a little careful about gretting dirt on the plants.

Althongh eanhifowers are a little more difienlt to grow than eabbages, we liave no doubt they are much more nutritions and digestible as food. Wo have said more about the cultiration of the brassiea family in grardens than we shall of any other, hecanse the rarions sorts may be grown in a great uneasure as a second crop, or to fill up waste places, and therefore it is economica!, because it affords such a great quantity of food.

527. Carrots, Beets, Parsueps, Salsify, and Horserarish. $-\Delta l 1$ these plants require one grand feature in their enltivation, and one which many farmers neglect. It is a perfeet trenching of the carth, not less than two feet deep, and far better if it is three feet. They all sneceed best on a ratler light loan, not too sandy, which was manured the previous year with old manure. If desirable to continue planting the same plat with these roots, let them come in rotation, and use no manure that is not in a rery pulverulent condition. Guano, at the rate of three or four lundred pounds per acre; superphospliate, at the rate of five lundred pounds per acre; lime, at the rate of fifty bushels per aere; unleached aslies, at the rate of ten to twenty bushels per acre, are all good fertilizers for droot erops. All these roots are apt to grow pronged and ill-shapen in fresh-manured gronnd, as they always do in ground badly spaded or plowed, unless prepared by the very best kind of surface and subsoil plowing.

528. Carrots, for early use, may be sown as soon as the ground is dry. For winter use, the last of May or first of June in the latitude of New lork. They are best preserved for winter use in dry sand. The hest early varety is Early Horn; the best for winter, or stock, is the Improred Long Orange, though some prefer the Altringham. The large, white, Belgian earrot has been eultivated here, but the yellow is still the favorite.

529. Reets should be sown rely early for greens. The Early Flat Bassano" or Early Blood Turnip-Beet will produce food soonest; but for win- 


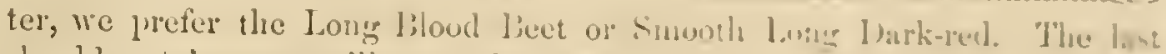
sluould not be sown till near the first of . Iune. Ii it mature's early. 11. top part, whicle grows ont of gromml, is rerge wouly. Always sonk hen -

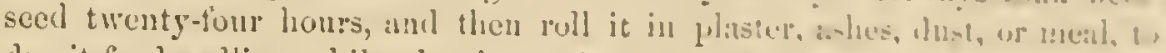
dry it for handling while planting. In outuce wo secal will plani a row che humbled feet long.

530. I'arsucps should be sown carly, and maty be left where they erow

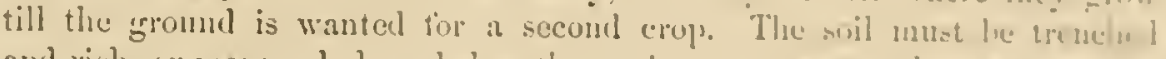

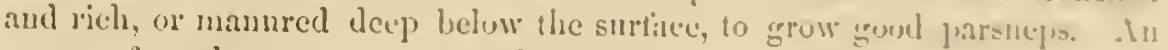

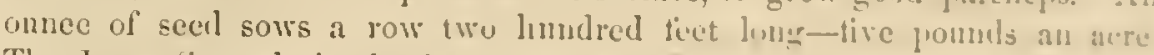
The Long Smooth is the best varicty. Parsnels are cxcellent finkl ir Etock.

5:31. Salsify, or Oyster /'lant, shoml] be sown carly in sprimg: an munce of seed to a row thirty feet long. Jike parsneps, illey are injurured ly stauling all winter where they grew.

liorseralish, is a plant of the genns Cachlearin, which is a sort of scurrygrass, and is unknown to, or, at lenst, uncultivalul by many farmers. Its

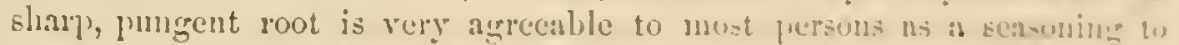
meats, and it is considered a healthy excitant of afjerties. It is as "1y grown from cuttings in any deep, rich soil, wen a mucky one that is suit. wet. It is best after standing out all winter. In the vichity of cities it $i$.

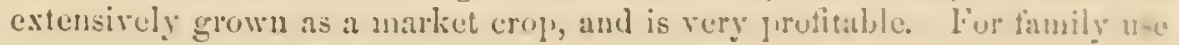
a few plants will sutice.

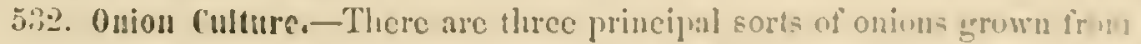
seed puodnced on the top-the reel, yellum, and white. "llsere is a kinl called Early Iied, aml the latre Wefluestichl lied: the latece grows the la rgest, and is best for field culture. 'llue Damers yellum varice? is mild fla-

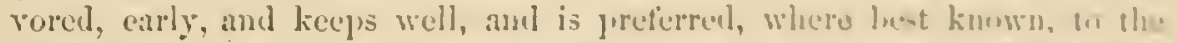
Jellow Dutch, which is known in sume places ats sirnsburn or silver-shin. The White Portugal onion is the millest, and geoul to grow der family use, hut requires great eare to kecp it wrel winfer. In zume parts of th.

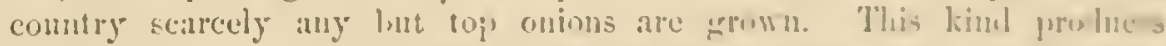
miniature ontons on the top wi the stalk, which are set to grow hullos irs use. Onions require a rich sturly loam, highly manuren with thorounghly

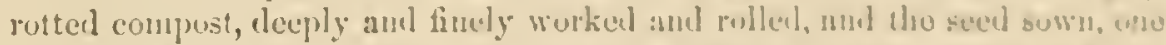

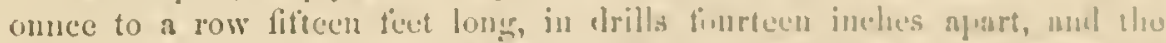

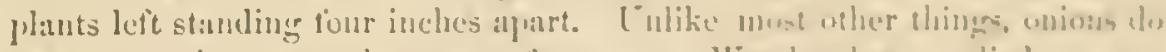
lest upon the sande plat year atter year. Winel anles. mpplied as fopp

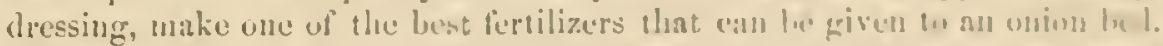

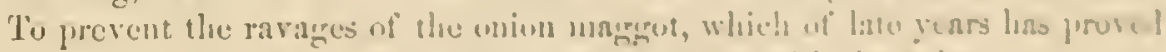

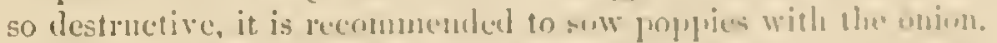

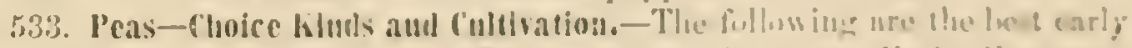

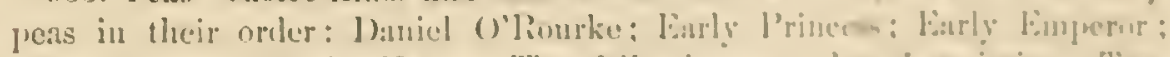

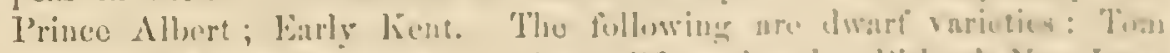

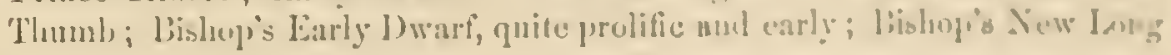


Podded, productive and grood quality ; Dwart-blue Imperial, highly recommended as a summer pea. The following are larger sorts, and are highly recommended: Clampion of England; Farbeard's Nonparcil : Champion of Scotland; Eugenie; Napoleon; Missonri Mamowfat; Large White Marlowtist, a late sort; Blackeyed Marrowfat, an excellent kind, worthy of gencral cultiration; British Queen, very prolific, long podded, and fine flarored; to which arld the sugar pea, with edible pods.

Judging from the little attention paid by many fimers to the cultiration of garden peas, we suppose they look upon them as lnxuries, only to be indulged in by a few, except in very small cuantities. In this they are quite in error. There is nothing grown that is nore nutritions and wholesome, and much more attention should be paid to their enltivation, so as to have a full daily supply, carly and late. The first planting should be made just as soon as the gromnd caul lo worked in spring, upon ground well manured the year before, or else with very fine old compost or gruano in the hill, but not in contact with the seed. In small gardens, or where ground is scarce for emly crops, plant potatoes and peas together. Land can not be too rich for peas, but if $i t$ is the richest of crude manure, more vines than seed will grow. Aslies and plaster ujon peas while glowing, when a few inelies ligh, will help them remalkably. Plant in double rows, a foot apart, so as to set buslies between. The largest sorts require four to six feet between the lines, and wo have found it advantageous to put them wide apart and plant a row af potatoes between. You want a pint of secd of the dwarf sorts, in a couble row, fitty or sixty feet long. The large growing sort will take a pint. to a liundied feet.

Pea-lugs injure bnt do not destroy the germination of seed peas. It is recommenderl to keep "them in sealed bottles, and if a picee of mum camplior as large as a pea is put in, it will destroy all bug life. One writer recommends planting peas tive inehes deep early in the spring to prevent the weevil. Ile plants beets at the same time between the rows of peas. Another writer recommends fall planting, or any time during winter when there is no frost in the ground.

534. Beans for the Garden-Good Sorts. - We reeommend eareful attention to the cultiration of garden beans, beeause they furnish such grood, cheap, palatalse fond. The following hall dozen sorts are the best that we can name of the dwarf or bush raviety, which give edible pods, called snap or string beans :

The Early Valentine grows exeellent, long, tender pods. Early Fellow Six-meelis is very prodnctive. Early Mohawk is not only prolific, lut hardy. The Early China is an old favorite; it is a white bean, with red eye. The Thonsand-to-One sort is also an old and rery popular kind. As young bean-plants are casily killed by frost, you must not plant them till that danger is past and the ground is light and warm. A pint of seed will plant a drill eighty feet long. Cover lightly without manure, and nerer hoe when the vines are wet, but stir the soil vely often, and use plaster and ashes. 
Of pole-heans, the lintly Duteh Casc-knite takes the leanl. It is carly, prolific, and grood green or dy. The pouls are sometimes caten, hut can mise be recommended. The pods of all the Cranberry liens are suod. Th. "Iforticultural Cinubery or Wren's Eigg" grows in beantirully rul-aripul pods, is of a light red amd cream color, speckled, of melinu size. and very" good, both in the pods and shelled. The White, or Marruwtit c'ratulerrs,

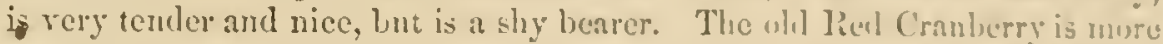
prolilie and hardy, but the pods are less tender, and beans une so dlelican in flavor, but it is a valualile sort tu rely upon. "The benn grum of goud size, roundish, and deep-red color.

535. Lima Reatts are a distinct order of plants from the urlers, and more difticult to cultivate, as they require a longer seisinn w warm weathor, anul

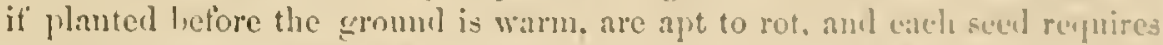
to be handled separately and put in the ground with the eyo downoral is insure their coming "1p.

The lest mamme tor Jima leans is superphosplute of liub. They erow in long, flat, rough pods, and the vines are such preat climbers. fhat they would go to the top of poles thirty fect high. The lust way in tu une proles fire or six feet high, and pinch back the vines, or train then horizuntally. Tuget an early start, set cach hean in a piece of sud two inchus spune. and place these suds in a shallow box in the kitchen. and keep tlem well watereal till it will answer to set ihe heans out aromed the poles.

536. California Beats.-A vnicty of heans new to the Atlantic States, in-

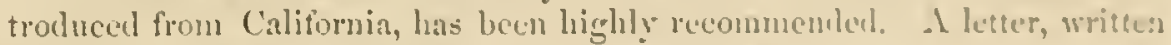
ly L. Norris, Windsor, Ashtabula Cumnty. O.. says of it:

"This bean is of medimm size, of a peach-hlow color, and rery" grolitiv" It requires only one, or at most two plants in cach hill, at it promlucen many

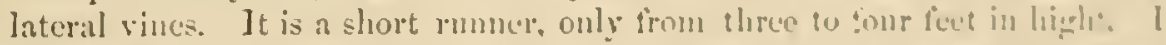
find by planting them with com. one bean in each hill answers the purpune well. Bu cooking these beans in tho folluwing way. they som-titnte a

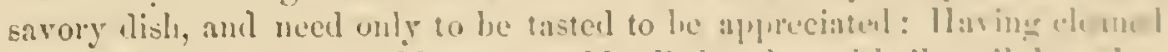

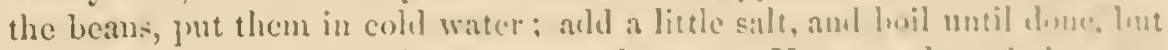
not so much as to have the leans crack open. Ilave rumb a frying-jan, with some lard, which leat until it nearly buils: thes tahe she lomm wut with a skimmer and put them into the fringelna and try them until th y

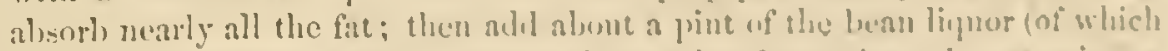

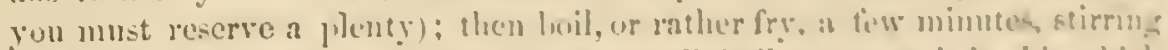

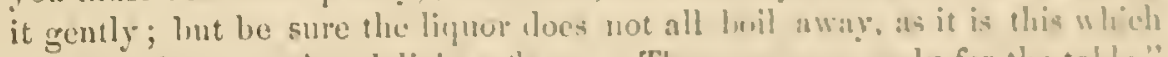
gires the beans suc! a elelicious thave. "They are mom reanly for the tahle."

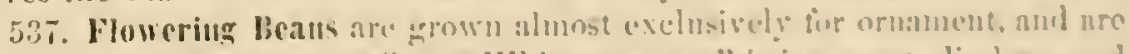

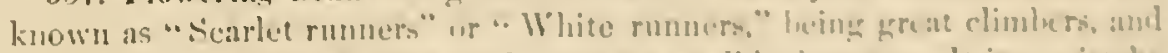

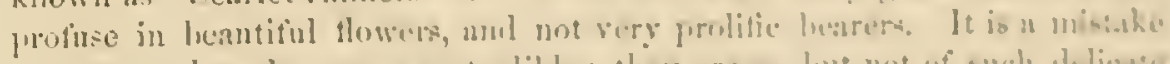

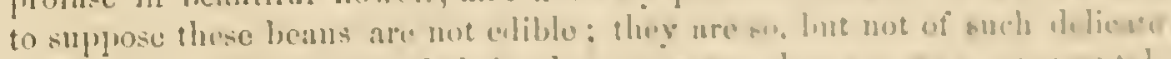

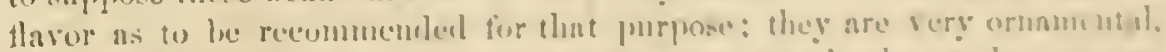

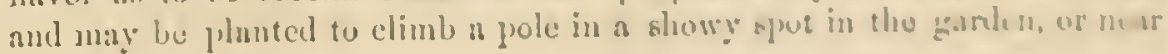


the house trained to trellises, or elimbing strings "y the house side, around windows, or along, a piazza front.

535. Asparagus, - But few farmers liare this delicions, early spring rege table in perfection, because they do not know how to cultivate it properly. It is a perennial plant, which, if once well set, produces its crop of tender; rich shoots, year after year, witl very little annual cultivation. It may be started from seeds or roots, which should be set in a decply-trencher ber well drained, and made just as rich as rich can be, and hearily salted. Every antumn, cut off the tops, and corer the lied with a thick coat of manure, salted; and in the spring, fork up the ground lightly, lictore the spronts start, mixing in the manure, and if any of it is motted, lay it as a muleh between the rows. Lime and ashes are both excellent for surfucedlessings. There are three rarieties of asparagus-the Large Green Purple Top, or Giant; the Improred Ghent; and Common Green-though some contend that the difference is more in cultivation than anything else. The common kind is certainly improved in size by high cultivation.

In May, 1S60, a Mr. Fecks, of Oyster Bay, L. I., exhilited, to the American Institute Farmers' Club, specimens of a giant asparagus, grown at Oyster Bay, originated from seed at Matinicock, L. I., the bed of which is now orer thirty years old. Some of the stalks were nearly an inch in diameter. He stated "that he had about four acres, which lie called only a 'small patel,' because other per'sons had more than twice as much, and he had been told that one man near Jamaica has seventy acres. II is beds are made upon good potato-land, plowed deep, and highly manured rith stable or hog-pen manure. At one year from seed, the plants are set in rows four feet apart, and fifteen or twenty inches apart in the rows. We trench fourteen inches deep, with manure at bottom, which is covered with three inclies of soil, and the roots set, and the trench filled gradually during the summer. In cultiration, we plow off the earth and put manure in the furrows abundantly. My bed is so near the level of salt water that the tide rises upon it at very high water, and the yield is $\$ 300$ an acre. We do not cut it much, if any, the first two years. We put fifty loads of manne per acre, and five hundred pounds of guano. Some growers use 1,500 pounds of guano per acre. The bunches of sixteen stalks weigh four pounds. The best asparagus is that which grows above ground. The white is always tough. We sometimes have bunches with eight inches of tender green."

It is a mistaken notion to cut or try to eat the white part of asparagus stalks. None but the tender green part is fit to eat. An article now before us has the following sensible remarks upon this subject. The writer says:

"The stalk is generally cut abbut four inches long, often not more than two or three inches, and from one third to one halt the length is white, showing it grew below the surface of the soil ; this part is always tough and bitter, and unfit to eat. In truth, it is never eaten, so that fully one lialf of the weight of a bunch of asparagus, purchased in the market, is a dead loss. 


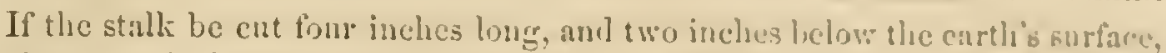

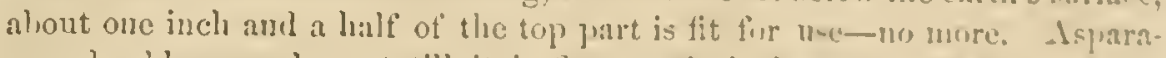
gus slonuld nerer be eut till it is fire or six inches ont of th. gromml. I often let it grow ten or twelve inches high. When five or six inches hiph. it should be eut abont a half inch ahove the ground; hut when ten or twelwe inches ligh, it should be ent six or seren inches ahove the surfice of the eartlı; or, if it be cut near the gromed, all the buttom part elumlit le rejected.

" Nier eutting it, take a sharp kuife, and commencing at the linser ent. foel your way along towarel the top, till you cone to where it is prefectly tender, then cut it off, throwing awa the lower purt.

"It is only the green, tender part that is above the gromul that is sweet, lealthy, and untritious, or fit to cook and eat. The white, tounh, and biter part, that grows below the carth's surface, is not half as gnol us corm. stalks, and slonld not be allowed to be sold in any" market in the civilizerl world.

"For prirste families, asparagus-beds should be male at consideralile rex. pense, and with unch care. Four or five dollars will ualic a hed that will amply supply, for many years in succession, a fauily of eight or teu per. sons, it properly taken eare of. To make a first-prate bel for that uumber in a tamily, makc it about five feet wide and twenty feet long. Dign ont the ground two and a half feet deep, and fill up with chips, sawhunt, tan, or sticks of woorl, packed close turgether, five or six inclues from the lontou. Then put in fire or six ineles of the strongest stable manure, aml fill up (n) the 'top with manure and dirt, about lalf-and-lialf.

"The bel is now fit to plant. Put your roots ahout ten inches apror., cach way, orer the entire bed, and then cover liem about three incles leap with the richest suil to be had, and sow evenly orer the mhole a peet ut commmu ealt and a pecli of ashes, mixed together. Asparagus is a marinceplaus, requiring salt and alkalies for fertilizers, which should be supplicel cuery Elring to make the juants flomrish.

" Rieep the beds clean of reeds and well manured, and for this quatity.

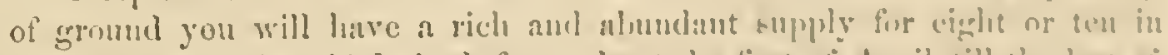

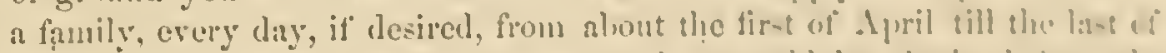
Jume. The yield will be tes times as much us could bo nlutainch from 110

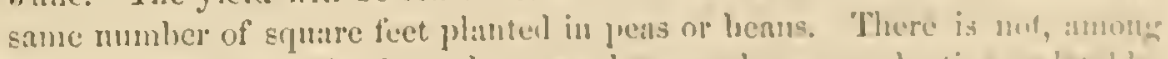
all the green vegretables brought to market, anohlier for productive. pul.otoble, untritious, and healthy us this plant.

"Where it is rased for market, in wrm, rich, vegetable mold shonhl he selecterl. A sancly lonm is better thatu chay."

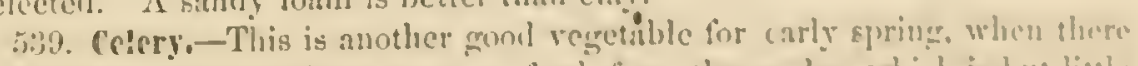
is a longring for something green ne fresle from the ganlen, which is line liesle known to fimmers in general. It is a hardy bicmuinl, grown from tecel boun in the spring, which will produce sech the scentul year. for the rahles the stalks ouly are used, and gensrally raw, though gooul cooked, nut to mato 
them tender and palatable, are grown in a peculiar way, which blanches and makes them erisp, tender, and pleasant to the taste, being aromatic and slightly pungent, sweet, and agreeable to all who are accustomed to eatting them. There are ecreral varieties in cultivation, some of the hest of which are named as follows: White Solid, Seymour's Superb White, Cole's Crystal White, Cole's Superb Red, Dwarf White French, Ineomparable; this is a dwarf sort, of a short, stiff, close habit, growing crisp, solid, and white, and keeps juicy and perfect longer than some other sorts. Laing's Manmotl Recl is the largest sort, and is highlily esteemed in Eugland, but not as much so here as Nonesuch, which is said to possess an excellent flavor, and keep well in spring without seeding. MLead's Improved White is a new American variety, getting into good repute. Celery-seed should be planted early in spring, and corered shallow in rich, mellow soil, beating the earth down compactly orer the seeds with the back of a spade. When the plants are three inches high, thin them ont to four inches apart, and keep then clear of weeds till six inclies ligh, and then transplant into trenches about a foot deep, first filling them half full of fine manure, well mixed with soil, and set the plants six inches apart, first shortening roots and tops. As they increase in size, draw in the sides of the trench, and continue to earth up, keeping the stalls and leares all drawn elose together, so the tops only show a few inches above the ridge. There is no better fertilizer than salt for this plant. Sprinkle the ground each time before earthing up, and take care each time to hold the stalks together, so that no dirt will fall into the center of the buncl. An ounce of celery-seed will produce some tive thousand plants. Both in the plant-bed and in the trenches, celery will drink up a great deal of water or liquid manure. Some recommend keeping the plints in the trenches constantly saturated with water, tinctured witin guano, or strong manure and salt. If kept constantly moist, the earthingr-up process may be deferred till late in the fall. One says:

"Late in antumm the whole bed is covered with forest leares, a foot or foot and a laalf thick, with a few comstalks to prevent their blowing away. From this bed the celery may be readily obtained at auy time, fresh, sweet, and crisp, during the winter."

Another covers the ridge with coarse mannre, so it will not freeze; and another takes up the plants, and packs thom in an upright position in a trench three feet wide, and eovers the whole with coarse unanme. This is only necessary where the plants are required in winter for market purposes. For family use, a few can be kept in ret moss, while the ground remains frozen. As a general rule, we believe the blacker the earth that celery is grown in, the whiter will it blanch. Some persons blanch with boards, set up against the plauts, corered with charcoal-dust. A writer in the Gurdener's Chronicle, London, recommends the use of sawdust, which he finds answers the purpose better than any other material, especially for late crops to be kept during the winter. IIe says:

"Having had some trouble in keeping late celery from rotting, where the 
soil was very retentive and daup, and the plants earthed up in the nsual manner, I used sawdust, and fouml that it answerew prertiecty. Jabt winter all the late celery was earthed up with sawlust, and it kequ quite sumbl till April, and no sligs or inscets attackid it muleroronnd, llue licals being rerg solid, clear, and crisp, and well flatrod. I had some donhts that the satw: dust from resinous trees might give the celery in disagrecalle tharor, but wn trial I found this not to be the case. Iefore the late ecvere frust ocenrreal in October I had just finshed the earthing up of all the late celery with faw wus?, and I find it is now wonderfully fresh. the fiost not liaving penctrated tur through the surfite to the liearts."

Another correspondent reconmenels clicrred eartl in preference to saw: dust, "as it will not only auswer the purpose as well, lut will thlow the rain-water to percolate more frecly to the routs of the flants, nul be of infinite service to a soil of a damp, retentive nature." The sawdust, lue lhinhs. will induce an injurious growth of fungi in the soil.

540 . Chiccory, -This is a garlen filant, scarecly kuown to Amerivan famers, thongh extensively grown in Englund, and within the last wen years it las become a fiborite article of growhl amd consumption. It gruss somerhat like carots, and its cultivatiun is similar, and its principal use is to furnisls a substitute for coflec, ol an article to mix with it, so it is to ut great cxtent with all that is solil in a burnt and grumul state for the pur. pose of reducing the priec, or it suld at the price of pure coffec, giving the manufacturel a larger profit.

The carrot-like roots of the eliecory are wasliel, sclapeel, nud cut intu small pieces, and kiln-dried, and then roased aml gromml like confect. Tu grive the chiccory an oily appearance like cotfec, lard is put in the roaster at the rate of two jounds to a lumbleel of lried roots. It is colured will le netian red, or logwood and malrogany dust, where the chiccury is to te sold nearly pure for "pure coffec."

Althongh not much grown here, we believe eno coflee rossters in Tork know its ralue to then, and import it in considerable gusutites. So doubt it may be profitably cultivatcd, not ouly for sale or use us a mubritute for cofice, but for a good forme crop in the tops. Sum it in dpril in drills a foot apart for hand hocing, just as you slonll carrots, un rich, deep soil, on such ground as would produce a gond carrot crop, nnd lunrven in atutumu. Some grow the jeaves blanched, to use ns n enlad, ly enking "Ip the ronts in antumu and trimuing ofl the tops, and setting the roots in samel in a dark cellar, when young hlanclied leaves start out. The ronts live wer

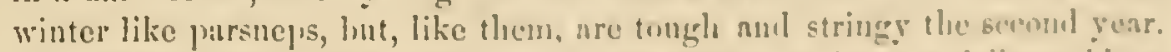
The leaves rescuslile dandelion, nud tops and roots have n delieate loither

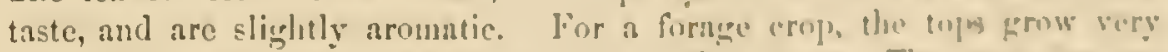

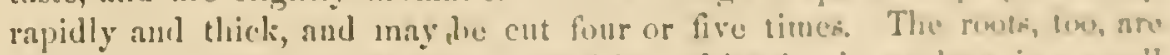
rery good for stock. We recommend its cultivation in gardens, in a small wily, until ita value is well testerl.

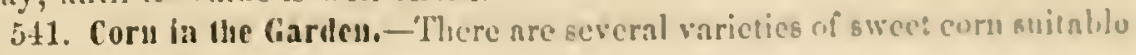


for early and late use. We will mention a few, and advise all farmers to select such an assortment as will serve to give them ears fit for the table through the longest season possible. The earliest may be started in hotbeds, and transplanted as well as any other plants, or it may be planted, as we lare recommended for early beans, in square bits of sod, or in small pots liept in the house, where it is warm and constantly moist. Smith's Early White is a dwart variety, which may be planted for the first yield in hills ouly two and a half fect apart. Darling's Extra Early sweet corn is thought by some to produce cars the earliest of any rariety; and the Early Red Cob is also a very early sort, growing short cars, eight or ten roweil, which fill well out to tho end. The Early Tusearora is a large variety, and matures early, but not as much so as the dwarf sorts. It is eiglit rowed, witl broad, white grains, and remains fit for boiling a long time. This sort requires a rery rich soil. For the main erop, the kind knowu as Large Sweet is perhaps the most productive; and for very late enting, Stowell's Erergreen or Burr's Mammoth Sweet should be planted in rieh hills, three and a half or four feet apart, as late as the middle of July. We have seen it yield well, planted late in August, by protecting the hills with stalks of the early sorts tied around them. It is also kept good till December by cutting or pulling up the hills and setting them in a dry cellar or ontbuilding. Botl of these late sorts grow ears with twelve to eighteeu rows, large grains on white cobs, and rery bushy stalks. There should be a planting of corn for family use every fortnight from April to August.

Where land is searee, we recommend planting eorn and potatoes in the same hill. The corn will be just as good as though no potatoes were there, and if the stalks of the corn are cut away as soon as the ears are mature enongh to boil, the yield of potatoes will be a fair one-in our experience just as good as hills alongside witlont con.

542. Early Garden l'otatoes. - It is quite important to farmers to know what are the carliest sorts of potatoes, since they are the most staple food article grown as garden vegetables, and we therefore name some of the most approved varieties. We have always found the nutmeg potatoes the carliest ot any, but objectionable on accomnt of their general small size, and because they do not yield well. There is a sort called "M[ammoth Nutmegs," which grow larger and yield better. The Nutmegs have a yery smooth skin, light jellow, with white flesh, and keep well, but are good for nothing for winter use. The Early June is a good potato, and more productive. The Extra Eirly White is said to be productive, and capable of producing a very early erop. The Early Wendell and Early Carpenter are both spoken of by those who grow them as the best early variety hnown. We have been well satisfied with the Buckeye as an early growing potato, but it did not keep well witl us. The Dykeman is not as early as some others, but answers first-rate to mature a week or two later. Either of these may be grown to great advantage in the garden, and we recommend that all of them should be tried, and proved which is best for each particular locality. 


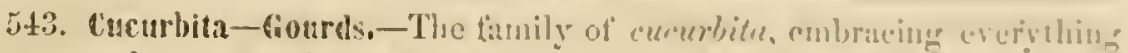

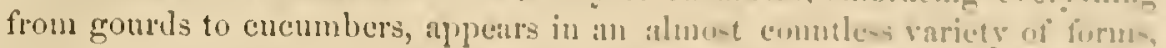

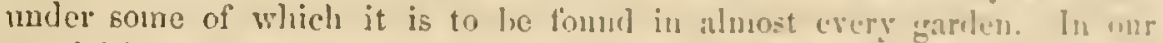

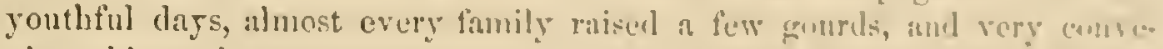
nient things they were, not only for water dippers, lut lushleps of a wront

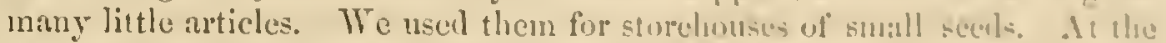

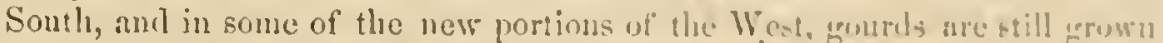

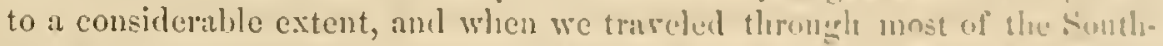
western States between 1540 and 15.50 , we should have thonght something

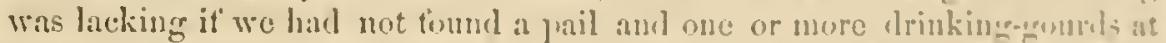
Eome convenient sjot about the house-ermerally on the front piazzas, where every traveler could help himseli to a drink of water. Often, tom, nn bi-ifing the springs ly the roadside or in the plantations, we have fontul elue in-

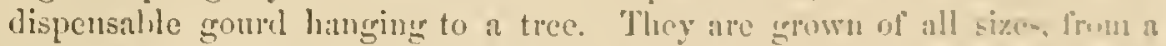

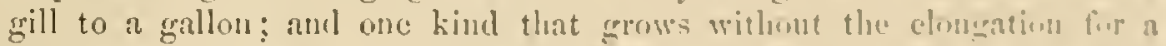

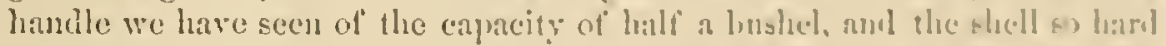

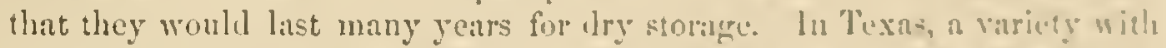
a depression in the midelle, and bull of eymal rize at each emel, is fir jumely

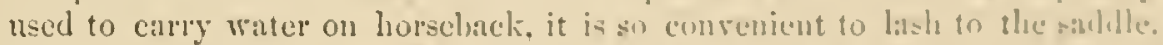

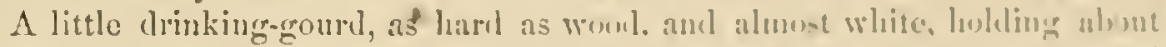
a thirel of a pint, was given us lyy a laty in Mi-sisippi, which atcenmpunichl

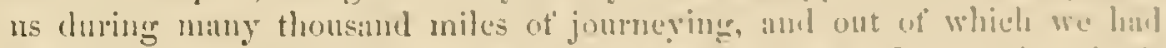

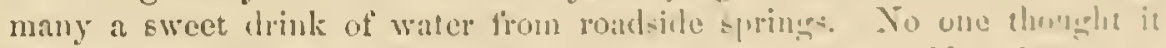
wortl while to steal a gourd from the waron, while a tumbler, fin cup or

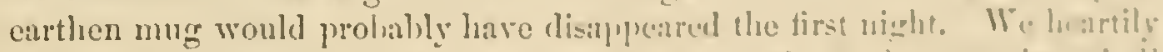

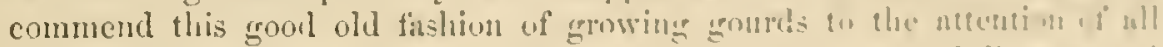

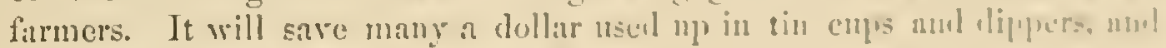
costly, fragile glass and cathenriale.

5t1. Cucumbers. - These ranely fail if planted in lills mate as rich as is is

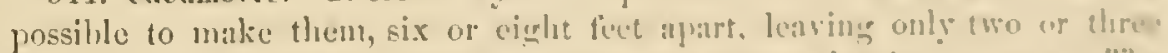
flants to run to vines fiom cuch hill. and sometimes that is exu may. "l\%

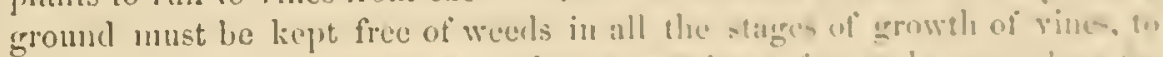

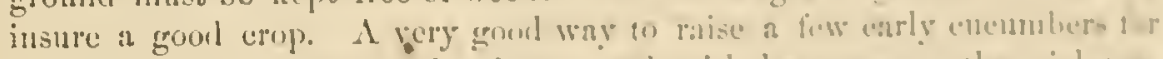

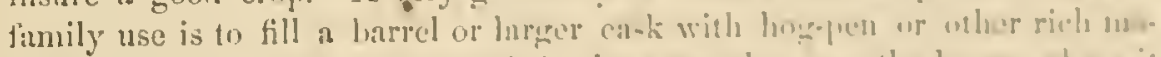

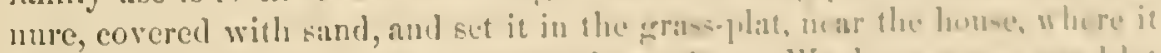

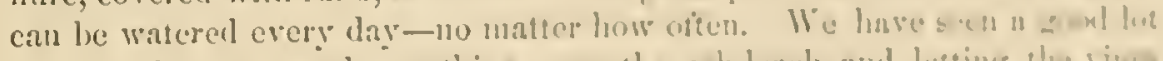

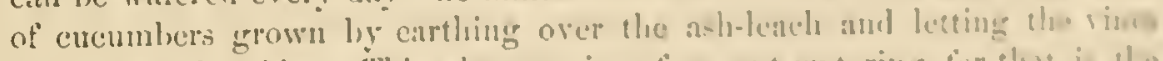

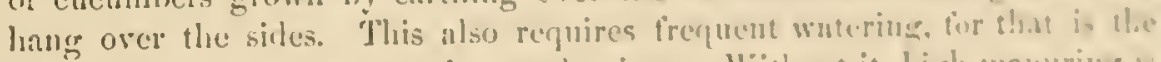
great source of all great garden protuctions. Wiehone je, ligh manuring is worthless.

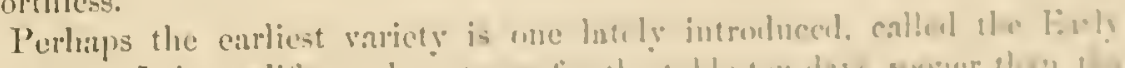

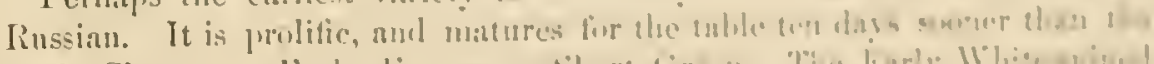

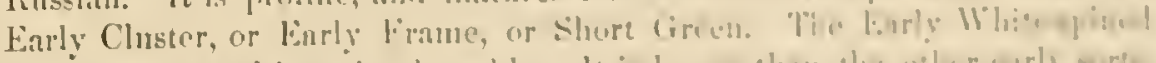

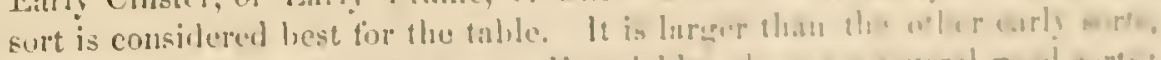

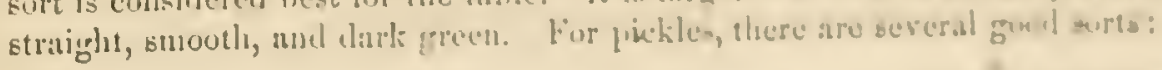


the Long Green Prickly; Long Green Turkey; Stockwood Ridge; and Carter's Long Ridge.

Fol' early use, cuenubers may be planted in sods inverted in a box that can be taken in and out of the house, according to weatler, until it is wam cnongh to set them in place. You can not make the, lills for cuenubers too rich. Some marliet grarleners divide the hills in quarters, and plant one forrth at a time, a week apart; so that if one planting fails, another will succed. The plants sliould be hoed frequently, and the bugs watehed carefully. Seed improves by age; an onnce will plant a hundred hills; thongh as they are planted on Long Island for market, an ounce would be needed for a dozen liills. The market gardeners put in such a quantity of seed, that the bugs are not able to eat all nntil some get too big for them.

545 . Musk-Melons should not be planted till the eartly gets warm, and then in liills dug deep and made rich with well-rotted manme. It is a good practice to pinch ont the bud of the main shoot as soon as half a dozen rough leares are formed, as that eauses lateral branches, and makes the fiuit set earlier. Light, dry, sandy loam made rich, and a dry, lot atmosphere, if the plants are kept moist, will grow fine melons. WVe think the Green citron, a small, rough green skin, roundisl form, the best sort. The Pineapple and Jenny Lind are similar, and execllent. The Nutmeg melon grows larger, with rough skin and greenish flesh, aromatic and sweet. Skillman's Fine Netted looks as thongh the green melon was bagged in a brown net, and is a very fine melon, and ripens early. The Christiana is a yellow-fleshed sort that ripens very early. It is a Massaclunsetts scedling.

546. Water-Melons, though grown in all the Northern States, nerer come to such perfection of exeellence as they do in warmer elimates. Here tlicy should be planted in May in light, lry ground, and they often do best upon almost pure beds of sand, laving lills prepared by digging ont large looles and filling them with manure, and covering it with soil. If the plants are watered witl a solution of two pounds of Pernvian guano in a barrel of water, their vigor will be much increased. It is a great object to get them forward as fust as possible. A very successful grower of water-melons mpon the granitic soil of Westchester County; N. Y., says :

"I dig a hole three feet wide and three feet deep or more, and fill it with cow-yard manure carly in the season-say 1st of May, and cover this with light soil, six or eight inehes decp, before planting the seeds. For mushmelons I mannre with well-decomposed manure, sown broadeast and worked into the soil. I would also work in a little of this fine manure in the top of the water-melon liills."

The vines fruit better if the leading shoots are frequently pinched back. Water-melon lills should be ten feet apart in rich, sandy loain or artificially enriched sand. Six or eight secds to a hill, not orer an incle deep, in fine, black soil, over any amonnt of rich manture, will produce rigorous vines. The varieties of water-melons are almost innumerable. The Mountain Sweet and Black Spanisl are our farorites. Cut-worms and bugs are the 
greatest pests of all vines, and the hest of the many remedies in our opinion is the cheapest, which is simply inclosing tho hill as soon as planted wirli a board box six or eight inehes high, drawing the carih up a litele nouml slue outside. It has been found muneessary to cover the toy, with this mus lin or flakes of eutton batting, except for the jurpose of kecoping the warh warmer. These hoxes should be male alout a foot square, and apperims cnongh to admit packing them in ne-ts to stow away as sun as the plants are large enumgh to allow of removing their woolen wnllen protrection. Other seeds may le protected by such huxes against exrateding hens, us they will seldom, if ever, gret inside to do mischici; and so long ats hens du mot ifestroy seeds or plants, or fruit in a garden, they are vicful, for they (at up) thousands of worms and lungs.

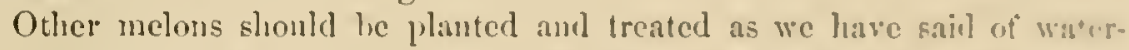
melons; and of all the various sorts of mus-inclons, the small growef molon that looks as though covered with in fine flaxen netting is the licat, to wur taste, though we hare great hopes that the new Persian molun, that grow' as big as the old musk-melon, will prove as rich as its first fruits imblicas.

Great care is necessary to save melou seed pure. Lincs of cucumblers and melous never should grow near to each other. Leut the truth low row membered, that the raricties of all this fanily will mix, and that secellimen seldum improve cither sort, and that the hest always sufter lye the contart.

Pees are inceat mixers of the pollen of fluwers, and they cam ouly lie frue rented by gretting up earlice in the moruing than the hecs. Select a numluer of femalc blossoms which lave opened during the night. They may lue known by growing on the end of the young squmsh, melon, cte., while the male blossoms ("talse hlows," as they" are when callewl) have mo fruit. séatter the pollen of the male blossons upmen the stumens of the femalo ones and earefully cover the batter with millinet, or nuything which will protect thems

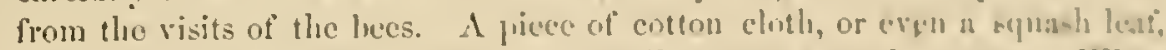
kept in place by a few clols of earth, will answer a gombl purpuned. When the blossom withers, the covering may lue removed, and the fruit marked by a colored string tied lonscly stomml the vine.

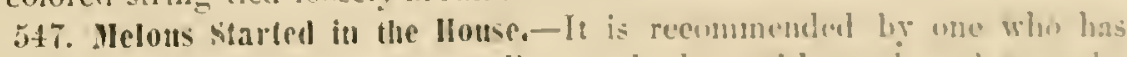
met with success, to till some small opeoll ha-kets with carth and start the

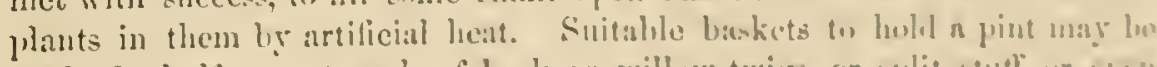

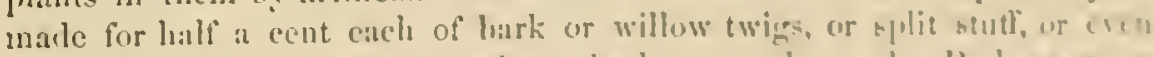

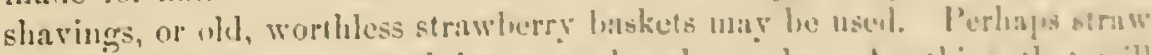
baskets would answer, and le very ches]! malle. Inylhing that will

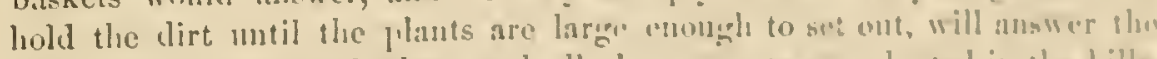

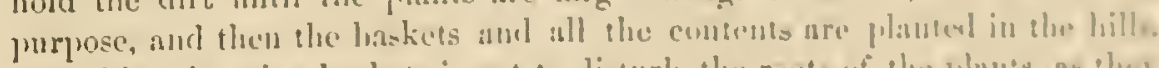

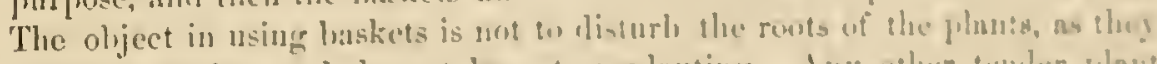

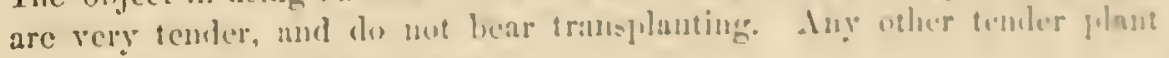
may be grown ju the sinne was.

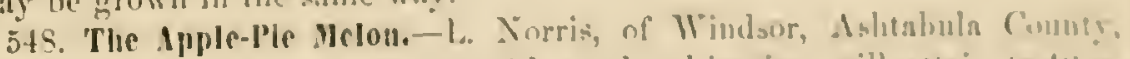
O., stys: "The apple-pio nelon, with good cultivetion, will uttais to fut is 
50 lis. cach, and if gatliered carefully when ripe, and kept in a dry, cool place, will lieep sound a year, and will always prove a good substitute for frut for pies or sweetmeats. To use, peel oft the skin, take out the pulp, ent fine, and stew thee or fonl hours, when the substance will resemble stewed green "lyples; to which add sugar and lemon-juice, and it will make pies that cis not easily be told from those of apples."

Another enltivator says: "This melon attains a large size; I hare grom specimens the past season, eighteen inches in length, weighing from 30 to 40 lbs. They are eylindrical in form; color, when ripe, a golden tint, rery solid, and flesh close-grained ; color of sceds, a dark green or blue; ripens in September, and will keep sound and good, it is said, for two years, but we have not as yet tested their lieeping qualitics. They prove hardy and of easy culture, and I consider this melon a valuable acquisition. We hare tested the quality of them for pies, and find them very delicious. To prepare one for cooking, peel and cut up the melon small, taking ont the seeds and soft pulp. Put the pieces in a preserving liettle with just enongh water to keep them from buming, and stew orer a tolerably brisk fire for three or four hours, or until the whole is redneed to a soft, pulpy mass, free from lumps, and thoroughly done. You have then a substance resembling green apples sterred, and by adding a little sugar and lemon-juice to it, and making it with erust in the usual war, it is impossible to tell it from a fresh apple-pic. If you desire a pie like pumpkin or custard of the melons, stew as abore directed, but omit the lemons, and bring the pulpy mass to the proper riclness and consistency by the addition of sugar, milk, and eggs. Little of either of these ingredients will be found necessary-only snfticient to give the melon color and flavor."

519. Squashes-Summer and Vinter Varieties.-The rarieties of squashes are so numerons, that almost erery neighborhood has some favorite. The most univereal one is the Boston Marrow, and next the Hubbard squash; the last the best, but being a newer variety, has only become generally known within a few years. They are both medium-sized, and are extremely rich food for winter use, simply boiled and eaten as a table regetable, as a substitnte for sweet potatoes, or for pies and other cookeries. The form of the first is orate, pointed, witl thin, salmon-colored rind, and flesh of deep orange color and fine-grained; keeping all winter. Average weight, six to eight pounds. The Hubbard is a better substitute for sweet potatoes than the other. It has a liard shell, and is an excellent lind to keep through the winter. It grows abont the same size as the Marrow, and is immensely prolific. The Lima Cocoanut is a variety much esteemed by some as a winter squash; it grows large, oblong, of a bluish color, rery finegrained, and sweet. The Honolnh, a new rariety, is said to excel all others in produetireness, fine flaror, aud good lieeping qualities. A large, almost white squash, which re have grown several ycars, we like full as well as either of the above for pies, and it is more liardy, and sure to produce a good crop in all situations. The flesh is sweet and ricl, but not as fine- 
grained as the others, hut it grows three or fond times lareer, with at smoosh, polished slin, the color of white wax. In size of frefit aml vimes, it in wore like pumplins than ordinary squastics. Among all new varictice, we shombl not forget the old Crookncels. It is a squash of goul eating and kecping quality, and not so delicate in its gromell as some others. Tleere is also a crook-necked smmmer squash, which is consilered by tho-e who have ngum it, the largest, the very best of all the summer valieties. It is early, prop cluetive, and one of the kind called bush, or urn-punning sorts. Is: colpor is yellow, and has a warty skin, and labl shell when ripe. The farly White, scolloped, a bush variety, we have grown with satisfaction a- wits eating qualities, though we thought it a sly bearer. The libls for symathes

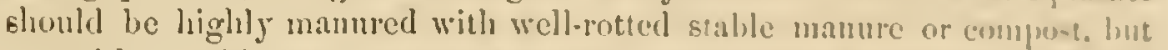
not with anything very putrescent, which will give oft :mumosia and kill the young plants, which are rery teuder. The seeds mun-t unt lne pluntul while there is any danger of frost, as a very slight dengee of cold will hill the vines while new. The use of salt in manure must he aroilent with ull the cucurbitr family, but plaster may be used to great allontage buth ats at fertilizes aml bur preventive.

550. Lgg-plants.-These garden plants are not as much erown in Donhorn

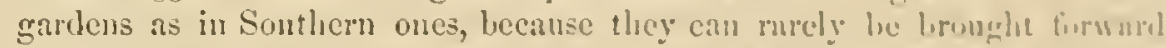
carly enough in the spring without the aid cit artilicial heas, an the young

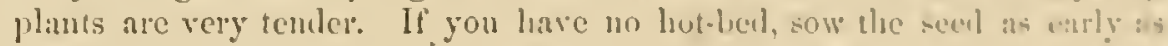
possible in a slyeltered, wam, dry situation, and fornece the gumbe flumis wilh hami-glasses or boxes, or some corering in cohl nights, mueil there an three or four inches high; and when the wenther has hecome stealily warm, transplant them into very rich, mellow soil, sutting the plants ewil uml a

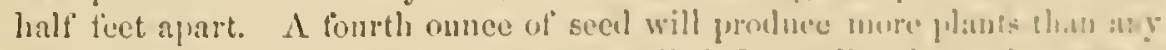
family wants. The earliest varicty is called longe l'uple, and armun at

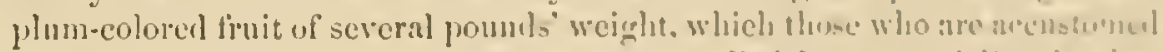

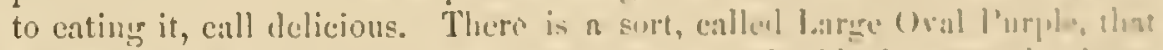

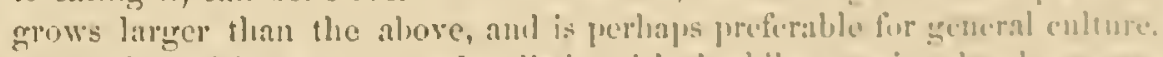

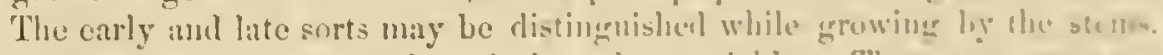

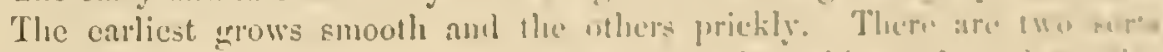

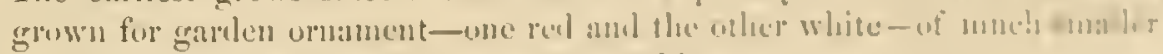
size than the Eorts generally groun tor" cunting.

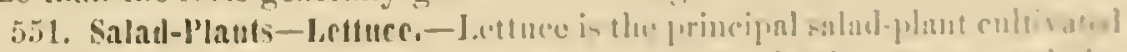

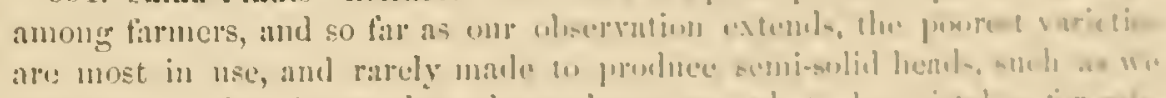

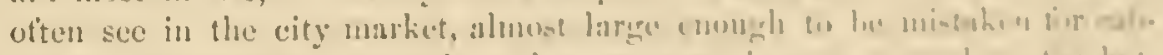

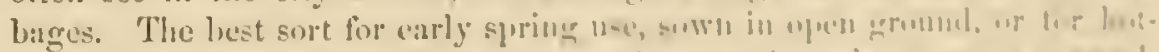

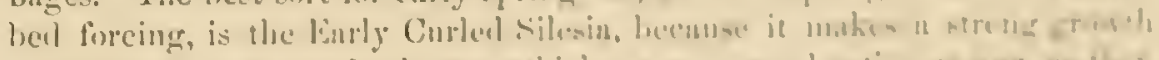

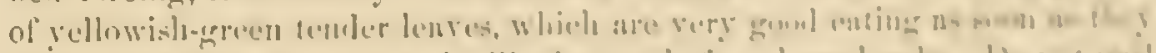

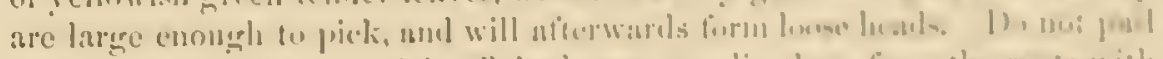

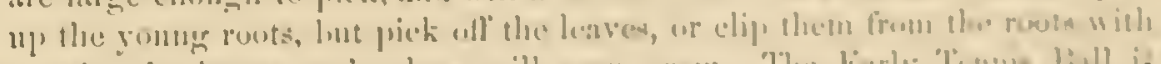

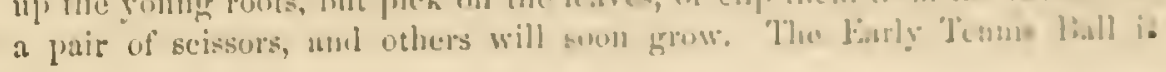


csteemed one of the hest varieties whieh form heads. Recollect that bone eorts of lettnce will not liead, with all your care, but the leares may be made more tender by tying them up, so that they will grow blauched. One of the lese sorts of nom-heading lettuee is the lee Cos, the leaves of which are brittle, growing long, narrow, and dark-green, and of somewhat an iey appearauce.

There are also four other sorts of Cos lettuce-the Paris Green, Paris White, Florence o. Golden, and Spotted Cos-each of which you will be told is best by the person who grows it, and no other. The hardiest sort is the Brown Duteh, which may be started in autumn, and slightly protected so as to cndure winter, and grow early in spring. It will form a loose head, but is not generally grown for lieads, but for the early young leares; the other eorts being preferable to it for heading. One of the largest varietics is called Large India; it is less enrled than the Silesia, and the leaves are whiter, slightly edged with pink. This kind endures the summer heats well, and forms large, round lieads, which eut solid and erisp. There are several other sorts, but what we have said of these is enough to show that there is a great variety in this family of garden plants.

To grow good lettuee, the utmost eare must be used in preparing the ground. The soil should be made as fine as the seed, and as rich as good garden mold ean be. The seed should be sown every fortniglt from February to June, to get a suecession of young plants. The ground must be kept loose between the rows, and it pays well to water with guano in a weak solution.

An onnee of lettnee sced will grow plants enongh for half a dozen families. It would require a bed about ten by twelve feet to sow all onnce of seed, and it would produce some 5,000 plants.

552. Mustard is often grown for salad, the white or yellow seed rariety being very good for that pulpose. It should be sown in the fall, or it may be started in, spring, in a hot-bed or warm southern exposure, in rows eix inches apart, and no matter how thick in the rows, as it is to be evit when two iuches ligh. The black seed kind is often sown for greens, as well as to grow seed for use or sale. It ripens seed in July or Angust.

553. Nasturtium.-This is another salad plant, when very young, though generally grown for its fruit, which is used for pickling. The pods are gathered before they ripen for this puryose, and some use the flower-buds, esteeming them as good as eapers. The oringe-colored flowers are also used for garnishing dislies. For salad, sow the dwarf rariety early in spring, in drills an incli deep, along borders of beds, so that what is not cut for salad may grow for ornameut.

554. Garden-Cress. - This is a favorite salad plant, and in this charaeter only the seminal plants are used. It is very liardy and prolific, and may be sowed once a week, from the opening of the ground in spring until the close of the season. Old ricl garden soil is the most congenial to it, but 
any lands of fine texture will, if properly pulverized and enriched with putrescent manure, produce a good erop.

Do not mistake this for the plant more known as peppergrass than it is as cress. The article we allude to grows anmully from secd or from rones, forming compact bunches of twenty or thirty stalks, which grow a too: high, and bear smootl succulent leares and an upright stem lull of eced-ponds, amme thing like tmmip. It is very apt to seed itself, and may beeome trouble some if care is not taken with it. It is so hardy that it kecps partinlly green all winter, under a very sliglut covering, gand jts greatest value is, that it affurds something green very carly in spring.

555. Hater-Cress (Sisymbrizun nasturtium) can be casily grown frosu seeds or roots, wherever there is a strcan or spring in the groum near the house. It grows best in situations where the roots are always in water, and in winter the whole plant is overflowed, and it particularly delights in pure water, clear and cold, such as runs in the litle spring-brooks. If you loup pen to have one that does not freeze, you may have water-eress at any time during winter. It is started by sowing the sechs or setting the plants in a suitalile Elot for its growth. After it once gets tixed as a habitant uf any place, it requires no eare in its cultivation.

556. Endive, a plant of the chiccory species, is often cultivated for a winter salad, thongh more used in stews anl for garnishing tables. The Green Curled is the hardiest sort, growing beantifully curled leaves, darkgreen, which are tender and erisp when young, and mich estemend ns salat by some persons, and are considered wholesone. The French use the liatiavian Endlve in stews and soups. It is a broad-leaf eort, which grows nut much enrled. This, when very young, is caten as salad, but is not abs groul as either the Green or White Curled. The seed is sown late in the spring, ur eben milldle of summer, for fall use, and the lenves are blanchenl for nec by "ying the onter leaves ofer the inner ones. An onnce of seed will sow a berl eight by ten feet.

55\%. Turnip-Sprouts, grown under a straw muleh, are lilanclied aml temder, and make a delicate, swect ealad, and may be had early in the spring wi:h a little care.

55S. Okra.- Cuder the heal of "Ilistory of Some Commun Ciarden Verretables" wo have told the uses of this plint. Its consumption lias in. creased so much in New lork since its introdnetion a lew yesrs since, that one market gardener of our actuaintance grew beven acres of it last renr $(1 \$ 60)$, part of the crop selling green and part elried. 'l"here is mo plane grown in the garelen that atlords chenper fool than okra. The ponk, in minp, make it mucilaginous and mutritions. 'There is a dwart ohru flant which does not grow more than two or three feet high, mul is rery prohtic al branches and pods, that for this latimde will, be a vuluable iunprosemess: over the large hind, which grows live or six finet longh. JRipo uhra noteds aro

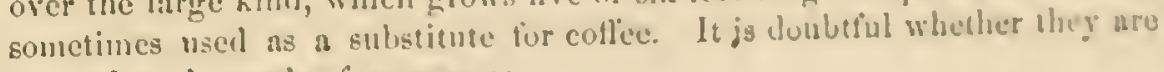
as good as the seculs of asparagus. 
Okra seed slould not be planted till the ground las become wam in spring, and may then be treated much like Indian-corn in all its enltiration, and grows well in soil suitable for corn.

559. Tomatoes. - The rapiclity with which this vegetable has been brought into almost universal use is well-nigh beyond belief. It is quite within the memory of middle-aged people that it was grown only beeause its fruit was olnamental, and by many supposed to be poisonons. Its common name in New Enghanl was "Love Apple," thongli no one loved it. Now there are not many timilies that do not esteem tomatoes as mucl as any garden vegetalble, and gardener's are constantly making efforts to produce new rarieties of inproved quality. Let no one suppose he has got the best sort until he has tried severial others. There is more difference in the quality and ralue for food of tomatoes than there is in potatocs. Wre will name a few of the best. We have grown a very large yellow tomato, which we prefer ores all otliers, because it is less acid, and the meat appears to have more of the food principle in it than any of the red ones, unless it is one called Fejee Island Tomato, which we think identical with one called "Perfected," and said to have been introdneed by C. Edwards Lester. It is a very large red sort, and rely good eating, and a litfle finer grained than one ealled the Large Mammoth Red. The poorest tomato in existenee is the one almost universally grown for the New Iork malket. It is of medium size, smooth, rounclish, with a tomgle slin, and sour, hard meat, frequently very hollow, partially filled with seerls and som water, and being generally gathered in a green state, is no more fit to eat than the vines it grows upon. It is grown becanse it bears transportation better than the good sorts, and it will sell to people who do not know how to appreciate a good tomato. As a general lule, to select good sorts of tomatoes for cultivation for family use, choose those which grow uneren-shaper rather than smooth, such as you can pull apart without cutting, the lobes separating with a glistening fracture. If you wish to liare some ripen earlier than the large sorts, you may choose a round, smooth, medinm size, called Early $\Lambda$ pple Tomato. For pickies and preserves there is a solt lnown as pear or fig tomatoes, being about the size and shipe of figs. There is a sinall yellow sort, grown for preserving, and so is the sort which grows about the size of potato-balls, and as round and smootl. A distinct variety, called Winter Cherrics (see 675), grows with a lusk about the size of large cherrics, and is mucl liked by some to eat out of hand. Care must be taken to prevent the different sorts of tomatocs from mixing, clse, if yon have a ehoice kind, you will be apt to lose it, as the inclination is to rmu down rather than up the seale of improrement.

The cultivation is very simple. In warm latitudes they are self-propagating. In this latitude, where the fumily lias no hot-bed, the sced should be sown for early nse in boxes or pots, in February and March. The seeds sown in boxes, if kept in a warm room, in the light of a window, will grow healthy plants, which, when two inches ligh, may be pricked out and set single in pots, and carefully nursed till all danger of frost is orer, in some warm, 


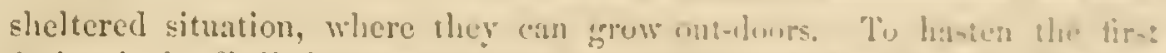

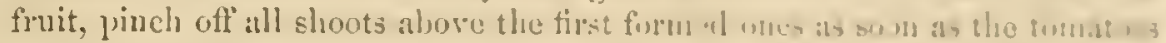

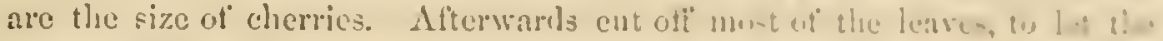
sun have its full force upon the finit; you will thus fect at suall cerpl a on al weeks ahend of the ripening when plinted out at phe orlinary timu a 1 lejt to the natural course of erowth. "To liare really eroul tomates. fis in h. eaten in a law state, which certainly is the mot ilelicions form in which they can be eaten, you must have a groul Eurt, and grow them on gennl lanl.

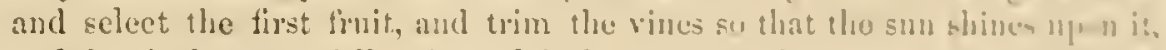

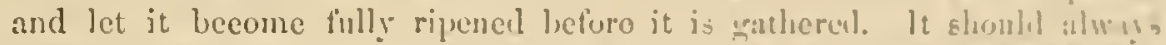

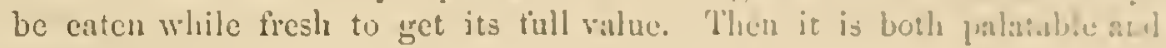
wholesone.

If the secel be sown in May, in good rich suil, of a warm unture. with a sufliciency of oll, well-rotted manue, there will rardy le auy duster of

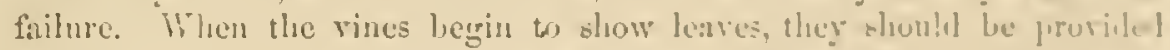
with a trellis, or tied to stakes fixed in the soil, to liecp the fruit frum luesus injured ly coming in contact with the dirt.

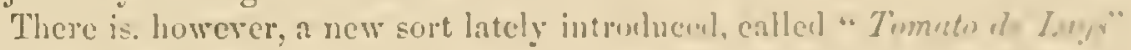
in France, and with wa, the [juright or Tree-linate, that re puires an whro port. Its stem is two fiet high or more, and su remarkaluly stronge atud siti,

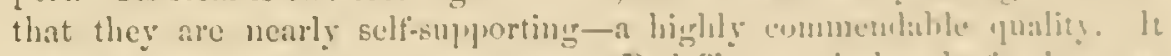

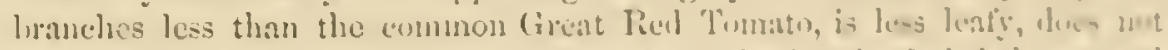
want so much pinching, does not bene su frecty, Lut its iruit is larger a, ll more regularly formed.

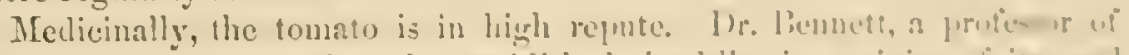
melieine of good standing, has publisherl the fillowing opinion of it ffo al qualitics:

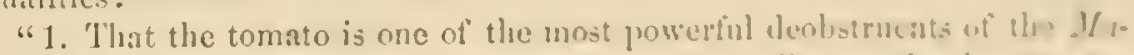

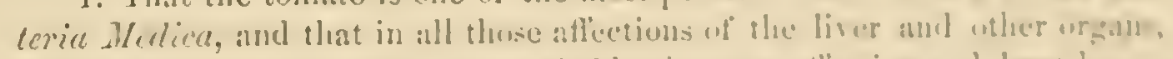

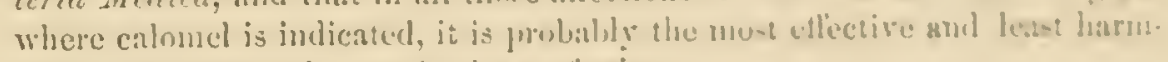
ful remerial agent linown in the proti-ainn.

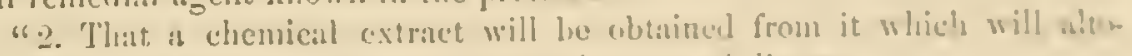
gether supersede the use uf ealomel in the cure of di-enter.

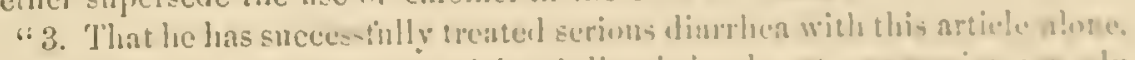

".t. That when used as an articlo ot dict, it is ahuest a mucreign rutudy" for dyspepsiat or indigestion.

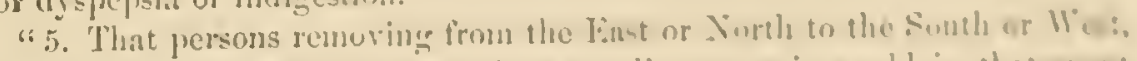

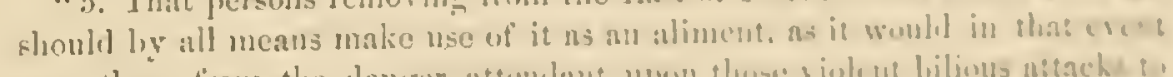

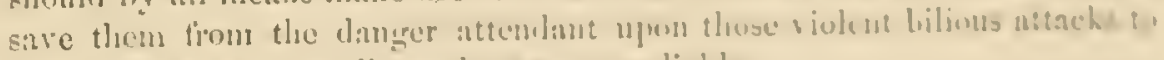
which almost all mancelinanted jersous aro liahle.

"G. That the eitizens in ordinary thould mahe nac of it cirlue raw, com he! or in the form of a cat-1p, with their daily fines, as it is the me the althy atucle in the Materies allimentariu."

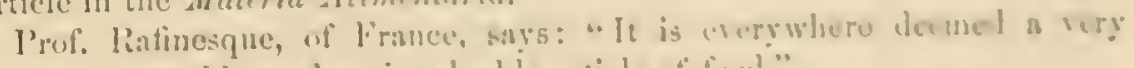
healthy vergetals]c, and an invaluablo article of fuend." 
Dunglison says: "It may he looked upon as one of the most wholesome and valuable esculents that belong to the vegetable kingdom."

A writer in the Farmer's liegister says: "It has been tried by several persons with decided success. They were afflicted with chronic congh, the primary cause of which, in one case, was supposed to be a diseased liver; in another, diseased lungs. It nitigates, and sometimes effectually checks, a fit of colghling."

The method most commonly adopted in preparing this fruit for daily use is to cut them in slices, and serve with salt, pepper, and vinegar, as you do eneumbers.

To stew tomatoes, remore them ripe from the vines, slice up, and put them in a pot over the stove or fire, without water. Stew them slowly, and when done, put in a small piece of good butter, and eat them as you do applesanee. Some add a little flonr-bread, finely crumbed, or a couple of crackers pulverized, to a quart of the stew.

560. Radishes.-Almost every family grows radishes, but every one does not grow them to perfection. The radish appears to kave originated from China, where it is still grown to much higher perfection than in any conntry of its adoption, and is largely used as an artiele of food throughout the year, one variety being grown especially for winter use. Although not a very nourishing sort of food, it is a very palatable condiment, and very aceeptable upon all tables in the spring season. The. tops are frequently nsed when quite new as a salad, and the green seed-pods make nice small piekles. To grow good radishes, your ground must be rich from manuring in previous years, or by guano in solution, or superphosphate, while the plunts are growing, and not by fresh putreseent manures. Radishes are only good when the growth is rapid. To have this they must have a good soil and frequent waterings, either naturally or artificially.

For early use, sow on mildly hot beds, or in boxes in-doors, and afterward in sheltered places, and water frequently, thinning out the weakest plants. Put in a few seed every ten days, as long as you want to continue the production, in drills ten inches apart, or with other seeds of slower growth, to mark the rows. An ounce of seed will plant a bed ten fect square. One of the best eirly sorts is known by the long name of Early Short-topped Loug Searlet. It grows laalf out of ground, and very crisp. The Olive-shaped ladish, lately introduced from France, is an early and favorite sort. It resembles the scarlet turnip radish; is rose-colored, oblong; top quite small, and if grown rapidly, is crisp and sweet. For our use, we prefer turnip radislies to the long sorts. Fol winter use, the Spanish, or Black radish, or a sort called Rose-colored China, is sown in the fall, and sathered before freezing, and packed in sand in a dry cellar.

561. Rhubarb, or Pie-Plant.-This raluable garden vegetable is ensily grown, and aftords the first thing in spring for pies and tarts. It is best to get roots for a start, as it is not always true to the kind from seed.

Autumn is the best time to make a rhubarb or pie-plant bed, and the 
roots may le put in at any time when the wealuer will alluie. Tho great secret of success is to get a deep, ricl, bed to herein will. It can not be too deep or too rich. We would dig it five fect deep for fimily mac, aml till uno foot with cobble-stone, if we conld, or with bruken lrick, timber, amb lirush, so arranged as to give a good drainage. Then till up witl surb, chip manure, wood's mold, good sril, and rieli-comprosterl mature in a homogeneous mass, casting away the sulsoil. Such a male heet will last s. long as its maker will, and it ten feet wide and twenty teet lols, set with three rows of roots, two feet a!nut in tho row, it will furmish the largest family with more than they can use, so that some of theile imlolent neighbors con get a portion. Exeept when grown for narket, we woulal not solect tho largest variety of rhubab. Seedling plants may be cut noter the tirst year to a small extent. It is good to mulch the berl sumuser mul winter. Sicel stalks must be kept earefully eut aw as lilst as they appear, and the bed must be riehly mumed every fill.

Some of the sorts in highest repute are the Vietoria, Linnaus, Tinyal .1!-

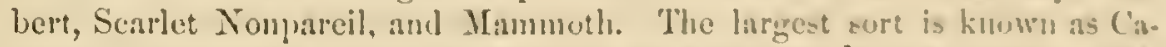
hoon's Seelling. It is butter esteemel for winc-nnating than entug. Fifteen hundred gallons an acre have heen male from this surt, frown upm well-draned, rich, loany land in Wisconsin. The stallis are ent in lengths of wo or tluee inches, and ground and pressed in a ciller-mill, ono lumelred pounds of stalks yiclding tun gallons of juice, which is mixul with su "4ful quantity of water, and about three and a lialf pounds of refined fugan to each gallon of the mixture. This, if treated like other small frnit wines, gives a palatable beverage, sabuble, and rerg profitable to the promer and manuficturer.

56:. Savory and Melleiual Garden Plants-l'lere is a varicty ut plants which every taluer's tumily should grow in the garden, which are uneful in the kitchen, nursery, or sick chanber, a few witheh we will nume.

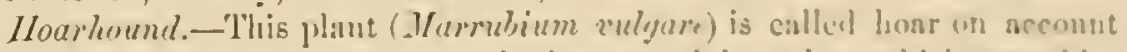
of the white, down growth upon the leaves nul branchus, which resembles

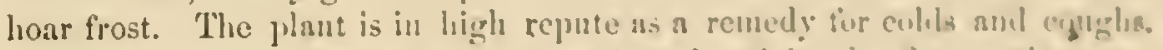

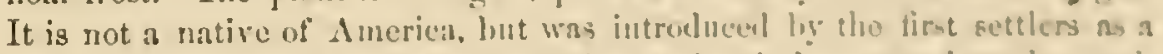
valuable medicinal plant, and from the farrlen it lass spreat to tho rome. side and fields in every fusorable loention, as it propagates realily fom the seed.

A good many other medicinal plants were intruslucel in the famo way a hoarhound by the New lingland pilgrims. Anomp then we may name lacender, from which spirits of lavender and oil of spike are make, alshongh

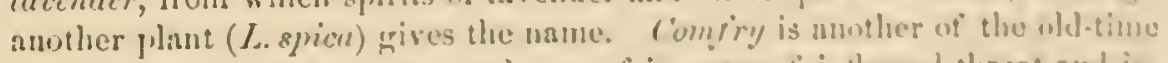
medicines that our ancestors male use of in eases of intamerl thron: an I i. . testincs, and for emollient poultices nul salsis.

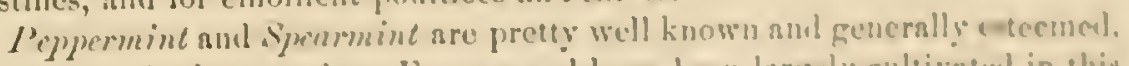
One, if not both, eome from boroper, anil lavo been largely cultivatul in this combry for tho vil which, when diluted, or "cut" with slenhul, forming 
essence of peppemint, is esteened as a remedy for flatulenee. Until the distillers of peppermint took to cheating by mixing oil of turpentine with their product, which spoiled the trade, the growing of peppermint was a good business in some of tle New England States; but since it has been so much injured by frand, it is not worth while for farmers to engage in its field culture at the present price of the oil, though it should be grown in gardens for family nse.

As a crop, this plant can be grown upon any moist, ricls soil; that which will prodnce good corn will grow peppermint. The land should be plowed deep, and it will be found adrantageous to use the sulsoil lifter, and the crop must he enltivated while the plants are small to keep the weeds down, and therefore slould be planted in rows eighteen inches apart. Spring is the best time to set ont a new plantation by offshoots or subdivision of old roots. The yield will be small the first year, and upon some land, after two or three years, it gets so full of grass as to render it necessary to turn the whole sod orer and let the mint crow up again, which it will do, and the process of turning under enriches the land. The mint is eut for distillation when in blossom, and we think yields from fifteen to twenty ponnds of oil per acre.

Tormwood is another imported plant, and is a very hardy perennial. Its leares, bruised and wet with vinegar, are esteemed a valuable application to sprains and bruises, and its bitter properties used to be esteemed as a tonic.

Balm, Saffron, Myssop, Lavender, Fennel, Bene, and Rosenary are all useful medicinal herbs to cultirate in gardens, and the following are grown for varions uses in cookery: Anise, Sweet Basil, Carraway, Coriamler, Dill, Fennel, Sweet MLarjoram, Summer Savory, Thyme, and Sage. The last is considered almost a necessity in some families, and is grown npon perennial loots. It is better, we think, to plant seed every year, and not keep the roots orel two years. All of the above-named herbs are grown by gardeners near cities to sell in market.

Parsley is another agrecable, sarory herb, much used as a gamish of meats on the table and scasoning of soups. It is casily grown in good garden mold. It is sometimes planted as a fringe for beds or walks in the garden. It is growi in some places for the roots, which are like small carrots, to feed to cattle. An ounce of seed is enough for a row two hundred fect long.

Peppers should always be grown in sufficient quantity for seasoning all soups and stews, as such is far healthier than pepper that we import.

The Long Cayenne is a very pungent sort, and grows up dwarf-stalks. The Cherry pepper is also a good dwarf sort. For pods to pickle green, grow the equash pepper, which has a tomato-shaped pod, rather mild, and very productive. The Sweet Mountain grows in a similar form, but much largel. The Sweet Spanish is the mildest of all for pickling or to eat green as a salad. 
Peppers slould be sown carly in light, warm soil in at sewal. bed, and trabs planted and manured witl guano water or hen-dung in sulution.

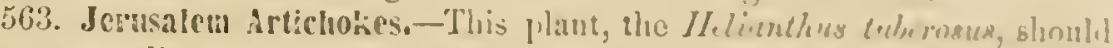
have a small comer in ererge garden, or somewlicre convenient ubuth the

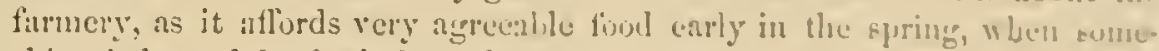

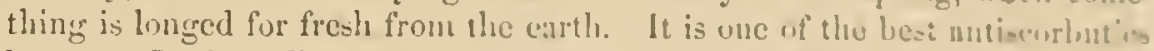

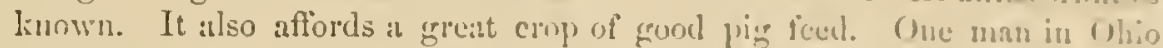
estimates the yield at the rate of 1,700 lushcls an acre. We recommen this plant as altogether prefurable for cultivation over the Chine-e yam. I)ioscorcre butatas, ahout which so much has been writtcu and said. " that is necessary to be knowu abont that plant we give in the next pars agraphl.

564. The Cunese Yam-This new esculent lias certainly ben te-tul longe onough in this country to deterune its true valuc for cultivation. "lhat is is palatalle and nutritions, when properly cooked, no one dunbs. 'Thut is woukl ever lic adopted as a substitute for tho cummun putato (Nidunus.

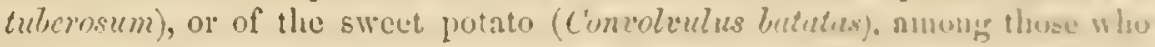
grow those roots as a sale crop, we have never lelieved, but have hoped that it miglit prove a valuable addition to our funily of lowet pruducing plants; but as yet we have not the evilence that this will be the case.

The Lomlon Gavileners' Chronide of September, 1sus, sabs uf the Cli. nese yau (Dioscorea bututes) that-

"Ilany exedlent results were obtaned last year in varinn parta of th. comutry, and gardeners begrin to understand the nature of this otunge prow duction, which, althongh provided for the fool of man, natnrally frows in the ground in sucls a way as to make it impossible fur lim to pull it up. It is now, too, arreed that the quality of the root, when properly coukical, i execllent.

"Wlicu first introdnech to Europo by the lirench, this enculcut was rew garded as a mere curiosity, and ualtrated accordingly: lut ercutualy such information concerning it was obtaned from M. de Montigny, frem l consul at Slianghac, as led to its receiving the attemtion due be at rout which mirght sume day be foumd groorl to cat.

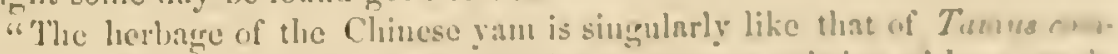

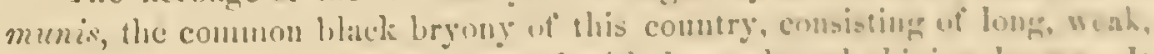

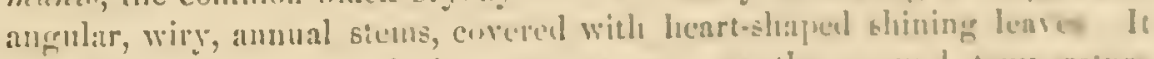

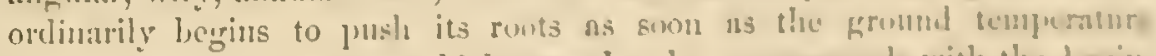

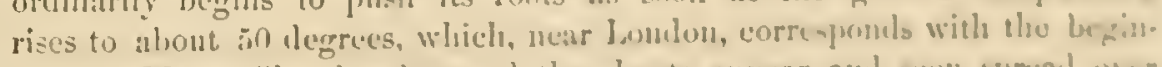

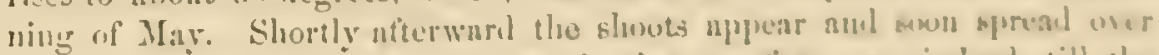
the surfice, not, however, with much vigur at first, nor, imlecel, till the month of dupust. The plant is evielently ocenpivel for numes we bo is making these true roots and preparing for the singular dendnpment of that

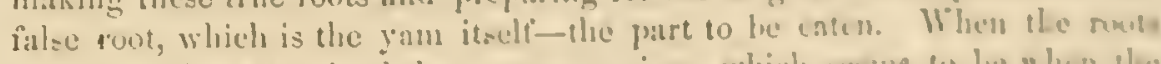

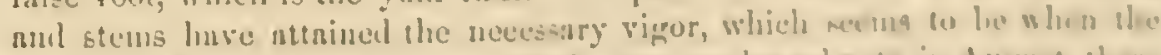

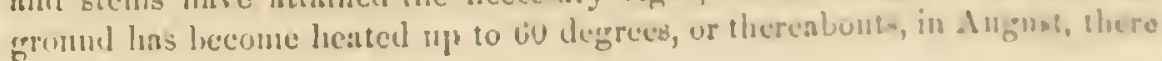


appears among the roots a soft, fleshy loom, which directs itself perpendicularly downward, and growing with considerable rapidity, soon becomes a club-shaped body, the small end of which is near the surlaee of the ground. This nuanmer of growth is exactly like that of the arrow-loot plant (I Larante. arundinacea), and contiunes until the cul of Oetober, when the yam is completed, and umder proper treatment will hare attained the length of from 15 to 24 inches, weighing about one pound. In France, specimens have been dug up weighing two and a half pounds, and measuring a yard in length. In its perfect state it resembles a very long trumpet gourd or a large parsnep, with the crown downward. The tail, which forms one third of the length, is cut off and dirided into incl lengths for propagation; the thicker part is caten. In the course of its downward growtl, the power of development is so great that the thick end will force its way into hard clay, and eren bury stones or fragments of pottery in its substance if its progress is snfficiently opposed. All obstacles ought to be carefully removed.

The best results in the cultivation of this yam lrave been obtained where tho temperature was highest, and the first oljeet of the gardener sliould be to obtain all the heat the sun can give lim in soil three feet deep.

The plant shonld be grown in ridges, made to run east and west, and rise eighteen inches abore the level, in earth trenched three feet deep. The yam will not be worth growing in poor or worm-out land, nor among stoues.

There is no donbt of one beneficial result from the attempt to cultivate this root, if the above directions are complied with. If it does not produce a profitable crop of yams, it will fit the gronnd most admirably for any other erop; and any man who has ever planted, grown, and gathered them, and afterward planted any otler crop upon the same ground, must be convineed of the advantage of deep cultivation, since the yams can not be extracted without digging two or three feet deep, which, even withont manure, is a most exeellent preparation for beets, carrots, parsneps, or anything else ever grown upon the farm, orchards included.

565. Swect Potatoes.-The first step in the cnltivation of sweet potatoes is to know how to spront them, as they are grown from sets, not from tubers planted in the lill. J. W. Tenbrook, of Rockville, Ind., published the following directions, which we eopy and approve.

"Arrangements should be made early in the winter to have frames and eorers made and seed potatoes, manure, and all necessary material for the hot-beds ready in due time.

"The potatoes slionld be kept in a warm, dry room, until they are plaeed in the hot-bed, which must be warm, as they will not bear a lower temperature than 40 degrees without injury.

"The location of the beds should be near a street or public road, on dry ground, with a southern inclination, and convenient to pond or branch water.

"The best material for a hot-bed is fresh horse-stable manure that lias not been rotted; and if mixed with one fourth to one half its bulk of either 
sawdust, fresh leaves, tan-bark, or straw, the heat would be more mild sud durable, and less liable to seald the putatocs.

"About the first or sceond week of April, in this latitule, lianl tho materials for the bed, and mis them together in a ridge where the level is to be male, and as soon as it is hot, shake it thoroughly, miximg the conhl and hot, wet and dry portions together, forming a hed on the top of the ground, running east nud west, which, when settled with the fork-not ranjhylshould be fourteen inclies high, more or less, as there is a greảer or hese from portion of manure used, and six inches wider on all sides than the trame to be placed orer it.

"Ilot-bed frames should be male of" two-inch oak plank, frnumel queperher at the conds with keys, so as to be easily taken apart and stured when mot in $11-\mathrm{e}$. They should not be over twenty fect in length, nor excecd four in willeh. The front, ol south side, should be eight inches high; the north, irom eightie to twenty, according to the slope of the gromml on which the leet stamly an tho top of the frame should have a pitch of eight 10 twedre inches to seceive the lieat of the sun, and to slied ofl the rain frecly. Tenporary berls are mato by setting slabs or plank on edge, and filling in the manure; but such beds are difticult to eover, and if used, the potatoes shonld not be laid withm six inelies of the sides. [See 595.]

"Cover the beds five inclues deep with the mellow earth, on which sut the fiancs and proceed to lay the potatues two inches aprart, with the top end of the potato toward the planks, and iunre them to the open nir. (ilansocovered hot-beds canse the plants to spring up tender and weak, and such plants do not grow, when set ont in the hill, like those raised in ofen luxts.

"The best eovers are made of strong viled unslin, tacked on lath, so that they can be rolled up conveniently. These covers will mlmit the light, blut off the ran, and bo cheaper in the cull than uther cosering, nnd sutlieicutly warm except in extrencly cold weather, when strnw or bome warm fouvering should be thrown over them. Trampled straw, or mats malo of rye strum, answer in the absence of better coretring.

"The beds shonld be watered in the crening with a suitable watering jwh to keep the earth in a good growing condition. If spring or well waser is

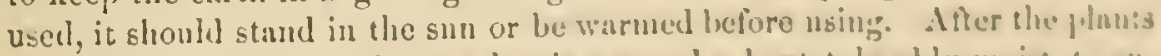

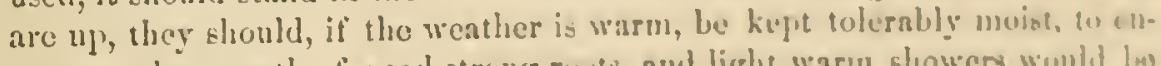
courage the growth of good strong ronts, and light, warm showers wemlit ho better than watering, but cold nul husy rains must be guarked aoninne, as they woukl soak into the beis and rnin thenu.

"Ditches should he formed around the locks, and the earth thrown up to keep the water from ruming under mol chilling then.

"Whan the plants aro threo inclues high, wul well sonted, they are reslo to pull, which is performed lyg suking hold of the plants with the thumb and foretingere of onc linmel, while the potane is hehl tirmly in its pluce wish the other. Curcless drawing, ly incxperienced perowns, ireynently destrons half the prefits of their beds. 
"When plants are to be sent a distance, they shonld be set in slrallow boxes, with their roots in wet earth or moss, but they must not be packed in wet weather, nor have their leaves wet, or they will rot immediately. Plants unay be taken off the beds and preserved in a cave or cellar for a week or fhore, with their roots packed in damp moss or eartl, if not packed too elose.

"If by bedding too early, or crowding, the plants should grow long and slender, they may be cut down to two or three inches in lengtli; but this shonld be aroided by griving plenty of room and air, and by working the earth in among the roots with the fingers as it is lifted up by the plants, and settling it by watering."

The best ground to grow a crop of sweet potatoes upon is sand, enriched witl very well-rotted mannre, leaf-mold, fine compost, gruano, or superphosphate. The hills are rounded up like monnds, a foot or more high. All who live upon sandy land, sonth of latitnde 41 degrees, can grow a few sweet potatoes in the garden, if not as a field erop. They are best preserved by packing in cut straw, in barrels, set in a stove-heated room, where the thermometer never will sink below 40 degrees, and rarely rise above 60 degrees. See 435 .

566. Hot Water for Seeds.-There are many sceds which may be greatly quickened in their regetating powers by the nse of hot water. Onion-seed, for instance, may be made to spront upon the instant by pouring boiling water upon it. You need not fear killing it. Put some in a sancer, and pour on water from a tea-kettle, and after a half minute pour it off again, and you may see the spronts slooting out the next minute; and if then planted, while hot and moist, in pulverulent earth, closely packed upon them, you will get them forward two or three weeks earliel. The same effeet will be produced upon all black, hard-shelled seed, sucl as onion, asparagus, sunflower, water-melon, apple, and many others. Locust.seed shonld be thoroughly scalded in boiling-hot lye, or several repetitious of hot water.

567. Cranberries in the Garden.-Cranberries have been so long looked upon as wild plants of swamps, that it is difficnlt for people to realize that they can be grown in gardens as well as strawberries, which are naturally a wild field growth.

Cranberries do maturally grow in swamps, bnt they may be made to grow artificially in good loamy garden soil, or that which is naturally a little mucky, such as is the most snitable for potatoes, if deeply worlied. The bcet soil, however, for cranberries, is almost pure sand, with water naturally standing, or percolating through it, within less than two feet of the surface. A bed occupying one rod and two fifths, in the garden of Cliarles B. Phelps, Colebrook, Conn., planted in June, 1S57, yielded three bushels in 1860 . The rines were taken from a natural bed, and set in small tufts, one foot apart in the rows, which were two feet apart, and these were kept clear of weeds until the whole ground became matted with vines. The bed then 
will continue longer in bearing than any bel of strawberries, withont conricling the eoil.

The eranberry is a semi-aquatic slender evergreen, content to oceupy that part of a farm which is too low and too wet io he userl for any obluer purpose, and is satisfied to feed on water, and the slighly nlluvinl deprosits afforded by the aljaecnt highliands, and does not, like sume oserorown annul plants, make heary drafts upon the soil.

For field culture of erubbries, all that we have said lice will be almost equally applicable, but the subject is trented more at largo in $\mathrm{X}$. Tin.

56S. Ninmber of Trees, Plants, or Rows to an Acre.-The following talules will aid any one in determining how many trees or plants he can grow upon one aere, which contains 43,560 superficial fect:

No. of feel apart.
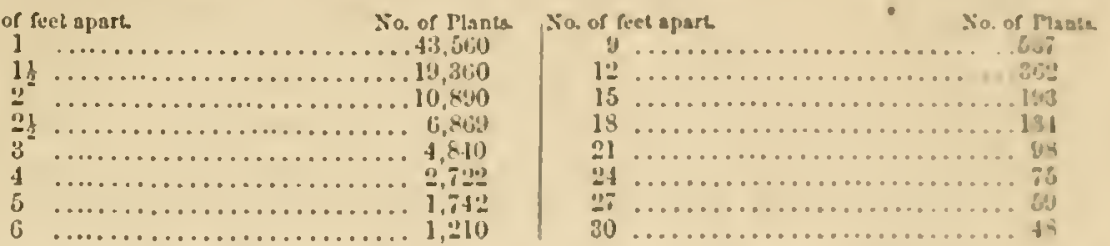

The following table shows the number of rows, of different widils, in a square aere, and number of plants an aere contains :

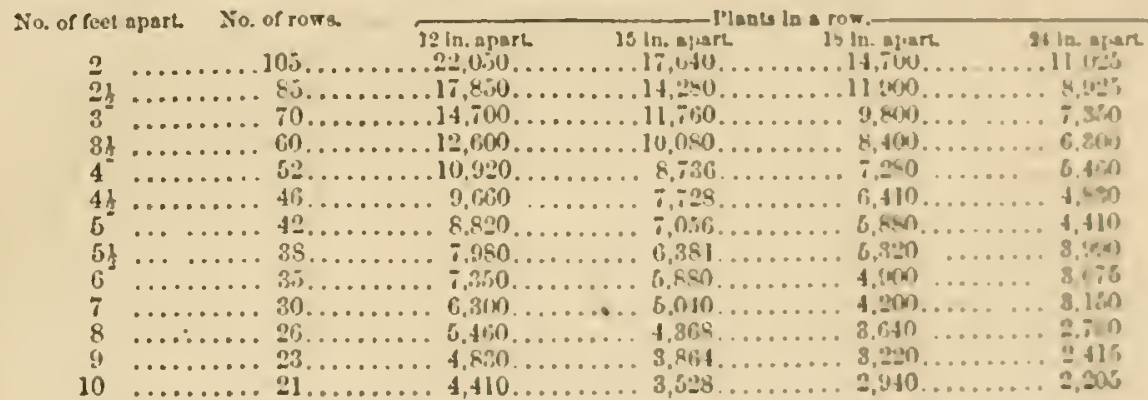

It is a conunon practice to measuro an ncre thirteen rods cach way; that gives an cxcess of nine rods. At the South, it is common to mensure seremis yads each way for an acre, which is mexcess of uto garls. In calcularing the number of plants per acre, set four leet apart-for instance, cabbage it is common to say" ten thousind per ace. "lhis nllows nearly nine humbleal missing plants. In garden work llese rules will always he nseful. 


\section{SECTION XXXI.-THE FLOWFR-GARDEN-VARIETIES AND CULTIVA-} TION OF FLOWERS.

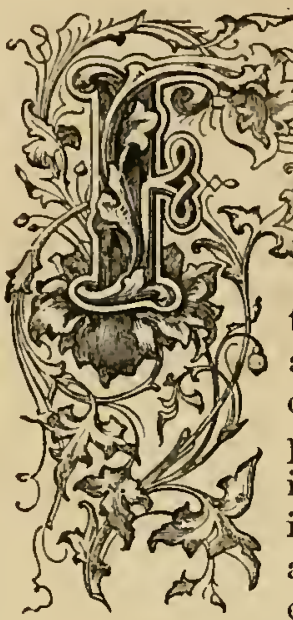

IRST, let ins talk a little about the moral influenee of flower culture. We are just as well satisfied of the beneficial moral effects of flower enltivation, as we are that the effects of their beauty upon the senses of nearly all beholders is pleasing. A mother who loves flowers is apt to infuse the same feeling into her children. $\Lambda$ love of flowers is a love of the beautiful; a love of the beantiful is a love of the good; and so step by step the child walks in the pleasant paths of love, till its mind becones thoronghly imbued with all the sentinents of moral goodness. There is no spot on the farm that grows such a "paying crop" as the little parterre near the dwelling, devoted to the cultivation of flowers. If it does not pay in golden coin, it does in all that makes life worth staying here for. What golden hours of joy are spent by the family in the flower-garden! What blessed influences such hours have upon the character of ehildreu! If you doubt the moral influence of flowers, look about you, and study the character of those who enltivate them in contrast with those who do not. We have long sinee scttled the question of the beneficial influences of flowers upon all families, sud therefore devote a little space to give, upon this subject, some very nsefill information.

569. Suitable Soil for a Flower-Garden,-Upon the subject of soil, we copy from the catalogue of Benjamin $\pi$. Bliss, of Springfield, Mrass., one of the most suecessful eultivators and sellers of flower-seeds in the United States, the following sensible observations:

"The soil best adapted to flowering-plants generally is a light friable loam, containing a moderate amount of vegetable matter, and sufficient sand to render it porous; but as it rarely liappens that the amateur has much choice of soil, it is fortunate that most of them will suceced in any but such as is of an extremely dry, sandy, or ealcareous nature, or of a stiff, lieavy, retentive character. In the former, the plants are sure to be starved, and in the latter, if they erer fairly take root, there is generally an undue development of the foliage at the expense of the flowers. In soils of this deseription much may be done by thoroughly breaking up the superficial er'nst, or, as it is technically termed, 'trenching' it at least one spade deep, digging in sharp sand or road-serapings, and if the operation be performed in autumn, so that the loosened soil is thoroughly exposed dnring the winter to the disintegrating influences of frost and other atmospheric agencies, the ad vantage will be greatly increased. 


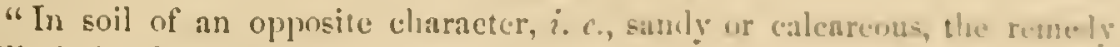
will obvionsly consist in the adelition of luam, in conjunctiun with reraveil leaves or old rotten manure; or where expesse is no object, the surface mab be cutirely remowed to the depth of eiglte or tom inches, and its flace buj plied with the best loany compust at haud. 'The use of strong crud. manu of an animal nature s!onld he aroided. In orlinarily gonsl soil un anmus light dressing of leaf-mold, decayed tuff, or thorunglyly rote? แmunte, in quantities proportioned to the jeipurements of the sail, clug an the depul of a few inches, will he all that is requisite. These shoull be applied in spribu. only just previous to sowing the sceds, or much of the benefit resuleing from their application will be lost, though a single digging may bo adrantagerusly given in autumn. In preparing the bels, care must be taken that they ase so arranged that the reromel may be a little clesated in the mildle, that sho water may rum ofl and the plants show to a better advaminge.

"It is particularly repuisite that seeds slioulel not he furn tom deap, whenee arises most of the failures of inexperienceal gardeners. The de pith at which seeds are sown will vary with their size; large secelt, such as thene of the Lupins, Sweet Pea, or Marvel of l'eru, may be three quarters of an

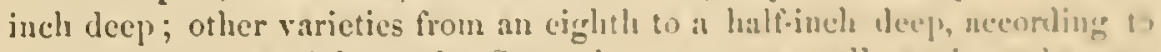
the size or nature of the secel. Some llat are very small recjuire to lie form on the actual surface, a slight gressure beiug thes snfticient to iubed theon to a proper depth. For the majority of the sceds at very thin covering sulitecs; if" sowed too deep, they are longer in geminating, and the small ome are liable to decuy. It sometimes insures a more even distrihmtin of very amall seeds, such as those of Campanula, Digimlis, etc., it they are intiundely" mixed betore sowing with a little fuc, dry fuil, the mixture lueing som the same way as the seeds. Woolly sceds, which alliere to ench ofluer, like the Globe Amaranthe, ete., should be rubbed with a linle tine sumd, ublich will generally separate them. In all cases, the more thinly the enewls aro strewn the better; when tro thickly sown, the secdlings becoune thots gated and sickly, an evil which no subsuducut thinning out will autirely remedy.

"If" the soil be dry and the weather sumby, it will he necesary to wa"r the seeds slight] from a very fine ro-e watering-put. lian-water is pre! ro

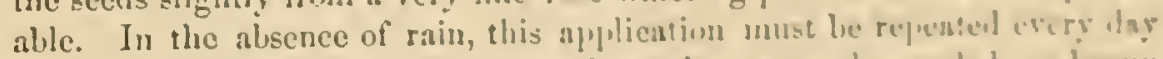
or two, for it is important to obscrse that, when onece the sects have he gan to swell, they aro peculinrly su-ceptilile to jujury from elronth, und will spe 3 .

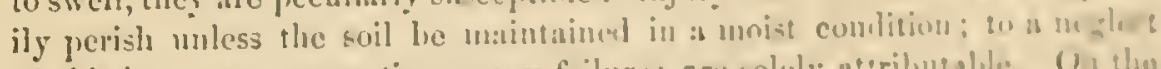
of this important precaution, many fathres are solely ntirihutalile. (H) tho

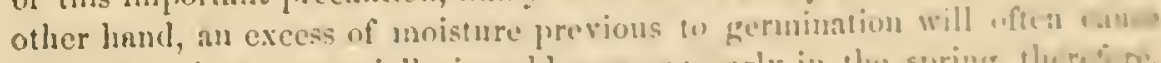

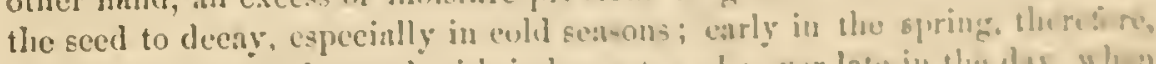
the water-pot must be used with juelgurent, and never late in the das, wh a frosts thrcaten."

Wo have fund the practice of warming water in the sun or lye fire heat

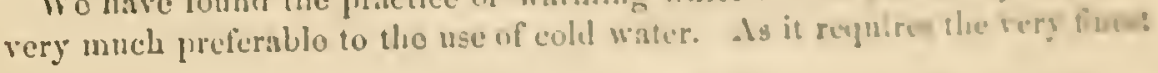


preparation of soil, we reeommend all who sow the most delieate flowerseeds to sift the earth throngl a sieve fine enough for corn-meal.

570. llow to Make a Flower-Bed.-The following extract, from a paper read before the Farmers' Club, tells how the author made a flower-bed upon a rery hard, rougl spot.

"I do not expect to tell a professed gardener, nor an amateur who already knows how, anything new; but I wish to tell some who do not know, how to make a flower-bed. At least I will tell low I make one, and leave it to others to follow suit or not, just as they ean afford. I receired, May 10tl, a package of choice flower-seeds, and a dozen bulbs of Gladiolus. As the old flower-lieds had already been appropriated, new ones must be made; and as there is always a right place relative to the house and other things, the right place in the present instanee fell in a very bad place-on a spot of sod just beneath the window that gires light to my writing-desk and book-ease. Here I marked out the forms of my beds in shapes to suit the ground, and not like any diagram laid down in the books. I first took ont a spading, as deep as I could drive the spading-fork, breaking up the turf and the remains of a mortar-bed left last antumn by the masons. This first spading and the loose earth left I threw one side, and the next spadedeep the other side. Then I took ont another spade-deep and carted it away, and all the stones, and that not a few, and then broke up another course still deeper, and then threw back the seeond spading, and then the first, forking it all over loose and mellow. Next I put in a heary eharge of rich manure, and orer that garden-mold and leaf-mold, mixing all up and raking fine. Next I put a coat of sand, and then rich garden-mold, old rotted sods, and leaf-mold, mixed and sifted. Now the bed was ready for the seeds, and after being marked off to suit the faney of her who does the planting, they were covered by sifting earth orer them, and watered. It is true this was a laborions job, but onee done, it is done forever. Here is a bed of earth, rich and mellow as an ash-heap, more than thirty inches deep, with a subsoil of coarse sand, gravel, and decayed granite roek, that gives good drainage. It will require only an annual dressing of compost, and a light forking and raking, to keep it in order to produce the most lovely ornament that ever added beanty to a farm-house- a beautiful bed of flowers. Early this spring-almost as soon as the snow was away-there eame, first the little crocuses, and these were followed by the hyaeinths, and tulips, and dielytra speetabilis-beauty upon beauty, enough to pay richly for all the labor of making a flowerbed.

"What man with a head a whit better than a pumpkin or a eabbage-head would devcte his whole sonl to food regetables, and refuse his family the gratifieation and cheap happiness of a flower-bed?

"What woman with a soul above soft-soap and serubbing-brushes, that would live in a country home and not insist upon 'woman's right' to hare a flower-bed-ah ! to have her house surrounded with flowers, blooming from spring till snow comes again?" 
571. Cultivation of Iardy dumuals,-Hardy astanals are tlooso plast: that flower and ripen their fruits and perish in one senson, but many of sheon may be sown in antumn to flower early the next year. Marely numal, grow withont artificial heat, and come to pertection in the npen grousuls; but what are known as half hardy plants secl prishing a lisle, excepes in very favorable localitics. Tender and small sected varieties sometimes inil, not on account of the had growing propertics of tho seeds, bus kuldy trum bad management. Delicate seeds, like the Calceolaria, or Chinese primrobe, must not be sown in the open gromml. Ono proty complaincel stast -omo fine seeds failed to grow which were sown from nno to two inclues deepliterally huried. The most incxperienced in gardening inatsers can sow nwee: peas, but it repuires a praticed hasd to look after such delicate sce ls as Calccolaria, Cineraria, Fuchsia, and suclı like.

Many persons think that when they make a hole in the soil with a irnucl, and throw in such small seed as Mignonette, that it should be sure fo grow: and it it does not, they lay the hlane upon the seed, whes in mise ense's ont of ten the fanlt is in sowing too decp. Tho proper deple for planting th swer

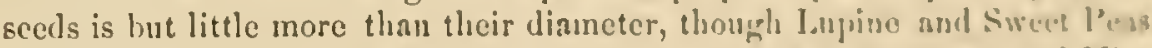
may be planted ono inch deep; but such sinall secels as l'urtulaca und Mi :nonette require to be sown almost upon the surfince of the suil. Simbe sed are diffienlt to germinate. Cypuess seed require to lu soaken in warm wa. ter about one hour. The ecels of the Globe Amarandhus are covered with a thick woolly substance, which greatly retards germination, and if plan without soaking, few, if any, will come up. 'The nust convenient moflom of sowing anmuls is to take a round-pointed stick, with which draw a circle six or ciglat juclies in dianeter, and from nu eights of an incls 10 an inclu deep, according to the sire of the seed to be sown, placing a lahel wish the name in the conter. The labels ought to be five or six inclues lomp. frain', l white, and marked with a lead pencil before the paint geta dry; in thin wy the nane will last a long time. Iarkspurs, and many of tho laarely na. when sown late in sutumu, lic domant all winter, therely muhus much stronger plants, and flowering carlier than llose sows in spring. The dwart Rocket Lartispurs, when suwn on tho celges of tho Inrdes, jo cess a beantitul sights with their varions culors; the becel repulures to he fam in October, and protected hy a slight covering of straw during winter. l'b ox Drummondia are of all shades and coloris; shey delight in a mul 1 amed

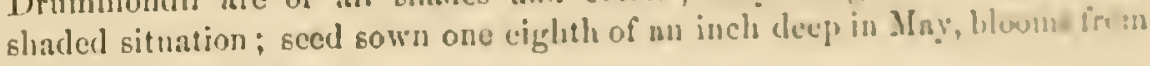
June until Oetoloer.

572. LIst of choice Annuals.-Tho following choico list of harely anmuale

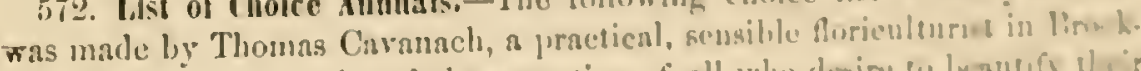
lyn, N.Y. It is worthy of tho sttention of all who desire su lnausfs th is homestead.

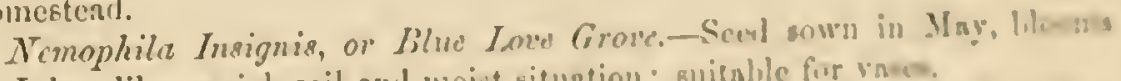
in July; likes a rich soil and moist situntion; suibule fur vans.

Abronia Umbellaka. - A very pretly annusl, with lung tratinn oituns 
bearing beantiful lilac and white flowers; very fragrant suitable for vases; seed may be sown carly in $\Lambda$ pril, flowering in June.

Aster Chinensis, or China Aster.-This beantiful anmul comprises over twenty-five different varieties. Truffaut's, for general cultivation, is the best, on account of the beauty of its flowers and variety of their colors; seeds sown in the open gromnd in May, in rich soil. All single or semi-clonble flowers should be pulled up and thrown away.

Calliopsis, or Coreopsis.-This is a very showy annual-fonteen different varieties; flowers, bright yellow, mottled with a rieh velvety erimson, highly ornamental; seed may be sown in October or early in April; easily trausplanted.

Balsam, or Lady's Slipper.-A well-known tender annual. The camelia-flowered contains twelve varieties, of all slades and eolors, varionsly striped and mottled. Seed sown in the open ground in the latter part of May. To have them early, seed should be sown in pots in the louse in April, and transplanted to the garden when four inches high. Plant singly, pulling up all semi-donble or single flowers.

Cuphec Platycentra.-A very pretty annual or green-house perennial, with scarlet and purple flowers, suitable for vases; flowering all summer, and in winter, if taken up in antmm and kept in the house; sown in pots in the lionse in April. Plants may be procured from any florist for a trifle.

Cypress Tine.-A splendid running vine, delicate foliage, bright erimson flowers, of a star shape; Alba, pure white. Seed sown in the latter part of May; likes a rich soil. A very ormamental pyramid may be made by setting a straight pole in the ground six or eight feet high, surrounded by a hoop three or four feet in diameter, fastened to the ground with three pegs; rum strings from the top of the pole to the hoop. Sow the seed ontside of the hoop. It may also be trained over arches or vases.

Lathyrus Odoratus, or Sweet Pea.-One of the prettiest and most fragrant of the popular annuals which ornament the flower-garden. The sweet pea grows fom or five feet high in rich soil. The plants shonld be tied to a stake or an old tree. Sow the seed in April ; flowers in July.

Ageratum Mexicanum.-A half hardy annual, with light blue flowers. Seed sown in May; flowers in July, blooming profusely until killed by the frost.

Alyssum Maritimum, or Sweet Alyssum.-This is a hardy annual, growing one foot high; flowers white; very fragrant. Seed may be sown in autumn or early in spring.

Cacalia, or Scarlet Tassel Flower.-A very pretty annual, with searlet and orange tassel-shaped flowers. Seed sown first of May; blooms from July until Oetober.

Eschscholtzia California, or California Gold Flower.-Flowers bright yellow, very showy. This, with slight protection during winter, will flower the seeond season; blooms from June until October.

Clarkia Elegans.-A hardy annual, very showy. Seed sown in Septem- 
bel flowers much letter than when sown in spring. For spring eoring, plant carly in April, in poor soil.

Mirabilis Jalapa-commonly called Four.0'clock, from its lialit of opening its flowers about that time in the niternoon. Mirclilis is a latin word for wonderful. The roots of this plant, when dricd, form the princigal constituent of the jalap of druggists. It is gencrally considered nu ammul; it lias a lauge tuberous root which, if taken up in Octoluer, aud Eiurul in a dry cellar, will flower the second season. Seed sown in April; tluwers in June.

Scaliosa, or Dfouming Bride. $\mathrm{\Lambda}$ varicty of colors, from $\mathrm{n}$ jet black to $\mathrm{s}$ deep lilac. Seed sown ju May; blooms in the latter part of Junc.

Zinnia Elegans.-One of the most showy aununls in cultivation; Aluwers, brilliant ecarlet, white, orange, and light purple. The new douhle-flowereal Zinniaforms a heautiful addition to this class of annual tlowers. The thwers resemble the double French marigold; they will bear traneplantiug. Sext sown in May; blooms in July.

Clintonic Elegans.-A beautitul, tender annual, covered witl deep-lulue flowers; grows about six inches high. Seed sown in IIay, in light, rich suil; blooms in July and $\Lambda$ ngrust.

Gomphena Globosa, or Globe Amaranthus.-löive diflerent colors; tho secls are rather diflicult to veretate; they rerpuire to lie soaked in warru water. The flowers, if gathered and kept in at dry jlace, will retain lluir color for several years. Seed sown in Miy.

Mignonctle is onc of the swcelest of the aumuals. Thousands of pots of $i t$ are sold annually in the markets of P'uris and London. It has been fonnd growing upon the walls of ruins nea l'aris, springing from cvery cresiev where the seed could gemmate, and scenting the air with its frngrance. The mignonette is of rery casy culture; in rich soil it grows luxurianely. but with pone flowers, that hare little or no frngrance; but in poor soil the thus: ers will be large and very fragrant. When once the seeds nre plasted, it will retain possession of the soil, springing up year after year. Seed som in May almost mpon the surface of the soil.

Among the curious ammals is the Mimosa, or Sinsifive I'lant. Sired sown in the open ground in May, in rich suil. This singular plant, at the slightest touch, eloses its leares.

" Henk with nlee rense the charte iniranas aturits.

from encls rule louch willufraws her tenuler lande."

Mesembryanthemum, or Jee Plant. - This curious plant lins thick lenses, which have the appearance of heing covered witl ice; verg ormanental sur vases. Seed sown in Mny.

Loasa Acanthifolia. - A ruming vine, coserel with curious yellow then: ets; the stem and leaves are covered with liain or suall brintem, which, upon leing tonched, leave a stinging scusatiun sinilar to nettles. Sievl sown in May.

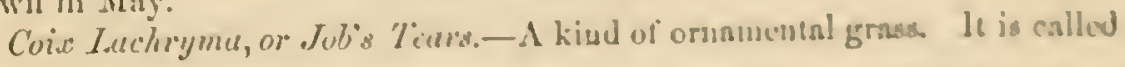


Jol's tears on account of its shining, pearly seed, which, by a considerable stretch of the imagination, may be likened to a falling tear. Seed sown in May lialf an incli deep.

The Avena, or Animated Oat, is a curiosity. When the seeds hare fallen off, their strong beard is so sensitive to the rarious changes of the atmospliere, that they are continually in motion, like some insect crawling on the ground. Seed sown in April.

Anagalies, or Pimpernel.-A dwarf-trailing plant, with blue and pink flowers. The anarallis has been termed the Poor Man's Barometer. Not the pimpernel alone closes its flowers when exposed to dainp air, but many other plants are equally sensitive. Stellaria Media, or Chickuced, and many others, shut their flowers upon the approach of rain.

Another gardener gives the following list as a choiee selection for a small garden :

Alyssum Maritinum-Sweet Alyssum.-A rery desirable dwarf annual, with small, white, honey-scented flowers in great profusion, blooms for a long time.

Asters.-Showy, hardy annuals. The fine German and French asters are certainly among the finest flowers we have.

Bulsams.-The camelia-flowered balsams are most beautiful, and rery desirable.

Cucalia, or Tassel Flower.

Calliopsis, or Coreopsis.-Very showy and rich.

Candytuft.-A large quantity should be grown of this plant for bouquers. Clarkia.

Eschscholtzia.-Very showy and handsome.

Everlasting Flower.-Fine for winter bonquets.

Four-o'clocks.-A well-linown plant, desirable in large gardens.

Globe Amaranthus.-Excellent for winter bouquets.

Jacobea, or Senecio.-Very pretty.

Marigold.-The dwarf varieties are pretty.

Mignonette.-Sow plenty of this for bouquets.

ITasturtiums.-The dwarf varieties mucli resemble Tom Thumb geraniums, and are very desirable.

Nemophila, or Love Grove.-Plants with very small but pretty flowers. Dwarf.

Petunias.- -1 mong the very best plants; of easy culture, and flowering profusely the whole season.

Phlox Drummondii.-The very best annual; of long duration in bloom, rieh in color, excellent for bonquets; unequaled in all respects, in my estimation.

Poppies.-Very showy, and great variety.

- Portulaca.-One of the best annuals.

Scabiosa, or DLourning Bride.-Showy.

Stocks,-Many annual varieties are cultivated, and are rery desirable.

Sweet Sultan.-Quite pretty.

Whitlavia.-A very beantiful blue flowering annual.

Zinnia.-Very showy, free flowering plants.

573. Hardy Flowering Ilerbaccous Plants.-The following list gires a good 
assortment of some of the most desirable hardy flowering plants, sume of which grow and bloom in leanty erey year witl atmost no care. of course the list can be greatly cxtended, or seluctions can lue umle from this and others to suit each taste. To many who in not know what is bulect. these lists will be useful gurdes. We will brietly notice sume of the mo ? desirable sorts.

Achillea Ptamica.-Of the double-flowering "ariety, dwarf, continues in bloom a long tiune, good for bouquets, flowers small, of a pure while.

Aconite.-Monkshood, mostly with blue flowers; vurions lifigh.

Althea Rosea.-Mollyhoch, dumblo varietics, very henuriful, sll culore; six or seren fect high.

Anemone Japonica.-Japanese Wind-flower, purplisli red flowers. donlile; about two feet in hight. high.

Baptisice Australis.-False Indigo, fine bluo flowers: wo to three fu:

Campanula.-Bell-flower, many varieties, with white and bluo slowen: rarious hights, all pretty.

Delplinium.-Larksjur, one of the best herbaceons plante, with fino bluo or white flowers. D. formosum and grandifloum are the best.

Dictammus Fraximella, or Gas plaut.

Dielytra, or Dicentre Spectabilis.-The very finest herbsceons plant.

Funkia, or Day lily, many varietics; all desirable.

Iris, or fleur de lis (flower de luee).

Lychnis Chalcedonich.-The double variety has splendil scarlet flomers.

Phloxes.-A splendid class of plants, all beartiful, withont any execpion.

Pyrethrum.-Feverfew, double white llowers, very nent and jretey.

Spirea.-Meadow Sweet, many rarictics, all desirable.

Tratescantia.-Spiderwort, with white, hlue, or red tlowers, very jretty.

Talerian.-A tall-growing plant, with fragrant white tlowers.

Tiole Oclorata.-Sweet Violet, very fragrumt.

Chrysenthemum.- Inch injproved of iate years, and in several varietio, is one of the most desirnble of hardy flowering plants, and is very unde loved wherever known. It is one of the very last to flower and cheer us with its many-headed blossoms for the last three months of the departing year, when most other plants lave gone their way. Then, masin, it is one of the very best window plants. It not only flnurishes, hut lusuriates indoors, if properly cared for. As florn! ornaments for the green-houso ant conservatory, they are unsurpassed.

To get carly flowers from elirysanthemum soed-plants, yon must fow the

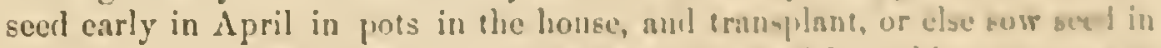
a very nicely prepared waru bel in May. lic carthl to thin ont, so na to give ample room for the planta to branch nut.

5it. Bulbous Flowering liants. - Tho earlise flowen of the garlen como from bulbs planted in nutumn. In a weil.prepared lowl, niculy shelurenl with a cont of leaves, the crocuse: bengin to bluom aluont as somen as tho 
covering is removed, after the frost is ont of the gronnd. All tender bulbs and perennials under a coating of leaves will keep somnd till spring. It is necessary to lay brush or something else over the leaves, to hinder their blowing away by the winds. Leaves make the best kind of covering for all tender things. Frost rarely penetrates throngl a thick coating of them, as may be seen during our most severe weather; by removing a bed of leares the ground will be found unfrozen.

There is 110 sight more striking to the eye than the effect produced in early spring, when delicate snowdrops and the modest, many-colored crocuses enamel the lawn, or make the garden lovely with their staintess purity, and with the brilliancy of their colors. Coming, as they do, before the swallow, these firstlings of the season have a special claim to the popular regard. They are the harbingers of buds and blossoms, of leafy trees and unbound waters, of sunshine and of singing birds, and when their tender green spears begin to push themselves throngh the soil, we know that nature is awakening fiom her winter slumbers, and that more genial weather is at hand. These little pilgrims tbat come to us with glad tidings, and that put on for our delight the gayest robes, and silently, yet eloquently, assure us that we are entering upon a new cycle of soft sunshine, and bland airs, and fragrant odors, deserve to be more eherished than they usually are by all comntrywomen. Of' all the flowers that bloom, those that come to us earliest are entitled to receire the most cordial welcome, and it is for this that we appeal in behalf of the more general culture of bulbous flowers.

We appeal to all farmer's' wives and daughters for a more general cultivation of flower gardens and parterres around the house, because we beliere in their humanizing influences; in the lessous they teach, and the sympathies to which they appeal. We believe every family who has ground should cultivate IIyacinths, Tulips, Jonquils, Crocus, Crown Imperials, Iris, Snowdrops, Polyanthus, Narcissus, Double Narcissus, Lilies, Gladiolus, and Dalilias. To these add Peonies, Dielytra (Dicentra) Spectabilis, and many other hardy herbaceous plants, such as Hollyhocks and the Pliloxes, Tucca filamentosa, ete.

Of all the bulbons flowering plants, the gladiolus takes the lead, according to our fancy. The varieties of $G$.gandavensis are numerous, robust, stately, with beautiful taper leaves of bright green, and long raeemes of exquisitely beantiful lily-shaped flowers, comprising every variety of shade of colors, which can be kept up by timely planting from July to October in the open air; and then, before hard frosts come, if stalks with undereloped luds are cut and set in water in the house, they will continue to bloom some time longer. The bulbs must be taken up for winter, and need about the same protection as onions.

Several bulbs, hyacinths in particular, may be grown in any room where water will not freeze, in glasses adapted to the purpose, so that the bulb rests in the mouth of the glass, and sends its roots down into the water. Dark-colored glasses are preferable to white glass. The water should not 
be allowed to rise more than to toneh the hotton of the bull,; otherwiso they will rot. When furst put in glasses, lhey should le storel awny in a dark, cool place, till the roots are about an inch loner. If the rons du mot grow vigorously, give two or three drops of liartshorn in each fresh supply of water, and put in the grlass a small lump of chareval. The waic shonlu be changed every fortnight, or three weeks itt liarthest; but to do this the plant must not be taken out, but the grass held horizuntally, aml the water poured off. Soft or rain-water should always be used. Iiy this morle ul treatment, and not kecping them in 200 warm or close a jilnce, they will bloom beantifully.

They may also be grown in the house in pots, in the open light and air. The bottom of the pot slsould have plenty of broken siles in it to allow of perfect dlainage, and be frequently, but unoderately, suppliul with water. Do not stand the pots in saneers of water.

575. The Ilollyhock is a fune flower to grow in clumps about a lawn, and may" be made perennial by not allowing the stalks to ripen seeds. Is there have leen great improvements inade in these llowers, we anuex the nanes that two dozen fine sorts are known by among seelsusen.

576. Select List of Hollyhoclis.-1. Anak (Birchan).-Crimsm; tluwers of a fine form and full.

2. Iilack: Prince (Gibbon). - Flowers large and rery domisle; Ulack.

3. Jiennus (Birchan).-Light erimson; a tiuc, slowy variety.

4. Charles Baron (Chater).-Flowcrs very large and tull; culor pink, sliadel with salmon.

5. Beauty of Chestnut (Paul).-Flowers of a iery tine form: spiku .osig? and beautifully furnished with flowers of a beansiful hright rosy real; in icy fise rariety.

6. Charles Turner (Black).-Spike rery closo; thwers of tine form, large, and of good substanee; color decp crimson; extra tine.

7. Commander-in-Chiof (Baron).-Flowers large nnd sluwy ; dark-rexl.

S. Kiva (loake).-Flowers large, shape rery tine: culor prench.

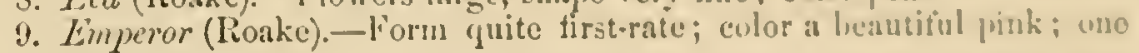
of the linest.

10. Ficlicia (Birchan).-Flowers and spike of excellent furm nml substance; color anctlyst; extra.

11. General Lem (Veiteli).-Spiko very line, llowers till size: colo: briglit red.

12. Ilon. Mrs. Ashley (linake).-Flowers medium-sized, of great ulepeh, and very double; color a deliente peach.

13. Lilac Model (Chater).-lolowers inedium-sized, full, nud of boul bubstance.

14. Mrs. Foster (Turner). - I noblo spike; tlowers large, vi tirst-rnto form; color heautiful lightit ruse.

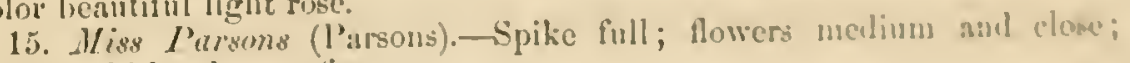
colol pinkish salınon; time.

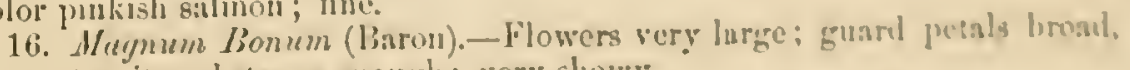
but not plute substanco inounh; very showy.

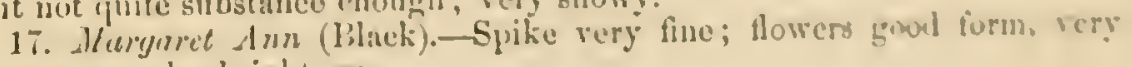
compact; culur bright rose. 
1S. Model of Perfection (Baron).-Many better models at the present day; color creamy white.

19. Susannah (Veitch).--Flowers medium-sized and moderately smooth; color creamy white.

20. Pypramid (Parsons).-Flower medium-șized; spike close and good; color buff.

21. Poupre de Tyre (Bircham).-A noble spike; flowers large and free; color rich dark-purple; a first-rate variety.

22. Penelope (Bircham). - A very showy and beautiful variety; color fine rose.

23. Walden Gem (Chater).- Spike very fine; flowers large and of fine forn ; color deep crimson.

24. Minnie Gray (Loring).-Size medium, form good; eolor white.

As these have all been produced by planting seeds, and saving none but the finest flowering plants, we recommend a continuance of the practice by all who grow lollyliocks.

577. The Verbena is an alnost indispensable plant in lawns, it is so pretty to fill up eut figures in the sward. The name, verbena, is an unmeaning one, being derived from the Latin herba, which means any low, spreading plant. This plant has been very long in cultivation, and it was used in ancient times in some of the sacred eeremonies, the altars and priests' heads being wreathed with rerbenas. Celsus speaks of the use of verbenas as a febrifuge in sickness, but it is doubtful whetler it was the same plant known now by this name. The verbena is indigenous in the country, of Buenos Ayres, and was talien from there to England in 1825, and to this country ten years later, by Robert Buist, of Philadelphia. Now it is known everywhere and is everywhere a favorite, as its cultivation is simple, and its lowcreeping habit and pretty flowers will keep it in favor until some new rival comes to take its place. It flourishes best in sandy, rich loam, in gardenbeds, and blooms from midsummer till late in antumn, and if potted, continues in bloom through the winter. Verbenas do not require frequent watering; they will grow upon very dry ground, and wet in exeess mildews and injures them. For pots, take half-and-half leaf-mold and good loam, and add sand enough to give a preponderance of sand in the whole mixture. As it is naturally a running plant, it must be cultivated in that way, and not, as we have seen it, with stiff, upright stems. Nothing is more easy than producing new varieties of colors in verbenas. We have only to grow seedlings and select the best and cast away the remainder. All colors, exeept light-blue and jellow, have been obtained. The following are the names of a few of the latest new rarieties, with their characteristics annexed :

Giant of Battles.-Flower and truss large, habit good, foliage large; color dark-scarlet, with purplish eye; a new imported variety.

Dred.-Flower medium, habit weak, a good bloomer, but of a dull, purplish, lake color; pretty for variety.

Admiral Dundas.-Foliage and habit good; color velrety scarlet; fine.

Celestial.-A strong, rapidly growing variety, the leaves often two inelies 
across; truss large, elongated, forming a fine head; color pink, with darker cye; desirable for its size and color.

Mrs. Abbott.- Habit and toliage good, truss small; color very dark, velvety purple, light eye; fine.

Evening Star.-Color dark-crimson, with well-defined whitish-pink eve; growth small; a decided noreliy, amel a very striking llower.

Rosy Gem.-A lovely verbena, foliage and flower of medium size; color rosy lake, with light eye; extra finc.

For an ordinary purpose, howerer, somo that liave been long in use, that can be bought for a tenth or a hundredih part of the price of these new sorts, might give equal satisfaction, for the rarictics have been so multiplied that it is difficult to tell which are the favorites.

57S. Nowers Grown as a Farm Crop.-There are many jersous in France who grow flowers as an exclusive erop. It is their solo dependence. "Tho growing of flowers, for the production of fine essential oils and for medicinal purposes, is contined mainly to the sonthern portion of the departnsent of Var, lying on the Meditemanean, aljoining the late Inlian, but now French, province of Nice. There are extensire factories in Nisues, Monspelier, Nice, and in Algeria, bnt the great eenter of this brauch of industry is tho town of Grasse, lying some few miles inland, and its eca-port, Cannes, the winter residence of Lord Brougluam.

"It wonld be impossible to state, even approximately, the product of the flower-ficlds of this interesting regrion. There are no less than sixty finctories in Grasse, giving employment, in the varions departments of ficld and in-dour labor, to 5,000 persons. Many manufacturers grow their own tluwers, withers bny them in the open marliet daily, and still others aro sujplied ly contracts. The latter system provails among the lealing lowses. Comerenes are made at a fixed price for a term of years for thu total prodict of a firm, at rates varying from $S$ to 10 cents per bilogramme ( $2 \frac{1}{3}$ lhs.) of rose lenves, up to $\$ 1$ for tuberose leaves, and even ligher rutes for violet leares, which last are mainly grown at Nice. The average prices are nbout as folluws:

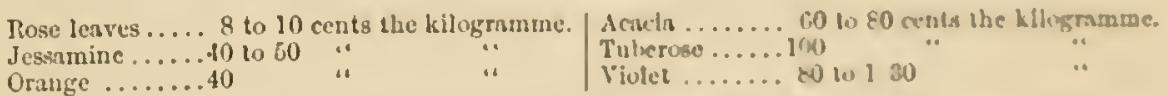

"These are the leading garden flowers used in Grasse; nuly" fmall quant: ties of the jonquil, nareissus, minnonette, ete, are cultivated. I great breadth of land is devoled to lavender, rosemary, lhyme, nul other medieinal plants, which are sold at much luwer rates than tie uhore.

"Ille preparation of all these plants diviules itsclt uninly into funr chases:

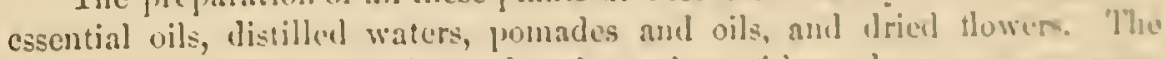

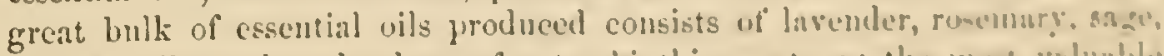
thyme, spikenarl, and others of a terebinthine maturo: the mons voluable oils producel in any quantity are those of Neroli mul Petist Cisaius. "17wo

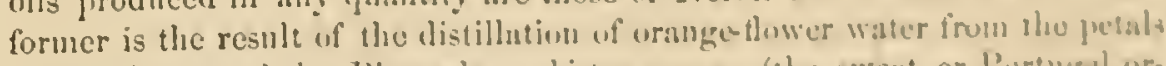
of the flowers of tho ligigarade, or bitter urnngo (the sweet or l'urtugal or. auge yiclding an inferior product, and the later is ulotajued from tho grem 
leaves of the same tree. The price of Neroli varies, with the seasons, from $\$ 30$ to $\$ 45$ the ponnd, and of Petits Grains from $\$ \$$ to $\$ 12$. These two oils are extensively used in the composition of Cologne water, and in combination with bergamot, give it its distinetive eharacter. The orange-flower water is consumed in immense quantities in France, in the 'ean sucrée, so nniversally drank in the hot season. This, by the way, is the only shape in which a Frenehman will drink water at all. The Bigarade orange-tree requires ten years to mature and twenty to obtain perfection, and yields an arerage of seventeen pounds of flower's per anmmm.

"Rose water is also distilled in large quantities. A result of its distillation is an excedingly small quantity of otto of rose of the very highest quality; it appears in small supernatant grains or drops, whieh are earetully slimmed off and rectified. It is superior to the famous Kizanlik, or Turkish otto, and congeals, at ordinary temperatures, in beautiful, transparent crystals. The 'Tose de Mai,' or double May rose, is the one universally grown.

"Another very eostly article, of" which less than one ounce had been produced in 1555 , is the essential oil of jessamine. Up to that period its existence in the plant was stontly denied by the distillers, although to what other principle the fine odor of the plant was due, they failed to prove. In that year an Algerian eliemist obtained a minute quantity, which cost him, as we were informed, at the rate of 17,000 francs the kilogramme, or $\$ 90$ the ounce. It lias, sinee then, been produced at a cheaper rate, but still toc dear for eommercial purposes. The wild Arabian jessamine is grafted on the cultivated plant of the same species, acelimated, and bears for many years, if not winter killed, yielding 90 to $150 \mathrm{lbs}$. of flowers per thousand plants. It is closely trimmed in spring, and deeply covered in winter. The caterpillar is its most formidable enemy.

"A most important branch, and one in which great rivalry exists, is the preparation of perfumed pomades and otto, which have a two-fold use : first, as bases for the finer kind of pomatums and hair oils; and next, as a medium for obtaining spiritnous extracts for the toilet, snch as Lubin's wellknown extracts for the handkerchief. Their preparation is the most interesting and curious feature of the Grasse establishments, and merits a word of description. For the oils, the inodorous virgin olife oil is used, expressed from olives just before their maturity.

"The pomade 'body,' which is prepared in winter, is composed of one part of beef suet and two parts of leaf lard, thoroughly hashed, washed in several waters, and among the best manufacturers it is washed several times in rose water to deprive it of all unpleasant odor, and then carefully melted and stored away in linge tin cans in airy, cool vaults, for use in the season of flowers. The busy operations of the year commence with the rose season.

"There are two processes for impregnating the pomade body and the oils with the floral odors-one by infusion, the other by 'enflenrage.' The first is employed for the strong, less volatile odors of the rose, orange, and 
acacia; the latter for the sensitive, ethereal pertumes of the jusamine, aulue.

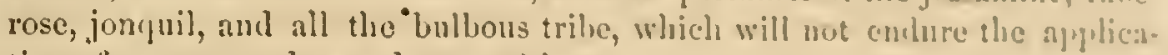
tion of eren a moderate degree of lieat.

"And first, ly intusion ; alout 100 liilogranumes of alse ponale londy ure

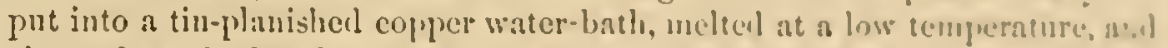

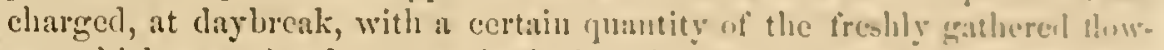
ers, which are stirred constantly during the dily and nighti, the mas lecing

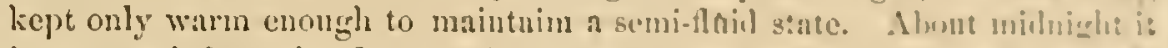
is removed from the fire, put into strome lines male of fisli-cord, amb sur jected to heavy pressure in large, perforalterl, vertical iron cylimlers, blaml. ing on marble bed-plates, which are gently warmen to prevent the conse lation of the exuling mass. Text morning tiresh leaves are added, and iho process repeated daily until the desired strungth of pertume is ohininerl. when the pomade is put into eylindrical tin boxes nud sealed np for ohipr ment. The oils are treated in like manner, but are filered insteanl of pre-nenl.

"In preparing the oils, conrse, heary, spongy cotton chets, nado coprecially for this purjose at Marseilles, are saturatel with nil nud flreal upun sle netted frames; flowers are then strewn thekly upon them, and they new piled up ju like manner as the pomales. When sufteciently chargent wits odor, the oil is expressed from the cloths by puwerfinl lesers.

"Many hundred-weight of flowers and lichlus are dricel snnusly, am] are rhrionsly used in the healing ate, and in the composininn of scemb-hans, cachous, funing pastils for the sick clamber, and kindred compunma of the perfumer's art.

"The Parmezan, or donble vinlet, is grown umler the flimle of trew, aml yields a delicate and delighteful perfume. It was the tisworite entur of the Athenians under I'ericles, and is now the fishomale secut of the l'ari-imu bear monde.

"The flower furms receive the higlsest culture: underalrniming is mo: practiced, but great attention is paicl to irrigation. Somo fleds lave n conme plete network of irrigating tubes sulstantially laid in cenent. A cumn'ms warfare is waged upon insects, each fluut hiving, ns wish us, its fuet lworer. grub, or bug, and 'cternal vigilance is the frice" of success. "lic lus: in summer is intense, though tempered ly the sen lorecze, and the wine $r$ in times as rigrorous as in Wrashington or Richmume.

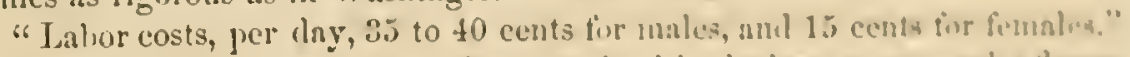

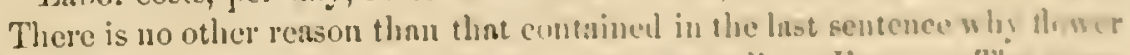

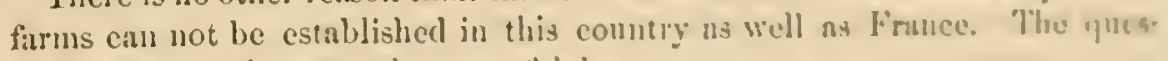
tion rests entirely upon tho cost of labor.

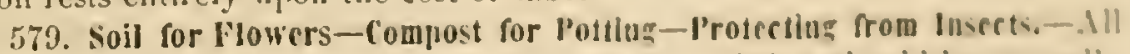

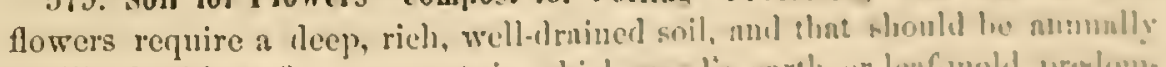
fertilized with a fine compust, in which woml's earels or lenf-imolil promlente inates. The following directions of a jrantenl ganlener, thongh given mostly in reference to potting plants. will ho fouml uscful, the sane wil being good for flower-beds, particularly for an numual dressimg. 
"To liare suitable compost for plants, the different soils should be mixed for some time before they are wanted. In making composts, the following soils should be obtained: First, soil and turf from an old pasture; second, decompozed horse or cow manure; third, peat soil or leaf-mold from the woods; fourth, white sand; fifth, eoarse sand or gravel; sixtl, eharcoal and broken pots. The charcoal and broken pots are for drainage. $\Lambda$ suitahle compost for fuchsias, roses, and geraniums consists of one part white sand, one of leat-mold, and one of decomposed manure and turf-mold. These should be well mixed together and sifted before nsing. $\Lambda$ compost for eactns is made of sand, leaf, and turf-mold, with a good drainage of charcoal and broken pots. All bulbons roots require a very rich soil composed of equal parts of sea sand, rotten cow manure, peat soil, and good turf-mold.

"In taking plants out of pots, all that is necessary is to put the hand on top of the dirt and then turn the pot bottom up, and hit a gentle rap, and the ball of earth will slip out. Most people water plants too little. Two or three times a week is necessary, or oftener in a dry store room.

"To grow flowers in the greatest perfection, gardeners often eorer them and take great pains to preserve them free from contact of inseets or the pollen of other flowers.

"The thing of most importance in potting is suitable soil. Many persons imagine that all that is requisite is carth, be it good or bad. We lave seen plants potted in common street mamure, the owners laboring under the impression that it was the very best kind beeause it was black.

"Unsuitable soil and large pots generally given to small, weak plants for the purpose of eausing them to grow, is, in nine eases out of ten, the cause of their death.

"Giving small pots to weak plants eneonrages the growth of the roots toward the side of the pot in scarch of air and moisture. In potting plants, glazed pots should never be used, as they prerent the evaporation of all impurities through the sides of the pot.

"Of all the insects which infest house plants, the green fly, red spider, and mealy bug are the most diffieult to get rid of. They are casily destroyed in the green-house by tobaceo smoke. For parlor plants, take a pail of soft water, invert the plant over the pail, cover the surface of the pot with a piece of paper to prevent the soil from falling ont, and brush the leaves downward with a dust brush, dipping the plant in the water screral times. The mealy bug may be found in the axils of the leaves of orangetrees, camelias, passion flowers, and various other plants. They look like small specks of cotton, and are only to be got rid of by picking them off. If plants should happen to get frozen, they should be syringed with cold water and screened from the rays of the sun. Thus plants are frequently saved that would otherwise be destroyed." 





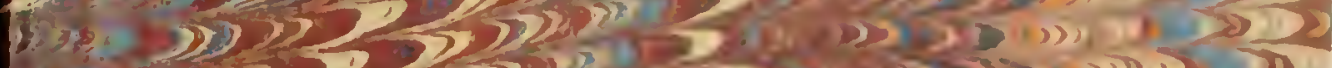

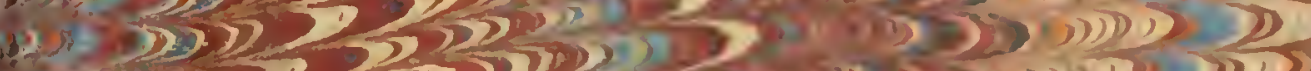

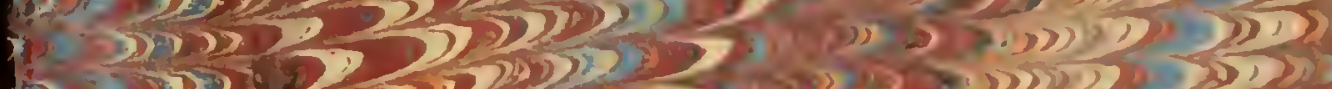

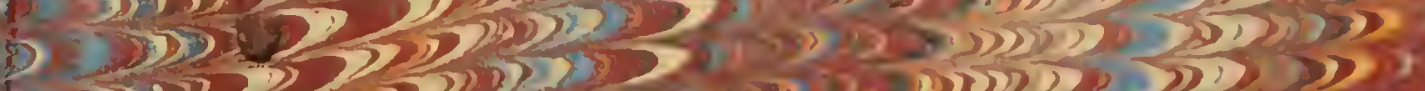

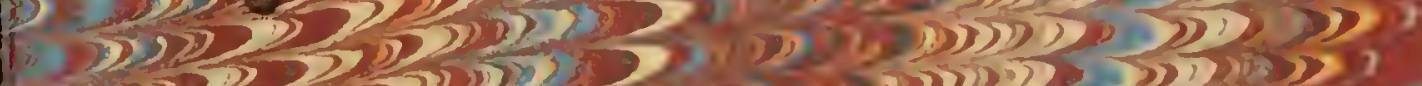

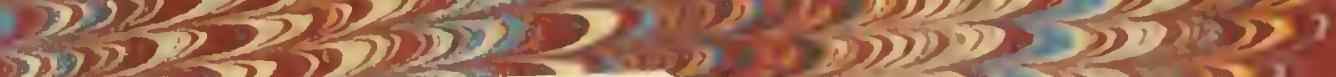

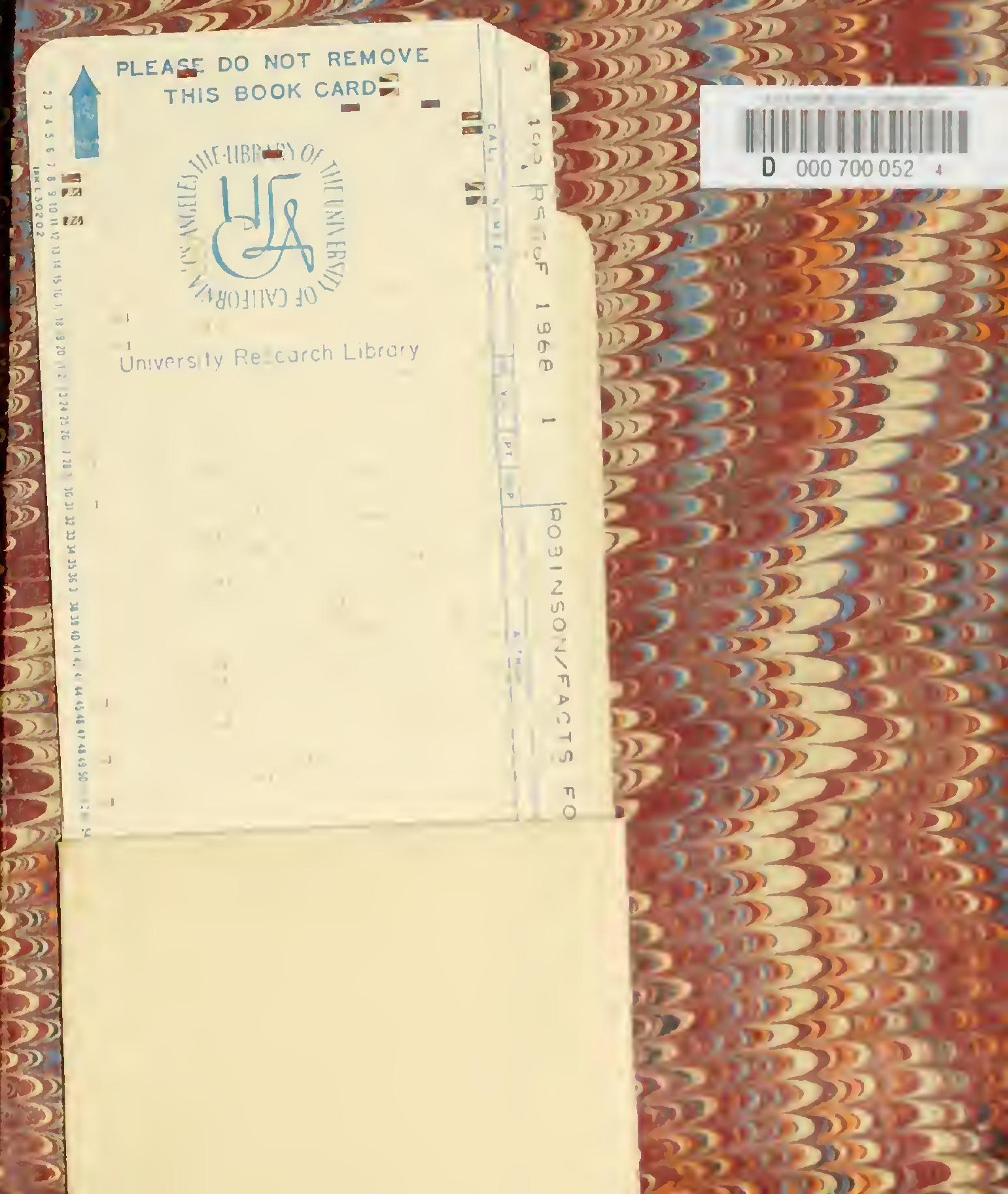




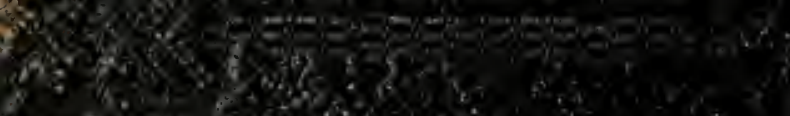

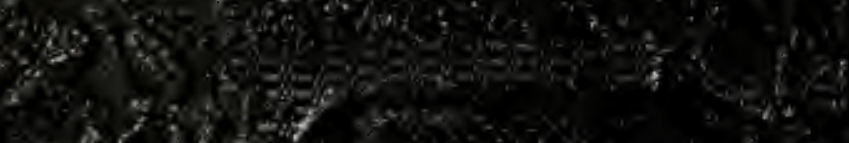

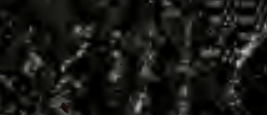

Fis.

is

t. 3

$10+x^{2}$

0

2

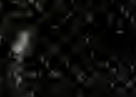

18:

is 1

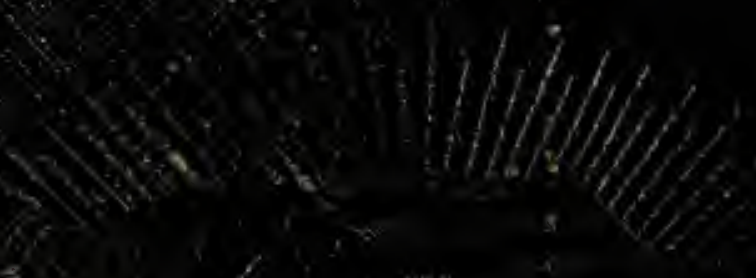

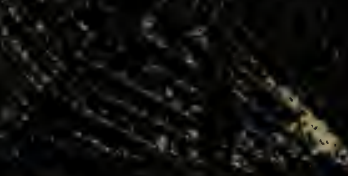

- 8

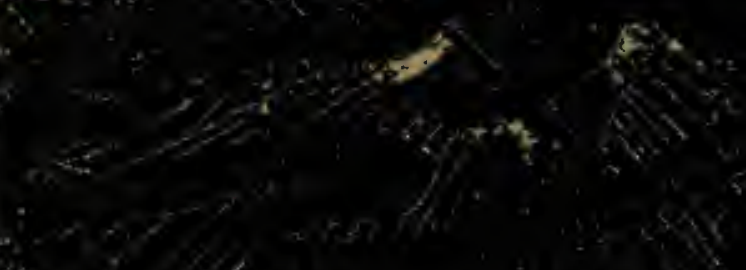

5

8 .

-

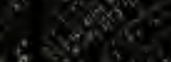

ts

,

$4 \% 8 \%$

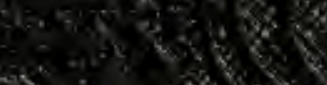

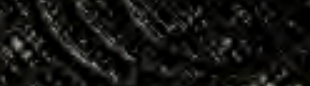

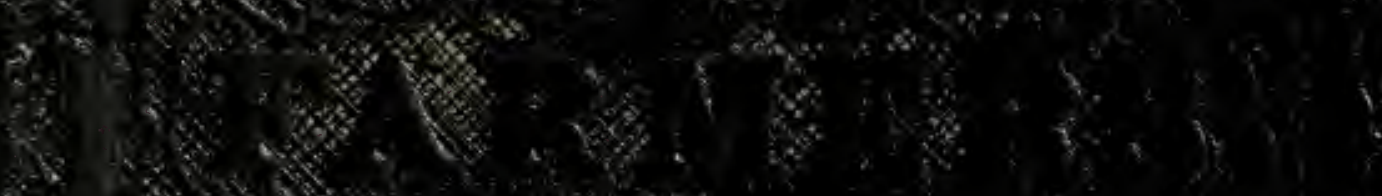

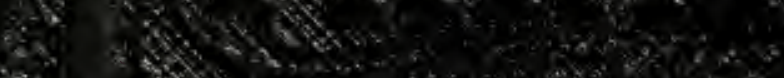

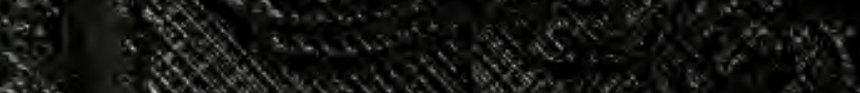

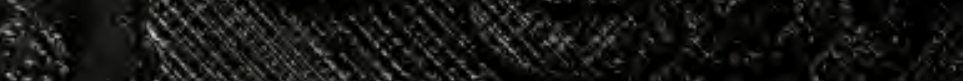

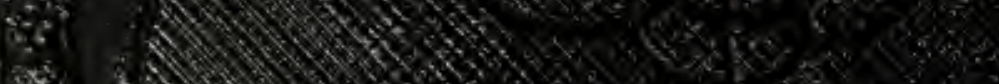

(x) 3 (1)

S.

to.

18

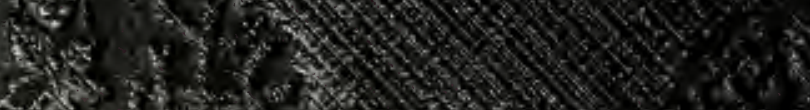

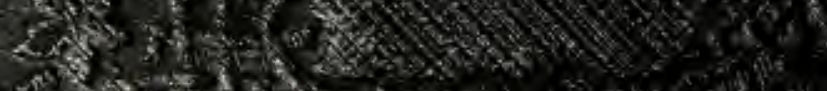

N 13.

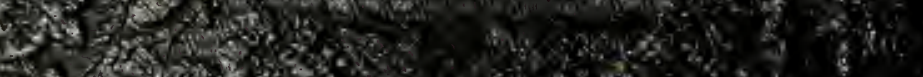

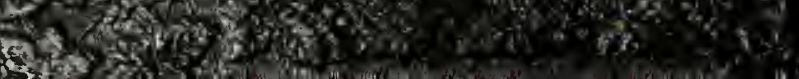

